\title{
A tipologia dos edifícios de apartamentos e sua relação com o tecido urbano da cidade - um estudo de suas transformações nos últimos 40 anos.
}

Dissertação apresentada à

Faculdade de Arquitetura e Urbanismo da Universidade de São Paulo

para obtenção do titulo de Mestre em Planejamento Urbano e regional.

Orientador:

Prof. Dr. Cândido Malta Campos Filho 
Autorizo a divulgação total ou

parcial deste trabalho, pelos meios

convencionais ou eletrônicos, para

fins de estudo e pesquisa, desde

que seja citada a fonte.

Jorge Pessoa de Carvalho

jorgepc@uol.com.br

Projeto gráfico, diagramação, tratamento de imagens e

produção gráfica

Gisele Fujiura

Davi Tavares

\section{Revisão dos textos:}

André Ricardo de Souza

\footnotetext{
Carvalho, Jorge Pessoa de

C331t A tipologia dos edifícios de apartamentos e sua relação com o tecido urbano da cidade - um estudo de suas transformações nos últimos 40 anos. / Jorge Pessoa de Carvalho. --São Paulo, 2008.

$224 \mathrm{p}$ : il.

Dissertação (Mestrado - Área de Concentração: Planejamento Urbano e Regional) - FAUUSP.

Orientador: Candido Malta Campos Filho

1.Morfologia urbana - São Paulo (SP) 2.Arquitetura (Tipologia) 3.Edifícios de apartamentos I.Título
} 
Para Paula, Isabel e Miguel. 



\section{AGRADECIMENTOS}

Este trabalho não teria sido possível sem a colaboração de professores, amigos e familiares. A eles eu expresso meus agradecimentos.

Ao prezado professor Cândido Malta Campos Filho, pela sua orientação, seu apoio e incentivo durante toda elaboração deste trabalho;

aos professores Rafael Perrone e Eduardo Alberto Cuce Nobre, membros da banca de qualificação, pelas sugestões que ajudaram a definir melhor os objetivos deste trabalho;

ao meu amigo e professor Nuno de Azevedo Fonseca, pelas sugestões de leituras e pelos livros emprestados;

ao Escritório Almeida Leite, especialmente às figuras do Dr. Jorge Barnsley Pessôa Filho, Marcelo Pessôa e Shirley Pontes, por gentilmente abrirem seus arquivos para esta pesquisa;

ao arquiteto Benjamin Adiron Ribeiro, pela entrevista concedida;

à minha aluna Luciana Schlieper, pela sua preciosa ajuda na primeira fase dos levantamentos de campo, e à Ana Beatriz Palma, aluna da FAU, pela sua colaboração na fase final dos levantamentos;

ao meu cunhado André, pela leitura e revisão final dos textos deste trabalho;

às minhas queridas Catherine Otondo e Marina Grinover, pela ajuda, pelo incentivo e por segurarem as pontas dos nossos trabalhos profissionais nas vezes em que tive que me ausentar do escritório;

ao Luis Colombo, Regis Sugaya, Elizabet Paez, amigos que direta ou indiretamente ajudaram na realização deste trabalho;

aos meus pais, Anna Maria e Luiz Carlos, pela orientação e ajuda incondicional;

a Paula, minha mulher, pela leitura e revisão dos os textos necessários para elaboração deste trabalho e, sobretudo, pelo seu amor e sua paciência ao dividir o cotidiano com quem elabora uma dissertação de mestrado. 

HWGAR DIK उROTR:
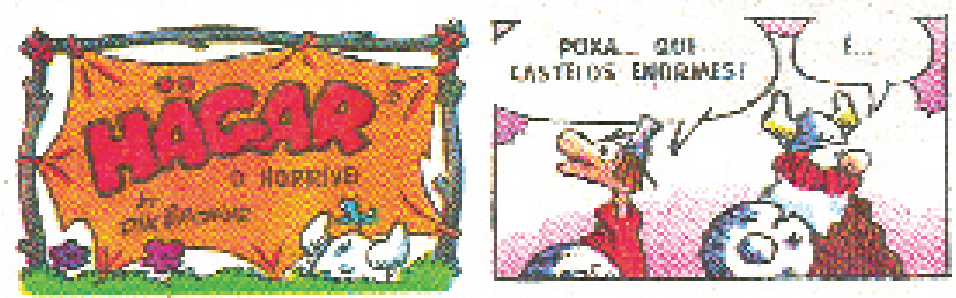

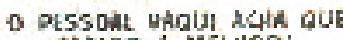
MAIM 1 MLLOR'

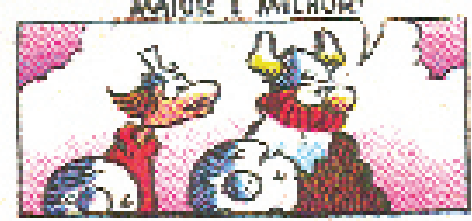

- HCOWEL.. ND MO PASSADO AQL
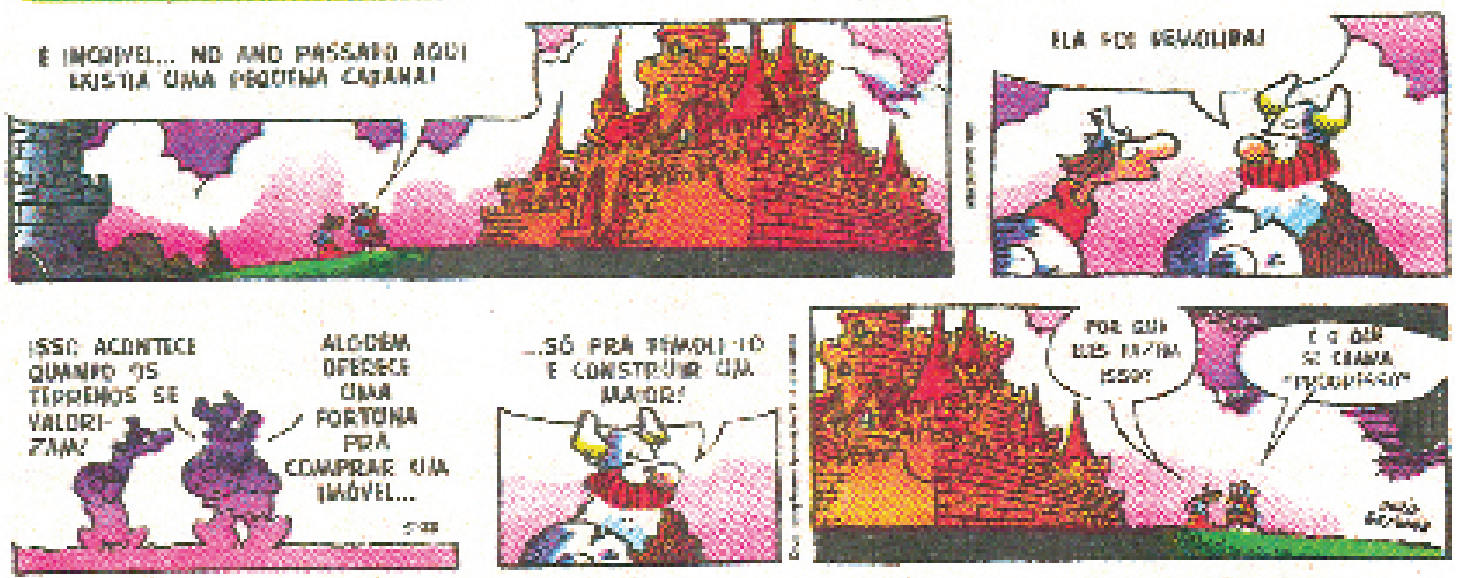

Hagar, de Dik Browe. Fonte: Folha de S. Paulo Domingo, 5 de novembro de 2006 



\section{RESUMO}

Esta dissertação analisa os principais fatores que influenciaram a tipologia arquitetônica dos empreendimentos residenciais produzidos pela configuração produtiva incorporação imobiliária na cidade de São Paulo nos últimos 40 anos. Analisa também como a produção deste setor imobiliário vem alterando os tecidos urbanos pré-existentes da cidade com empreendimentos que alteram a sua tipologia arquitetônica original e o uso do espaço público no entorno das edificações, mantendo inalterado o traçado viário e demais espaços da cidade - em outras palavras, as conseqüências do uso novo do traçado velho.

Palavras-chave: Tipologia arquitetônica. Tecidos urbanos. Configuração produtiva

\section{ABSTRACT}

This dissertation analyzes the main factors that influenced the architectural typology of housing development projects built by real estate development corporations in the city of São Paulo in the last forty years. It also analyzes how the real estate sector's production has changed the city's pre-existent urban fabric with development projects that alter the architectural typology and the land use of the public space surrounding the new buildings, while at the same time keeping unchanged the road system and the remaining city spaces - in other words, the consequences of the new use of the old grid.

Key words: Architectural typology. Urban fabric. Productive configuration. 



\section{SUMÁRIO}

INTRODUÇÃO

1.1- 0 conceito de tipo _ _ $\quad 20$

1.2- A origem do conceito de Tipologia Arquitetônica:

Quatremère de Quincy e Durand _ _ 22

1.3- O Movimento Moderno $\quad 25$

1.4- A crítica ao funcionalismo Moderno e a formação do Team 10 28

1.5- 0 Neo-Racionalismo italiano e a Terceira Tipologia

1.6- A nova Escola Francesa $\quad 34$

1.7- A Escola Catalã _ $\quad 37$

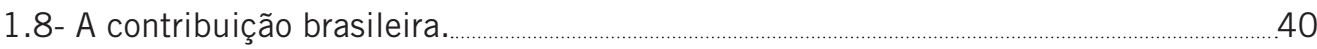

CAPÍTULO 2 - 45

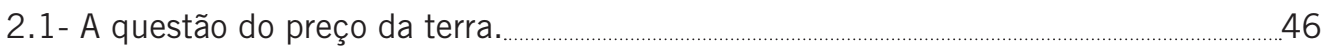

2.2- A Legislação e o preço da terra. $\quad 47$

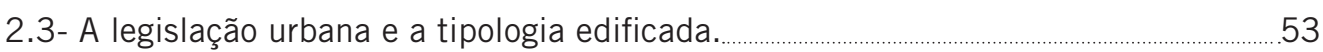

2.4- O Tecido Urbano e sua relação com a tipologia imobiliária.............................59

2.5- 0 marketing imobiliário e a sua relação com a tipologia. ...__

CAPÍTULO $3 \quad 65$

3.1-Introdução. — 66

3.2- Identificação da base de dados: O Escritório Almeida Leite.....__ 66

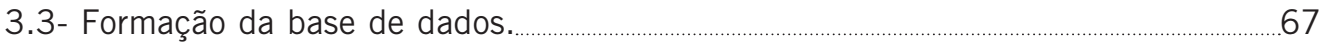

3.4- Análise Comparativa das Tipologias Arquitetônicas. …_ 122

3.5- Análise Comparativa das Tipologias de Tecidos Urbanos. . _ _ _ _ _ _ _ _ 127

CAPÍTULO $4 \quad 133$

4.1- Introdução. $\quad 134$

4.2- 0 desenvolvimento do bairro de Higienópolis. …… _ _ _ _ _ 135

4.3- A transformação do tecido urbano de Higienópolis. . . . 139

4.4- O desenvolvimento do bairro do Itaim Bibi... $\quad 146$

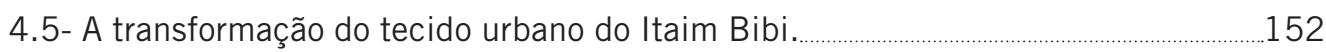

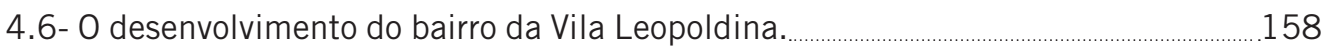

4.7- A transformação do tecido urbano da Vila Leopoldina. . _ _ _ _ _ _ _ 162

4.8- Análise dos tecidos urbanos atuais. $\quad 168$

CONCLUSÃO 171

REFERÊNCIAS BIBLIOGRÁFICAS $\quad 175$

ANEXO 181 

INTRODUÇÃO 
A interdependência entre a forma do edifício e a forma urbana é uma das relações mais importantes entre a cidade e o projeto de arquitetura. A forma urbana é, simultaneamente, produto e produtora da tipologia arquitetônica edificada. O edifício, portanto, não pode ser entendido como um acontecimento isolado na cidade, mas como parte integrante de um complexo sistema de relações espaciais e formais com todo o espaço urbanizado à sua volta. Os edifícios constituem parte da forma do espaço urbano, estabelecendo com esta uma relação dialética. "A tipologia edificada determina a forma urbana e a forma urbana é condicionadora da tipologia edificada" (LAMAS, 1999, p. 86).

A forma do edifício é a tradução de uma solução arquitetônica para um conjunto de problemas inseridos em um contexto urbano, tais como circulação, insolação, ocupação no lote, acesso à rede de serviços urbanos etc. A solução da forma deve satisfazer ainda a critérios funcionais, econômicos, mercadológicos, tecnológicos, estéticos, além de obedecer a uma legislação urbanística específica.

A disciplina Desenho Urbano caracteriza-se, fundamentalmente, pela concepção do espaço físico onde habita o ser humano. Essa concepção é inicialmente formal, porém não deve se restringir apenas ao edifício, ou às relações entre as edificações e os espaços por elas definidos, mas acima de tudo deve ser compreendido como a articulação entre o mundo privado e o mundo público que o entrelaça, especialmente o sistema viário, os sistemas de transportes e de serviços sociais que atuando conjuntamente determinam o tecido urbano.

O planejamento urbano, ao tratar das questões da estruturação do espaço das cidades, estuda a sua problemática sócio-ambiental enquanto diferenciação funcional desses espaços, a segregação social que está associada à distribuição das riquezas entre os grupos sociais, e o papel da renda fundiária na distribuição desta mesma riqueza entre os proprietários, os não-proprietários e os agentes públicos que também dela se apropriam através de impostos, taxas e preços. A organização do espaço sendo muito dependente da rede infra-estrutural que lhe dá suporte, tem nela um fator organizador por atrair atividades urbanas para os troncos infra-estruturais. As centralidades urbanas decorrem daí.

A produção do espaço urbano de uma cidade é, segundo o professor e urbanista Cândido Malta Campos Filho, um processo coletivo que envolve a sociedade como um todo e depende essencialmente de sua base econômica (CAMPOS FILHO, 2004a). As forças sociais de uma sociedade do tipo capitalista definem quem são os agentes produtores do espaço urbano, os que se apropriam da renda fundiária ali gerada, os consumidores dos produtos imobiliários e os seus usuários que, situados fora do mercado imobiliário, não são necessariamente consumidores (CAMPOS FILHO, 2004a).

Ao analisar como esses agentes sociais se articulam entre si na produção da cidade, Campos Filho propõe separá-los em configurações produtivas. Para ele, se partirmos, como fez Solá Morales, do fato de que o espaço urbano é produzido em três níveis, o do parcelamento (P), o da urbanização (U) e o da edificação (E), verificaremos que a articulação no tempo entre esses níveis é dependente das diferentes configurações produtivas. A atuação das diferentes configurações produtivas, cada qual fiel à sua lógica de produção e defendendo interesses econômicos próprios, resulta em diferentes tipos arquitetônicos que, combinados com a produção do parcelamento e da rede infra-estrutural e de serviços sociais, produzem os diferentes tipos de tecidos urbanos, cada um propiciando ou 
dificultando determinados modos de vida. Assim, o estudo da lógica das configurações produtivas imobiliárias fornecerá uma chave para compreendermos as características dos espaços que elas produzem e transformam.

A extensão da idéia de tipo arquitetônico para tipos de tecidos urbanos, bem como a importância de sua análise, vem sendo afirmada por importantes arquitetos tais como Giulio Carlo Argan, Aldo Rossi, Phillipe Panerai e Manuel de Solá-Morales. São seguidores críticos do movimento moderno em arquitetura que perceberam a importância de se conhecer a lógica da formação dos tecidos urbanos no processo de produção do espaço da cidade, dos condicionantes sociais da sua produção e consequentemente do atendimento adequado das demandas sociais envolvidas.

A configuração produtiva do tipo incorporação imobiliária para fins capitalistas de venda ou aluguel é hoje o grande agente transformador do espaço urbano, sobretudo nas áreas centrais das principais cidades brasileiras ${ }^{1}$. Entender a dinâmica da industria imobiliária, os fatores que influenciam a sua produção e, principalmente, a tipologia resultante deste processo produtivo se torna imprescindível para a compreensão de como estão ocorrendo essas transformações do espaço urbano, principalmente na cidade de São Paulo, maior metrópole do pais. As transformações das tipologias de tecidos urbanos da cidade de São Paulo a partir da mudança das tipologias arquitetônicas praticadas pelos agentes empreendedores imobiliários nos últimos quarenta anos na cidade de São Paulo são o objeto de estudo deste trabalho.

Com esse estudo pretende-se compreender quais são os critérios (econômicos, funcionais, tecnológicos, mercadológicos, legislativos ou de localização) determinantes na formação da tipologia arquitetônica praticada por empresas de incorporações imobiliárias, na cidade de São Paulo, e qual o seu impacto na transformação do tecido urbano pré-existente. O primeiro passo foi conhecer os tipos. Para isso foi necessário um levantamento sistemático descritivo. Em seguida compreender a lógica das configurações produtivas que os produziram, os interesses sociais em jogo, o papel do Estado nesse processo produtivo, o resultado do mesmo em termos de valor de troca, com destaque para a apropriação da renda fundiária, e do valor de uso.

Para desenvolver este tema busquei, no capítulo 1, "O CONCEITO DE TIPOLOGIA EM ARQUITETURA", aprofundar a compreensão do conceito de tipo divulgado por Giulio Carlo Argan, em seu artigo "Sobre o conceito de tipologia arquitetônica" escrito em 1962. Argan considera incontestável o fato de que certas tipologias arquitetônicas foram formadas pela prática da arquitetura ao longo da história. Considera genuíno, portanto, que as questões relacionadas à tipologia arquitetônica sejam colocadas como um importante instrumento, não apenas para a análise, mas também para o processo de projeto dos arquitetos.

Procurei então discutir o desenvolvimento do conceito de tipo dentro do contexto da arquitetura e sua evolução histórica, desde a época pré-industrial, passando pelo movimento moderno e chegando ao movimento pós-moderno da arquitetura. Para as origens do conceito de tipo recorri a referências ao trabalho de pensadores franceses do séc XVIII, como Antoine Chrisostome Quatremère de Quincy e Jean Nicolas Louis Durand, presentes em textos de autores contemporâneos como os arquitetos e pesquisadores gaúchos Ronaldo de Azambuja Ströher (2001) e Eneida Ripoll Ströher (2001) entre outros.

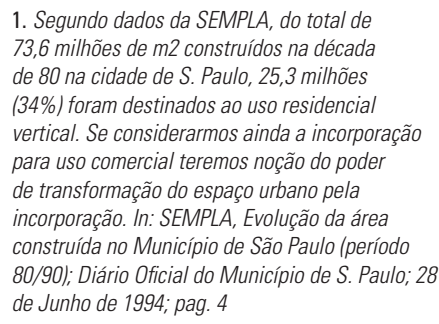

1. Segundo dados da SEMPLA, do total de 73,6 milhões de m2 construídos na década de 80 na cidade de $S$. Paulo, 25,3 milhões (34\%) foram destinados ao uso residencial vertical. Se considerarmos ainda a incorporação para uso comercial teremos noção do poder de transformação do espaço urbano pela incorporação. In: SEMPLA, Evolução da área construída no Município de São Paulo (período 80/90); Diário Oficial do Município de S. Paulo; 28 de Junho de 1994; pag. 4 
Apesar de não haver unanimidade de opiniões quando se trata do surgimento do conceito de tipo em arquitetura, a maioria dos estudiosos deste tema considera que este foi aprofundado e sistematizado pela primeira vez por Quatremère de Quincy em seus estudos sobre as origens da arquitetura. Os tratados que buscavam criar uma metodologia de projeto publicados por Durand, entre 1799 e 1805, também têm importância fundamental para a consolidação do conceito de tipo.

Busquei também discutir o pensamento geral dos arquitetos do movimento moderno que, seduzidos pelas novas possibilidades apresentadas pela indústria em franco desenvolvimento, passam a propor uma arquitetura totalmente original, que refletisse as novas condições de vida proporcionadas pela revolução tecnológica. Os arquitetos deste movimento passam a ter sérias restrições ao conceito de tipo atrelado às formas históricas.

Foram colocadas então as contribuições do grupo "Team 10" na formulação da crítica aos fundadores do movimento moderno, especialmente Le Corbusier e Gropius, que visavam superar as simplificações sociológicas próprias deste movimento, considerarando positivas as contribuições do estudo da história das cidades através de uma avaliação crítica das tipologias arquitetônicas e urbanísticas.

A reconstrução das cidades européias após a Segunda Grande Guerra foi a grande responsável por trazer novamente à tona o debate acerca do conceito de tipo. Este debate se baseia principalmente nos trabalhos de arquitetos italianos como Argan, Ernesto Rogers e Aldo Rossi, que passam a considerar a cidade histórica um bem cultural que deve ser cuidadosamente reconstruído. Esta nova geração de arquitetos entende a arquitetura como um processo de conhecimento e, portanto, volta a considerar a crítica e a história da arquitetura como instrumentos de projeto. Rossi considera de fundamental importância os tecidos urbanos da cidade histórica e é nele que busca referências para seus projetos. Relaciona tipologia arquitetônica à morfologia urbana e estabelece uma correspondência entre os tipos edificados e as formas características da cidade em que são construídos.

A Formação Social das tipologias de tecido Urbano foram estudadas neste capítulo a partir dos trabalhos do sociólogo Jean-Charles Depaule e dos arquitetos arquitetos Philippe Panerai e Jean Castex, da Escola de Versalhes, e também do arquiteto Manuel de Solà-Morales y Rubió, do Laboratório de Urbanismo da Escola de Arquitetura de Barcelona. SolàMorales considera que as tipologias de tecidos urbanos são o resultado de três momentos da produção dos espaços das cidades: o momento do parcelamento do solo, o momento da urbanização e o momento de edificação, cada qual resultante de idéias e projetos próprios. Estuda então as diferentes formas de crescimento Urbano relacionando-as à diferentes combinações entre estes momentos de produção do espaço das cidades.

Finalmente coloquei as contribuições de arquitetos e pesquisadores brasileiros na evolução do conceito de tipologia arquitetônica e tipologia de tecidos urbanos, especialmente o trabalho de Cândido Malta Campos Filho. A sua contribuição está na inclusão, na análise proposto por Solà-Morales, do estudo das configurações produtivas de cada um dos três agentes produtores do espaço urbano. Para Campos Filho, a cada configuração produtiva em sua organização seqüencial na produção de P, U e E corresponde um resultado físico-espacial, favorecendo diferentes modos e estilos de vida. É o que denomina tecidos urbanos, com os seus vários tipos evoluindo no tempo. 
No capítulo II, "O MERCADO IMOBILIÁRIO E SUA RELAÇÃO COM A TIPOLOGIA", discuto os principais fatores que influenciam a tipologia praticada pela configuração produtiva do tipo incorporação imobiliária em São Paulo e quais são as suas conseqüências para a cidade.

Na primeira parte deste capítulo eu discuto como alguns fatores sociais urbanos, tais como a concentração de renda em pequenas parcelas da população, o déficit de infra-estrutura de serviços públicos e sua concentração em poucas áreas da cidade, vão influenciar o preço do solo urbano. Discuto também como esses fatores criam dificuldades para a reprodução do capital do setor imobiliário e qual a conseqüência tipológica em seus produtos.

Na segunda parte, discuto aspectos da legislação urbana que também influenciam o preço da terra, mais especificamente a Lei de Zoneamento que esteve em vigência na cidade de São Paulo por mais de trinta anos ${ }^{2}$ e como ela estruturou o mercado imobiliário configurando eixos de valorização do solo urbano.

$\mathrm{Na}$ terceira parte deste capítulo discuto outros aspectos da legislação urbana que vão influenciar diretamente a tipologia edificada, particularmente o mecanismo conhecido como Fórmula de Adiron, e as faixas de ventilação e iluminação exigidas pelo Código de Obras do Município.

Na quarta parte discuto como tecidos urbanos em níveis distintos de desenvolvimento vão determinar diferentes produtos imobiliários com diferentes tipologias, e como a inserção destes produtos imobiliários vai afetar um tecido urbano pré-existente.

Finalmente na quinta parte discuto questões relativas ao marketing imobiliário e como elas afetam a tipologia edificada.

No capítulo III, "LEVANTAMENTO DE TIPOLOGIAS DE EDIFÍCIOS RESIDENCIAIS", foi feito um levantamento de tipologias de edifícios produzidos na cidade de São Paulo desde a década de 40 até os tempos atuais e posterior análise de sua transformação ao longo do tempo, buscando compreender as condicionantes desta transformação. Para execução deste trabalho escolhi como a minha base de dados a carteira de edifícios residenciais administrados por uma tradicional empresa administradora de condomínios e bens imóveis da cidade de São Paulo. Após a catalogação de todas as unidades foi feita uma entrevista com o diretor responsável pela empresa para saber quais as condições em que cada um dos edifícios fora construído e posterior classificação por data de construção e por configuração produtiva. Percebemos, porém, que estas informações nem sempre estão disponíveis, pois são raras as vezes em que a administradora participa da geração do empreendimento como incorporadora ou investidora. Na maioria dos casos a empresa administradora desconhece a configuração produtiva que originou o empreendimento que administra. Existem, porém, aqueles edifícios que estão sob administração desta empresa desde a sua construção, ou ainda aqueles em que a administradora participou intensamente de sua incorporação; para estes existem informações precisas. Sabe-se também com precisão quando os edifícios se constituem como condomínios ou como domínios, ou seja, se têm vários donos ou se pertencem a uma única pessoa ou família. Quando se trata de um domínio, fica evidente que o edifício fora construído para obtenção de uma renda através de aluguel. Quando se trata de um condomínio, sabemos que as unidades do edifício foram vendidas, não sabemos porém se foram vendidas no 
momento de sua construção, caracterizando uma incorporação, ou se foram construídas para obtenção de renda de aluguel e vendidas apenas posteriormente.

O levantamento realizado consistiu na obtenção das plantas, cortes e fachadas dos empreendimentos escolhidos, e, quando possível, os desenhos que foram apresentados à Prefeitura Municipal de São Paulo na ocasião do pedido de alvará de aprovação e construção. Esses documentos apresentam informações extremamente úteis para a análise tipológica, como desenho do edifício, representação gráfica dos recuos, quadro de áreas, nome do proprietário, nome do responsável pelo projeto e do responsável pela construção.

Foi feito também um levantamento dos tecidos urbanos no entorno de cada edifício escolhido, e demonstrado em perspectiva isométrica a volumetria, o uso atual e a provável configuração produtiva das construções vizinhas.

Com os dados levantados e documentados foi feita, na segunda parte deste capítulo, uma análise comparativa das tipologias arquitetônicas edificadas e, na terceira parte, uma análise das tipologias de tecidos urbanos em que estes edifícios foram edificados.

No capítulo IV, “LEVANTAMENTO DE TIPOLOGIAS DE TECIDOS URBANOS”, foi feito um levantamento de tecidos urbanos presentes nos bairros Higienópolis, Itaim Bibi e Vila Leopoldina. Partindo da hipótese de que a legislação urbana é um dos principais fatores de formação de tipologias dos edifícios e, portanto, de tecidos urbanos, esses bairros foram escolhidos por terem tido seus processos de verticalização consolidados em diferentes épocas - no caso da Vila Leopoldina, ainda se encontra em processo de consolidação - e sob diferentes legislações urbanas. Higienópolis, bairro central, já estava com seu processo de verticalização consolidado na época da promulgação da Lei Geral de Zoneamento, em novembro 1972, e do Código de Edificações, de 1975. Pelas suas características foi considerado pelo zoneamento como sendo Z3, "Uso predominantemente residencial, de densidade demográfica média”. Em 1972 o processo de verticalização do bairro Itaim Bibi já havia começado, mas ainda não estava consolidado, o que significa que parte dos edifícios do bairro foi construída anteriormente à lei de zoneamento e o Código de Obras de 1975 e outra parte edificada posteriormente a estas leis. Para que houvesse os mesmos parâmetros de análise, foi levantada uma área do Itaim Bibi também considerada pelo zoneamento como Z3. O mesmo procedimento foi feito em ralação à Vila Leopoldina, bairro onde o processo de verticalização se iniciou posteriormente à promulgação desta duas leis.

A análise comparativa das tipologias dos edifícios (capítulo III), permitiu uma avaliação de como a legislação urbana é determinante na formação da tipologia dos edifícios na cidade de São Paulo. A análise comparativa do levantamento dos tecidos urbanos de três bairros de São Paulo permitiu, por sua vez, verificar como a tipologia dos edifícios é determinante para a formação dos tecidos urbanos da cidade. 
CAPÍTULO 1

\section{O CONCEITO DE TIPOLOGIA EM ARQUITETURA}


1. MARTí ARÍS, Carlos. Las variaciones de la indentidad - Ensayo sobre el tipo en arquitectura, 1993, p. 18

\section{1 - O CONCEITO DE TIPO}

"Enquanto o saber tradicional da arquitetura manteve sua vigência, o homem veio utilizando, de um modo direto e imediato, a experiência precedente. A arquitetura era então uma arte eminentemente coletiva, cujo exercício dependia estreitamente da existência de modelos normativos dos quais partia-se sempre, como algo certo e firmemente estabelecido. Assim, quando o mestre da Catedral de Bourges defronta-se com a construção do edifício, não parte de alguns dados abstratos e carentes de forma; seu ponto de partida é, pelo contrario, um modelo definido baseado nas experiências imediatamente precedentes: Senlis, Noyon, Laon,... Do mesmo modo opera o mestre de Chartres com respeito a Bourges, acrescentando mais um anel à cadeia de exemplos anteriores, avançando por um lento caminho de depuração e aperfeiçoamento." (MARTÍ ARÍS, apud STRÖHER, R, 2001, p. 12) ${ }^{1}$

Se por um lado a obra arquitetônica pode ser vista como uma manifestação artística, única e original, por outro pode ser vista também como objeto que é produzido em série. De acordo com o que nos conta Carlos Martí Arís, quando a arquitetura ainda era "uma arte eminentemente coletiva", qualquer obra de arquitetura podia servir de base para uma outra igual ou semelhante. Assim, ao longo da história, foram sendo construídos edifícios repetidos ou semelhantes para atender a necessidades semelhantes. As mudanças ocorridas nos padrões arquitetônicos, foram decorrentes das experiências pessoais de cada construtor, de novas técnicas construtivas, novos materiais e principalmente de novas demandas funcionais. Desta maneira, em decorrência de semelhanças entre suas formas e funções, as edificações se agrupam em diferentes "tipos".

Giulio Carlo Argan, em seu artigo "Sobre o conceito de tipologia arquitetônica" (ARGAN, 2001) escrito em 1962, considera incontestável o fato de que, ao longo da história, certas tipologias arquitetônicas foram formadas e transmitidas pela literatura e pela prática da arquitetura para as próximas gerações. Considera legítimo, portanto, que as questões relacionadas à tipologia arquitetônica sejam colocadas tanto no processo histórico como no processo ideativo e operativo dos arquitetos individualmente.

Mas como se forma um tipo arquitetônico? Se os edifícios são agrupados em "tipos" devido às semelhanças entre formas e funções, estes tipos, obviamente, não podem ser formulados a priori, mas deduzido de uma série de exemplares existentes.

"O nascimento de um tipo é portanto condicionado ao fato de já existir uma série de edifícios que têm entre si uma evidente analogia formal e funcional. [...] No processo de comparação e superposição das formas individuais para a determinação do tipo são eliminados os caracteres específicos dos edifícios isolados e são conservados todos e apenas os elementos que comparecem em todas as unidades de série. O tipo se configura assim como um esquema deduzido através de um processo de redução de um conjunto de variantes formais a uma forma-base comum." (ARGAN, 2001, p. 66)

A forma de um edifício pode ser analisada por diferentes aspectos. Primeiro: aspectos quantitativos, que referem-se ao coeficiente de aproveitamento, massa construída, taxa de ocupação e outras características quantificáveis; segundo: aspectos funcionais, que refere-se às atividades do edifício, as categorias de uso do solo; e terceiro: aspectos figurativos, de natureza estética. 
Argan considera no entanto que o processo de formação de uma tipologia "não é um mero processo classificatório e estatístico, mas um processo conduzido com vistas a uma finalidade estética precisa. [...] Seu escopo é fornecer um guia tipológico ao arquiteto ao longo de todo o percurso de seu processo ideativo" (ARGAN, 2001, p. 67). Com esta afirmação, Argan retoma a questão da necessidade do apoio da tipologia ao processo de projeto, participando da metodologia de projeto.

Para Argan, o processo de projeto conta com três componentes ou camadas. A primeira camada é o conhecimento histórico; a segunda camada é a análise crítica do existente. Mas como se realiza esta crítica? Dividindo o existente em categorias - distinções entre grupos de coisas existentes através das afinidades e características comuns a todos os fenômenos desta categoria. Desta maneira, dividindo o existente em categorias, está colocada a questão da tipologia. A terceira camada é o momento da imaginação (ou hipótese), o momento da criação do arquiteto. Argan define a trajetória do projeto com a seguinte frase: "daquilo que lembramos àquilo que prevemos e desejamos" (ARGAN, 1993, p. 159). Para ele é impossível conceber uma idéia de projeto que não seja crítica de um tipo existente, de tipos existentes. "Em todo projeto arquitetônico há portanto um aspecto tipológico: seja no sentido de que o arquiteto busca conscientemente aproximarse de um tipo ou afastar-se dele, seja no sentido de que toda obra arquitetônica visa, definitivamente, a colocar-se como um tipo" (ARGAN, 1993, p. 159).

O uso da tipologia como metodologia de projeto encontra também algumas críticas. A mais freqüente argumenta que a escolha de um tipo constitui um momento de rigidez e inércia e que tomá-la como início para o processo de projeto limita o processo ideativo do artista, tirando sua liberdade e induzindo a uma repetição sem reflexões.

Para se contrapor a este pensamento, Argan recorre à definição de tipo formulada por Quatremère de Quincy em seu histórico Dictionnaire d'Architecture:

“A palavra 'tipo' não representa tanto a imagem de uma coisa a ser copiada ou imitada perfeitamente quanto a idéia de um elemento que deve ele mesmo servir de regra ao modelo [...]. O modelo, entendido segundo a execução prática da arte, é um objeto que se deve repetir tal qual é; o tipo é, pelo contrário, um objeto segundo o qual qualquer pessoa pode conceber obras que não se assemelharão em nada entre si. Tudo é preciso e dado no modelo, tudo é mais ou menos vago no tipo." (QUATREMĖRE DE QUINCY, apud ARGAN, 2001, p. 66) ${ }^{2}$

Argan argumenta que se o tipo é vago ele não pode sugerir uma forma definida, mas apenas um esquema de forma que se apresenta com um valor indefinido de uma imagem ou de um signo. Sendo o tipo o resultado de um processo regressivo, a forma-base que se encontra deve ser entendida como princípio que implica em si a possibilidade de infinitas variantes formais.

"Mediante a redução ao tipo o artista se livra da influência condicionante de uma determinada forma histórica, neutraliza-a: assume o passado como um fato consumado e portanto não mais suscetivel de desenvolvimento. Ficando com a definição de Quatremère, pode-se dizer que o tipo surge no momento mesmo em que a arte do passado cessa de propor-se como modelo condicionante ao artista que trabalha. A escolha de um modelo implica um juizo de valor: reconhece-se uma determinada obra de arte como perfeita e se busca imitá-la. Mas quando a obra entra na esquematicidade e na indistinção do tipo não há mais um juizo de valor que empenhe a ação
2. Q OUATREMĖRE DE QUINCY, Antoine Chrisostome, Dictionnaire d'Architecture I - II, Librairie d'Adrien Le Ceire et Cie, Paris, 1832. 
individual do artista: o tipo é aceito, mas não é 'imitado', isto é, a repetição do tipo exclui aquele processo criativo que é, na tradição do pensamento estético, a 'mimese'. Enfim, o momento da aceitação do tipo é um momento de suspensão do juízo histórico; e, como tal, é um momento negativo, mas 'intencionado' no sentido da formulação de um novo valor na medida em que, pela sua própria negatividade, põe para o artista a necessidade de uma nova determinação formal, de uma ideação". (ARGAN, 2001, p. 68)

\section{2 - A ORIGEM DO CONCEITO DE TIPOLOGIA ARQUITETÔNICA: QUATREMÈRE DE QUINCY E DURAND.}

Não existe uma unanimidade de opiniões entre teóricos e estudiosos da arquitetura quando se trata do nascimento do conceito de tipo em arquitetura, mas a maior parte dos textos escritos sobre este tema nos últimos 40 anos considera que o conceito de tipo arquitetônico foi aprofundado e sistematizado pela primeira vez pelo teórico francês Antoine Chrisostome Quatremère de Quincy (1755-1849) em seus estudos sobre as origens da arquitetura. Especialmente interessado no tema da imitação em arquitetura, Quatremère de Quincy considerava de fundamental importância a clara distinção entre os conceitos de tipo e modelo como instrumentos teóricos básicos com os quais se opera a mimese arquitetônica.

Preocupado com os descaminhos da arquitetura, Quatremère considerava que a sua única possibilidade era o retorno aos princípios fundamentais que a originaram.

"Assim, não obstante sua recomendação para que os arquitetos retornassem continuamente ao tipo [...], sua preocupação parece ter sido sempre mais profunda e filosófica do que uma mera indicação de um 'esqueleto' de forma ou a do suprimento de dados para determinar um processo classificatório". (STRÖHER, R, 2001, p. 11)

De uma maneira consistente como até então não havia sido feita, Quatremère distinguiu os conceitos de modelo e tipo, sendo este uma idéia inicial ou uma "filosofia" daquele. O modelo, relacionado a uma "copia literal", torna-se um objeto visível, palpável, objetivo demais para ser usado adequadamente em uma abstração filosófica. O tipo, por outro lado, tem como princípio algo subjetivo, intangível, "um conceito metafísico ao qual todas as manifestações físicas deveriam ser relacionadas". (VIDLER, apud STRÖHER, R, 2001, p. 11) $)^{3}$

"Em todos os países, a arte de construir corretamente nasceu de um germe preexistente. Para tudo é necessário um antecedente; nada, em qualquer gênero, provém do nada, e isso deve ser aplicado a todas as invenções humanas. Vemos também que todas as coisas, a despeito de modificações posteriores, conservam de maneira sempre visível, sempre evidente ao sentimento $e$ à razão, seu princípio elementar. É como uma espécie de núcleo em torno do qual se agregam e ao qual são coordenados, ao longo do tempo, os desenvolvimentos e as variações formais aos quais o objeto é suscetível. Temos assim milhares de coisas em cada gênero; e uma das principais ocupações da ciência e da filosofia é procurar a origem e a causa primitiva. Eis o que devemos chamar de tipo em arquitetura, como em todas as outras invenções e instituições humanas". (Quatremère de Quincy, apud STRÖHER, R, 2001, p. 9)4 
O conceito de tipo de Quatremère, embora possa ser traduzido em formas e esquemas, refere-se especialmente ao processo de aprendizado das lições da natureza, no qual o ser humano, ao suprir suas necessidades físicas e culturais de abrigo e espaço para o convívio dos indivíduos, acaba por criar uma segunda Natureza, que reflete sua inteligência e sua sensibilidade aplicada na solução dos problemas criados pela própria Natureza, transformando assim a sua arquitetura na "máscara embelezadora da necessidade". (conforme Rond d'Alambert, apud STRÖHER, R, 2001, pág. 12)

Mas devido à dificuldade de lidar com a abstração do conceito de tipo, e também para que suas idéias servissem para orientar a prática da arquitetura e reconduzi-la aos seus caminhos originais, Quatremère recorreu em seus textos a passagens bem objetivas, que mostram um conceito de tipo identificado com uma lógica de forma/função, baseado na razão e no uso:

"Aplicamos ainda a palavra tipo, na arquitetura, a certas formas gerais e características de um edifício que as recebe. Essa aplicação cabe perfeitamente nas intenções e no espírito da teoria precedente. De resto, ainda podemos, se desejarmos, empregar muitos usos próprios a certas artes mecânicas, que podem servir de exemplo. Ninguém ignora que uma quantidade de móveis, de utensílios, de vestimentas tem o seu tipo necessário baseado no emprego que deles fazemos e nos usos naturais aos quais os destinamos. Cada uma dessas coisas tem, na verdade, não o seu modelo, mas seu tipo nas necessidades e na natureza. Malgrado aquilo que o espirito industrial bizarro procura inovar nesses objetos, contrariando o instinto mais elementar, quem não prefere num vaso a forma circular à poligonal? Quem não acredita que a forma das costas do homem deva ser o tipo do encosto de uma cadeira? Que a forma arredondada não seja o único tipo razoável para o penteado de uma cabeça??. (Quatremère de Quincy, apud STRÖHER, R, 2001, p. 14)

Ao desenvolver sua formulação do conceito de tipo, Quatremère demonstrou ter consciência da dialética existente entre objetividade e subjetividade inerente ao conceito, da necessidade de produzir uma abstração a partir de vários dados concretos ou, inversamente, a de concretizar, num exemplar, a abstração de um conceito. Desta forma, a partir de sua formulação, "pode-se detectar uma característica marcante que tem acompanhado o conceito [de tipo] até os dias de hoje e que é, justamente, a contraposição entre o abstrato e o concreto, representada pela dificuldade em traduzir aquele 'germe' num esquema de forma razoavelmente compreensível”. (STRÖHER, R, 2001, p. 15)

Se Quatremère de Quincy buscou na história e na filosofia elementos para sua formulação do conceito de tipo, um outro autor, contemporâneo seu, de maneira muito mais pragmática, foi buscar na ciência e na tecnologia os elementos para a mesma formulação: Jean Nicolas Louis Durand.

Na condição de professor da Escola Politécnica de Paris, o engenheiro Durand tinha a missão de capacitar seus alunos para a prática de todas as disciplinas relacionadas a construção, inclusive a mais subjetiva delas: o projeto de arquitetura. Para isso escreveu dois tratados, publicados entre 1799 e 1805, cuja intenção era criar uma metodologia de projeto que pudesse ser aplicada ao exercício profissional cotidiano dos seus alunos. 
5. Segundo Ronaldo Ströher Elementos de arquitetura faz parte das definições formuladas por Durand em seu trabalho e se referem a pilares, escadas, cornijas, etc. Já os espaços por eles confoemados seriam os Elementos de composição.
6. MADRAZO, Leandro, Durand and the Science of Architecture, In Journal of Architectural Aducation, 48/1, setembro de 1994.
"Declaradamente, a preocupação de Durand era a de tornar o exercício de projeto uma atitude prática e objetiva, profundamente envolvida com a racionalidade e a economia da construção e em contraposição direta com os ideais artísticos e subjetivos que caracterizavam antecessores e contemporâneos seus". (STRÖHER, R, 2001, p. 17)

Nos trabalhos de Durand, exemplares arquitetônicos do passado, considerados como modelos, eram simplificados, esquematizados, reduzidos e decompostos em partes, numa espécie de investigação da "anatomia da arquitetura". Sua intenção era, através de uma análise racional das formas e volumes, deduzir um esquema geométrico que serviria de princípio para a formulação dos espaços mais adequados às necessidades humanas. Num segundo momento, o arquiteto aplicaria os "elementos de arquitetura e de composição" que considerasse mais adequados para "vestir" o esquema geométrico resultante.

Durand entendia que a os elementos de arquitetura e suas formas já estavam consolidados pelo uso e pela natureza dos materiais, por isso oferecia como modelo uma série de soluções de escadas, pátios, vestíbulos, etc., cabendo ao arquiteto, dentro dos critérios de economia e comodidade e, tendo em mente a composição, dispor esses elementos em seus projetos.

Outros trabalhos anteriores aos de Durand já propunham uma amostragem e comparação de exemplares arquitetônicos do passado, dentro de uma metodologia de criação arquitetônica baseada em modelos precedentes. Os métodos propostos por Durand, entretanto, tinham a inovação de não apenas apresentar os modelos do passado mas, também, a essência geométrica deste modelos, desenhados lado a lado. Ninguém até então havia dissecado tanto o processo de projeto, em busca de uma simplificação geométrica das diversas partes componentes de um edifício e reduzido ao mínimo sua subjetividade como fez Durand.

É claro que algo de subjetivo ainda permanecia no processo de projeto pois, como o próprio Durand reconhecia, apenas os arquitetos, de posse de todos os elementos de arquitetura, teriam especial competência para juntar todas as peças do processo numa composição adequada.

"Pode-se afirmar que o que Durand estava pretendendo com a simplificação e regularização dos desenhos era usar os edifícios individuais para ilustrar alguns princípios genéricos de arquitetura. Por essa razão ele teria achado necessário eliminar traços individuais ou acidentais sujeitando as representações dos edifícios a um processo de regularização. Nesse contexto, os edifícios antigos proviam o material de fundo com o qual Durand exemplificava a sistematização do conhecimento arquitetônico". (MADRAZO, apud STRÖHER, R, 2001, p. 18) ${ }^{6}$

Apesar de Durand em todo o seu trabalho não mencionar diretamente a palavra ou o conceito de "tipo", essa redução a um esquema geométrico de forma acabou sendo identificado como "tipificação" do edifício.

Ao contrário de Quatremère, cujo enfoque filosófico conduzia a uma abordagem em que as condições específicas do sitio - físicas e culturais - eram fundamentais para a compreensão da obra arquitetônica, Durand, ao propor como instrumento de análise crítica uma sistemática de decomposição e redução do edifício a um esquema geométrico, parece desconsiderar as condições específicas e o processo cultural que produziram os exemplos por ele selecionados. Essa sistemática, ao desvincular a obra arquitetônica de seu 
contexto físico, cultural ou tecnológico, contribui para a racionalidade da análise de suas formas geométricas, mas desconsidera os motivos específicos que a configuraram.

"Entretanto, no papel predominante que Durand atribui aos elementos, reside a principal debilidade de sua teoria. Cita-se com freqüência uma frase em que Durand, ponderando a importância dos elementos, assinala que estes são para a arquitetura 'o que as palavras são para o discurso e as notas para a música. Se aceitamos os termos em que esta analogia está proposta, poderemos dela extrair importantes conseqüências. Com efeito, do mesmo modo que resultaria inaceitável definir o discurso como uma mera combinação de palavras ou a música como uma simples justaposição de notas, também, ao privilegiar univocamente o caminho que leva dos elementos ao todo, como modo de construir a arquitetura, corre-se o risco de empobrecê-la e desnaturá-la.

Para que exista música, discurso ou arquitetura, não bastam os elementos, requer-se também uma estrutura, uma idéia geral que governe as relações que existem entre eles, em função de determinados objetivos. A estrutura manifesta-se por meio da reunião dos elementos mas, de certo modo, os precede. Ela é um princípio ordenador, capaz de fazer com que os elementos desempenhem o papel que lhes corresponde: uma idéia nuclear que move a mão do artífice. Essa estrutura, que no caso da arquitetura coincide com seu princípio tipológico, resulta ser, assim, a grande ausente na teoria de Durand". (MARTÍ ARÍS, apud STRÖHER, R, 2001, p. 12) ${ }^{7}$

Pudemos constatar que os trabalhos de Durand e de Quatremère têm enfoque radicalmente diferentes quando se trata da teoria e da prática da arquitetura mas, independente da abordagem, ambos os teóricos direta ou indiretamente acabaram por vincular seus trabalhos à idéia de tipo. De certa maneira, a grande diferença entre estas duas abordagens do conceito nos mostra toda a complexidade e as diferentes interpretações que a idéia de tipo possibilita.

\section{3 - O MOVIMENTO MODERNO}

Na primeira metade do séc. XX, com o advento do movimento moderno na arquitetura, as questões relativas à tipologia foram negadas e acabaram relegadas ao esquecimento. O pensamento geral dos arquitetos deste movimento era o de que uma arquitetura totalmente nova deveria surgir e vincular-se à nova maneira de ver o mundo, refletindo o progresso da era das máquinas e as novas condições de vida proporcionadas pela revolução tecnológica. Houve então uma tendência ao menosprezo pelas formas históricas da arquitetura e pelas lições que estas poderiam fornecer. Seus ideais de originalidade entraram em conflito com a noção de precedência contida no conceito de tipo, que para eles significava "imobilidade, um conjunto de restrições impostas ao criador, que devia gozar de liberdade total"' (MONEO, apud STRÖHER, E, 2001, p. 34). Para Le Corbusier somente uma nova arquitetura poderia exprimir o "espírito novo" da "civilização maquinista" e seria capaz de enfrentar os problemas decorrentes dos processos de industrialização e urbanização assistidos desde a virada do século.

Os grandes problemas habitacionais gerados pelos deslocamentos de populações em busca de trabalho durante a revolução industrial fizeram da habitação coletiva o principal tema nas discussões sobre a cidade desde o final do século XIX e passa a ser o principal programa dos arquitetos do movimento moderno após a Primeira Grande Guerra.
7. MARTÍ ARÍS, Carlos. Las variaciones de la indentidad - Ensayo sobre el tipo en arquitectura, 1993, p. 140.

8. MONEO, Rafael, De la tipologia. Revista Summarius $n^{\circ} 79,1984$. 
9. KOPP, Anatole. Quando o moderno não era um estilo e sim uma causa. São Paulo, Nobel/Edusp 1990, pág. 44.
10. Neste trecho Barone cita Pevsner que localiza as origens do Movimento na Inglaterra fundamentada na nova concepção artística e cultural presentes no mundo ocidental a partir da revolução industrial. PEVSNER, Nikolaus. Pioneiros do desenho moderno, Lisboa, Ulisseia, 1943.

11. GROPIUS, W. Systematishe vorarbeit für rationallen wohnungbau. Bauhaus Journal vol. 2.
12. Declaração de La Sarraz, de 1928, in LE CORBUSIER, A Carta de Atenas. São Paulo. Hucitec, Edusp, 1993.
A nova arquitetura acreditava que os problemas habitacionais da sociedade industrial deveriam ser superados pelos instrumentos que ela própria geraria: a situação da indústria em desenvolvimento e suas novas tecnologias possibilitariam enfrentar o problema da necessidade da produção em massa e, apesar de a edificação nunca ter sido objeto de produção industrial de fato, era essa nova realidade que inspirava o espírito da modernidade.

"Para cobrir o déficit de habitação acumulado durante a [primeira] guerra (perto de um milhão de alojamentos) e substituir os cortiços operários do século XIX, o simples retorno aos métodos de antes da guerra não seria suficiente. Era necessário pôr em pratica outros métodos de construção [...]" (KOPP, apud BARBARA, 2004, p. 25) ${ }^{9}$

A arquitetura pretendia inserir-se entre as novas formas de produção industrial e assim solucionar os problemas decorrentes do novo contexto social. A idéia era desvencilhar a arquitetura de seu processo produtivo artesanal, diferente em cada localidade do planeta, e dar à arquitetura um caráter universal. A nova relação entre o objeto e seu processo de produção "incorporava as 'formas' mais progressistas da época, e a missão da arquitetura, como agente do progresso, era aceitar e, talvez mesmo, dominar essas formas" (VIDLER, 2006, p. 285). Para que o objeto arquitetônico pudesse vir a ser produzido em grande escala, este deveria abrir mão de todos os elementos que não fossem estritamente necessários para a sua finalidade, além disso, as formas geométricas elementares eram consideradas as mais adequadas para a operação das máquinas. A "racionalização do desenho arquitetônico para adequação aos modos industriais de produção estava ligada ao desejo de emancipar as formas artísticas dos padrões acadêmicos pré-estabelecidos, fundamentando-os na associação entre forma, utilidade e beleza" (PEVSNER, apud BARONE, 2002, p. 36) ${ }^{10}$

A discussão a respeito da unidade habitacional mínima tinha como fundamento o desempenho econômico da produção da habitação. Para Gropius, "a maioria das pessoas têm necessidades similares. A estandardização caminha portanto no sentido de um avanço econômico, de maneira a satisfazer essas necessidades similares das massas de uma maneira simples e similar" (GROPIUS, apud BARONE, 2002, p. 35) ${ }^{11}$.

A arquitetura moderna comprometia-se a apresentar o desenho dessa estandardização, privilegiando a questão da racionalização das formas para a adequação aos modos industriais de produção. "A arquitetura não é mais a arte de construir. Tornou-se ciência" disse Kopp. (KOPP, 1990, p. 47)

Com a intenção de consolidar a nova linguagem arquitetônica como a única sintonizada com o seu tempo e unificar os parâmetros do desenho moderno, Le Corbusier organiza em 1928, na cidade suíça de La Sarraz, o primeiro Congresso Internacional de Arquitetura Moderna (CIAM), com a participação dos principais expoentes da arquitetura moderna. O resultado deste congresso foi a elaboração de uma declaração de princípios e diretrizes com o objetivo de "tirar a arquitetura do impasse acadêmico e colocá-la em seu verdadeiro meio, que é o econômico e social"12. A discussão da arquitetura deveria ser colocada em termos urbanísticos e para os congressos seguintes foram eleitos dois temas centrais presentes nos principais problemas da civilização industrial: a habitação social coletiva e a cidade funcional.

Para os arquitetos modernos havia entre os dois temas uma continuidade intrínseca. "Esse modo de conduzir a discussão da nova arquitetura refletia a idéia de que a organi- 
zação do espaço moderno partia da resolução do problema da célula de habitação para chegar ao arranjo mais correto das unidades em termos da cidade" (BARONE, 2002, p. 29). Conceber o edifício habitacional como unidade de uma série organizadora e estruturadora da cidade constitui o fundamento da arquitetura moderna. A proposta de cidade racionalista de Ernest Ray, por exemplo, baseava-se em uma concepção mecânica e era desenvolvida de acordo com um processo somatório linear:

"Várias camas formam uma célula de casa, várias células de casa formam uma unidade tipológica ou edifício, vários edifícios formam um bairro, vários bairros formam a cidade" (MONTANER, 2001, p. 140) ${ }^{13}$

Nesse sentido, era de interesse do movimento moderno em arquitetura promover uma discussão sobre a cidade baseada nos mesmos critérios de racionalização, economia e padronização como vinha sendo discutido o tema da habitação social.

A formulação da Carta de Atenas, em 1933, por ocasião do IV CIAM, realizado naquela cidade, consolidou o tema da cidade funcional como central nas discussões dos arquitetos do movimento moderno. A carta idealizava um modelo urbanístico universal e abstrato, baseado na separação analítica das quatro funções primárias da cidade: habitar, recrear, trabalhar e circular. A reprodutibilidade dos espaços funcionalistas constituíam-se como símbolo do progresso das cidades.

Ao fazer a analogia da casa com a máquina e propor que "se tomasse como modelo para o projeto arquitetônico o próprio processo de produção" (VIDLER, 2006, p. 285), Le Corbusier, paradoxalmente, proporcionava uma nova maneira de se entender o conceito de tipo, que utilizava referências formais externas à disciplina arquitetônica.

"Se aceito o determinismo segundo o qual toda invenção necessita de um precedente, não surpreende que o movimento moderno recorra a referências selecionadas entre os padrões produtivos próprio do universo maquinista com ajuda de imagens extraídas das vanguardas artísticas" (GRACIA, 1992, p. 127).

Configura-se então um segundo campo tipológico significativo para a arquitetura e próprio do movimento moderno, que se valia do modo de produção industrial e da natureza mecânica dos objetos produzidos em série como referências analógicas para as edificações. Pilotis, estrutura independente, fachadas e plantas livres são alguns exemplos de padrões sugeridos por Le Corbusier, presentes em sua obra e posteriormente convertidos em tipos.

A nova tipologia proposta pelos arquitetos modernos, assim como o caráter de obra de arte original e universal impresso no objeto arquitetônico, estava intimamente vinculada a um novo padrão urbanístico proposto por Le Corbusier, baseado no edifício autônomo, liberado dos limites impostos pela estrutura fundiária da cidade tradicional.

Como aponta Huet, após a Segunda Guerra Mundial a urgência de uma política de reconstrução para as cidades destruídas vinha ao encontro das idéias propostas por Le Corbusier: a construção maciça de habitações, a forte intervenção do Estado, a utilização da indústria fundada pela ação do Estado e a gestão urbana eficaz e simplificada pela própria ordem de composição, repetida e mecanizada (HUET, apud BARONE, 2002, p. $46)^{14}$. O urbanismo funcionalista foi então adotado como solução genérica nas periferias das cidades arrasadas pela guerra alcançando resultados significativos.
13. Neste trecho Montaner cita a ideia de cidade racionalista de Ernst May.

14. HUET, B. A cidade como espaço habitável, em $A U n^{\circ}$ 9. Dez./Jan. de 1986/7. 


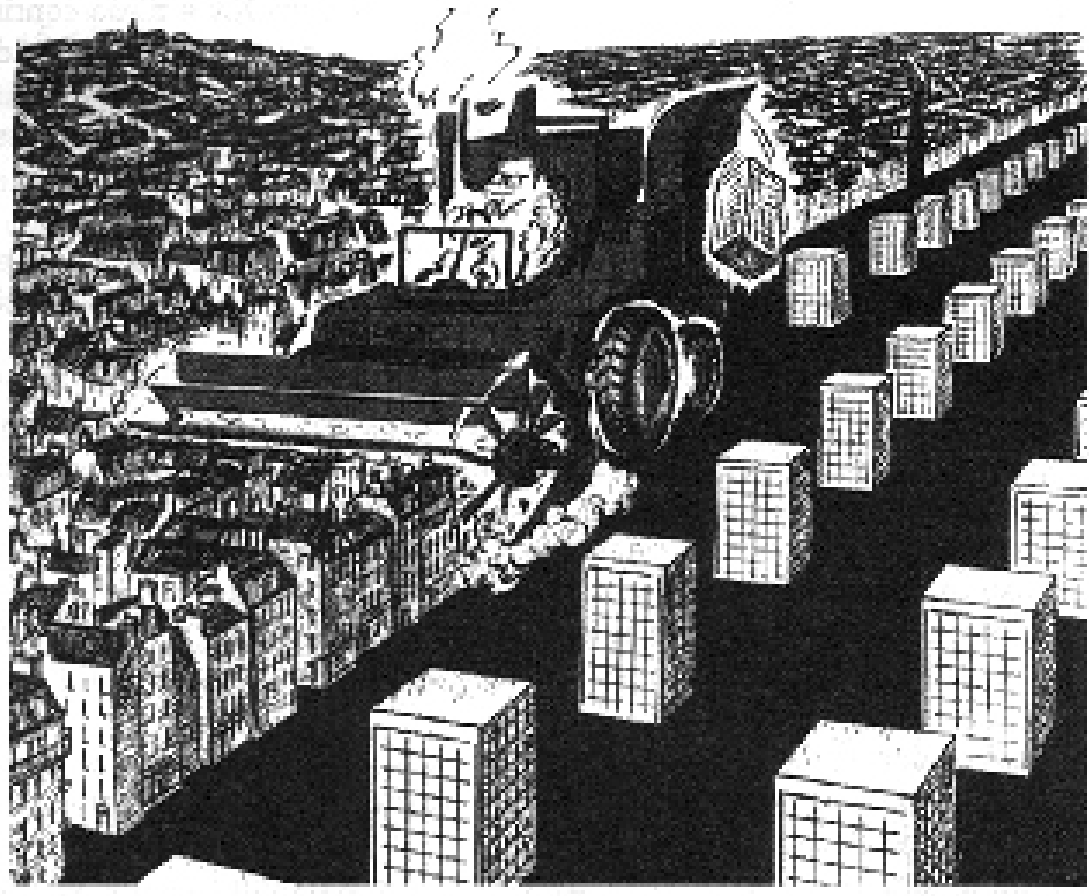

Figura 1.1 - Cartum de J. F. Batellier em "Sans retourn ni consigne" criticando a destruição modernista do antigo tecido urbano. (apud HARVEY, 2006, p. 28)
Mediante a contínua construção de edificações que obedeciam aos preceitos da tipologia modernista, o tecido urbano da cidade tradicional foi sistematicamente sendo destruído e novas tipologias urbanas foram incorporadas ao elenco histórico, como é o caso da quadra ou super-quadra.

"No caso da quadra ou super-quadra livre deveríamos falar inclusive em arquétipo, ao multiplicar-se em vários tipos reconhecidos e dada a sua importância na radical transformação da forma urbana. Neste sentido a super-quadra podia ser designada também como tipo de tipos" (GRACIA, 1992, p. 128).

É neste contexto de radical transformação da forma urbana e destruição dos tecidos das cidades tradicionais que começam a aparecer pensamentos críticos às propostas do movimento moderno, em especial às tipologias dos tecidos urbanos ditos funcionais.
15. Para um aprofundamento das questões do Team 10 ver BARONE, 2002.

\section{4 - A CRÍTICA AO FUNCIONALISMO MODERNO E A FORMAÇÃO DO TEAM 10.}

Na retomada dos trabalhos do CIAM após a Segunda Guerra a liderança de Le Corbusier continua a prevalecer, assim como a tendência de analisar os problemas das cidades segundo o modelo da segregação funcional e de promulgar modelos universais para a arquitetura e urbanismo modernos. A experiência da reconstrução das cidades européias no pós-guerra e a redução das questões do movimento moderno a uma visão universal e estritamente funcionalista acabou servindo de alavanca para o seu questionamento a partir da década de 50. É nesta década que uma nova geração de arquitetos passa a freqüentar as reuniões do CIAM, colocando uma série de questionamentos e interferindo no rumo das discussões. As suas principais críticas eram dirigidas ao modelo universal, dogmático do urbanismo funcionalista proposto pela Carta de Atenas, que para eles se tratava de uma concepção abstrata, pouco condizente com as necessidades humanas essenciais. Este grupo de jovens arquitetos ficou conhecido posteriormente como o Team $10 .{ }^{15}$

A origem do grupo foi marcada pela necessidade dos arquitetos da nova geração de discutir a humanização dos espaços produzidos pela arquitetura moderna a partir da crítica ao funcionalismo proposto pelo CIAM. Não se tratava de negligenciar as efetivas conquistas sociais da geração anterior, mas de incorporar na produção da arquitetura moderna a questão das inter-relações humanas no espaço construído.

Para esta nova geração, as inter-relações humanas, tão necessárias no processo de apropriação do espaço, eram desconsideradas no modelo monumental proposto por Le Corbusier, que anulava as dimensões individuais dos habitantes do espaço e suas necessi- 
dades de expressão. "O urbanismo considerado e desenvolvido nos termos da Carta de Atenas tende a produzir cidades nas quais a associação humana vital é expressada inadequadamente", afirmou Peter Smithsom (apud BARONE, 2002, p. 58) ${ }^{16}$. Na sua maneira de entender era preciso introduzir nas discussões da arquitetura moderna as peculiaridades de cada sociedade a fim de se criar espaços com identidade própria.

O novo grupo passa a questionar a validade dos princípios universais do urbanismo funcionalista através da noção de que o ser humano se organiza em comunidades e se identifica com o local onde habita a partir dos seus próprios valores culturais. Para eles, não era mais possível pensar a cidade segundo a segregação funcional proposta pela Carta de Atenas. A redução da cidade a um mecanismo composto por quatro funções básicas não se mostrava uma maneira eficiente de abranger toda a complexidade inerente às questões do urbanismo.

Os jovens arquitetos pretendiam substituir a segregação funcional da cidade moderna por uma visão mais orgânica, que contemplasse a noção de comunidade como base para o processo de organização do espaço. Esta visão orgânica, rechaçada pela geração anterior, foi retomada pelo grupo mais jovem e considerada como essencial para criar as relações humanas no espaço. Ela tratava a cidade a partir de uma visão que considerava uma divisão por escalas em oposição à divisão por funções proposta pelo urbanismo moderno.

"Nesse sentido, a casa era uma primeira unidade de associação. A segunda não era a quadra, [...] mas a rua, ou o espaço entre as formas construidas, que organizaria esta segunda escala de vida urbana a partir das relações entra os moradores e o espaço. A terceira escala de aproximação, o bairro, era uma escala intermediária entre a arquitetura e o urbanismo, e guardava a proporção territorial das comunidades urbanas." (BARONE, 2002, p. 70)

Entre as escalas da casa e da cidade, havia a noção da rua e do bairro como organizadores do espaço urbano, preenchendo o que os arquitetos da nova geração consideravam um vazio deixado pelo movimento moderno na relação entre a arquitetura e o urbanismo.

A eleição da rua e do bairro como organizadores das relações humanas no espaço urbano recolocava na pauta de discussões do CIAM questões que foram negligenciadas pelos arquitetos da geração anterior, como a cidade existente e sua tipologia, configuradas através de processos históricos e com relevantes significados para a memória urbana.

Havia nesse sentido uma ruptura com os preceitos universais do movimento moderno. Os arquitetos da nova geração buscavam estabelecer uma nova relação entre a arquitetura e o urbanismo através de uma linguagem arquitetônica ancorada em referências tipológicas retiradas da cidade existente. Com a intenção de dar continuidade ao tecido urbano das cidades e incorporar padrões culturais da população, estes arquitetos buscavam por formas que dialogassem com o entorno pré-existente através do uso de gabaritos adequados, do desenho do edifício no lote e a adaptação da arquitetura às condições locais. A incorporação da variedade cultural das comunidades servidas era uma alternativa apresentada pelos futuros membros do Team 10 ao rigor de base abstrata e à repetição de padrões pré-estabelecidos propostos pela doutrina funcionalista.

O Team 10 se consolidou como um grupo intelectual a partir de 1954 quando este time de jovens arquitetos fica responsável pela organização do $10^{\circ}$ e último CIAM $^{17}$. A ori-
16. SMITHSON, Peter. Statement on habtat, Doorn, 1954.
17. Foi por organizar o $10^{\circ}$ congresso que o grupo passou a ser conhecido com o Team 10. 
18. Banham, Reyner. Magaestructuras: futuro urbano del passado reciente. Barcelona. Gustavo Gili, 1978 gem do grupo não foi marcada pelas afinidades entre os seus membros ou identidade de conteúdo entre suas propostas de trabalho. Ao contrário, foi a crença na impossibilidade de uma tendência única universal que uniu os jovens arquitetos e os levou a intervir no processo de discussão encaminhado pela geração anterior dentro do CIAM.

Apesar da extinção dos congressos, as atividades do Team 10 se prolongaram por trinta anos, entre 1954 e 1984. Duas características fundamentais acompanham a sua trajetória: a necessidade de humanização dos espaços produzidos pela arquitetura moderna e a garantia de pluralidade de visões entre seus membros.

Na sua análise das atividades do Team 10 ao longo dos trinta anos de sua existência, Barone (2002) distingue três momentos: o primeiro, de 1954 a 1959, quando as atividades do grupo ainda estavam vinculadas à sua participação nos CIAM; o segundo, de 1959 a 1962, período de afirmação das principais atividades do grupo; e o terceiro momento, de 1962 a 1984, quando se apresentam três vertentes distintas de posicionamento dos seus membros em relação à arquitetura.

As discussões que caracterizam a primeira fase do grupo, ainda associadas às atividades dos CIAM, são focadas na critica aos preceitos universais da arquitetura e do urbanismo modernos. A critica ao funcionalismo da Carta de Atenas foi fundamental para a consolidação do Team 10 como um grupo de jovens arquitetos que desafiava os mestres a admitir uma nova responsabilidade social a partir da discussão das relações humanas criadas através do espaço construído. A humanização do espaço urbano se tornava uma referência fundamental para a nova geração que via nesta idéia a possibilidade de superação da rigidez formal do urbanismo funcionalista.

Na segunda fase do grupo, ainda segundo Barone, o Team 10 pretendeu se afirmar pelas diferenças que caracterizavam os trabalhos de seus membros. Para identificar essas diferenças o grupo passou a organizar reuniões onde os participantes puderam apresentar seus trabalhos mais relevantes. O critério de relevância era o significado da arquitetura enquanto instrumento de ação sobre a sociedade. Através dessas apresentações foi possível verificar as diferentes posturas de projetos de cada um, indicando a viabilidade das múltiplas interpretações das noções fundamentais da arquitetura moderna.

Finalmente, na terceira fase de discussões do grupo, as diferentes posturas de projeto apresentadas por seu membros se consolidam em três vertentes principais. Uma vertente configurou-se como continuidade na crença corbusiana na elaboração de modelos formais arquitetônicos para a resolução dos problemas sociais. Essa vertente foi liderada pelo casal inglês Peter e Alison Smithson. Um tema recorrente em seus trabalhos era o uso de megaestruturas. Barone cita Reyner Banham para dizer que "as megaestruturas não eram apenas estruturas de grande porte, tinham uma característica diferencial: reuniam todas as funções urbanas em um único edifício, de dimensões monumentais, recriando em seu interior um substituto para a própria cidade" (BANHAN, apud BARO$\mathrm{NE}, 2002$, p. 93 $)^{18}$. As megaestruturas forma criticadas por serem completamente alheias à realidade urbana e, portanto, desarticuladoras da malha da cidade.

A segunda vertente desenvolveu critérios próprios para a concepção da forma e foi denominada de estruturalista. Sua principal liderança foram os holandeses Aldo van Eyck e Jacob Bakena. Em seus trabalhos a forma quadrada foi largamente utilizada como 
solução de planta. A planta estrutural coincide com uma retícula quadrada que abriga os ambientes. O resultado é uma estrutura geométrica que permite várias possibilidades. A retícula se expande em algumas direções e retrai em outras, formando espaços abertos e fechados, possibilitando uma nova relação entre interior e exterior. Barone cita como exemplo o projeto do Orfanato de Amsterdan, de van Eyck, "onde toda a arquitetura se compõe de círculos e quadrados que se abrem e fecham para construir a espacialidade da transição entre dentro e fora" (BARONE, 2002, p. 123).

A terceira vertente se afirmou pela valorização das tradições locais, através do uso de referências formais e do respeito às questões culturais locais. Essa vertente, que procurava compatibilizar o uso de elementos tipológicos retirados da arquitetura tradicional a uma linguagem e um modo de produção modernos, foi representada principalmente pelos italianos Ernesto Rogers e Giancarlo De Carlo. Rogers se colocava como partidário do resgate da linguagem formal tradicional característica de períodos anteriores ao movimento moderno como premissa para que novos projetos se inserissem nos contextos culturais onde eram construídos. Para ele a atitude de caráter anti-histórico da geração anterior era inaceitável. Rogers apresenta o projeto da Torre de Velasca feito pelo escritório BBPR ${ }^{19}$ : um edifício de escritórios no centro da cidade de Milão, construído com tecnologias modernas, mas que resgata uma linguagem tipológica medieval. Neste edifício, Rogers afirma o valor do regionalismo cultural, recorrendo às possibilidades tipológicas da memória arquitetônica italiana, sem abrir mão dos dispositivos tecnológicos modernos que se colocam a serviço da idéia formal. Para ele era indispensável a consideração das "preexistências ambientais", estruturas monumentais construídas ao longo da história e presentes principalmente no cenário urbano italiano, que impunham limites às intervenções arquitetônicas modernas em determinados entornos.

A posição defendida por Rogers gerou muita polêmica pois era tida como reacionária por boa parte do Team 10. A crítica incidia sobre o retorno a linguagens tipológicas do período pré-moderno interpretada por muitos como um retrocesso e acabou culminando na sua retirada do grupo. As idéias de Rogers, no entanto, repercutiram na produção arquitetônica

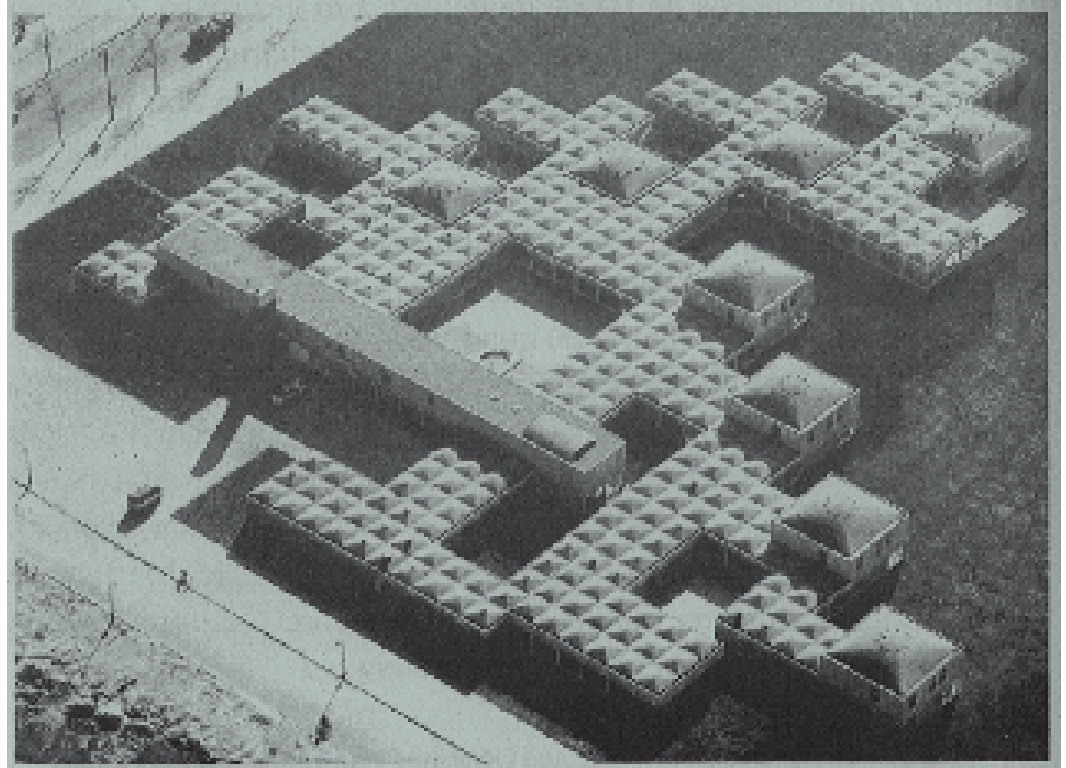

Figura 1.2 - Orfanato de Amsterdan. (Fonte: BARONE, 2002, p. 122)

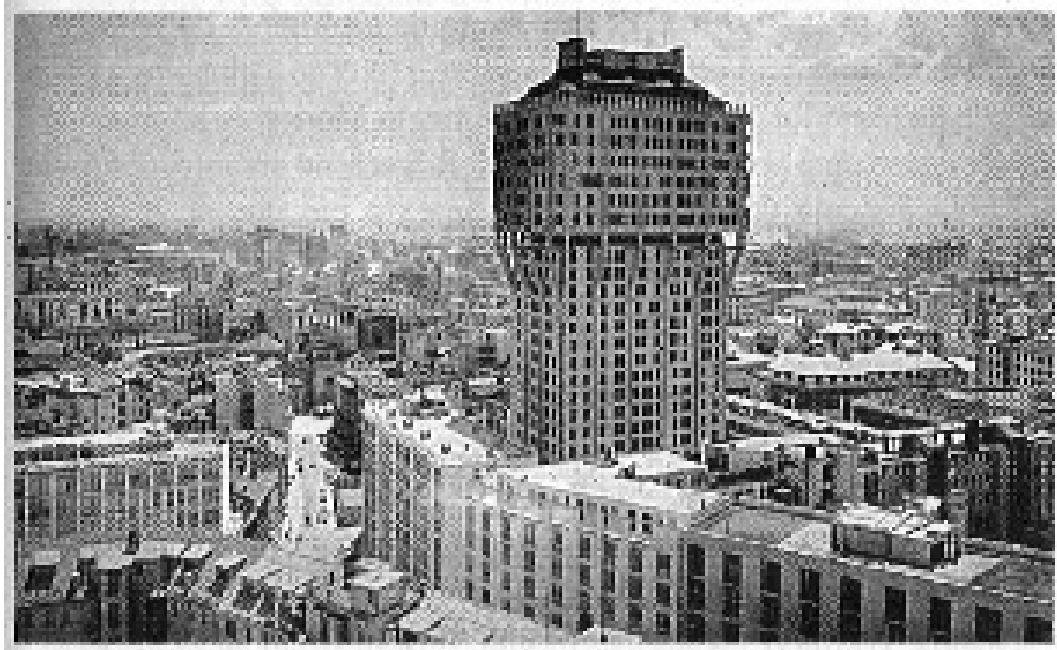

Figura 1.3 - Torre de Velasca. (Fonte: BARONE, 2002, p. 89) 
20. Montaner se refere ao artigo El concepto de tradición en la arquitectura neoclásica de Milán. in Rossi, Aldo, Para una arquitectura de tendência. Escritos: 1956 - 1972, Editorial Gustavo Gili SA, Barcelona, 1977.

21.Fazem parte deste movimento também conhecido como "la tendenza" os discípulos de Ernesto Rogers: Aldo Rossi, Carlo Aymonino, Manfredo Tafuri, Giorgio Grassi, Guido Canella Vittorio Gregotti, Gae Aulenti, Marco Zanusso, Luciano Semerani e Giancarlo De Carlo.

22. In ARGAN, Giulio Carlo, Projeto e destino. Editora Ática, SP, 2001

23. AYMONINO, Carlo. Entrevista publicada em Revista $2 \mathrm{C}$ - Construcción de la ciudad n ${ }^{0} 1$ Fevereiro de 1975. desse período, principalmente em paises onde a presença cultural da arquitetura é de primeira ordem, como a Itália. Muitos arquitetos optaram por incorporar referências tipológicas da arquitetura histórica em linguagens e tecnologias modernas de construção.

\section{5 - 0 NEO-RACIONALISMO ITALIANO E A TERCEIRA TIPOLOGIA}

A mudança de visão em relação à cidade decorrente de um pensamento crítico ao novo urbanismo propagado pelo movimento moderno deve ser entendido dentro de um contexto em que, após a tragédia da Segunda Guerra Mundial, a Europa passava por um esforço de reconstrução e reformulação de sua arquitetura. A cidade, como um bem histórico e cultural, se torna algo enfermo que deve ser cuidadosamente reconstruído. Em 1956 Aldo Rossi publica um artigo em que desenvolve um conceito transmitido pelo seu mestre, Ernesto Rogers, que está relacionado com a história e a memória. Trata-se do conceito de tradição, "que deve ser entendido como uma ordem a partir da qual podemos alcançar uma outra, mais ampla e nova, por meio da critica racional" (MONTANER, 2001, p. 139 $)^{20}$.

As discussões sobre a questão tipológica voltaram então à cena arquitetônica e vão encontrar a sua máxima expressão no início da década de sessenta no movimento neo-racionalista italiano ${ }^{21}$. Trata-se de uma nova geração de pensadores e arquitetos que entende a arquitetura como um processo de conhecimento e, portanto, volta a considerar a crítica e a história da arquitetura como instrumentos de projeto. Um fato decisivo para a retomada da questão tipológica foi a publicação, em 1962, de um artigo de Giulio Carlo Argan denominado Sobre o conceito de tipologia arquitetônica ${ }^{22}$, que divulgara a definição de tipo dada por Quatremère de Quincy em seu Dicionário de Arquitetura.

"Não cabe a menor dúvida [de] que esta contribuição de Argan, entre outras, explicaria a aparição na Itália de um livro como 'A arquitetura da cidade.' Como se sabe, Rossi manifestou um claro interesse por Quatremère de Quincy, um tratadista que segue fundamentando a arquitetura ao princípio da mimesi durante a primeira metade do séc. XIX, e cuja abordagem serve de base para toda a teoria analógica contida na 'tendenza' italiana" (GRACIA, 1992, p. 125).

Segundo Montaner, A arquitetura da cidade, de Aldo Rossi, é "um dos livros mais influentes da arquitetura do século XX. Um texto que alcança um papel representativo similar aos dos tratados da época clássica. [...] Seu propósito é entender a arquitetura em relação à cidade, sua gestão política, memória, diretrizes, traçado e estrutura da propriedade urbana" (MONTANER, 2001, p. 139).

A grande influência desta obra de Rossi cria uma atmosfera cultural favorável a valorizar o lugar como único, e a vincular a arquitetura ao lugar, "estabelecendo limites à transformação que toda a intervenção arquitetônica supõe" (GRACIA, 1992, p. 128). Ao reformular o conceito de tipo, Rossi atribui extrema importância ao tecido urbano da cidade que passa a ser o novo princípio estruturador da tipologia. Cada tipologia arquitetônica deve estar relacionada à morfologia urbana, e o que interessa é como se estabelece uma correspondência entre os tipos edificados e as formas características da cidade em que são construídos. Carlo Aymonino defende que "a arquitetura deve ser referida à história da cidade e não à história da arte" (AYMONINO, apud GRACIA, 1992, p. 128). ${ }^{23}$ 
Desta forma, nos anos sessenta configura-se uma nova maneira de entender a arquitetura, o que Anthony Vidler chama de "A terceira tipologia":

"Poderíamos caracterizar o atributo fundamental dessa terceira tipologia como a adoção, não de uma idéia abstrata, nem de uma utopia tecnológica, mas da cidade tradicional como seu foco de interesse. É a cidade que lhe oferece material para a classificação, e as formas dos seus artefatos é que lhes fornecem as bases de sua reorganização" (VIDLER, 2006, p. 285).

Esta concepção da cidade como referência para uma nova tipologia é, de fato, uma críitica explícita à fragmentação, descentralização e desintegração formal do tecido urbano da cidade geradas pelas tipologias do movimento moderno.

"Se o inferno do movimento moderno eram os bairros fechados, superlotados e insalubres das velhas cidades industriais e o Paraíso eram os enormes espaços iluminados pelo sol e repletos de áreas verdes [...], em sua critica ao urbanismo moderno, a nova tipologia eleva ao nível de princípio o tecido contínuo da cidade, a nítida distinção entre o público e o privado delimitada pelos muros [que formam] a rua e a praça. Seu pesadelo é o edifício isolado construído no meio de um parque indiferenciado" (VIDLER, 2006, p. 288).

Outra dura crítica à arquitetura moderna presente no trabalho de Rossi é o que ele chamava de "funcionalismo ingênuo". Para Rossi as formas não são resultado direto de suas funções, vão muito além das estritas funções.

"Sempre afirmo que os lugares são mais fortes que as pessoas; o cenário, mais forte que o acontecimento. Esta possibilidade de permanência é o único elemento que faz a paisagem ou as coisas construídas superiores às pessoas" (ROSSI, apud MONTANER, 2001, p. 139).24

A experiência acumulada da cidade permite compreender uma tipologia que desafia a relação existente entre a forma e a função e demonstrar que não existe uma relação unívoca e linear entre elas. As várias décadas de reutilização de edifícios históricos demonstraram que a forma é mais forte que qualquer atribuição de usos.

"Além do sinalizado por Aldo Rossi, é destacável o fato de que a arquitetura das últimas décadas se distinguiu por sua capacidade de reconverter a velha arquitetura para novos usos. Uma das imagens mais genuínas da situação pós-moderna da arquitetura é a dos contrastes formais que gera esta mudança de uso: estações convertidas em museus, palácios reabilitados como sede de administrações públicas, igrejas convertidas em escritórios, museus ou discotecas" (MONTANER, 2001, p. 140).

A permanência da forma do edifício em relação a sua função, ou o fato de uma mesma forma ser compatível com diferentes funções, reforça a teoria de Rossi de que a tipologia do edifício deve estar relacionada ao tecido urbano, elemento morfológico da cidade com grande capacidade de permanência.

A arquitetura européia das décadas de sessenta e setenta adotou, como referência para sua evolução, o retorno à sua própria história e tradições. Este retorno a certos valores próprios da cidade tradicional abriu caminho para uma valorização da caracterização tipológica dos edifícios antigos enquanto referência mais adequada para a construção lógica da própria cidade. A análise histórica e tipológica foi amplamente usada como instrumento de criação arquitetônica e, segundo Montaner, teve como conseqüência re-
24. ROSSI, Aldo, Autobiografia científica, Editorial Gustavo Gili S.A., Barcelona, 1984. 
sultados muito variados: "desde obras que conseguiram uma síntese atrativa e rigorosa entre tradição e inovação até obras nas quais o peso da linguagem histórica acabou sendo excessiva" (MONTANER, 2001, p. 149).

Montaner aponta dois caminhos para o uso deste mecanismo de retorno. O primeiro caminho busca na visão do passado a obtenção de critérios de ordem de composição e abstrações das formas clássicas, com a intenção de criar uma nova ordem compatível com as demandas da atualidade. Cita como exemplo a obra de Aldo Rossi, Giorgio Grassi entre outros arquitetos italianos. O segundo caminho não propõe a criação de uma nova ordem, mas busca na história modelos para a recriação de um ambiente urbano com atmosfera pré-industrial. Cita como exemplo a obra dos irmãos Rob e Leon Krier e Rita Wolf, além dos arquitetos da denominada Escola de Bruxelas, com suas propostas radicalmente anti-industriais.

Vidler critica este segundo caminho recusando a nostalgia de suas evocações históricas e rejeitando suas citações estilísticas. Para ele a vitalidade da terceira tipologia está no engajamento com as demandas do presente e não na mitificação do passado.

"Neste movimento, a cidade e a tipologia se reafirmam como as únicas bases possíveis para a restituição de um papel crítico a uma arquitetura que, de outra forma, acabaria sucumbindo ao ciclo aparentemente interminável de produção e consumo"(VIDLER, 2006, p. 289).

\section{6 - A NOVA ESCOLA FRANCESA}

Até meados dos anos 1960 o urbanismo francês moderno era sempre associado aos "esquemas diretores" e "planos de massa" que dava ao projeto urbano uma dimensão abstrata e imprecisa. Nesta época, caracterizada pelo desenvolvimento demográfico e econômico do pós-guerra, a produção de habitação social estava apoiada nos preceitos do "alojamento mínimo" promulgado pela Carta de Atenas. Sua falta de adequação às condições de vida e a má qualidade de suas execuções tornariam, vinte anos mais tarde, esses bairros em áreas urbanas degradadas, onde se materializam os mais diversos problemas sociais (PANERAI et alii, 1986).

A Ecole des Beaux-Arts se convertera em um lugar da mais absoluta inércia ideológica. A cidade, como objeto de trabalho dos arquitetos, era sistematicamente ignorada, tanto na esfera do ensino como na das práticas urbanísticas, e o problema da habitação social era relegado à expansões urbanas em áreas cada vez mais distantes. A falta de publicações, a ausência de debates e o desconhecimento das experiências e textos estrangeiros, são fatos que evidenciavam o vazio existente naquele ambiente acadêmico, no que se refere à reflexão teórica e a investigação.

Os estudos de morfologia urbana baseados nos temas de Henri Lefèbvre e na leitura dos textos, até então inéditos na França, de Saverio Muratori, Carlo Aymonino e Aldo Rossi, proporcionaram aos arquitetos Philippe Panerai e Jean Castex e ao sociólogo JeanCharles Depaule a oportunidade de repensar os preceitos da orientação funcionalista a luz de uma revalorização dos tecidos urbanos das cidades tradicionais. A valorização da morfologia da cidade histórica e suas tipologias forneceu outras bases para se pensar um urbanismo radicalmente diferente daquele proposto pela Carta de Atenas. "É importan- 
tíssimo que neste contexto tenha surgido uma paixão pelo reencontro com o medido e rigoroso, com a cidade articulada e fragmentária” (PANERAI, 1986, p. 9).

Nos anos de 1974 e 1975 Panerai desenvolve sua pesquisa da construção arquitetônica da cidade a partir de sua ordem cadastral e das constantes tipológicas que configuram seu tecido, e do interesse destes como peças que compõem o tecido urbano total.

Em 1980 Philippe Panerai escreve "Elementos de Análise Urbana”, onde adiantava uma concepção metodológica em que a noção de tecido urbano se tornava fundamental para as novas discussões sobre a cidade. Para Panerai a visão arquitetônica das cidades não deve limitar-se apenas aos seus momentos excepcionais - o monumento ou outras obras singulares - mas também aos valores estéticos, teóricos e culturais dos tecidos urbanos comuns edificados em sua generalidade, onde a vida das cidades tem uma expressão mais completa e onde as arquiteturas ordinárias se materializam com toda a sua riqueza, constituindo a forma permanente das várias partes da cidades.

Mas é em "Formas Urbanas: de la manzana al bloque", que, segundo Solà-Morales, Panerai defende a "arquitetura da cidade" como junção da arquitetura de todas as partes da cidade como "peças de um puzzle multifacetado cheias de significados parciais e referências quase universais" 25 .

O livro de Panerai, Castex e Depaule, ao analisar cinco exemplos de intervenções urbanísticas consideradas paradigmáticas, constitui um claro resumo da história do urbanismo do séc. XX. Os autores analisam o quarteirão fechado haussmanniano, as cidades jardins inglesas e os agrupamentos residenciais da expansão territorial holandesa como amostras de uma ordem edificatória totalmente vinculada à forma urbana - às ruas, aos lotes, às forma de uso. Em seguida analisa os bairros de Frankfurt e a Cité Radieuse como início da quadra aberta, dos edifícios isolados, independentes da divisão cadastral, cuja autonomia rompe com as referências formais da cidade e, em sua opinião, destrói a continuidade dos espaços urbanos elementares.

"Se tivesse que escolher uma palavra que qualificasse este estudo, a mais justa seria a 'agonia.' A agonia de uma organização espacial determinada: a quadra, característica das cidade clássica européia que o século XIX transforma e o XX extingue. Na quadra subentende toda uma concepção da cidade cuja evolução pretendemos delimitar" (PANERAI, 1986, p. 16).

Na verdade, o tema que preocupa Panerai é a dimensão física das cidades, a lógica dos espaços que constituem o tecido urbano no qual a quadra é um elemento determinante. Segundo Panerai a eleição da quadra se justifica por se tratar de um nível onde é possível avaliar especificamente a relação da arquitetura com a cidade, permitindo assim um questionamento sobre as alterações que tal relação tem experimentado.

Panerai apóia suas investigações sobre a cidade na hipótese de que o espaço físico constitui um campo de análise objetivo. Através da observação arquitetônica se pode alcançar um primeiro nível de significação; pelas diferenças ou semelhanças entre esses espaços se originarão outras análises posteriores: histórica, econômica e sociológica. Sua atenção se volta especialmente para a relação existente entre organização espacial e prática social, que considera prioritária. "Evidentemente, a cidade não é independente dos grupos sociais que a produzem, que nela vivem e que a transformam. (...) Henri Lefèbvre definia a cidade como a projeção, no solo, das relações sociais" (PANERAI, 2006, p. 14 a 16).
25. Manuel de Solà-Morales, no prefácio da edição espanhola de PANERAI, 1986, p. 10. 


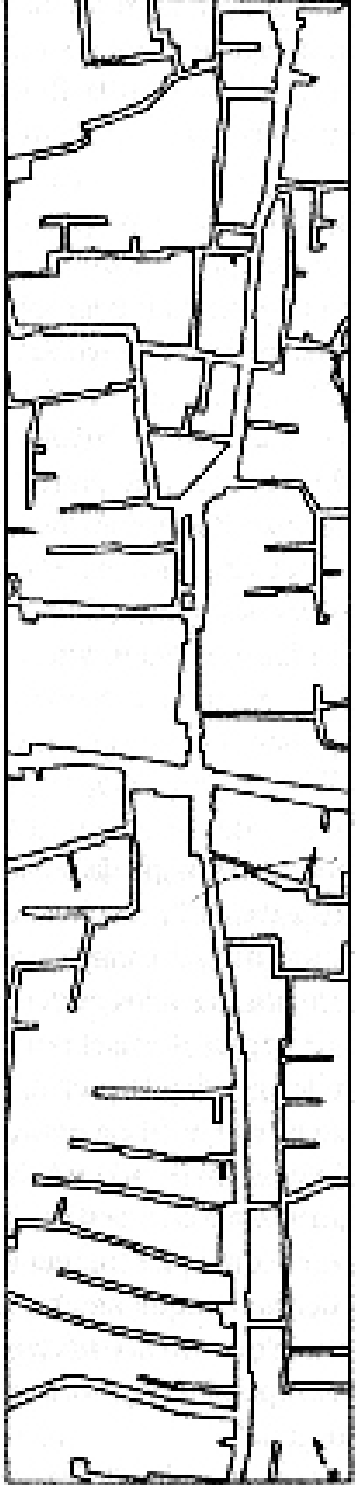

vias

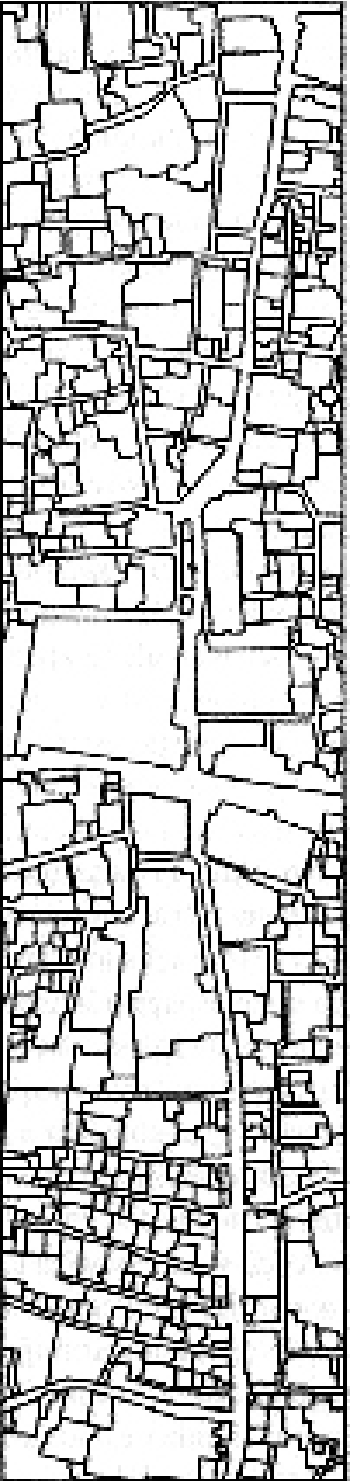

nartelas

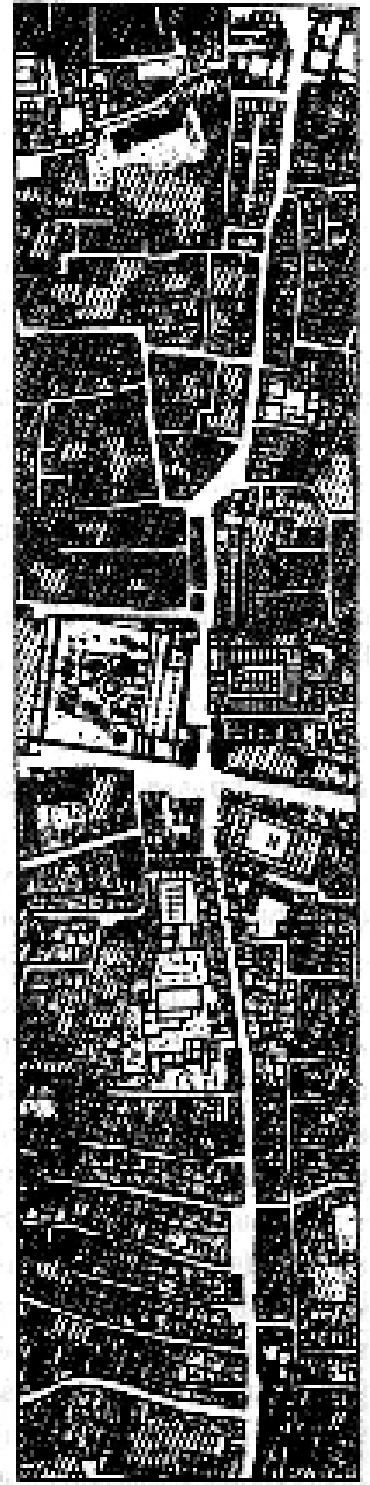

edilicuşc̄es
Figura 1.4 - Tecido urbano do centro antigo da cidade do Cairo. (Fonte: PANERAI, 2006, p. 80)
Segundo Panerai o tecido urbano é constituído pela superposição ou imbricação de três conjuntos: a rede de vias, os parcelamentos fundiários e as edificações. A relação rua/parcela é o fundamento para a existência do tecido urbano; à rua estão associados, de ambos os lados, os lotes. Esta relação também organiza a massa edificada: as edificações podem estar no alinhamento do lote ou recuadas, podem ser geminadas ou recuadas, altas ou baixas, mas têm sempre a rua como referência. A submissão do construído ao espaço público tem, entre outras conseqüências, uma relação de solidariedade entre os edifícios, mesmo quando estes pertencem a épocas ou tipos diferentes (PANERAI, 2006).

Para Solà-Morales, o reconhecimento arquitetônico dos tecidos urbanos e os valores de urbanidade que estes mostram quando a relação entre parcelamento e edificação se configura segundo espaços comuns bem definidos são armas teóricas contra os esquemas do urbanismo funcional e, mais diretamente, contra as propostas de Le Corbusier. Panerai se engaja em uma polêmica: "a denúncia veemente da ignorância do fenômeno urbano presente tanto no urbanismo funcionalista da tabula rasa como do mimetismo simplório das tendências mais contemporâneas" (PANERAI, 2006, p. 12).

Um primeiro objetivo, segundo Panerai, que poderia ser atribuido à análise urbana seria $o$ de contribuir para a compreensão da cidade contemporânea. Porém, para entender a cidade é necessário elaborar um corpo de conhecimento urbano em que se misturam a abordagem histórica, a geográfica, o trabalho cartográfico, a análise arquitetônica, a observação dos sistemas construtivos e dos modos de vida. "Conhecer a forma das cidades e reconstituir sua história é também orientar uma maneira de projetar” (PANERAI, 2006, p. 12).

A importância da pesquisa francesa está na investigação da gênese da forma urbana. Diferente do que propunha Rossi, não é o monumento que definirá o local, mas o parcelamento, o sistema de vias e as constantes tipológicas. 


\section{7- A ESCOLA CATALÃ}

Desde sua origem, em 1969, o Laboratório de Urbanismo da Escola de Arquitetura de Barcelona, na Universitat Politècnica de Catalunya, se propôs a elaborar elementos para uma metodologia, até então inexistente, de análise da forma urbana construída. Buscou-se um método racional de compreensão da forma urbana atento tanto às causas do crescimento urbano e seus conteúdos sócio-econômicos como às diferentes maneiras de produção da cidade e suas diferentes formas resultantes.

Solà-Morales considera que os fenômenos clássicos determinados pelas ciências sociais como origem de todo o processo de urbanização, baseados na cadeia conceitual da "industrialização - migração - urbanização", são insuficientes e por demais generalistas para a compreensão das diferentes formas de crescimento urbano. Em parte reconhece nestas teorias um valor específico; no entanto, se detém desde o princípio em descrições comparativas segundo os diferentes tipos de crescimento urbano. Sua colaboração para uma visão mais disciplinar do crescimento das cidades está no fato de colocar as políticas de fomento e planejamento, os eixos infra-estruturais e o mercado de solo como causas imediatas do crescimento urbano. Em suas palavras:

"um enfoque microeconômico do crescimento urbano (deveria se chamar microurbanístico, não pela escala dimensional, mas por analogia com as lógicas da teoria econômica) na qual todo fator globalizante aparece como estranho e excepcional, e onde a idéia do processo urbano se assimila muito ao funcionamento liberal-competitivo das diversas formas urbanas, em um tecido que resulta a posteriori uma imagem expressiva de sua lógica de formação" (Solá-Morales, 1997, p. 14).

Desta forma o estudo do crescimento urbano se faz através de uma análise das relações entre as diferentes formas de crescimento da cidade e as forças que constituem seu motor e conteúdo. Esta análise procura esclarecer o conteúdo social das diferentes tipologias presentes na malha urbana.

Os elementos da teoria de Solà-Morales, que denomina de unidades de forma, são a infra-estrutura e os traçados, o parcelamento do solo e os tipos de edificações. Sobre estes vão atuar, ao longo do tempo, diferentes mecanismos de construção, uso e transformação, através da ação voluntária dos diferentes promotores ou proprietários. Em síntese, o autor propõe um estudo das formas de crescimento urbano como expressão de diferentes formas de gestão e ocupação do solo, ou seja, seu parcelamento, urbanização e edificação.

Nesta perspectiva, as diferentes maneiras de organizar o traçado das ruas, a divisão dos lotes e construção dos edifícios (infra-estrutura, parcelamento e tipos) são formas de urbanização, parcelamento e edificação que, através de diferentes combinações, dão lugar a diferentes formas urbanas. Entender a variedade da forma urbana significa entender a cidade como "resultado de idéias e projetos sobre a forma da urbanização somado à forma do parcelamento somado à forma da edificação, cada uma delas resultantes de idéias e projetos próprios, com ritmos de execução diferentes, com momentos de origem diferentes e âmbitos de escala também diferentes" (Solà-Morales, 1997, p.15). Para SolàMorales a decomposição conceitual da forma em três níveis superpostos - urbanização, parcelamento e edificação - diferentes entre si, com lógicas próprias, diferentes condi- 
cionantes sociais e históricos (projetados às vezes conjuntamente, mas as vezes com total independência), é um passo analítico que nos abre um importante canal para a compreensão de todas as formas urbanas presentes nas cidades.

"O projeto urbanístico é (...) [elaborado] para dar forma a um processo físico (...), que combina solo, edificação e infra-estrutura. (...) A construção da cidade é parcelamento + urbanização + edificação. Mas estas três operações não são atos simultâneos, nem encadeados sempre de igual maneira. Ao contrário, de suas múltiplas formas de combinar-se no tempo e no espaço originase a riqueza morfológica das cidades" (Solá-Morales, 1997, p. 19).

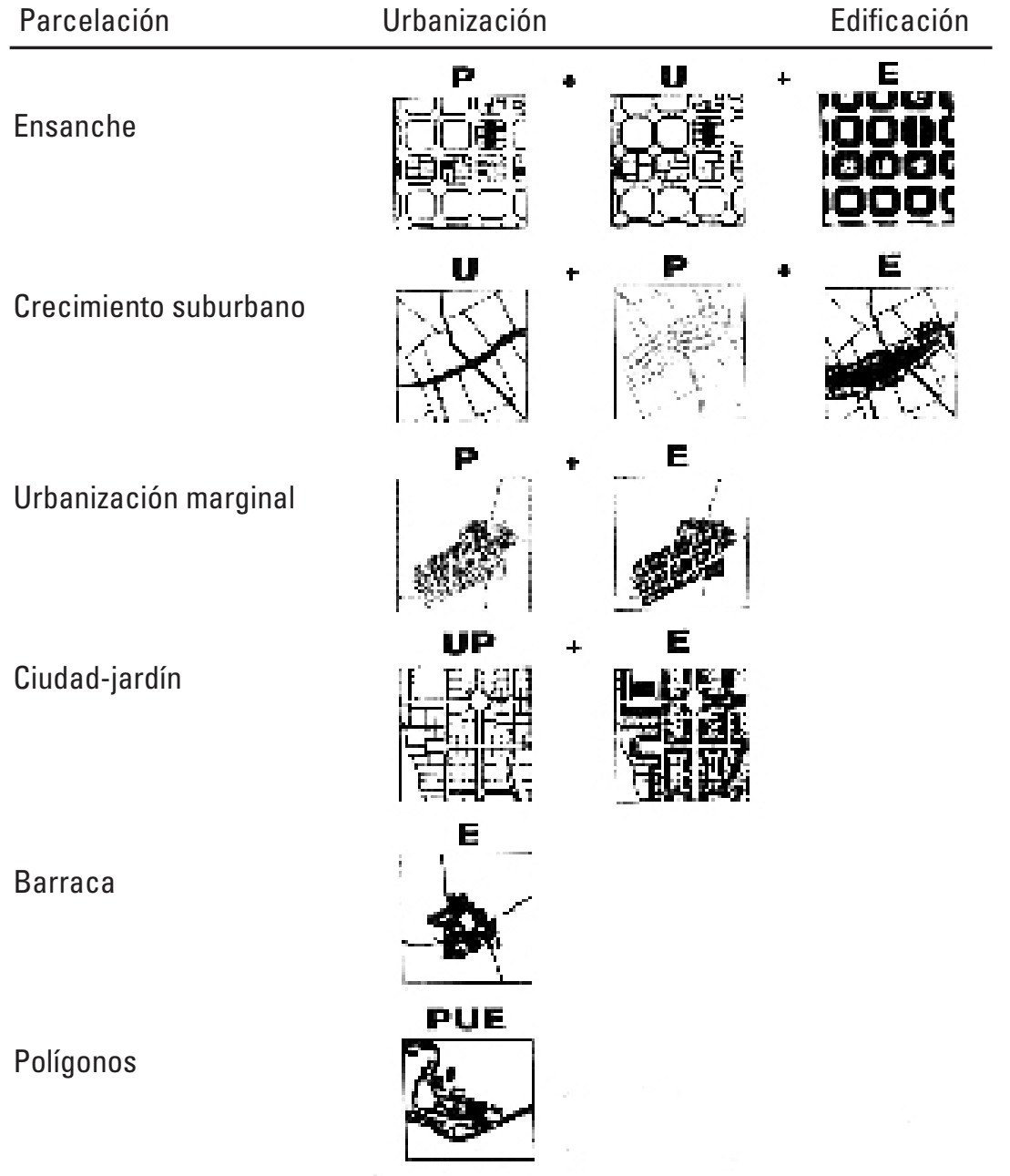

Figura 1.5 - As formas de parcelamento, urbanização e edificação. (Fonte: SOLÁ MORALES, 1997, p. 21)
Solà-Morales analisa, através desta metodologia, seis tipologias diferentes de crescimento urbano em Barcelona que considera como paradigmas. São elas:

a) $\mathrm{O}$ crescimento horizontal da cidade, a partir do núcleo histórico, com traçado viário predefinidos pelo Plano de "Ensanches" de Ildefonso Cerdá;

b) O crescimento suburbano que ocorre próximo a linhas infra-estruturais regionais;

c) A urbanização marginal, a partir de loteamentos clandestinos;

d) Os loteamentos suburbanos regulares , baseados na tipologia das cidades jardins;

e) As "Barracas", ou favelas, onde não existe urbanização nem parcelamento, apenas as edificações;

f) Os "Polígonos", ou conjuntos habitacionais, construídos em sua maioria pelo poder público para as classes de menor renda.

Para Solà-Morales, Cerdá, quando projeta os Ensanches de Barcelona, tem muito claro para si os tempos e os atores da cena urbanística. A retícula de infra-estrutura projetada para a cidade estabelece a forma do assentamento, e seu processo de urbanização é marcado pelo ritmo dos investimentos públicos. Após o momento da urbanização entra em cena um segundo momento: o de parcelamento interno dos quarteirões em lotes, encadeado por um ritmo mais lento, com regularidades menos freqüentes. Ao contrário da urbanização, o parcelamento dos ensanches, ainda que intimamente ligado ao traçado, não obedece a um único projeto; é feito por iniciativa de diferentes proprietários ou promotores imobiliários em diferentes momentos. Urbanização e parcelamento 
tiveram momentos e ritmos distintos, "mas o projeto de Cerdá os tinha igualmente bem incorporados: o primeiro em sua determinação absoluta, o segundo em sua gama de possíveis variações" (SOLÁ-MORALES, 1997, p. 20).

A edificação dos ensanches acontece então em um terceiro momento, muito mais difuso e variável, com uma diversidade de promotores, arquitetos, ordenanças e tecnologias que, para Solà-Morales, é especialmente enriquecedora. Para ele, a beleza do resultado está no desenho do traçado proposto por Cerdá.

Da mesma forma, nas "cidades jardins" o traçado é o responsável pela imagem que expressará a organização do solo. Para Solà-Morales, quando Unwin projeta Hampstead, tem na cabeça um encadeamento de formas baseado no traçado viário e na divisão do solo em lotes. A idéia inicial é fixa, e a diversidade das formas surge no momento posterior de edificação urbana. A forma urbana foi pensada para desenvolver-se a partir de um ato primário de implantação, que é o momento único do parcelamento e urbanização inicial. O momento posterior, de edificação, é muito mais aberto e fragmentado, executado por múltiplos promotores e diferentes desenhos. Desta forma fica claro que tanto nos ensanches como nas cidades jardins, a força figurativa dos projetos se situa no momento do processo em que as decisões estão mais concentradas, o momento inicial e mais permanente: o traçado.

Solà-Morales, considera que o traçado deve ser usado como instrumento de projeto capaz de ordenar as diferentes construções futuras sem mover sua forma fixada inicialmente. Para Lamas o traçado é um dos elementos mais claramente identificáveis na forma de uma cidade; ele estabelece a relação mais direta entre a cidade e o território, e seu caráter de permanência lhe permite resistir às transformações urbanas que ocorrem ao longo do tempo (LAMAS, 1999, p. 100).

O tempo, além do espaço, se torna um elemento fundamental na concepção urbanística. A combinação, ao longo do tempo, das diferentes operações sobre o solo tem como resultado algo que é a expressão de um processo encadeado em que as formas e os momentos construtivos se sucedem com ritmos próprios - um processo temporal materializado em formas estáticas.

Solà-Morales considera que a relação "morfologia urbana x tipo edificado" proposta pelos italianos e franceses para analisar a arquitetura das cidades, é insuficiente por desconsiderar o fator tempo.

"Por isso a relação morfologia-tipo colaborou pouco para o projeto urbano. Favoreceu os mimetismos, os arqueologismos. Legitimou até o abuso as reconstruções e as recuperações. A força de suas sugerências atua quase sempre no sentido do retrocesso. E para a cidade contemporânea não pode proporcionar mais que o desprezo (ou um ressentimento entre a ignorância e a nostalgia)." (Solá-Morales, 1997, p. 19)

A contribuição da escola catalã está na abertura da análise urbana a um campo mais amplo que a estrita observação tipológica proposta pela tendenza italiana e ratificada pela escola francesa, onde o conceito de tipologias descritivas é superado pelo de tipologias estruturais, ou seja, onde a compreensão do processo de crescimento das cidades, com atenção especial à lógica de suas formas físicas, é objeto e tema do planejamento urbano. 
26. REIS FILHO, Nestor Goulart; Quadro da Arquitetura no Brasil. São Paulo. Editora

Perspectiva, 1970. Apud ANTONUCCI, 2005, p. 89

\section{8- A CONTRIBUIÇÃO BRASILEIRA}

Os estudos de tipologias arquitetônicas, assim como a análise urbana pelo método tipológico, nunca foram muito difundidos no Brasil. Denise Antonucci (2005) considera duas hipóteses que colaboraram para este fato. A primeira hipótese aponta para o fato das discussões sobre tipologia terem voltado à cena arquitetônica européia como parte de um questionamento teórico que combatia o urbanismo funcionalista proposta pelo movimento moderno, e ter seu auge nas décadas de 60 e 70. Nesta época o Brasil vivia um encantamento com o projeto de Lúcio Costa para Brasília, síntese dos princípios promulgados pela Carta de Atenas, defendidos por Le Corbusier. A segunda hipótese seria o estreito vínculo dos estudos tipológicos aos movimentos de preservação do patrimônio histórico, arquitetônico e urbanístico, muito presentes nos paises europeus e pouco referenciados no Brasil.

Antonucci cita como sendo pioneiro o trabalho desenvolvido pelo professor Nestor Goulart Reis Filho, que analisa a evolução da tipologia residencial no Brasil, desde o Império até a década de $1940^{26}$. Suas pesquisas relacionavam a arquitetura com as estruturas urbanas e com a evolução social e cultural brasileira. A primeira série de seus estudos tratava da inserção da edificação no lote urbano, procurando sempre destacar a interdependência entre a arquitetura e as estruturas urbanas.

Cândido Malta Campos Filho cita como outra importante contribuição o trabalho do arquiteto e antropólogo carioca Carlos Nelson Ferreira dos Santos. Ferreira dos Santos realizou um levantamento do uso público e comunitário da rua no bairro do Catumbi, no início da zona norte do Rio de Janeiro, ao lado do túnel e viaduto Rebouças, que veio a cortar e transformar o bairro. Seu estudo mostra como uma reurbanização afeta e transforma um modo de vida urbana tipicamente brasileiro, carioca e popular, em que a rua vira extensão das casas e do comércio que a envolvem. Segundo Campos Filho a seriedade científica do seu estudo ainda o qualifica como um dos melhores trabalhos para entendermos que as ruas não foram feitas apenas para circular, e que a disputa da circulação de veículos com os demais usos vai destruindo essas importantes dimensões sociais de convívio urbano, próprias de uma cidade de qualidade. (CAMPOS FILHO, 2004b)

No entanto, é o trabalho de Campos Filho que dá o maior impulso nesta área de conhecimento no Brasil. Buscando bases teóricas para o desenvolvimento do planejamento urbano, Campos Filho fez um levantamento da problemática social na produção das tipologias dos tecidos urbanos das cidades nas sociedades capitalistas. Procurou desenvolver uma teoria que esclarecesse a produção de mais-valia urbana através da implementação de infra-estrutura e serviços públicos e de empreendimentos imobiliários e que também apontasse como alguns se apropriam desta mais-valia coletiva por meio da propriedade do solo, o que considera especulação imobiliária. Sua teoria forneceu explicações para compreendermos os dois principais mecanismos especulativos imobiliários presentes nas cidades brasileiras: a retenção de terrenos vazios à espera de valorização, encarecendo a implementação da infra-estrutura e de serviços urbanos, e a exagerada verticalização que congestiona uma infra-estrutura pré-existente exigindo sua ampliação paga com dinheiro público e que irá valorizar os imóveis de poucos proprietários.

Em seu primeiro livro, "Cidades Brasileiras: seu controle ou o caos", com primeira edição em 1988, Campos Filho desenvolve uma análise do processo social de produção, apro- 
priação e consumo do espaço urbano brasileiro, buscando relacionar este processo à formação das estruturas urbanas e de seus tecidos correspondentes. Para embasar sua análise, apresenta uma teoria social centrada na compreensão dos processos especulativos que deformam os processos produtivos, em termos de um embate entre a acumulação primitiva e a reprodução ampliada do capital no quadro do capitalismo brasileiro atual.

Campos Filho se dedica à análise da evolução histórica dos tecidos urbanos a partir das metodologias desenvolvidas por teóricos europeus como Phillipe Panerai, Aldo Rossi e, sobretudo, Manuel de Solá-Morales. Ele parte da teoria de Solà-Morales de que o tecido urbano é resultado da soma das produções da urbanização (U), parcelamento (P) e edificação (E), e avança no sentido de analisar quem são os agentes produtores dessas três fases, buscando distinguir o que nesta produção pode ser considerado capital industrial produtivo e o que pode ser considerado processo especulativo.

Na elaboração de sua teoria, propõe a análise do que chama de "configurações produtivas imobiliárias" bem como da maneira específica como estas irão produzir os espaços das cidades, resultando em tipologias próprias. A atuação das diferentes configurações produtivas, cada qual fiel à sua lógica de produção e defendendo interesses econômicos próprios, resulta em diferentes tipos arquitetônicos que, combinados com a rede infraestrutural e de serviços sociais, configura os diferentes tipos de tecidos urbanos.

Ao analisar como esses agentes sociais se articulam entre si na produção do tecido urbano da cidade, Campos Filho propõe separá-los em configurações produtivas. Propõe então dois tipos de configuração produtiva para o produção de parcelamentos do solo (P): 1) o loteamento, onde os proprietários do solo se associam em geral com um técnico habilitado para parcelar o solo, produzindo lotes a partir de abertura de vias e praças; e 2) o desmembramento, onde o proprietário é diretamente o agente parcelador e onde todas as parcelas têm acesso por uma via oficial pré-existente, dispensando a necessidade de abertura de novas vias e praças.

Campos filho propõe também dois tipos de configurações produtivas para a urbanização (U): 1) a que produz a rede de infra-estruturas como água, saneamento básico, asfalto, energia elétrica, etc.; e 2) a que produz os serviços sociais, principalmente os de educação, saúde, cultura e lazer.

Propõe ainda cinco tipos de configurações produtivas imobiliárias (E): 1) por encomenda, 2) rentista, 3) incorporação imobiliária, 4) pública e 5) auto-construção.

A configuração produtiva por encomenda acontece quando um cidadão solicita a um arquiteto ou construtor um projeto para sua residência ou local de trabalho. Este busca as soluções arquitetônicas mais adequadas às suas necessidades específicas, o que pressupõe que este imóvel terá um alto valor de uso. É geralmente a preferida de que pode pagar por um projeto exclusivo.

A configuração produtiva pública acontece quando o Estado, em suas diversas instâncias, encomenda aos arquitetos projetos para construção de edifícios, que podem ser administrativos, para uso público ou para habitação popular. Quando se trata de edifícios administrativos ou para uso público como museus, teatros, escolas, hospitais o que se busca é um alto valor de uso. Quando se trata porém, de produção pública de habitação para baixa renda, o projeto arquitetônico deve se adequar às exigências das empreiteiras 
no que se refere à racionalidade dos processos construtivos, padronização de materiais, entre outras; o que se busca nestes projetos é, portanto, um alto valor de troca. Esse tipo de produção pública de habitação surge da pressão popular crescente dos que não conseguem adquirir ou alugar moradia no mercado imobiliário formal e não se conformam em ter que se sujeitar as incertezas e baixa qualidade do mercado informal do loteamento irregular ou da favela.

A configuração produtiva por auto-construção é realizada geralmente por e cidadãos de baixa renda que, com seus próprios recursos e força de trabalho, produzem a sua própria moradia. Estes cidadãos buscam, dentro de suas limitações, alcançar o maior valor de uso possível para seus imóveis.

A configuração produtiva capitalista rentista produz imóveis com intenção de se extrair uma renda mensal através de um aluguel. Geralmente é feita por pequenos capitais, ligados a pessoas físicas, que vêem na construção de imóveis para aluguel um investimento seguro para suas economias. Neste caso é necessário que o imóvel tenha valor de troca, pois deve se adaptar a uma grande diversidade de inquilinos e para isso seu projeto deve se adequar às exigências deste mercado.

A configuração produtiva capitalista do tipo incorporação imobiliária produz imóveis para a venda no mercado imobiliário. Esta configuração produtiva geralmente é adotada por grandes empresas incorporadoras, construtoras ou financiadoras que vêem na produção e venda de imóveis uma maneira de reproduzir seu capital. Buscam portanto, em seus empreendimentos, o maior valor de troca possível para se atingir as maiores margens de lucro.

Para Campos Filho, para cada configuração produtiva, em sua organização seqüencial na produção do parcelamento, urbanização e edificação, corresponde um resultado físico espacial específico, que ele denomina "tecido urbano".

Os tecidos urbanos são o resultado de uma interação entre o poder público e os agentes privados. Aos agentes públicos (federal, estadual e municipal) cabe o papel principal, pois eles detém o poder de implantação das infra-estruturas, que são elementos estruturadores do espaço urbano. "Nesse contexto, a organização do mercado imobiliário tem no Estado um agente que exerce um papel central, seja como regulador do uso do solo, seja como regulador do sistema de financiamento da produção imobiliária, seja como provedor de infra-estrutura e na regulação e na prestação de serviços urbanos como os de transporte e saneamento ambiental" (CAMPOS FILHO, 2003c).

Os agentes privados agem em função de uma disponibilidade atual ou futura dessa infra-estrutura de serviços como valor de uso e também como valor de troca, nesse último caso buscando somar aos ganhos imobiliários de natureza industrial os de natureza especulativa ou fundiária. A maneira em que se articulam as configurações produtivas imobiliárias com as configurações produtivas de infra-estruturas e serviços sociais já define o caráter mais produtivo ou mais especulativo da produção do espaço urbano, colaborando, quando de caráter especulativo, para o processo de exclusão social. 
Em seu mais recente livro, "Reinvente seu bairro", de 2003, Campos Filho apresenta quatro tipos elementares de tecido urbano. Os tipos elementares nasceram de uma análise da oferta diferenciada de acessibilidade, que atrai para as linhas de maior acesso os pontos do comércio, serviços e atividades industriais. O crescimento da malha urbana vai entrecruzando as linhas de maior acessibilidade, conformando a concentração de comércio, serviço e indústrias, e também de moradias, adensadas horizontal ou verticalmente.

Eis os tipos elementares apresentados por Campos Filho:

Tipo 1 - Tende ser aquele que nasce da ausência de planejamento, geralmente na periferia do espaço urbano da cidade, sem relação com bairros vizinhos. Corresponde a um bairro isolado em formação, em geral situado em posição periférica em uma mancha urbana.

Tipo 2 - Muito semelhante ao tipo 1, com a diferença de que há um relacionamento com bairros vizinhos e, por conseguinte existe em seu interior o entroncamento de duas vias importantes, em geral vias estruturais ou coletoras. O resultado do cruzamento de 2 linhas de acessibilidade gera uma centralidade mais especializada pela necessidade de atender um maior número de cidadãos.

Tipo 3 - É aquele que nasce a partir de um planejamento prévio, público ou privado, geralmente situado nas periferias urbanas da época em que foi implantado, podendo posteriormente tornar-se centrais. Quando essa iniciativa é do loteador, é em geral destinado às classes medias e altas, como é o caso da Cia. City em São Paulo; quando é do poder público, em geral é destinado as classes populares, como nos "conjuntos habitacionais".

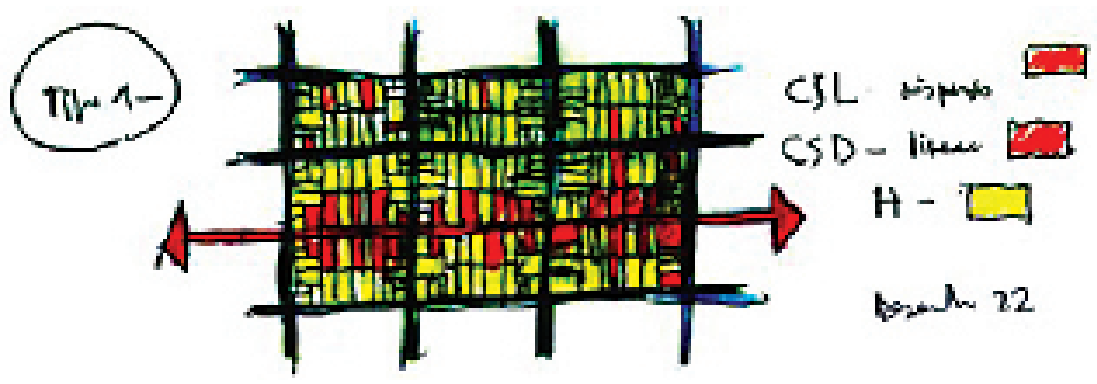

Figura 1.6 - Tecido Urbano Básico TIP01. Fonte: Campos Filho, 2003c

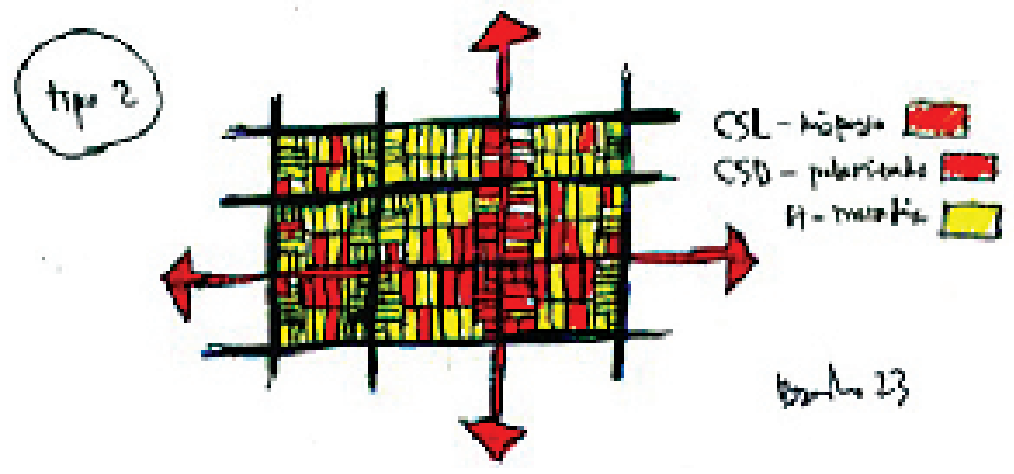

Figura 1.7 - Tecido Urbano Básico TIP02. Fonte: Campos Filho, 2003c

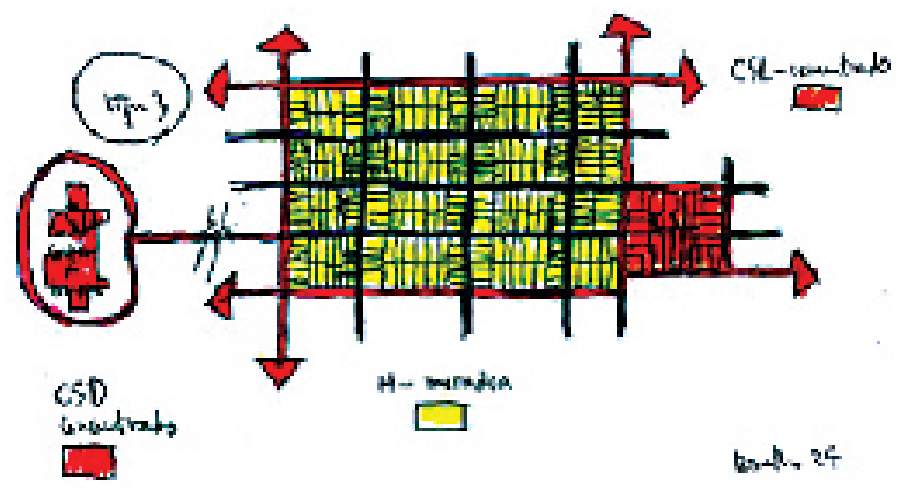

Figura 1.8 - Tecido Urbano Básico TIP03. Fonte: Campos Filho, 2003c 


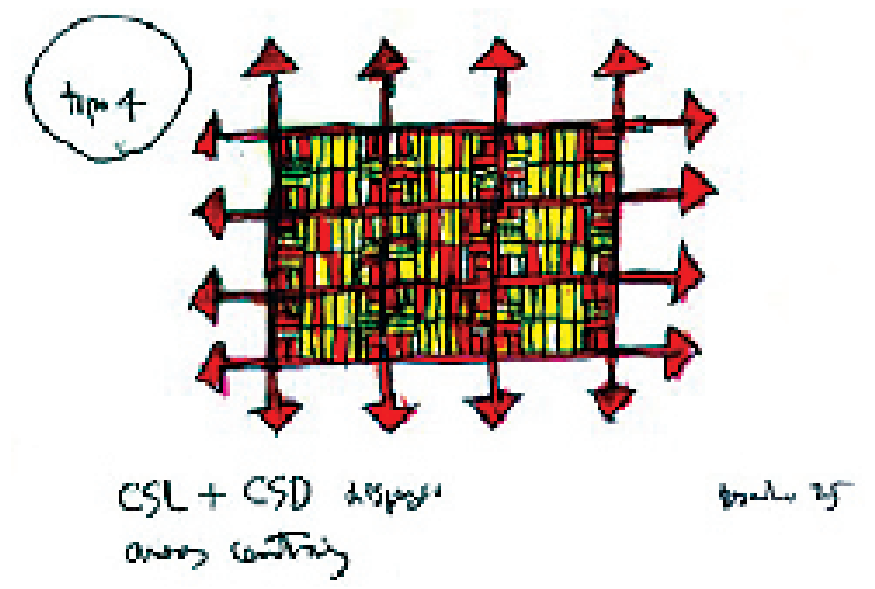

Figura 1.9 - Tecido Urbano Básico TIP04. Fonte: Campos Filho, 2003c
Tipo 4 - É o bairro que se transformou em área central dentro da estrutura urbana devido à expansão do território da cidade e acaba por sofrer um processo de adensamento.

O tipo 4 pode corresponder a uma evolução do tipo 2, centralidades não lineares com várias ruas se entrecruzando todas com muito tráfego justificadores de um comércio mais diversificado formando uma mancha urbana de várias quadras justapostas em duas direções. Os centros de cidades apresentam em geral tecidos urbanos do tipo 4 assim como as centralidades de mais alto nível espalhadas pelas grandes cidades. Os centros de bairro são de tipo 1 (de comércio e serviço de nível local, de apenas apoio cotidiano à moradia) ou de tipo 2, já com certa diversificação como agências bancárias, lojas de roupa e de eletrodomésticos.

Estes quatro tipos básicos de tecidos urbanos podem ser desdobrados em diversos outros tipos associados a diferentes intensidades e mesclas de usos e atividades. Campos Filho considera a problemática da transformação dos tecidos urbanos onde, historicamente, "um bairro da cidade pode ter sido iniciado como tipo 1, passando pelo tipo 2 e chegando ao tipo 4. Este é o caso de muitos bairros que foram periféricos e se transformando em centrais em São Paulo com o crescimento do território da cidade" (CAMPOS FILHO, 2003, p. 65). Esses processos de transformação dos tecidos pode ser para melhor, para algo diferente, igualmente bom ou ruim ou para pior que a situação existente.

Para Campos Filho, a noção da estrutura dos tecidos urbanos permite compreender e transportar a lógica mais geral da produção capitalista do espaço para as questões espaciais mais ligadas ao cotidiano da atuação do arquiteto e urbanista. 
CAPÍTULO 2

A INCORPORAÇÃO IMOBILIÁRIA E
SUA RELAÇÃO COM A TIPOLOGIA 
1. Segundo dados do cadastro imobiliário da Prefeitura de São Paulo de 1977, 44\% da áre urbana da cidade era composta por terrenos vazios. (Cogep - Cadastro TP-CL-1977). Apud CAMPOS FILHO, 2001, p. 51

\section{1 - A QUESTÃO DO PREÇO DA TERRA.}

A especulação imobiliária urbana é uma maneira pela qual os proprietários de terra têm seus imóveis valorizados através de uma renda transferida de outros setores produtivos da economia. Essa transferência de renda acontece quando investimentos feitos por terceiros em determinadas regiões da cidade valorizam todos os imóveis desta região. A situação mais comum de transferência de renda por valorização imobiliária acontece com os investimentos públicos em infra-estrutura e serviços urbanos feitos pelos governos municipais e estaduais. Esse processo se dá paralelamente ao crescimento das cidades, tornando os terrenos periféricos cada vez mais centrais e mais próximos dos investimentos em infraestrutura e serviços urbanos, geradores de valorização imobiliária. O conhecimento deste processo por parte dos proprietários tem como conseqüência uma enorme quantidade de terrenos vazios na malha urbana à espera de valorização imobiliária ${ }^{1}$. A retenção especulativa de terrenos vazios na malha urbana faz com que a cidade se espalhe demasiadamente e que o cidadão tenha que percorrer distâncias muito maiores que percorreria caso esses vazios não existissem. As famílias de baixa renda são levadas cada vez mais para longe do emprego, do comércio e dos serviços públicos de saneamento, transporte, educação, saúde e lazer; e as prefeituras, com seus recursos limitados, são obrigadas a levar cada vez mais longe uma infra-estrutura que não seria necessária se não houvesse uma periferia tão distante (CAMPOS FILHO, 2001). A ampliação da rede de serviços e infra-estrutura urbana realimenta o processo resultando assim num círculo vicioso.

Nas cidades brasileiras um outro fator agravante é a concentração de renda em uma pequena parcela da população, que resulta numa concentração espacial da classe mais enriquecida da sociedade numa pequena parte da cidade. Essa concentração acontece geralmente nas áreas mais centrais, que são as regiões mais urbanizadas das cidades, com maior oferta de emprego, comércio, infra-estrutura, serviços públicos e serviços em geral, especialmente os de cultura e lazer. A escassez de oferta de áreas com alto grau de urbanização nas cidades, por insuficiência de recursos governamentais, faz com que, nessas regiões, a comercialização de áreas urbanas tenha uma enorme liquidez e se transformem em verdadeiros leilões, elevando cada vez mais o preço da terra.

Para entendermos como o preço da terra interfere no ciclo de reprodução do capital do setor imobiliário é necessário compreender o ciclo de reprodução do capital da industria em geral. Segundo Topalov, o capital-dinheiro transforma-se em meios de produção e força de trabalho, que engendram um processo produtivo resultando numa mercadoria com valor maior que a soma dos custos dos meios de produção e da força de trabalho, tendo produzido assim a mais-valia. Com a venda da mercadoria, o capital investido e a mais-valia voltam à forma de capital-dinheiro, renovando o ciclo e possibilitando o prosseguimento à acumulação (TOPALOV, 1979).

Sendo a constante renovação deste ciclo de reprodução do capital a condição para a sua acumulação, deparamo-nos com duas especificidades do setor imobiliário que o diferenciam dos demais processos produtivos e que dificultam a reprodução do seu capital: 1) a relação de dependência do espaço construído com o solo urbano, que leva o proprietário de terras a ter certo controle, em forma de renda, sobre essa produção; e 2) o longo período de giro de capital se comparado a outros segmentos produtivos (JARAMILLO, 1982). 
O preço da terra portanto impõe-se de maneira específica como obstáculo à produção do setor imobiliário, pois diferentemente do que acontece com outras atividades industriais, onde a terra assume um caráter de base para a produção, o processo produtivo de imóveis requer um novo terreno ao início de cada novo ciclo de produção. O terreno circula junto com a mercadoria, fazendo parte desta. O terreno mais o edifício construído formam a mercadoria imobiliária.

A função comum a todo incorporador é a "transformação de parte do capital de promoção em terreno suporte para a construção da mercadoria imobiliária e posteriormente na própria mercadoria imobiliária" (COSTA, 2002, p. 50), enquanto a outra parte do capital vai financiar a industria de construção. Em nenhum momento a parte do capital transformada em terreno adota a forma de capital produtivo (matéria prima, máquinas, força de trabalho); adota primeiramente a forma de terreno e depois a forma de produto e só então está pronto para voltar à forma de capital financeiro ${ }^{2}$.

Se para cada início de um novo ciclo de produção imobiliária é necessário um novo solo urbano, a tendência deste à escassez eleva seu preço, criando dificuldades para a reprodução do capital neste setor produtivo.

Os três fatores citados anteriormente - a retenção especulativa de terrenos urbanos, a concentração de renda em uma pequena parte da cidade e o controle dos proprietários sobre a renda fundiária - associados à dependência do solo urbano no setor imobiliário, acabam por dificultar e encarecer o processo de produção imobiliária pois contribuem para a elevação do preço da terra. O preço da terra, por sua vez, interfere de maneira determinante na tipologia dos edifícios, uma vez que o alto valor do solo urbano faz com que os empresários imobiliários pressionem os governos municipais por coeficientes cada vez maiores, para construir prédios cada vez mais altos e com maior numero de unidades (CAMPOS FILHO, 2001). Ao andarmos por São Paulo percebemos claramente que os edifícios produzidos pelo mercado imobiliário revelam a total sujeição da sua tipologia à rentabilidade do solo.

A verticalização excessiva das áreas centrais provoca a saturação e congestionamentos das redes de infra-estrutura urbana, exigindo a sua ampliação ou substituição por outras de maior capacidade. Os recursos públicos investidos nessa contínua reestruturação de áreas já urbanizadas são viabilizados através da arrecadação dos impostos de todos os cidadãos, mas a valorização imobiliária decorrente desses investimentos é transferida apenas aos poucos proprietários da área, caracterizando este processo como um mecanismo de concentração de renda e agravante das injustiças sociais (CAMPOS FILHO, 2001).

\section{2 - A LEGISLAÇÃO E O PREÇO DA TERRA.}

As normas que regulam a cidade, suas construções e sua estrutura fundiária interferem diretamente na estruturação do seu mercado imobiliário. Juntamente com os investimentos em infra-estrutura, a legislação configura eixos de valorização do solo, hierarquizando mercados. A legislação urbana ao determinar o potencial construtivo, as categorias de uso permitidas e dimensionamento das construções de cada um dos lotes da cidade também influencia de maneira direta o preço do solo urbano e, consequentemente, a tipologia dos edifícios.
2. Segundo Campos Filho, apesar deste capital não ser um capital produtivo, em geral esta atividade do incorporador não tem característica especulativa no sentido de reter terras para esperar uma futura valorização. Seu ganho está na mais-valia gerada pela transformação do uso do solo associada às benfeitorias executadas pelo capital industrial de construção. "A atividade empresarial imobiliária é produtiva quando investe capital e se utiliza do trabalho produtivo do trabalhador para produzir uma mercadoria, que será a urbanização de uma área, o lote urbanizado, e todos os tipos de edificação (...). Nessa atividade produtiva haverá produção de valor, que é riqueza social". (CAMPOS FILHO, 2001, p. 67) 
3. Foi substituída pela lei $n^{0} 13.885$, aprovada em 25 de agosto de 2004.

4. 0 PDDI foi elaborado em 1971, na gestão do Prefeito Figueiredo Ferraz

5. 0 Coeficiente de Aproveitamento (CA) estabelece a área construída computável máxima permitida para cada lote ao multiplicar seu índice pela área do mesmo. Assim, em um lote de $2.000,00 \mathrm{~m}^{2}$ com $\mathrm{CA}=4$ é permitida a construção de $8.000,00 \mathrm{~m}^{2}$ de área computável. Existem ainda os ambientes cujas áreas construídas não são computáveis nesta conta: subsolos para estacionamento de veículos, o pavimento térreo quando nele não existem unidades habitacionais ou comerciais, portaria, ático, entre outros.
6. Lei municipal $n^{\circ} 7.805$, de Novembro de 1972, art. 24
Na cidade de São Paulo a lei 7.805, de 1972, Lei Geral de Zoneamento, Parcelamento, Uso e Ocupação do Solo vigorou na cidade até fevereiro de $2005^{3}$. Nela foram demarcados perímetros para cada trecho da cidade definindo a zona em que se insere, e estabelecidas as categorias de uso e as dimensões das edificações permitidas para as diferentes zonas definidas pela lei. Inicialmente foram criadas oito zonas distintas, numeradas de Z1 a Z8, mas ao longo dos mais de trinta anos que se passaram desde a promulgação da lei, esse número cresceu até dezenove. Além da criação de novas zonas, as emendas também se referiram à classificação de novos usos e detalhamentos dos critérios de ocupação das edificações.

Seguindo a tendência de baixar o potencial construtivo da cidade que vinha desde a formulação do Plano Diretor de Desenvolvimento Integrado (PDDI) ${ }^{4}$, a Lei de Zoneamento de 72 baixou ainda mais os coeficientes de aproveitamento ${ }^{5}$ máximo dos lotes. Estipulou o coeficiente máximo de 3,5 mas limitou a sua aplicação apenas à Z5, 1\% da área da cidade, basicamente o centro histórico e a avenida Paulista. Outros $10 \%$ da área da cidade, contidas em Z3 e Z4, poderiam chegar aos coeficientes 2,5 e 3 respectivamente. E a imensa maioria dos terrenos urbanos, atingindo quase $70 \%$ da área da cidade, contidos em Z2, poderiam construir apenas uma vez a área do lote.

É neste contexto que os proprietários, se sentindo prejudicados pelo corte no potencial construtivo de seus terrenos, passam a pressionar as autoridades municipais para um aumento nos coeficientes. Este movimento é apoiado por construtores e incorporadores que também desejavam praticar coeficientes maiores. Foi então negociada a introdução, ainda na Lei 7.805 de 72, de um mecanismo que permitiu a elevação dos coeficientes de aproveitamento nas principais zonas da cidade. Este mecanismo ficou conhecido como "fórmula de Adiron" e permitiu a elevação dos coeficientes desde que fossem diminuídas as taxas de ocupação do lote. Assim foi permitido o aumento do coeficiente de aproveitamento para 4 nas zonas Z5 e também para as zonas Z3 e Z4. Através da aplicação da mesma fórmula poder-se-ia chegar ao coeficiente 2 na Z2, Z11, Z13, Z17 e Z18, mas apenas para a categoria de uso R3, conjunto residencial.

Assim como o posicionamento geográfico em relação às áreas mais urbanizadas da cidade, o potencial construtivo do terreno urbano, definido por sua Zona de Uso e Ocupação, é fator determinante na formação de seu preço. Definir este potencial através do zoneamento, acaba determinando o preço do solo e consequentemente, a tipologia arquitetônica edificada.

Se por um lado são mais valorizadas as localizações capazes de gerar as maiores densidades e diversidades de ocupação, por outro lado, localizações com baixo potencial construtivo e ocupações mais restritivas também podem ser muito valorizadas quando resultam em bairros diferenciados, com alto valor de uso. Nestes casos a legislação urbana tem um papel decisivo na valorização de um loteamento, ao definir para ele usos e formas de ocupação mais restritivas. Este é o caso da Zona 1 na Lei de Zoneamento de 72. $\mathrm{Na} \mathrm{Z1}$, zona exclusivamente residencial de densidade demográfica baixa, as normas urbanísticas definem características que somente uma ocupação de alta renda tem capacidade para se adequar: uso exclusivamente residencial unifamiliar, área mínima de lote igual a $250 \mathrm{~m} 2$, frente mínima de dez metros, recuo frontal e de fundos mínimo de 5 metros e recuo lateral de 1,5 metros em pelo menos um dos lados; taxa de ocupação de $50 \%$ e coeficiente de aproveitamento igual a 1. 
No caso da Z1, o zoneamento oficializa uma ocupação semelhante às cidades jardins, com baixo potencial construtivo, baixa densidade demográfica e cujos lotes devem reservar grande parte de suas áreas para jardins permeáveis. Mesmo limitando o potencial de aproveitamento dos terrenos, suas características introduzem elementos que garantem a sua valorização: a qualidade de vida, o alto valor de uso e a exclusividade.

Com o intuito de proteger as zonas Z1 de vizinhanças com usos e ocupações que ameaçariam suas principais características urbanísticas, foram criadas, ao seu redor, zonas que funcionam como uma espécie de cinturão de proteção. É o caso das zonas Z17, que permite usos de serviços e comércios de âmbito local, e Z18, que permite usos de serviços e comércios de âmbito local e de âmbito diversificado ${ }^{7}$; ambas permitem coeficientes e ocupações semelhantes à Z2 mas impõem um gabarito de altura máximo de 25 metros, equivalente a nove andares. Apesar da restrição de altura e do potencial construtivo relativamente baixo, estas duas zonas também são bastante valorizadas pelos empreendedores imobiliários por estarem ao redor da regiões com muita área verde, principalmente os lotes lindeiros à $\mathrm{Z} 1$, por terem a valorizada vista para os jardins de uma área residencial.

Se o preço do solo urbano depende do seu posicionamento geográfico em relação à cidade, depende também das características construtivas definidas por sua Zona de Uso e Ocupação. Maiores coeficientes construtivos associados a uma permissão de usos mais diversificados constituem um alto valor de troca, muito valorizado pelo mercado imobiliário. Baixos coeficientes e usos mais restritivos como na $\mathrm{Z} 1$ proporcionam um alto valor de uso. Definir estas características através do zoneamento, nada mais é que definir o preço do solo e, conseqüentemente, a tipologia arquitetônica da edificação.
7. Lei no 9.049, de 24 de Abril de 1980.

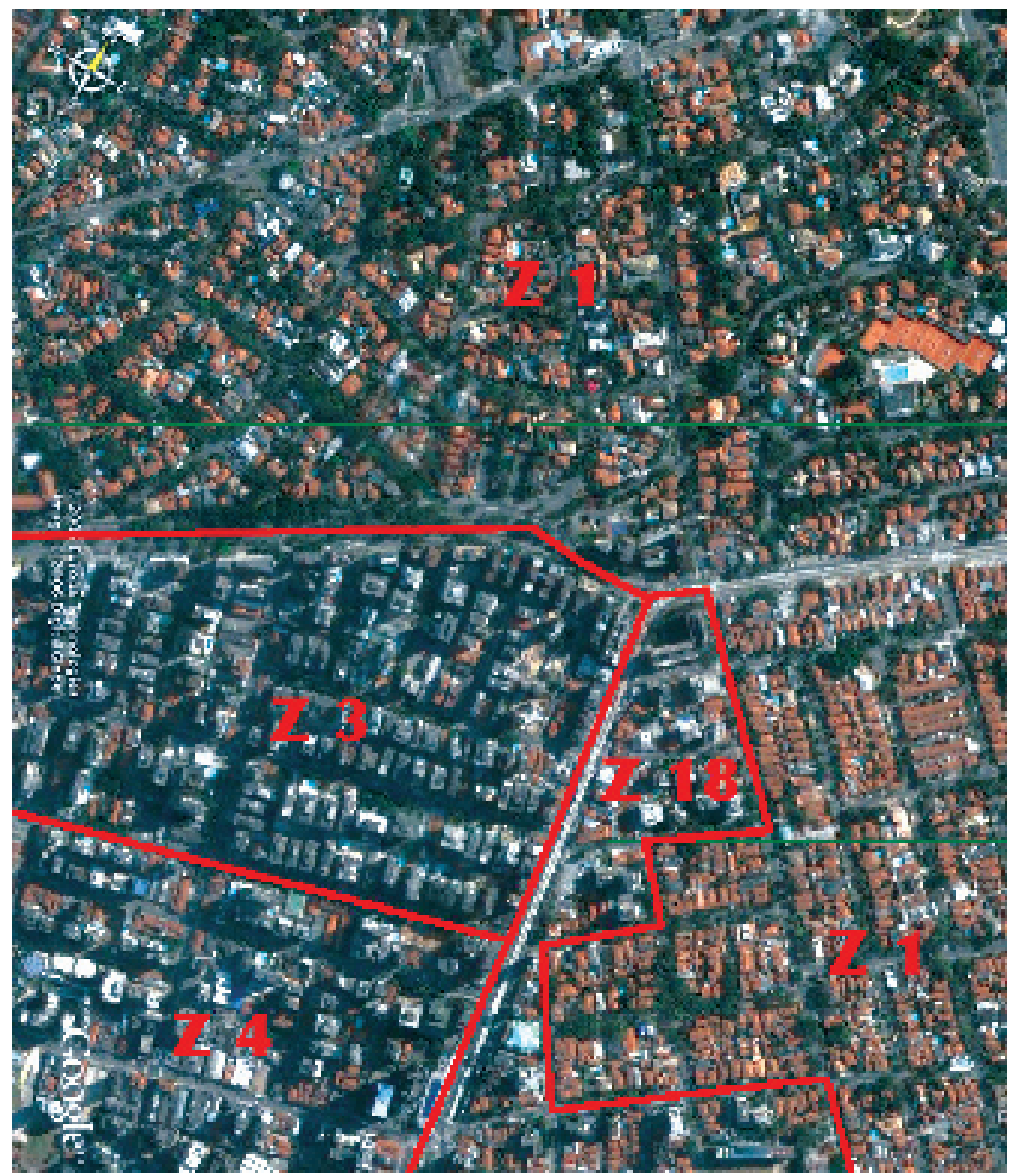

Figura 2.1 - Vista aérea da cidade de São Paulo, Av 9 de Julho com

Av. São Gabriel, mostrando a divisão das zonas de uso. Fonte: Google Earth.

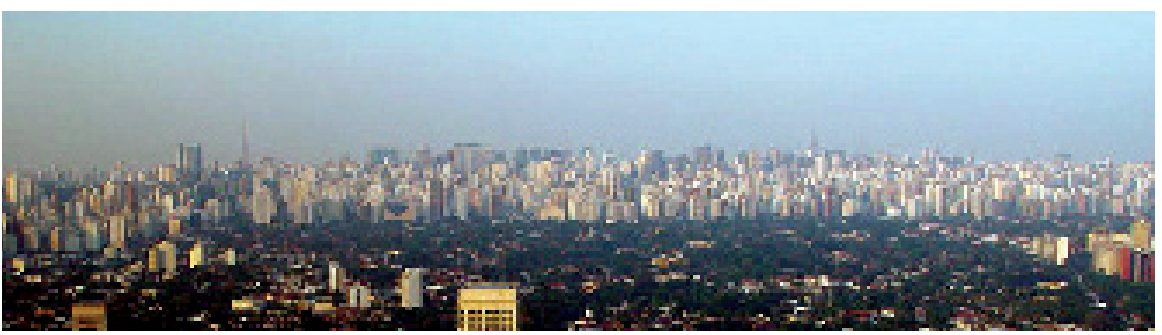

Figura 2.2 - Vista da área dos Jardins (Z1) com bairro de Cerq. César (Z4) ao fundo. 
Figura 2.3 - Mapa simplificado do zoneamento de São Paulo.
Ao olharmos o mapa da Lei de Zoneamento de 72, percebemos claramente que a maior diversidade de suas zonas estão situadas na porção sudoeste da cidade de São Paulo. Se analisarmos a distribuição das áreas mais permissivas do ponto de vista do coeficiente de aproveitamento, percebe-se que quase $90 \%$ do potencial construtivo de São Paulo se encontra neste setor da cidade. $\mathrm{O}$ mesmo se pode observar com relação às zonas mais restritivas como a Z1. Concentra-se assim, nesta pequena parte da cidade, a maior parte de suas categorias e sub-categorias de uso, identificando esta região como concentradora das paisagens formais ricas e valorizadas e, conseqüentemente, com maior capacidade de atrair investimentos e melhoramentos para a região. No restante da cidade apenas um mar de Z2, pontilhadas por pequenas áreas de Z3 ou Z4, zonas de maior potencial construtivo, no centro de cada um dos bairros, ou então zonas industriais.

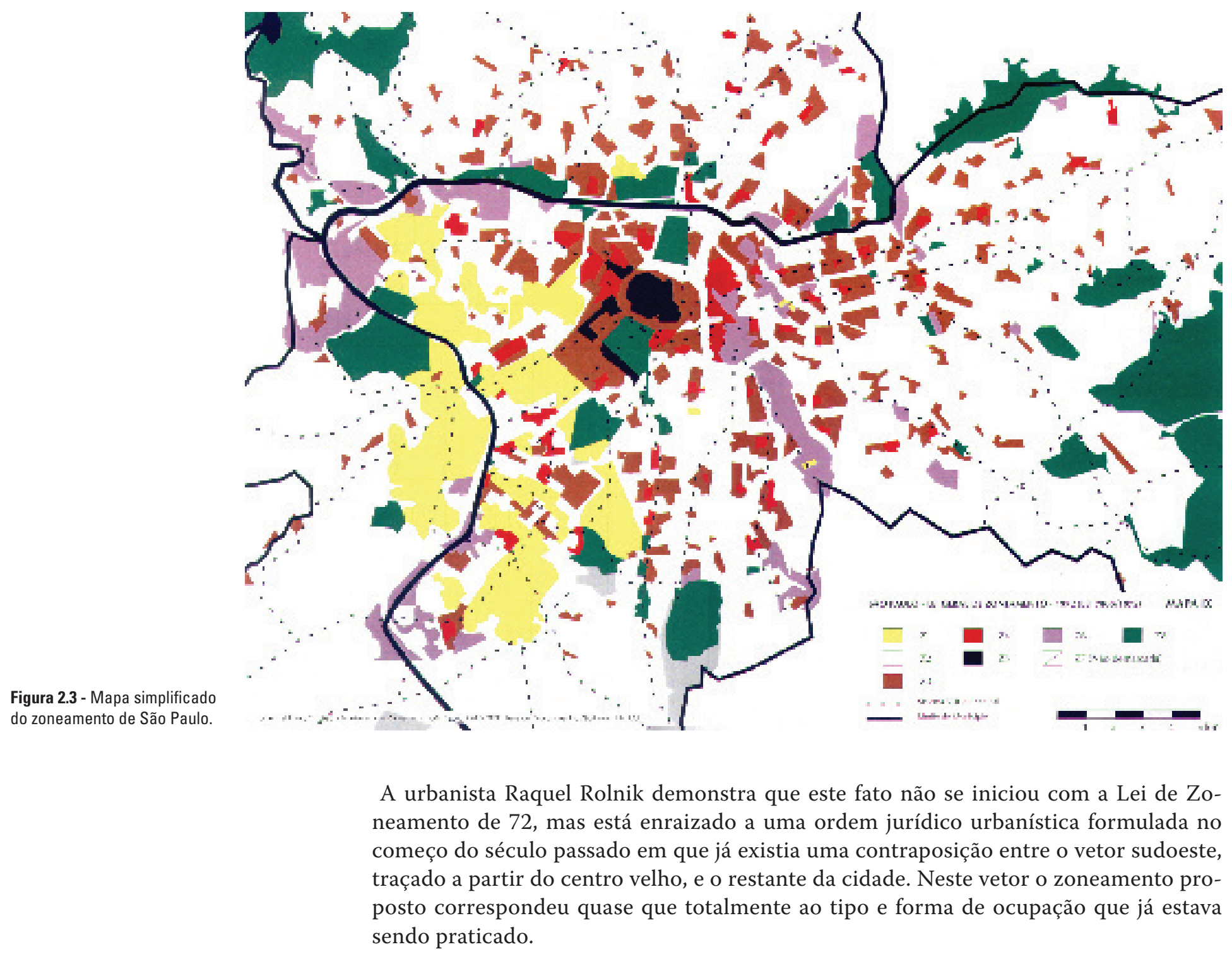


"Portanto, ao declarar que só ali, onde já estavam concentrados os terrenos mais valorizados, poder-se-iam praticar os coeficientes mais altos e os usos mais diversificados, a lei se transformou em indexador, reiterando o status quo de distribuição de riqueza imobiliária de cidade". (ROLNIK, 2003, 201)

O arquiteto e urbanista Benjamin Adiron Ribeiro, responsável pela formulação da lei do Zoneamento de 72, confirma, em entrevista concedida para elaboração deste trabalho, que seu critério para a delimitação dos perímetros das zonas de uso foi baseado na estrutura urbana existente na época. Seu trabalho foi quase que inteiramente fundamentado na pesquisa do Padre Lebret, sociólogo francês que fez um levantamento da estrutura urbana da cidade de São Paulo em meados da década de 1950, e nas atualizações que haviam sido feitas, dez anos mais tarde, pelo grupo de urbanistas contratados pela prefeitura para a elaboração do PUB, Plano Urbanístico Básico.

"A maior parte do meu trabalho foi baseado na pesquisa [de] Lebret, e nas atualizações que haviam sido feitas. Porque o PUB refez toda pesquisa urbana e atualizou... Isso porque a cidade tinha crescido bastante em dez anos [...]. Eu tinha todo esse material. Então o critério foi baseado na estrutura que já existia, corrigida apenas dentro desta orientação de transformar a cidade numa cidade de grelhas viárias. Essa foi a correção. Então foi isso, o critério foi esse, foi baseado na pesquisa urbana disponivel na época. [...] o histórico então da coisa é essa: chegamos à lei de zoneamento através, primeiro da pesquisa Lebret, depois do PUB."

Sobre a concentração das zonas mais permissivas na porção sudoeste da cidade, Adiron Ribeiro justifica:

"Havia uma área muito adensada que nós não podíamos pura e simplesmente jogar no chão; e nesta área foi mantido o adensamento, sob um controle um pouco maior porque se reduziu o coeficiente de aproveitamento. Havia uma área que era pouquíssimo adensada; foi mantida com o seguinte raciocinio: que a cidade não é um ser morto, a cidade é um ser vivo, e a legislação tem de ser também dinâmica. Então admite-se que se as tendências de crescimento indicassem que, em determinada região da cidade, estava-se caminhando para um desenvolvimento maior, então a legislação e o zoneamento imediatamente estudariam aquilo ali para verificar quais alterações convenientes. [...] Um processo de planejamento tem que ser dinâmico! Não é questão para rever daqui a dez anos, nada disso! Plano Diretor é revisto a cada semana! A equipe permanente, o sistema permanente de planejamento tem que estar continuamente trabalhando. $O$ conceito básico é este. ${ }^{9}$

Adiron Ribeiro nos conta ainda as condições sigilosas em que o seu trabalho foi executado:

"O [prefeito Figueiredo] Ferraz, que era um homem honesto, sabia muito bem que o negócio ia ser uma briga de foice no escuro na hora de definir os limites de cada perímetro. Então ele me chamou e disse: 'Olha, Adiron, eu lamento muito, mas você não vai ter mais hora de folga neste ano que vai correr, enquanto você está de preparando a proposta. Você vai ter que trabalhar não oito horas, nem seis, que é a sua obrigação como funcionário; você vai trabalhar doze, quatorze por dia [...] porque você vai ter que, pessoalmente, delimitar todos os perímetros. Vai ser a sua obrigação pessoal! Você não vai poder entregar isso a ninguém, ninguém! Você é a única pessoa na qual eu tenho confiança, portanto o seu trabalho vai ter que incluir, além de redigir a lei sob todos os outros aspectos, você vai ter que sentar na prancheta você mesmo, e não vai poder dar acesso a essa informação a ninguém! Você não pode dar acesso a essa informação porque na hora que você der acesso começa uma briga, principalmente se esse acesso for privilegiado.
8. Informação pessoal fornecida em entrevista realizada em 8 de Novembro de 2007 em São Paulo. 
Então foi isso, eu passei um ano desgraçado, o pior ano da minha vida. Fiz esse trabalho, não transpirou nenhuma informação e o projeto foi para câmara dos vereadores pronto. O Ferraz [...] chamou os vereadores e disse: 'olha vocês não vão poder ficar discutindo isso não. Toda a parte conceitual vocês vêm discutindo há dois anos, desde que começou a elaboração do Plano Diretor, que já foi aprovado. Toda a parte conceitual tem sido discutida exaustivamente, não só por vocês, vereadores, politicos como por todos os interessados: IAB, Ordem dos Advogados... todo o mundo! Os aspectos conceituais foram discutidos, os padrões foram todos discutidos, a definição dos tipos de zona e a forma pela qual cada tipo de zona seria controlado foi discutido exaustivamente por todo mundo dentro e fora da prefeitura, dentro e fora da câmara municipal. Agora, os perímetros, infelizmente vocês não vão poder ficar discutindo, porque senão não vai dar. Primeiro porque as pressões vão ser muito violentas sobre vocês, agora que está entregue a proposta; e segundo porque isso não vai acabar nunca, nós não conseguir aprovar essa legislação nem daqui a dez anos. Então na hora que eu entregar a proposta para vocês, vocês vão ter dois ou três dias para aprovar.' Isso nunca aconteceu na Câmara Municipal! E o grupo dele, que era a maioria, teve que obedecer a orientação. Receberam e aprovaram. Então realmente a proposta não transpirou em tempo útil para que houvesse uma movimentação. Foi assim!"’o

As diferenças entre o rico vetor sudoeste e o restante da cidade também transparecem na qualidade e acesso à infra-estrutura urbana, decorrentes da discrepância entre o ritmo e o volume dos investimentos públicos, que associados a grandes investimentos privados, foram capazes de sustentar, neste último século, a posição de região mais valorizada da cidade, criando e recriando pólos de atratividade dentro do próprio vetor.

Não é novidade que as ações do Estado em geral estejam alinhadas aos interesses do mercado imobiliário, concentrando os investimentos públicos justamente nas áreas mais bem servidas da cidade e causando um enorme déficit na oferta de infra-estrutura de serviços e equipamentos urbanos em outras áreas, configurando assim os eixos de valorização imobiliária.

A arquiteta Mariana Fix demonstra em sua dissertação de mestrado que a região das avenidas Engenheiro Luís Carlos Berrini e Brigadeiro Faria Lima foi amplamente beneficiada pelos investimentos públicos em sistema viário e infra-estrutura urbana. Somente na década de 90 cerca de $85 \%$ dos investimentos públicos desse tipo foram canalizados para esta região, para a execução de obras como o túnel Ayrton Senna, o prolongamento da av. Faria Lima e a abertura das avenidas Hélio Pellegrino e Águas Espraiadas, hoje denominada de avenida Roberto Marinho (FIX, 2003). Mais recentemente, a execução de novas obras como os túneis da avenida Rebouças e da avenida Cidade Jardim e as obras do complexo de pontes estaiadas que ligará a avenida Roberto Marinho aos dois lados da Marginal Pinheiros demonstra que este processo ainda não acabou.

"Um elemento importante na compreensão deste processo é a crescente segregação espacial e suas dimensões relativamente reduzidas. Com efeito, cada vez mais [as camadas de alta renda] se concentram em uma área relativamente pequena da metrópole, trazendo para esta área, inclusive, os elementos de alta renda das cidades, que ela absorve e homogeneiza e, cada vez mais, essa área desequilibra totalmente a estrutura urbana, dado o peso relativo que ela assume na metrópole. As elites não só dotam sua área geral da concentração dos mais elevados padrões de serviços públicos e privados, mas também manipulam o espaço no sentido de não só minimizar para si os custos e tempos de deslocamento, mas ainda no de transferir para aquela área geral todos os principais órgãos de condução política e econômica da sociedade." (VILAÇA, 1978, apud CAMPOS FILHO, 2001, p. 45) ${ }^{11}$
11. VILAÇA, Flávio - "A estrutura territorial
da metrópole sul-brasileira", FAU-USP, 1978, pág. 335 a 338. Tese de Doutoramento. 
A falta de investimentos em políticas urbanas de inclusão é geradora de tensões sociais proporcionadas por essa disparidade de condições de vida convivendo no mesmo espaço urbano. As diferenças entre as camadas sociais ricas e pobres se ampliam, gerando uma intensificação dos conflitos sociais, expressos nos crescentes índices de criminalidade e violência que assolam as nossas cidades.

\section{3 - A LEGISLAÇÃO URBANA E A TIPOLOGIA EDIFICADA.}

Vimos que o zoneamento urbano, por determinar os parâmetros de uso e ocupação da cada uma das zonas da cidade, e também por sua capacidade de agregar valor ao solo e atrair investimentos, acaba por configurar as tipologias edificadas em cada pedaço da cidade. Há, no entanto, especificidades da legislação urbana, contida na própria Lei de Zoneamento e também no Código de Obras do Município que irá configurar de maneira específica a tipologia praticada pela indústria imobiliária.

A fórmula de Adiron, mecanismo introduzido na Lei de Zoneamento de 1972 para que se pudesse aumentar os coeficientes originalmente definidos, cria, em contrapartida, uma proporção inversa entre coeficiente de aproveitamento e taxa de ocupação do lote, definida por uma fórmula matemática.

\section{TABELA PARA AUMENTO DO COEFICIENTE DE APROVEITAMENTO}

$$
\begin{array}{ll}
\mathrm{c}=\frac{\mathrm{T}}{\mathrm{t}}+(\mathrm{C}-1) & \text { PARA TERRENOS }<1000 \mathrm{~m}^{2} \\
\mathrm{c}=\frac{\mathrm{T}}{\mathrm{t}} \times \mathrm{C} & \text { PARA TERRENOS } \geqslant 1000 \mathrm{~m}^{2}
\end{array}
$$

Onde:

$\mathrm{c}=$ coeficiente de aproveitamento do lote a ser utilizado;

$\mathrm{t}=$ taxa de ocupação do lote a ser utilizado;

$\mathrm{C}=$ coeficiente de aproveitamento máximo do lote;

\begin{tabular}{|c|c|c|c|c|c|c|c|c|c|c|c|c|c|}
\hline \multirow{2}{*}{\multicolumn{2}{|c|}{$\frac{Z 2, Z 11, Z 13, Z 17, Z 18}{\text { SOMENTE PARA R3 }}$}} & \multicolumn{4}{|c|}{$\mathrm{Z3}$} & \multicolumn{4}{|c|}{ Z4 } & \multicolumn{4}{|c|}{$\mathbf{Z 5}$} \\
\hline & & \multicolumn{2}{|c|}{$A<1000 \mathrm{~m}^{2}$} & \multicolumn{2}{|c|}{$A \geqslant 1000 \mathrm{~m}^{2}$} & \multicolumn{2}{|c|}{$A<1000 \mathrm{~m}^{2}$} & \multicolumn{2}{|c|}{$A \geqslant 1000 \mathrm{~m}^{2}$} & \multicolumn{2}{|c|}{$A<1000 \mathrm{~m}^{2}$} & \multicolumn{2}{|c|}{$A \geqslant 1000 \mathrm{~m}^{2}$} \\
\hline $\mathrm{t}$ & c & $\mathrm{t}$ & c & $t$ & c & $t$ & c & $t$ & c & $\mathrm{t}$ & c & $\mathrm{t}$ & c \\
\hline 0,25 & 2,00 & 0,20 & 4,00 & 0,31 & 4,00 & 0,35 & 4,00 & 0,52 & 4,00 & 0,53 & 4,00 & 0,70 & 4,00 \\
\hline 0,50 & 1,00 & 0,50 & 2,50 & 0,50 & 2,50 & 0,70 & 3,00 & 0,70 & 3,00 & 0,80 & 3,50 & 0,80 & 3,50 \\
\hline
\end{tabular}

$\mathrm{T}=$ taxa de ocupação máxima do lote.
A tabela acima mostra na linha cinza os coeficientes de aproveitamento (c) e taxas de ocupação (t) básicos determinados pela lei de zoneamento para as diferentes zonas da cidade. Na linha amarela temos o coeficiente de aproveitamento máximo em que se pode chegar ao aplicar a Fórmula de Adiron e sua respectiva contrapartida na diminuição da taxa de ocupação.

Adiron Ribeiro nos conta que existe nesta fórmula uma clara intenção sanitarista, uma vez que, se com maiores coeficientes os edifícios serão maiores e mais altos, eles deverão ser também mais esbeltos, para que sua massa construída não impeça uma ventilação e insolação adequada para a sua vizinhança.
Figura 2.4 - Tabela demonstrativa da aplicação da fórmula de Adiron. Fonte: elaborada pelo autor. 
"Para você melhorar, certamente, as condições de insolação, as condições de ventilação dos aposentos. É um problema basicamente de salubridade. [Outra vantagem] é que nós vamos poder deixar mais áreas de infiltração para as águas pluviais nas edificações. Isto que eu considero de extrema importância." ${ }^{\prime 2}$

Esta determinação da lei, no entanto, não traz apenas as óbvias conseqüências para a tipologia arquitetônica do edifício mas também para a implantação do edifício no lote e sua relação com a cidade em sua volta.

Partindo do princípio de que o empreendedor imobiliário, com intenção de diluir o custo do terreno no maior número possível de unidades, vai optar sempre pelo coeficiente de aproveitamento máximo permitido pela lei, os arquitetos, portanto, na hora da criação do projeto arquitetônico, trabalharão sempre com a taxa de ocupação mínima.

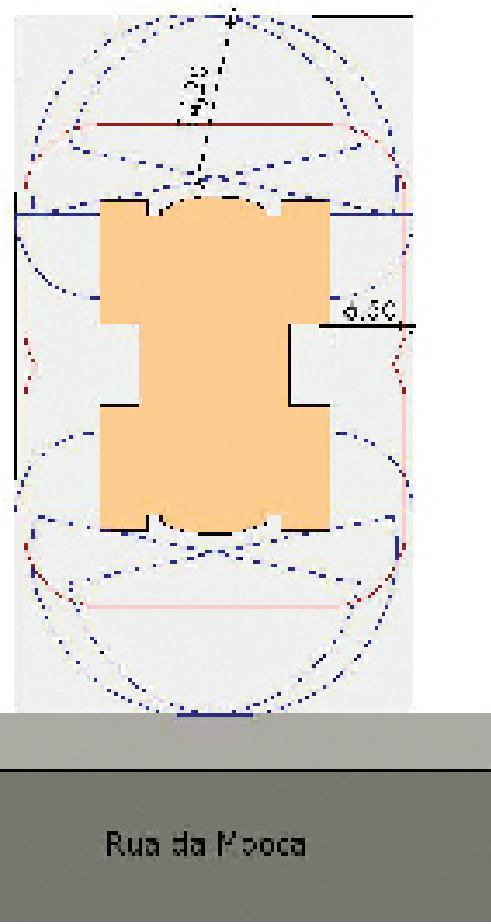

Figura 2.5 - Projeto com demosntração gráfica dos recuos exigidos. Fonte: elaborada pelo autor
A primeira e mais clara conseqüência da aplicação da fórmula de Adiron para a tipologia dos edifícios se refere à sua altura: o aumento da área construída em menor área de projeção faz com que a altura dos edifícios cresça em grandes proporções. No caso dos lotes contidos em Z2, zona mais abrangente da cidade, ao se aplicar a fórmula de Adiron pode-se dobrar o seu coeficiente de aproveitamento, passando de 1 para 2, mas, para isso, a área de projeção da construção deve ser diminuída pela metade. Isto significa que o edifício ficará quatro vezes mais alto do que ficaria caso não existisse este mecanismo na lei.

A massa construída e, por conseqüência, a altura do edif ício está diretamente relacionada com o tamanho do lote a ser edificado. Diferentes tamanhos de lotes configuram, portanto, diferentes alturas de edifícios. A altura do edifício, por sua vez, influencia diretamente o tamanho dos recuos obrigatórios exigidos por lei. Apesar da lei de zoneamento estabelecer recuos frontais, laterais e de fundos semelhantes para as principais zonas da cidade, o Código de Obras do Município ${ }^{13}$ estabelece faixas de ventilação e iluminação ${ }^{14}$ livres de construções, que
13. Lei 11.228 de 1992

14. Para melhor compreensão dos recuos exigido pela legislação urbana de São Paulo ver YASUNAGA, Emílio. Verticalizacão Habitacional no Município de São Paulo. São Paulo,

Dissertação de Mestrado - FAUUSP, 2007 especialmente 0 capítulo 4. estão diretamente relacionados com o número de andares da edificação, e que acabam por se configurar como recuos muito mais restritivos que os estabelecidos pelo zoneamento. Apresenta-se aqui uma segunda conseqüência da fórmula de Adiron: com o aumento da altura dos edifícios, efeito da aplicação da fórmula, as faixas de iluminação e de ventilação se tornam tão grandes e restritivas que não sobra outra opção para os arquitetos a não ser implantar o edifício no centro do lote.

A ilustração acima mostra a representação gráfica das faixas "A", de ventilação, em vermelho e "I", de insolação, em azul, exigidas pelo Código de Obras do Município. A faixa de ventilação deve circunscrever toda a construção a uma distancia calculada através da seguinte fórmula: 
Faixa $\mathrm{A}=3+0.35 \times\left(\mathrm{n}^{\circ}\right.$ de pavtos. -14$) \geq 3$.

A Faixa de Iluminação é representada por um semi-círculo cujo raio é calculado pela fórmula:

Faixa $\mathrm{I}=3+0.70 \mathrm{x}\left(\mathrm{n}^{\circ}\right.$ de pavtos. -8$) \geq 3$.

Por conta da grande altura dos edifícios, a faixa de iluminação se torna tão restritiva que, para implantar o edifício no terreno, algumas vezes é necessário chanfrar o canto de prédio.

Uma terceira conseqüência da aplicação da fórmula de Adiron, menos perceptível mas de fundamental importância para a cidade, se refere ao uso do solo. Para que não haja aumento na projeção do empreendimento e conseqüente diminuição do coeficiente de aproveitamento, a área do pavimento térreo não pode ultrapassar a área de projeção do pavimento tipo. Este fator, somado ao fato de o edifício estar implantado no centro do lote, desestimula o uso comercial do térreo por este estar situado longe da rua. É desta maneira que, após a Lei de Zoneamento de 72, o uso misto das edificações foi se extinguindo na cidade. Mesmo nas zonas que permitem usos diversificados dos seus lotes, essa diversidade se limitou apenas ao nível da quadra. Com a sistemática ocupação da cidade por empreendimentos imobiliários que buscam sempre o maior coeficiente, o uso misto vai ficando cada vez mais raro. No caso específico das Z11, Z13, Z17, Z18 e principalmente da Z2 - grande maioria da área da cidade - o uso misto das edificações fica impossibilitado, uma vez que a aplicação da fórmula de Adiron, condição sine qua non para qualquer incorporador, pode ser feita apenas para a categoria de uso R3, conjunto residencial.

O Conjunto Residencial, R3, tem suas características estabelecidas pelo artigo 19 da Lei 8.881 de $1979^{15}$ e uma das principais é a exigência de um círculo de 16 metros de diâmetro, descoberto, destinado a área de lazer. Considerando que o lote regular mínimo estabelecido por lei para a zona 2 tem as dimensões de 5 X 25 metros, é necessário pelo menos quatro lotes para que se possa cumprir esta exigência. Quatro lotes unidos configuram uma área de $500 \mathrm{~m}^{2}$; mas, pela fórmula de Adiron, nesta zona pode-se ocupar apenas $25 \%$ do lote, a área de projeção máxima desse empreendimento poderia atingir $125 \mathrm{~m}^{2}$, o que não é suficiente para um padrão econômico de construção, tipo "H", com quatro apartamentos por pavimento e a circulação vertical no centro. Tomemos como exemplo um edifício com quatro apartamentos de $50 \mathrm{~m}^{2}$ por pavimento, mais área para circulação vertical com escada e elevadores. Para um pavimento tipo com essas características é necessário uma laje com, ao menos, $220 \mathrm{~m} 2$. Considerando que a área do pavimento tipo é, na maioria das vezes, igual a área de projeção do empreendimento, significa que, para aplicação da Fórmula de Adiron, esta área deve corresponder até ao máximo

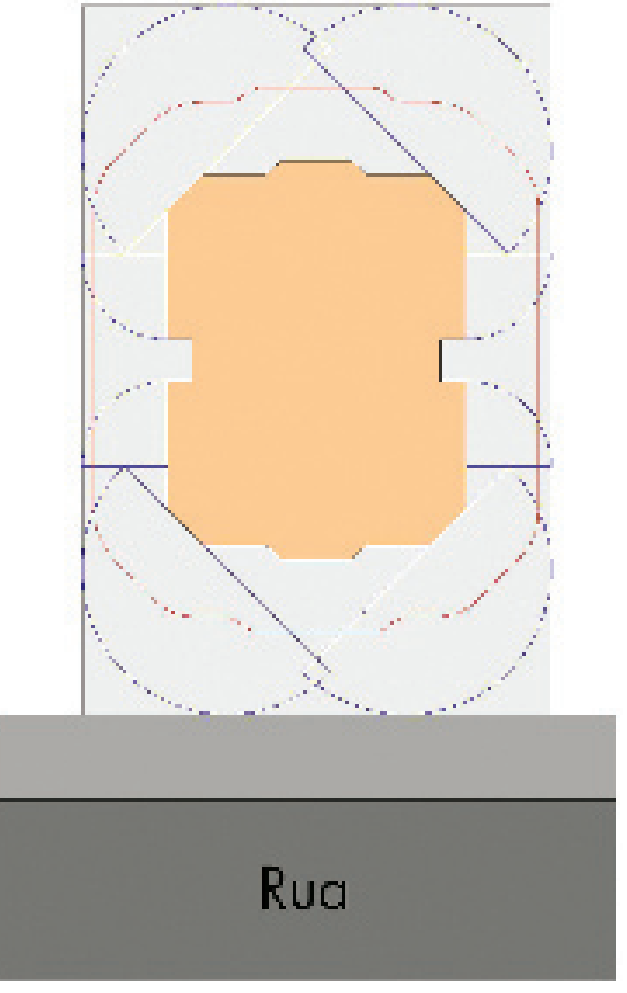

Figura 2.6 - Edifício em São Paulo com cantos chanfrados. A ilustração demostra que muitas vezes isso ocorre por conta da faixa de iluminação. Fonte foto: tirada pelo autor. llustração elaborada pelo autor.
15. 0 Art. 19 da lei 8.881 substitui o Art. 18 da lei 8.001 de 1973 . 
16. A distinção das fórmulas para terrenos maiores e menores de 1.000 metros acontece por ocasião de Lei 8.881 de 79. Anteriormente não havia esta distinção e a fórmula utilizada para todos os terrenos era a mais restritiva; posteriormente foi utilizada apenas para os terrenos menores que $1.000 \mathrm{~m}$
17. Informação pessoal fornecida em entrevista realizada em

8 de Novembro de 2007 em São Paulo. de $25 \%$ do tamanho total do lote que, portanto, necessitaria ser no mínimo quatro vezes maior, de $880 \mathrm{~m} 2$, ou seja, correspondente a sete lotes típicos da zona 2.

Analisando desta forma podemos perceber uma quarta conseqüência da fórmula de Adiron: ela acaba por limitar as oportunidades imobiliárias para os pequenos investidores, uma vez que sua aplicação requer condições que apenas operações de remembramento ou proprietários de grandes lotes podem cumprir, promovendo assim circunstâncias especiais para os incorporadores, circunstâncias especiais que não se restringem apenas à Z2. Como podemos observar na tabela acima, nas Z3, Z4 e Z5 a própria lei de zoneamento estabelece fórmulas diferentes para terrenos com áreas menores ou maiores que mil metros quadrados. Em terrenos com área menor que mil metros quadrados, para se atingir o coeficiente de aproveitamento máximo, a taxa de ocupação acaba se tornando muito mais restritiva que para terrenos maiores que esta área. ${ }^{16}$

Uma quinta conseqüência da fórmula de Adiron reside no fato da lei restringir a sua aplicação apenas ao uso residencial na maior parte da cidade. Nas Z2, Z11, Z13, Z17 e Z18, a condição da aplicabilidade da Fórmula de Adiron, e portanto a possibilidade de se atingir o coeficiente 2 , ser somente para o uso residencial, não incentiva o investimento em empreendimentos comerciais, fazendo com que muitas áreas sem vocação para o uso residencial, por estarem em avenidas de tráfego intenso ou em áreas de forte comércio de rua, mas inseridas nessas zonas, sejam desvalorizadas pelo mercado imobiliário, gerando muitas vezes abandono e degradação. Um caso exemplar é o da região do Largo da Batata, principalmente as ruas Cardeal Arcoverde e Theodoro Sampaio em seus trechos mais próximos à avenida Brigadeiro Faria Lima. Apesar de estarem inseridos em um dos eixos mais valorizados de São Paulo, o eixo Faria Lima - Berrini, com as torres comerciais mais modernas da cidade, esta região, por estar em uma Z2 e permitir aumento de coeficiente apenas para o uso residencial, permanece sem atrativos para a incorporação imobiliária.

Adiron Ribeiro conta que os membros do SECOVI chegaram a propor outras formas, que não a diminuição da taxa de ocupação, para se atingir um maior coeficiente de aproveitamento, como por exemplo, o pagamento de uma taxa extra para a Prefeitura de São Paulo. Adiron se negou a aceitar esta proposta por considerar que ela esbarraria na ética profissional.

"No SECOVI eram Paulo Germano, Romeu Chap Chap, Samuel Con e mais uma meia dúzia de outros cujo nome eu nem lembro mais. Mas gente boa, pessoal bom. Eu discutia com eles de forma bastante profissional. Eles me vieram com a seguinte proposta: 'escuta nós não podíamos, através de uma negociação, quem sabe pagando taxas extras ou coisa assim, nós não podíamos obter um coeficiente melhor?' Eu ouvi essa proposta e disse: não! Não podemos, não podemos! Mas se vocês quiserem negociar outra coisa eu aceito a negociação. Vocês têm aqui nesse quadro 2, na proposta de lei, a taxa de ocupação, que a meu ver é generosa, e não difere muito daquilo que é permitido no código de obras. [...] Então vamos negociar isso, não vamos negociar vocês pagarem uma taxa por fora para obter um coeficiente maior porque isso ai vira negociata, dei$x a$ de ser negociação e vira negociata! Vamos negociar a taxa de ocupação? Então vamos. Então começamos a negociar e levamos eu diria que um mês debatendo a negociação em torno da taxa de ocupação. [...] Eu não vou dizer que é produção matemática minha não... Eu estabeleci as condições: eu quero isto, eu que quero negociar a taxa de ocupação, se vocês me apresentarem alguma coisa em que a taxa de ocupação se reduza eu estudo, se for razoável, eu aceito." ${ }^{17}$ 
Podemos compreender que um funcionário público honesto como o arquiteto Adiron Ribeiro não olhasse com bons olhos qualquer tipo de pagamento em dinheiro como forma de contrapartida por um benefício conseguido. Também temos que considerar que as teorias que hoje embasam o planejamento urbano não estavam totalmente desenvolvidas na década de 1970, época em que a legislação foi formulada. São Paulo perdeu, no entanto, a oportunidade de se instituir, naquele momento, a "outorga onerosa", um dos instrumentos legais mais avançados para o combate de uma das principais modalidades de especulação imobiliária. Este instrumento foi usado pela primeira vez em São Paulo apenas em 1995, mas somente para a região contemplada pela lei 11.732, de março daquele ano, que instituiu a Operação Urbana Faria Lima. A outorga onerosa foi aprovada pelo Estatuto da Cidade em 2001 e implementada na cidade através do seu Plano Diretor, em 2002. O primeiro município brasileiro a instituir este instrumento, nove anos antes de sua aprovação pelo Estatuto da Cidade, foi Belém do Pará, com seu Plano Diretor, de autoria de Candido Malta Campos Filho, aprovado em 1993. A outorga onerosa é justamente uma taxa paga pelos empreendedores imobiliários à prefeitura dos municípios como contrapartida para se obter licença de construção acima do coeficiente básico gratuito, podendo atingir um coeficiente máximo, também definido por lei para cada zona de uso da cidade. Este montante em dinheiro seria então empregado para financiar a implementação de uma infra-estrutura urbana de suporte adicional exigida pela verticalização acima dos níveis básicos, que é geradora de valorização imobiliária.

Adiron Ribeiro considera a outorga onerosa desnecessária pois entende que a simples possibilidade de se construir mais irá gerar mais recursos para a municipalidade, na medida que aumentará a arrecadação do Imposto Predial Territorial Urbano (IPTU).

"A médio e longo prazo na zona em que você permite construções maiores já de cara, [...] você vai de fato recuperar o valor que você precisa para reforçar a infra-estrutura por que você vai pagar imposto e IPTU sobre muito mais [área construída] do que você pagaria se você fizesse térreo, se você fizesse dois pavimentos. Então o retorno que vai haver não vai ser a curto prazo [...]. E planejamento se faz a médio e a longo prazo, não se faz para obter vantagens hoje ou para fazer uma negociata hoje, não. Não é assim que se faz planejamento, você tem que enxergar os resultados a médio e longo prazo. Então é a forma do urbanista raciocinar, se ele raciocinar sempre com o curto prazo - 'pague agora porque você esta fazendo agora' - ele não estará fazendo conceitualmente planejamento urbano, ele estará fazendo uma imposição de arrecadação de dinheiro, que teoricamente seria só para prefeitura, para interesse coletivo, mas que infelizmente nós sabemos que não acontece bem assim, que acaba não sendo bem isso." ${ }^{18}$

Campos Filho considera, no entanto, que o IPTU, com "alíquotas variando de $1 \%$ a 3\% de um valor venal que, por sua vez, corresponde de $1 / 2$ a $1 / 20$ do valor real, de modo algum faz retornar à comunidade o investimento em infra-estrutura por ela realizado através do governo." (CAMPOS FILHO, 2001, p. 51)

Caso a contrapartida para o aumento do coeficiente não tivesse sido a taxa de ocupação, poderiam ter sido evitadas também as quatro primeiras conseqüências da aplicação da fórmula de Adiron citadas acima: o excessivo aumento na altura dos edifícios; os recuos restritivos que jogam o prédio para o centro do lote; o fato da área do pavimento térreo ter de se restringir à projeção do edifício, inibindo o uso misto das edificações; e as cir- 
cunstâncias especiais que indiretamente foram criadas para os grandes proprietários. Estas quatro conseqüências da aplicação da fórmula de Adiron estão relacionadas à diminuição da taxa de ocupação, e influenciaram diretamente a tipologia construída e a qualidade dos tecidos urbanos da cidade.

A aplicação da fórmula de Adiron, associada às exigências de faixas de iluminação e ventilação pelo Código de Obras, foi determinante para a formação de uma tipologia característica praticada pelo mercado imobiliário ao longo dos últimos quarenta anos na cidade de São Paulo. Tipologia esta bastante diferente daquela que podemos observar na região central ou em bairros como Santa Cecília e Higienópolis, que já se encontravam consolidados na ocasião do promulgação da lei de zoneamento de 1972. Esta tipologia pode ser claramente observada em regiões de maior concentração de renda, como Moema, Itaim Bibi, Vila Olímpia, Vila Nova Conceição, Tatuapé, Vila Leopoldina, entre outras, bairros que sofreram processos de verticalização nas últimas décadas e, portanto, foram edificados sob os parâmetros desta legislação. Uma tipologia de torres altas e estreitas, fisicamente isoladas, ocupando uma pequena parte do lote, com diferentes alturas e diferentes afastamentos da rua e, na maior parte da cidade, de uso exclusivamente residencial. Com pavimentos térreos cheios de equipamentos e serviços exclusivo para moradores e com implantações que não são mais objeto de um desenho urbano, suas áreas externas se tornaram apenas espaços residuais, resultado do que sobra da implantação do edifícios no lote, sem comunicação com cidade ao seu redor.

A conseqüência da independência física dos edifícios é que eles deixam de se relacionar espacialmente e formalmente entre si. A boa qualidade arquitetônica individual de diferentes edificações não pode por si só dar boa forma ao tecido urbano. "Um conjunto de qualidade, se não for integrado num contexto, surge desarticulado e desprovido de verdadeira significação, tal como um conjunto de belas palavras não chega para constituir uma frase. O discurso arquitetônico pressupõe a relação dos edifícios com o espaço urbano e o seu enquadramento numa estrutura" (LAMAS, 1999, p. 307).

Desde as mais antigas cidades até o período moderno, a edificação urbana foi dependente da divisão cadastral do lote. Construir a cidade foi também separar o domínio privado do domínio público. O espaço remanescente da implantação do edifício no lote deve ser compreendido como articulação entre estes domínios pois estabelece com o espaço urbano um diálogo que pode ser positivo, possibilitando uma conexão, ou negativo, representando uma segregação.

A tipologia resultante da legislação urbana de São Paulo, que vem sendo praticada pelos empreendedores imobiliários nestes últimos quarenta anos representa uma segregação. Além de reprimir o uso misto das edificações, que proporcionaria uma maior permeabilidade do público nos pavimentos térreos, maior presença de pessoas nas ruas nas diferentes horas do dia permitindo um uso mais democrático da cidade, favorece o aparecimento de bolsões de moradia para específicas faixas de renda, evidenciando os locais de maior renda e aumentando assim as tensões sociais. Tensões que acabam assumindo uma vertente de violência e de medo.

A discussão deste tema se torna importante na medida em que antropólogos urbanos, como Teresa Pires do Rio Caldeira, relacionam diretamente a forma urbana (e portanto a tipologia arquitetônica edificada) à violência. 
"Esse 'novo conceito de moradia' articula cinco elementos básicos: segurança, isolamento, homogeneidade social, equipamentos e serviços. A imagem que confere maior status (e é mais sedutora) é a da residência enclausurada, fortificada e isolada, um ambiente seguro no qual alguém pode usar vários equipamentos e serviços e viver só com pessoas percebidas como iguais. Os anúncios apresentam a imagem de ilhas para as quais se pode retornar todos os dias para encontrar um mundo exclusivo de prazer entre iguais. Os enclaves são, portanto, opostos à cidade, representada como um mundo deteriorado, no qual não há apenas poluição e barulho, mas, o que é mais importante, confusão e mistura, isto é, heterogeneidade social" (CALDEIRA, 2000, p. 265).

\section{4 - 0 TECIDO URBANO E SUA RELAÇÃO COM A TIPOLOGIA IMOBILIÁRIA.}

Vimos anteriormente que a escassez de terra é um obstáculo para a reprodução do capital de incorporação. Essa escassez é ainda mais acentuada nas áreas mais centrais e equipadas da cidade criando a necessidade, por parte do incorporador, de um permanente processo de requalificação simbólica do espaço urbano no intuito de criar novas localizações para a sua atuação. Dentro do ramo da incorporação imobiliária residencial esta prática se realiza através de três maneiras: 1) a destruição física de construções desvalorizadas dentro de áreas valorizadas; 2) a requalificação de áreas urbanas decadentes através de políticas públicas e investimentos públicos ou privados e 3) a expansão de fronteiras urbanas, criando novos espaços de moradia em áreas anteriormente suburbanas ou não urbanas. (Costa, 2002)

No processo de incorporação imobiliária, a terra, incorporada ao produto, tem como seu mais valioso atributo a sua localização física no espaço urbano, na medida em que isso representa o acesso aos equipamentos urbanos bem como a distinção da estratificação social. É interessante discutir como essa localização vai influenciar a formatação do produto imobiliário e, portanto, a sua tipologia.

Pedro Abramo relaciona a combinação dos bens que formam a "cesta de consumo" da mercadoria imobiliária ao grau de interesse do consumidor, elaborando gráficos de variação e troca entre as características de localização e tamanho do espaço do imóvel. Segundo Abramo, uma localização distante das melhores centralidades manteria o grau de interesse do consumidor de média e alta renda na medida que ele fosse ganhando mais espaço no seu imóvel. O mesmo aconteceria no sentido inverso: conforme fosse se aproximando das melhores centralidades, o imóvel continuaria interessante ao consumidor mesmo tendo seu espaço reduzido. (Abrano, apud Costa, 2002) ${ }^{19}$

Esse grau de interesse em imóveis menores que estão mais próximos das melhores centralidades se dá, logicamente, pelo fato delas oferecerem ao consumidor um tecido urbano real, pré-existente ao empreendimento, onde se encontra uma gama de equipamentos urbanos de transporte, serviço e lazer que não estão presentes nos tecidos urbanos menos desenvolvidos das áreas mais distantes.

Nas localidades mais distantes, onde os terrenos são maiores e mais baratos, mas o tecido urbano encontra-se em estágio menos desenvolvido e, portanto, não oferece a seus mo-
19. ABRAMO, Pedro. Mercado e Ordem Urbana. Rio de Janeiro: Bertrand Brasil / FAPERJ, 2001 
radores equipamentos urbanos que gostariam, os empreendedores imobiliários tendem a incorporar esses equipamentos ao próprio empreendimento.

Surgem então um número cada vez maior de empreendimentos repletos de equipamentos de serviços e lazer que incluem piscinas, quadra esportivas (e até campos de futebol), cinemas, academias de ginástica, salões de beleza, lan houses, mercados e até escolas, criando assim, dentro de suas enormes áreas um tecido "artificial", privatizando equipamentos característicos dos espaços públicos com a intenção inclusive de afastar a heterogênea periferia vizinha de seus consumidores.

"Em um dia comum, a dona-de-casa Adriana, 39, sai de manhã para a sua aula de ginástica, passa no salão de beleza para fazer as unhas, leva o filho ao curso de inglês (ou, dependendo do dia, para as aulas de natação, judô e futebol) e compra no mercadinho algum ingrediente que falta para o almoço. Ao fim do dia, ainda acompanha os treinos da filha na quadra de tênis e, se der, assiste a um filme no cinema com as suas amigas. Para fazer todas essas atividades, porém, nem Adriana nem seus filhos precisam colocar um pé que seja para fora do condominio em

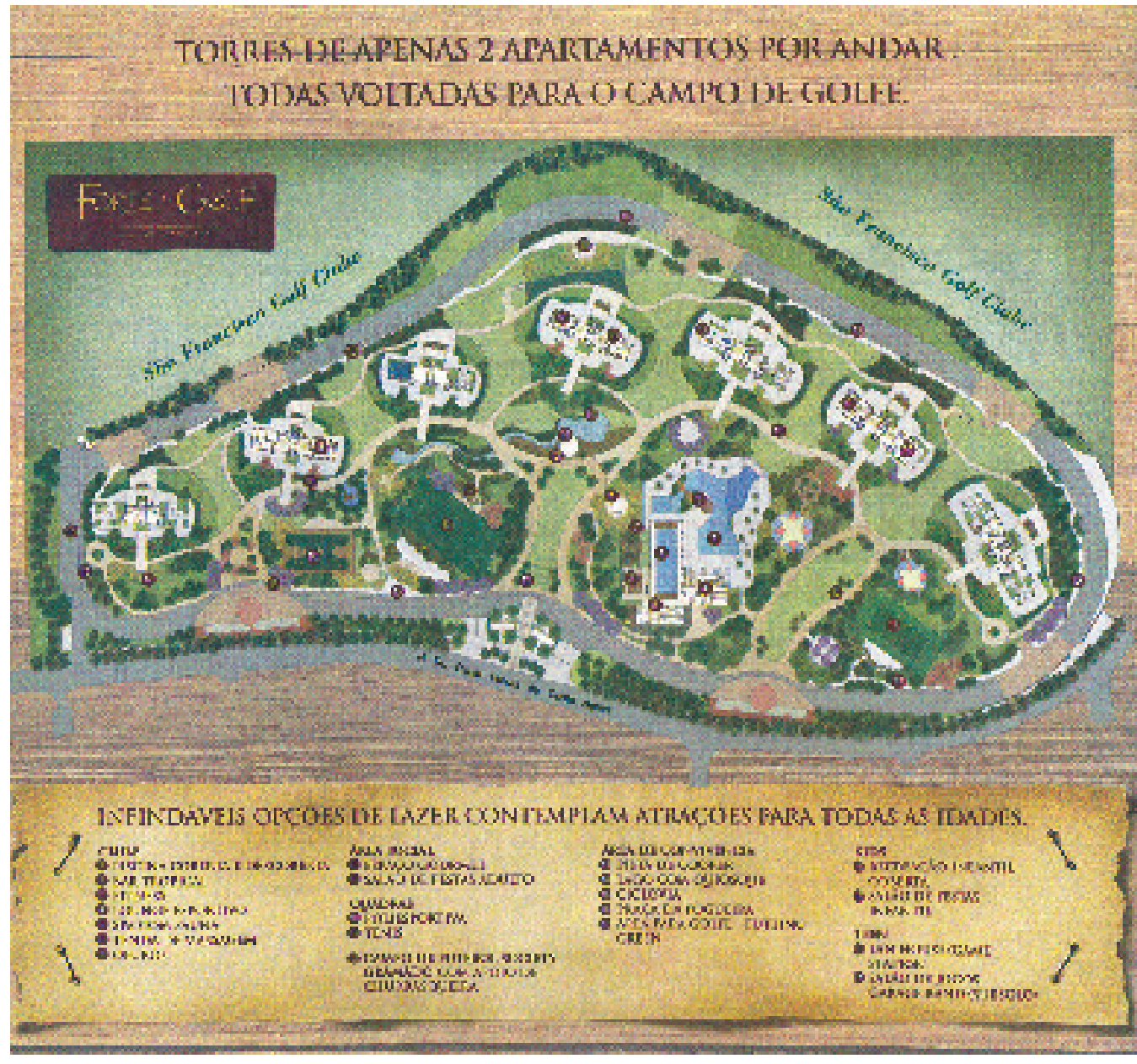

Figura 2.7 - Implantação do empreendimento Forte do Golf retirada do seu catálogo. A legenda mostra as "infindáveis opções de lazer". Fonte: catálogo retirado do estande de vendas em julho de 2005. que vivem, na zona sul de São Paulo." (Texto retirado da reportagem 'Novos prédios estimulam o enclausuramento'. FOLHA DE S. PAULO, Caderno COTIDIANO, 19 de junho de 2005.)

Ao criar dentro de suas áreas um tecido "artificial", cuidadosamente planejado e miraculosamente transformado, os empreendimentos tornam-se sistemas autônomos que permitem uma prática social que não depende dos outros sistemas ao seu redor. Passa a ocorrer então uma negação do seu entorno imediato e uma valorização apenas do que é privado em detrimento do que é público.

O processo de desenvolvimento da cidadania e da tolerância também ficam prejudicados, uma vez que se trata de ambientes herméticos, afastados da diversidade das ruas, socialmente homogêneos e que valorizam apenas a convivência entre iguais.

Os empreendimentos, com seus longos perímetros cercados ou até murados, dão as costas para a 
maior parte do sistema viário que os circunda, acarretando em ruas e calçadas mal conservadas e abandonadas, que permanecem desertas por também serem mal vigiadas, uma vez que o cuidado e a segurança estão concentrados apenas na única portaria de acesso ${ }^{20}$.

"As pessoas têm uma "neura" de segurança e, em vez de exigir que os problemas da cidade sejam resolvidos, retiram essa responsabilidade do poder público, passam a viver em espaços privados e satisfazem seus desejos individualmente. O indivíduo ganha. O cidadão perde".21 (Texto retirado da reportagem 'Urbanistas criticam o isolamento de morador', FOLHA DE S. PAULO, Caderno COTIDIANO, 19 de junho de 2005.)
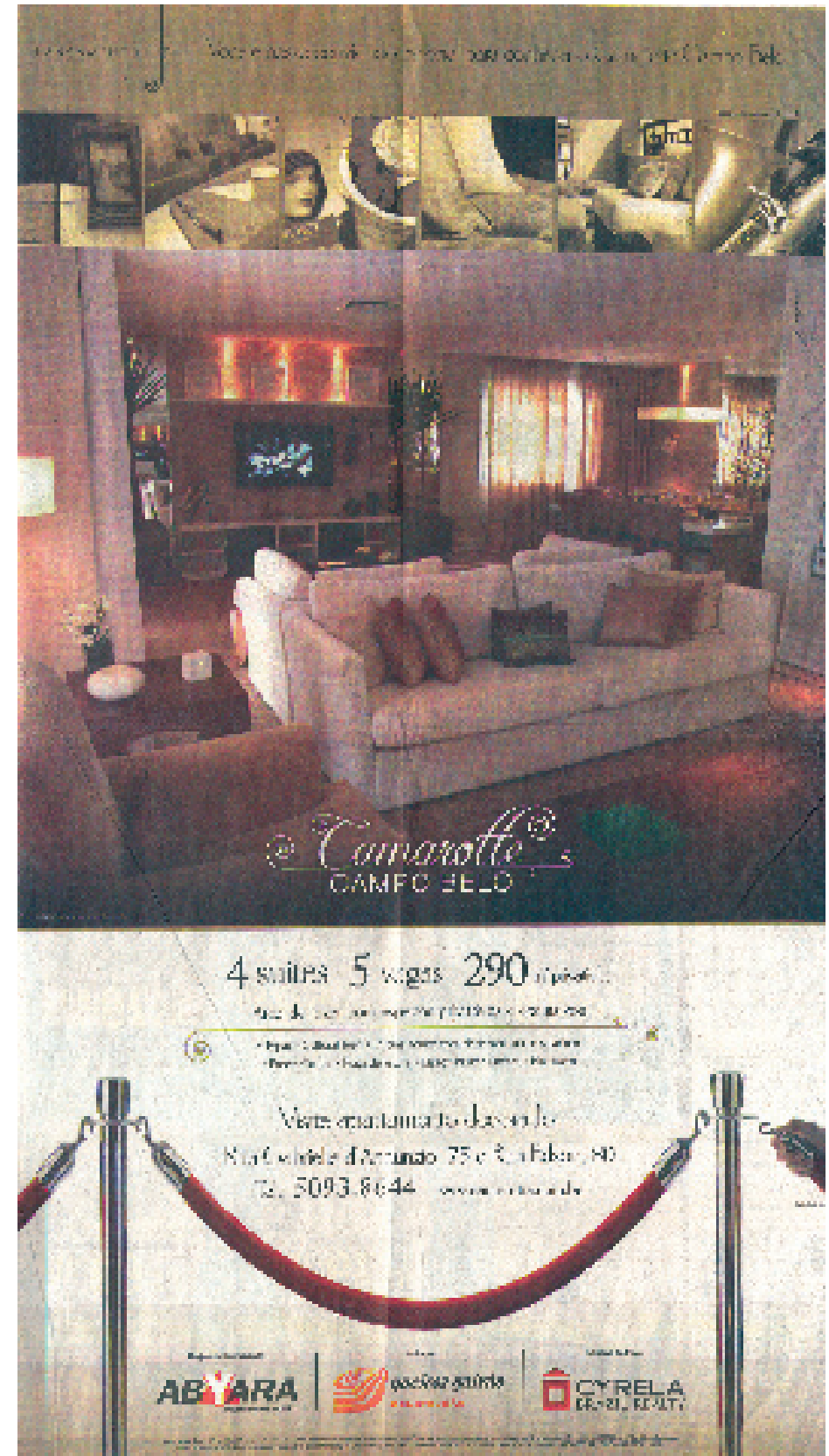

20. Ver Fotos 8 e 9 em CALDEIRA, 2000, p. 246

21. Texto atribuído a Margarida Limena diretora da Faculdade de Ciências Sociais da PUC de São Paulo.

Figura 2.8 - Anúncio de página inteira de jornal mostra o empreendimento Camarotte Campo Belo. 0 nome "camarotte" já pressupõe ambientes exclusivos. Mas o texto reforça: "áreas de lazer com espaços privativos e exclusivos". Barreiras de pessoas ilustram 0 anúncio.

Fonte: Folha de S. Paulo de 18 de março de 2007. 


\section{5 - O MARKETING IMOBILIÁRIO E A SUA RELAÇÃO COM A TIPOLOGIA.}

Como vimos no início deste capítulo, a longa duração do ciclo de reprodução do capital da indústria imobiliária também cria dificuldades para a sua acumulação se considerarmos que, segundo TOPALOV (1979, p.111), o cálculo econômico do incorporador imobiliário se baseia na seguinte fórmula:

Taxa de Lucro $(\pi)=$ Lucro Líquido (G)

Capital Investido(C) X Tempo de retorno (t)

Observando esta fórmula ficam claras as estratégias para a maximização da taxa de lucro do capital de incorporação, onde pode-se aumenta-la com a minimização do capital investido ou com a diminuição do tempo de retorno deste capital.

Para garantir a eficiência dessas duas estratégias as empresas incorporadoras, nos últimos anos, têm investido cada vez mais num tipo de profissional especialista que, dotado de novas abordagens e instrumentações, vem conquistando cada dia mais espaço nos processos decisórios de formatação de seu produto: o profissional de marketing.

Philip Kotler define o marketing como "o conjunto de atividades que têm por objeto a facilidade de realização de trocas" (apud COSTA, 2002, p. 67). A abrangência da abordagem do marketing no processo produtivo se dá antes mesmo da realização da troca, compreendendo o desenvolvimento, avaliação e controle da produção, através do que chamam de "4Ps": Produto, Preço, Praça e a Propaganda(COSTA, 2002, p. 89).

Dessa forma, pretende-se agir de maneira a integrar as ações do incorporador, desde as fases de pesquisa das preferências dos consumidores, passando pela concepção do produto, até as estratégias de comercialização e divulgação do mesmo. É neste momento que o marketing imobiliário se apresenta como um novo instrumento de valorização e realização do capital de incorporação, posicionando a empresa no mercado e agregando valor ao seu produto desde a fase de produção até a sua divulgação.

O marketing imobiliário pode agregar valor ao seu produto, e conseqüentemente, aumentar seu preço de venda na medida em que estabelece nichos de mercado adequados, cria diferenciais competitivos e atrativos e posiciona a empresa no mercado criando uma grife imobiliária. Pode promover ainda a diminuição dos custos financeiros através do aumento da velocidade de vendas; diminuição dos custos de produção da obra estabelecendo aceitação de padrões de moradia que propiciem otimização dos recursos, tais como o barateamento dos acabamentos, a diminuição da metragem total dos apartamentos e o conseqüente aumento de frações ideais, diminuindo o custo do terreno na composição final do preço do imóvel e, finalmente, diminuindo os custos do terreno por (re)criar simbolicamente uma localização, valorizando áreas onde o terreno é mais barato.

A partir desse planejamento integrado que a gestão de marketing estabelece dentro da empresa imobiliária visando o máximo valor de troca para seus produtos, destaca-se a importância da comunicação destes, como forma de conceituá-los, ressaltar as suas vantagens e diferenciá-los frente à concorrência com o objetivo de atingir os consumidores desejados. 
Na sociedade atual, baseada numa cultura de consumo, a inserção da esfera cultural na produção industrial se torna um dos sustentáculos do capitalismo moderno. A cultura se torna uma alavanca ao consumo de mercadorias na medida em que estas, associadas a signos e imagens, passam a ter o poder de criar vínculos e estabelecer distinções sociais. Cada compra se torna um ato de construção da própria identidade do indivíduo e o produto adquirido, juntamente com toda a sua carga simbólica, contribui na caracterização e posicionamento deste indivíduo frente à sociedade.

O posicionamento de uma empresa imobiliária e de seu produto é definido pela maneira como ela o comunica aos seus consumidores. É nesta filosofia, orientada ao consumidor, que o marketing baseia as suas decisões de projeto. A comunicação do produto torna-se mais importante que o produto em si, e é com base nela que este será formatado.

É neste contexto que a publicidade assume o papel de protagonista na formação da imagem e de seus significados, passando a descrever e divulgar não mais um produto, mas um "estilo de vida" a ele associado. $\mathrm{O}$ produto é revestido de emoção, identidade e atitudes capazes de estabelecer uma atmosfera simbólica que, junto com ele, é consumida.

A imagem do produto imobiliário, associada a um conceito e a um discurso, é capaz de aumentar o seu preço de venda sem aumentar seu custo de produção; possibilita ainda a antecipação de sua venda e a realização mais rápida dos lucros.

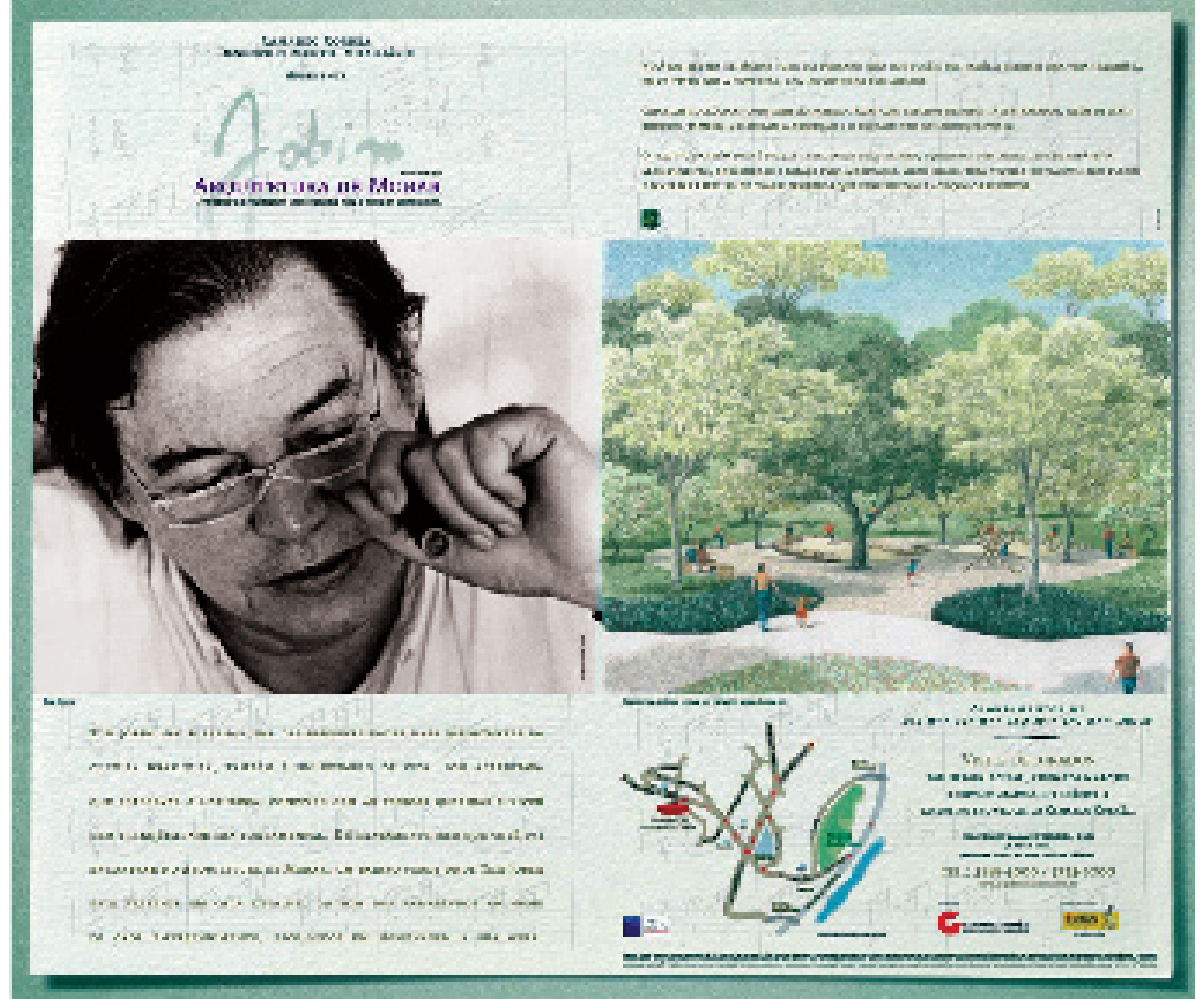

Figura 2.9 - Folheto virtual do empreendimento "Jobim - Arquitetura de morar" Fonte: www.arquiteturademorar.com.br em março de 2007.

“(...) As pessoas compram desenho de produto e não o produto. Então a gente faz esses materiais [mostra panfleto publicitário]. Aqui o que a gente vende na verdade são desenhos. Então você vê: é tudo fotografia, desenho de lobby, desenho de fachada; na verdade a gente não está vendendo o tangível. Por enquanto aqui a gente está vendendo um sonho. Então a gente participa diretamente da plástica do negócio. Aqui, por exemplo, acabaram de lançar um produto que é um dormitório com $70 \mathrm{~m} 2$ com um preço exorbitante. Vendeu tudo!" (Rogério Santos, gerente de marketing da TECNISA, apud Costa, 2002, p. 89 e 90).

A influência da propaganda imobiliária não se dá somente nas etapas finais de venda e divulgação, mas também na definição do produto, utilizando sua capacidade persuasiva e expressiva para influenciar no partido arquitetônico que se vai adotar.

"Os produtos imobiliários estão com valores agregados e isso a agência [de publicidade] tem participado bastante, realmente, de criar diferenciais, de destacar essa segmentação, isso émui- 
to legal. O mercado imobiliário consegue focalizar um nicho de terceira idade, um nicho assim de "singles"; a gente usa essa linguagem, a gente lança apartamentos que tem caras separados, desquitados, gente que gosta de viver sozinha, a gente cria essa comunicação, e o empreendimento tem uma série de serviços para atender esse tipo de consumidor; tem imóveis para a terceira idade, que é uma outra série de produtos e de serviços para atender esse segmento. Então a agência tem participado bastante nos valores e nos serviços desses produtos e a comunicação é um reflexo desse tratamento, dessa pesquisa. Diferente do Mercado Imobiliário do passado, onde você tinha um produto único, quer dizer, você vendia um espaço, $60 \mathrm{~m} 2$ e a publicidade tinha que se desdobrar e inventar moda para tornar aquele produto diferente, atrativo..." (Maurício Eugênio, sócio da Eugênio Publicidade, especializada em propaganda imobiliária, apud Costa, 2002, p. 77).

A propaganda se torna um instrumento fundamental para a formação de valores arquitetônicos, recriando e recodificando os hábitos e preferências no consumo do espaço. Os limites da criação publicitária e da criação arquitetônica ficam então obscuros. A busca de valores de uso inerente ao trabalho do arquiteto se ofusca frente à necessidade, por parte do empreendedor imobiliário, de um produto com alto valor de troca. Fica então visível a perda de importância do arquiteto e urbanista na definição desses valores frente ao profissional de marketing que se propõe a metaforizar o consumo da arquitetura e se introduz como o emissor das decisões nesse processo de produção e transformação do espaço, que tanto influencia a paisagem urbana. 
CAPÍTULO 3

\section{LEVANTAMENTO E ANÁLISE DE TIPOLOGIAS DE EDIFÍCIOS RESIDENCIAIS}




\section{1 - INTRODUÇÃO}

Neste capítulo analisaremos as tipologias de alguns edifícios construídos na cidade de São Paulo em diferentes épocas. O objetivo desta análise é avaliar as tipologias próprias de cada época e quais os fatores que a influenciavam. Para isso foi feito um levantamento de treze edifícios residenciais, construídos em locais e datas diferentes na cidade de São Paulo. Não se trata de edifícios considerados exemplares por seu interesse arquitetônico ou histórico, mas edifícios comuns, ou "ordinários" como se referia Panerai ${ }^{1}$, que constituem a paisagem da maior parte da cidade. Para observar os fatores referentes à legislação urbana que influenciaram suas tipologias, foram analisadas as plantas apresentadas para a apreciação dos técnicos municipais na ocasião da construção de cada um dos edifícios. Através da análise destes documentos foi possível também aferir os padrões urbanísticos de aproveitamento, ocupação dos lotes, recuos e massa construída além de indícios sobre a sua configuração produtiva. Foi feito também uma análise da evolução dos tecidos urbanos de cada micro-região onde os diferentes edifícios foram implantados através da comparação do mapa GEGRAN, elaborado em 1972, com uma foto aérea atual. Foram feitas ainda duas maquetes eletrônicas de cada uma das micro-regiões onde pode-se observar em perspectiva a altura e a massa construída das construções do entorno. A primeira maquete mostra o uso das edificações (residencial, comercial, serviços ou institucional). A segunda maquete mostra a provável configuração produtiva das construções (autoconstrução, por encomenda, rentista, incorporação imobiliária ou pública). A intenção deste levantamento é que ele sirva como uma base de dados empíricos para uma análise da evolução dos tecidos urbanos e tipologias, possibilitada pela comparação dos exemplos escolhidos.

Para execução deste levantamento foi usado como base de dados a carteira de edifícios residenciais administrados por uma tradicional empresa administradora de condomínios e bens imóveis da cidade de São Paulo. Após catalogação de todas as unidades foi feita uma entrevista com o diretor responsável pela empresa para saber quais as condições em que cada um dos edifícios fora construído. O principal objetivo desta entrevista foi descobrir quais foram construídos para que suas unidades fossem vendidas, o que caracteriza uma incorporação imobiliária e quais foram construídos para que suas unidades fossem alugadas, caracterizando um rentismo.

\section{2 - IDENTIFICAÇÃO DA BASE DE DADOS: O ESCRITÓRIO ALMEIDA LEITE.}

A base de dados empíricos em que foi realizado o levantamento se baseia na carteira de prédios residenciais que são administrados pelo Escritório Almeida Leite, tradicional escritório de administração de bens imóveis de São Paulo.

"O Escritório Almeida Leite foi fundado em 17 de dezembro de 1940 por Jorge Barnsley Pessôa e Paulo Mendes de Almeida. Leite, para o exercício de "arrendamento de propriedades e locação a terceiros", como suporte à banca de corretagem de imóveis, na qual militavam o Cel. Aristides de Almeida Leite, que já na época era antiga e grandemente conceituada na cidade de São Paulo.

Hoje sua sede se localiza no Jardim América, após ter estado 20 anos na Rua Álvares Penteado 
e outros 30 anos na Rua Marconi. Sua direção é exercida pelos sucessores do fundador, Jorge Barnsley Pessôa Filho, Marcelo Bocaiuva Barnsley Pessôa, Shirley Pontes e Silvana Mendes Couto que, em função de suas formações específicas, dirigem o Escritório Almeida Leite contando com uma equipe de profissionais qualificados e com um moderno sistema informatizado, acessando diretamente a rede bancária recebedora e pagadora, resultando em uma prestação de contas clara e segura.

Nestas mais de seis décadas de existência, o Escritório Almeida Leite foi e é honrado como procurador de inúmeras personalidades, tais como ex-governadores, a exemplo de Adhemar de Barros, Lucas Nogueira Garcez, Carlos Alberto Carvalho Pinto e imortais como Plínio Barreto e Lygia Fagundes Telles, somente para citar alguns entre nossos mais de mil clientes, muitos deles de famílias cuja administração já percorre cinco gerações."

Em meados da década de trinta, o então Deputado da Assembléia Constituinte do Estado de São Paulo e candidato à Presidência da República, Ademar Pereira de Barros, compra um edifício de oito pavimentos com 16 apartamentos, localizado na Al. Eduardo Prado, nos Campos Elísios, que estava sendo comercializado pelo o Cel. Aristides de Almeida Leite, importante corretor daquela época. Após o golpe militar de 10 de novembro de 37, chefiado pelo presidente Getúlio Vargas, que implantou o Estado Novo, cancelando as eleições e suprimindo os partidos políticos e os órgãos legislativos do país, Ademar perde seu mandato de deputado estadual, e considerando sua situação política instável, resolve exilar-se fora do pais. O Cel. Aristides indica a Ademar de Barros o engenheiro Jorge Barnsley Pessôa, recém formado na Politécnica, e amigo de seu filho para "tomar conta" do edifício recém comprado enquanto ele estivesse fora do pais. Ademar de barros retorna ao Brasil, em abril de 1938, como interventor do governo do Estado de São Paulo, e satisfeito com os serviços executados pelo eng. Pessôa, entrega toda a sua carteira de bens imóveis para que este administre. Assustado com tamanha responsabilidade, Pessôa procura o Cel. Aristides e junto com ele e seu filho Paulo Mendes de Almeida Leite fundam, em 1940 o Escritório Almeida Leite, primeiro escritório de administração de bens imóveis do pais. Nestes mais de sessenta anos de existência, além de administrar bens de terceiros, incorporou alguns prédios e passou a administrar condomínios. ${ }^{3}$

\section{3 - FORMAÇÃO DA BASE DE DADOS.}

Dos 47 edifícios residenciais administrados pelo Escritório Almeida Leite apenas 13 $(27,6 \%)$ tinham suas plantas arquivadas em poder da empresa administradora. É muito comum que as plantas fiquem em poder dos síndicos dos edifícios no próprio condomínio; também podem estar emprestadas a algum morador ou ter sido perdidas ao longo do tempo. Os motivos que levaram a empresa administradora estar em posse das plantas desses 13 edifícios é aleatória e externa à esta pesquisa.

Considerando que $27,6 \%$ representa uma boa amostragem do total dos edifícios administrados pelo escritório, usaremos as informações disponíveis destes edifícios para a nossa análise comparativa das tipologias praticadas de 1944, data do edifício mais antigo com plantas disponíveis, até 1998, data do edifício mais recente.
2. Texto retirado do site: www.eal.com.br

3. Informações conseguidas através do site www.eal.com.br e entrevista realizada em 17 de abril de 2007 com o diretor proprietário Jorge Barnsley Pessôa Filho. 
Os edifícios com plantas disponíveis são:

1. Edifício sito à rua Piauí, 1207, de 1944;

2. Edifício sito à rua Frederico Abranches, 136, de 1944;

3. Edifício sito à rua Caiubí, 200, de 1946;

4. Edifício sito à da rua Bela Cintra, 619, de 1953;

5. Edifício sito à rua do Triunfo, 134, de 1956;

6. Edifício sito à rua da Consolação, 3721, de 1966;

7. Edifício sito à rua São Vicente de Paula, 435, de 1968;

8. Edifício sito à rua Arthur de Azevedo, 1411, de 1973;

9. Edifício n 19, da rua Jesuíno Arruda, 521, de 1973;

10. Edifício sito à rua Sergipe, 309, de 1979;

11. Edifício sito à rua Lourenço de Almeida ,567, de 1987;

12. Edifício sito à rua Ouro Branco, 101, de 1992;

13. Edifício sito à rua Iperoig, 418, de 1998.

Figura 3.1

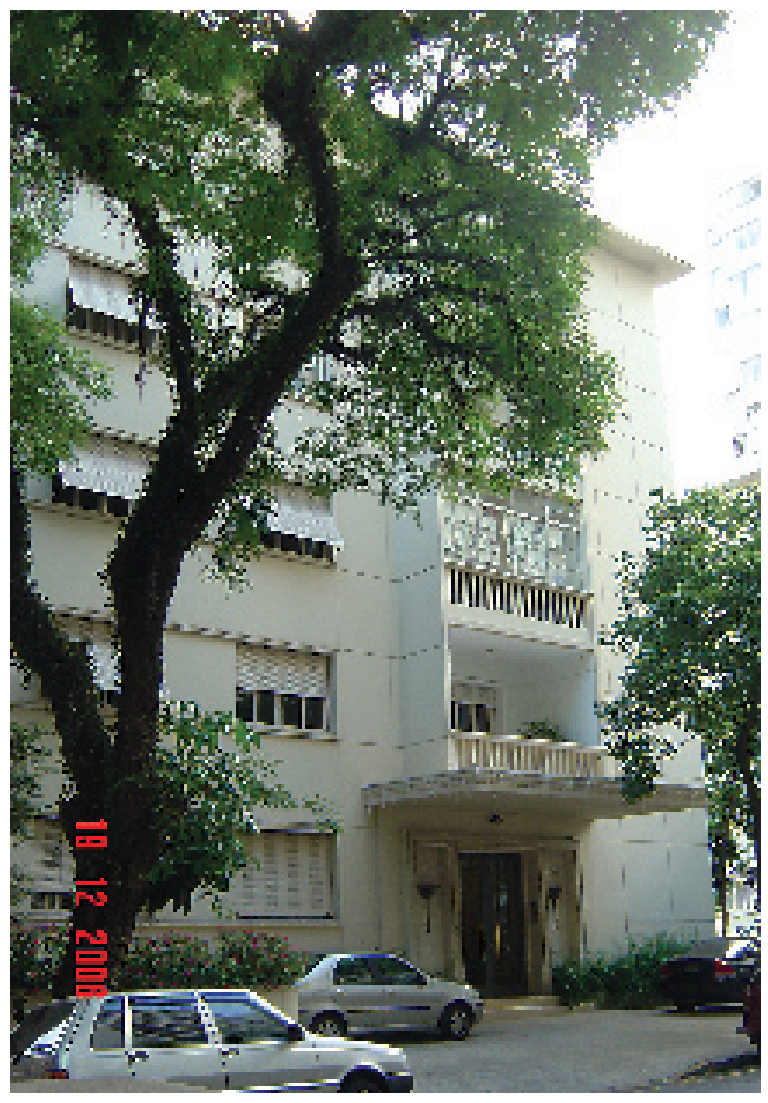

\section{EDIFÍCIO No 1}

- Endereço: Rua Piauí, n 1207 , Higienópolis.

- Data da construção: 1944.

- Edifício de uso exclusivamente residencial.

- Atualmente constitui um condomínio.

- Não temos informaçõe precisas a respeito do propósito de sua construção, se para renda ou para venda.

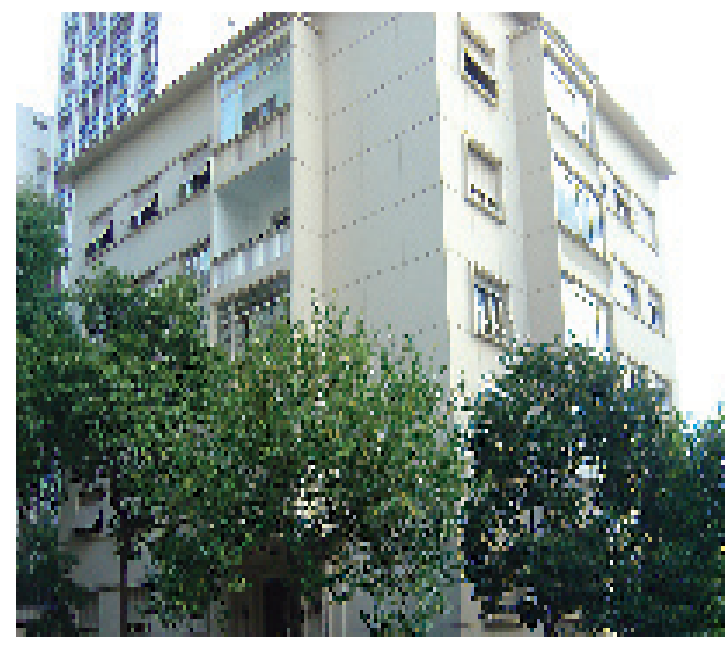

Figura 3.2 


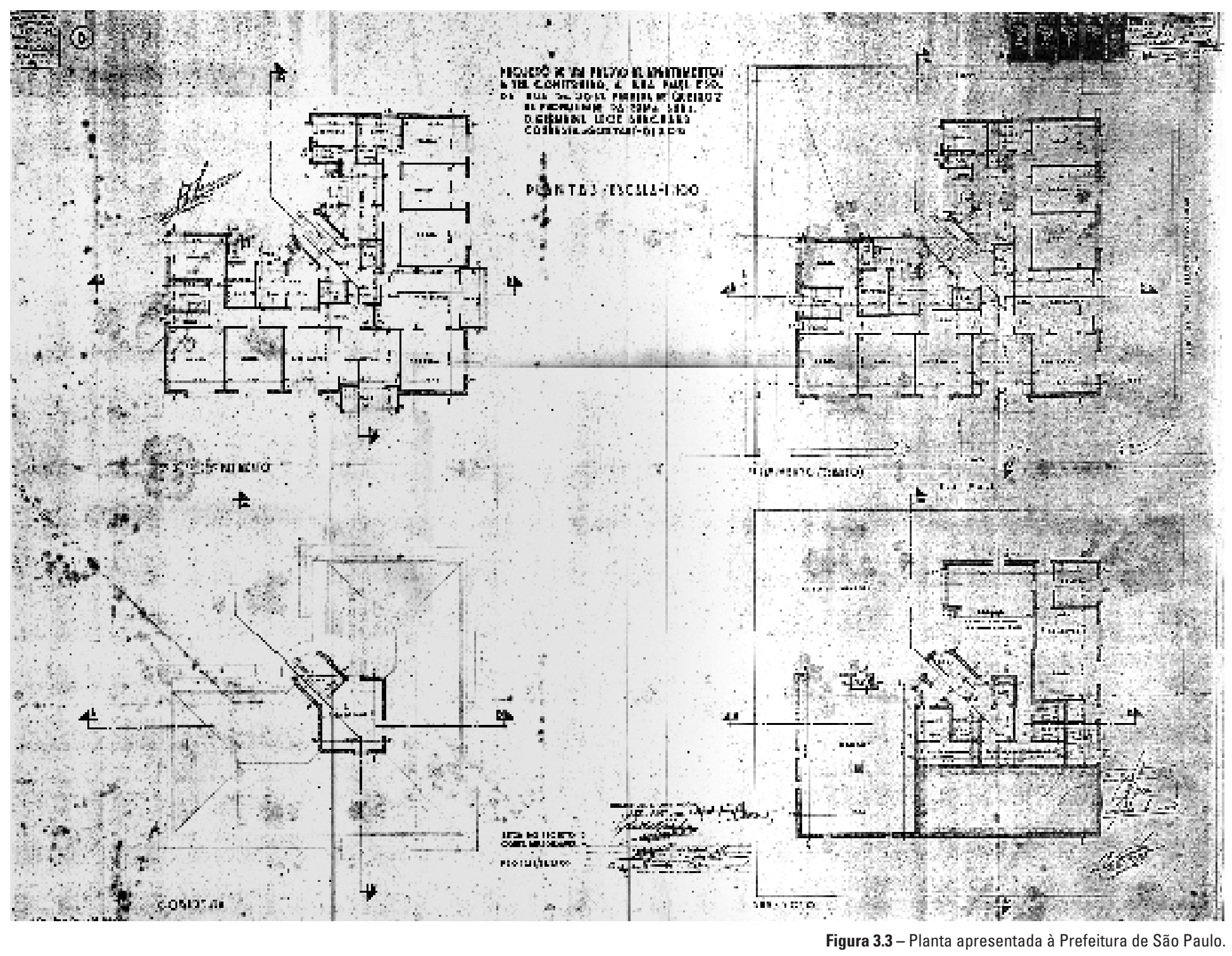

Figura 3.4 - Carimbos no verso da planta
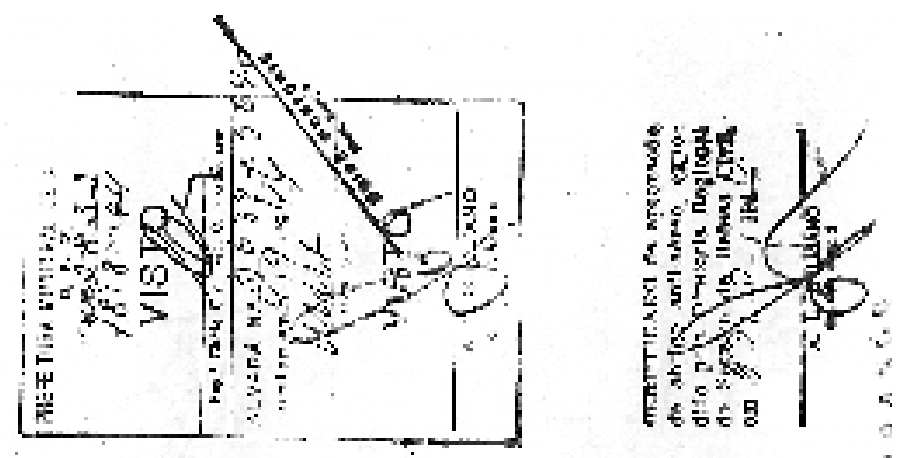

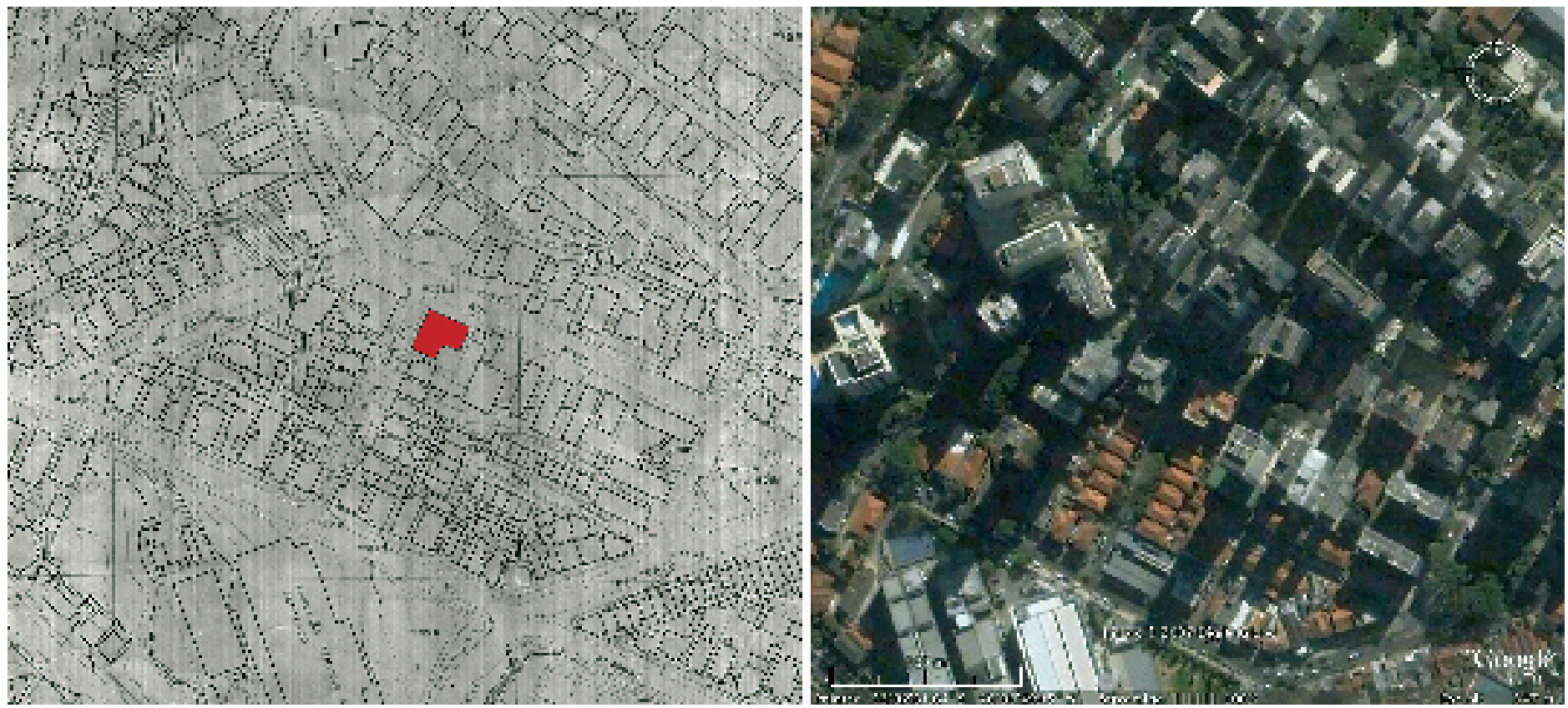

Figura 3.5 - Mapa do Gegran, de 1972, da região da rua Piauí e foto aérea recente do mesmo local. (Fonte foto: Google Earth)
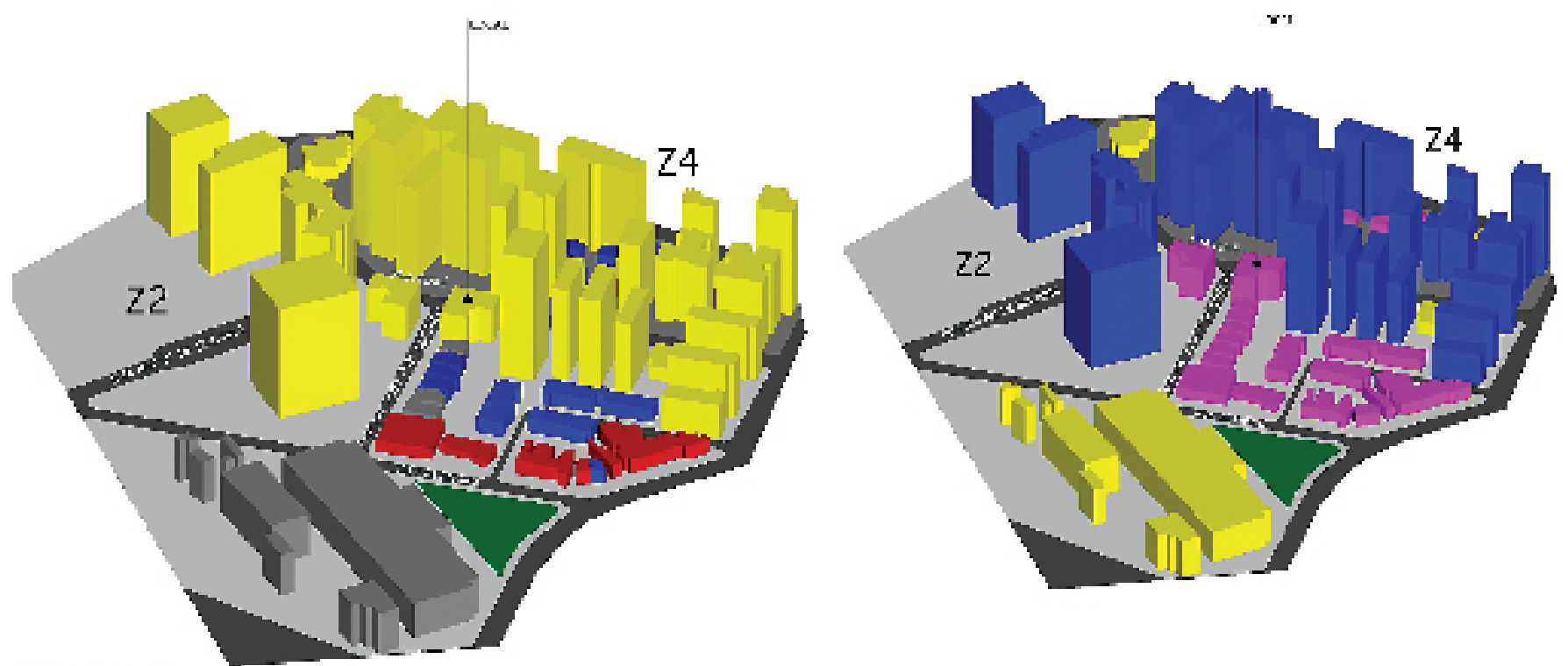

SOS ATULS 5

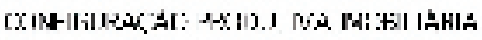
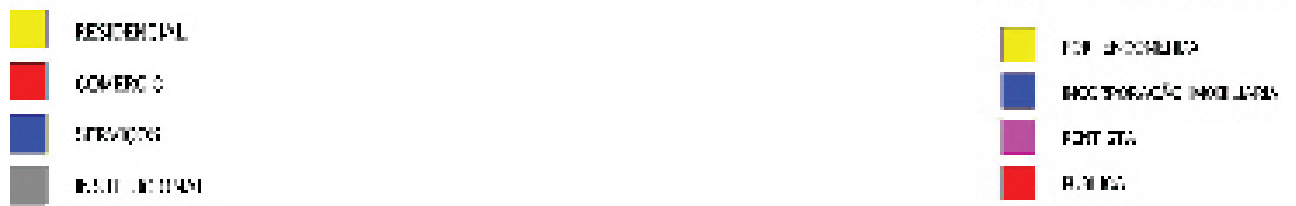

Figura 3.6 - Lavantamento do tecido urbano da rua piauí, esquina com rua Dr. José P. de Queiroz. (Fonte: elaborado pelo autor a partir de levantamento de campo) 
Trata-se de um edifício exclusivamente residencial, projetado e construído pela empresa Arquitetura e Construções LUZ-AR Ltda de responsabilidade de Alfredo Pereira de Queiroz, para a Sra. Germaine Lucie Burchard, "Condessa de Gontaut - Biron". O edifício tem um subsolo, pavimento térreo e quatro pavimentos tipo. Foi implantado com afastamentos de 4,00 m para a rua Piauí, 5,97 m para a rua Dr. José Pereira de Queiroz e com recuos laterais de $3.00 \mathrm{~m}$ e $3.50 \mathrm{~m}$. O subsolo é apenas meio enterrado e lá estão localizadas a entrada de serviço, com acesso à escada e ao elevador de serviço, as garagens, com capacidade para seis veículos, pátio de manobra descoberto, o apartamento do zelador, vestiários para funcionários, casa de bombas, caixa d'água e sala de descontaminação. No subsolo encontramos ainda uma exigência da municipalidade própria para uma época de guerra: um abrigo anti-aéreo com capacidade para 72 pessoas. No pavimento térreo encontram-se a entrada social, com acesso ao elevador social, à escada e ao elevador de serviço e dois apartamentos com três dormitórios, dois banheiros, salas de estar e jantar, varanda, cozinha, terraço de serviço e dependências de empregada. Em cada um dos quatro pavimentos tipo encontram-se mais dois apartamentos com as mesmas características, totalizando 10 unidades de aproximadamente 171,46 m2. Pelo programa e área dos apartamentos e pela presença de garagens para autos no subsolo podemos concluir que eram destinados às classes com renda média ou média alta. Sendo pavimento térreo mais quatro pavimentos tipo, cada qual com aproximadamente com 342,93 m2, contabilizamos uma área computável total de 1.714,66 m2. Se dividirmos pela área do terreno, de 827,73 $\mathrm{m} 2$ teremos um coeficiente de aproveitamento igual a 2.07. Se dividirmos a área do pavimento tipo de $342,93 \mathrm{~m} 2$ pela área do terreno termos uma Taxa de Ocupação igual a 0.414 .

Localizado em um lote de esquina entre a rua Piauí e a rua Dr. José Pereira de Queiroz, em Higienópolis, o edifício está situado em uma Z2. Podemos verificar pelo levantamento do tecido urbano da região que existe uma forte predominância de edifícios residenciais, a maioria de altura bem superior ao edifício estudado. Podemos reparar também a presença de alguns renques de pequenas residências situados na Z2, entre a rua Piauí e a rua Alagoas. Essas antigas residências estão atualmente todas ocupadas pra estabelecimentos comerciais ou empresas prestadoras de serviços. Existe ainda na região uma grande área institucional de ensino: o campus da Fundação Armando Álvares Penteado (FAAP). Recentemente um grande empreendimento residencial ocupou os terrenos das casas existentes ao lado esquerdo de quem sobe a rua Dr. José P. de Queiroz. Este empreendimento é posterior à data da foto aérea e por isso aparece somente no levantamento do tecido urbano da região. 


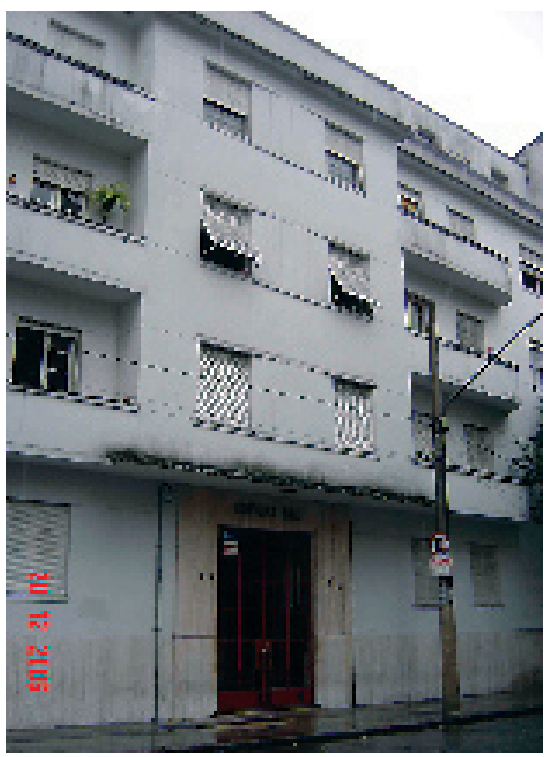

Figura 3.7 - Foto de edifício.

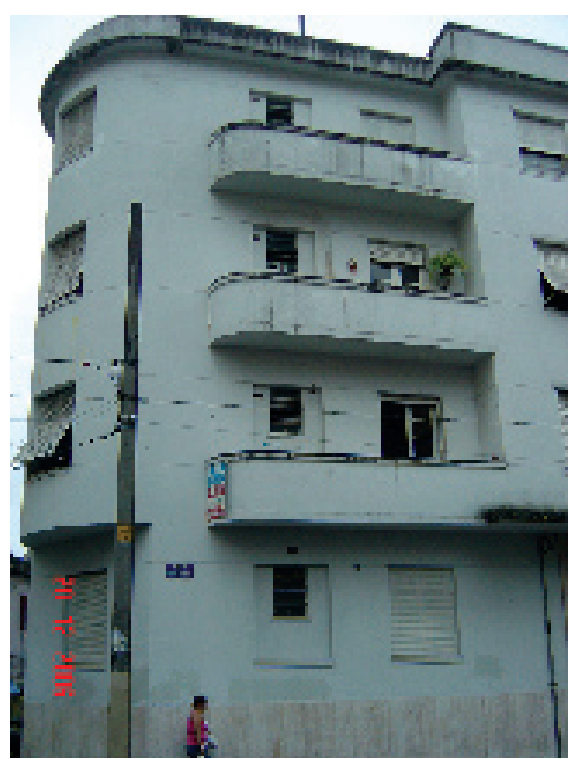

Figura 3.8 - Foto de edifício

\section{EDIFÍCIO N² 2}

- Endereço: Rua Frederico Abranches, nº 136, Santa Cecília.

- Data da construção: 1944.

- Edifício de uso exclusivamente residencial, com oito unidades.

- Constitui um domínio, ou seja, todos as unidades pertencem a um mesmo proprietário ou seus descendentes.

- Construído para a renda de seu proprietário.
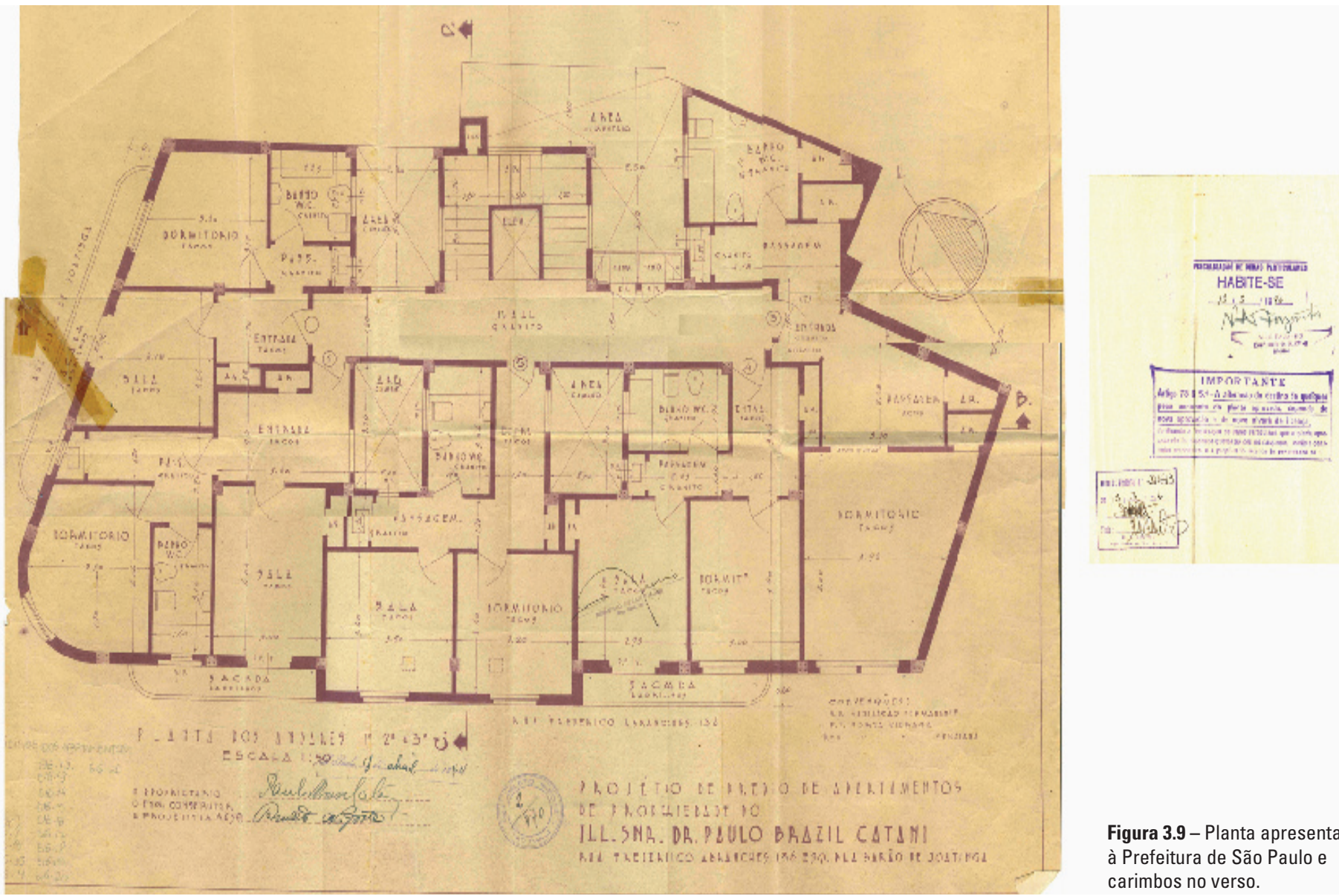

Figura 3.9 - Planta apresentada à Prefeitura de São Paulo e carimbos no verso. 


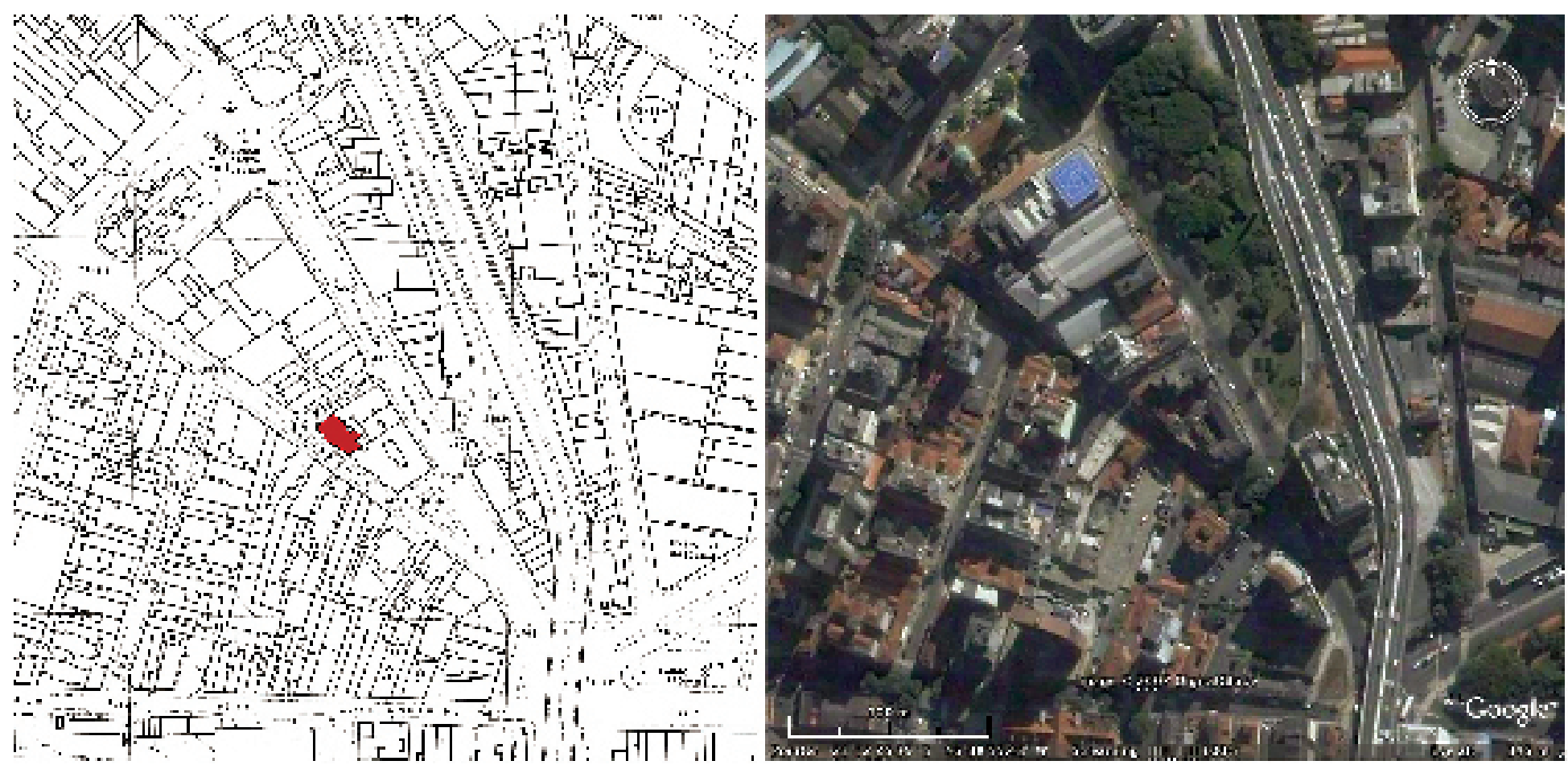

Figura 3.10 - Mapa do Gegran, de 1972, da região da rua Frederico Abranches e foto aérea recente do mesmo local. (Fonte foto: Google Earth)

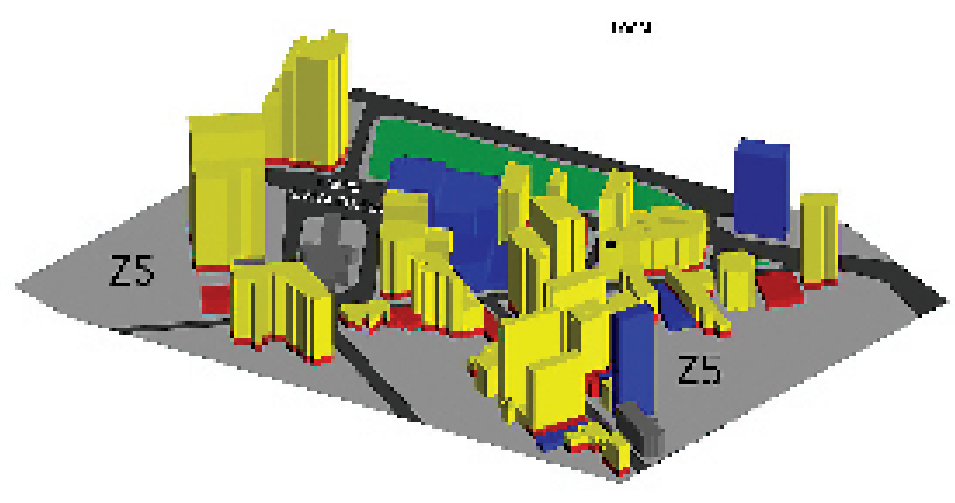

USOS ATJAIS

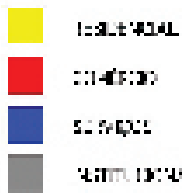

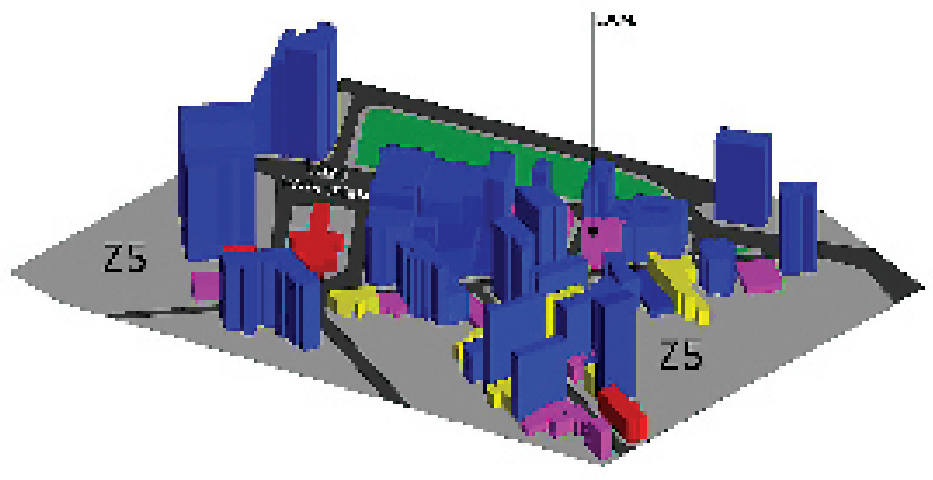

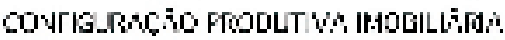

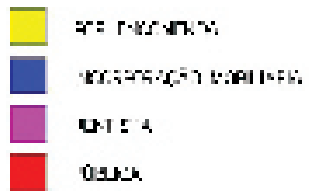

Figura 3.11 - Lavantamento do tecido urbano da rua Frederico Abranches com rua Barão de Joatinga. (Fonte: elaborado pelo autor a partir de levantamento de campo) 
Trata-se de um edifício exclusivamente residencial, construído por encomenda de seu proprietário, Dr. Paulo Brasil Catani. Situado em um lote de esquina entre a rua Frederico Abranches e a rua Barão de Joatinga, em Santa Cecília, o edifício conta com subsolo, pavimento térreo, três pavimentos tipo e ático. O edifício foi implantado no alinhamento das duas ruas, e também sem recuos laterais ou de fundos. No subsolo encontram-se apenas uma caixa d'água e um depósito que, segundo carimbo da municipalidade, também seria usado como abrigo anti-aéreo. No pavimento térreo encontram-se a entrada do edifício, com acesso à escada, um elevador e quatro apartamentos tipo kitchenette, com sala/cozinha dormitório e banheiro. Em cada um dos três pavimentos tipo encontram-se mais cinco apartamentos com as mesmas características, totalizando 19 unidades. No ático encontra-se a casa de máquinas do elevador, caixa d'água e apartamento do zelador. A pequena área dos apartamentos e a ausências de garagens indicam que eram destinados às classes de renda baixa.

Na planta apresentada à Prefeitura do Município de São Paulo, não consta quadro de áreas, mas, considerando que o edifício ocupa quase $100 \%$ do terreno e tem térreo mais três andares além de ático e subsolo, podemos concluir que seu coeficiente de aproveitamento é aproximadamente 4,0.

Na ocasião da promulgação da Lei de Zoneamento, em 1972, a região foi considerada como Z5. Existe uma forte predominância de edifícios residenciais, de diversas alturas, quase que a totalidade deles com algum tipo de comércio ou serviço no térreo. Podemos verificar também a presença de alguns edifícios comerciais e de uma área institucional, onde se encontra a Igreja de Santa Cecília. O quarteirão entre o Elevado Costa e Silva, a rua Sebastião Pereira e a Rua Ana Cintra foi totalmente desapropriado e demolido para dar lugar a uma grande área verde.

Figura 3.12 - Foto do edifício

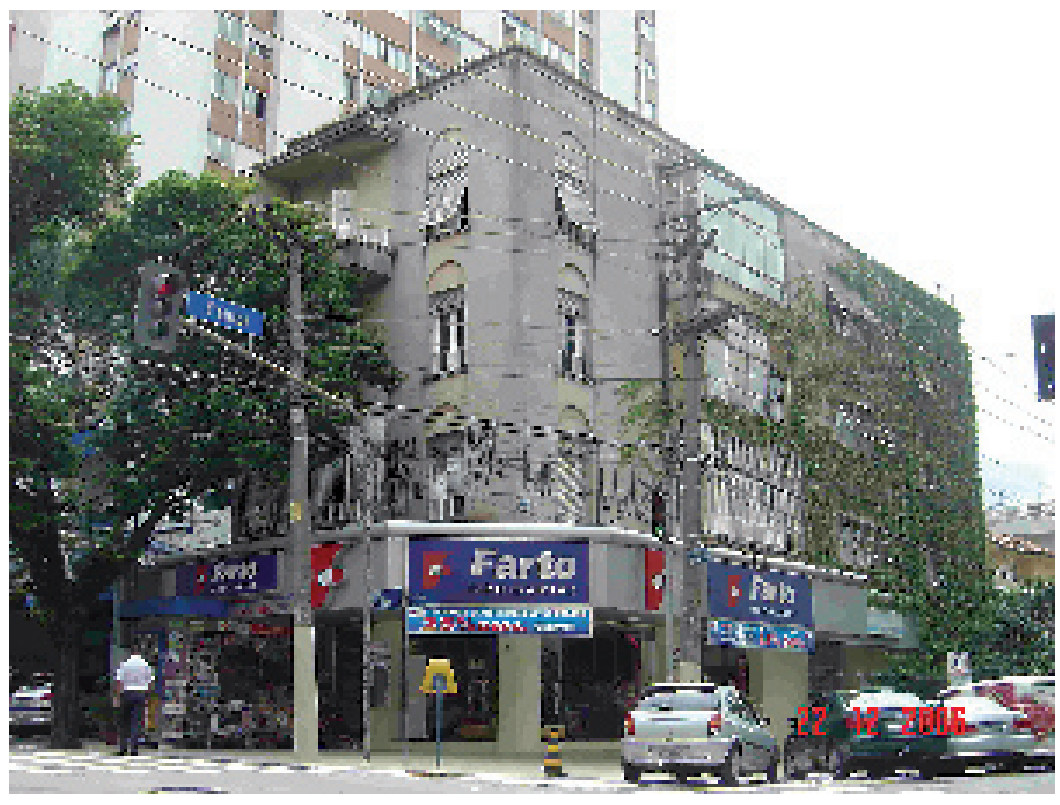

\section{EDIFÍCIO Nº 3}

- Endereço: Rua Caiubí, no 200, esquina com Rua Cardoso de Almeida, Perdizes.

- Data da construção: 1946.

- Edifício de uso misto, com uma loja no térreo e três apartamentos residenciais.

- Constitui um domínio, ou seja, todos as unidades pertencem a um mesmo proprietário ou seus descendentes.

- Construído por um médico. Ele e sua esposa ficaram com a loja no térreo e um apartamento; os outros dois apartamentos foram dados a cada uma de suas filhas, para uso próprio ou obtenção de renda através do aluguel. 


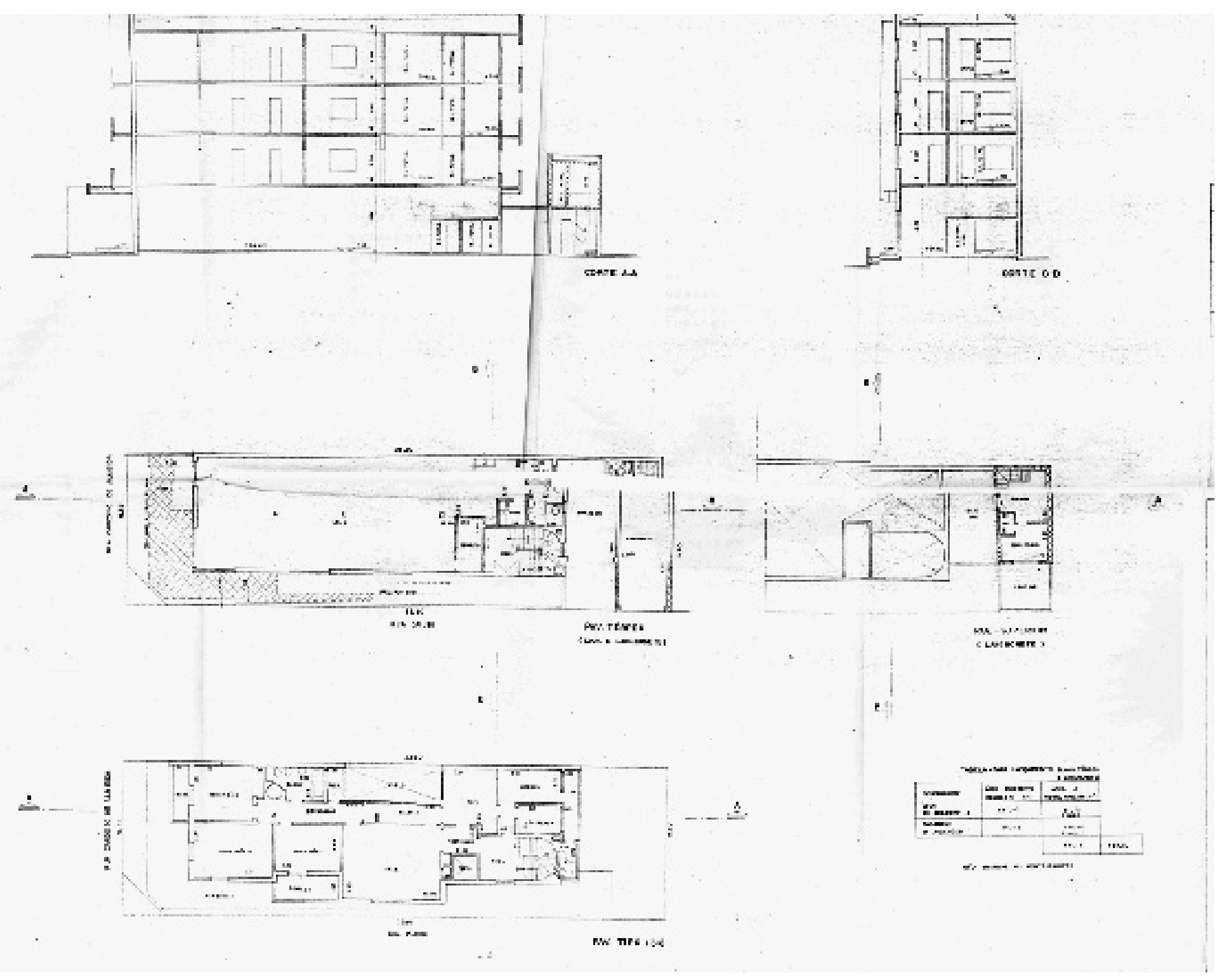

Figura 3.13 - Planta apresentada à Prefeitura de São Paulo 
CUADRO DE ÁREAS $\left\{\mathrm{m}^{\mathrm{z}}\right\}$ :

\begin{tabular}{|c|c|c|c|c|c|}
\hline & 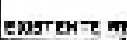 & monemans & A.tennur & Lenirat & TOTAL \\
\hline 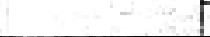 & cevp. & noseres. & mone 7 & Are cous: & \\
\hline 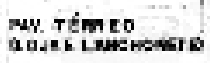 & 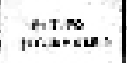 & - & Mexes & 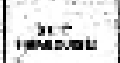 & wes..1 \\
\hline $\begin{array}{l}\text { MNe surepion } \\
\text { OLMMCHSWETEI }\end{array}$ & & & ni * & $\ldots$ & $\Delta \infty$ \\
\hline mungo (x) & 'es.tast & & & - & , nst \\
\hline rotal & נימ & & 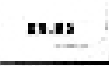 & טי." & $\operatorname{ten} x$ \\
\hline TOEAL & $\therefore \quad-7$ & & & 80 & \\
\hline
\end{tabular}

Figura 3.14 - Carimbo e quadro de áreas da planta apresentada à Prefeitura de São Paulo.

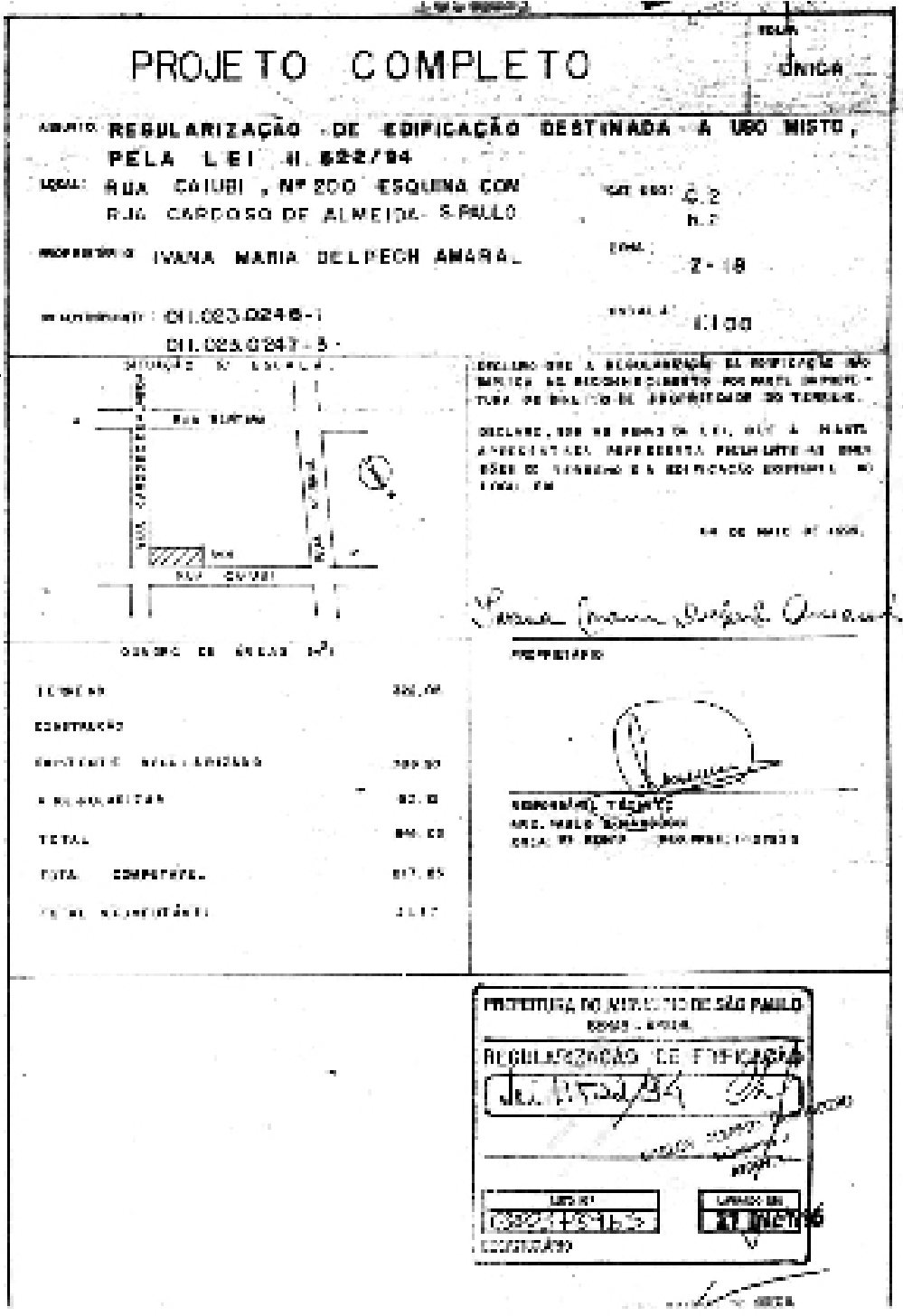




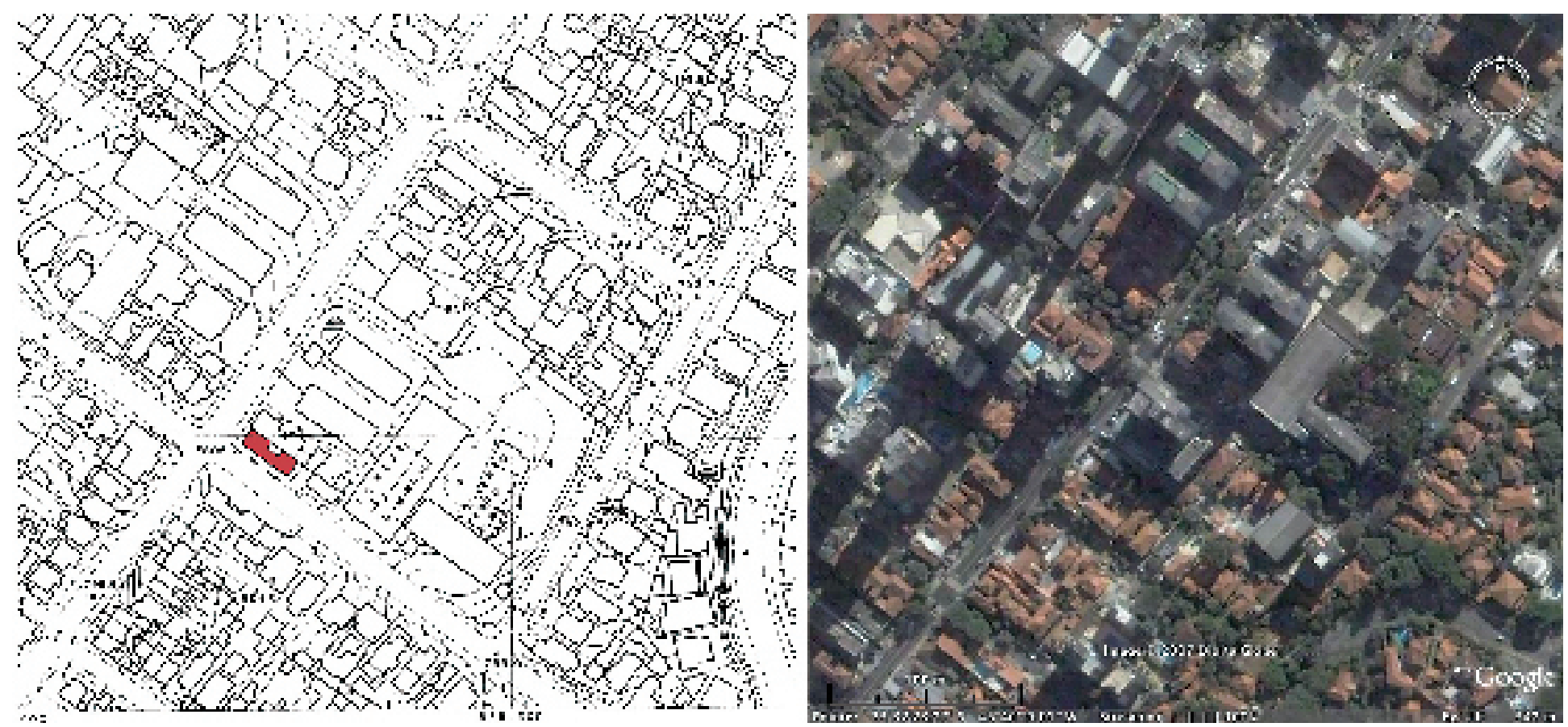

Figura 3.15 - Mapa do Gegran, de 1972, da região da rua Caiubi e foto aérea recente do mesmo local. (Fonte foto: Google Earth)

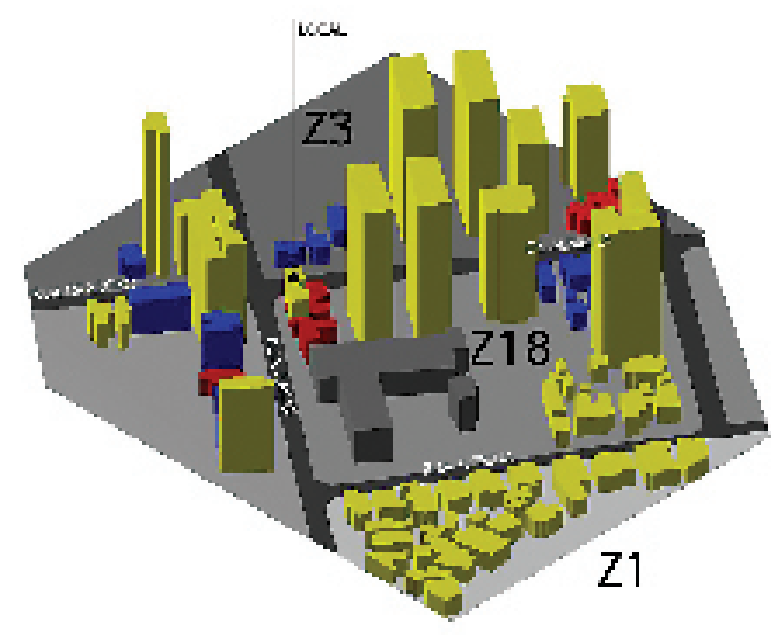

USOS ATLAIS

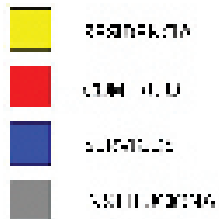

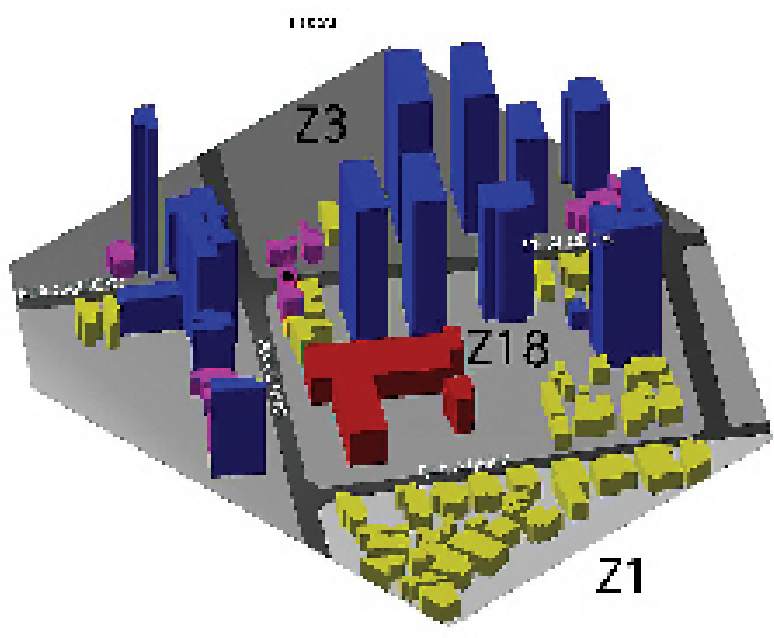

TONTIGLIRAC $\bar{A} O$ PRODUTIVA IMORII IÁRIA

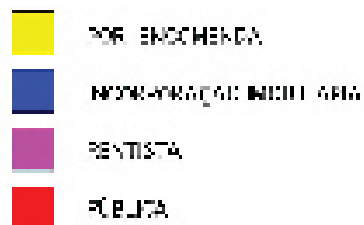

Figura 3.16 - levantamento do tecido urbano da rua Caiubí, esquina com rua Cardoso de Almeida. (Fonte: elaborado pelo autor a partir de levantamento de campo) 
Trata-se de um edifício de uso misto, situado em um lote de esquina entre a rua Caiubí e a rua Cardoso de Almeida, em Perdizes, com térreo e mais três pavimentos tipo. O edifício foi implantado com afastamento de 4 metros para a rua Cardoso de Almeida e de 1 metro para a rua Caiubí, sem recuos laterais ou de fundos. No pavimento térreo encontramse a entrada do edifício, com acesso à escada que leva aos pavimentos superiores (não há elevador), uma loja com pé direito de 4 metros, com acesso diretamente pelas ruas, e duas garagens cobertas para autos. Em cada um dos três pavimentos tipo encontra-se apenas um apartamento com três dormitórios, um banheiro, sala, copa, cozinha, terraço de serviço e dependência de empregada, totalizando 3 unidades residenciais de 190,40 m2. Não existe apartamento para zelador. As características dos apartamentos, com uma boa área, ambientes amplos e a presença de garagens para autos indicam que eles eram destinados às classes de renda média e média alta. A informação da administradora - que acompanhou o processo de construção - de que os apartamentos poderiam ser para uso próprio das filhas do empreendedor reforçam esta hipótese.

O projeto a que tivemos acesso, apresentado à Prefeitura de São Paulo, é datado de 1994 e se trata de um pedido de regularização, valendo-se da Lei 11522/94 (anistia). Assina como proprietária a Sra. Ivana Maria Delpech Amaral, provavelmente uma das filhas do médico que encomendou a construção, já que, por informação da administradora, o edifício continua pertencendo à família. O quadro de áreas demonstra uma área de terreno de 322,05 m2 e uma área existente regular de 788,90 m2. Partindo da hipótese de que a área regular é a área original de construção do prédio, temos um coeficiente de aproveitamento de 2,45. Posteriormente, uma das garagens foi transformada em "lanchonete", sua cobertura foi estendida até o alinhamento da rua Caiubí e um andar superior foi construído contendo uma cozinha, um w.c. e um escritório. Também posteriormente foi executada uma marquise de cobertura para a loja. As novas construções do lanchonete assim como a marquise da loja são os objetos do pedido de regularização.

O levantamento realizado nos mostra uma região de transição entre uma zona onde se pôde promover um adensamento, atingindo-se coeficientes de até 4 (Z3) para uma zona estritamente residencial unifamiliar cujo coeficiente de aproveitamento dos lotes é no máximo 1. Podemos verificar, nas zonas onde se pôde atingir um maior coeficiente de aproveitamento e onde o uso não residencial é permitido, um tecido urbano mais heterogêneo com construções de diversas alturas e usos, com predominância do residencial, principalmente em edifícios. Notamos também alguns pequenos edifícios de escritórios comerciais e pequenas construções, provavelmente antigas residências que hoje abrigam prestadores de serviços. Na Z1 verificamos um tecido totalmente homogêneo, onde todas as construções têm temanhos semelhantes e com o mesmo tipo de uso. Existe ainda uma grande área institucional onde se encontram a Igreja de São Domingos e o Convento Santo Alberto Magno, atualmente ocupado pelo Colégio Pentágono. 


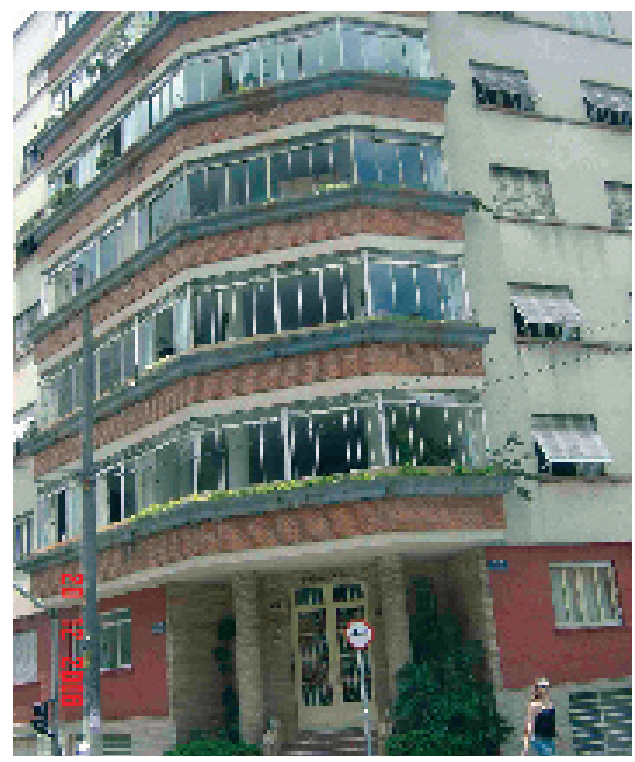

\section{EDIFÍCIO No 4}

- Endereço: Rua Bela Cintra, nº 619, Cconsolação.

- Data da construção: 1953.

- Edifício de uso exclusivamente residencial.

- Constitui um domínio, ou seja, todos as unidades pertencem a um mesmo proprietário ou seus descendentes.

- Construído para a renda de seu proprietário.

Figura 3.17 - Foto do edifício

Figura 3.18 - Planta de implantação.

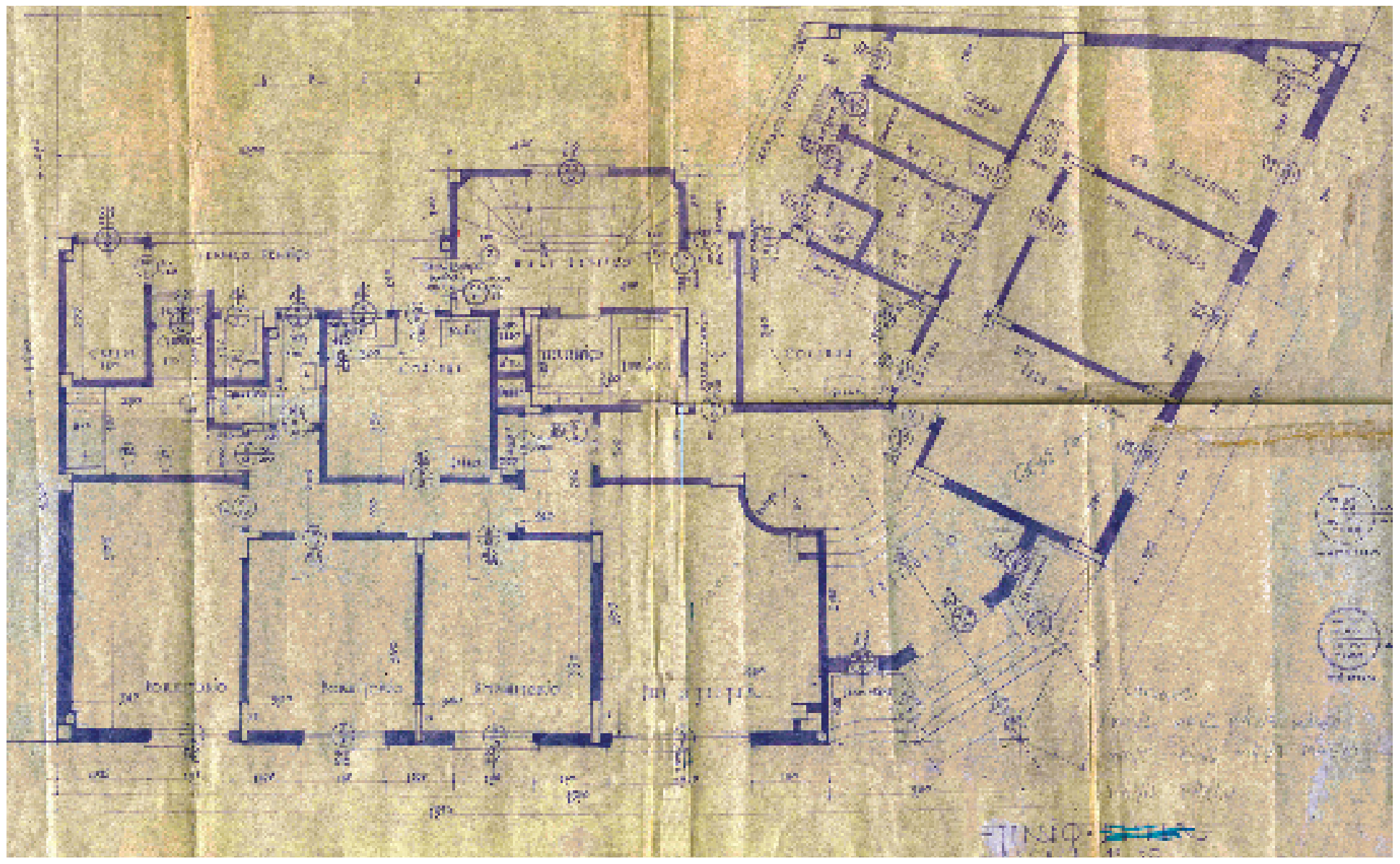




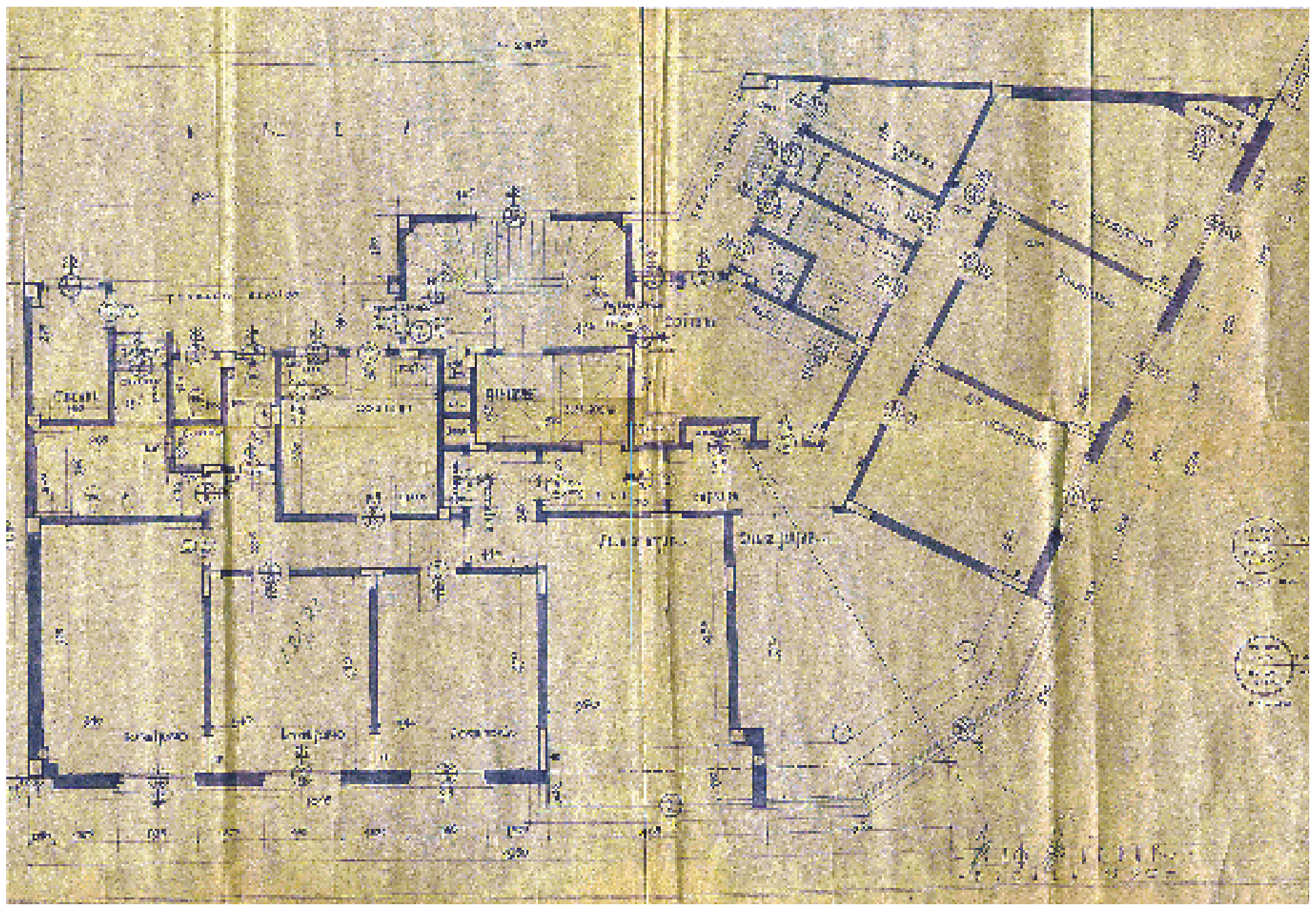

Figura 3.19 - Planta do pavto tipo. 


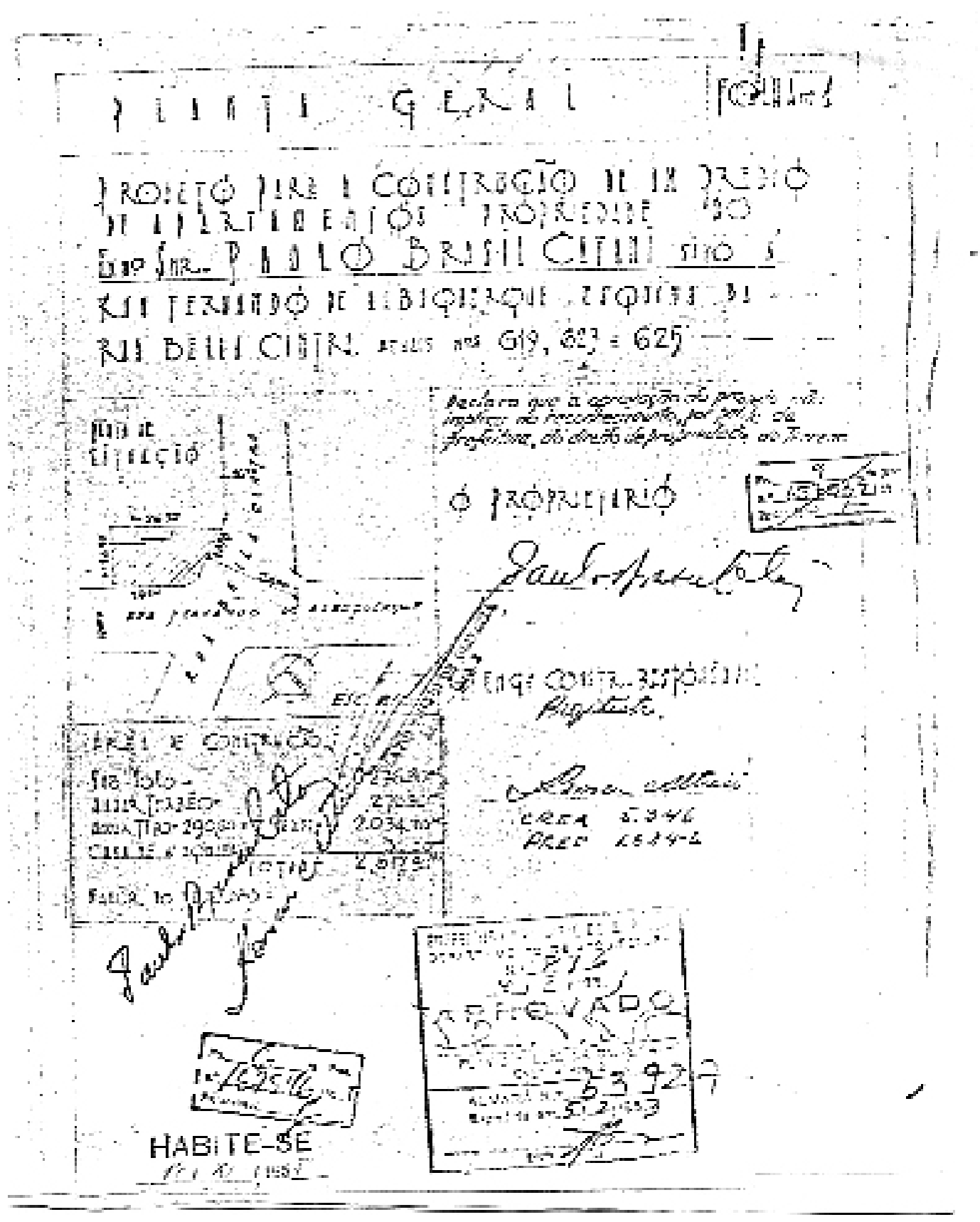

Figura 3.20 - Carimbo da planta

apresentada à prefeitura de São Paulo. 

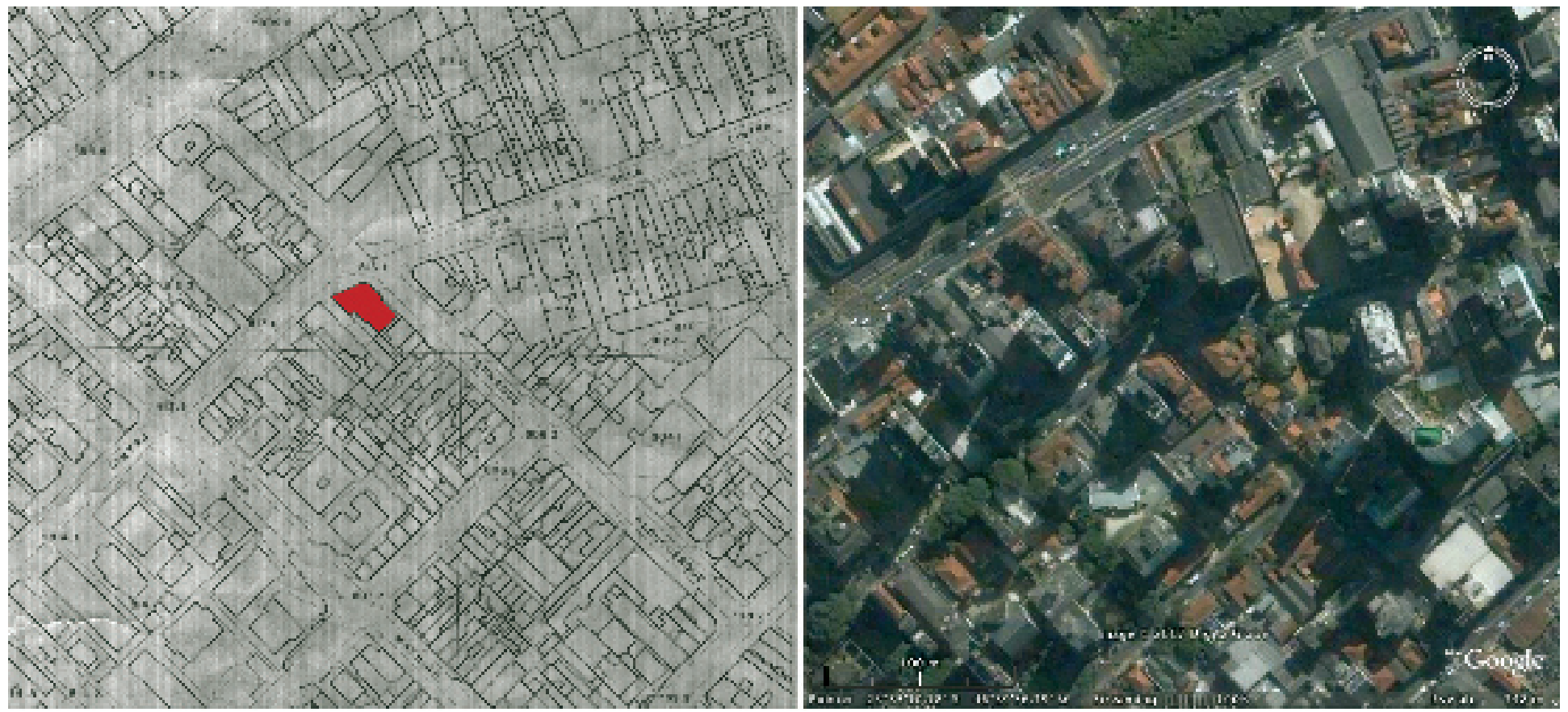

Figura 3.21 - Mapa do Gegran, de 1972, da região da rua Bela Cintra e foto aérea recente do mesmo local. (Fonte foto: Google Earth)

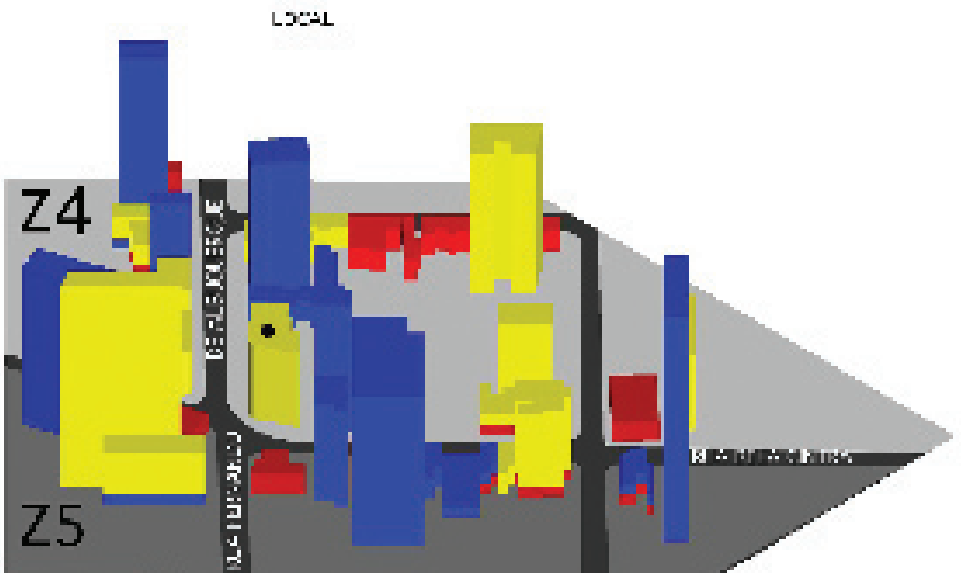

USOS ATUAIS

HirSitrM:La

DO:tFCIO

scroccs

INETT_CNNAL

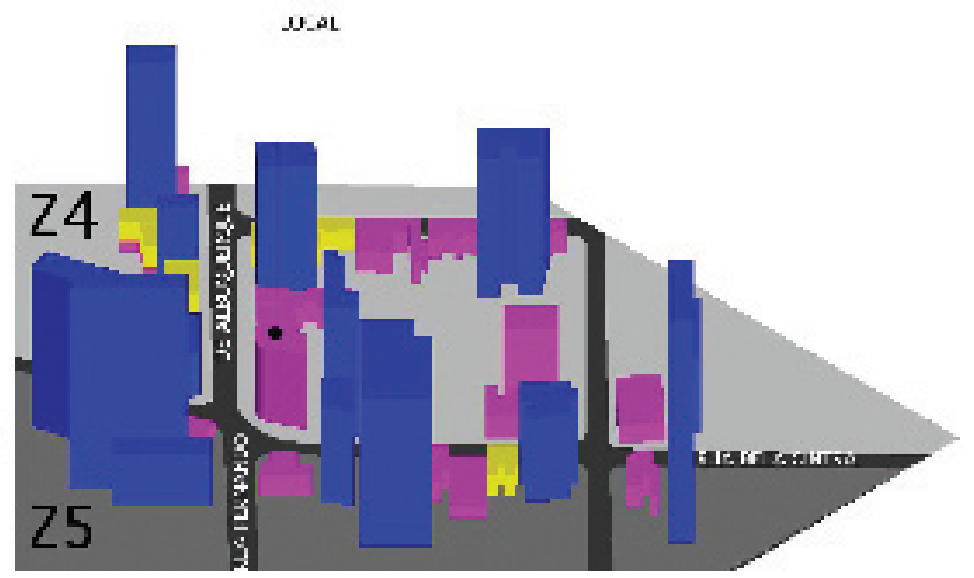

\section{CONFIGURAÇAO PRODUTIVA IMOBILẢRIA}

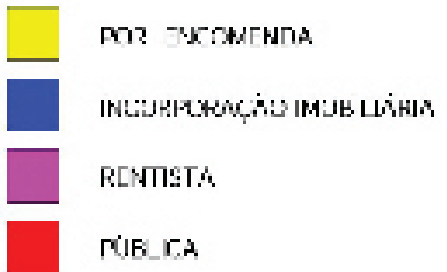

Figura 3.22 - Levantamento do tecido urbano da rua Bela Cintra, esquina com rua Fernando de Albuquerque. (Fonte: elaborado pelo autor a partir de levantamento de campo) 
Trata-se de um edifício exclusivamente residencial, de propriedade do Sr. Paulo Brasil Catani, situado em um lote de esquina entre a rua Bela Cintra e rua Fernando de Albuquerque, bairro da Consolação, com subsolo, térreo, seis pavimentos tipo e ático. $\mathrm{O}$ edifício foi implantado no alinhamento das duas ruas, e também sem recuos laterais ou de fundos. O subsolo é apenas meio enterrado e lá encontram-se a entrada de serviços do edifício, com acesso à escada e ao elevador de serviço, casa de bombas, reservatório de água, casa das caldeiras e o apartamento do zelador, além de um pátio coberto para estacionamento de veículos. No pavimento térreo encontram-se a entrada do edifício, com acesso ao elevador social, para a escada e elevador de serviço e dois apartamentos com três dormitórios, dois banheiros, sala, cozinha, terraço de serviço e dependência de empregada, com área total de 145,30 $\mathrm{m} 2$. Em cada um dos seis pavimentos tipo encontram-se mais dois apartamentos com as mesmas características, totalizando 14 unidades. No ático encontra-se a casa de máquinas do elevador e a caixa d'água. As características dos apartamentos indicam que eram destinados às classes de renda média e média alta. Segundo informação da administradora duas filhas do proprietário ocupam apartamentos no edifício. As outras 12 unidades estão alugadas.

No projeto apresentado à Prefeitura de São Paulo já consta um carimbo com planta da situação e quadro de áreas. O quadro de áreas demonstra uma área construída total de 2.617,30 m2. Se subtrairmos a área de subsolo, teremos uma área computável de 2.341,50 m2. O Quadro de áreas não cita a área do terreno, pela escala tiramos uma área aproximada de $343,00 \mathrm{~m} 2$ o que representaria um coeficiente de 6,82 .

O edifício, no entanto, foi aprovado com térreo mais sete pavimentos tipo e construído com apenas seis. Se diminuirmos da área computável 290,60 m2, área de um pavimento tipo, teremos um total computável de 2.050,40 m2, que representa um coeficiente igual a 5,98.

Pelo levantamento feito na região, verificamos um tecido urbano bastante heterogêneo, com edifícios de vários tamanhos, tanto residenciais como comerciais, e também construções baixas com diversos usos. Essa heterogeinidade é própria de zonas mais permissivas como as Z4 e Z5. 


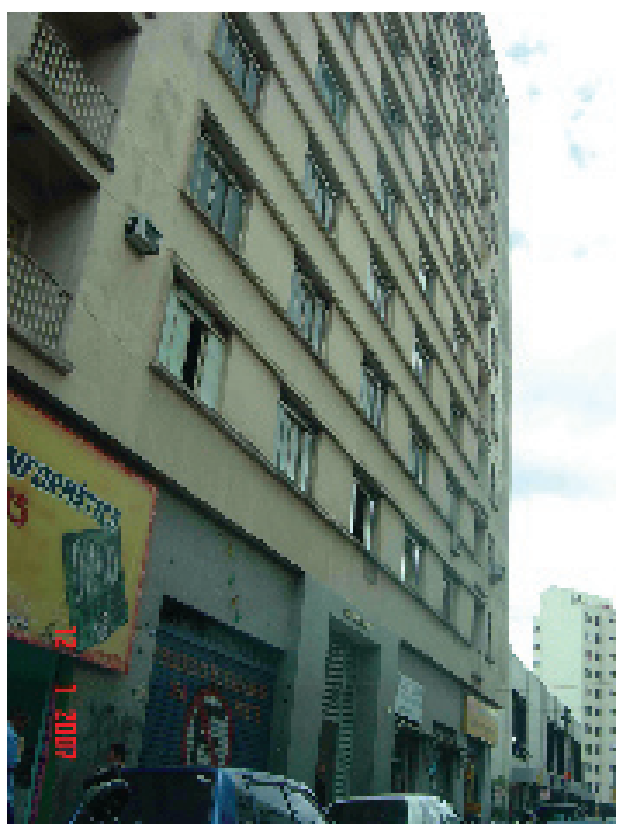

Figura 3.23 - Foto do edificio.

\section{EDIFÍCIO N 5}

- Endereço: Rua do Triunfo, no 134, centro.

- Data da construção: 1956.

- Edifício de uso misto, com lojas no térreo e apartamentos residenciais.

- Os apartamentos, posteriormente, foram convertidos em conjuntos comerciais.

- Atualmente constitui um condomínio.

- Construído para venda de suas unidades.

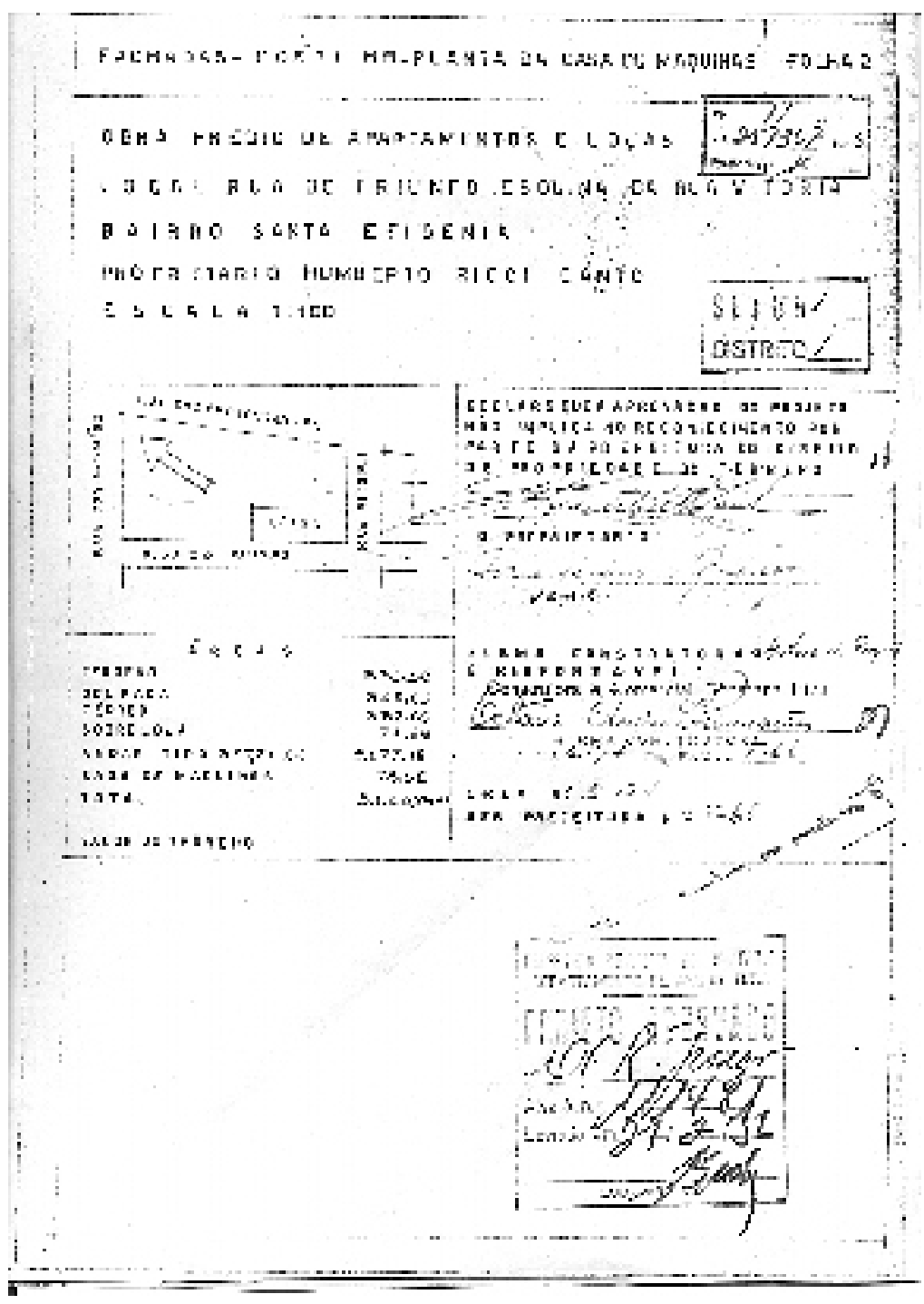




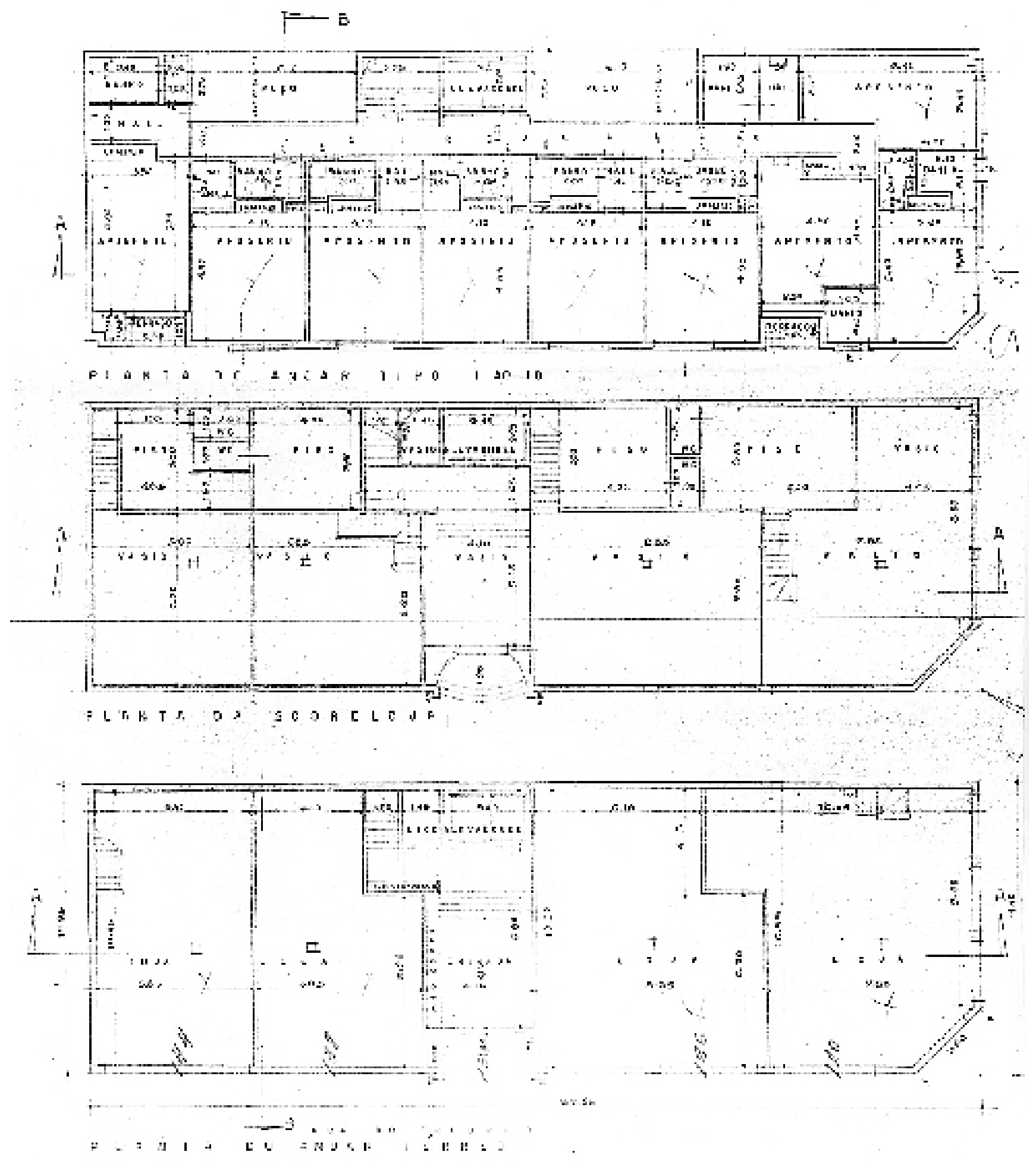

Figura 3.25 - Plantas apresentadas à Prefeitura de São Paulo. 


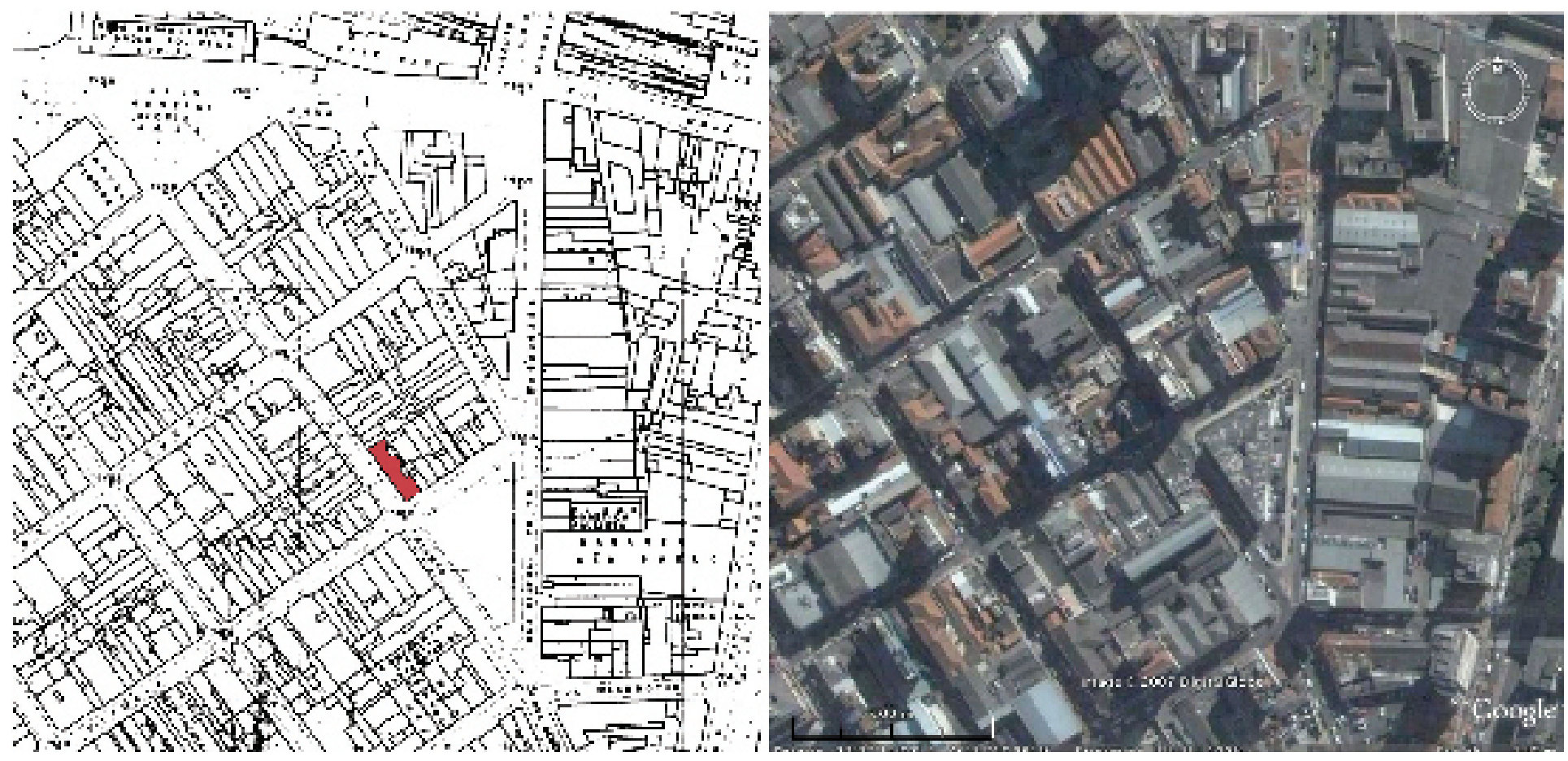

Figura 3.26 - Mapa do Gegran, de 1972, da região da rua do Trinfo e foto aérea recente do mesmo local. (Fonte foto: Google Earth)

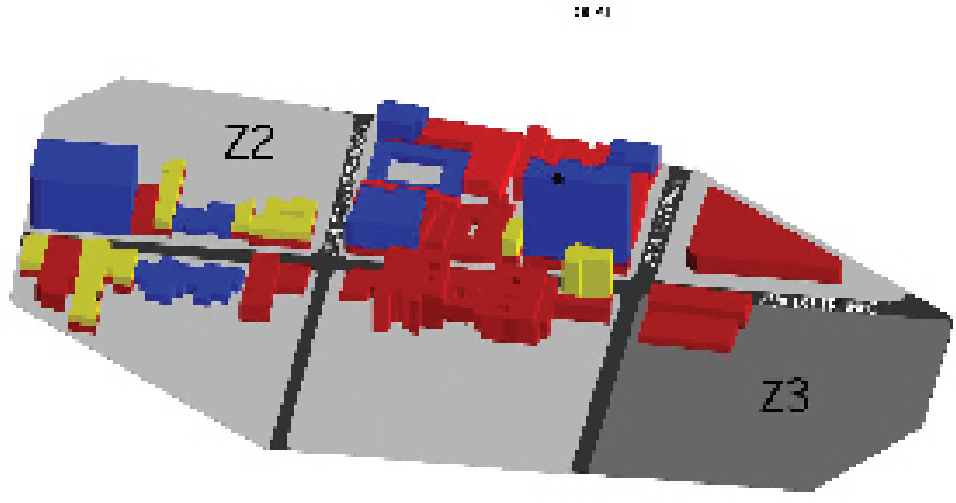

IISOS ATI.AIS

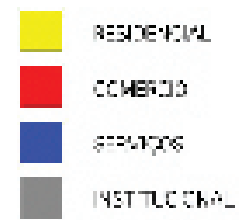

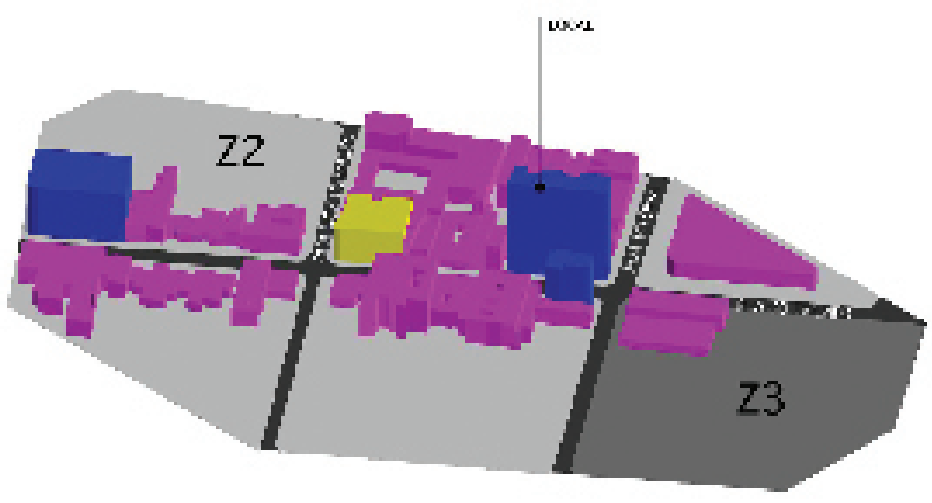

CONFIGURACABO PROOUTRA IMOBILIARIA

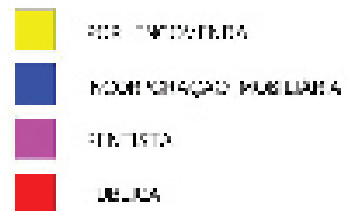

Figura 3.27 - Levantamento do tecido urbano da rua do Triunfo, esquina com rua Vitória. (Fonte: elaborado pelo autor a partir de levantamento de campo) 
Trata-se de um edifício construído pela empresa Construtora e Comercial Soberana, que também assina a responsabilidade pelo projeto. Assina como proprietário o $\mathrm{Sr}$. Humberto Ricci Canto. O edifício está situado em um lote de esquina entre a rua do Triunfo e a rua Vitória, bairro da Luz, com térreo, mezanino do pavimento térreo, dez pavimentos tipo e ático. O edifício foi implantado no alinhamento das duas ruas, e sem recuos laterais ou de fundos. No pavimento térreo encontra-se a entrada do edifício, com acesso à escada e dois elevadores. Ainda no pavimento térreo, mas com acesso apenas pelas ruas, encontram-se 4 lojas, cada uma com seu mezanino. Em cada um dos dez pavimentos tipo encontram-se nove apartamentos tipo kitchenette, com sala/dormitório/cozinha e banheiro, totalizando 90 unidades residenciais com área variando entre 30 e $35 \mathrm{~m} 2$. No ático encontram-se a casa de máquinas do elevador e apartamento do zelador. Pelas características dos apartamentos evidenciam que eram destinados às classes de baixa renda.

No projeto apresentado à Prefeitura de São Paulo já consta um carimbo com planta da situação e quadro de áreas. O quadro de áreas demonstra uma área de terreno de 335,80 m2 e uma área ocupada de 340,65 m2, ou seja, uma taxa de ocupação de 1,014, o que significa que a projeção do pavimento tipo deve invadir o passeio público. Demonstra ainda uma área construída total de 3.563,25 m2. Se subtrairmos a área da casa de máquinas, temos um total computável de $3.484,73 \mathrm{~m} 2$, que significa um coeficiente de aproveitamento de 10,37 .

Segundo informações do Escritório Almeida Leite, que administra o edifício desde o término de sua construção, nesta ocasião todas as suas unidades, tanto residenciais quanto as lojas comerciais foram colocadas a venda. Muitos compradores dos apartamentos, no entanto, não estavam interessados em alugá-los para terceiros, tampouco usá-los como moradia; estavam, sim, interessados em usá-los como escritório comercial ou como ateliê. Desde o início, portanto, o edifício tinha, no pavimento térreo as lojas e nos pavimentos tipo unidades residenciais e unidades comerciais. Ao longo dos anos o uso residencial foi se extinguindo e todas as unidades dos pavimentos tipo tiveram seu uso mudado para comercial.

O levantamento do tecido urbano nos mostra que o edifício estudado é o mais alto da região levantada, caracterizada por construções baixas, de dois a três pavimentos, com alguns poucos edifícios com até cinco pavimentos. Podemos notar uma forte predominância do uso comercial na região, seguido pelos serviços e alguns poucos edifícios residenciais, todos destinados às classes de baixa renda. 


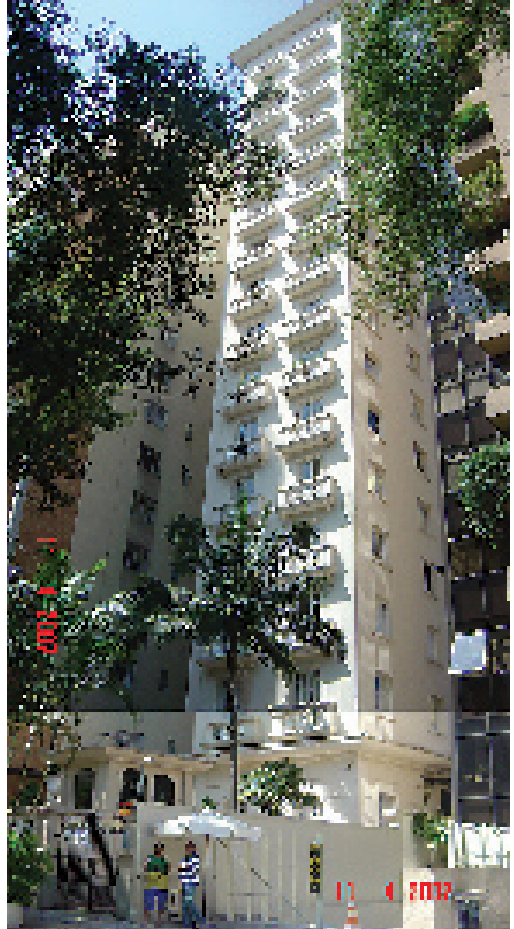

Figura 3.28 - Foto do edifício.

\section{EDIFÍCIO Nº 6}

- Endereço: Rua da Consolação, n 3721 , Cerqueira Cesar.

- Data da construção: 1966

- Edifício de uso exclusivamente residencial.

- Constitui um condomínio.

- Não temos informaçõs precisas a respeito do propósito de sua construção, se para renda ou para venda.

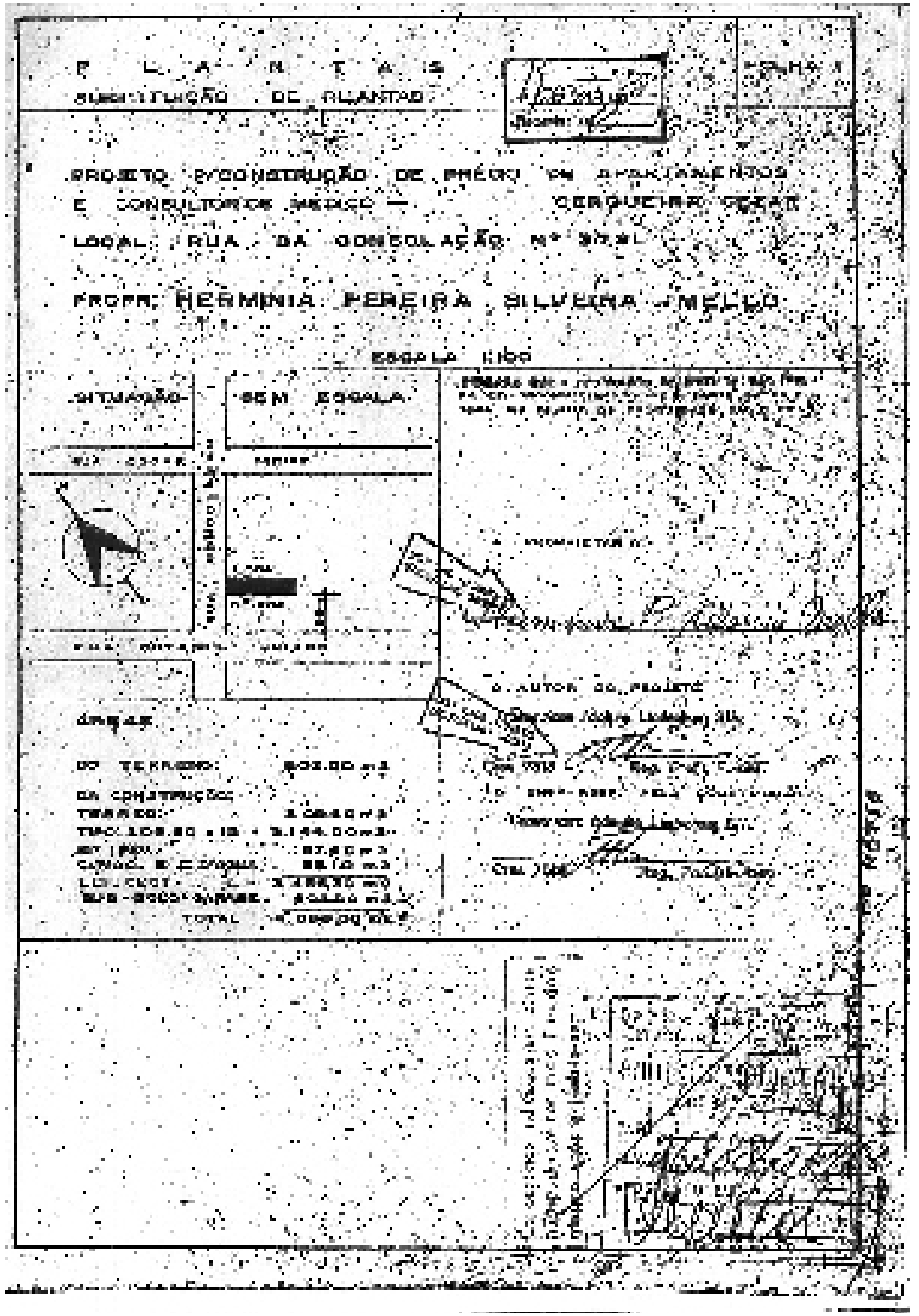

Figura 3.29 - Carimbo da planta apresentada à Prefeitura de São Paulo 


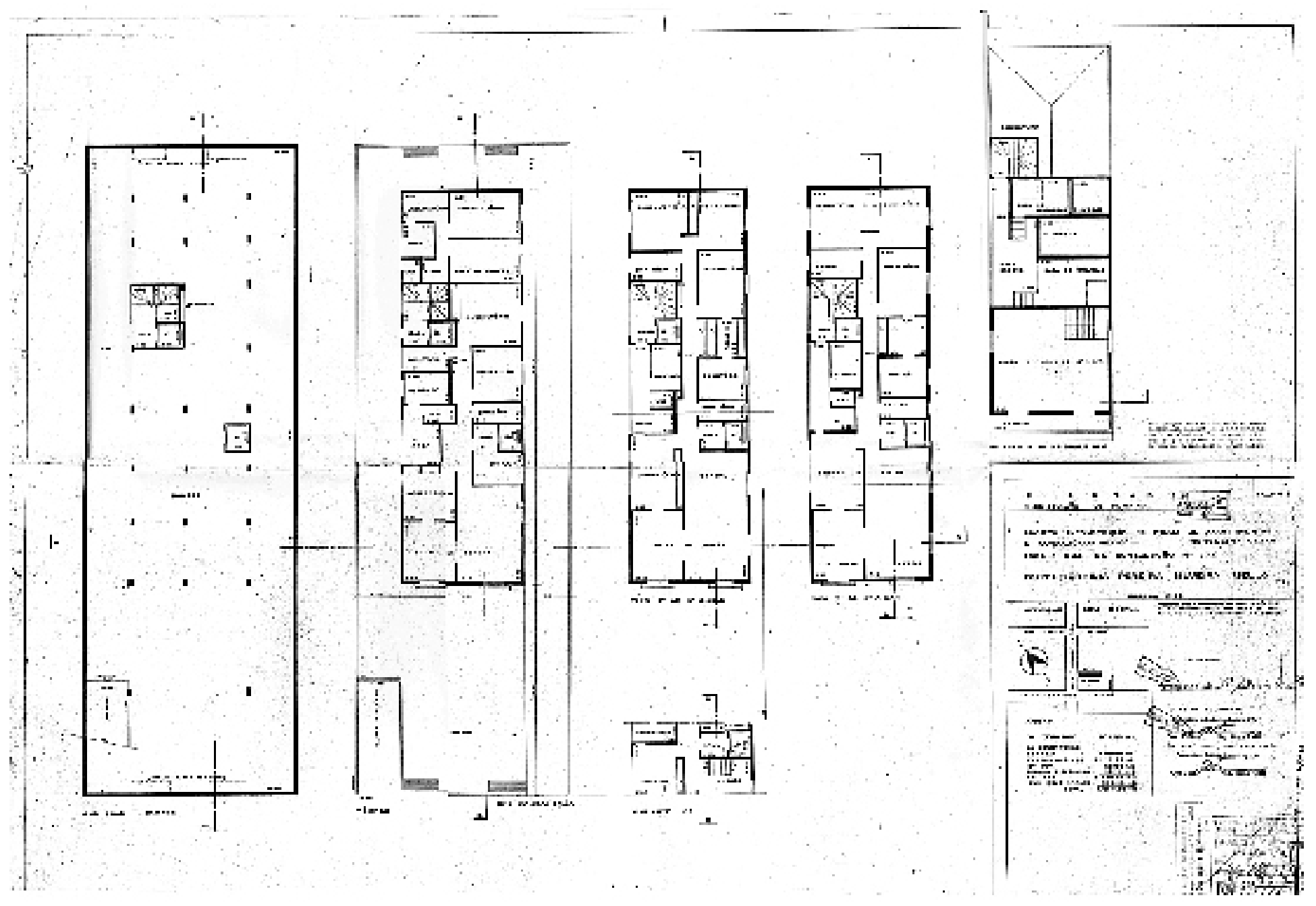

Figura 3.30 - Planta apresentada à Prefeitura de São Paulo. 

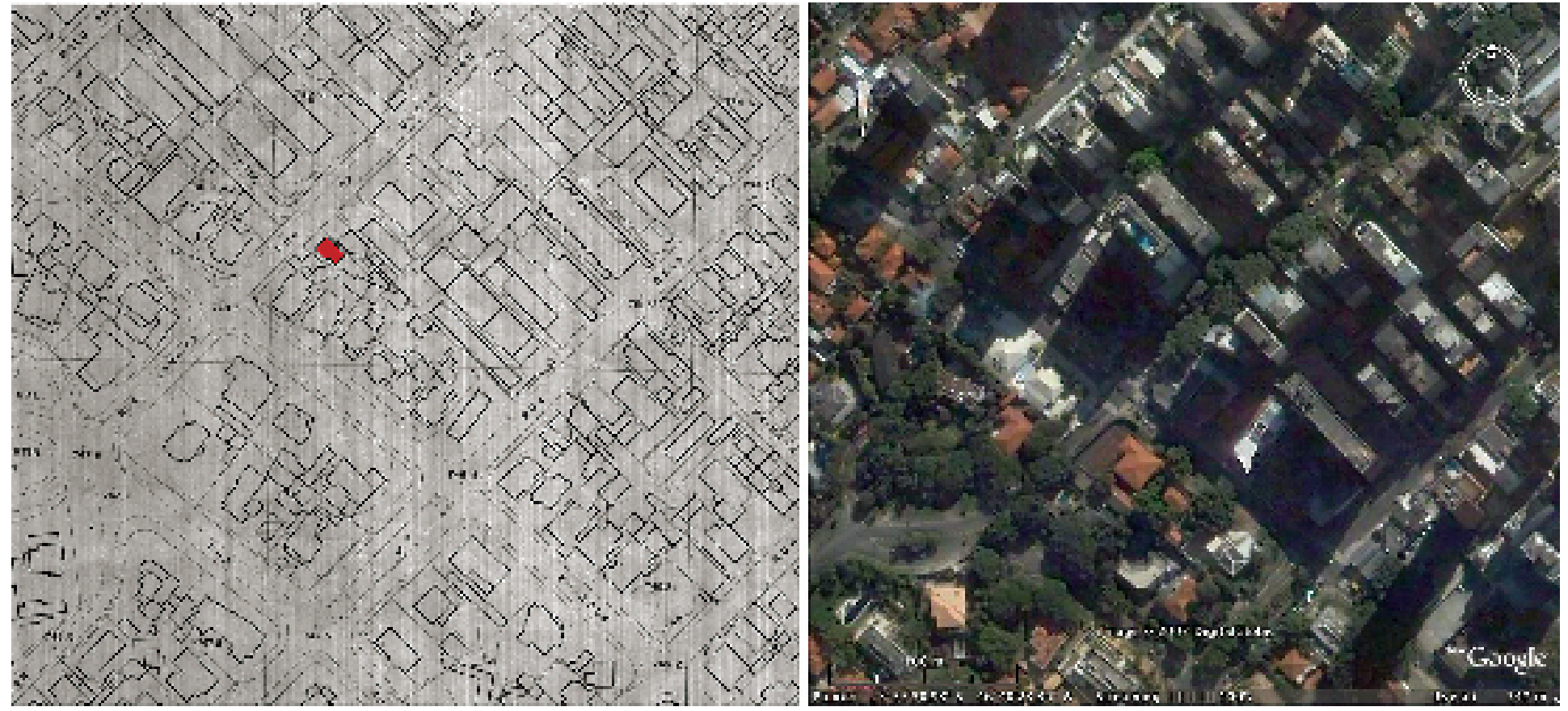

Figura 3.31 - Mapa do Gegran, De 1972, da região da rua da Consolação e foto aérea recente do mesmo local. (Fonte Foto: Google Earth)
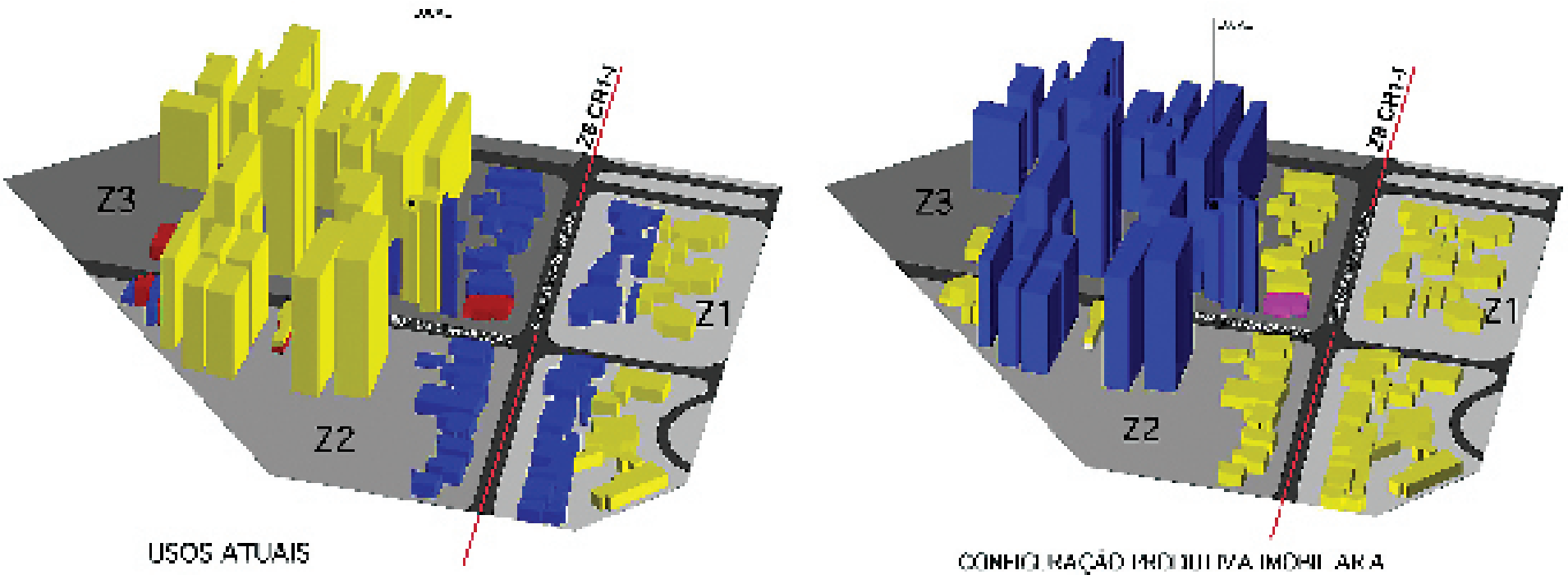

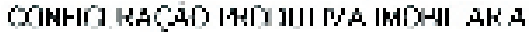
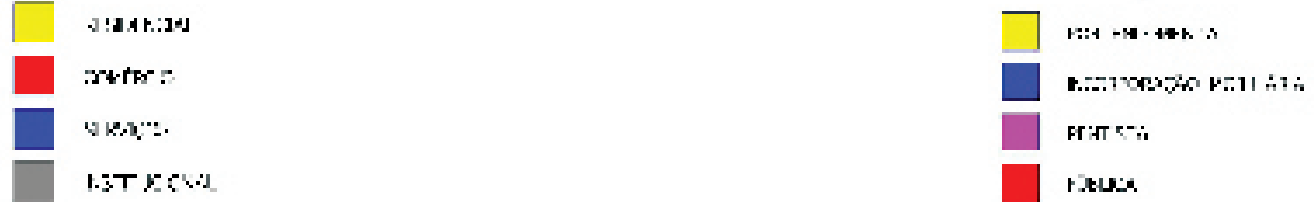

Figura 3.32 - Levantamento do tecido urbano da rua da Consolação na altura do ${ }^{0}$ 3721. (Fonte: elaborado pelo autor a partir de levantamento de campo) 
Trata-se de um edifício aprovado na Prefeitura Municipal de São Paulo como sendo de uso misto, com subsolo, térreo, catorze pavimentos tipo, mais um apartamento duplex de cobertura ocupando o $15^{\circ}$ e parte do $16^{\circ}$ pavimentos e ático. O edifício foi projetado e construído pala empresa Adolpho Lindenberg S/A, e a Sra. Hermínia Pereira Silveira Mello assina como proprietária. Segundo a planta apresentada à prefeitura os primeiros seis pavimentos tipo são destinados a consultórios médicos e os outros oito pavimentos tipo mais o apartamento de cobertura são destinados à habitação. O edifício foi implantado com afastamento de 13,90 m para a rua da Consolação e recuos laterais e de fundos de 3,00 m. O Subsolo ocupa toda a extensão do terreno e é destinado exclusivamente ao estacionamento de veículos, sem determinar o número de vagas. No pavimento térreo encontram-se a entrada de serviço, com acesso à escada, ao elevador de serviço e a um sanitário de funcionários e a entrada social do edifício, com acesso ao elevador social e a um apartamento destinado a consultórios médicos, com duas salas para médicos, dois banheiros, duas grandes salas de espera, laboratório, terraço de serviço, depósito e banheiro de empregada. Ainda no pavimento térreo encontra-se um outro apartamento destinado a consultórios, com dimensões menores e com entrada pelo corredor lateral externo do edifício. Este consultório contém uma sala para médicos, sala de espera, laboratório, banheiro e terraço de serviços. Em cada um dos seis pavimentos tipo destinados a consultórios encontra-se apenas um apartamento com área igual à soma dos dois do pavto térreo, com as mesmas características do apartamento maior, mas com uma sala a mais para médico. Nos oito pavimentos tipo destinados a residência encontra-se apenas um apartamento, com configuração idêntica aos consultórios médicos, mas com outras denominações. Estes apartamentos contêm uma suíte com closet e banheiro, mais dois dormitórios, um banheiro, sala de estar, sala de jantar, cozinha, terraço de serviço e dependência de empregada. O $15^{\circ}$ pavimento, residencial, é praticamente idêntico aos outros, tendo apenas como variante uma escada de acesso a um salão privativo no $16^{\circ}$ andar. Neste último andar encontram-se também as casas de máquinas dos elevadores e duas caixas d'água. $\mathrm{O}$ empreendimento totaliza 9 unidades residenciais e mais 8 unidades para consultórios. As características dos apartamentos e consultórios indicam que são destinados às classes de renda alta e média alta.

O projeto apresentado à Prefeitura Municipal de São Paulo apresenta um quadro de áreas que mostra a área do terreno igual a $602,00 \mathrm{~m} 2$ e a área computável total igual a $3.466,30 \mathrm{~m} 2$. Isto significa um Coeficiente de Aproveitamento igual a 5,76. A área ocupada do lote é $208,80 \mathrm{~m} 2$ (8 X 26,10) determinando uma taxa de ocupação igual a 0,35.

Segundo o Escritório Almeida Leite, quando passou a administrar o edifício, este já estava configurado como condomínio e todas as suas unidades tinham o uso residencial, incluindo aquelas que foram aprovadas como consultórios médicos.

O levantamento do tecido urbano nos mostra que esta também é uma região de transição entre uma zona onde se pôde promover um adensamento, atingindo-se coeficientes de até 4 (Z3) para uma zona estritamente residencial unifamiliar (Z1) cujo coeficiente de aproveitamento dos lotes é igual a 1. Podemos verificar na Z2 e Z3 uma forte predominância de edifícios com uso residencial, poucos edifícios comerciais e algumas construções baixas com uso de serviço ou comércio. Entre a Z1 e as zonas de maior adensamento existe uma zona-corredor Z8 CR1-1, onde é permitido, além de e residências, escritórios de prestadores de serviços sem operação de vendas. Suas características urbanísticas são semelhantes à Z1, ou seja: lote mínimo de $250 \mathrm{~m} 2$, Coeficiente de Aproveitamento igual a 1, Taxa de Ocupação de 0.50 . O posto de abastecimento localizado nesta zona-corredor, na esquina da rua Estados Unidos com Rua Consolação, funciona de forma irregular. 


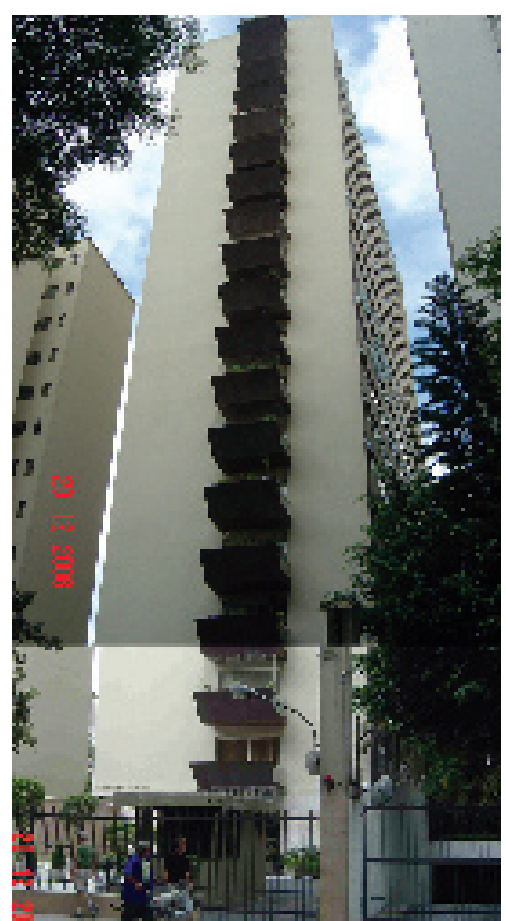

Figura 3.33 - Foto do edifício.

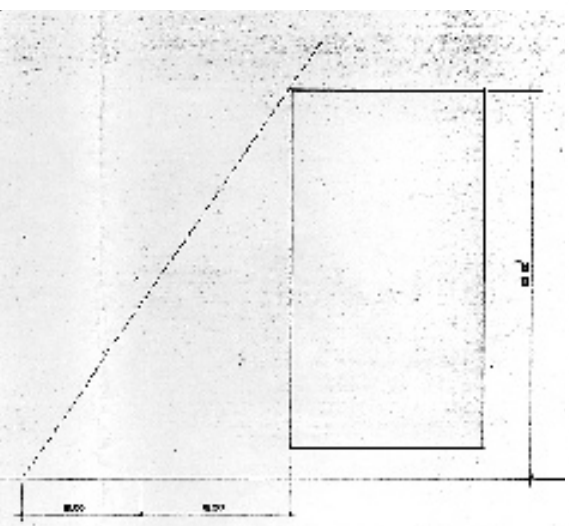

westric ac atrine

Figura 3.34 - Demonstração do gabarito de altura e carimbo da planta apresentados à Prefeitura de São Paulo

\section{EDIFÍCIO Nº 7}

- Endereço: Rua São Vicente de Paula, n 435 , Higienópolis.

- Data da construção: 1968.

- Edifício de uso exclusivamente residencial.

- Constitui um condomínio.

- Não temos informações precisas a respeito do propósito de sua construção, se para renda ou para venda.

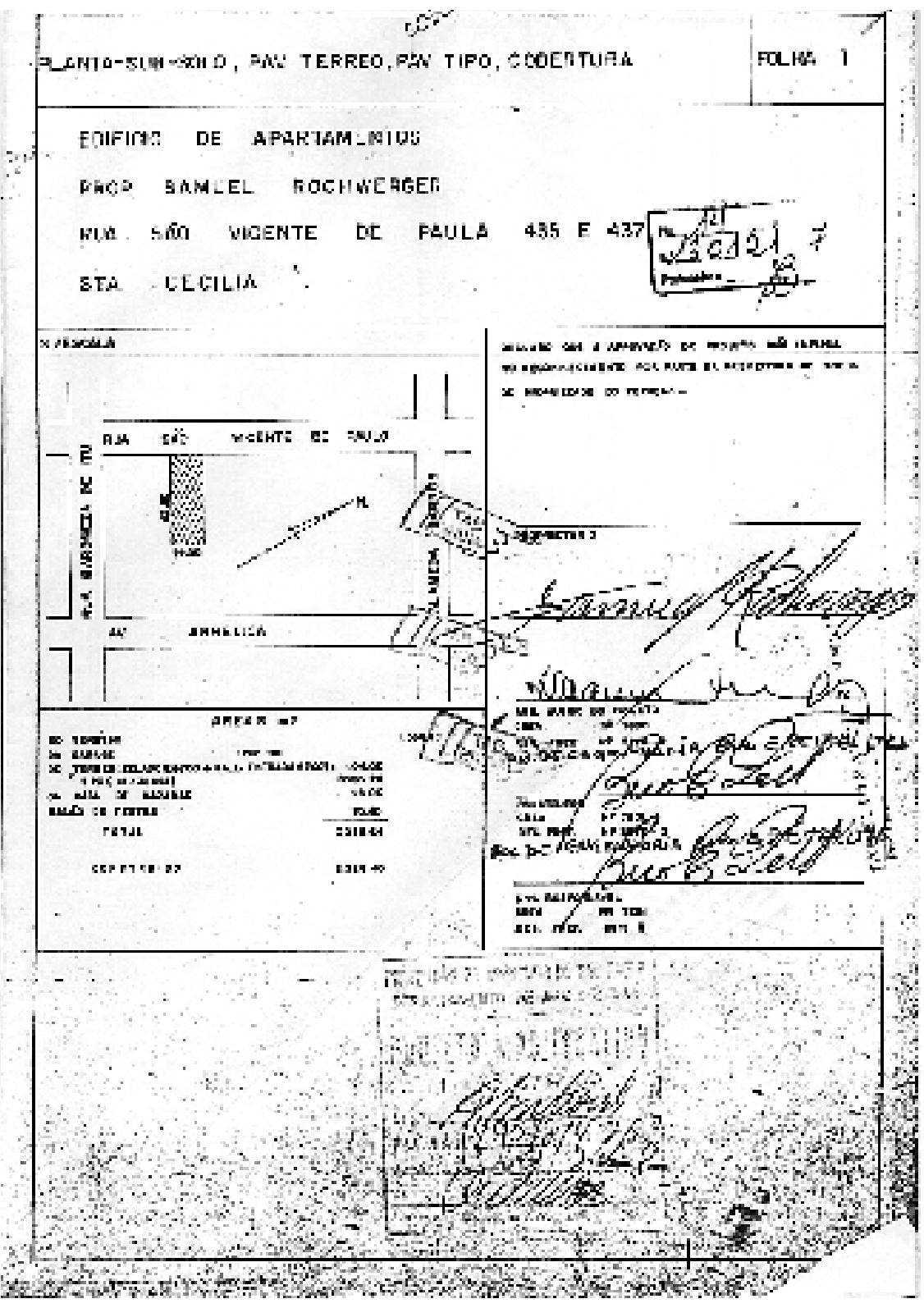




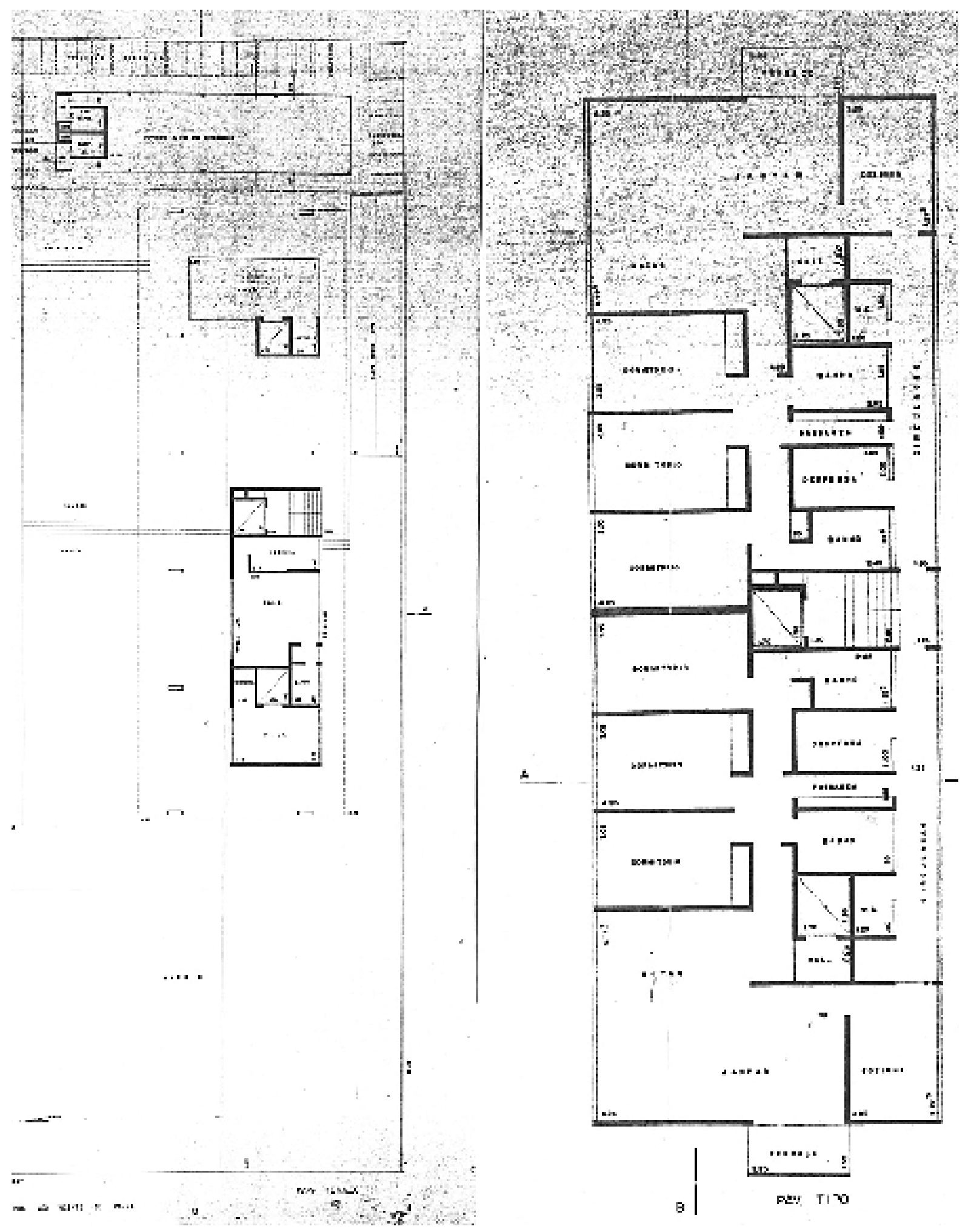

Figura 3.35 - Plantas apresentadas à Prefeitura de São Paulo. 


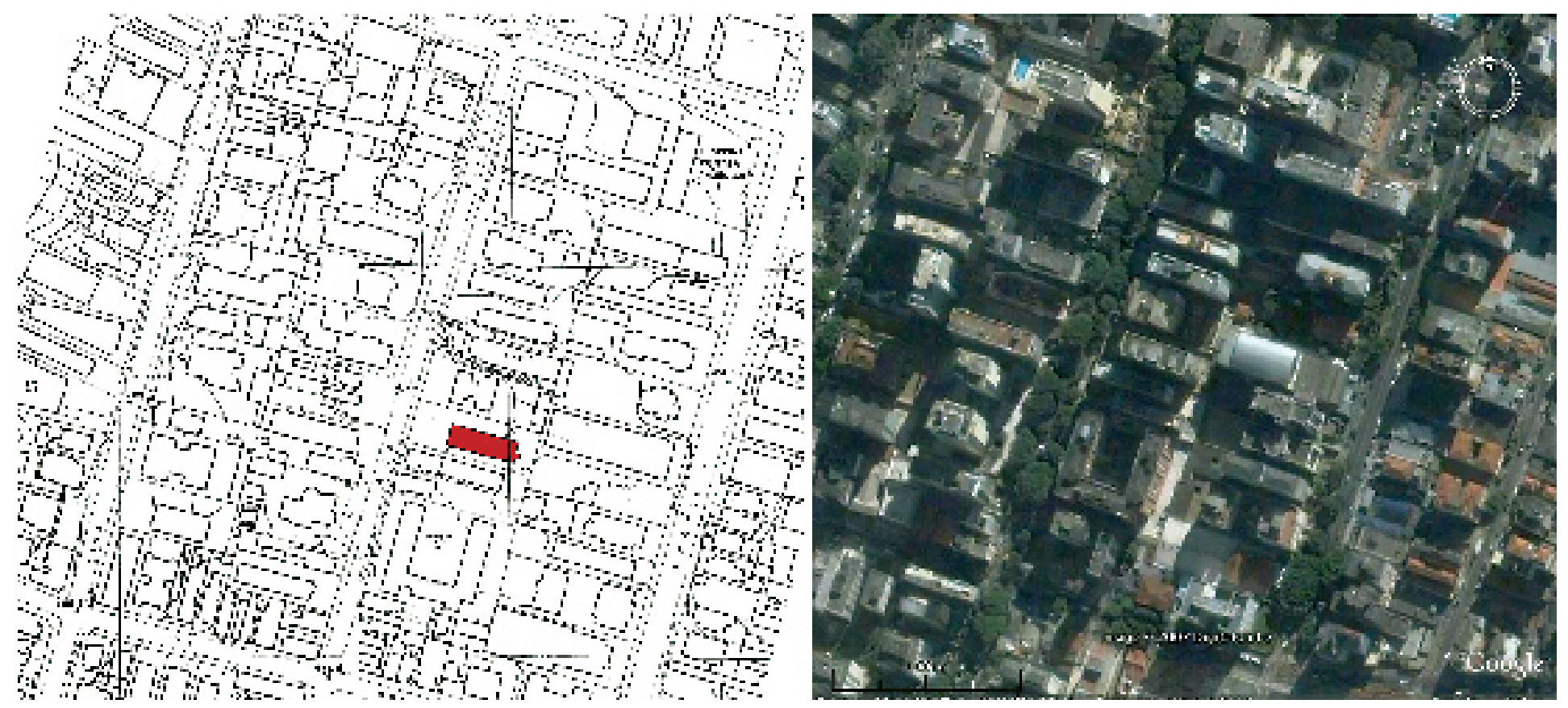

Figura 3.36 - Mapa do Gegran, de 1972, da região da rua São Vicente de Paula e foto aérea recente do mesmo local. (Fonte foto: Google Earth)

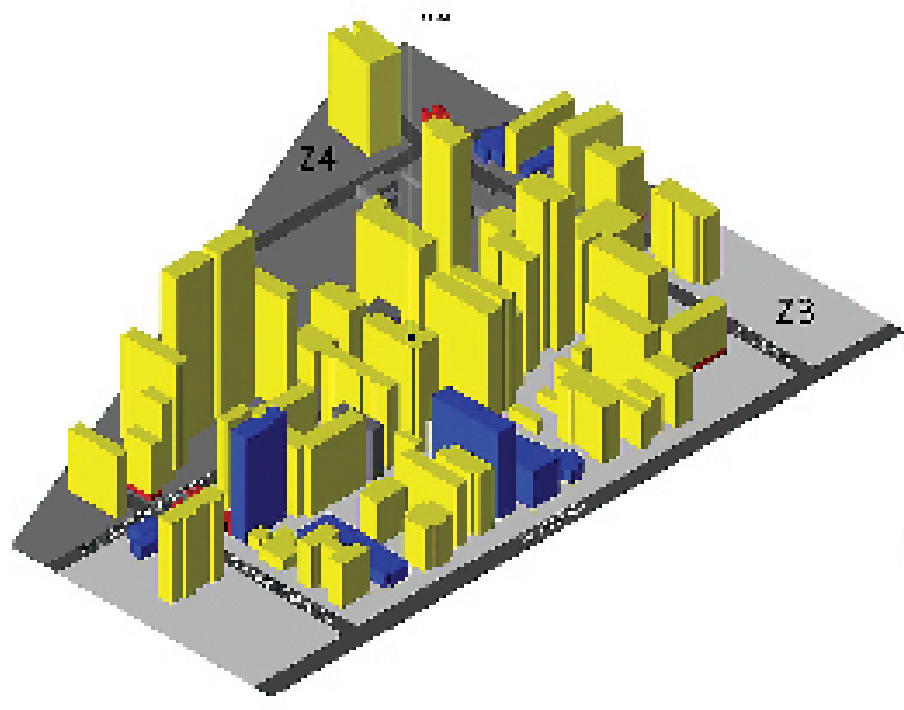

UEx $/$ Thists

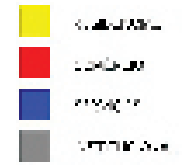

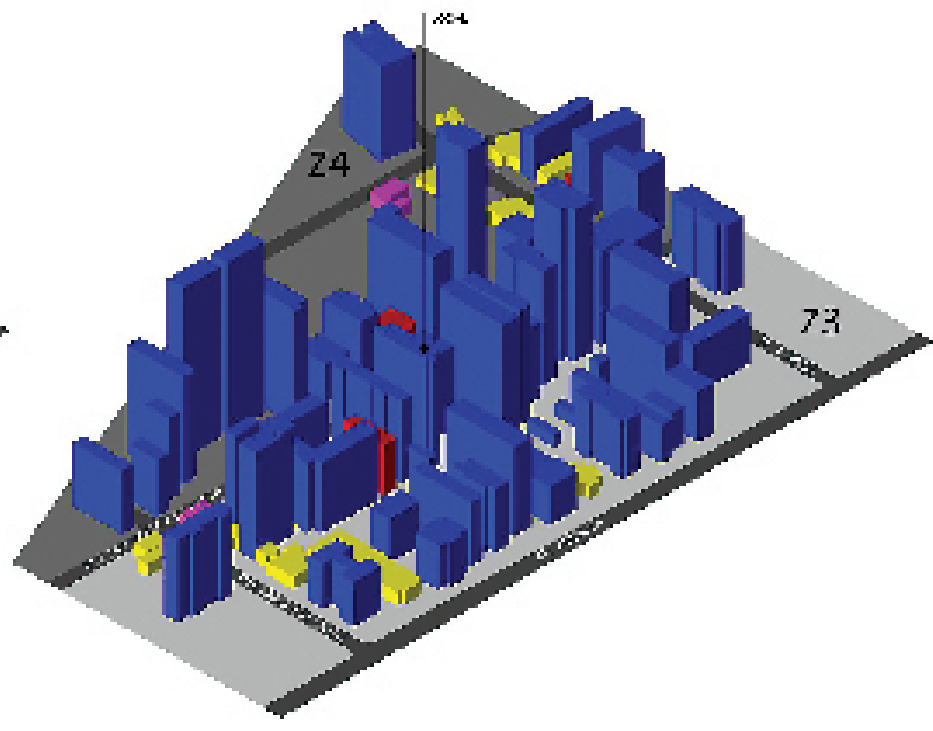

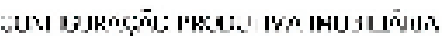

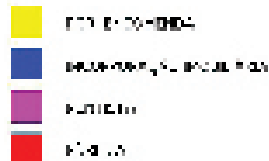

Figura 3.37 - Levantamento do tecido urbano da rua São Vicente de Paula na altura do $\mathrm{n}^{\circ}$ 435. (Fonte: elaborado pelo autor a partir de levantamento de campo) 
Trata-se de um edifício exclusivamente residencial com subsolo, térreo, dezoito pavimentos tipo e ático. O edifício foi implantado com afastamento de $19,50 \mathrm{~m}$ para a rua São Vicente de Paula, recuo lateral de $3,00 \mathrm{~m}$ do lado direito e não demonstrado do lado esquerdo, e 3,00m de fundos, considerando o salão de festas. O subsolo ocupa todo o terreno e é destinado exclusivamente para estacionamento de veículos, mas não demonstra a quantidade de vagas. No pavimento térreo do edifício, sobre pilotis, encontram-se duas entradas sociais com acesso aos respectivos elevadores sociais, um para cada bloco de apartamentos, a entrada de serviço, com acesso à escada e ao elevador de serviço e o apartamento do zelador. Fora da projeção do edifício, ainda no térreo, encontra-se o salão de festas. Em cada um dos dezoito pavimentos tipo encontram-se dois apartamentos com uma suíte completa mais dois dormitórios, um banheiro, sala de estar, sala de jantar, varanda, cozinha, terraço de serviço, circulação íntima entre serviços e área íntima e dependência de empregada, totalizando 36 unidades residenciais. No ático encontramse as casas de máquinas dos elevadores, barrilete e caixas d'água. As características dos apartamentos indicam que são destinados às classes de média alte e alta renda.

O projeto apresentado à Prefeitura de São Paulo mostra como proprietário do empreendimento o Sr. Samuel Rochwerger e como autor do projeto e construtora a empresa Sociedade de Engenharia Baro E. Zeitel Ltda. Apresenta ainda um Quadro de Áreas que demonstra uma área construída computável de 7.268,64 m2 para um terreno de 1.364,00 $\mathrm{m} 2$, ou seja, um coeficiente de cproveitamento de 5,33. Não há a demonstração da taxa de ocupação, mas por escala calculamos uma taxa de 0,40 , considerando as projeções do edifício e do salão de festas.

O projeto também apresenta uma demonstração gráfica do cálculo da altura máxima permitida para o edifício baseado no Código Artur Saboya, que determinava que a altura máxima do edifício junto ao alinhamento era igual a uma vez e meia a largura da rua. Para uma maior altura o edifício deveria se afastar do alinhamento, respeitando sempre a Linha de Gabarito. No caso deste edifício situado na rua São Vicente de Paula, cuja largura demonstrada é de 16 metros, a altura máxima no alinhamento seria de $24 \mathrm{~m}$. Para se alcançar a altura desejada de 52,60 m houve o afastamento de 19,50 m do edifício em relação ao alinhamento, como demonstrado no croqui apresentado à Prefeitura.

O levantamento do tecido urbano mostra uma região bastante adensada, com predominância de edifícios altos, a sua maioria de uso exclusivamente residencial. A comparação da foto aérea recente com o mapa do GEGRAN de 1972 demonstra que a grande maioria dos edifícios da região já estavam construídos na ocasião da Lei de Zoneamento, e provavelmente por este motivo foi considerada como Z3 e Z4. 


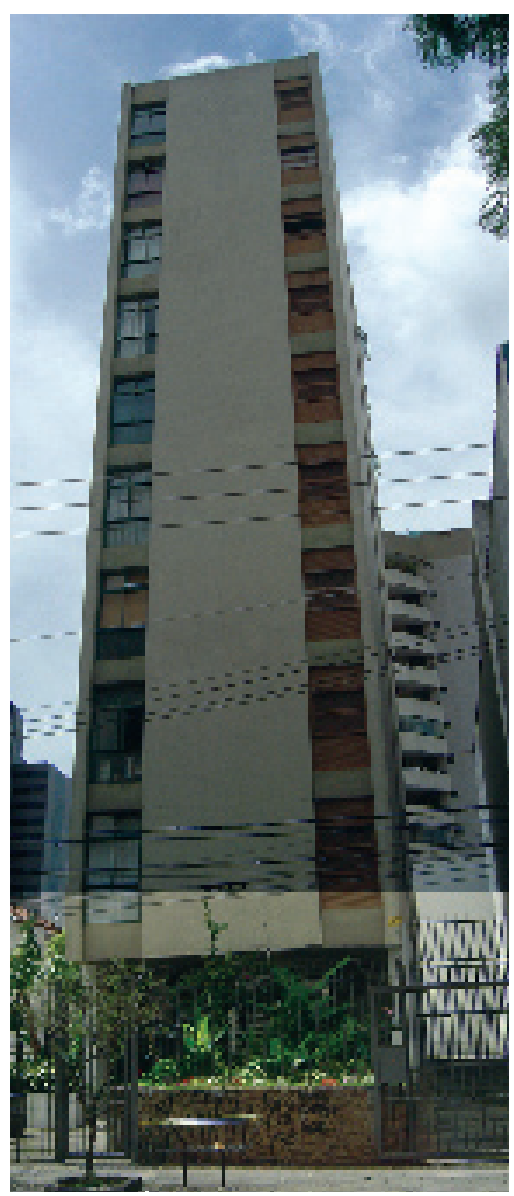

Figura 3.38 - Foto do edifício
Figura 3.39 - Plantas apresentadas à prefeitura de São Paulo.

\section{EDIFÍCIO Nº 8}

- Endereço: Rua Arthur de Azevedo, n² 28, Pinheiros.

- Data da construção: 1973.

- Edifício de uso exclusivamente residencial.

- Constitui um domínio, ou seja, todos as unidades pertencem a um mesmo proprietário ou seus descendentes.

- Construído para a renda de seu proprietário.

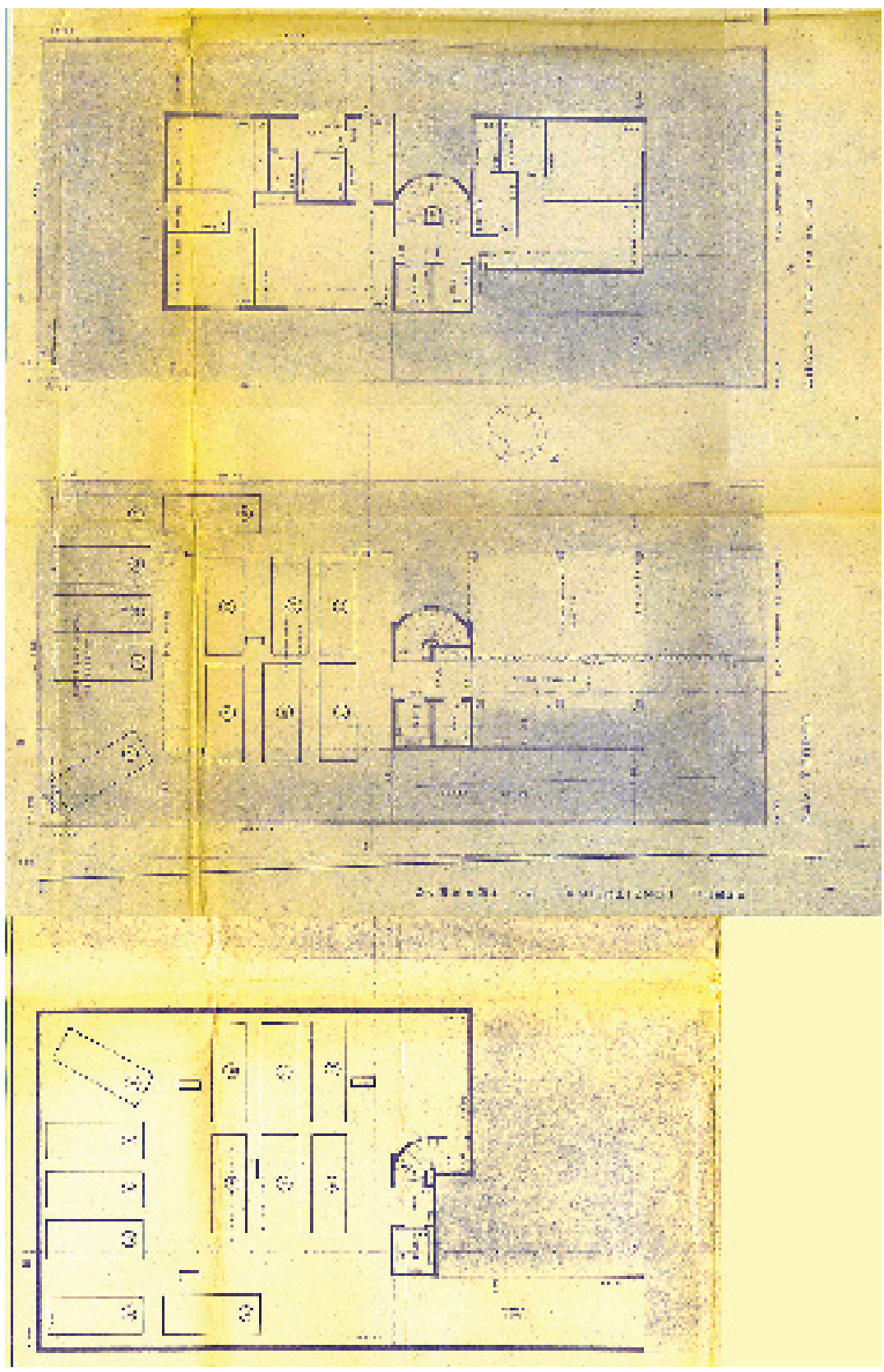




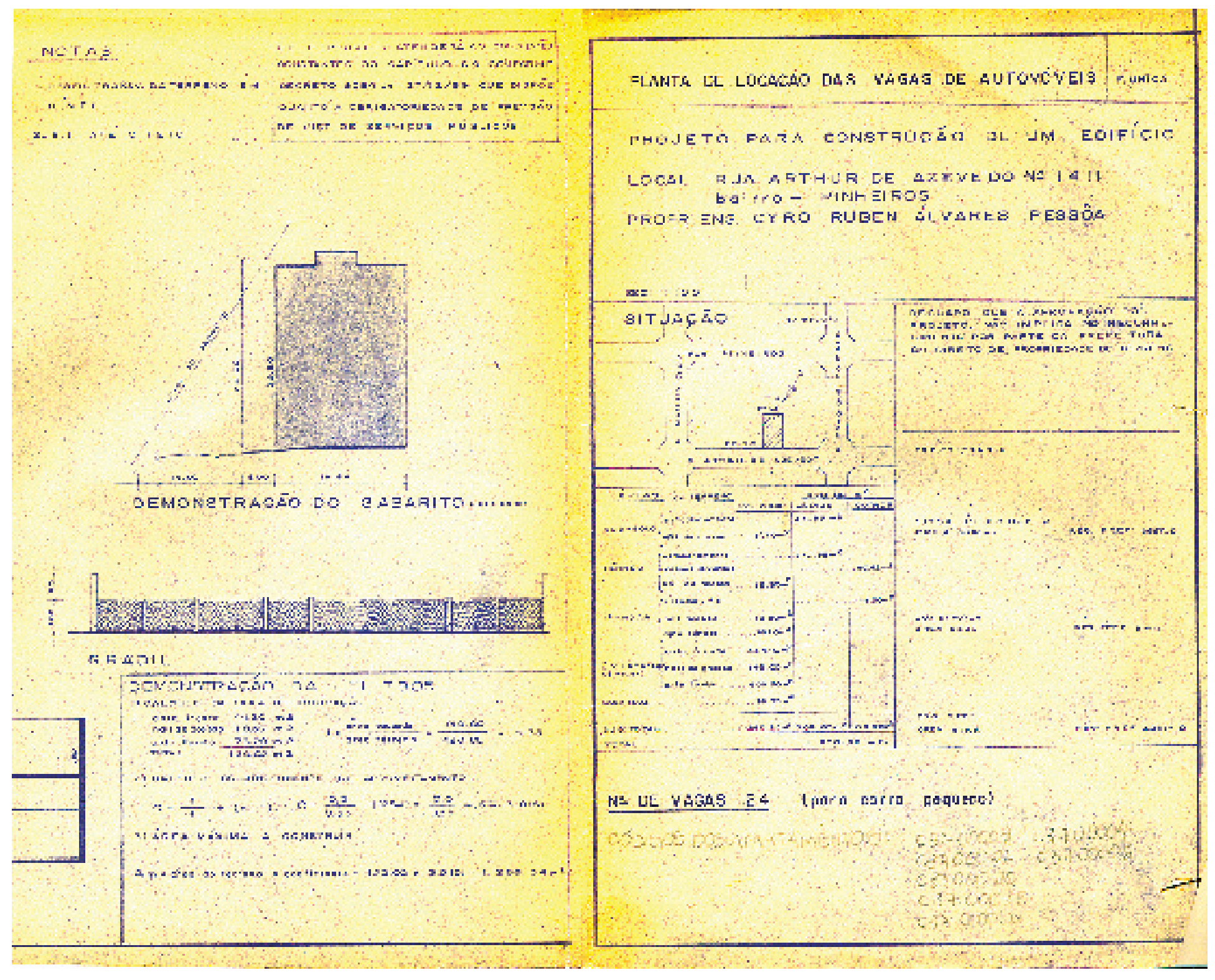

Figura 3.40 - Demonstração do gabarito de altura, demonstração "da lei 7805" sobre o cálculo do coeficiente de aproveitamento e carimbo da planta apresentados à Prefeitura de São paulo. 

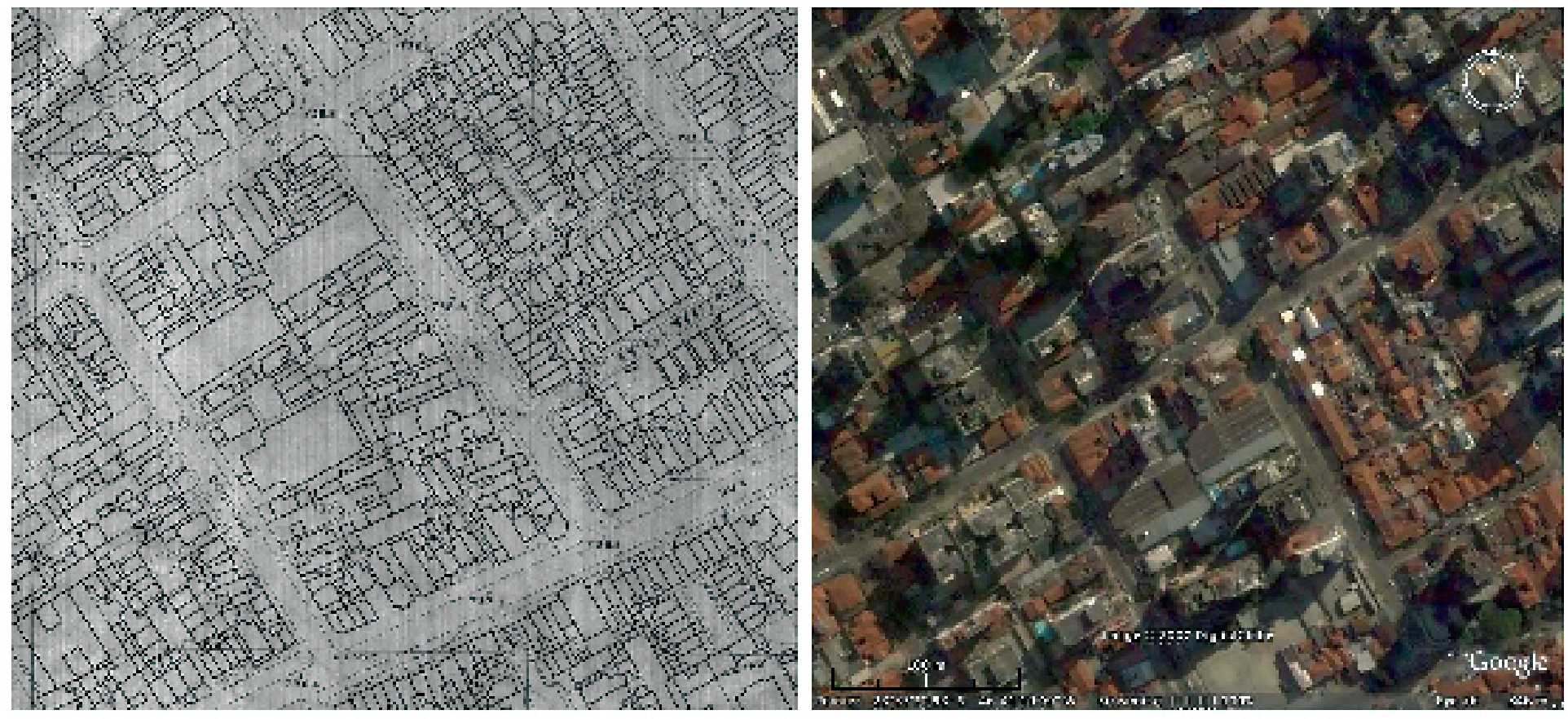

Figura 3.41 - Mapa do Gegran, de 1972, da região da rua Arthur de Azevedo e foto aérea recente do mesmo local. (Fonte foto: Google Earth

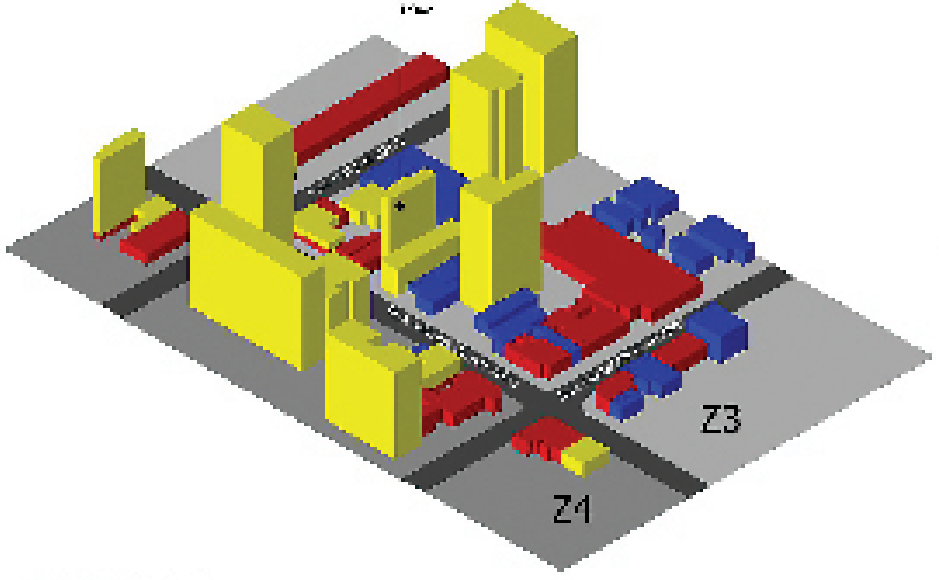

USOS ATU'Js

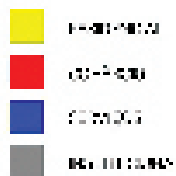

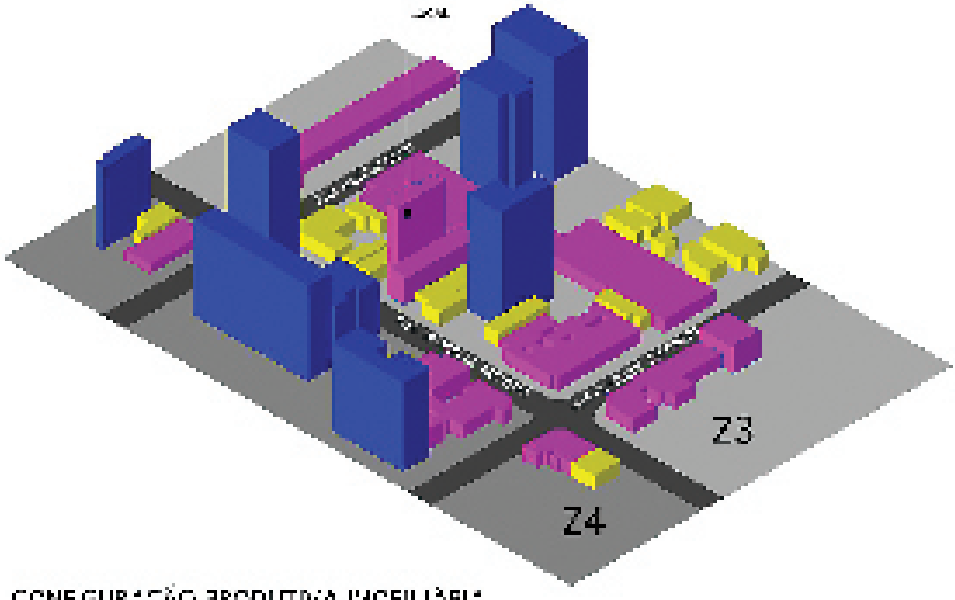

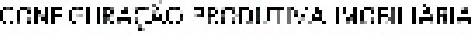

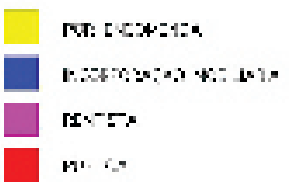

Figura 3.42 - Levantamento do tecido urbano da rua Arthur De Azevedo na altura do n 1411. (Fonte: elaborado pelo autor a partir de levantamento de campo) 
Trata-se de um edifício exclusivamente residencial com subsolo, térreo, nove pavimentos tipo e ático. O edifício foi implantado com afastamento de 5 metros para a rua Arthur de Azevedo, recuos laterais de 3,00 e de fundos de 5,16 m. O subsolo ocupa apenas metade do terreno e é destinado exclusivamente ao estacionamento de doze veículos. No pavimento térreo encontram-se a entrada do edifício, com acesso aos dois elevadores e à escada, e vagas para mais doze veículos. Em cada um dos nove pavimentos tipo existem dois apartamentos com diferentes áreas: $\mathrm{O}$ apartamento da frente, com 44,30 m2, tem um dormitório, um banheiro, sala, cozinha e lavanderia. O apartamento de fundos, com 76,20 m2, tem dois dormitórios, um banheiro, sala, cozinha, lavanderia e dependência de empregada. No ático encontra-se apenas a casa de máquinas dos elevadores. Ao zelador é destinado, segundo planta apresentada à Prefeitura, o apartamento menor do primeiro pavto tipo. As características dos apartamentos indicam que são destinados às classes de renda média.

O projeto apresentado à Prefeitura Municipal de São Paulo indica como proprietário do empreendimento o Engenheiro Cyro Ruben Álvares Pessôa mas, não sendo o documento que recebeu os carimbos de aprovação da Prefeitura, nele não consta as assinaturas e o nome do construtor. O projeto apresenta a "demonstração da lei 7805", de 1972. Começa demonstrando o cálculo da taxa de ocupação igual a 0,33; apresenta em seguida o cálculo do coeficiente de aproveitamento do lote baseado na Fórmula de Adiron. Para uma ocupação de 0,33 chegou-se a um coeficiente igual a 3,0151.

O projeto também apresenta uma demonstração gráfica da altura permitida para o edifício baseado no Código Artur Saboya. No caso deste edifício, aprovado pela municipalidade após a Lei de Zoneamento de 1972, o afastamento de 5 metros demonstrado é o recuo mínimo exigido pela lei para a Zona 3. Desta maneira, no recuo, o edifício poderia chegar a altura máxima de $31,5 \mathrm{~m}$, mais que os 28,80 demonstrado.

O levantamento realizado na região nos mostra um tecido urbano bastante heterogêneo, pouco adensado, com edificações de diversas alturas ocupadas com diversos tipos de uso. Existe na região uma leve predominancia do uso residencial. 


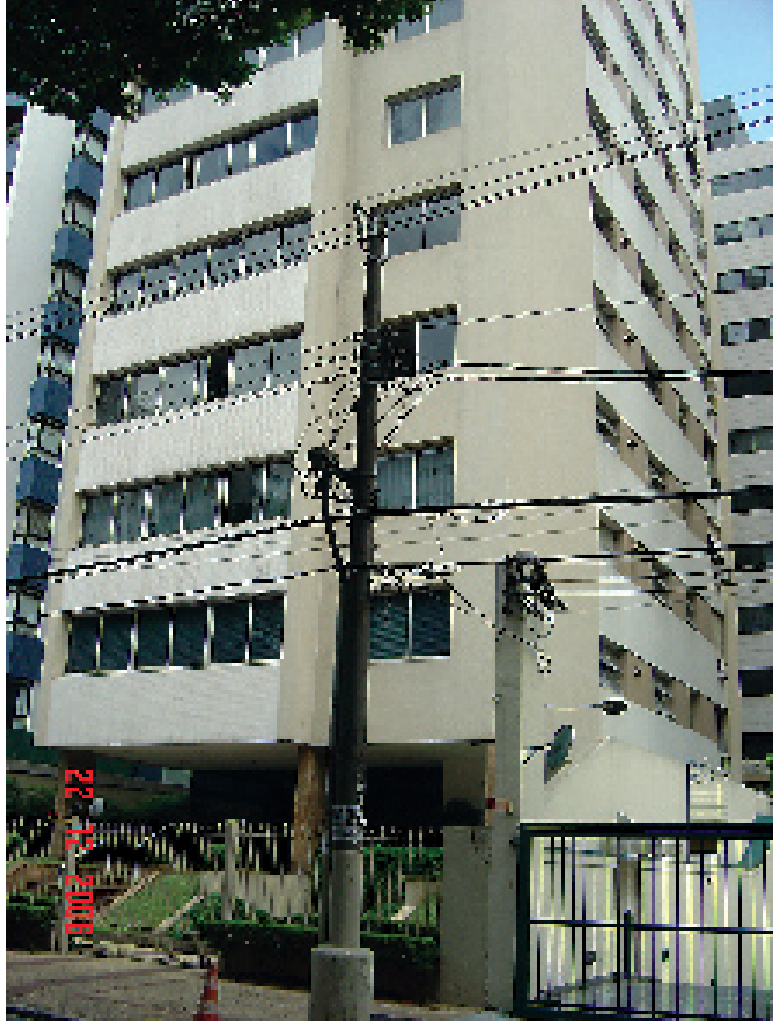

Figura 3.43 - Foto do edifício.

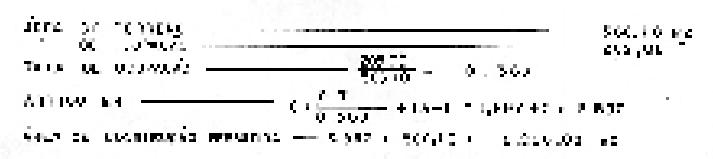

Figura 3.44 - Carimbo do projeto

apresentado à Prefeitura de São Paulo

\section{EDIFÍCIO Nº}

- Endereço: Rua Jesuíno arruda, n 521, itaim bibi.

- Data da construção: 1973.

- Edifício de uso exclusivamente residencial.

- Constitui um condomínio.

- Não temos informações precisas a respeito do propósito de sua construção, se para renda ou para venda.

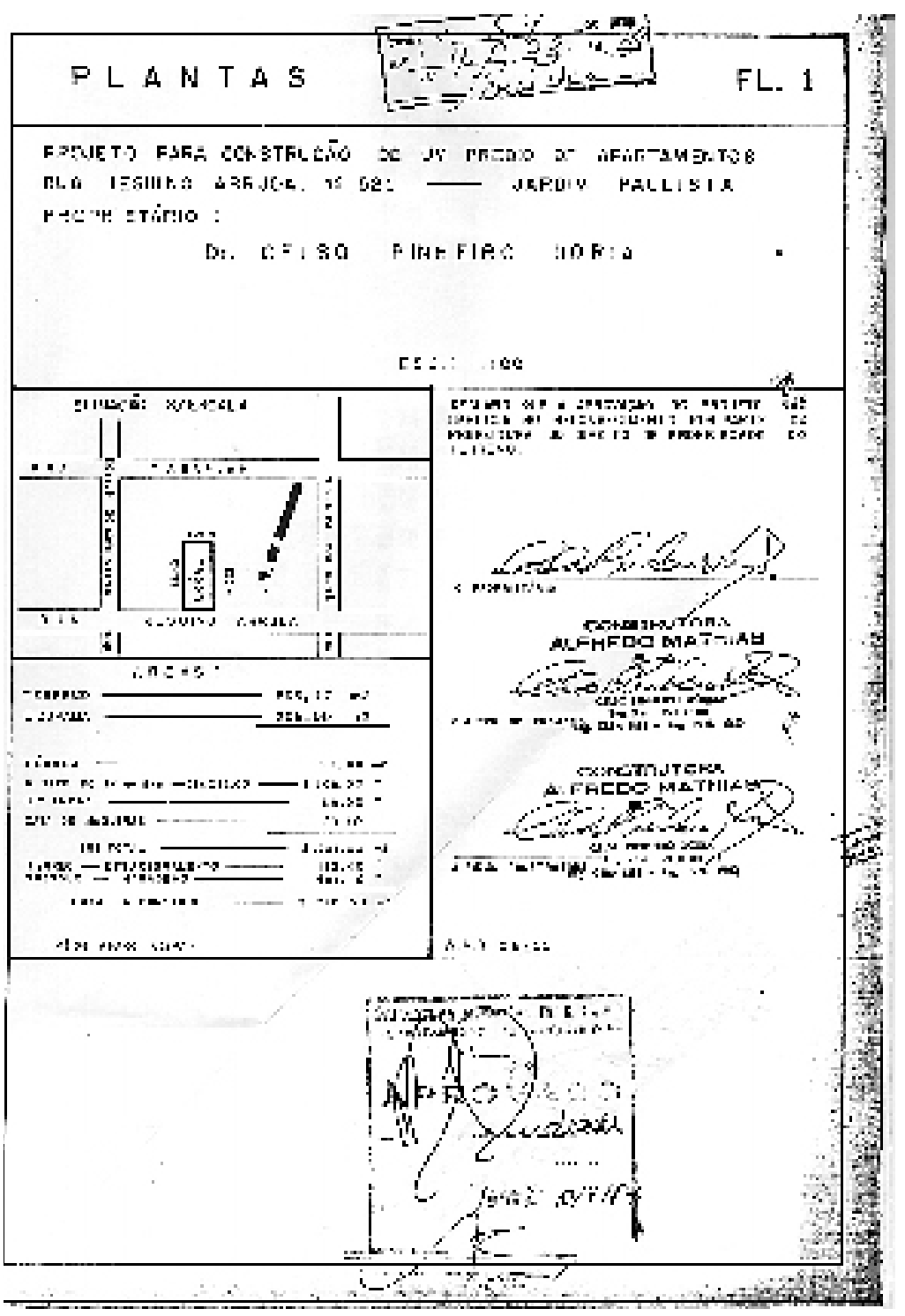




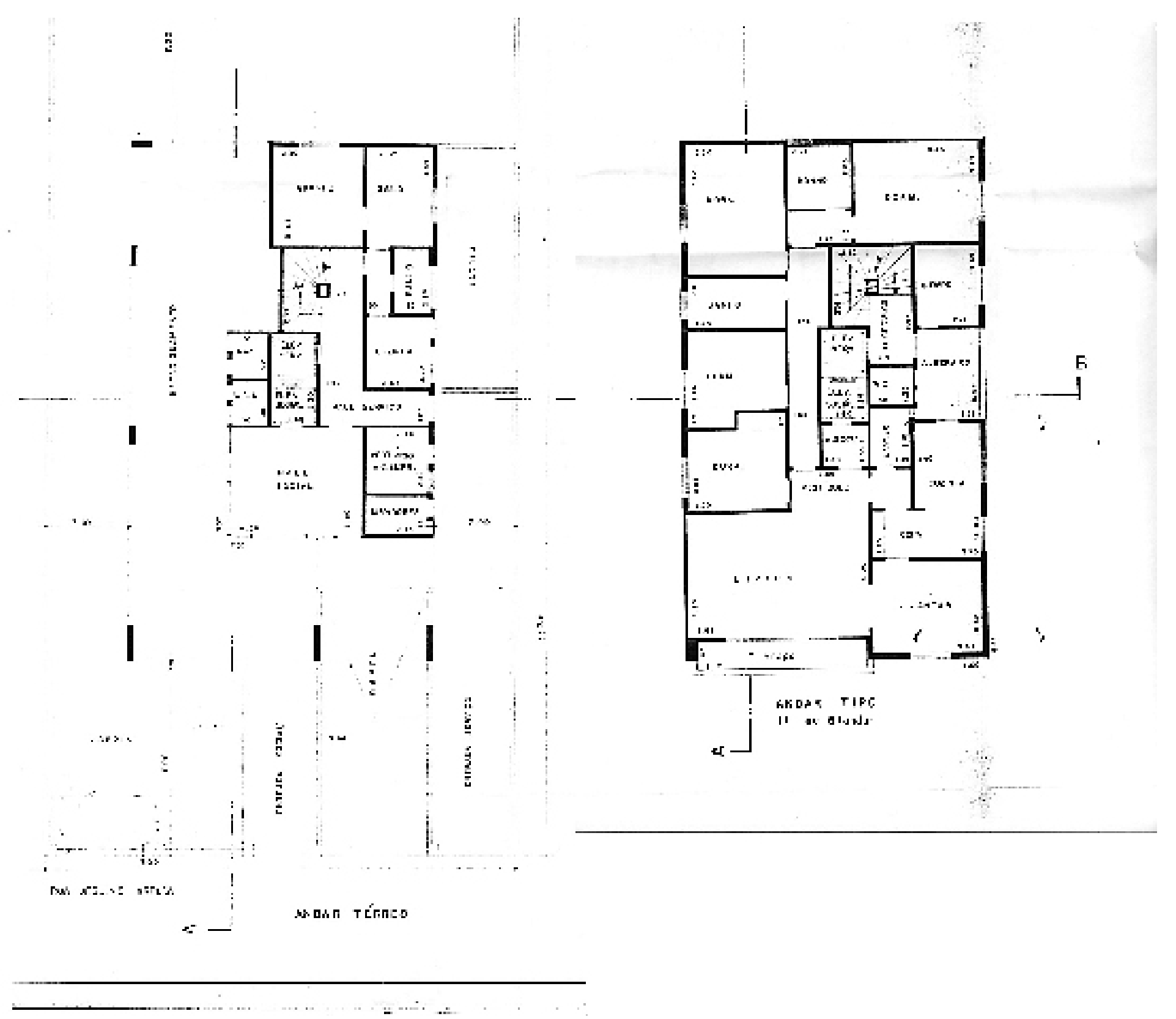

Figura 3.45 - Planta do térreo e pavto tipo apresentada à Prefeitura de São Paulo 


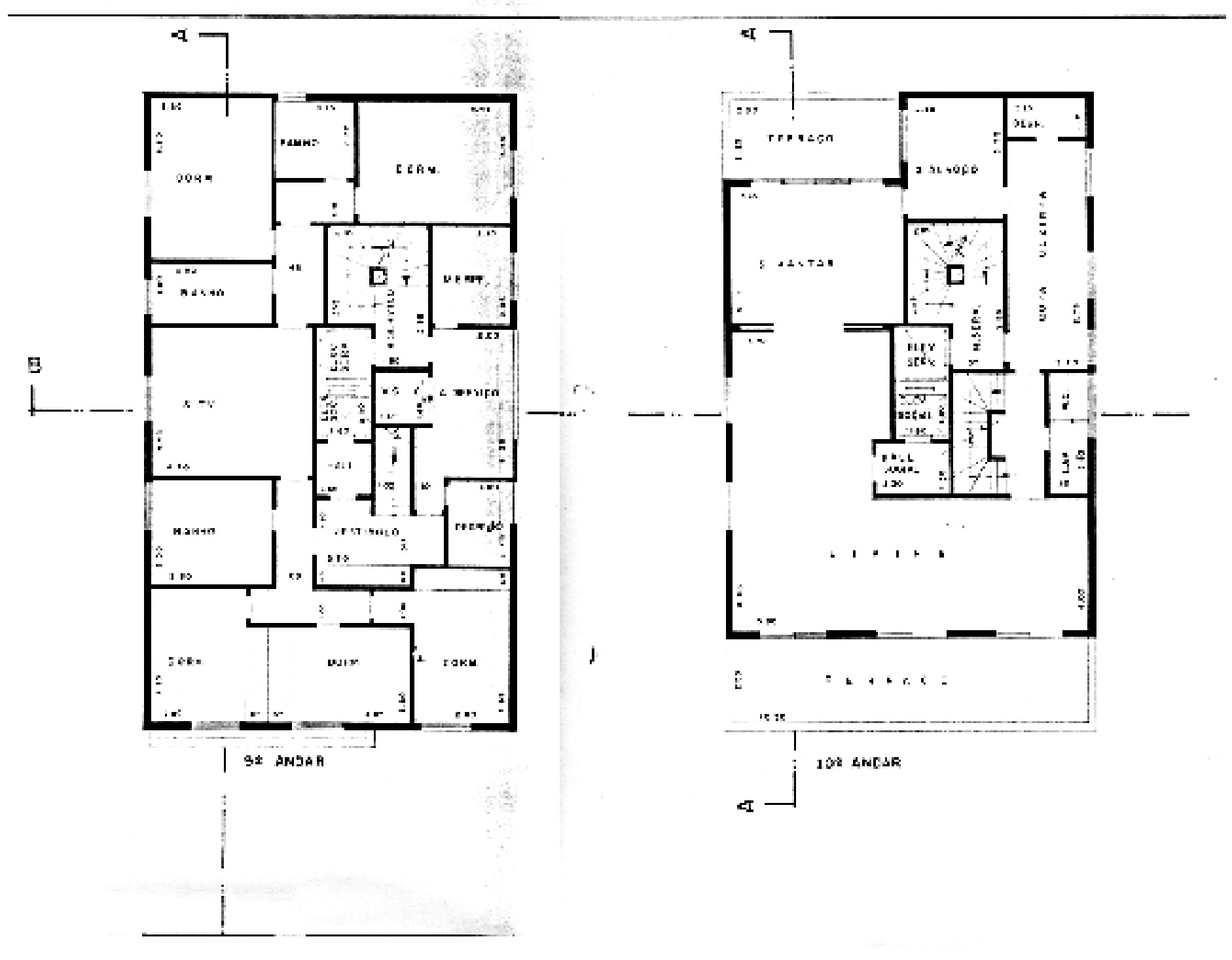

Figura 3.46 - Planta dos pavtos de cobertura apresentada à Prefeitura de São Paulo 

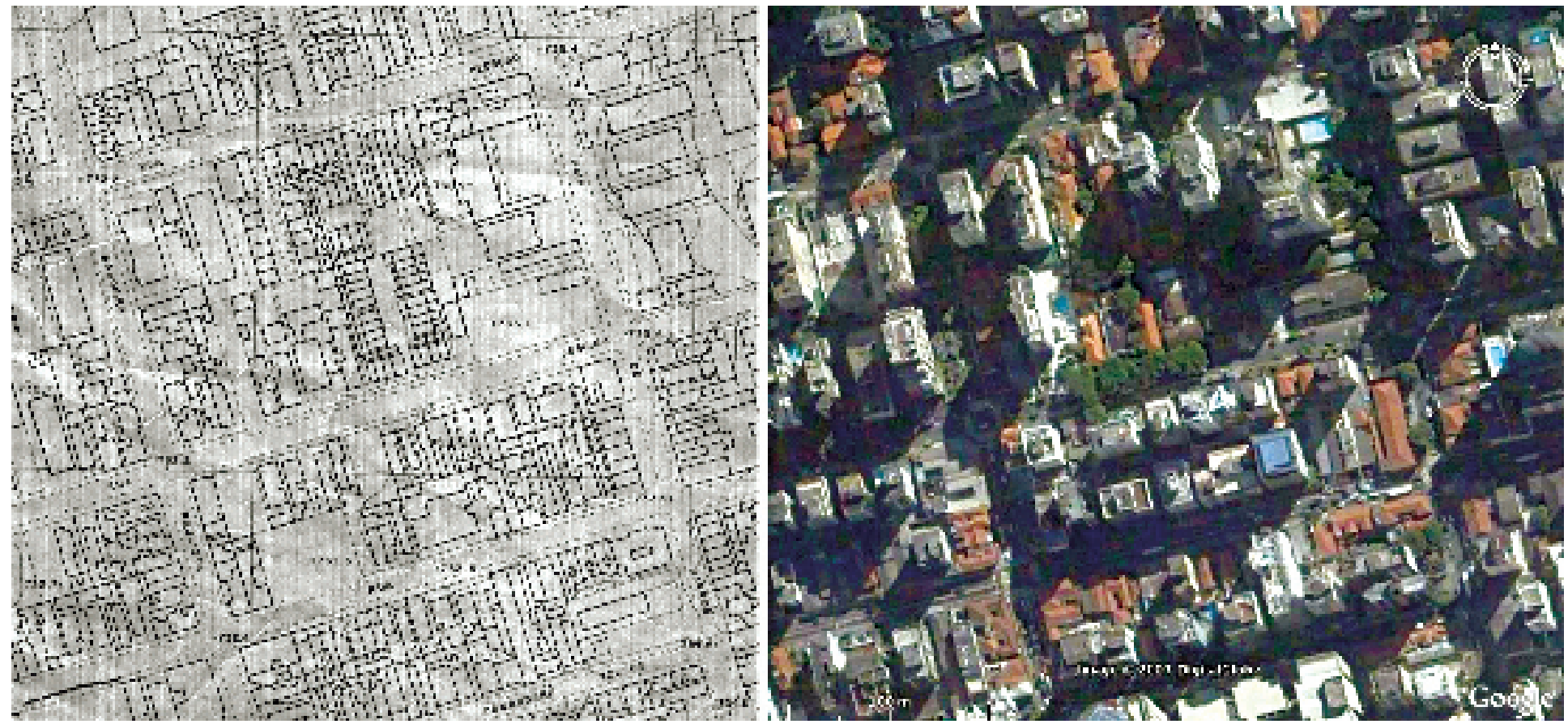

Figura 3.47 - Mapa do Gegran, de 1972, da região da rua Jesuino Arruda e foto aérea recente do mesmo local. (Fonte foto: Google Earth)

15is

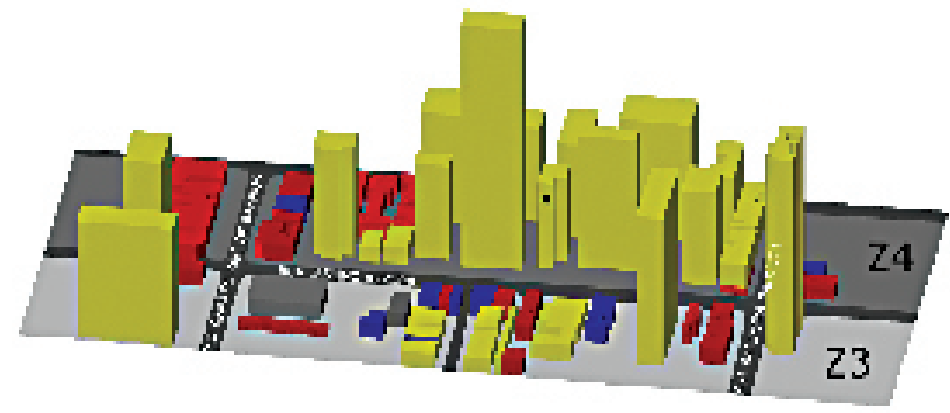

USOS ATUAIS

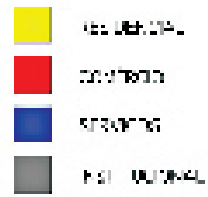

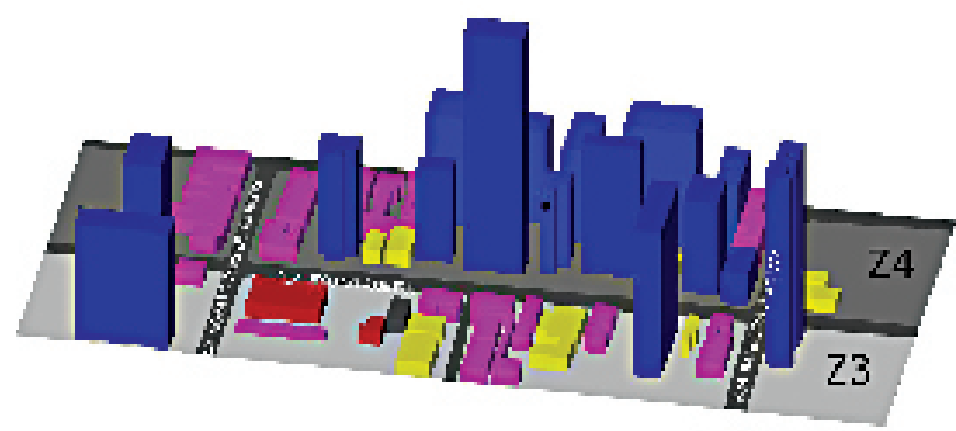

CON'TIJACRO PROOUTMA IMCEIUARRIA.

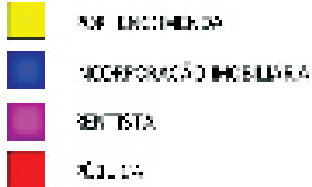

Figura 3.48 - Levantamento do tecido urbano da rua Jesuino Arruda na altura do $\mathrm{n}^{\circ}$ 521. (Fonte: elaborado pelo autor a partir de levantamento de campo) 
Trata-se de um edifício exclusivamente residencial com subsolo, térreo, oito pavimentos tipo, mais um apartamento duplex de cobertura ocupando o $9^{\circ}$ e o $10^{\circ}$ pavimentos, e ático. O edifício foi implantado com afastamento de 7 metros para a rua Jesuíno Arruda, recuos laterais de 3,00 m e de fundos de 7,30 m. O subsolo, destinado exclusivamente ao estacionamento veículos, com 19 vagas, tem um afastamento de 5,00 m do alinhamento. No pavimento térreo encontram-se a entrada social do edifício, com acesso ao elevador social, a entrada de serviço com acesso à escada e ao elevador de serviço, apartamento para o zelador; a planta original previa ainda local para estacionamento de veículos. Cada um dos oito pavimentos tipo tem apenas um apartamento com uma suíte completa, mais três dormitórios, um banheiro, sala de estar, varanda, sala de jantar, lavabo, copa, cozinha, terraço de serviço e dependência de empregada. O apartamento de cobertura tem, no $9^{\circ}$ pavimento, uma suíte completa mais cinco dormitórios, dois banheiros, sala de TV, terraço de serviço e dependência de empregada. No $10^{\circ}$ pavimento encontram-se a sala de estar com terraço, a sala de jantar, também com terraço, sala de almoço, copa, cozinha e despensa. Existe ainda uma escada privativa ligando os dois pavimentos do apartamento de cobertura. No ático encontra-se apenas a casa de máquinas dos elevadores. As características dos apartamentos indicam que são destinados às classes de renda alta e média alta.

O projeto apresentado à Prefeitura Municipal de São Paulo indica como proprietário do empreendimento o Dr. Celso Pinheiro Dória e como construtora e autora do projeto a empresea Construtora Alfredo Mathias S.A., cujo engenheiro responsável é próprio Dr. Celso Pinheiro Dória. O projeto apresenta a o cálculo do coeficiente de aproveitamento baseado na Fórmula de Adiron. Em um terreno de 566,10 m2, tem uma área ocupada de $209,00 \mathrm{~m} 2$, portanto uma taxa de ocupação de 0,369 . Demonstra uma área computável de $2.203,00 \mathrm{~m} 2$, o que significa coeficiente de aproveitamento de 3,892 .

O edifício foi executado com algumas diferenças em relação ao projeto aprovado: no térreo não existe o estacionamento demonstrado e nos pavimentos tipo uma extensão da sala ocupou o que era demonstrado como varandas. Considerando-se que o quadro de áreas demonstra um pavto tipo de 212,00 m2 e uma projeção (ocupação) de 209,00 m2, presume-se que parte da área da varanda (que está além da projeção do $9^{\circ}$ andar) não conste como área de projeção, somente como área computável do tipo. O fato da sala se estender para a varanda altera então a taxa de ocupação o que deveria acarretar na diminuição do coeficiente.

O levantamento realizado mostra um tecido urbano heterogêneo com edifícios de diversas alturas, quase todos de uso exclusivamente residencial, e construções baixas com usos diversificados. 


\section{EDIFÍCIO N 10}

- Endereço: Rua sergipe, n 309, higienópolis.

- Data da construção: 1979.

- Edifício de uso exclusivamente residencial.

- Constitui um condomínio.

- Construído para venda de suas unidades.

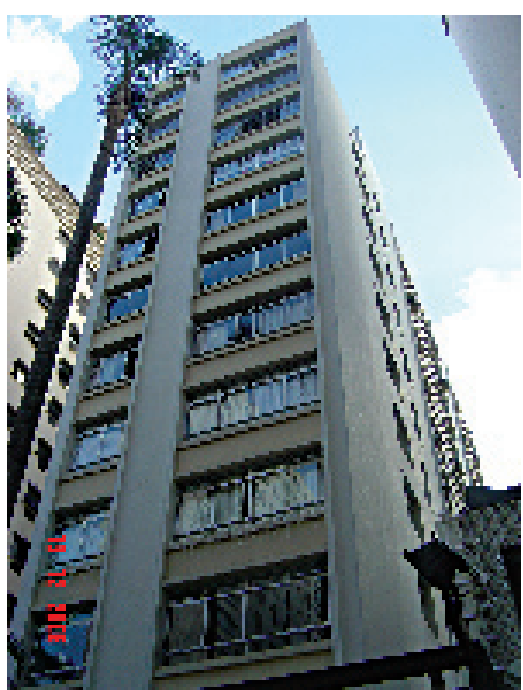

Figura $\mathbf{3 . 4 9}$ - Foto do edifício

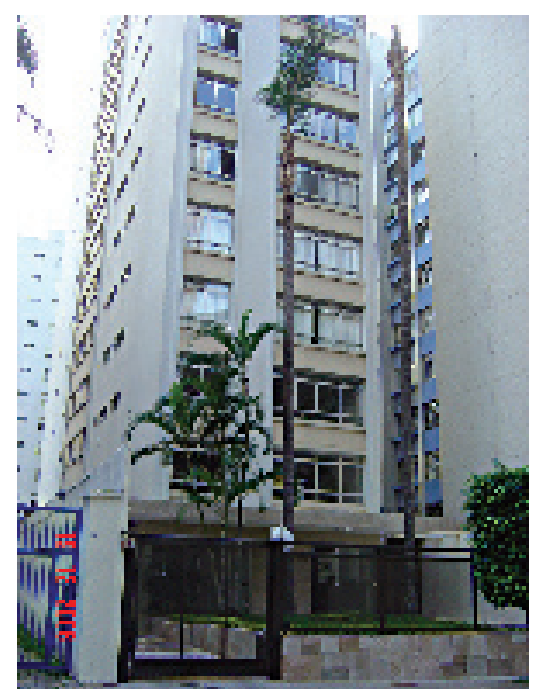

Figura 3.50 - Foto do edifício.

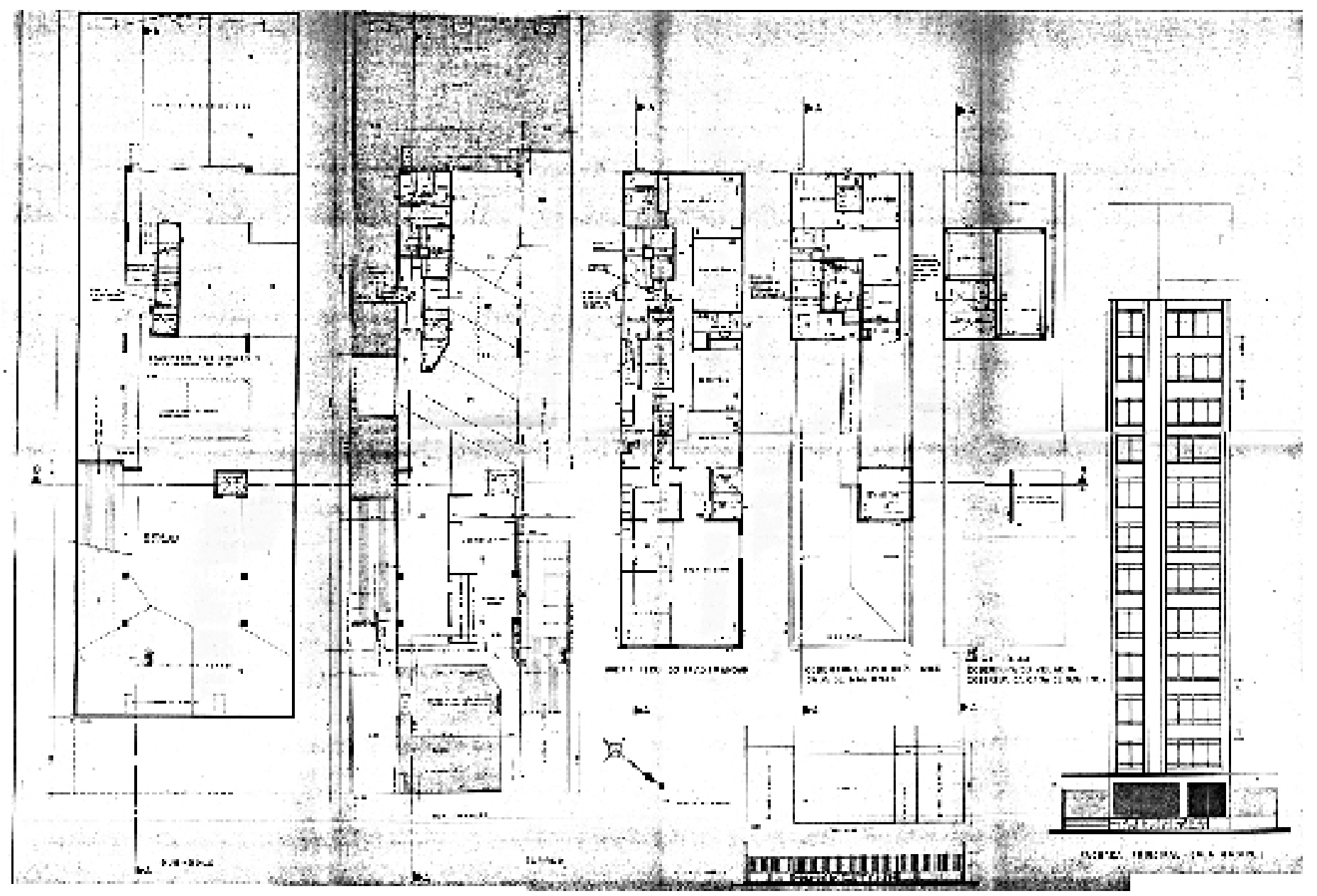

Figura 3.51 - Projeto apresentado à Prefeitura de São Paulo. 


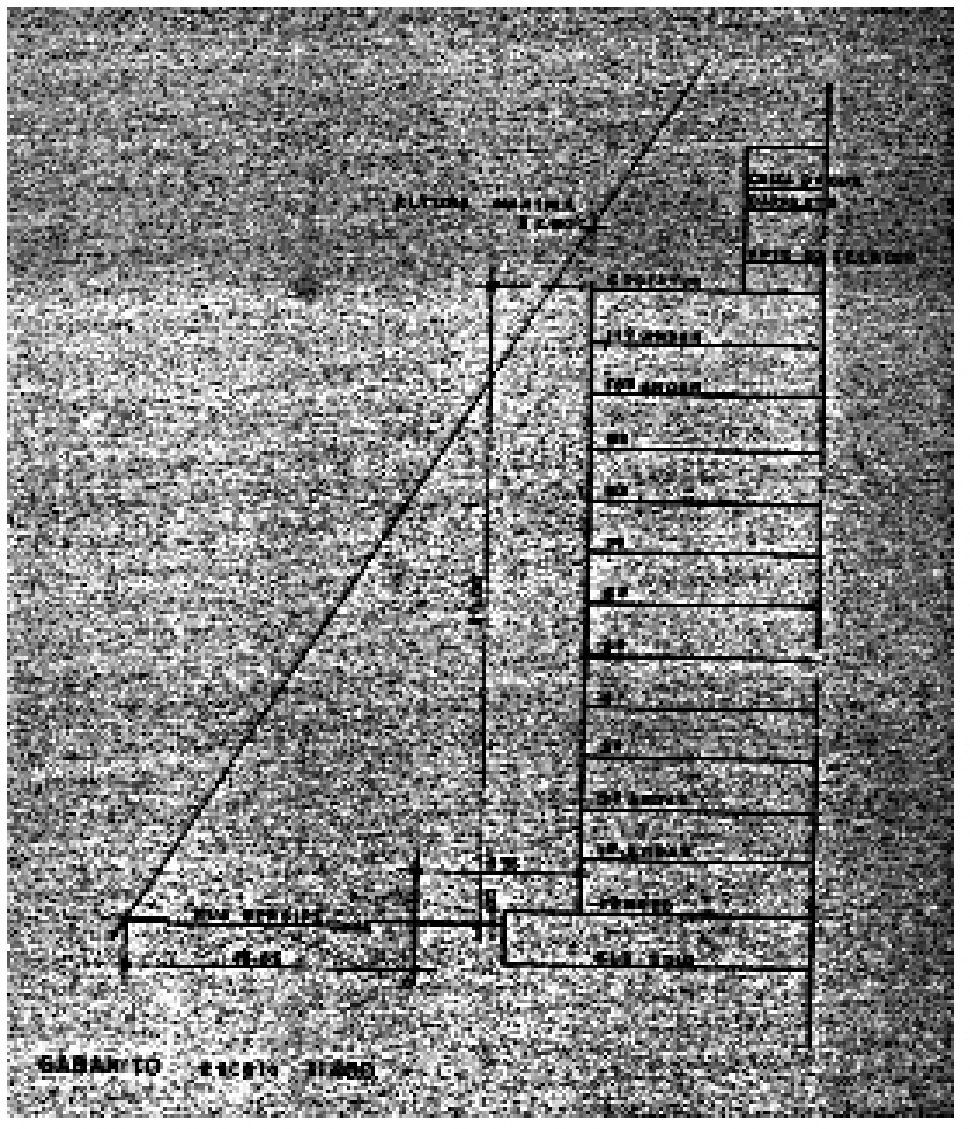

Figura 3.52 - Carimbo do projeto apresentado

à Prefeitura de São Paulo e cálculo do

coeficiente de aproveitamento.

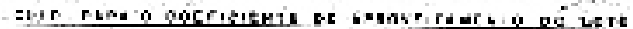

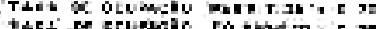

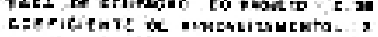

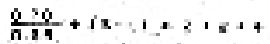

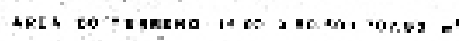

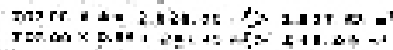

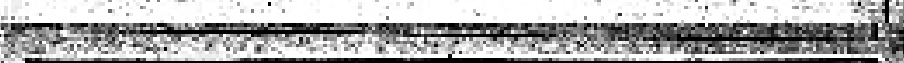

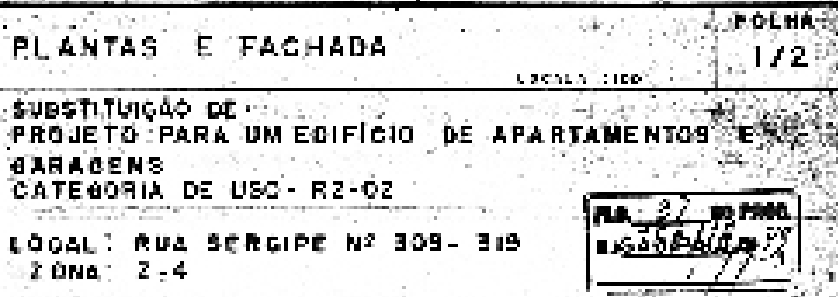

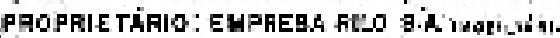
$\because$ iftas

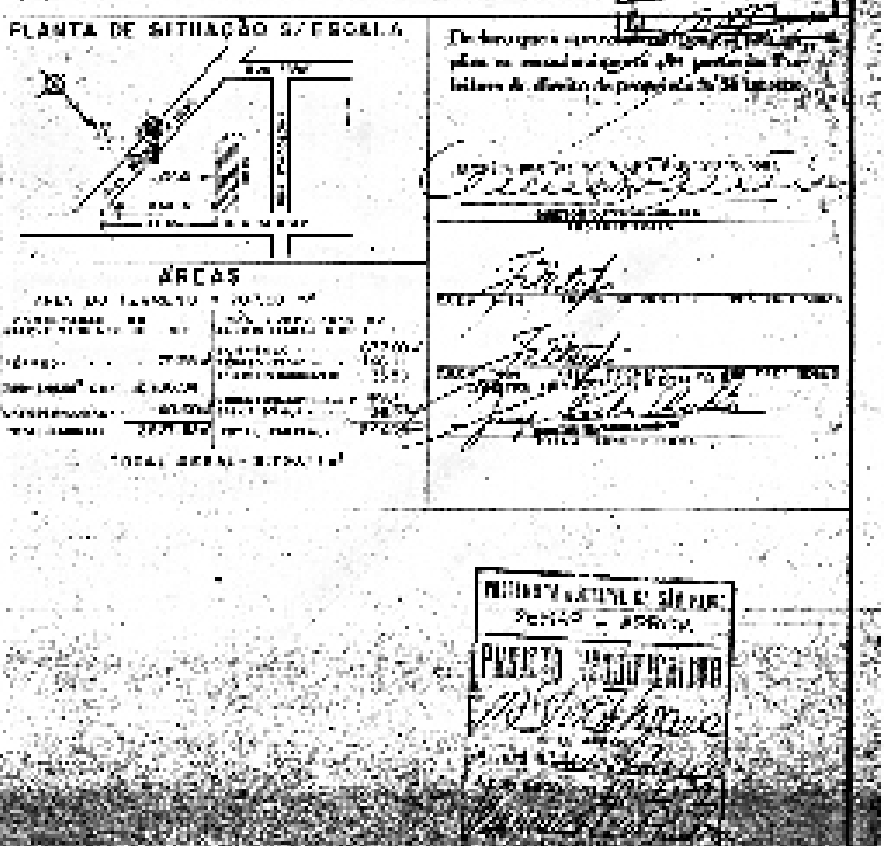




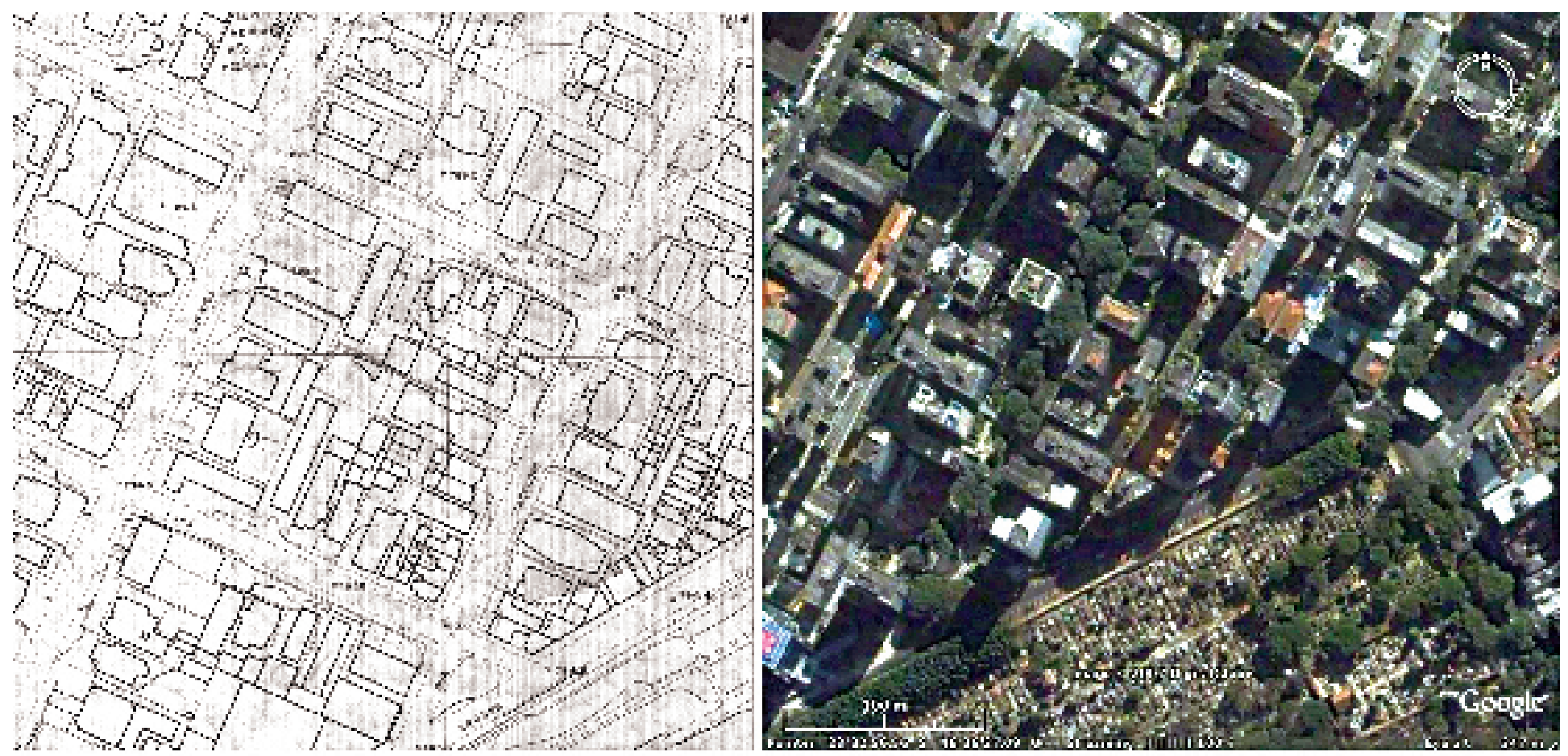

Figura 3.53 - Mapa do Gegran, de 1972, da região da rua Sergipe e foto aérea recente do mesmo local. (Fonte Foto: Google Earth)

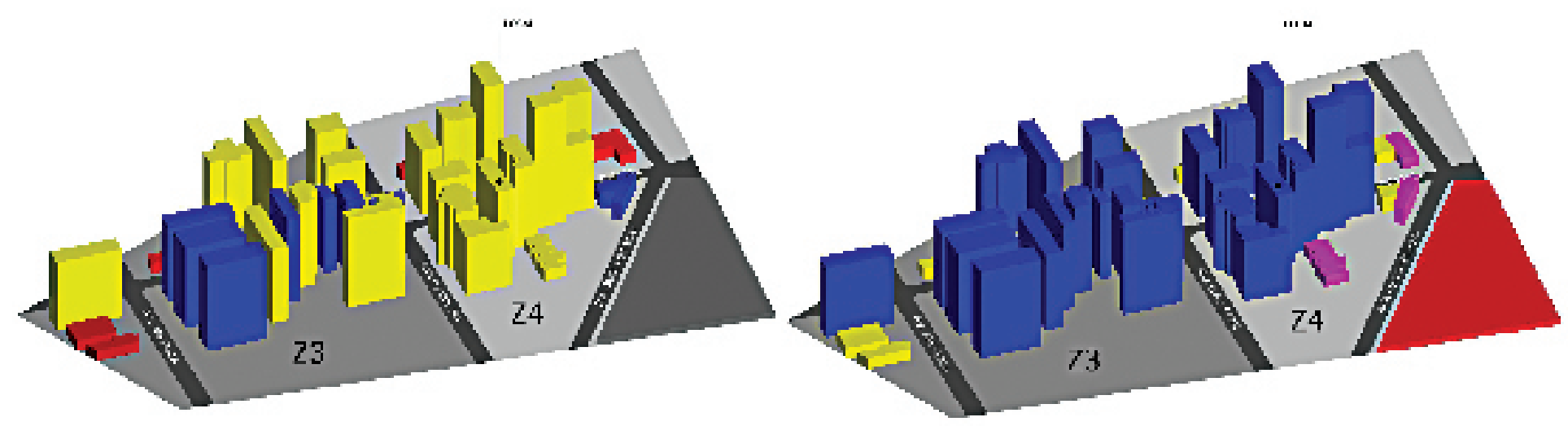

LEOS NTLAKS

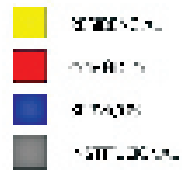

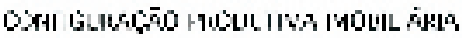

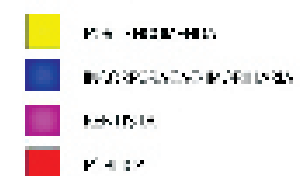

Figura 3.54 - Levantamento do tecido urbano da rua Sergipe na altura do no 309. (Fonte: elaborado pelo autor a partir de levantamento de campo) 
Trata-se de um edifício exclusivamente residencial com subsolo, térreo, onze pavimentos tipo e ático. O edifício foi implantado com afastamento de 9,35 m para a rua Sergipe, recuos laterais de 3,00 e 3,10 m e de fundos de $10,00 \mathrm{~m}$. O subsolo é destinado exclusivamente para estacionamento de veículos, com 9 vagas, e tem um afastamento de $5 \mathrm{~m}$ do alinhamento. No pavimento térreo encontram-se a entrada social do edifício, com acesso ao elevador social, a entrada de serviço, com acesso à escada e ao elevador de serviço, depósito, vestiários de funcionários e vagas para mais cinco veículos. Cada um dos onze pavimentos tipo têm apenas um apartamento com uma suíte completa mais dois dormitórios, um banheiro, sala de estar, sala de jantar, sala íntima, lavabo, copa, cozinha, terraço de serviço e dependência de empregada, totalizando 11 unidades residenciais. No ático estão localizadas a casa de máquinas dos elevadores e o apartamento do zelador. Há ainda mais um pavimento com barrilete e caixa d'água. As características dos apartamentos indicam que são destinados às classes de renda alta e média alta.

O projeto apresentado à Prefeitura Municipal de São Paulo mostra como autor do projeto e responsável técnico pela construção a empresa Construtora Richter \& Lotufo S/A e como proprietária a Empresa Rilo S.A. Imobiliária e Incorporadora que indica que este empreendimento foi uma incorporação imobiliária. O projeto apresenta o cálculo do coeficiente de aproveitamento do lote baseado na fórmula de Adiron, tendo como resultado o coeficiente 4, máximo permitido para a zona de uso. Para atingir este coeficiente, no entanto, foi necessário que a Taxa de Ocupação se mantivesse em 0,35, abaixo do máximo permitido pela zona igual a 0,50 .

O projeto também apresenta uma demonstração gráfica do cálculo da altura máxima permitida para o edifício baseado no Código Artur Saboya. No caso deste edifício situado na rua Sergipe, cuja largura demonstrada é de $15,85 \mathrm{~m}$, a altura máxima no alinhamento seria de $23,77 \mathrm{~m}$. Para se alcançar a altura desejada de $34,00 \mathrm{~m}$ foi necessário o afastamento de 9,35m do edifício em relação ao alinhamento. É importante salientar que o projeto apresentado à prefeitura a que tivemos acesso, datado de 1979, se trata de um projeto modificativo de outro aprovado em 1975. A legislação a que este devia obedecer é a que estava vigente naquele ano, na ocasião do protocolamento da primeira versão na Prefeitura Municipal, provavelmente antes de 20 de junho de 1975, data da aprovação do novo Código de Obras do Município (Lei 8.266/75) que iria abolir a linha de gabarito e estabelecer novas regras para a implantação dos edifícios no lote.

O levantamento realizado na região mostra um tecido urbano relativamente homogêneo, com edifícios de altura semelhantes, na sua maioria de uso residencias, mas também podemos encontrar edifícios comerciais e pequenas construções com comércio e serviço. Existe ainda uma grande área institucional ocupada pelo Cemitério da Consolação. 


\section{EDIFÍCIO No 11}

- Endereço: Rua Lourenço de Almeida, n 567, Vila Nova Conceição.

- Data da construção: 1987.

- Edifí́cio de uso exclusivamente residencial.

- Constitui um condomínio.

- Não temos informações precisas a respeito do propósito de sua construção, se para renda ou para venda.

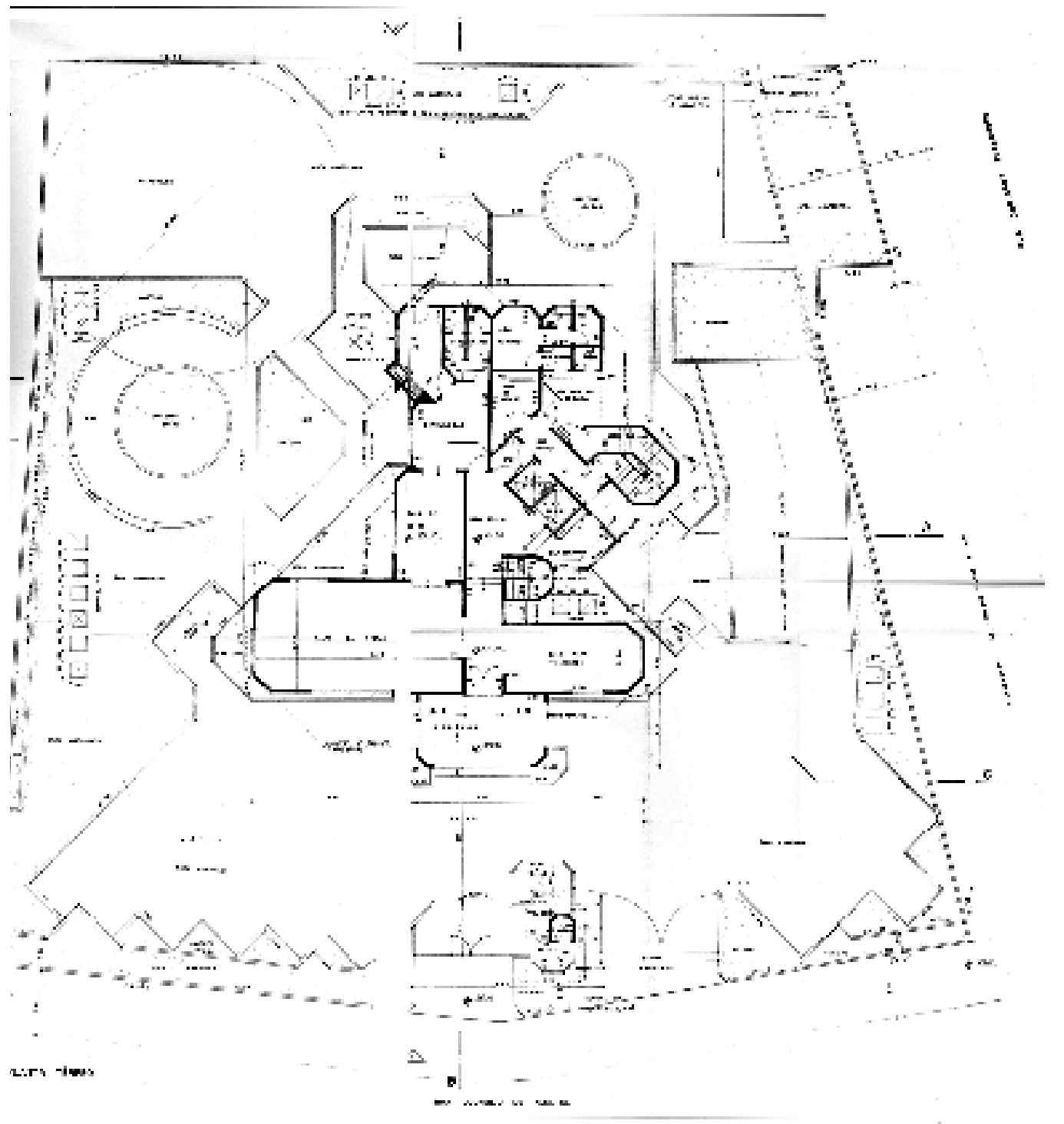

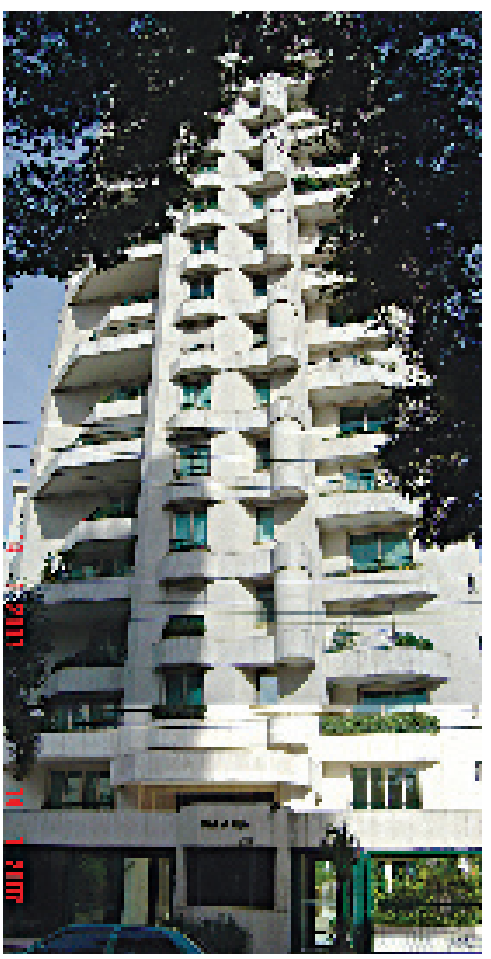

Figura 3.55 - Foto do edifício.

Figura 3.56 - Planta de implantação do empreendimento apresentado à Prefeitura de São Paulo. 


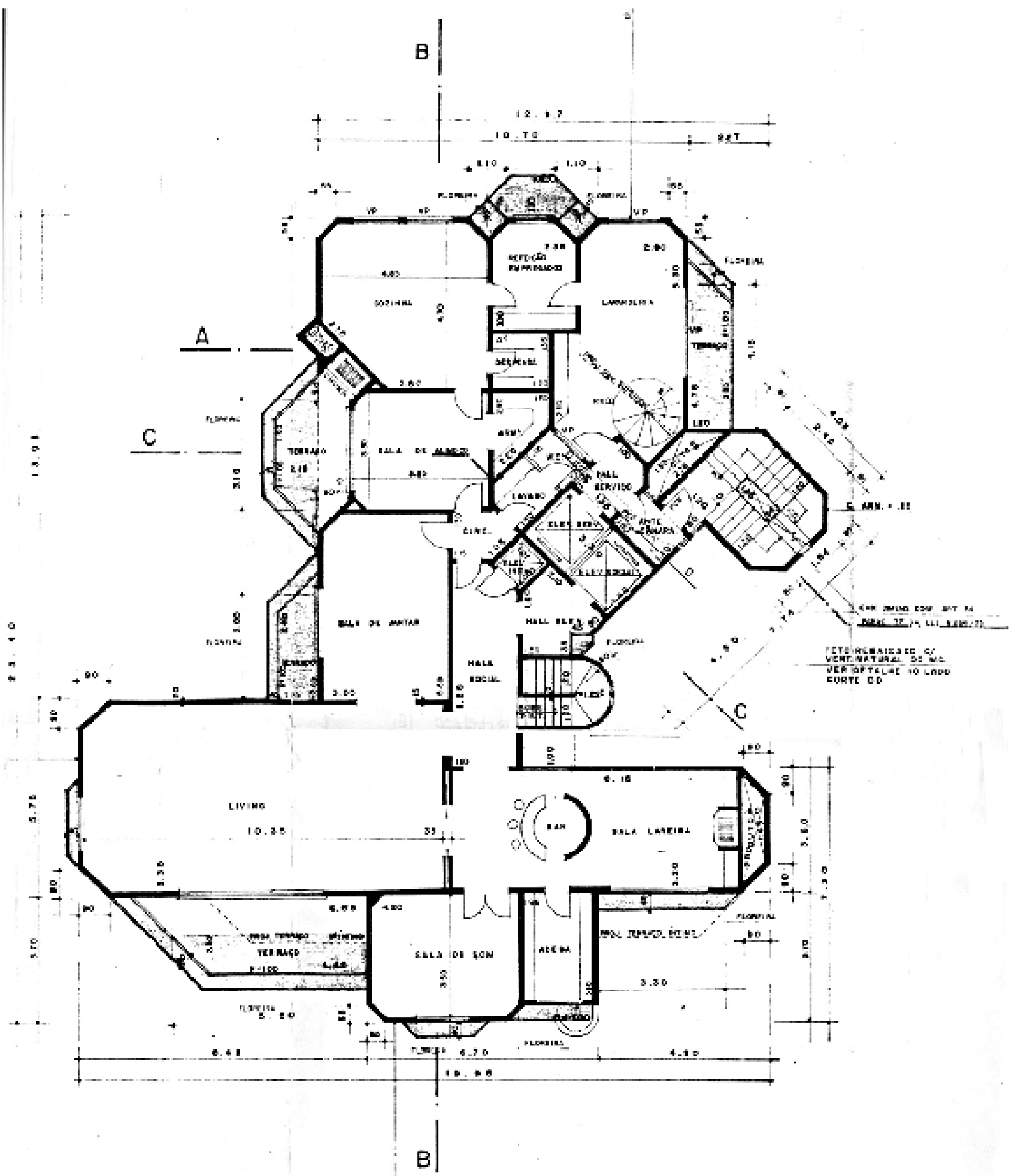

Figura 3.57 - Planta do pavto inferior do

apto duplex tipo do empreendimento

apresentado à Prefeitura de São Paulo. 


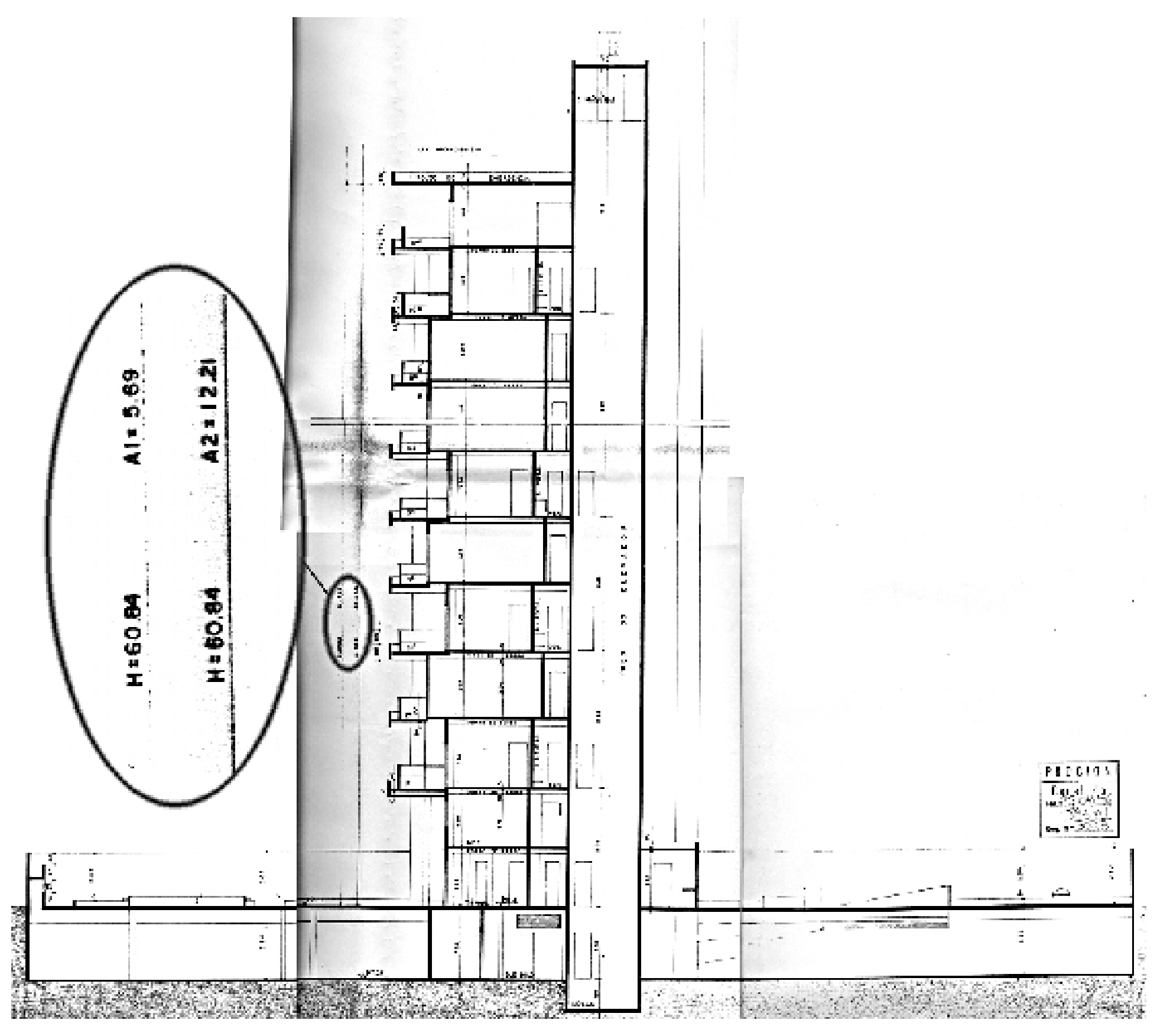

Figura 3.58 - 0 corte apresentado à Prefeitura mostra a altura do edifício e suas respectivas faixas $\mathrm{A} 1 \mathrm{E} A 2$. 


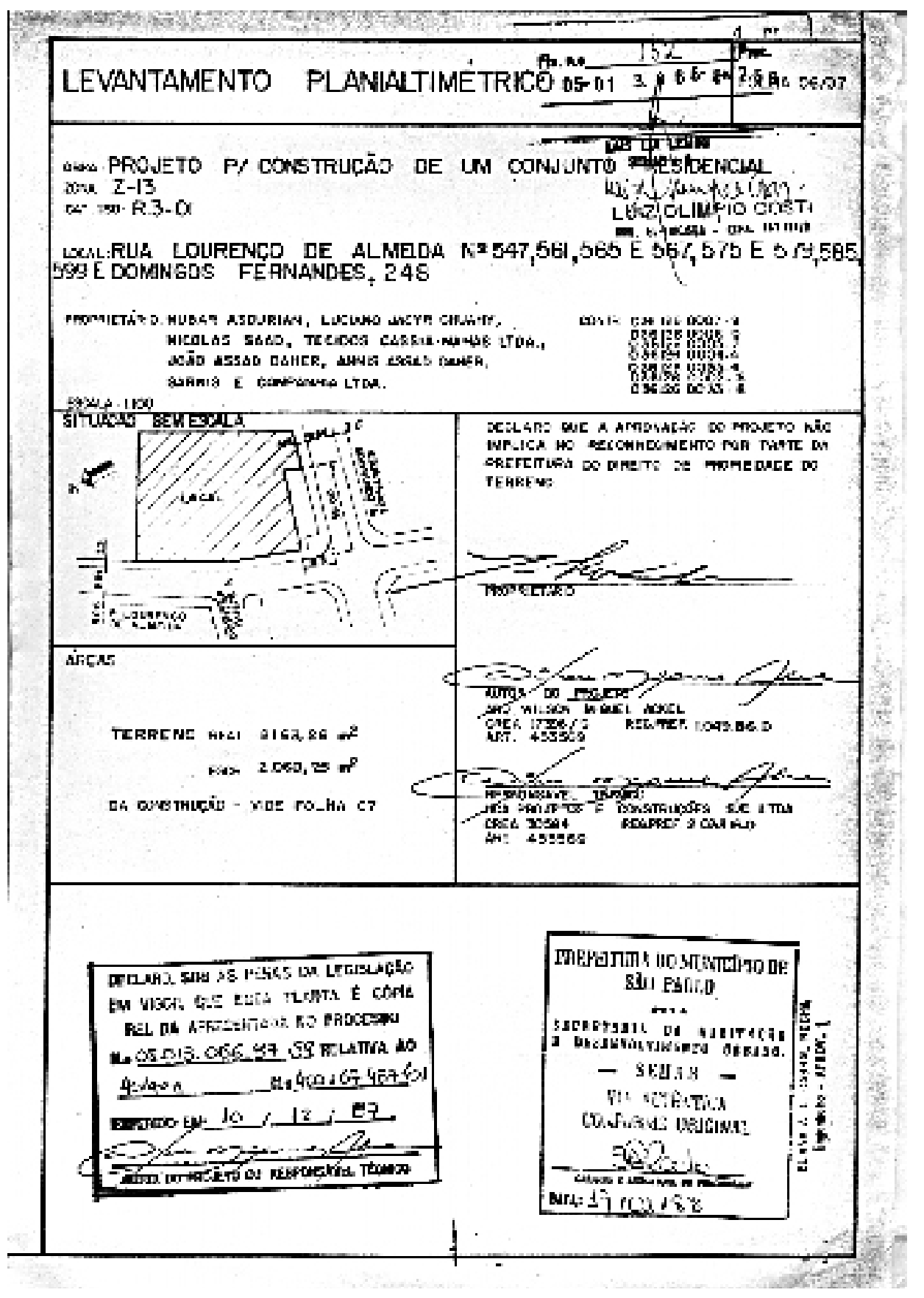



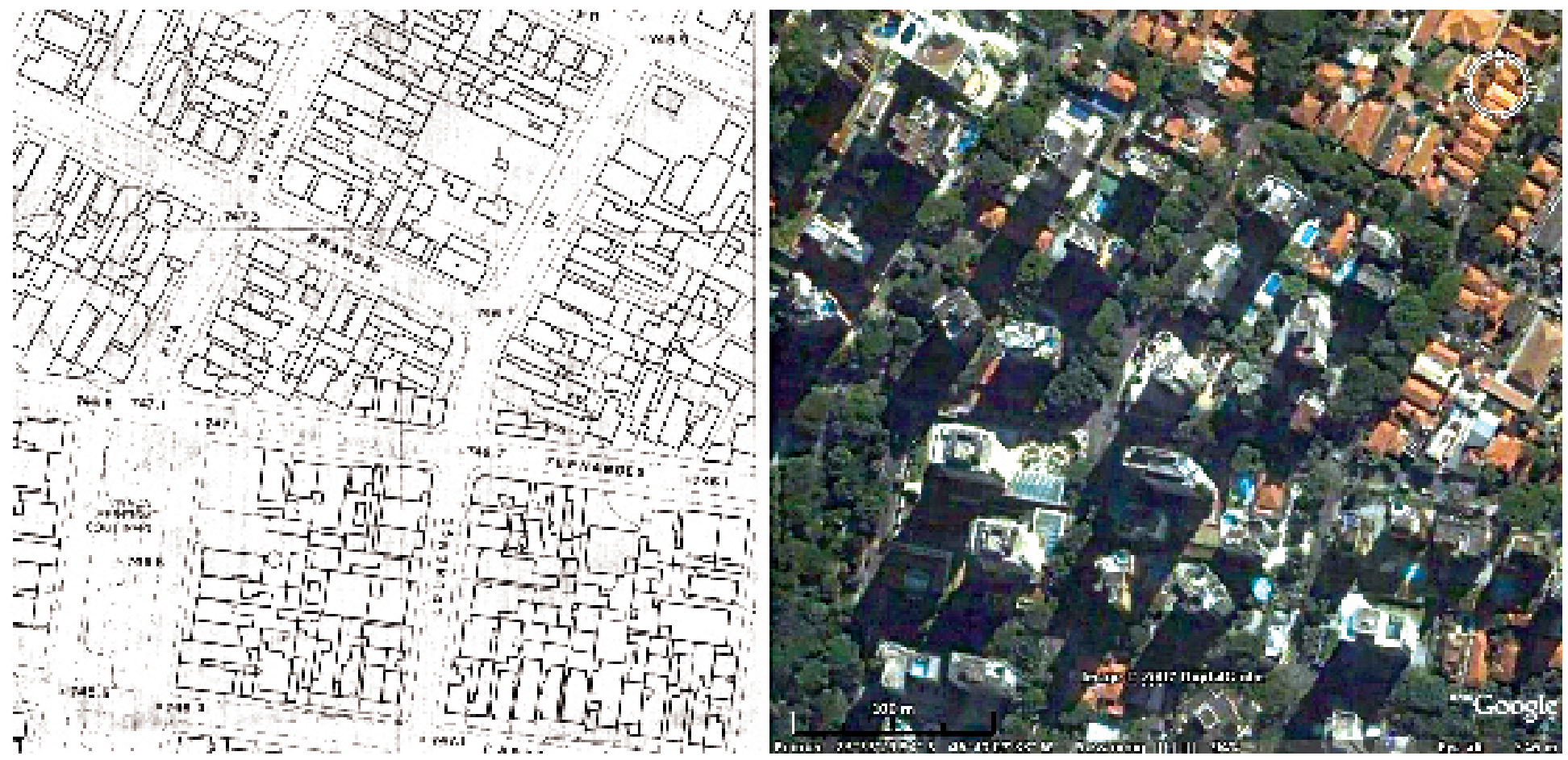

Figura 3.60 - Mapa do Gegran, de 1972, da região da rua Lourenço de Almeida e foto aérea recente do mesmo local. (Fonte foto: Google Earth)
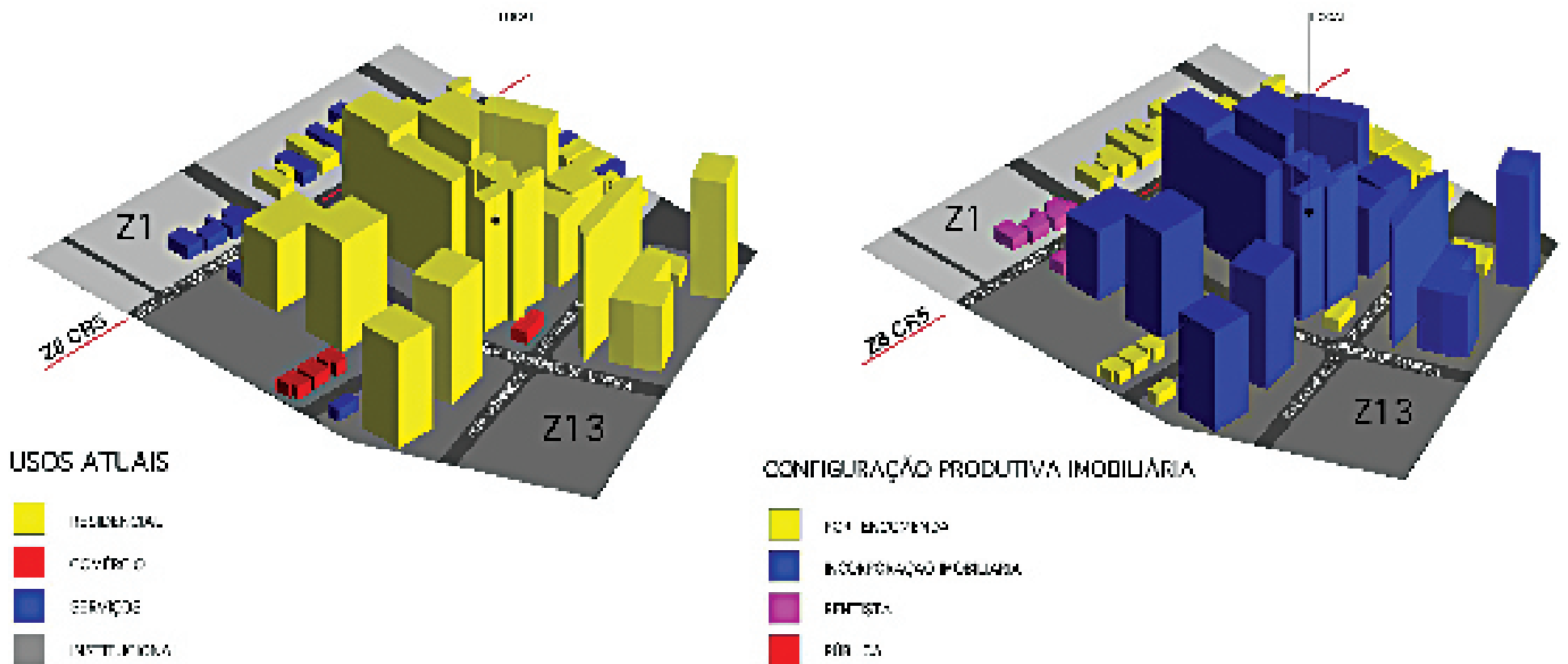

Figura 3.61 - Levantamento do tecido urbano da rua Lourenço de Almeida na altura do ${ }^{\circ}$ 567. (Fonte: elaborado pelo autor a partir de levantamento de campo) 
Trata-se de um edifício exclusivamente residencial com subsolo, térreo, mezanino do pavto térreo, 17 pavimentos tipo e ático. Os primeiros quatorze pavimentos contêm apenas sete apartamentos duplex, o $15^{\circ}, 16^{\circ}$ e o $17^{\circ}$ pavimentos contêm apenas mais um apartamento triplex de cobertura, totalizando oito unidades. $\mathrm{O}$ edifício foi implantado no centro do lote com grandes afastamentos de todos os lados: $13 \mathrm{~m}$ de frente para a rua Lourenço de Almeida, 12,5 m na lateral esquerda, $9 \mathrm{~m}$ na lateral direita e 12,5 m de fundos. O ubsolo tem 57 vagas para estacionamento de veículos e 9 depósitos, e tem um afastamento de $5 \mathrm{~m}$ do alinhamento. No pavimento térreo encontram-se a portaria, a entrada social do edifício, com acesso ao elevador social, e a entrada de serviço com acesso à escada e ao elevador de serviço; encontra-se ainda salão de festas com copa e dois sanitários, sala para visitantes e sala para seguranças. No mezanino do pavto térreo encontram-se o apartamento para o zelador e sala para recreação. No andar social dos apartamentos encontra-se a sala de estar para dois ambientes e varanda, sala de lareira, sala de som, bar, adega, sala de jantar com varanda, lavabo, sala de almoço com varanda e churrasqueira, cozinha, sala de refeições para empregados e lavanderia com varanda. Todos os apartamentos têm escada privativa de serviço, escada privativa social e elevador privativo para acesso ao pavto íntimo. Não tivemos acesso às plantas dos pavimentos íntimos dos apartamentos, do apartamento triplex e do ático. As características dos apartamentos indicam que são destinados às classes de alta renda.

O projeto apresentado à Prefeitura Municipal de São Paulo mostra como proprietário do empreendimento um grupo de pessoas, como autor do projeto o arquiteto Wilson Miguel Ackel e como responsável técnico a empresa UCA Projetos e Construções, sob responsabilidade do próprio arquiteto. O projeto apresenta, no pavto térreo, a demonstração da área de lazer descoberta representada por um círculo de $16 \mathrm{~m}$ de diâmetro. Pelo fato de o jogo de desenhos estar incompleto, não tivemos acesso ao quadro de áreas do empreendimento, apenas à área do terreno real de $2.163,26 \mathrm{~m} 2$, e a área de escritura de 2.060,25 m2. Por se tratar de uma Z13, presume-se que o coeficiente de aproveitamento deva se aproximar de 2,00, índice máximo para esta zona e, aplicando a fórmula de Adiron para terrenos maiores que 1.000,00 m2, a taxa de ocupação deve ser menor ou igual a 0,25 .

O projeto mostra nos desenhos dos cortes a altura do edifício $(60,84 \mathrm{~m})$ e as faixas A1, de aeração, e A2, de iluminação, de acordo com a Lei 8.266 de 1975.

O levantamento realizado nos mostra que esta é uma região tecidos urbanos onde ocorre uma transição de um tecido urbano mais adensado, situado na Z13, com predominância de edifícios altos de uso exclusivamente residencial, para um tecido pouco adensado, próprio de uma Z1, com predominância de residências unifamiliares. Entre as duas zonas citadas existe uma zona-corredor Z8 CR5 que, quando lindeira a um Z1 permite o funcionamento de empresas prestadoras de serviço sem operação de vendas. 


\section{EDIFÍCIO N 12}

- Endereço: Rua ouro branco, no 101, jd. paulista.

- Data da construção: 1992.

- Edifício de uso exclusivamente residencial.

- Constitui um condomínio.

- Construído para a venda de suas unidades.
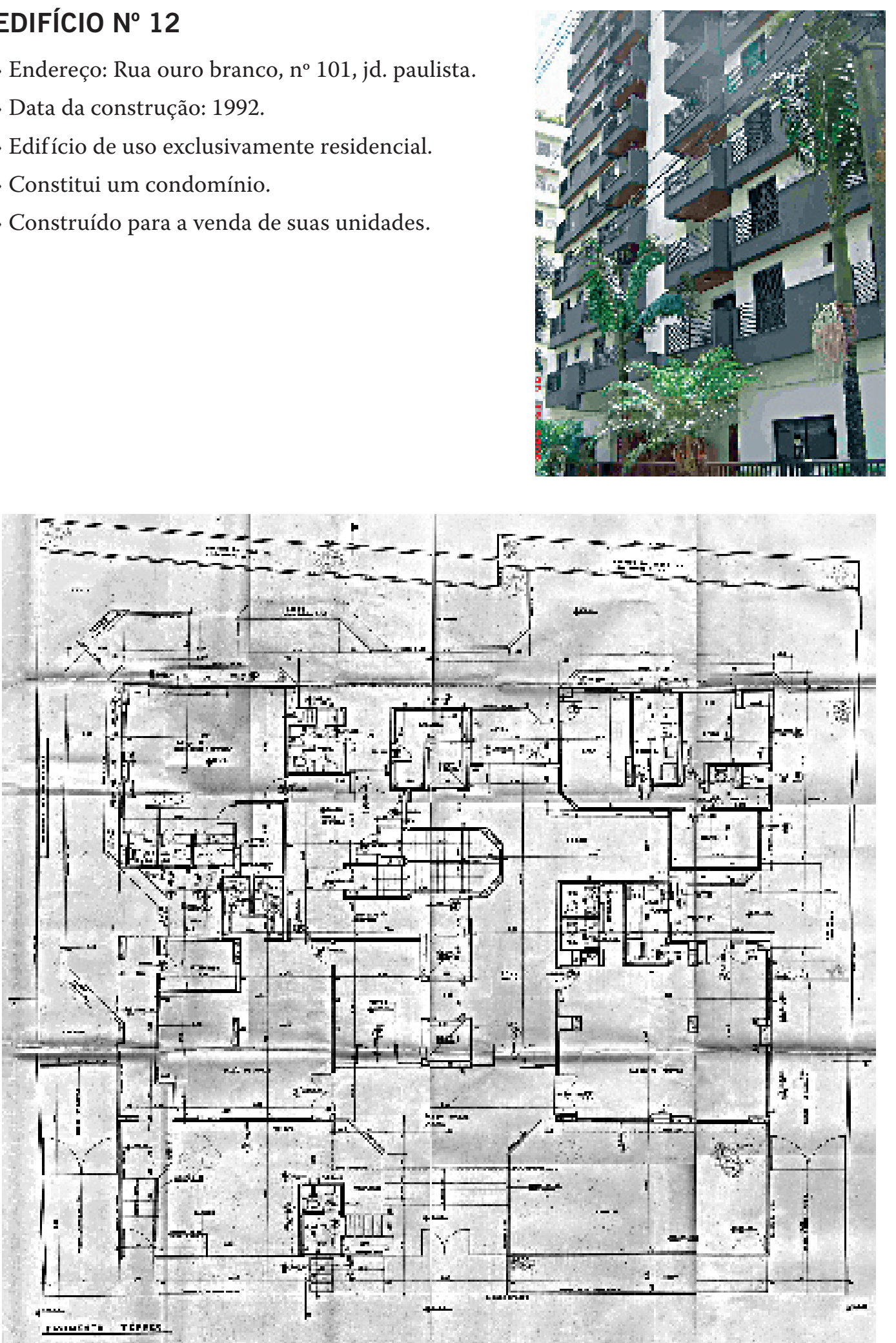

Figura 3.62 - Fachada do prédio.

Figura 3.63 - Planta executiva da implantação do empreendimento. 


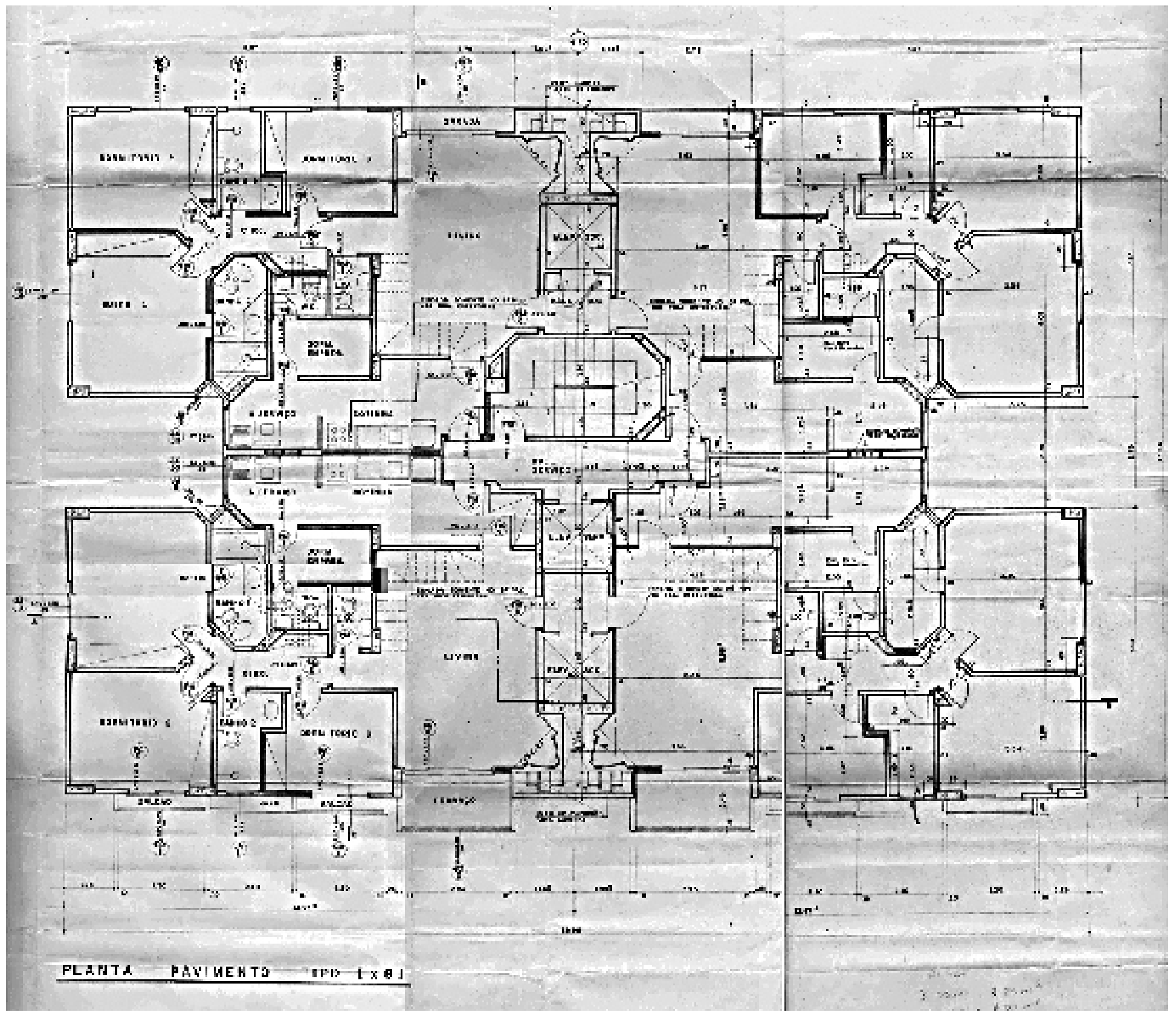

Figura 3.64 - Planta executiva do Pavto Tipo do empreendimento. 


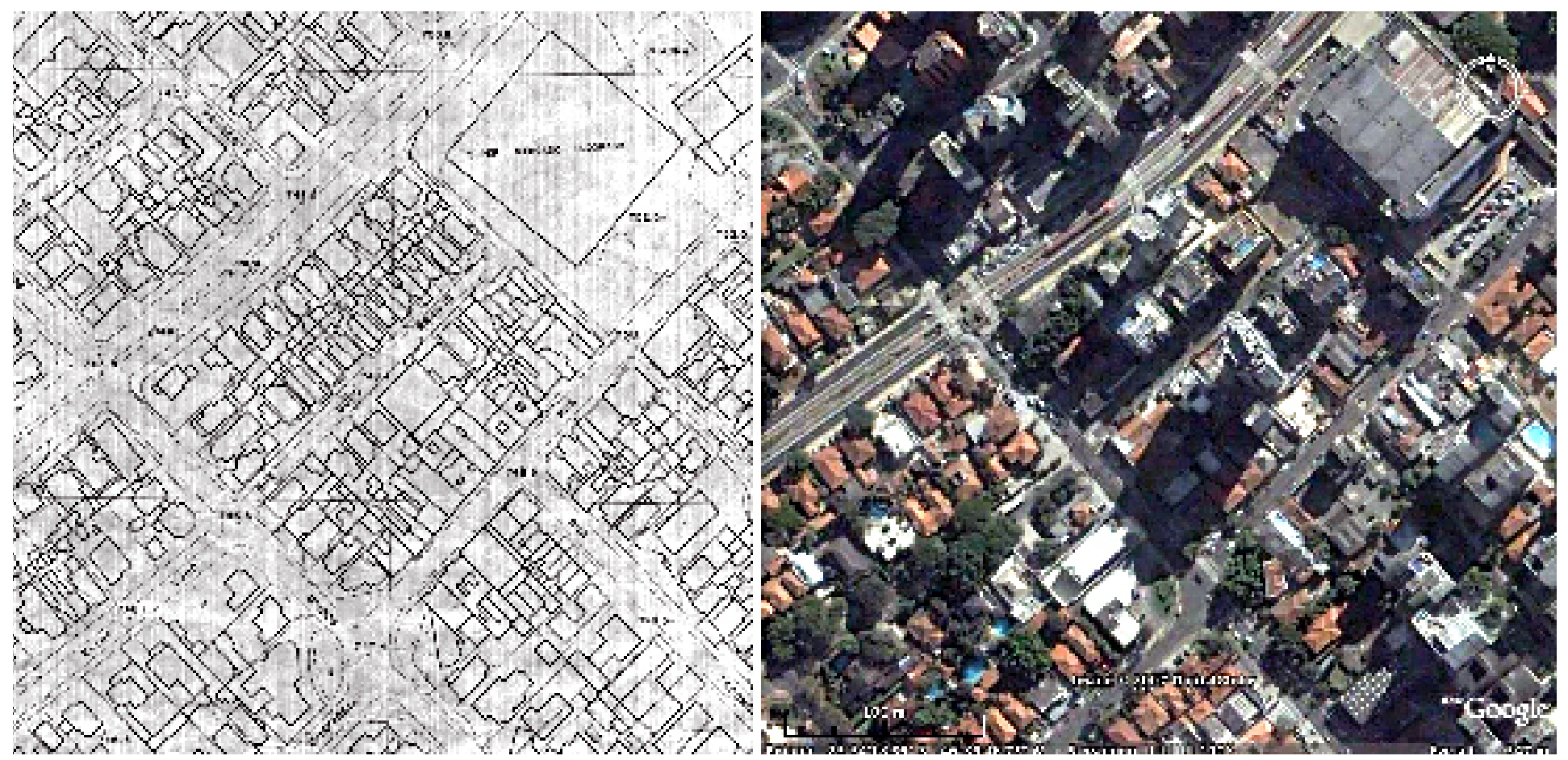

Figura 3.65 - Mapa do Gegran, de 1972, da região da rua Ouro Branco e foto aérea recente do mesmo local. (Fonte Foto: Google Earth)

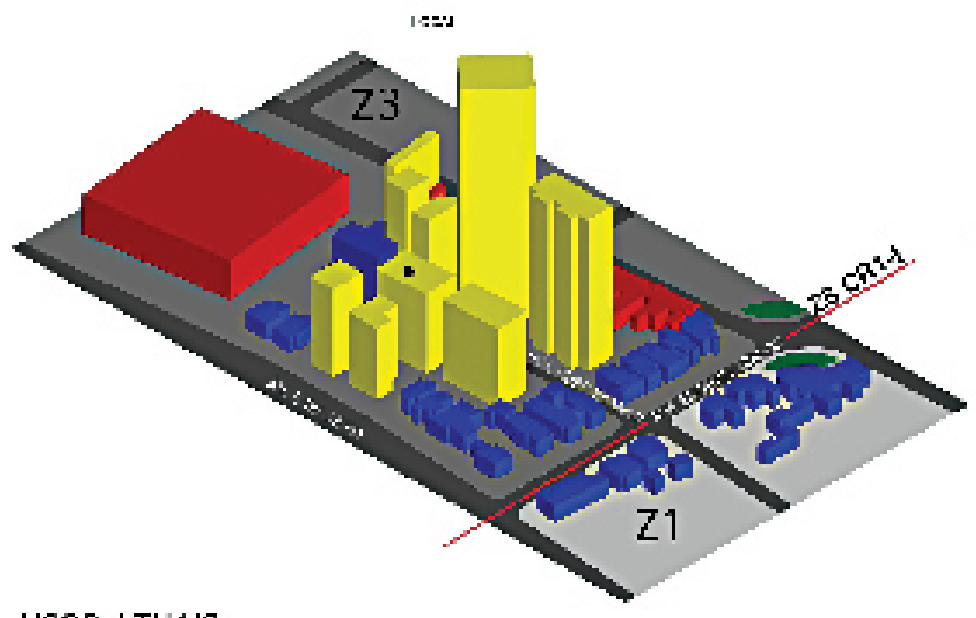

USOS ATLAIS

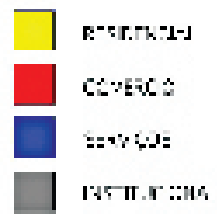

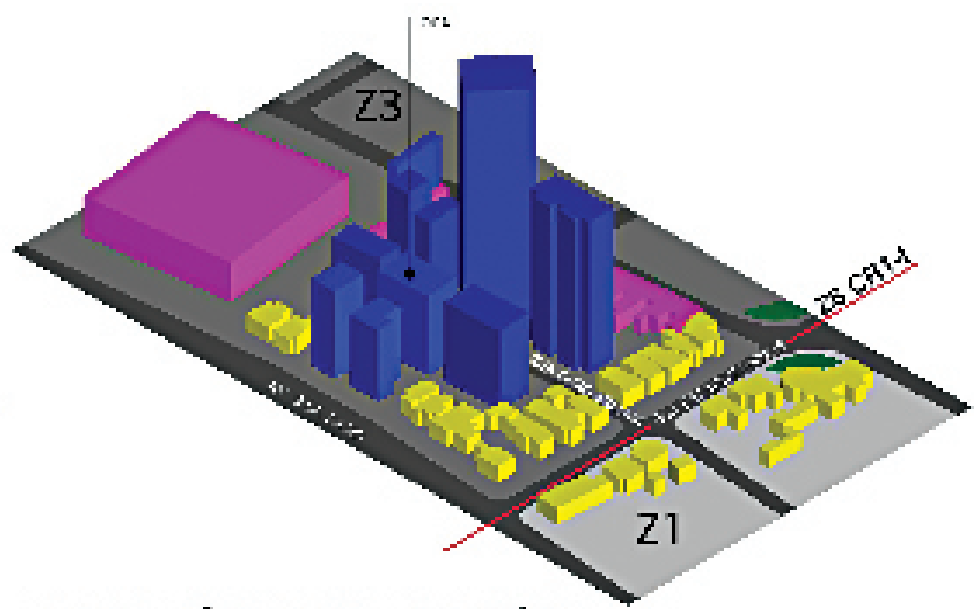

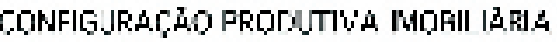

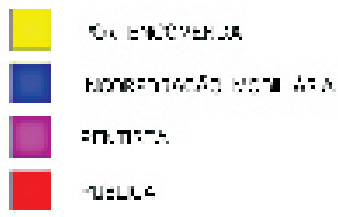

Figura 3.66 - Levantamento do tecido urbano da rua ouro branco na altura do $\mathrm{n}^{0} \mathbf{1 0 1}$. (Fonte: elaborado pelo autor a partir de levantamento de campo). 
Figura 3.67 - Foto do prédio $\mathrm{n}^{0} 13$.

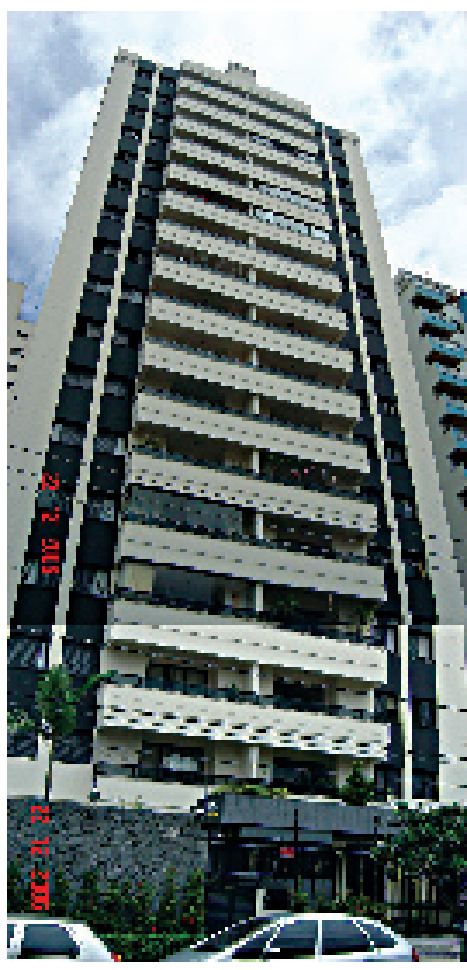

Trata-se de um edifício exclusivamente residencial com dois subsolos, térreo, 8 pavimentos tipo, pavimento de cobertura e ático. O edifício foi implantado com afastamento de 7,00 metros para a rua Ouro Branco, recuos laterais de 3,15 e de fundos de 5,20 m. Não tivemos acesso às plantas dos subsolos. No pavimento térreo encontram-se a portaria com sanitário, a entrada social do edifício, com acesso ao elevador social, a entrada de serviço, com acesso à escada e ao elevador de serviço, apartamento para o zelador, salão de festas, com copa e dois sanitários, salão de jogos com dois sanitários, sauna com ducha e dois sanitários, e vestiário para funcionários. Cada um dos 8 pavimentos tipo têm quatro apartamentos com uma suíte completa, mais dois dormitórios, um banheiro, sala de estar, varanda, sala de jantar, lavabo, cozinha, terraço de serviço e dependência de empregada. Cada apartamento do $8^{\circ}$ pavto tem acesso, por escada privativa, a um pavimento de cobertura, do qual também não temos a planta. No ático encontram-se a casa de máquinas dos elevadores, barrilete e caixa d'água. As características dos apartamentos indicam que são destinados às classes de renda média alta.

O projeto a que tivemos acesso não é o projeto apresentado à Prefeitura de São Paulo, mas o projeto executivo do edifício. Nele é indentificado como proprietário do empreendimento a empresa E.Z. Empreendimentos Imobiliários, entre outros, e como autor do projeto a empresa PROJECON S/C Ltda. Não consta no entanto quadro de áreas, coeficiente de aproveitamento ou taxa de ocupação. Pelas medidas do projeto executivo calculamos uma área computável total igual a $3.487,81 \mathrm{~m} 2$, uma projeção de $435,97 \mathrm{~m} 2 \mathrm{e}$ um terreno de área igual a aproximadamente $1.000,00 \mathrm{~m} 2$. A taxa de ocupação portanto é igual a 0,43 o coeficiente de aproveitamento igual a 3,488. Se aplicarmos a Fórmula de Adiron $(\mathrm{c}=\mathrm{T} / \mathrm{t} \times \mathrm{C})$ para terrenos com áreas igual ou superiores à $1.000,00 \mathrm{~m} 2$ teremos como resultado os mesmos valores.

O levantamento da região da rua Ouro Branco nos mostra um tecido urbano de transição entre uma zona mais adensada e mais heterogênea, Z3, com ediícios residenciais, casas comerciais e também ocupadas por prestadores de serviços, para uma zona pouco adensada e homogênea, Z1, com residências unifamiliares. Entre as duas encontr-se uma zona-corredor Z8 CR1-I com construções que um dia foram residenciais e agora são ocupadas por prestadores de serviços ou algum comércio camuflado como "showroom".

\section{EDIFÍCIO No 13}

- Endereço: Rua Iperoig, n 418, Pompéia.

- Data da construção: 1998.

- Edifício de uso exclusivamente residencial.

- Atualmente constitui um condomínio.

- Não temos informações precisas a respeito do propósito de sua construção, se para renda ou para venda. 


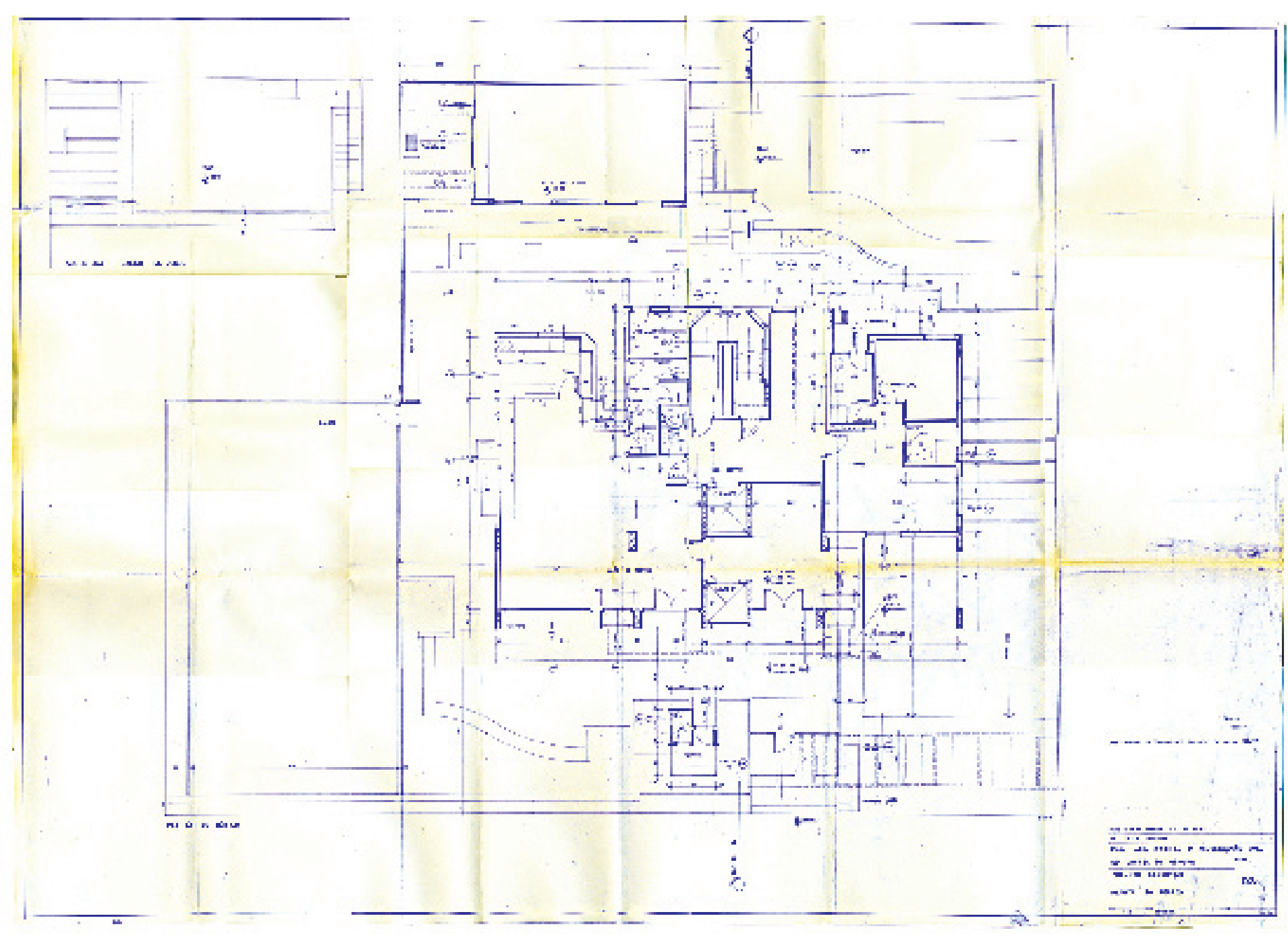

Figura 3.68 - Planta executiva da implantação do empreendimento. 


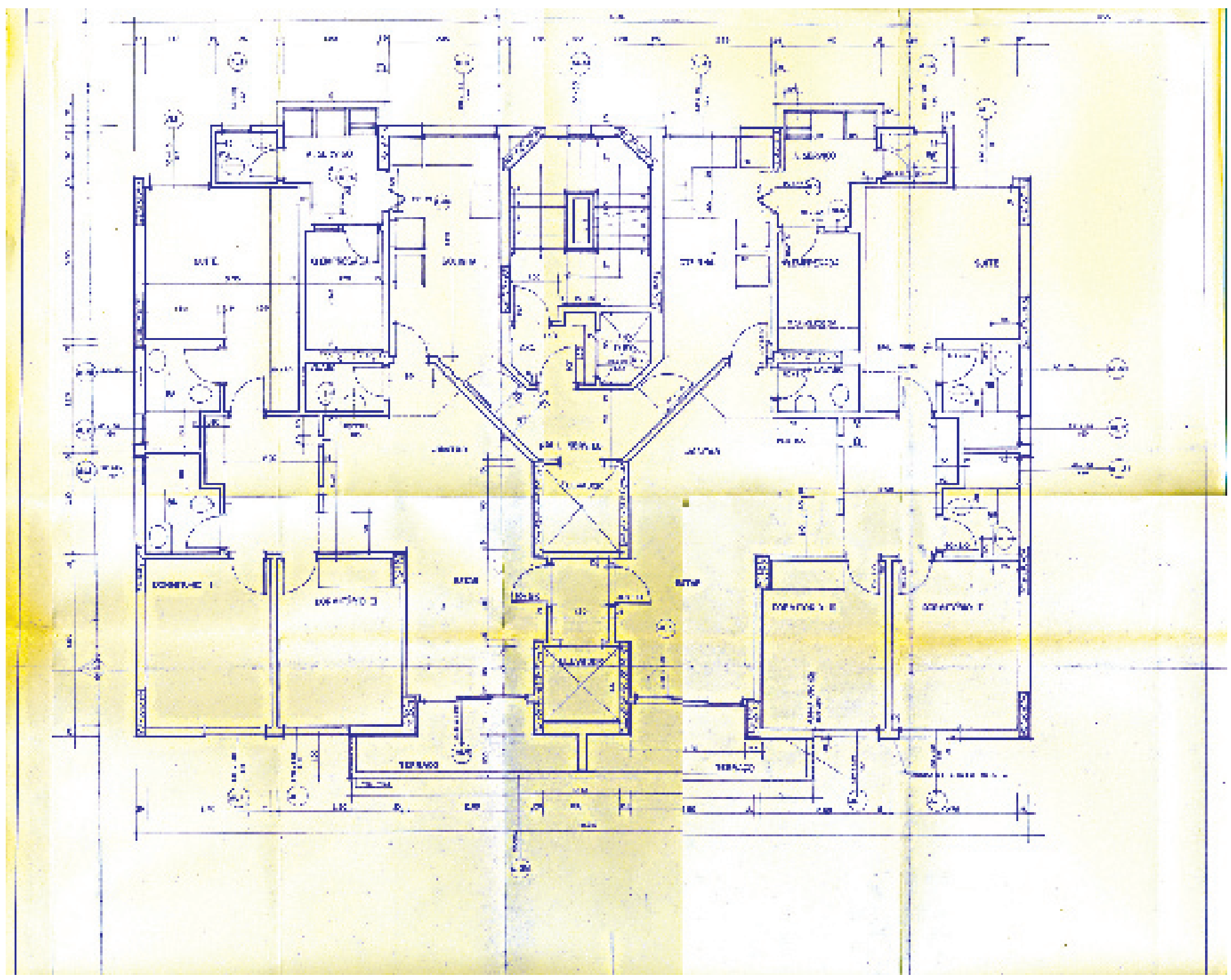

Figura 3.69 - Planta executiva o pavto tipo do empreendimento. 


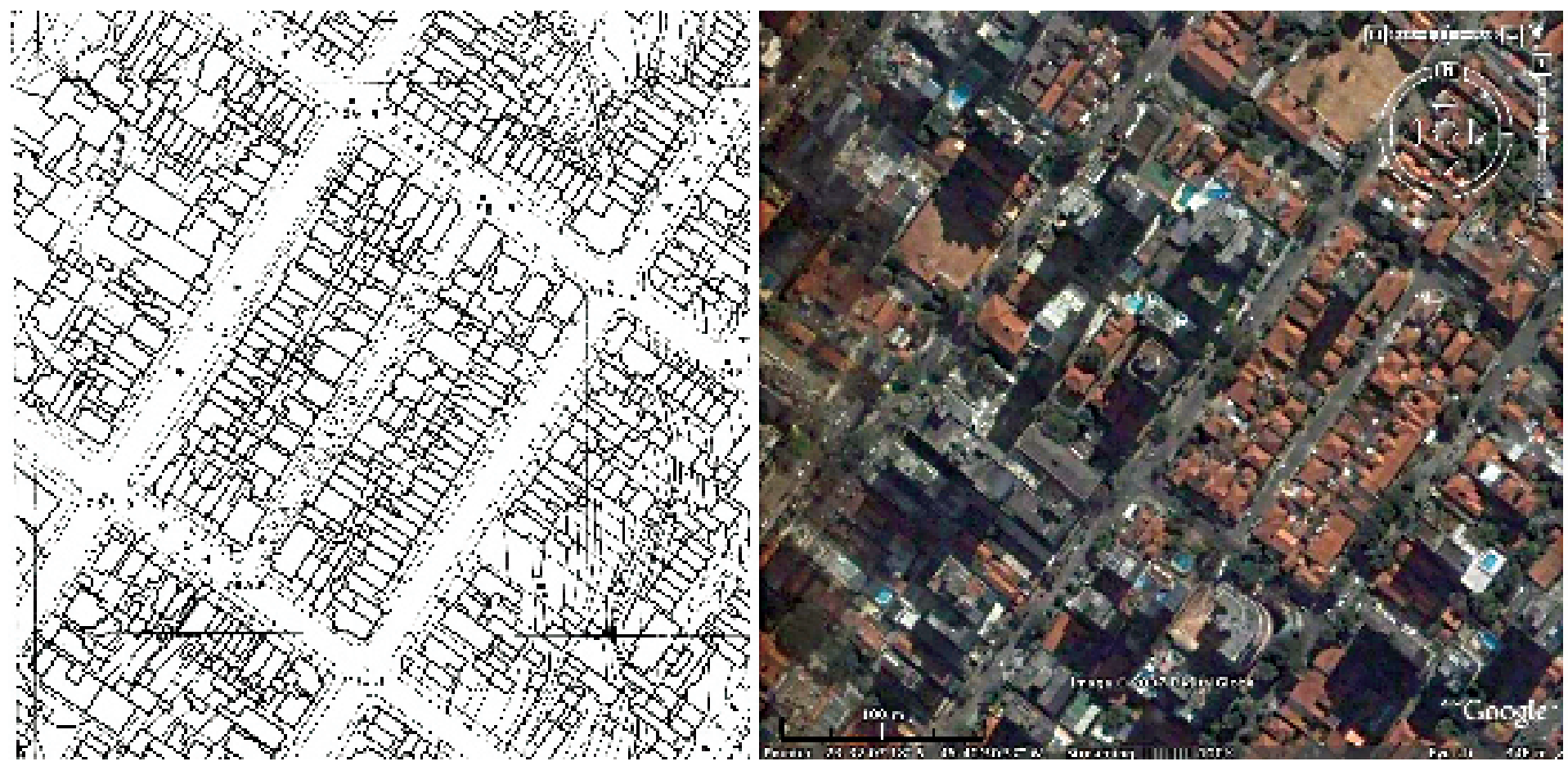

Figura 3.70 - Mapa do Gegran, de 1972, da região da rua Iperoig e foto aérea recente do mesmo local. (Fonte foto: Google Earth).

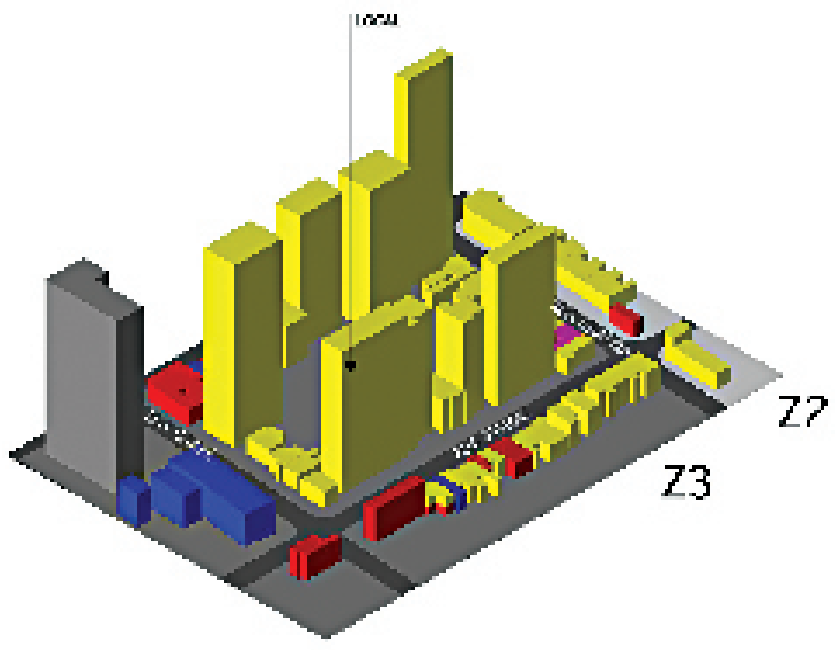

USOS ATUAIS

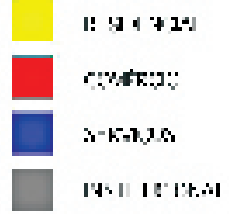

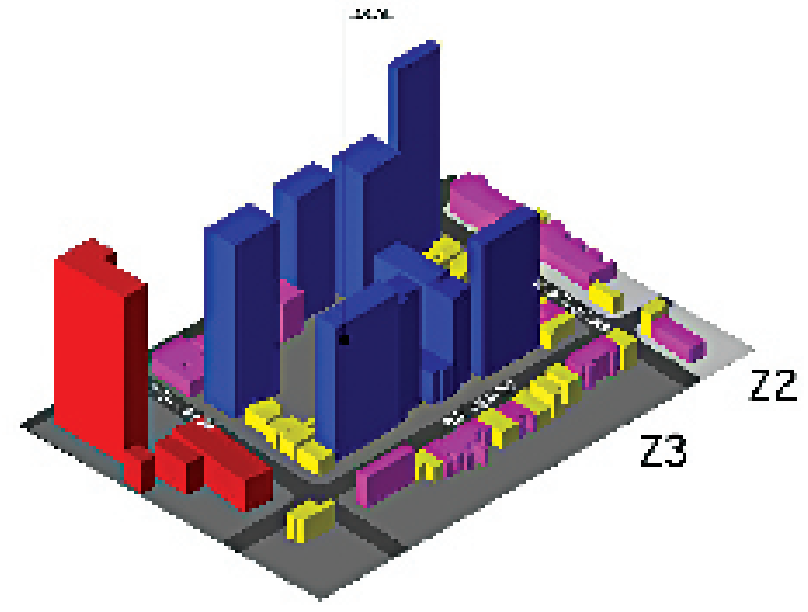

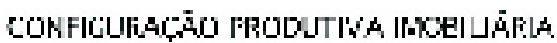

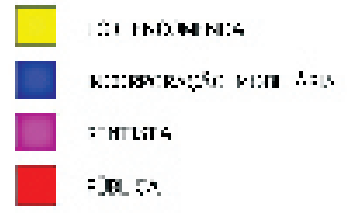

Figura 3.71 - Levantamento do tecido urbano da rua Iperoig na altura do $n^{\circ} 418$. (Fonte: Elaborado pelo autor a partir de levantamento de campo) 
Trata-se de um edifício exclusivamente residencial com dois subsolos, térreo, 16 pavimentos tipo e ático. O edifício foi implantado com afastamento de 7,60 metros para a rua Iperoig, recuos laterais de 3,75 e de fundos de $9,40 \mathrm{~m}$. Os subsolos são destinados para 65 vagas de estacionamento de veículos e 32 depósitos, um para cada apartamento, e têm recuo de apenas $0,80 \mathrm{~m}$ para o alinhamento. No pavimento térreo encontram-se a portaria com sanitário, a entrada social do edifício, com acesso ao elevador social, a entrada de serviço, com acesso à escada, ao elevador de serviço e ao apartamento para o zelador, salão de festas, com copa e dois sanitários, salão de jogos, churrasqueira, piscina e dois vestiários . Cada um dos 16 pavimentos tipo têm dois apartamentos com uma suíte completa, mais dois dormitórios, um banheiro, sala de estar, varanda, sala de jantar, lavabo, cozinha, terraço de serviço e dependência de empregada. No ático encontra-se a casa de máquinas dos elevadores, barrilete e duas caixas d'água.

O projeto a que tivemos acesso não é o projeto apresentado à Prefeitura de São Paulo, mas o projeto executivo do edifício, e nele consta como responsável pelo projeto de arquitetura e construção a empresa Enix Arquitetura e Construções Ltda. Não consta porém o nome do proprietário, quadro de áreas, coeficiente de aproveitamento ou taxa de ocupação. Pelas medidas do projeto executivo pudemos concluir que a área do terreno é aproximadamente $1.000,00 \mathrm{~m} 2$, a area do pavimento tipo é igual a $250,00 \mathrm{~m} 2$ e a área total computável é igual a $4.000 \mathrm{~m} 2$, ou seja, taxa de ocupação igual a 0,25 e coeficiente de aproveitamento igual a 4,00.

O levantamento da região nos mostra um tecido urbano bastante heterogêneo, com edifícios residenciais, residências unifamiliares e antigas residências ocupadas por comerciantes ou prestadores de serviços.

\section{4 - ANÁLISE COMPARATIVA DAS TIPOLOGIAS ARQUITETÔNICAS}

A análise comparativa dos 13 edifícios levantados buscou identificar semelhanças entre as características das edificações segundo três critérios: 1) configuração produtiva, 2) padrões urbanísticos e 3) uso da edificação.

Do conjunto de 13 edifícios levantados, sabemos que 4 deles foram construídos para que seus proprietários obtivessem uma renda mensal com o aluguel das unidades pois até os dias de hoje constituem domínios, ou seja, todos as unidades pertencem a um mesmo proprietário ou seus descendentes. São eles o edifício da rua Frederico Abranches (1944), o edifício da rua Caiubí (1946), o edifício da rua Bela Cintra (1953) e o edifício da rua Arthur de Azevedo (1973). Sabemos também que pelo menos dois dos edifícios levantados, o edifício da rua Sergipe (1975) e o edifício da rua Ouro Branco (1992) foram construídos através de incorporação imobiliária pois, nestes dois casos, no carimbo das folhas dos projetos que tivemos acesso, consta como proprietário empresas incorporadoras.

Para os outros sete edifícios levantados não obtivemos informações precisas sobre suas configurações produtivas. Sabemos que atualmente constituem condomínios, o que significa que suas unidades foram vendidas; não sabemos no entanto se os edifícios foram construídos para o mercado de venda, e suas unidades vendidas no momento de sua construção, ou se foram construídos para obtenção de renda através de aluguel e apenas 
posteriormente suas unidades foram vendidas por razões diversas. Todos os edifícios levantados são posteriores à promulgação da Lei do Inquilinato de 1942, fator fundamental para a ampliação da produção de imóveis destinados ao mercado de venda. Até 1942 era bastante intensa a construção de moradias para aluguel, mas a Lei do Inquilinato congela o preço dos aluguéis gerando um imediato impacto neste mercado. A conseqüência foi a drástica redução de novas construções para moradia de aluguel, abrindo frente para um mercado imobiliário de compra e venda, ou seja, incorporações imobiliárias.

Destes sete condomínios, cinco têm pessoas físicas assinando como proprietário os carimbos dos projetos apresentados à prefeitura, o que deixa dúvidas sobre sua configuração produtiva, se para renda ou para venda. Estes são os edifícios da rua Piauí (1944), da rua do Triunfo (1956), da rua da Consolação (1966), da rua São Vicente de Paula (1968) e da rua Jesuíno Arruda (1973). No projeto de prefeitura do edifício da rua Lourenço de Almeida (1987) consta como proprietário do empreendimento um grupo de pessoas, todas de origem sírio-libanesa, o que indica a possibilidade de um terceiro tipo de configuração produtiva: a de um edifício encomendado a uma construtora, a preço de custo, financiado por um grupo de pessoas que se reúne para este fim e após o termino da obra cada qual fica com a sua unidade para uso próprio. As características físicas do edifício em questão, muito diferentes do padrão de edifícios construídos para venda ou aluguel, evidenciam este tipo de configuração produtiva, que não busca obtenção de unidades com valor de troca, mas com alto valor de uso específico para estas pessoas.

Não tivemos acesso aos projetos de prefeitura do edifício da rua Iperoig, e portanto, não temos o nomes de seu proprietário.

Passando para o critério dos padrões urbanísticos, podemos detectar muito facilmente aqueles que foram implantados sem nenhum tipo de recuo. São eles os edifícios rua Frederico Abranches (1944), rua Bela Cintra (1953) e Rua do Triunfo (1956). O edifício da rua Caiubí tem um recuo para a rua Cardoso de Almeida de quatro metros e de um metro para a própria rua Caiubí (1946), mas não apresenta recuos laterais ou de fundo. Todos eles foram edificados até a década de cinqüenta. O único edifício desta época que está implantado no centro do lote com afastamentos de todos os lados é da rua Piauí, de 1944. Provavelmente por se tratar de apartamentos destinados à classes de maior renda e estar localizado num bairro elegante como Higienópolis, manteve as características tipológicas das residências "de prestígio"4 presentes na região.

É interessante notar que até o ano de $1957^{5}$ não existe um padrão definido para o coeficiente de aproveitamento do terreno. Encontramos empreendimentos com coeficiente de aproveitamento baixos como os edifícios da rua Piauí e da rua Caiubí, com coeficiente de aproveitamento de 2,45 aproximadamente. Encontramos também empreendimentos com coeficiente de aproveitamento extremamente altos como os edifícios da rua Bela Cintra $(7,63)$ e da rua do Triunfo $(10,61)$. Nesta época havia duas únicas limitação para o tamanho das construções: uma era o gabarito de altura imposto pelo Código Artur Saboya, vigente desde 1934; outra era a capacidade de investimentos financeiros do proprietário.

Em relação ao uso dos edifícios temos, neste conjunto de 13 prédios, dois que foram de fato construídos para o uso misto: o edifício da rua do Triunfo, com quatro lojas no
4. Ver capítulo 4 desta dissertação.

5. Ano da promulgação da lei 5.261, que limiava o aproveitamento dos lotes. 
6. Segundo informação do Escritório Almeida Leite, empresa administradora. térreo e o edifício da rua Caiubí, com uma loja no térreo. O Edifício da rua do Triunfo, por estar numa região bastante deteriorada da cidade, acabou tendo seus apartamentos convertidos em escritório ${ }^{6}$.

Quanto ao edif ício da rua da Consolação (1966), apesar de ter sido aprovado como sendo de uso misto, com apartamentos residenciais e consultórios médicos, acreditamos que desde o "habite-se" ele seja usado exclusivamente para residências. É interessante notar que a disposição das alvenarias nos andares dos consultórios é exatamente idêntica aos andares residenciais. Onde se lê, nos andares residenciais, sala de estar e jantar, cozinha e dormitórios, nos consultórios se lê, respectivamente, sala de espera, laboratório e consultório. Também pudemos notar que no quadro de áreas do empreendimento, onde é mostrado o total da área computável, o autor do projeto cita a Lei 5.261 de 1957. Esta lei foi promulgada pelo então prefeito Anhaia Mello para limitar o coeficiente de aproveitamento na cidade de São Paulo, refletindo a posição daqueles que defendiam um controle mais rígido do crescimento da cidade, propondo formas de ocupação urbana de menor densidade. Para tanto a Lei de 1957 determinou, entre outros parâmetros, um coeficiente de aproveitamento de no máximo quatro vezes a área do terreno para construções residenciais, e de até seis vezes para usos de serviços. No caso do edifício em questão, se dividirmos sua área computável total de 3.466,30 m2 pela área do terreno, 602,00 m2 teremos um coeficiente de aproveitamento de 5,757, maior do que seria permitido caso o edifício fosse exclusivamente residencial. Tendo em vista que os andares destinados a "consultórios" não têm as características de consultórios médicos e sim de residências, fica evidente que neste caso trata-se de uma manobra para burlar a lei para conseguir um aproveitamento maior. No pavimento térreo, o que foi aprovado como um consultório menor, com entrada pela passagem lateral deve provavelmente ter sido convertido em apartamento para o zelador.

O coeficiente de aproveitamento determinado pela Lei 5.261/57 foi bastante burlado. Os edifícios eram aprovados como sendo comerciais para se beneficiarem de um coeficiente mais elevado mas ocupados por residências. Essa dualidade de coeficientes máximos permaneceu inalterada até 1966 , quando a lei $n^{\circ} 6.877$, de 11/05/66, fixou o coeficiente 6 para todos os usos. Essa lei oficializava o que já vinha ocorrendo na pratica, às vistas grossas da administração, isto é a aprovação de edifícios com C.A. = 6 para fins de escritório, mas de fato construídos para fins residenciais (FIGUEROA, apud BARBARA, 2004). Essa discussão vai culminar com a Legislação de Uso e Ocupação do Solo de 1972, que reduzirá drasticamente os coeficientes.

O edifício da rua São Vicente de Paula, de 68, já se beneficia da Lei 6.877/66 para atingir um coeficiente de 5,33. É interessante (ou intrigante) notar como, apesar de a legislação permitir o coeficiente 6, abria-se mão de atingir o coeficiente máximo. Com um terreno de 1.364,00 o empreendimento poderia atingir uma área computável máxima de $8.184 \mathrm{~m} 2,915,36 \mathrm{~m} 2$ a mais que o aprovado e construído. Isso representaria, pelas áreas demonstradas no quadro de áreas, 2,35 pavimentos tipo a mais, ou seja, mais dois apartamentos tipo e ainda mais dois apartamentos du-

\author{
7. 0 coeficiente de aproveitamento determinado
pela Lei $5.261 / 57$ foi bastante burlado. Os edifícios \\ eram aprovados como sendo comerciais para se \\ eram ocupados por residências. Essa dualidade \\ de coeficientes máximos permaneceu inalterada
até 1966 , quando a lei n ${ }^{0} 6.877$, de $11 / 05 / 66$, \\ fixou o coeficiente 6 para todos os usos. Essa lei \\ às vistas grossas da administração, isto é a \\ de escritório, mas de fato construídos para fins \\ residenciais Figueroa, Mário. Habitação Coletiva \\ FAUUSP, 2002 (apud BARBARA, 2004). Essa \\ Uso e Ocupação do Solo de 1972, que reduzirá \\ drasticamente os coeficientes.
} Figura 3.72 - Nota presente no auto de vistoria do edifício da rua
da Consolação. o mesmo texto se encontra carimbado nas folhas do projeto da Prefeitura.

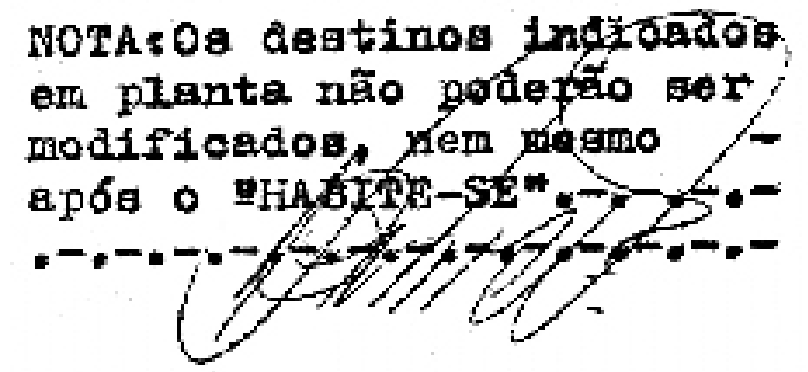


plex, com um pavimento de cobertura com amplos terraços, tão valorizados nos dias de hoje. Esse acréscimo de mais dois pavimentos completos esbarraria no limite do gabarito de altura demonstrado no projeto, mas bastaria uma mudança no projeto arquitetônico para resolver esta questão. A ausência de preocupações em atingir o coeficiente máximo demonstra uma satisfação com o rendimento do empreendimento no estado em que se encontra. Pode demonstrar também um respeito ao projeto arquitetônico, tão desvalorizado nos dias de hoje. De feições mais modernistas, o edifício tem o térreo livre, sob pilotis, e um salão de festas situado ao fundo do terreno, fora da projeção do edifício. Estas são características que irão desaparecer com a promulgação da lei 7.805, a Lei de zoneamento de 1972.

Por conta da relação de proporção inversa entre coeficiente de aproveitamento e taxa de ocupação criada pela fórmula de Adiron, a preocupação com a diminuição da ocupação do lote se torna fundamental para se atingir o coeficiente máximo. Os equipamentos de lazer que antes se espalhavam pelo terreno pelo pavimento Térreo em construções complementares, agora vão se concentrar na área de projeção do pavimento tipo.

O edifício da rua Arthur de Azevedo, de 1973, exprime bem as dificuldades criadas pela nova lei de zoneamento de 72. Localizado em uma Z3 mas construído em um lote pequeno, de apenas $420,00 \mathrm{~m} 2$, o empreendimento, para atingir seu coeficiente máximo de 4 vezes a área do terreno, poderia, segundo a fórmula de Adiron, ocupar apenas 20\% de sua área, ou seja, $84 \mathrm{~m} 2$. Mas, mesmo que o empreendedor optasse por um pavto tipo de apenas $84 \mathrm{~m} 2$, para atingir o coeficiente máximo teria que construir um edifício de vinte andares, cuja altura ultrapassaria muitas vezes o limite da altura determinado pela linha de gabarito demonstrada em projeto. Não tendo outra opção além de abrir mão do aproveitamento máximo de seu terreno, o empreendedor propõe um planta de pavimento tipo extremamente enxuta, mesmo assim ocupando 33\% do terreno e atingindo um coeficiente igual a 3,0151.

O edifício da rua Jesuíno Arruda, tambémde 1973, foi construído em um terreno maior, de $566,10 \mathrm{~m} 2$, e está localizado em uma Z4, zona mais permissiva que a Z3, podendo ocupar até $35 \%$ da área dos lotes para atingir o coeficiente máximo igual a 4 . O empreendimento, no entanto, ocupa $36,9 \%$ do lote e consegue um coeficiente de 3,897. Para atingir o coeficiente 4 seria necessário diminuir $12 \mathrm{~m} 2$ do pavimento tipo.

O edifício da rua Sergipe, de 1975, também localizado em Z4, foi construído em um lote ainda maior, de 707,00 m2, e conseguiu atingir o coeficiente máximo permitido para a zona ocupando para isso apenas os $35 \%$ da área do terreno permitido pela fórmula de Adiron. Apesar de diminuição da projeção, conseguiu uma laje relativamente grande, de $246,08 \mathrm{~m}^{2}$, e uma altura de edifício que respeita o máximo permitido pela linha de gabarito. Ao contrario dos projetos anteriores, que não atingiram o coeficiente máximo permitido por lei, a eficiência deste projeto se dá, provavelmente, por ter sido executado por uma empresa incorporadora, que vê nesta atividade industrial e mercantil uma maneira de reprodução de seu capital.

Infelizmente não tivemos acesso aos quadros de áreas dos outros três empreendimentos. Presume-se porém que o objetivo dos empreendedores é sempre chegar o mais próximo possível do aproveitamento máximo. 
8. Foi revogada pela Lei no 11.228 de 25 de junho de 1992, que está em vigor até os dias de hoje.
O edifício da rua Lourenço de Almeida, ad 1987, está situado numa Z13, cujo coeficiente pode chegar no máximo em 2,00. Pelo tamanho do edifício acreditamos que tenha atingido o coeficiente máximo. Para isso a sua ocupação não pode ter passado de $25 \%$ do terreno, o que, observando sua implantação, nos parece bem possível. Seu lote tem $2.060,25 \mathrm{~m} 2$ de área de escritura, o maior terreno de todos os edifícios levantados. Terrenos grandes são característica típica de empreendimentos em Z13, assim como também em Z2, Z11, Z17 e Z18, pois são zonas com coeficiente baixo e pouca área proporcional de ocupação. Também porque, para atingir o coeficiente máximo de 2,00, sua categoria de uso deve ser obrigatoriamente o R3, conjunto residencial, que exige uma área de lazer, livre de construções, representada por um círculo de $16 \mathrm{~m}$ de diâmetro, que deve ser implantado no terreno e ocupa sozinho mais de $200 \mathrm{~m}^{2}$ do lote.

Podemos verificar uma diferença de tipo de planta e de tipo de implantação deste edifício em relação aos cinco anteriores. Enquanto os anteriores têm forma de lâmina e estão implantados próximos aos alinhamentos, o edifício da rua Lourenço de Almeida tem forma de torre e está implantado no centro do lote. Isso se deve ao então novo Código de Edificações da Cidade de São Paulo, Lei 8.266 de 1975', que, entre outras coisas, estabeleceu a obrigatoriedade das faixas A1 e A2, de aeração e iluminação, respectivamente, que regulava os afastamentos obrigatórios para as edificações na implantação das torres no lote. Este instrumento tinha como objetivo assegurar a segurança contra incêndio, a insolação, à ventilação, a salubridade e o conforto térmico das edificações (Yasunaga, 2007).

A faixa A1 deveria circundar toda a edificação enquanto a faixa A2 deveria abranger todas as janelas dos ambientes considerados de permanência prolongada, como salas e dormitórios. As faixas eram proporcionais à altura dos edifícios e eram determinadas pelas seguintes fórmulas:

A2 $=\mathbf{H} / 4-3 \geq 3 \mathrm{~m}$.

Sendo $\mathrm{H}$ a altura do edifício. Para a altura de 60,84 do edifício em questão era necessário uma faixa A1 de 5,69 m e uma faixa A2 de 12,21 m, o que explica os grandes afastamentos deste edifício em relação às divisas do seu terreno.

O Edifício da rua Ouro Branco, construído em 92, provavelmente teve seu projeto aprovado ainda na vigência da lei 8.266 , mas por ser um edifício baixo, de apenas 8 pavimentos tipo, suas faixas A1 e A2 acabam não sendo muito restritivas. Infelizmente não tivemos acesso às suas plantas de prefeitura, no entanto, pudemos observar que o edifício mantém a tipologia de torre implantada no centro do lote. A mesma tipologia se observa no edifício da rua Iperoig e na grande maioria dos edifícios mais recentes construídos na cidade. A Lei 11.228, de 1992, que revogou a Lei 8.266 e instituiu o novo código de obras, vigente até os dias de hoje, manteve as faixas de aeração e iluminação, mudando seus nomes para "faixa A" e "faixa I" respectivamente, bem como alterando suas fórmulas e suas representações gráficas em planta. A faixa de aeração deve circunscrever toda a construção a uma distância calculada através da seguinte fórmula: 
Faixa $A=3+0.35 \times\left(n^{\circ}\right.$ de pavimentos -14$) \geq 3$

A faixa de iluminação é representada por um semi-círculo cujo raio é calculado pela fórmula:

Faixa $I=3+0.70 \times\left(n^{\circ}\right.$ de pavtos -8$) \geq 3$

Finalmente, se tomarmos como exemplo o edifício de rua Iperoig, com 16 pavimentos tipo, a sua "faixa A" deve circundar todo o edifício a uma distancia de 3,70 m e sua "faixa I" deve abranger os ambientes de longa permanência com um semi-círculo de raio igual a 8,60 metros.

\subsection{ANÁLISE COMPARATIVA DAS TIPOLOGIAS DE TECIDOS URBANOS}

Vigente por mais de trinta anos na cidade de São Paulo a Lei 7.805, Lei de Zoneamento de 1972, teve fundamental importância na transformação ou na consolidação dos tecidos urbanos da cidade, principalmente daqueles que ainda não se encontravam consolidados na ocasião da promulgação desta lei. Zonas com maiores coeficientes construtivos associados a permissão de usos mais diversificados constituíram tecido mais heterogêneos. Este é o caso das zonas Z3, Z4 e Z5, onde podemos encontrar construções baixas com uso residencial unifamiliar ou que um dia foram residências mas ao longo do tempo tiveram seu uso modificado para comércio ou serviços, ou ainda as que já foram construídas para estes usos. Podemos encontrar também construções altas como edifícios residenciais e edifícios comerciais. Zonas com baixos coeficientes e usos mais restritivos proporcionam tecidos mais homogêneos, como na $\mathrm{Z} 1$, onde todas as construções regulares são baixas e com uso extritamente residencial. Existem ainda aquelas zonas intermediárias, que permitem a diversidade de usos, mas na sua maioria com potencial construtivo baixo. É o caso das zonas Z2, Z11, Z13, Z17 e Z18, onde encontramos construções baixas com usos diversos e edifícios altos apenas residenciais.

Definir estas características por meio do zoneamento é também definir as tipologias edificadas em cada uma das zonas, a capacidade de agregar valor ao solo e atrair investimentos, o que acaba por configurar as tipologias de tecidos urbanos em cada perte da cidade.

O tecido urbano da região do edifício da rua Piauí já se encontrava bastante consolidado na ocasião da lei de zoneamento de 72. A maioria dos edifícios que pudemos observar em foto aérea recente da região já se encontrava cadastrados no mapa do Gegran de 1972. A rua Piauí, no entanto, se tornou um divisor entre uma Z3, em seu lado direito de quem segue para a rua Rio de Janeiro, e uma Z2 em seu lado esquerdo. Podemos verificar que muitas das pequenas casas contidas em Z2 ainda permanecem intactas e acreditamos que isso se deve a vários motivos. Um deles é o fato das ruas Tinhorão, Colina e Dr. José Pereira de Queiroz serem ruas estreitas, com menos de dez metros de largura, o que inviabiliza a construção de prédios ${ }^{9}$. Podemos observar que na rua Barão de Bocaina,
9. Nos lotes com frente e acesso para ruas com largura inferior a $10 \mathrm{~m}$, só é permitido as categorias de uso residencial unifamiliar ou multifamiliar horizontal, A construção de edifícios sem restrições de altura sómente é permitida nos lotes com acesso por vias de mais de $12 \mathrm{~m}$. Em vias com larguras inferiores a $12 \mathrm{~m}$ e superiore à $10 \mathrm{~m}$ é permitido a construção de edifícios residenciais com gabarito máximo de $25 \mathrm{~m}$ de altura. Lei 10.015, de 1985. 
mais larga, as residências foram totalmente substituídas por edifícios. Outro motivo é a presença da FAAP na rua Alagoas, o que torna essas pequenas casas da região muito atrativas para serem ocupadas por pequenos comércios e serviços que atendem aos alunos da instituição. Isso faz com que os alugueis continuem em alta e que estes imóveis continuem tendo um bom retorno para seus proprietários rentistas.

É interessante notar que na outra esquina entre as ruas Piauí e Dr. José Pereira de Queiroz, existe um edifício quase idêntico ao edifício estudado, apenas com a planta invertida. A disposição destes edifícios, localizados simetricamente em relação à rua Dr. José Pereira de Queiroz e os dois idênticos renques de residências dispostos ao longo dos dois lados desta pequena rua, indica a possibilidade de todo este conjunto ter sido edificado pela mesma empresa construtura, por encomenda da mesma proprietária, provavelmente para obtenção de renda com aluguéis. A coincidência de sobrenomes entre o construtor responsável pela edificação do prédio estudado, Alfredo Pereira de Queiroz, e a pessoa homenageada pelo nome da rua, Dr. José Pereira de Queiroz, reforça esta hipótese. Podemos observar que o edifício em construção na esquina da rua Alagoas com a rua Dr. José Pereira de Queiroz ocupou todos os terrenos de todas as casas do lado esquerdo desta; sua portaria de acesso, porém, será obrigatoriamente pelar rua Alagoas, com mais de $12 \mathrm{~m}$ de largura. $\mathrm{O}$ empreendimento, destinado às classes de alta renda, provavelmente construirá no alinhamento da rua Dr. José P. de Queiroz um muro alto para a proteção dos seus condôminos, diminuindo a segurança e a qualidade de vida dos ocupantes das casas do outro lado da rua.

O tecido urbano da região do edifício da rua Frederico Abranches também já se encontrava consolidado na época de lei de 1972 e até os dias de hoje se encontra pouco modificado. Podemos observar que quase todos os edifícios não apresentam recuos em relação ao alinhamento das ruas e ocupam quase $100 \%$ do lote. Por estar em uma zona central, com grande ocupação, foi considerado pela Lei de Zoneamento de 72 como uma Z5, que permite uma grande diversidade de usos. Alguns dos edifícios foram demolidos e transformados em estacionamentos, provavelmente por ser este um bom investimento numa região com deficiência de vagas para automóveis. Apesar de central, a região ainda é bastante ocupada por edifícios residenciais, com apartamentos pequenos voltados à uma classe de renda média baixa e estudantes de instituições das proximidades como a Santa Casa ou a Universidade Mackenzie. Os pavimentos térreos, no entanto, são em sua maioria ocupados por comércios ou serviços, o que proporciona uma grande quantidade de pedestres nas ruas. O quarteirão entre o Elevado Costa e Silva, a rua Sebastião Pereira e a Rua Ana Cintra foi totalmente desapropriado e demolido para dar lugar a uma grande área verde.

O tecido urbano da região do edifício da rua Caiubí nos permite analisar as transformações de três zonas diferentes: uma Z3, uma Z18 e uma Z1. Pudemos observar, comparando o mapa do Gegran de 72 e a foto aérea recente, que apenas a Z3 sofreu mudanças significativas, tendo casas unifamiliares substituídas por edifícios residenciais. Os quarteirões inseridos em Z18 tiveram poucas alterações; apenas dois edifícios que não constam no mapa do Gegran, aparecem na foto aérea: um na rua Bartira e outro na rua Cardoso de Almeida. O quarteirão do edifício da rua Caiubí tem uma grande parte ocupada pela por uma propriedade onde se encontra a igreja São Domingos e o convento Santo Alberto Magno, atualmente ocupado pelo Colégio Pentágono. Este fato certamente contribuiu para a pouca transformação da quadra. A criação da Z18 pela Lei 9.049 de 24 de abril de 
1980 também cria dificuldades para a incorporação nesta quadra. Diferente da Z3, onde o Coeficiente de Aproveitamento pode chegar a 4, na Z18 pode chegar apenas a 2 e somente para conjuntos residenciais. Já falamos anteriormente que isso acarreta na necessidade de áreas maiores para se realizar empreendimentos. Existe uma outra restrição que é própria das Zonas 17 e 18: a altura máxima de 25 metros para os edifícios ${ }^{10}$. Existem edifícios nesta quadra que têm alturas muito superiores a 25 metros. Isso se deve ao fato de já estarem lá na ocasião da lei de 1980, com pudemos constatar na análise do mapa do Gegran. As características da Z1 se mantiveram intáctas desde 1972, como mostra a comparação entre a foto aérea recente e o mapa do Gegran. Isto se deve ao fato da Z1 ser uma zona estritamente residencial unifamiliar, o que impede a construção de edifícios. Mesmo anteriormente à Lei de Zoneamento, tratava- se de um loteamento protegido por restrições impostas pelo loteador, registradas nas escrituras primitivas dos terrenos.

O tecido urbano da região do edifício da Rua Bela Cintra é outro que já se encontrava consolidado em 1972 e apresenta poucas mudanças até os dias de hoje. O mapa do zoneamento mostra que nesta região foram cravadas duas zonas com características semelhantes, a Z4 e a Z5. Ambas permitem usos bastante diversificados. Diferem principalmente no que se refere à taxa de ocupação máxima para se atingir o coeficiente 4 pela fórmula de Adiron, como podemos observar na tabela da página 53. A dificuldade em se notar esta característica diferente em cada uma das zonas se dá principalmente pelo fato de que a maioria dos edifícios da região foi construída em épocas anteriores à Lei de Zoneamento. A região tem edifícios predominantemente residenciais e muitas casas do tipo sobrado ocupadas por pequenos comércios e serviços, como restaurantes e bares.

O tecido urbano da região do edifício da rua do Triunfo também já se encontrava consolidado na ocasião da Lei do Zoneamento de 1972 e, de lá para cá, também sofreu poucas modificações. Com certeza o próprio zoneamento contribuiu para a estagnação e deterioração da área. Apesar de estar localizado numa região central, foi considerada uma Z2 perante a lei de zoneamento. A zona 2, como já foi dito, permitia um aumento de coeficiente de uma pra duas vezes a área do terreno apenas para o uso residencial. Essa restrição acaba não incentivando novos empreendimentos em regiões inseridas em Z2 e sem vocação residencial como é o caso da região da rua do Triunfo. Por sua proximidade com a rua Santa Efigênia, a região tem predominância de comércio de produtos eletrônicos; tem também muitos pequenos hotéis para suprir a demanda gerada pela intensa prostituição existente na região. Nos últimos anos sofreu grande deterioração, chegando a ser conhecida como "Cracolândia" pelo alto comércio e consumo de drogas. Atualmente é objeto de uma grande intervenção urbana por parte do poder municipal.

Na região do edifício da rua da Consolação temos quatro zonas com características bastante diferentes: Uma Z3, uma Z2, uma Z1 e uma Z8CR1-1, corredor de serviços. No levantamento do tecido urbano que fizemos na região, pudemos detectar nitidamente as diferenças de tipologias e de usos entre a Z3, a Z8CR1-1 e a Z1, tendo respectivamente edif ícios residenciais ou comerciais, casas com prestadores de serviços e residências unifamiliares. No entanto entre a Z3 e a Z2 observamos pouca diferença. Isso se deve ao fato de a maioria dos edif ícios desta região já estarem construídos na ocasião do zoneamento e com características semelhantes, muitos com coeficiente próximos de 6 vezes a área do terreno. Na esquina da rua da Consolação com a rua Estados Unidos funciona um posto de combustível para abastecimento de veículos, cujo uso é considerado comércio. O uso comercial no entanto não é permitido na zona-corredor Z8CR1-1, considerado um cor- 
redor de serviços. O posto de abastecimento funciona portanto de forma ilegal.

A rua São Vicente de Paula também é um divisor entre uma Z3 e uma Z4, zonas com características relativamente semelhantes. Mas, como na rua da Consolação, a maioria de seus edifícios já estava construído na ocasião da Lei de Zoneamento de 1972. A rua tem predominância de edifícios residenciais, com comércio e serviços nas ruas próximas como a alameda Barros e avenida Angélica. Nesta avenida observamos alguns antigos palacetes residenciais transformados em serviços como bufês ou clubes.

A rua Arthur de Azevedo, assim como a rua São Vicente de Paula, também divide uma Z3 e uma Z4. A diferença entre as duas se dá pelo fato desta estar em uma região mais afastada do centro da cidade, e seu tecido urbano ainda se encontrar em processo de transformação na ocasião da lei de 1972. Ao compararmos a foto aérea recente com o mapa do Gegran podemos observar na foto uma série de edifícios que ainda não estavam construídos em 1972. As pequenas casas que vemos preservadas até hoje estão em ruas muito estreitas, com menos de dez metros de largura, que impossibilitam a construção de edifícios, como a travessa Arthur de Azevedo, rua Pascoal Delgado e rua Estela Sezefreda.

Assim como os dois casos anteriores, a rua Jesuíno Arruda também é um divisor entre uma Z3 e uma Z4. Na comparação entre o mapa do Gegran, e a foto aérea recente pudemos perceber claramente que, daquela época para hoje o bairro sofreu uma intensa transformação. Só na quadra onde se encontra o edifício levantado, dez edifícios foram construídos. Apesar do zoneamento da região permitir o uso misto das edificações, os edifícios construídos após a lei de 1972 são, na sua maioria, de uso exclusivamente residencial, e todos dirigidos a uma mesma faixa de renda. A diversidade de usos se dá pelo fato de algumas casas ainda estarem preservadas e ocupadas com comércio e serviços para suprir a demanda gerada pelo grande número de apartamentos construídos na região.

Caso semelhante ocorre na região do edifício da rua Sergipe: os edif ícios mais recentes são de uso exclusivo de residências apesar do uso misto ser permitido pelo zoneamento, e a diversidade se dá pelo uso comercial dos poucos sobrados do bairro e dos térreos de alguns edifícios mais antigos.

O tecido urbano do bairro de Vila Nova Conceição, região do edifício da rua Lourenço de Almeida, foi completamente transformado entre 1972 e os dias de hoje. Na parte que foi considerada pelo zoneamento como Z13 quase a totalidade das casas foram substituídas por edifícios residenciais. Pela foto aérea percebemos que são prédios altos e estão inseridos em grande lotes, com muita área verde e equipamentos de lazer. Esta é uma característica de zonas de densidade média como a Z13, onde o coeficiente aproveitamento pode atingir o máximo 2, necessitando assim terrenos maiores para a construção de edifícios altos. A exigência do círculo de $16 \mathrm{~m}$ de diâmetro livre de construções aumenta ainda mais a necessidade de grandes terrenos. Este motivo nos leva a concluir que as poucas casas restantes entre os edifícios, se não tiverem a possibilidade de se agruparem para formarem terrenos maiores, permanecerão ali por muito tempo, pois seus terrenos, isolados, são insuficientes para a incorporação de um edifício. Este fato é bom para o bairro pois a grande quantidade de moradores dos edifícios gera demanda por comércio e serviços na região e, sendo o uso misto dos edifícios proibido nesta zona, esses comerciantes e prestadores de serviços poderão se instalar nestes poucas casas restantes. É bom também para os seus proprietários, pois terão seus imóveis disputados 
por várias empresas interessados em se instalar na região, mantendo assim o valor do aluguel sempre em alta.

O caso do tecido urbano da região do edifício da rua Ouro Branco é muito semelhante ao da região do edifício da rua da Consolação, com três zonas com características bastante diferentes: uma Z3, um corredor de serviços Z8CR1-1 e uma Z1, tendo respectivamente edifícios residenciais, casas com prestadores de serviços e residências unifamiliares. O tecido urbano foi bastante modificado de 1972 para cá, com várias casas substituídas por edifícios.

Ao analisarmos a região do edifício da rua Iperoig, na Pompéia, percebemos um bairro que está em pleno processo de transformação. Vários edifícios foram construídos substituindo pequenas casas residenciais, várias outras pequenas casas mudaram de uso residencial para comercial e ainda muitas das casas permanecem residenciais. A tendência é que mais edifícios executados por incorporação imobiliária sejam construídos no bairro, substituindo as casas ainda existentes. A rua Pelágio Lobo por ser muito estreita impossibilita que o acesso a futuros edifícios seja feito por ela, mas os terrenos situados entre esta pequena rua e as ruas Iperoig para um lado e Campevas paro o outro, podem ser totalmente ocupados por edifícios com acesso por essas duas ruas, ou seja, a rua Pelágio Lobo, no futuro, pode não ter função alguma, não ter acesso a nenhum lote, apenas aos grandes muros característicos dos fundos de grandes edifícios residenciais.

É interessante notar o grande paradoxo que está em curso nestes bairros, assim como em outros onde o processo de verticalização é mais antigo, como Higienópolis, Cerqueira César, Itaim Bibi e Pinheiros. Estes bairros são valorizados justamente por sua diversidade de usos, ou seja, pelo fato do morador descer de seu apartamento e, em pequenas distâncias percorridas a pé, ter acesso a uma grande quantidade de serviços como padarias, restaurantes, farmácias ou mercados. Essa qualidade de vida atrai cada vez mais moradores ao bairro e cada vez mais empreendimentos exclusivamente residenciais são lançados substituindo as poucas casas comerciais restantes, e portanto, diminuindo cada vez mais aquilo que é o maior atrativo para os moradores: a diversidade de usos. 
CAPÍTULO 4

\section{LEVANTAMENTO E ANÁLISE DE TIPOLOGIAS DE TECIDOS URBANOS}


1. A Fórmula de Adiron e suas conseqüências para a tipologia dos edifícios foi analisada no Capítulo 2 desta dissertação.

\subsection{INTRODUÇÃO}

Vimos no capítulo anterior como a tipologia dos edifícios residenciais se modificou ao longo do tempo; vimos também que as causas importantes dessa transformação foram as modificações que ocorreram na legislação urbana. Podemos citar ao menos duas alterações da legislação urbana que influenciaram significativamente a tipologia dos edifícios: 1) a lei 7.805, Lei Geral de Zoneamento, Parcelamento, Uso e Ocupação do Solo de novembro de 1972 que, entre outras mudanças, dividiu a cidade em zonas de uso e ocupação, definiu o coeficiente de aproveitamento (CA) e a taxa de ocupação (TO) máximos de cada uma das zonas, determinando assim uma drástica redução do potencial construtivo dos lotes da cidade, e, principalmente, criou um mecanismo conhecido como fórmula de Adiron $^{1}$, através do qual foi possível aumentar o CA dos lotes de cada uma das zonas na medida em que se diminuísse sua TO, de acordo com fórmula matemática estabelecida pela lei; 2) a lei 8.266 de junho de 1975, conhecida como Código de Edificações, que substituiu o antigo Código Artur Saboya e, entre outras coisas, revogou a linha de gabarito e criou as Faixas "A1", de aeração e "A2", de iluminação, que devem ficar livres de construções, estabelecendo com isso novos padrões de implantação do edifício no lote.

Considerando que a tipologia edificada é um dos principais elementos na formação das tipologias dos tecidos urbanos, podemos afirmar que a legislação urbana, ao influenciar a forma do edifício, acaba por influenciar também a forma da cidade.

Este capítulo nasceu da necessidade de uma análise comparativa entre tecidos urbanos de bairros da cidade de São Paulo que tiveram seus processos de verticalização ocorridos em diferentes épocas e sob a regulamentação de diferentes legislações. Desta maneira pretendemos observar diferenças nas características destes tecidos urbanos e compreender quais dessas diferenças são de fato responsabilidade da legislação urbana.

Foram escolhidos para levantamento de tecidos urbanos os bairros de Higienópolis, Itaim Bibi e Vila Leopoldina. Higienópolis, bairro próximo ao centro histórico da cidade, já estava com seu processo de verticalização consolidado na época da promulgação da Lei Geral de Zoneamento, em novembro 1972. Pelas suas características foi considerado pelo zoneamento como sendo Z3 -"uso predominantemente residencial, de densidade demográfica média". Em 1972, pelo que verificamos, o processo de verticalização do bairro Itaim Bibi já havia começado. Muitos dos edifícios do bairro foram construídos anteriormente à promulgação da lei de zoneamento, e outros muitos foram edificados já sob as novas regras desta lei. Para que houvesse os mesmos parâmetros de análise, foi levantada uma área do Itaim Bibi também considerada como $\mathrm{Z3}$ pelo zoneamento. $\mathrm{O}$ mesmo procedimento foi feito em ralação à Vila Leopoldina, bairro onde o processo de verticalização se iniciou posteriormente a estas duas leis e ainda se encontra em vias de consolidação.

É importante salientar que o Código de Edificações de 1975, que substituiu o antigo Código Artur Saboya, não substituiu ou modificou a Lei Geral de Zoneamento de 72, que esteve em vigência até fevereiro de 2004. São leis complementares, que apenas acrescentam novas regras para as novas edificações.

O Código de Edificações de 1975 foi substituído em 1992 pelo atual Código de Obras e Edificações (lei 11.228/92), mas, como nos mostra Yasunaga (2007), as alterações propostas pelo novo código no que se refere às faixas de iluminação e aeração foram ir- 
relevantes em relação ao que já existia e, portanto, não alteraram significativamente a tipologia das edificações.

\subsection{O DESENVOLVIMENTO DO BAIRRO DE HIGIENÓPOLIS}

Segundo Prado 2 (apud Antonucci, 2005), em 1561 os padres jesuítas recebem por doação de Martin Afonso de Souza, proprietário da Capitania de São Vicente, uma sesmaria denominada de Campo Largo, que era delimitada a oeste pelo caminho de Sorocaba, hoje a avenida Consolação; ao sul pela estrada do Araçá, hoje avenida Dr. Arnaldo; a leste pelo ribeirão Pacaembu, hoje, canalizado, está sob a avenida Pacaembu; e ao norte pela rua do Pacaembu, atual avenida Higienópolis. A topografia acidentada propiciou a divisão desta área em três partes denominadas Pacaembu de baixo, Pacaembu do meio e Pacaembu de cima.

2. Prado, Maria Cecília Naclério Homem. Higienópolis, grandeza e decadência de um bairro paulista. São Paulo, PMSP, 1980.

Com o confisco dos bens dos padres jesuítas, em 1767, após sua expulsão da cidade, as três partes das sesmarias foram adquiridas em hastas públicas respectivamente por Clemente José Gomes Camponeses, Manoel Simões e Gabriel Antunes de Fonceca (PRADO, apud ANTONUCCI, 2005). Essas terras altas, situadas na encosta do espigão, eram tidas como saudáveis pelo seu clima ameno e suas características rurais. Desfrutavam de certa proximidade com o centro da cidade o que propiciava a construção de casas "nem tanto urbanas, nem tanto rurais" (ANTUNUCCI, 2005, p. 201).

No final do século XIX, grandes fazendeiros que utilizavam suas casas na capital, geralmente sobrados de taipa localizados no triangulo central, apenas como residência eventual, passam a fixar em território urbano sua residência principal. Este foi o caso de Dona Veridiana da Silva Prado que em 1878 estabeleceu-se definitivamente em São Paulo e, em 1884, mandou construir, nos altos de Santa Cecília, junto à rua do Pacaembu (Av. Higienópolis) um palacete com materiais e planta inteiramente importados da Europa. Posteriormente, Dona Maria Antonia da Silva Ramos e Dona Maria Angélica Barros também se estabelecem na região. Dona Angélica fixou residência na Chácara das Palmeiras, onde mandou edificar, na esquina da Avenida Itatiaia, atual av. Angélica, com alameda Barros, "uma réplica do castelo de Charlottenburg, conforme planos, materiais e decoração encomendados na Alemanha" (PRADO, apud ROLNIK, 2003, p. 107). O prestígio dessas três senhoras, detentoras de destacado papel na sociedade paulistana de então certamente contribuíram para o desenvolvimento do viés elitista dos loteamentos exclusivos abertos na região na década de 1890 .

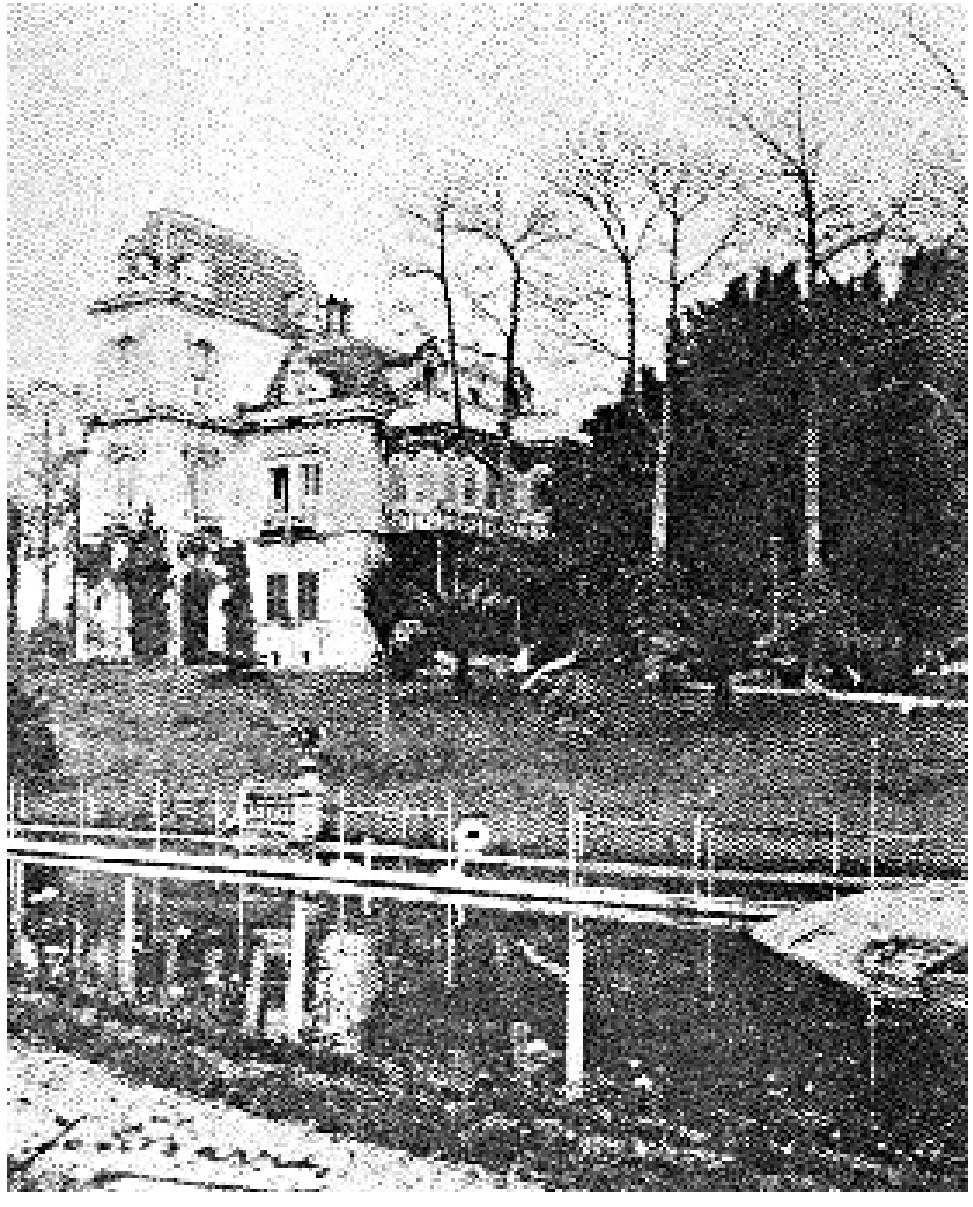

Figura 4.1 - Palacete de Dona Veridiana da Silva Prado na Esquina da rua D. Veridiana com Av. Higienopolis. (Fonte: Prado, 1980, P. 46) 
3. GARCEZ Benedito Novaes O Mackenzie. São Paulo, Casa Editorial Presbiteriana, 1970
Segundo ROLNIK (2003), desde o final de 1870 sucessivos investimentos foram feitos pela municipalidade para estimular o loteamento de chácaras a oeste do triângulo central. O mais importante deles foi a construção do Viaduto de Chá, que uniu o centro ao Morro do Chá, superando pela primeira vez o obstáculo representado pelo vale do rio Anhangabaú. "Constituiu-se assim a 'cidade nova', na zona oeste da cidade, cujas terras, segundo o próprio prefeito João Teodoro, 'estavam nas mãos de gente de grande fortuna" (GARCEZ3', apud ROLNIK, 2003, p. 108).

A construção do Viaduto do Chá foi fundamental para a marcha ao sudoeste que se seguiria na cidade e o episódio de sua construção ilustra bem as relações entre o processo político de decisão a respeito da provisão de infra-estrutura urbana e a valorização imobiliária de áreas da cidade. Sua construção viabilizou os principais empreendimentos imobiliários do final do século XIX: Higienópolis e Paulista (ROLNIK, 2003).

A abertura do Bulevar Buchard - primeiro nome do loteamento de Higienópolis - em 1895, estabeleceu um novo padrão de loteamento destinado às classes de alta renda, introduzindo elementos diferenciadores: a salubridade e vista de lugares altos.

\section{"Boulevard Buchard.}

São estes esplêndidos terrenos situados no ponto mais alto e mais saudável da cidade, com linha de bonde em toda a Avenida Higienópolis, servidos também pelos bondes que percorrem a rua D. Veridiana, bem como já servidos com água, gás e esgotos. Contém este aprazivel bairro 14 ruas todas arborizadas, com um aspecto delicioso. Ali se acham situados os colégios - ginásios infantis, o Ginásio Americana [Colégio Mackenzie] e em construção o seminário Sinodal da igreja presbiteriana de São Paulo, bem como diversos prédios de muito gosto, o que tudo vai cada vez aumentando o valor aliás reconhecido daqueles terrenos. Pela elevação desses terrenos em boa altura acima da cidade, vêem-se de todos os pontos os mais risonhos e encantadores panoramas.

Ficam assim prevenidos os srs. capitalistas de

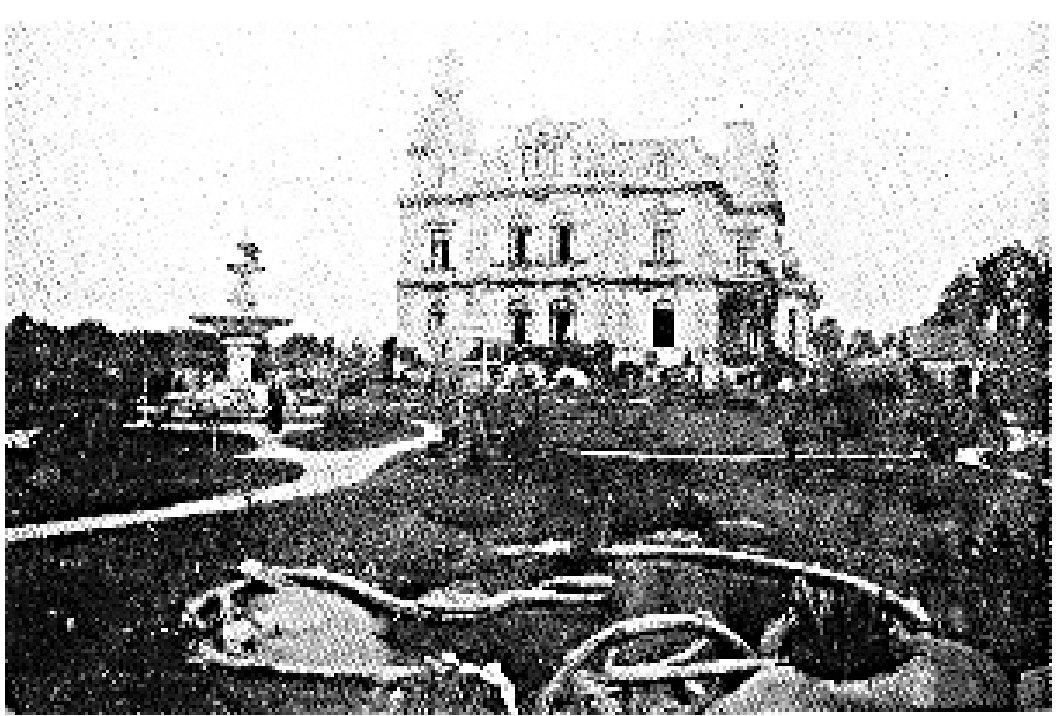

Figura 4.2 - Palacete de dona maria angélica barros na esquina da Av Angélica com Al. Barros. (Fonte: prado, 1980, p. 50) bom gosto para um bom emprego de capital. Para informações tratar na Rua São Bento, 59" (JORGE $E^{4}$, apud ROLNIK, 2003, p. 110).

A legislação restritiva completava o chamariz mercadológico do bairro, ao perpetuar, através da lei 355 de 3 de junho de 1898, a condição de exclusividade do uso residencial "de prestígio”. As construções de casas nas avenidas Higienópolis e Itatiaia eram obrigadas a respeitar ao menos 6 metros de recuo entre o alinhamento e a frente da casa para a execução de jardins, assim como um espaço não menor de 2 metros de cada lado. Esta era a forma de garantir a não subdivisão dos espaços e impedir sua utilização para outros fins que não exclusivamente residenciais, "ao mesmo tempo em que se garantia a presença dessa paisagem 
- jardins e arvoredos - reminiscência senhorial da fazenda no interior do bairro". (Rolnik, 2003, p. 111)

Em 1912 o poder municipal desapropriou terrenos de Germanie Buchard para criar a praça Higienópolis, atual praça Buenos Aires, cujo projeto assina o renomado paisagista francês Joseph Antoine Bouvard, na época responsável pelos projetos do Vale do Anhangabaú e do Parque Dom Pedro II.

O início da verticalização do bairro de Higienópolis, a partir do ano de 1933, se dá justamente no entorno desta praça e na av. Angélica. A construção de edifícios acentuou-se na década de 1940 nas áreas mais antigas do bairro, onde predominavam os lotes de maior dimensão e, portanto, mais valorizados. Alguns dos palacetes do bairro encontravam-se abandonados por seus proprietários ou estavam alugados, servindo de pensão ou até mesmo como cortiços. Seus proprietários - em sua maioria herdeiros - impossibilitados de mantê-los preferiam vendê-los para a construção de edifícios. Em outros casos as famílias proprietárias substituíram as residências originais por edifícios de apartamento para seu próprio usufruto ou para obtenção de renda através de aluguéis (PRADO, apud ANTONUCCI, 2005).

Com a verticalização e o aumento da densidade populacional, o comércio começa a aparecer nas travessas das avenidas principais, ajudando na transformação do bairro, originalmente estritamente residencial. Nesta época foram construídos edifícios residenciais com uma característica até então inédita: lojas comerciais no pavimento térreo.

Com a crescente substituição dos palacetes por prédios de apartamentos o bairro perde sua característica horizontal e passa a ser ocupado por uma classe média emergente. Seu processo de transformação se acentua na década de 1950, quando a avenida Angélica perde sua arborização original por conta de seu alargamento, cujo objetivo era facilitar a crescente circulação de veículos. A verticaliza-

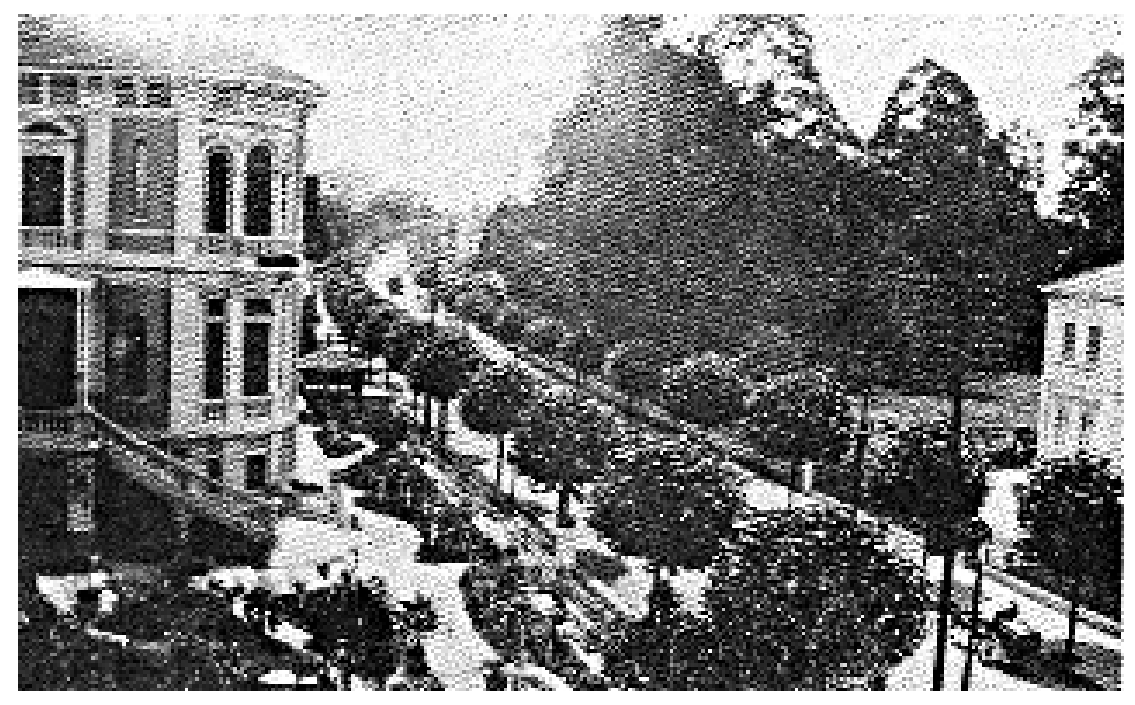

Figura 4.3 - Av. Higienópolis no começo do século XX. Fonte: Prado, 1980, p. 94

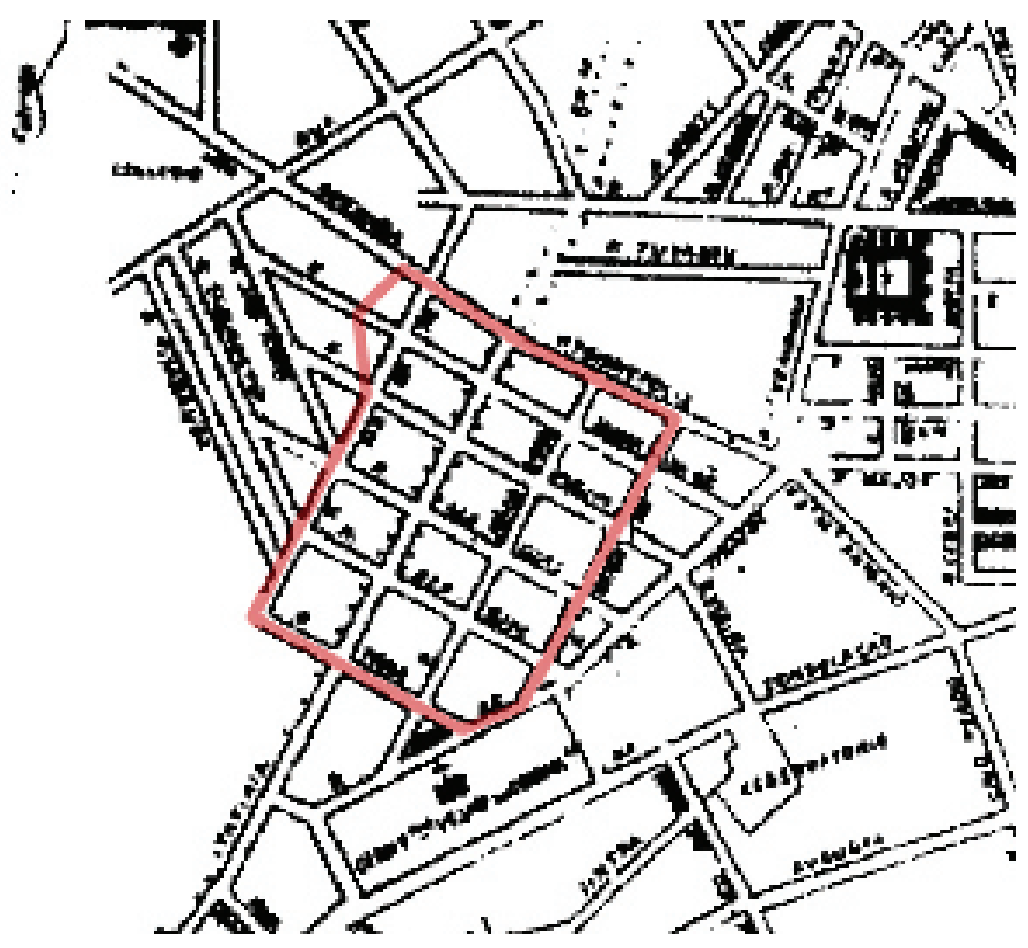

Figura 4.4 - Mapa da cidade em 1897 já mostra o arruamento do bairro de Higienópolis. Em destaque a área levantada. Fonte: Planta Geral de São Paulo Organizada sob a direção do Dr. Gomes Cardim - 1897. 
5. SOMEKH, Nadia. A (des)Verticalização de São Paulo. São Paulo, Dissertação de Mestrado, FAUUSP, 1987 ção trouxe também problemas relativos ao abastecimento de água e à coleta de esgoto, insuficientes para atender o maior número de famílias moradoras. (SOMEK ${ }^{5}$, apud ANTONUCCI, 2005)

Após a década de 1960 a verticalização migra para outros bairros emergentes da cidade, pois em Higienópolis já eram raros os lotes ainda disponíveis para a construção de edifícios. Segundo Somekh, no período entre 1972 e 1979, Higienópolis e Santa Cecília juntos tiveram apenas 5 empreendimentos construídos (SOMEKH, apud ANTONUCCI, 2005).

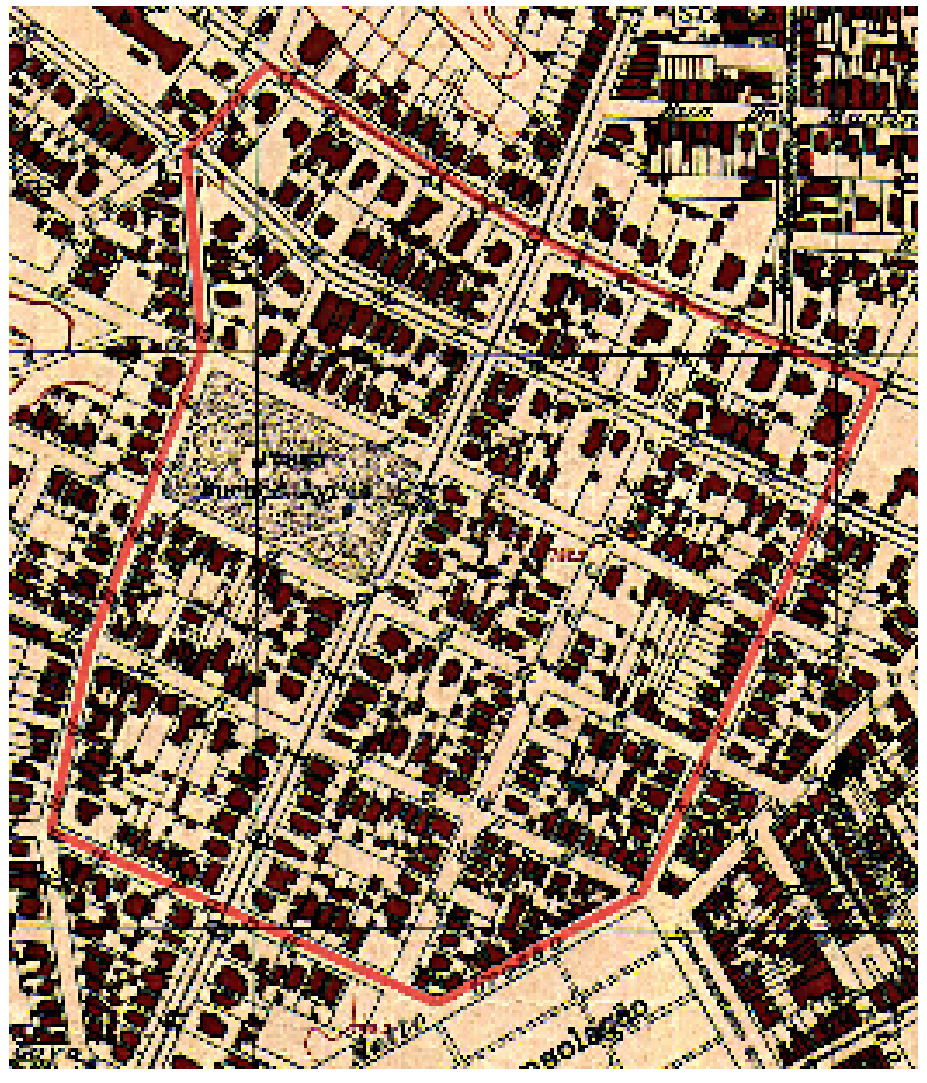

Figura 4.5 - Mapa topográfico da cidade em 1930. Em destaque a área levantada do bairro de Higienópolis. (Fonte: Mapa topográfico do município de São Paulo executado pela empresa Sara Brasil S/A - 1930.)

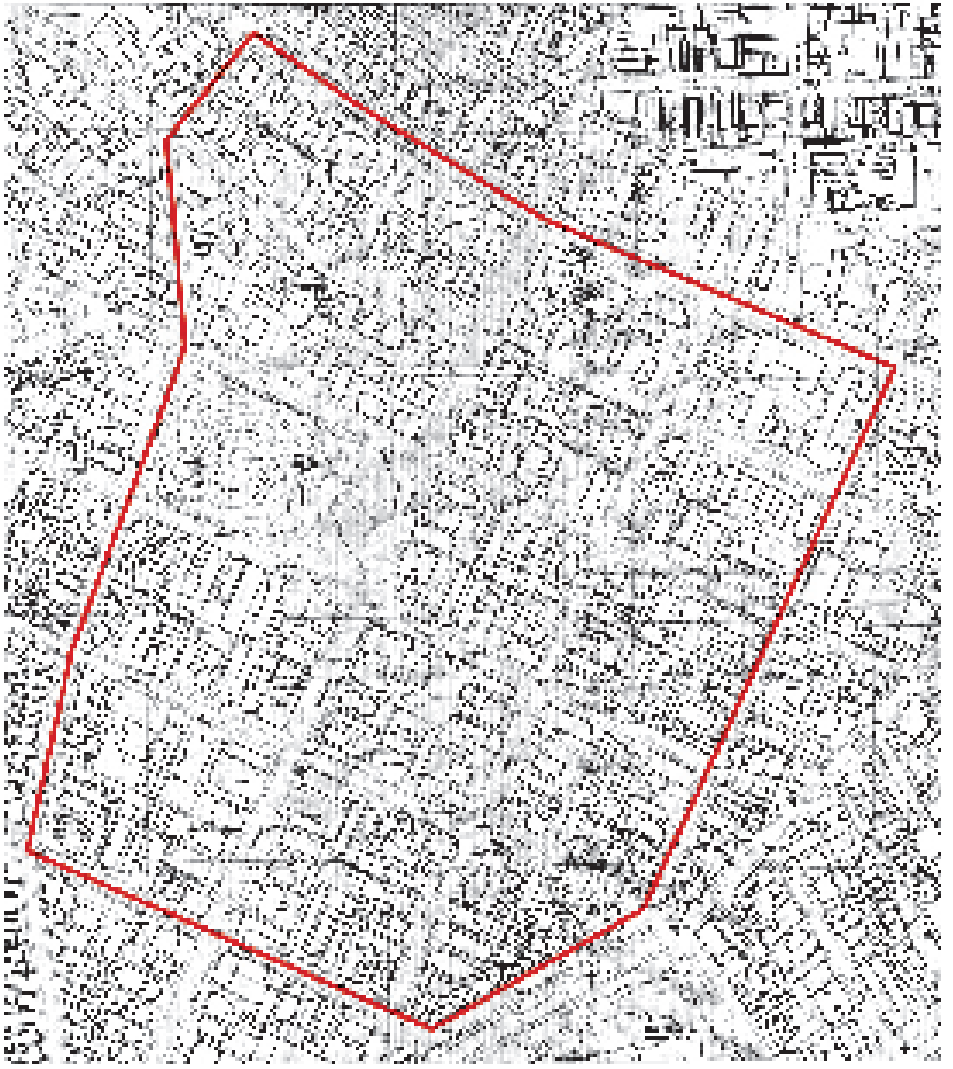

Figura 4.6 - Mapa do Gegran do bairro de Higienópolis. em destaque a área levantada do bairro. (Fonte: Gegran). 


\subsection{A TRANSFORMAÇÃO DO TECIDO URBANO DE HIGIENÓPOLIS.}

Ao analisarmos a evolução dos tecidos urbanos de cada um dos três bairros levantados a partir da comparação entre as plantas Sara Brasil de 1930, GEGRAN de 1972 e foto aérea atual, podemos constatar que todos, sem exceção, sofreram e ainda estão sofrendo transformações. O loteamento de Higienópolis, como vimos anteriormente, foi executado pela empresa Germanie Buchard a partir de um rígido planejamento, tanto urbanístico como mercadológico, e com o provimento da infra-estrutura necessária para um produto destinado às exigentes classes de alta renda. Analisando o processo de formação inicial do bairro segundo a metodologia proposta por Solà-Morales, verificamos que este sofreu, concomitantemente, um processo de parcelamento e urbanização para posteriormente sofrer um processo de edificação, ou seja, PU + E.

De acordo com a metodologia de análise proposta por Cândido Malta Campos Filho, o bairro de Higienópolis sofreu primeiramente a atuação das configurações produtivas de parcelamento, representada pela empresa loteadora Germanie Buchard, e de Infra-estrutura, representada pelo Poder Público Municipal, que forneceu iluminação pública e redes de água e coleta de esgotos. Posteriormente sofreu as atuações das Configurações Produtivas Imobiliárias em cada um dos lotes disponíveis. Sendo, na época, este lotea-

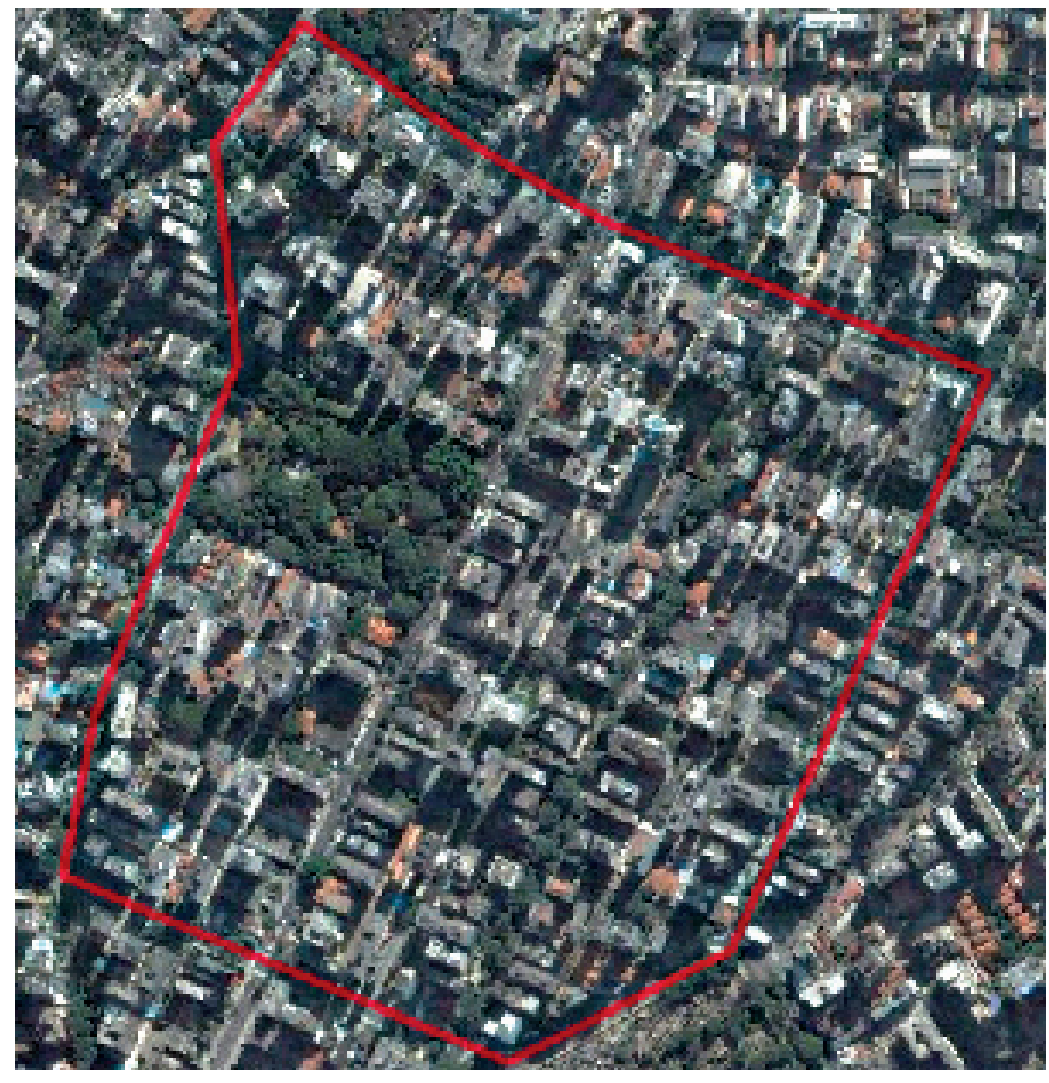

Figura 4.7 - Foto aérea do bairro de Higienópolis. em destaque a área levantada do bairro. (Fonte: Google Earth). 


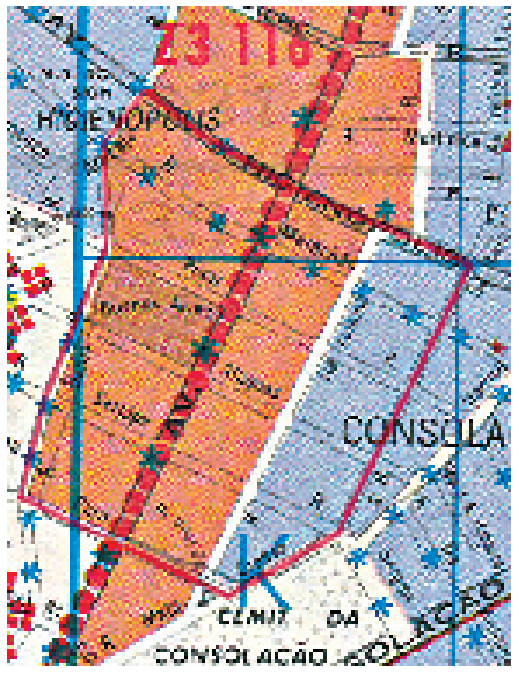

Figura 4.8 - Zoneamento bairro de Higienópolis. (Fonte: Geomapas, 1998). mento estritamente residencial unifamiliar, as Configurações Produtivas que atuaram no bairro foram as que denominamos "por encomenda", ou seja, residências construídas por encomenda de seus proprietários, através de projeto exclusivos, com objetivo de se conseguir um alto valor de uso para as famílias residentes. Ainda segundo a metodologia de Campos Filho, o tecido urbano que se formou no bairro, através da atuação destas três configurações produtivas, foi o do "tipo 3", ou seja, aquele que nasce a partir de um planejamento prévio, geralmente nas periferias urbanas da época em que foi implantado e posteriormente, como de fato foi comprovado, podendo ficar centrais. O loteamento do bairro Higienópolis, um empreendimento particular, de iniciativa da empresa Germanie Buchard, foi destinado às classes de alta renda.

O início da transformação do tecido urbano do bairro se dá, como foi visto, em meados da década de 1930, com a substituição de palacetes pelos primeiros edifícios residenciais, processo que se acentua na década seguinte. Nestas duas décadas, duas novas configurações produtivas começam atuar no bairro: a configuração imobiliária do tipo rentista, representada geralmente por famílias proprietárias que substituem seus antigos casarões por edifícios construídos para obtenção de uma renda proveniente do aluguel das unidades, reservando muitas vezes uma ou duas unidades para seu próprio usufruto ou de alguém de sua família; e a configuração produtiva do tipo incorporação imobiliária, representada por empresas ou capitalistas, que compram antigos casarões ou terrenos vazios, e constroem edifícios para a venda de suas unidades. Com a atuação das novas configurações produtivas, novas tipologias começam a ser edificadas. Surgem os edifícios altos, com até quinze pavimentos e subsolo, muitos de uso misto, com apartamentos residenciais nos pavimentos tipo e lojas no térreo. As lojas representam um excelente investimento para os proprietários rentistas, uma vez que o valor de seu aluguel é, geralmente, muito superior ao dos apartamentos residenciais.

Na década de 1970, o tecido urbano do bairro de Higienópolis já estava totalmente transformado. Nesta época, a maior parte dos casarões do bairro já haviam sido substituídos por edifícios, em sua maioria residenciais; edifícios de escritórios e consultórios médicos também foram construídos, principalmente na avenida Angélica. Os poucos palacetes restantes foram ocupados por empresas ou instituições que lhes deram outro uso. A transformação da paisagem do bairro, no entanto, não trouxe mudanças no perfil econômico de seus moradores pois os novos produtos imobiliários também eram destinados às classes de alta renda.

Atualmente podemos verificar no bairro a presença de várias instituições públicas, consulados, escolas de ensino médio e de ensino superior, hotéis, centros médicos, centros empresariais, centros culturais, restaurantes, igrejas e sinagogas, e até um shopping center que, juntos, proporcionam um intenso movimento, tanto de veículos como de pedestres.

Podemos considerar que Higienópolis hoje se caracteriza como uma centralidade não linear, com várias ruas se entrecruzando, todas com muito tráfego, justificando um comércio mais diversificado e formando uma mancha urbana de várias quadras justapostas em duas direções, ou seja, um tecido urbano do "tipo 4", segundo as definições de Campos Filho. 


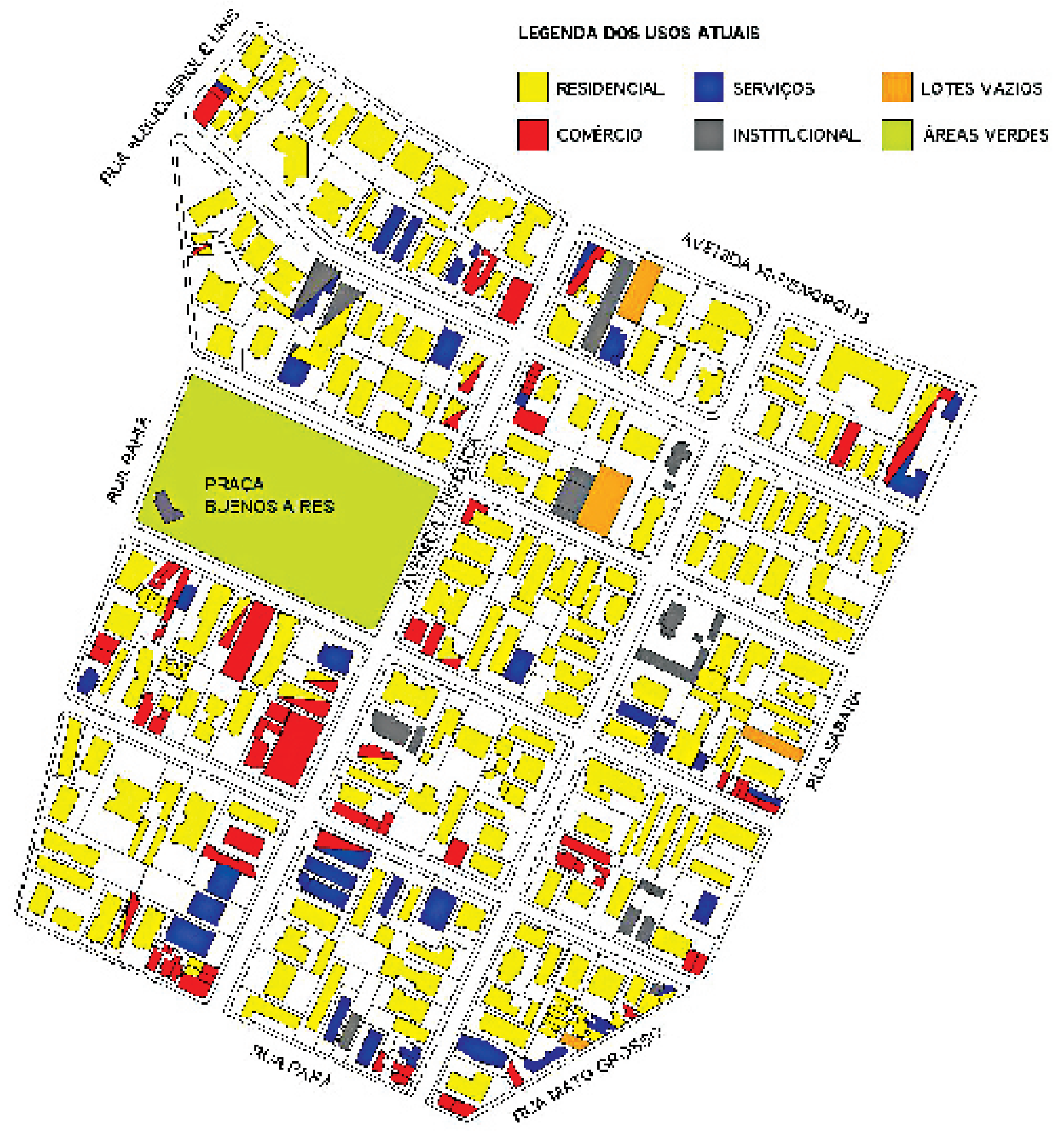

Figura 4.9 - Planta da área levantada do bairro de Higienópolis mostrando os usos das construções. (Fonte: elaborado pelo autor através de levantamento de campo). 


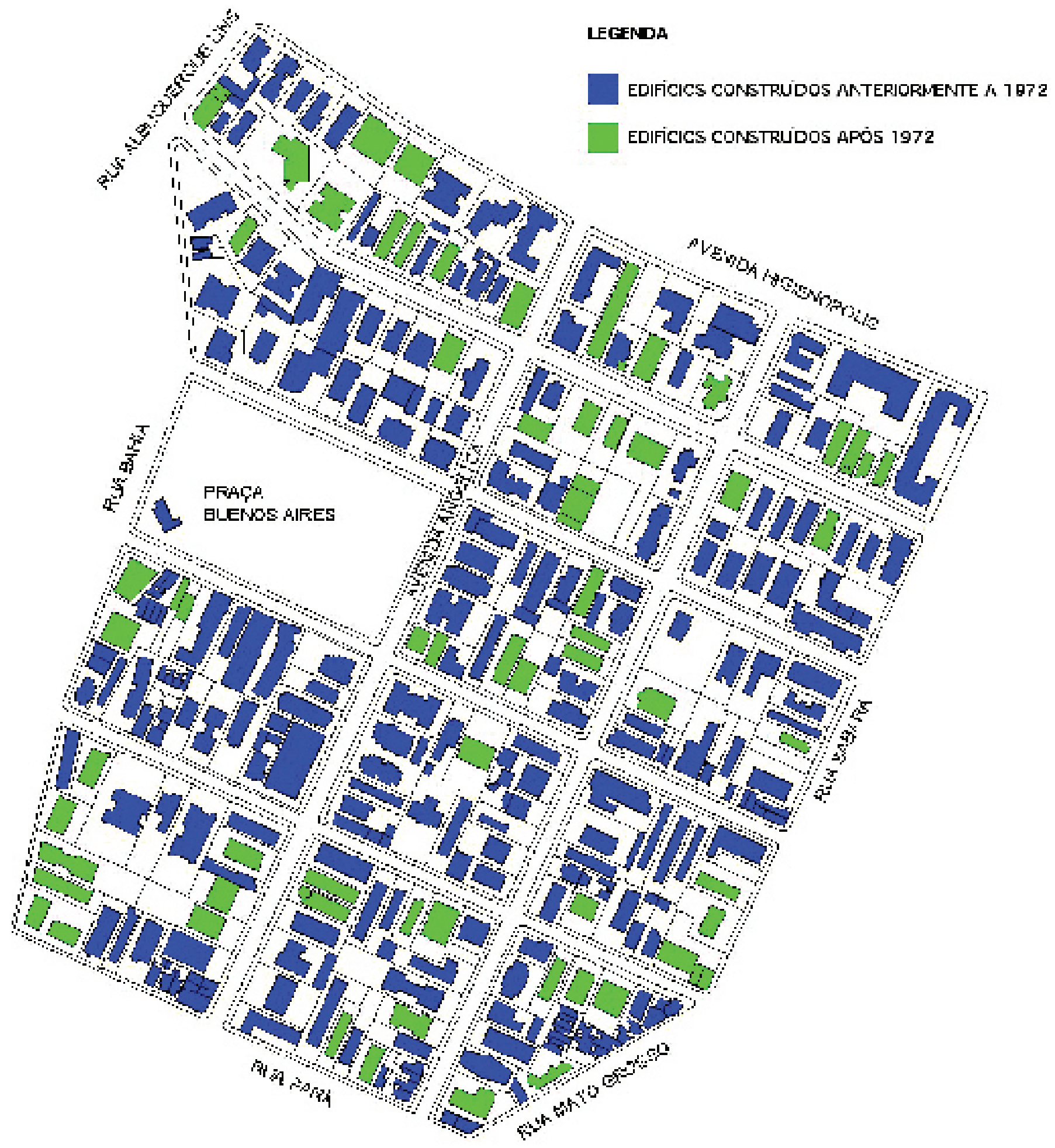

Figura 4.10 - Planta da área levantada do bairro de Higienópolis mostrando as construções anteriores e posteriores à lei de zoneamento de 1972. (Fonte: elaborado pelo autor através de levantamento de campo)). 


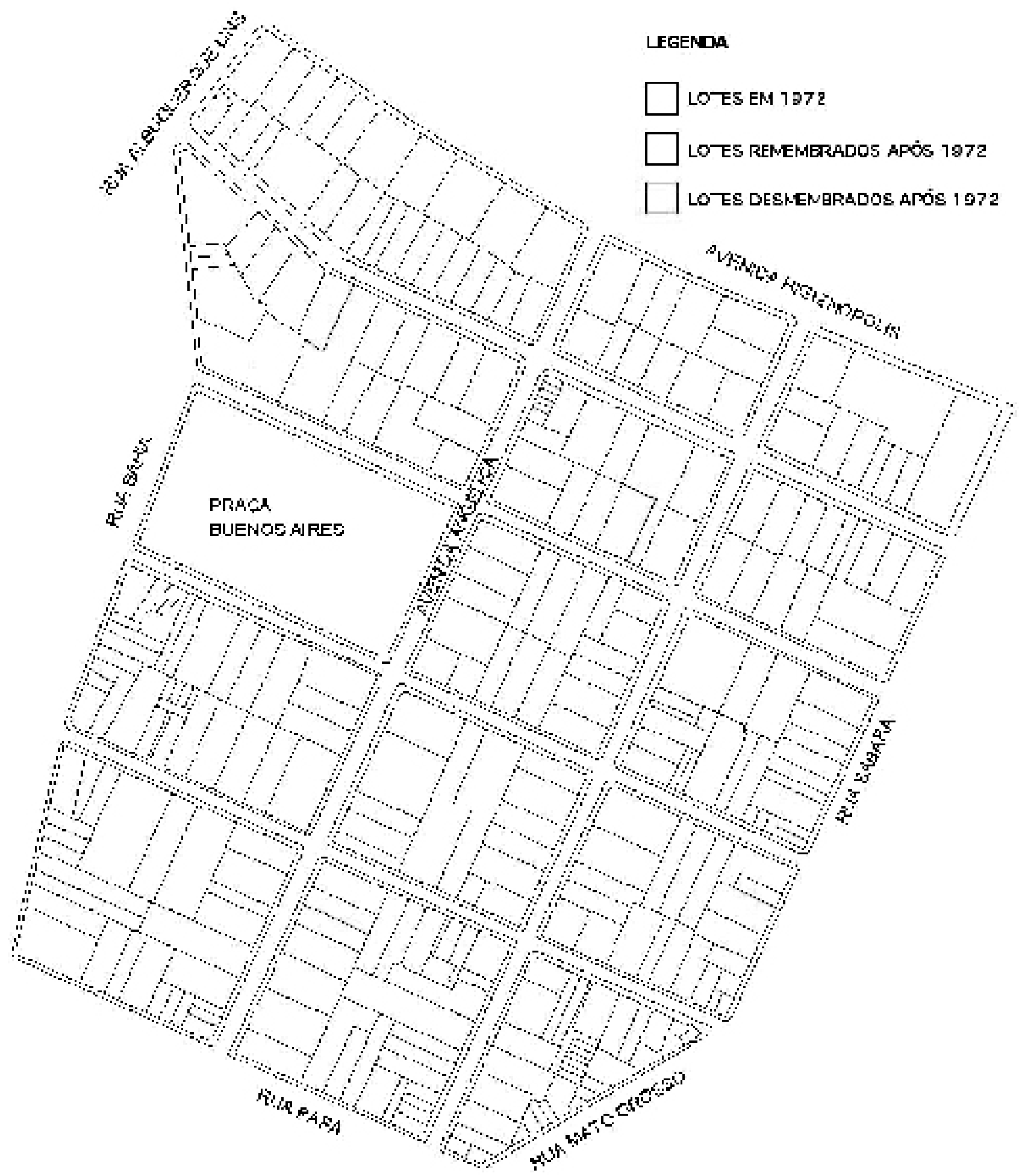

Figura 4.11 - Planta da área levantada do bairro de Higienópolis mostrando os desmembramentos e remembramentos dos lotes da região após 1972. (Fonte: elaborado pelo autor através de levantamento de campo). 


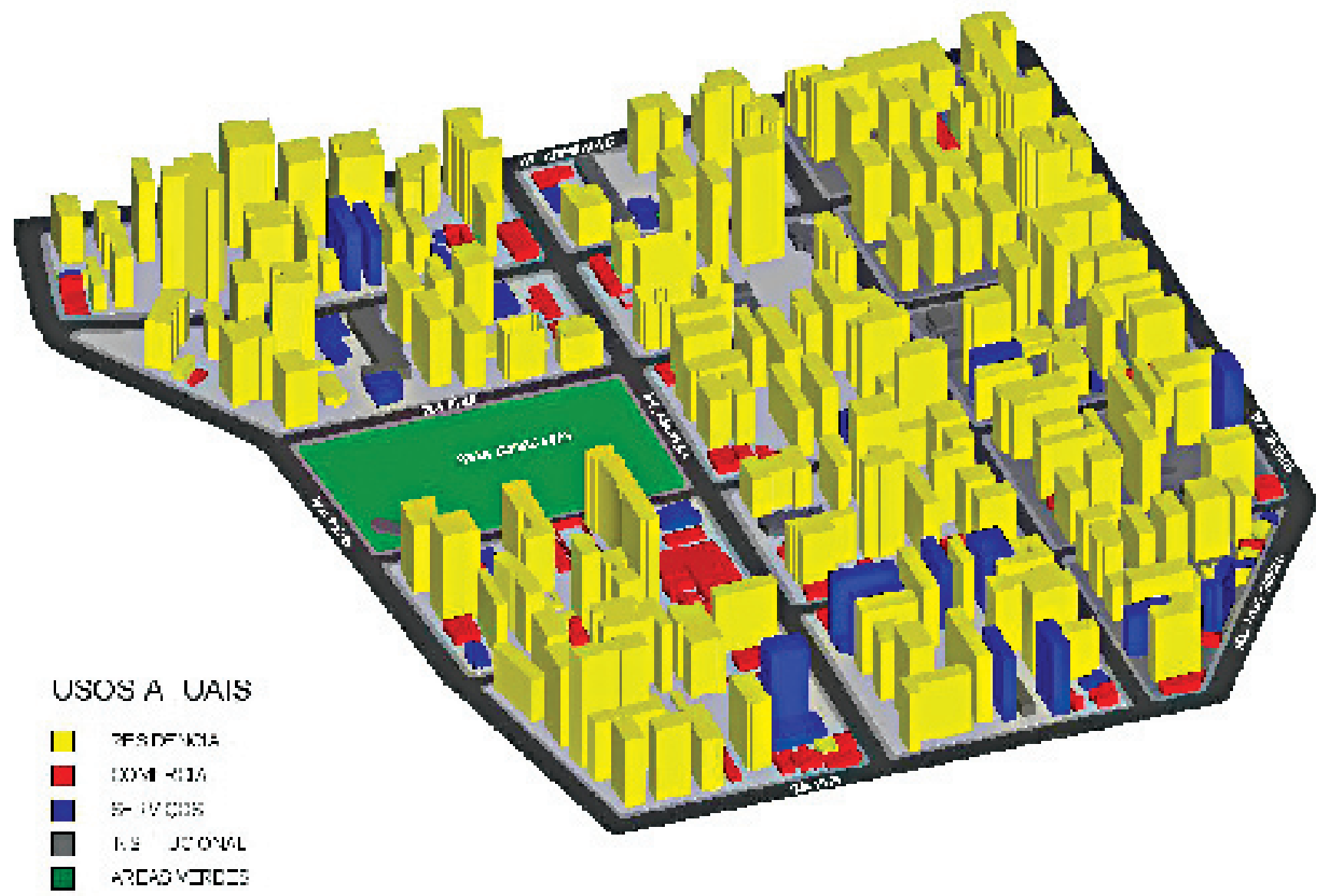

Figura 4.12 - Maquete eletrônica da área levantada do bairro de Higienópolis mostrando os usos atuais.

(Fonte: elaborado pelo autor através de levantamento de campo). 


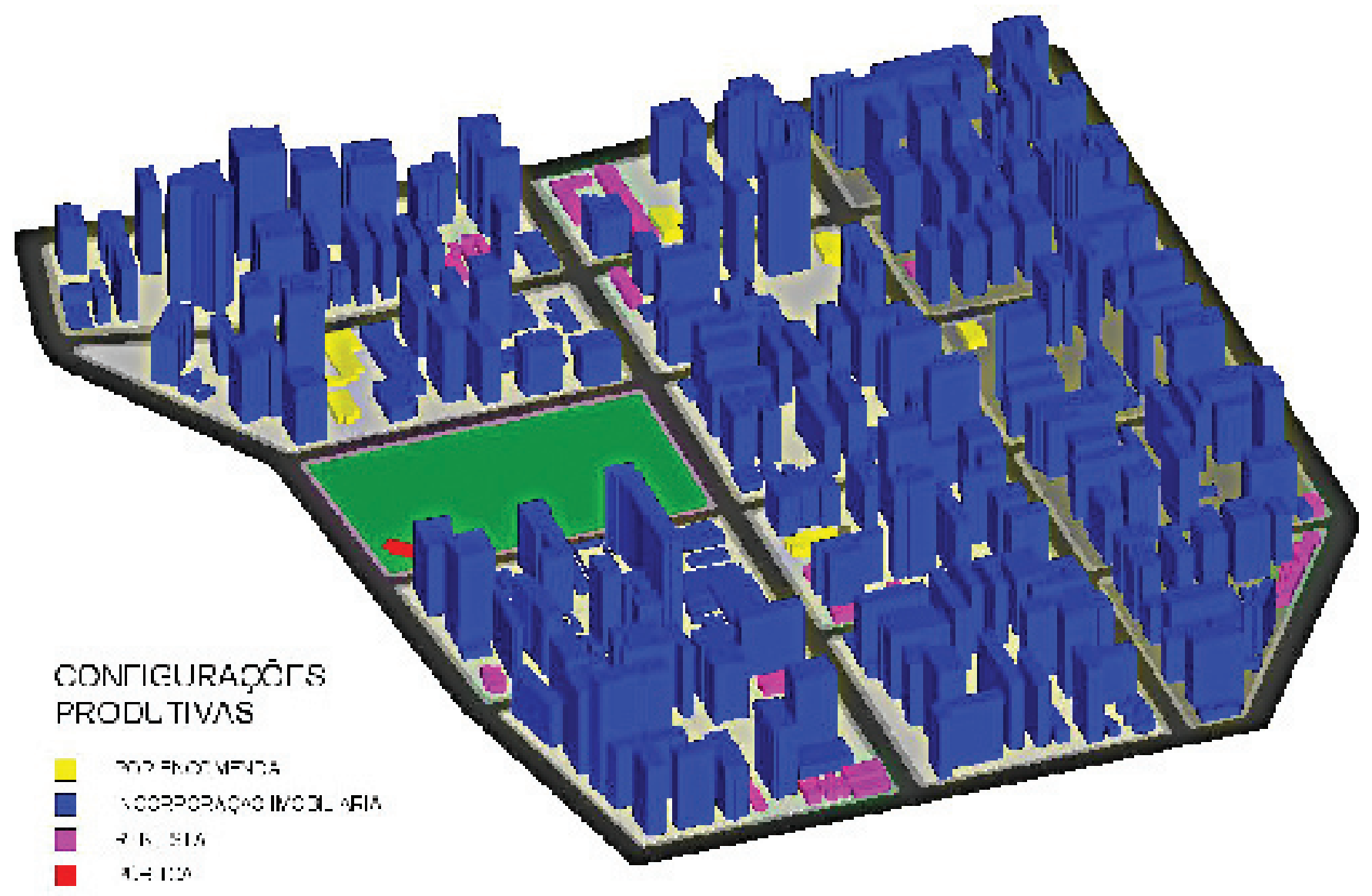

Figura 4.13 - Maquete eletrônica da área levantada do bairro de higienópolis mostrando as prováveis

configurações produtivas imobiliárias. (Fonte: elaborado pelo autor através de levantamento de campo). 
6. O córrego do Sapateiro era também conhecido como córrego do Curtume ou córrego do

Matadouro, pois, antes de chegar à chácara, passava próximo ao matadouro da Vila Mariana

\subsection{O DESENVOLVIMENTO DO BAIRRO DO ITAIM BIBI.}

"Com 140 alqueires, a porteira da entrada ficava na atual praça D. Gastão Liberal Pinto. Dentro dessa área havia apenas um rancho, além da Casa Grande. Era uma dependência que ficava à margem direita do rio Pinheiros... A casa-sede, que nessa época já era centenária (1896), tinha uma morada de 15 cômodos, com cachorros esculpidos em madeira nos beirais do telhado. Além desta, havia o paiol de madeira coberto com telhas, duas cocheiras com sete baias cada, cobertura para trole (charrete), quarto para depósito, viveiro com teto de zinco, duas alcovas, capela e quarto de hóspedes, um moinho d'água e o pomar. A casa foi construída em taipa de pilão, com telhado extenso que servia de proteção para a infiltração das chuvas.

Ninguém tem dúvidas de que este casarão de taipa, com mais de dois séculos, foi sede de uma fazenda muito anterior à chácara do Itaim. Tanto que sua localização à beira do rio Pinheiros, depois afastado com a retificação, indicava que o acesso a São Paulo era feito preferencialmente por água." (O Estado de São Paulo, 4 de outubro de 1984, apud LOPES e TOLEDO, 1988).

A extensa várzea onde hoje se encontra o bairro do Itaim Bibi servia de passagem para aqueles que pretendiam ir a Santo Amaro vindos do Centro ou de Pinheiros. Pertenceu a diversos proprietários. Em 1858 fazia parte do sítio de Dona Joaquina Duarte Ferraz, que o vendeu ao Sr. Carlos Ablas que, por sua vez, em 1864, o transferiu para Sr. João Ribeiro da Silva. A massa falida deste último foi adquirida em 1882 pelo Dr. António Pinto do Rego Freitas e após a sua morte passou a pertencer à sua esposa e posteriormente ao seu genro, Dr. Bento Ribeiro dos Santos Camargo que vendeu a propriedade ao general José Vieira Couto de Magalhães. Após a morte do general, a propriedade passou a pertencer ao seu filho, José Couto de Magalhães, primeiro a realmente se interessar pela área, onde passava temporadas de caça e pesca, e onde realizou inúmeras benfeitorias, dentre as quais a construção da estrada principal (atual Joaquim Floriano), com oito metros de largura, toda em pedregulho, que começava na atual praça Dom Gastão Liberal Pinto e terminava nos portões da Casa Grande. Em 1907, após a sua morte prematura, foi adquirida em hasta pública, por trinta contos e dez réis, pelo irmão do general, o Dr. Leopoldo Couto de Magalhães (LOPES e TOLEDO, 1988).

Nesta ocasião a chácara do Itaim tinha uma área de 148 alqueires, quase 360 mil metros quadrados. Seus limites eram: a leste a estrada de Santo Amaro até a av. Brigadeiro Luis Antônio e, depois desta, um limite onde hoje se encontra a av. São Gabriel; ao norte o córrego onde hoje se encontra a av. 9 de Julho estendendo-se até o córrego Verde, próximo ao lugar onde hoje está localizado o Shopping Iguatemi; a oeste o rio Pinheiros e ao sul o córrego Uberaba, onde hoje se localiza parte da av. Helio Pellegrino. A chácara era cortada ainda pelo córrego do Sapateiro ${ }^{6}$, onde hoje se localiza a av. Juscelino Kubitschek.

Localizada em um fundo de vale e sujeita a inundações periódicas do rio Pinheiros e seus afluentes, a chácara era considerada insalubre e quase não tinha atividade econômica. Era utilizada apenas como passagem e por atividades recreativas de seus proprietários, como caça e pesca. As poucas atividades econômicas ficavam à beira do Rio Pinheiros. Tratava-se de portos para secagem e peneiramento da areia trazida pelos barqueiros, posteriormente fornecida às construções, e de olarias que produziam tijolos e telhas com o barro também retirado do rio (LOPES e TOLEDO, 1988). 
Dr. Leopoldo foi o primeiro a efetivar uma ocupação definitiva da chácara, quando ali se instala com sua família. Em 1916 ocorre a subdivisão da área entre seus herdeiros que também se estabelecem na região instalando-se em chácaras menores onde construíram grandes casas rodeadas de jardins.

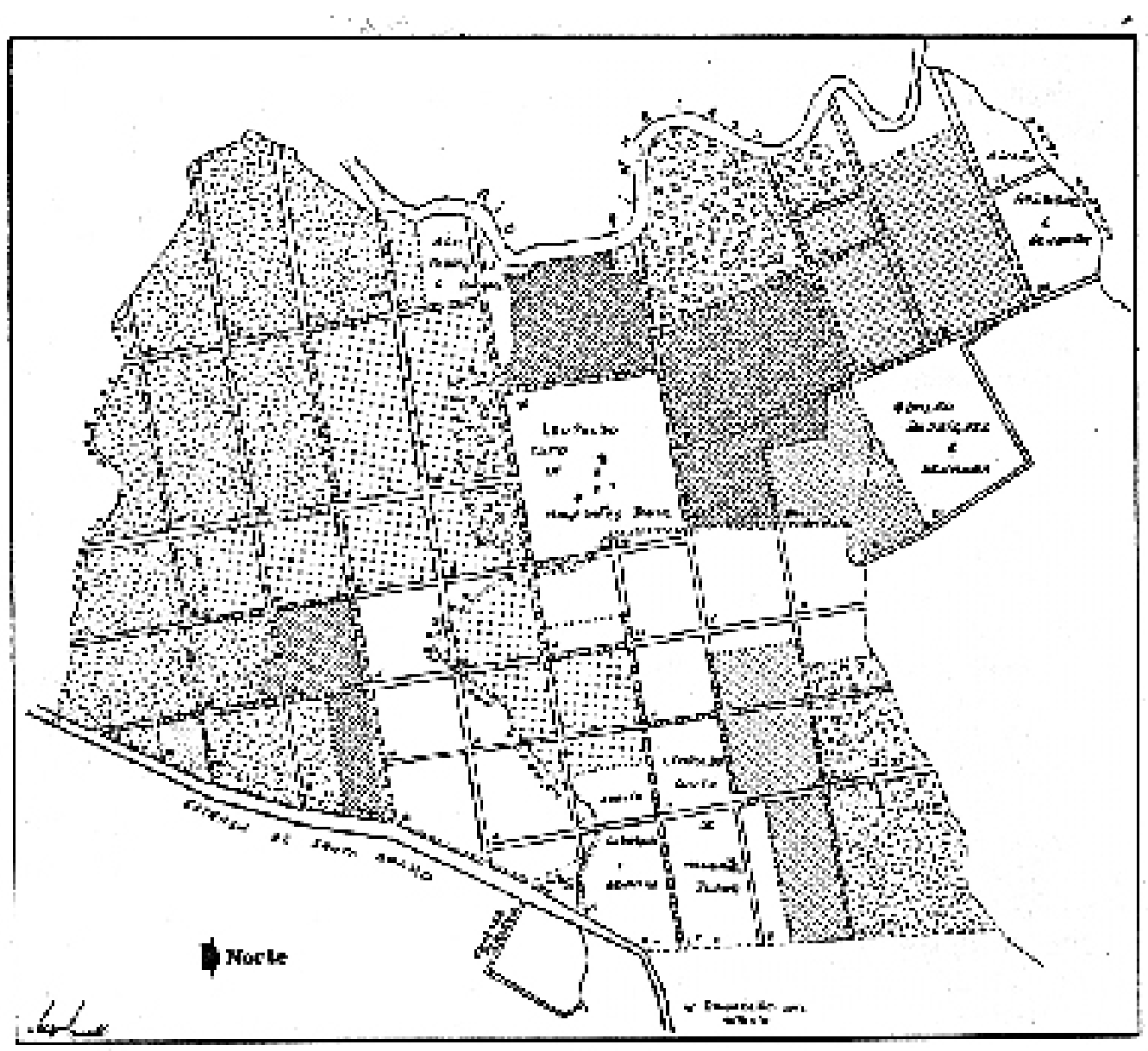

Planta do Levantamentos Divisaso Judicial do Sitio Itahlm.

Bairro dos Pinheiros em S. Pauld? Pertencen1e aos herdelros do Dr. LEOPOLDO COUTO DE MAGALHAES

Logerda

sascais:

C) ANTRHIDCATLOSDODOUTOMAGRLHAES

(i) J9SE SALLADOR EA COLFO RODRIGUES

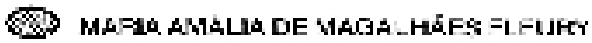

C. GALIFU GALILEI COUTODE MAGALHSES

F zULMIRA MACIIAOOO

OS LEOPDLDO COUTO MAGALHAEG

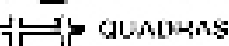

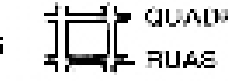

\% no

........ LIMITE DA PAFTILHR

VALA

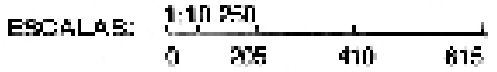

Figura 4.14 - Planta da divisão judicial da chácara do Itaim Bibi entre os herdeiros de Dr. Leopoldo. (Fonte: Lopes e Toledo, 1988, p. 20). 
Nesta época são abertas as primeiras ruas que funcionavam como passagem entre as diversas chácaras. Leopoldo Couto de Magalhães Jr., conhecido como Bibi, residiu na antiga sede da chácara, chamada de "casa grande", até vendê-la, em 1927, ao Dr. Brasílio Marcondes Machado, que a transformou na Casa de Saúde Bela Vista, inaugurando na região uma atividade que não era rural ou residencial. Bibi passou a residir com seu filho Arnaldo em sua nova residência que mandou construir na rua Joaquim Floriano, n. ${ }^{\circ} 72$ (LOPES e TOLEDO, 1988).

Estabelecidos na região, os herdeiros do Dr. Leopoldo Couto de Magalhães passaram a lotear o restante de suas terras. Ao contrário de Higienópolis e outros bairros da cidade, onde os loteamentos foram feitos por empresas profissionais, muitas vezes estrangeiras, o loteamento das pequenas chácaras de Itaim foi realizado pelos seus proprietários, sem que houvesse nenhum tipo de plano urbanístico. Este trabalho, na maioria das vezes, foi realizado pelo Dr. Arnaldo Couto de Magalhães, filho de Bibi, que optou pela divisão em lotes de pouca área, geralmente medindo $10 \mathrm{~m} \mathrm{X} \mathrm{50m} \mathrm{e} \mathrm{vendidos} \mathrm{a} \mathrm{prazo,} \mathrm{para} \mathrm{atender}$ a uma faixa popular de pequenos comerciantes, funcionários do comércio e homens de of ício. Também não impunha qualquer restrição às construções ou ao uso que fariam delas (LOPES e TOLEDO, 1988).

Na ocasião do loteamento o apelido de Leopoldo Couto de Magalhães Jr., o Bibi, passa a ser associado ao nome do bairro para diferenciá-lo de outro bairro da cidade, o Itaim Paulista; nesta época dizia-se: "os terrenos do Bibi". Posteriormente o nome Itaim Bibi torna-se oficial. Não pudemos apurar a data, mas é provável que tenha sido em 1934, quando o Itaim Bibi deixou de pertencer ao bairro de Pinheiros e, pela lei 6.731 de outubro deste ano passa a ser um Subdistrito.

Os primeiros a se instalarem no bairro eram italianos e portugueses, vindo diretamente da Europa ou de outros bairros da cidade como o Bexiga, onde os terrenos, mais próximos do Centro, estavam se tornando caros.

Ao deixar sua terra natal, na época da Primeira Guerra Mundial, o estudante de medicina David não imaginava que a prosperidade chegaria através de uma receita, segredo de família, conhecida por sua esposa Ana: o exótico marzipan. E foi assim, ela fazendo os doces e ele os vendendo na rua que, em 1925, iniciaram a fábrica Kopenhagen, com a primeira loja na cidade na rua Miguel Couto [...]. Entre os moradores mais antigos do bairro permanece a lembrança do 'seu' David, sentado em uma cadeira do lado de fora da fábrica, presenteando com chocolates as crianças que saíam da escola." (LOPES e TOLEDO, 1988, p. 30-31)

Na década de 1920 intensificou-se o povoamento do Itaim. O crescimento do número de indústrias em São Paulo aumentou consideravelmente a quantidade de trabalhadores; o desenvolvimento de bairros vizinhos destinados às classes de alta renda, como os "Garden City" - atualmente o bairro dos Jardins - ofereceu oportunidades de trabalho em construções ou em casas de famílias ricas. Estes fatores, associados aos preços convidativos dos terrenos, foram determinantes para a procura da região como bairro residencial popular.

As tipologias das casas que surgiram no bairro eram uniformes, geralmente constituídas de sala, quarto e cozinha, a maioria delas construídas no alinhamento dos lotes. Em muitos casos os cômodos da frente e do fundo do quintal tinha uma função econômica: "na frente um bilhar e mesas onde se servia uma bebida, no fundo do quintal a oficina de marcenaria" (LOPES e TOLEDO, 1988, p. 33); o meio da casa era onde a família vivia. 
Outras casas eram recuadas, com a frente e uma das laterais ocupadas por jardins e no fundo cercados e gaiolas onde se criavam animais como galinhas, coelhos e cabras. Se havia uma casa mais requintada é porque pertenciam aos donos do loteamento. Era comum que os comerciantes, geralmente imigrantes, quando se tornavam bem sucedidos, se transferissem para locais mais nobres da cidade.

Em 1927 a Lei Estadual n 2.249, em seu artigo 1º, concedeu a The São Paulo Tramway Light \& Power Company Ltd. autorização para retificar, alargar, aprofundar e canalizar o leito do rio Pinheiros. Em 1929 o bairro viveu a pior enchente de sua história. Arrancou o trilho do bonde, destruiu casas e o Clube Germânia, atual Esporte Clube Pinheiros, “ficou coberto até o telhado" (LOPES e TOLEDO, 1988, p. 42). A esta catástrofe se seguiu um grave problema social, pois a área inundada foi demarcada pela empresa com marcos de posse, a qual, alegando estar conforme a concessão feita em 1927 pelo Governo do Estado, apropriou-se da área, propondo indenizações irrisórias aos então proprietários ${ }^{7}$. A explicação oficial foi que o ano havia sido excessivamente chuvoso, porém nunca ficou comprovado que a chuva justificasse tamanha enchente.

Até meados do século XX o bairro era desprovido de infra-estrutura básica. A água para casa e para a criação era proveniente de poços, mas apenas nas regiões mais altas do bairro, onde a água dos poços era de boa qualidade. Nas proximidades do rio Pinheiros e dos córregos da região a água dos poços era salobra, imprópria para consumo. A rua Joaquim Floriano foi a primeira a receber água encanada, mas não temos a data precisa. As águas servidas escoavam diretamente para a rua, e para os esgotos haviam as fossas sanitárias. Estas só funcionavam a contento nas partes altas do bairro; nas partes baixas as fossas logo se enchiam e os detritos escoavam para a rua. A rede de coleta de esgoto só chegou ao bairro na gestão do governador Jânio Quadros (1955-58), mas se limitava apenas à rua Joaquim Floriano. Na gestão seguinte, a do governador Carvalho Pinto, a rede de esgoto se expande ao ser posto em prática o Plano de Ação do Governo do Estado (LOPES e TOLEDO, 1988).

A primeira linha de bonde que serviu ao bairro era a que ligava, no começo do século XX, o centro da cidade ao atual bairro de Santo Amaro. Em 1915 um contrato assinado entre a Cia. City e a Light estabeleceu a implantação de 15 quilômetros de novas linhas de bonde nos terrenos da City, incluindo 2 quilômetros para viabilizar o acesso ao Jardim América pala rua Augusta (ROLNIK, 2003). Duas linhas de bonde passam então a ser utilizadas pelos moradores do Itaim: a linha Jardim Paulista, que ligava o Largo São Francisco à esquina das ruas Veneza e Antônio Brito, e a linha Jardim Europa, que saía do Largo do Piques (atual Praça da Bandeira) e ia até a avenida Europa com rua Itália. Em meados da década de 1930 começa a circular a linha de ônibus Itaim, que ligava o Vale do Anhangabaú à rua Clodomiro Amazonas. A execução da av. 9 de Julho como parte do Plano de Avenidas de Prestes Maia (1938 - 45) transfere os trajetos de ônibus para essa artéria e as linhas de bonde são desativadas (LOPES e TOLEDO, 1988).

Segundo LOPES e TOLEDO (1988), o processo de verticalização do bairro do Itaim Bibi inicia-se na década de 1970, mas de acordo com nosso levantamento de campo, ao compararmos a situação atual com aquela mapeada pelo GEGRAN em 1972, verificamos que naquela época já se encontravam construídos muitos dos edifícios presentes hoje no bairro. Acreditamos, portanto, que o início da verticalização do bairro tenha se iniciado ainda na década de 1960. Podemos citar algumas razões que levaram ao início deste processo de verticalização do Itaim Bibi. A primeira razão é o fato das áreas disponíveis em outros locais considerados mais interessantes pelos investidores começarem a se esgotar.
7. As áreas passíveis de apropriação pela Light eram aquelas que ainda não estavam urbanizadas. 0 Largo de Pinheiros, o Jockey Club e o Clube Germânia ficaram de fora das pretensões da empresa (LOPES e TOLEDO, 1988). 
Figura 4.15 - Mapa topográfico da cidade em 1930. em destaque a área

levantada do bairro do Itaim bibi. (Fonte: Mapa topográfico do município de São Paulo executado pela empresa Sara Brasil S/A - 1930)
Na procura por novas regiões para expansão do mercado imobiliário, a localização colaborou para a escolha do bairro, por este ser vizinho aos Jardins, bairro residencial de alta renda, e por se encontrar ao lado de importantes artérias de ligação com o centro, como as avenidas 9 de Julho e Brigadeiro Luis Antônio. Teve importância também neste processo o fato de no bairro do Itaim Bibi os terrenos ainda terem preços bem acessíveis e não existir nenhuma restrição imposta pelo loteamento. Na década de 1970 dois motivos ainda colaboraram para a valorização do bairro: a canalização do córrego do Sapateiro e construção em seu leito da av. Juscelino Kubitschek, que liga a Marginal Pinheiros à av. Brigadeiro Luiz Antônio, e a lei de zoneamento de 1972, que considera esta área com Z3 e $\mathrm{Z} 4$, permitindo atingir o $\mathrm{CA}=4$.

As casas do bairro passam então a ser substituídas por edifícios residenciais, na sua maioria destinados às classes de média ou alta renda. O comércio, inicialmente apenas nos arredores da rua Joaquim Floriano, passa a se espalhar pelo bairro, principalmente ocupando a rua João Cachoeira que, a partir de 1975, torna-se a principal artéria econômica do bairro. O processo de verticalização se acentua nas duas décadas seguintes, quando a política econômica do governo, de abertura para as multinacionais, impulsionou a construção de vários edifícios comerciais, com forte presença de firmas internacionais.

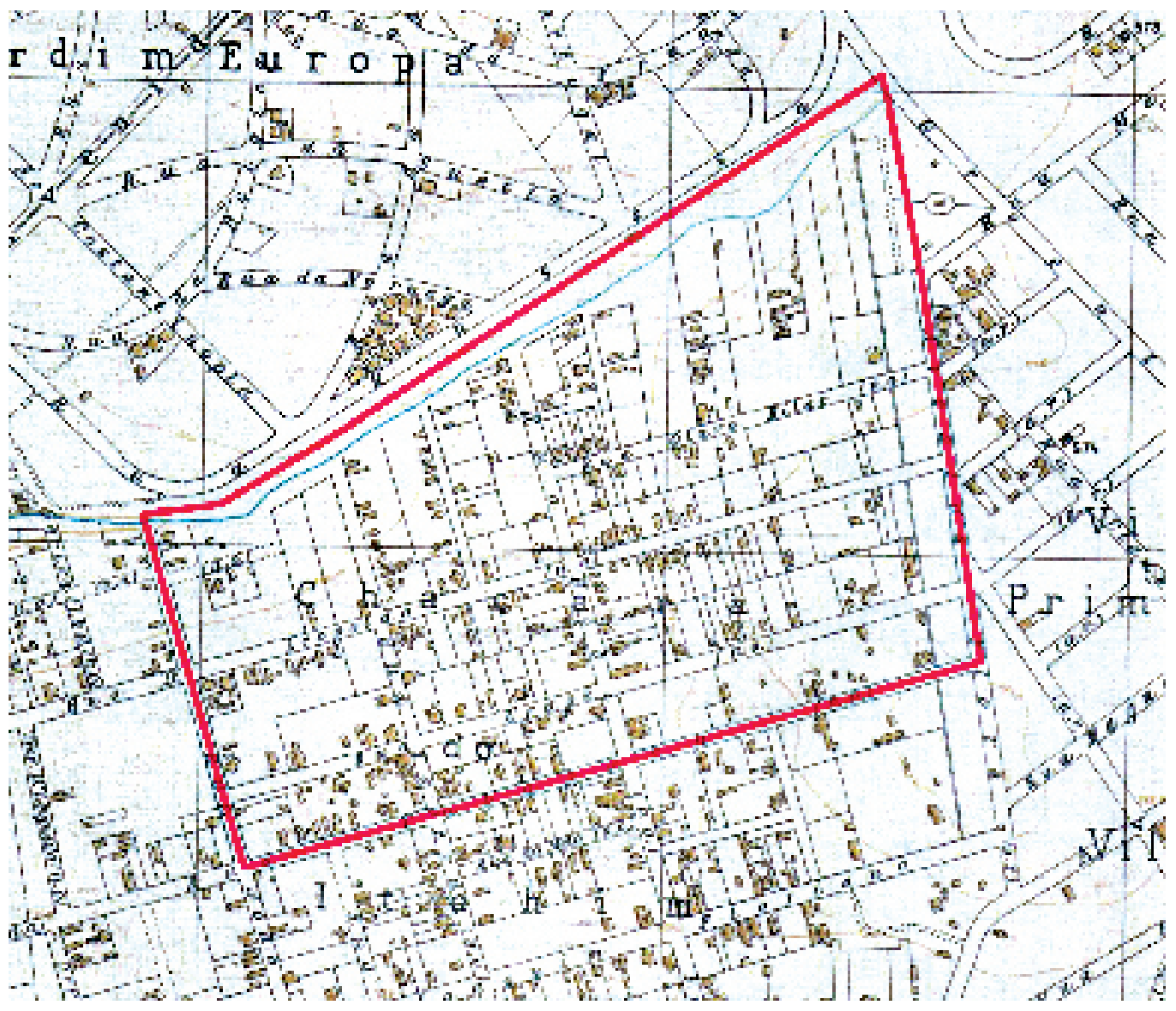



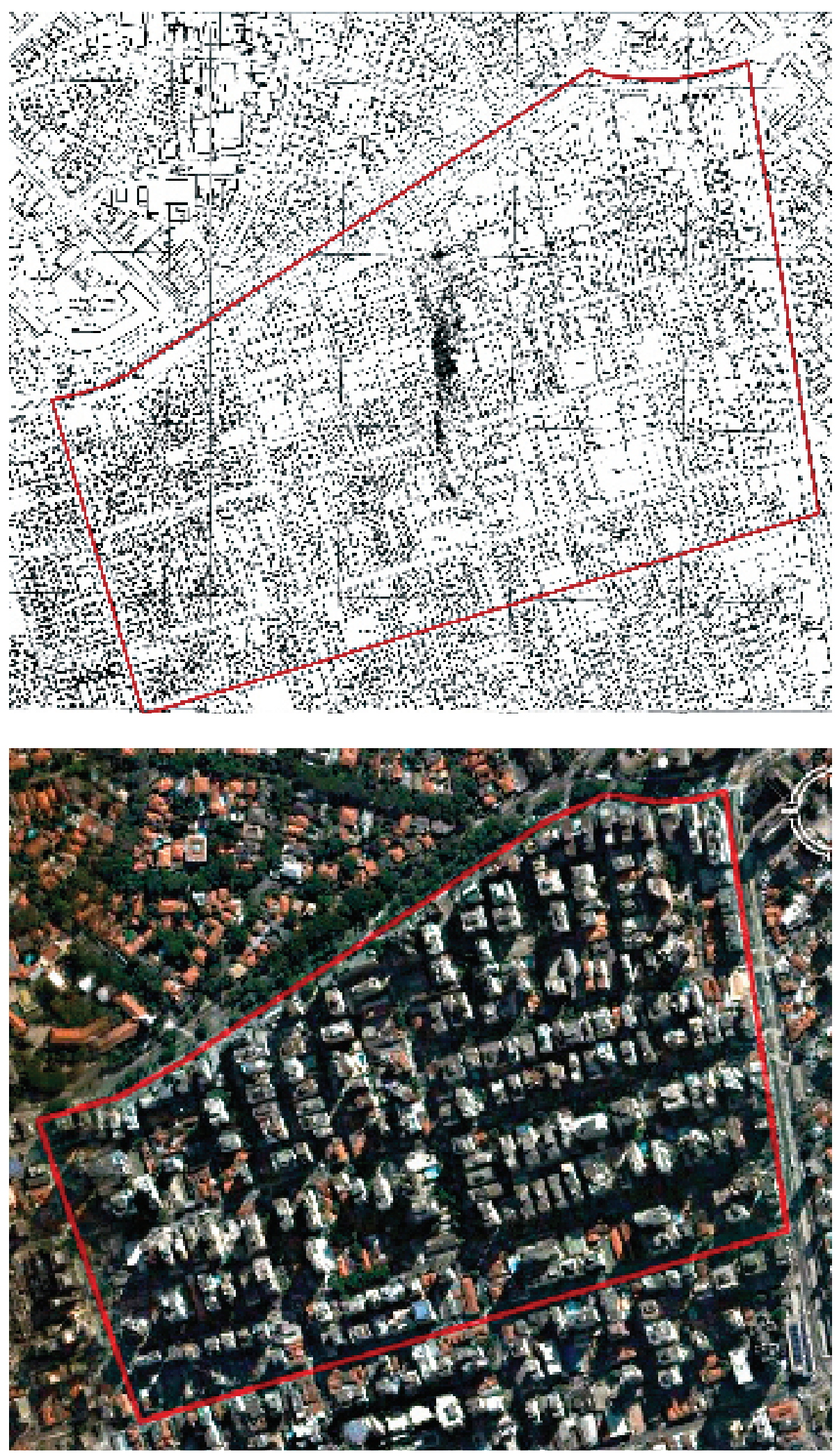

Figura 4.16 - Mapa do Gegran do bairro do Itaim Bibi. em destaque a área levantada do bairro. (Fonte: Gegran).

Figura 4.17 - Foto aérea do bairro do Itaim Bibi. em destaque a área levantada do bairro. (Fonte: Google Earth). 


\section{5- A TRANSFORMAÇÃO DO TECIDOS URBANO DO ITAIM BIBI.}

No bairro do Itaim Bibi, os loteamentos das pequenas chácaras dos herdeiros do Dr. Leopoldo Couto de Magalhães foram executados pelos próprios proprietários, sem nenhum planejamento urbanístico prévio. Porém, o fato de o loteamento ter sido coordenado por uma única pessoa, o Dr. Arnaldo Couto de Magalhães, permitiu que houvesse uma continuidade entre os diversos arruamentos. Destinados às classes populares, os lotes foram vendidos sem que houvesse nenhum tipo de infra-estrutura instalada além das ruas de terra. A infra-estrutura do bairro veio apenas muitos anos depois, provavelmente através das pressões feitas por moradores nos poderes públicos Municipal e Estadual. Podemos concluir, portanto, que no processo de sua formação o bairro sofreu primeiramente um processo de parcelamento, seguido de um processo de edificação e posteriormente um processo de urbanização, ou seja, $\mathrm{P}+\mathrm{E}+\mathrm{U}$.

Como não havia restrições para as construções e usos, várias configurações produtivas imobiliárias podem ter atuado no bairro desde o início de sua formação: a configuração por encomenda, principalmente para as residências mais requintadas, pertencentes aos donos dos loteamentos; a auto-construção, uma vez que muitos dos moradores do bairro trabalhavam como operários da construção civil; e a rentista, onde proprietários construíam pequenos renques de casas ou armazéns para aluguel.

Nas décadas de 1920 e 1930, época de sua formação, o bairro do Itaim Bibi estava situado na periferia da mancha urbana de São Paulo, sem relações com bairros vizinhos e muito dependente da rua Joaquim Floriano, onde se concentravam a grande maioria dos estabelecimentos comerciais do bairro. Podemos considerar, portanto, que o tecido urbano do bairro nesta época era o do "tipo 1". Com o incremento populacional ocorrido nas décadas seguintes, outras ruas começam a ter importância, principalmente as ruas Clodomiro Amazonas e João Cachoeira, onde começam a aparecer estabelecimentos comerciais e de prestação de serviços. Podemos considerar que

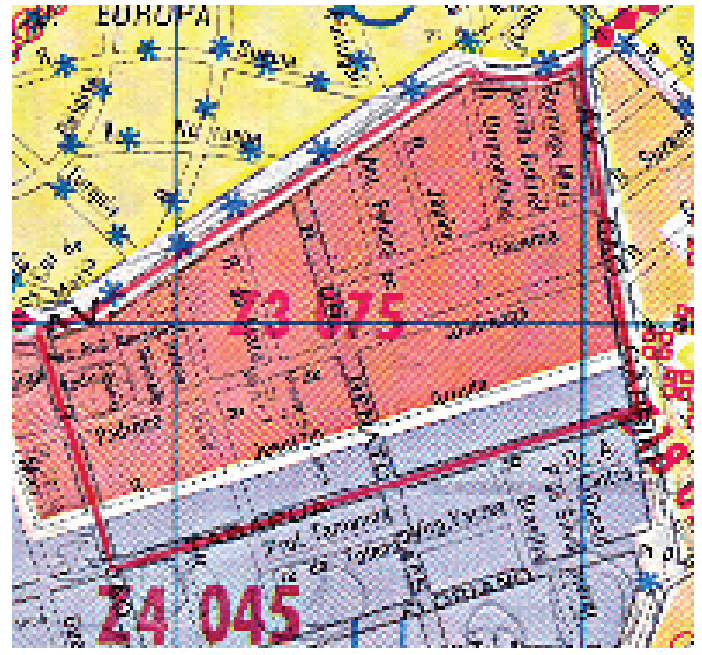

Figura 4.18 - Zoneamento bairro do Itaim Bibi. (Fonte: Geomapas, 1998). nas décadas de 1940 e 1950 o tecido urbano do bairro já tinha evoluído e se transformado em algo mais parecido com o "tipo 2".

A partir da década de 1960 a configuração produtiva do tipo incorporação imobiliária começa a atuar fortemente no bairro, remembrando os pequenos lotes para a construção de edifícios. A valorização do bairro do Itaim Bibi não apenas transformou sua paisagem, com a substituição das pequenas casas por prédios de apartamentos, mas também mudou o perfil dos seus moradores, atraindo para a região uma população pertencente às classes de mais alta renda.

Hoje o Itaim Bibi está situado no centro expandido de São Paulo, junto a um dos eixos mais valorizados da cidade: o eixo Faria Lima/ Berrini, com modernos edifícios empresariais. No bairro podemos constatar a presença de um comércio de rua bastante diversificado, lanchonetes, restaurantes, hospitais, centros médicos, centros empresariais, centros comerciais, hotéis, cinemas, concessionárias, escolas de ensino médio, hipermercado etc., caracterizando um tecido urbano do "tipo 4". 
I IGTVA DCG LGCE ATWNG

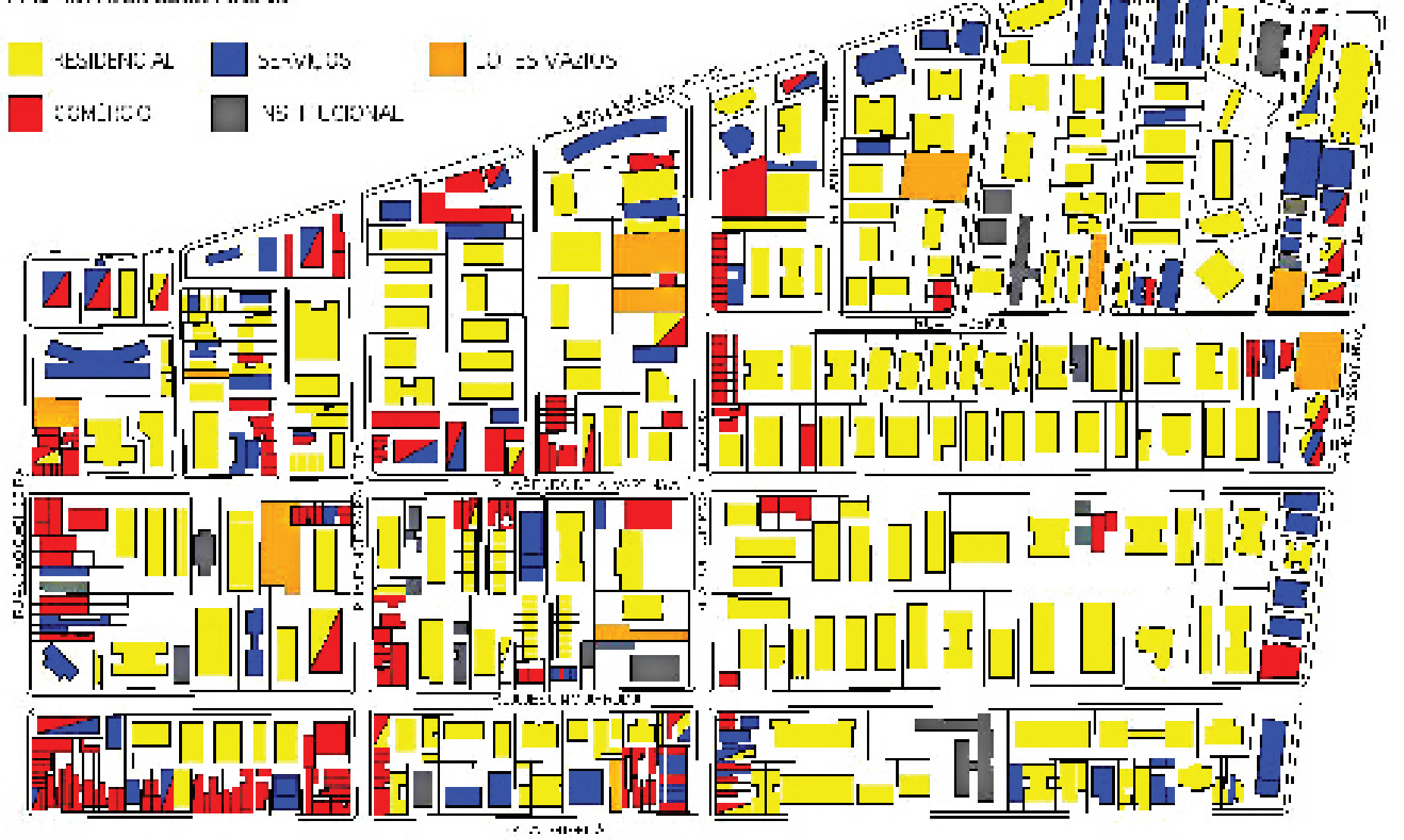

Figura 4.19 - Planta da área levantada do bairro do Itaim Bibi mostrando o uso das construções. (Fonte: elaborado pelo autor através de levantamento de campo). 
Figura 4.20 - Planta da área levantada do bairro do Itaim Bibi mostrando as construções anteriores e posteriores à lei de zoneamento de 1972. (Fonte: elaborado pelo autor através de levantamento de campo). 


\section{LEGENDA}

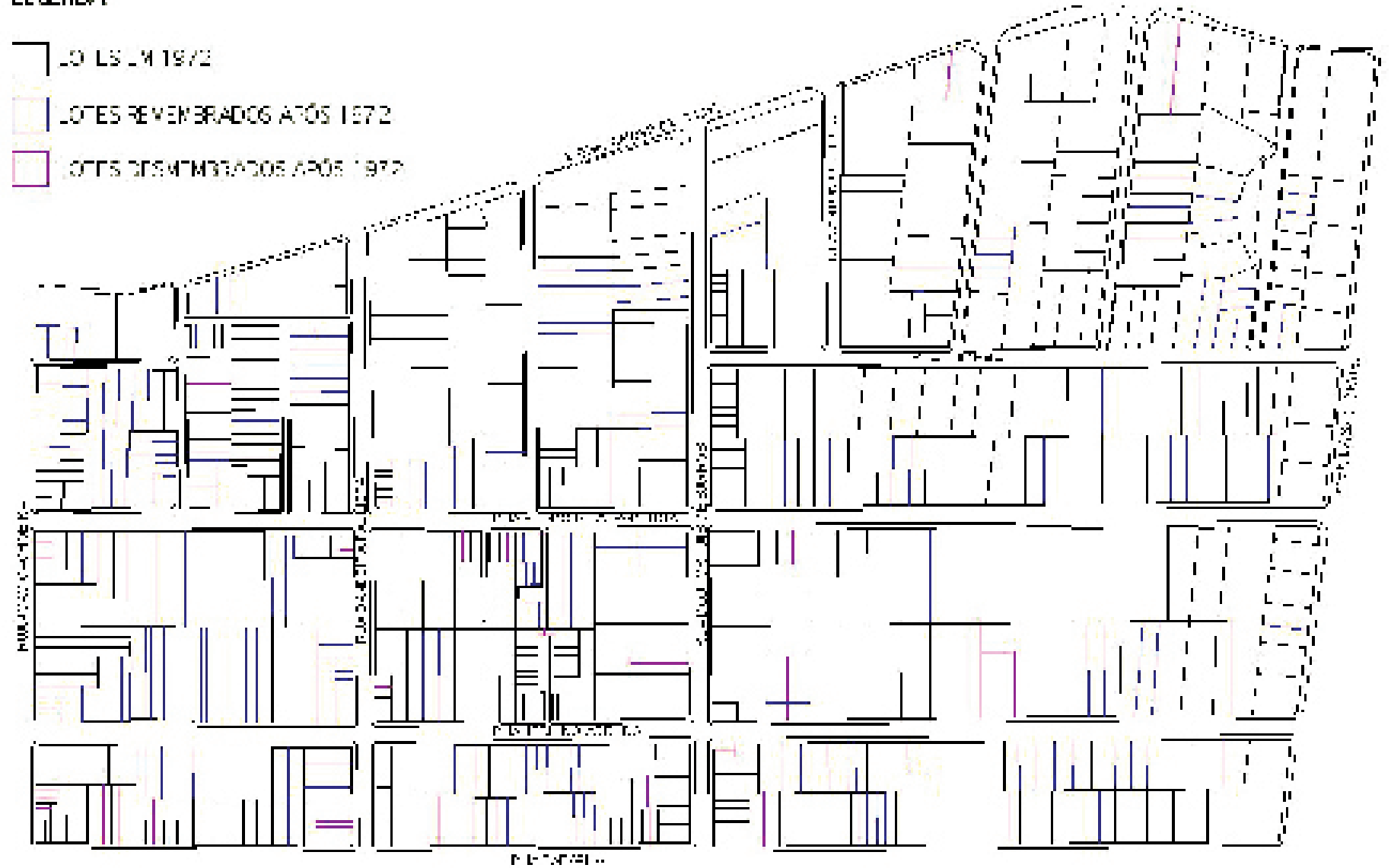

Figura 4.21 - Planta da área levantada do bairro do Itaim Bibi mostrando os

desmembramentos e remembramentos dos lotes da região após 1972.

(Fonte: elaborado pelo autor através de levantamento de campo). 


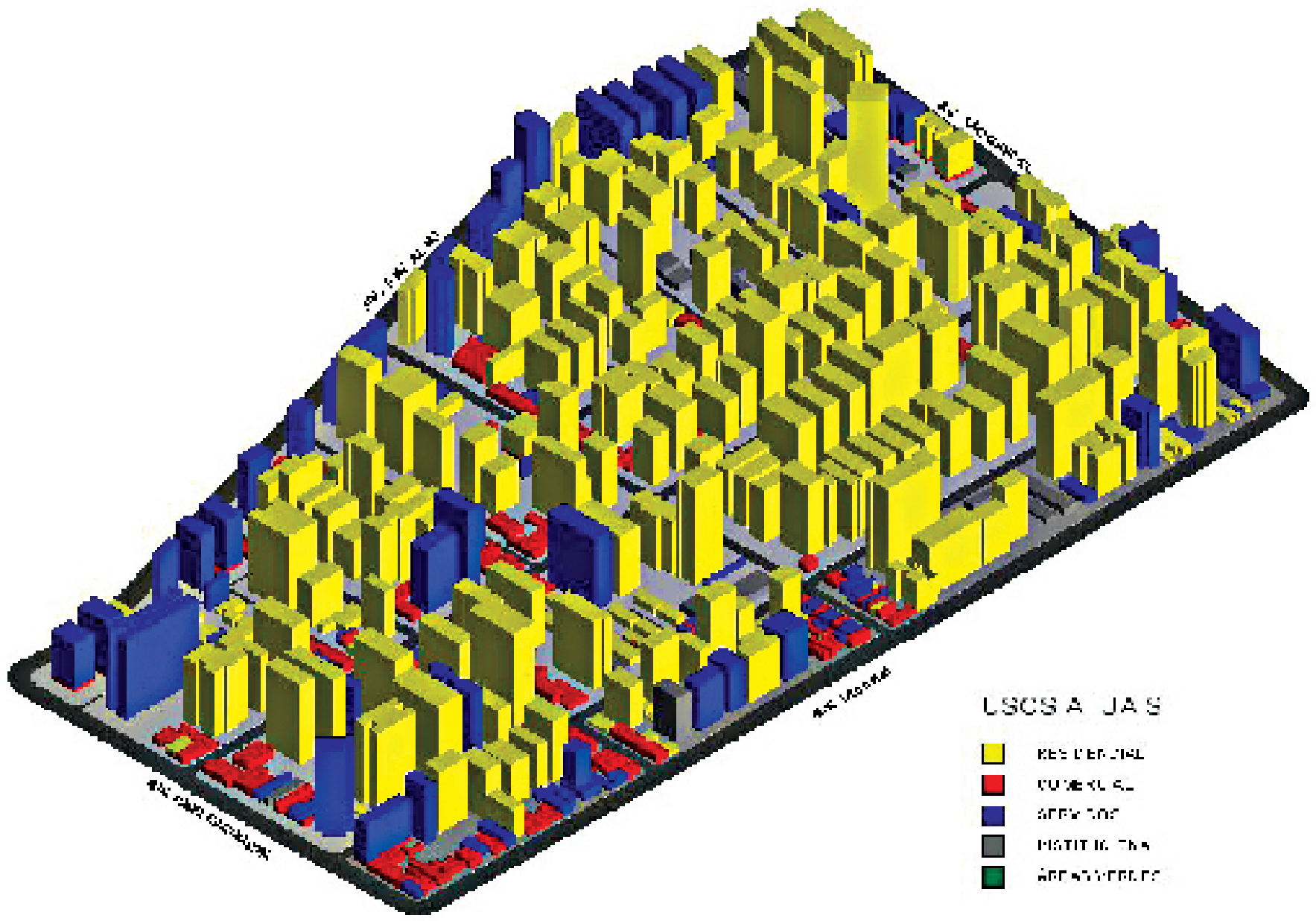

Figura 4.22 - Maquete eletrônica da área levantada do bairro do Itaim Bibi mostrando os usos atuais. (Fonte: elaborado pelo autor através de levantamento de campo). 


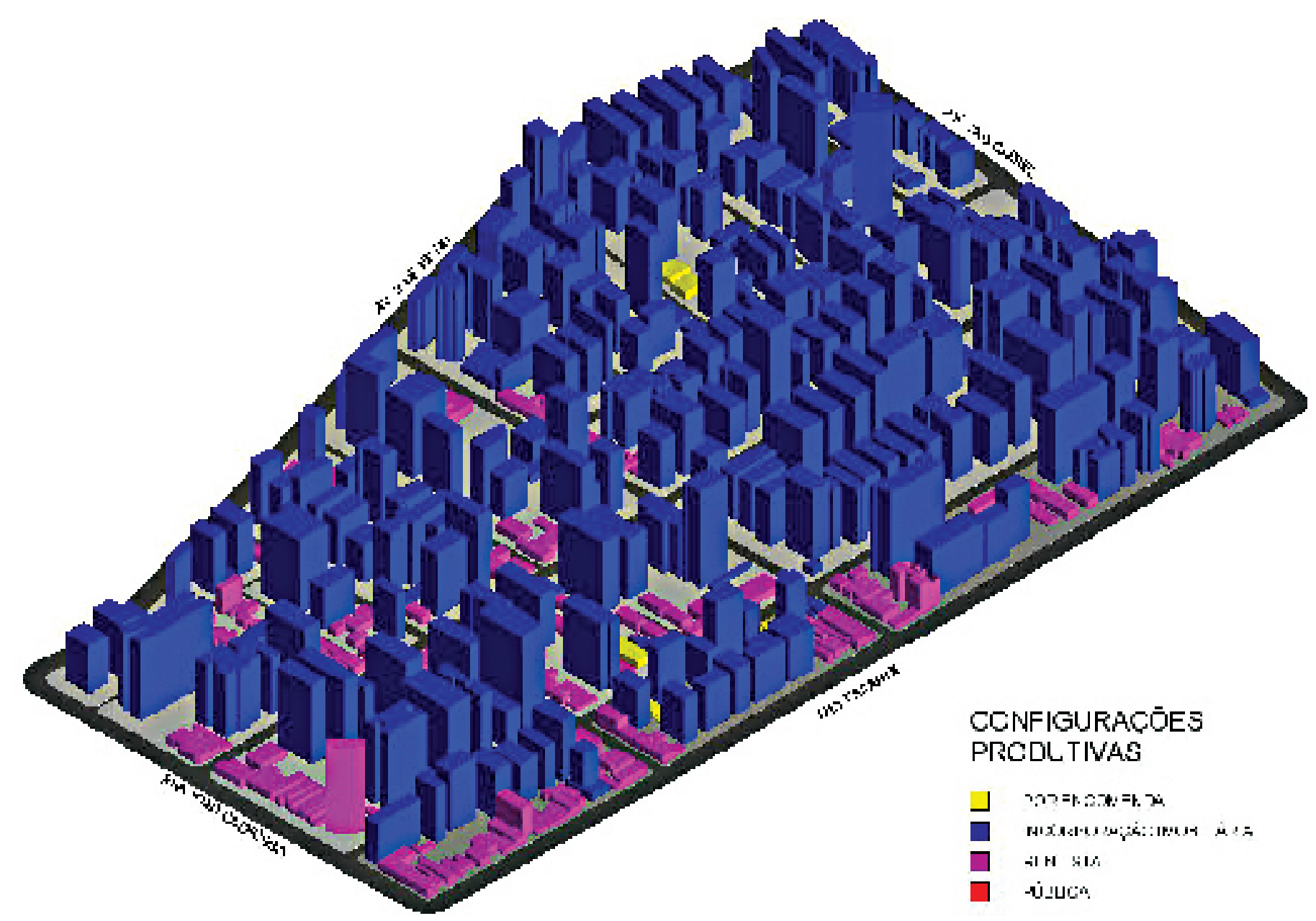

Figura 4.23 - Maquete eletrônica da área levantada do bairro do Itaim Bibi mostrando as prováveis configurações produtivas imobiliárias. (Fonte: elaborado pelo autor através de levantamento de campo). 
8. A principal via do bairro, a avenida Leopoldina, também foi uma homenagem a Leopoldina Kleeberg; posteriormente foi acrescentado ao nome da avenida o titulo Imperatriz, transferindo a homenagem para a primeira imperatriz do Brasil, esposa de D. Pedro I.

\subsection{O DESENVOLVIMENTO DO BAIRRO DA VILA LEOPOLDINA.}

A Vila Leopoldina surge em 1894, quando a empresa E. Richter \& Companhia executa um arruamento colonial no sítio do Emboaçava, formado pelos alagadiços do rio Tietê e do rio Pinheiros, nas vizinhanças do suburbano bairro da Lapa. A região foi dividida em terrenos de $1.000 \mathrm{~m} 2 \mathrm{em}$ média e o empreendimento recebeu este nome em homenagem a Leopoldina Kleeberg, uma das sócias da referida empresa ${ }^{8}$. A inauguração aconteceu em 11 de novembro daquele mesmo ano, com a realização de um grande piquenique que atraiu para a região mais de quinhentas pessoas que, para chegar ao local, utilizaram-se de barcos a vapor, navegando pelo rio Tietê. (SANTOS, 1980)

Dizia uma propaganda da época:

"A maior parte da dita Vila se compõe de terrenos extraordinariamente frutíferos, com clima suavilíssimo, que é adaptado especialmente às culturas de qualquer qualidade de plantação, tanto européia quanto brasileira. As plantações existentes dão ótimos resultados, coisa que qualquer um pode acertar. Mediante a construção de uma fonte, já foi demonstrado que a água é saníssima." (SANTOS, 1980, p. 67).

Além do uso dos barcos pelo rio Tietê, era possível chegar à região pelo trem da Estrada de Ferro Sorocabana, que transportava tanto pessoas como mercadoriass e passava pelo arruamento seis vezes por dia. Podia-se também pegar a "linha inglesa" - a São Paulo Railway, estrada de ferro que ligava Santos a Jundiaí - até a estação da Água Branca e de lá seguir por carroças em um trajeto de aproximadamente 40 minutos (SANTOS, 1980).

A principal atividade econômica do bairro da Lapa até então era o pouso de tropeiros que, vindos das regiões de Campinas e Jundiaí, passavam pela região antes de chegarem a São Paulo. Inaugurada em 16 de fevereiro de 1867, a São Paulo Railway foi fator primordial para o desenvolvimento deste bairro. Apesar do bairro estar situado entre duas estações de ferrovia, Perus e Água Branca, o trem costumava fazer uma parada simples, conhecida como "parada do Anastácio" nas proximidades da ponte de mesmo nome (SANTOS, 1980).

A Estrada de Ferro Sorocabana é inaugurada em julho de 1875, ligando a cidade de São Paulo ao interior. A exemplo da "inglesa" fazia uma parada simples na confluência com a Estrada da Boiada, atual Av. Diógenes Ribeiro de Lima.

Nos últimos anos do século XIX, o grande crescimento das atividades da estrada de ferro e seu elevado consumo de água (para alimentação das caldeiras), fez com que a São Paulo Railway determinasse a transferência de suas oficinas da região da Luz para um local próximo às águas do rio Tietê. A região escolhida foi a da Lapa. As oficinas entram em funcionamento em 1898 e, simultaneamente, inicia-se um processo de transformação da paisagem do bairro, que passa a ser um pólo de atração de mão-de-obra imigrante, particularmente italiana (SEGATTO, 1988).

Com as oficinas instaladas e, no ano seguinte, com a inauguração da estação da Lapa pela mesma companhia, "o bairro entra no século XX como um verdadeiro bairro urbano da cidade de São Paulo. Nas primeiras décadas deste século, o bairro da Lapa passa a receber uma infra-estrutura decorrente de sua rápida urbanização" (SEGATTO, 1988, p. 21). Com a instalação da estação, o Largo da Lapa, localizado na "Lapa de Baixo", transformou-se no primeiro pólo comercial do bairro. 
Em 1903 a linha de bonde que vinha do centro e parava na Água Branca se estende até a Lapa, favorecendo a aceleração do comércio da "Lapa de Cima". A valorização das principais ruas da Lapa com a chegada dos bondes motivou a municipalidade, em julho de 1907, "a despender a quantia de dez contos e quinhentos e vinte e cinco mil réis com melhoramentos necessários às ruas Trindade, Sete (Doze de Outubro) e Jundiaí, atual Barão de Jundiaí" (SANTOS, 1980, p. 78). Os ônibus, ou melhor, as jardineiras só chegaram ao bairro em 1924. Em 1911, o Governo do Estado firma um contrato com a Light para expansão da iluminação pública do bairro com lâmpadas incandescentes, para aquelas ruas que até então não eram servidas por gás (SANTOS, 1980).

Após o final da Primeira Guerra Mundial e com o aumento das imigrações, o bairro da Lapa passa a expandir os seus limites. A Vila Anastácio é urbanizada em 1919; a Vila Ipojuca, em 1921; a Cia. City realiza os loteamentos do Alto da Lapa e Bela Aliança a partir de 1920, segundo projeto do renomado arquiteto britânico Barry Parker, que também havia projetado os loteamentos do Jardim América e Jardim Europa (SEGATTO, 1988). Em 1926, a Vila Leopoldina, onde havia um loteamento colonial, passa a ser dividida em lotes populares pela empresa Siciliano \& Silva e Antônio A. Villares da Silva (SANTOS, 1980).

A mão-de-obra imigrante disponível, terrenos baratos e, principalmente, a proximidade com as ferrovias, proporcionou ao bairro a instalação de uma grande quantidade de indústrias como a Vidraçaria Santa Marina, a Cia. Fiat Lux, Frigorífico Armour, Fábrica de Tecidos e Bordados Lapa, Metalúrgica Martins Ferreira, entre outras. A partir de 1930, as indústrias da região, que se concentravam principalmente ao longo da estrada de ferro, passam a se expandir para outras áreas, especialmente Vila Anastácio e Vila Leopoldina. Vila Leopoldina passa então a concentrar grandes indústrias, com destaque para o ramo metalúrgico. O processo se acentuou após as décadas de 1940 e 50 com a retificação dos rios Tietê e Pinheiros, a construção das vias marginais e de estradas como a SP-050 (Rodovia Anhanguera, situada na rota São Paulo-Campinas) inaugurada em 1943 pelo então presidente Getúlio Vargas (SEGATTO, 1988).

Em 1954 foi criado o Mercado Municipal da Lapa, próximo à ferrovia. Em 1966, na Vila Leopoldina, surge o Centro Estadual de Abastecimento Sociedade Anônima - CEASA - com seus 478 mil metros quadrados. Alugando e arrendando seus armazéns, o CEASA criou para o paulistano condições reais de comercialização, afastando os atravessadores e intermediários e reduzindo consideravelmente os custos de operação dos produtos. Em maio de 1969 houve a fusão entre o CEASA e a CAGESP, Companhia de Armazéns Gerais do Estado de São Paulo, que desde então passa a se chamar CEAGESP, Companhia de Entrepostos e Armazéns Gerais do Estado de São Paulo (SANTOS, 1980).

Na década de 1990 o mercado imobiliário passa a se interessar pela Vila Leopoldina. Assim como ocorreu com o Itaim Bibi, colaborou para este interesse o fato de outras regiões de forte atuação deste mercado estarem em processo de saturação e, portanto, haver a necessidade de "criação" de novas áreas. A implantação do Parque Villa Lobos, em 1994, nas vizinhanças da Vila Leopoldina deu forte impulso ao mercado imobiliário, que viu na região uma nova possibilidade de expansão. A localização da região da Vila Leopoldina, situada ao lado de bairros de alta renda, como o Alto de Pinheiros, City Lapa e City Boaçava, e com fácil acesso pelas marginais e rodovias como Castelo Branco, Anhangüera e Bandeirantes, também foram fatores que colaboraram para o interesse deste setor pro- 
9. Informacão do Portal Da Vila Leopoldina, www.portalvilaleopoldina.com
Figura 4.24 - Mapa topográfico da cidade em 1930. em destaque a área levantada do bairro da Vila Leopoldina. (Fonte: Mapa topográfico do município de São Paulo Executado pela empresa Sara Brasil S/A - 1930) dutivo. Os grandes lotes industriais do bairro, muitos deles abandonados pelas suas empresas que se transferiram para outras localidades, mostraram-se ideais para uma nova modalidade de produto imobiliário que surgia: o edifício clube.

Aos poucos, o bairro foi ganhando um novo perfil, com a substituição de velhos galpões industriais e sobrados residenciais por prédios de apartamentos. Este processo vem se acentuando nesta última década e ainda está em vias de consolidação. Apenas na rua Carlos Weber, de janeiro a setembro de 2007, foram entregues ou estão em construção, nada menos que dez empreendimentos, todos residenciais ${ }^{9}$. Ao redor destes empreendimentos surgem novos estabelecimentos comerciais ou de serviços tais como academias e concessionárias de veículos.

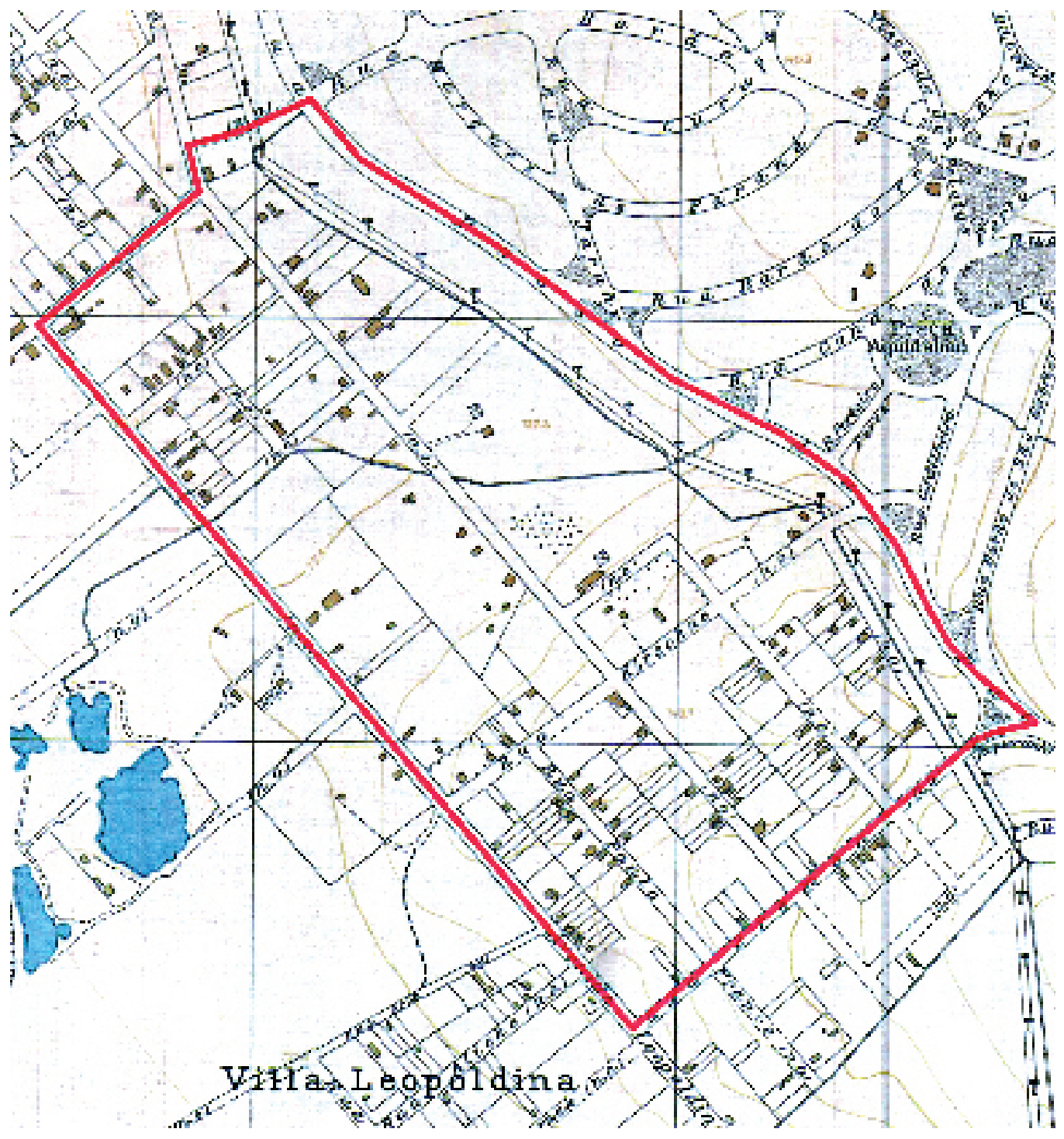



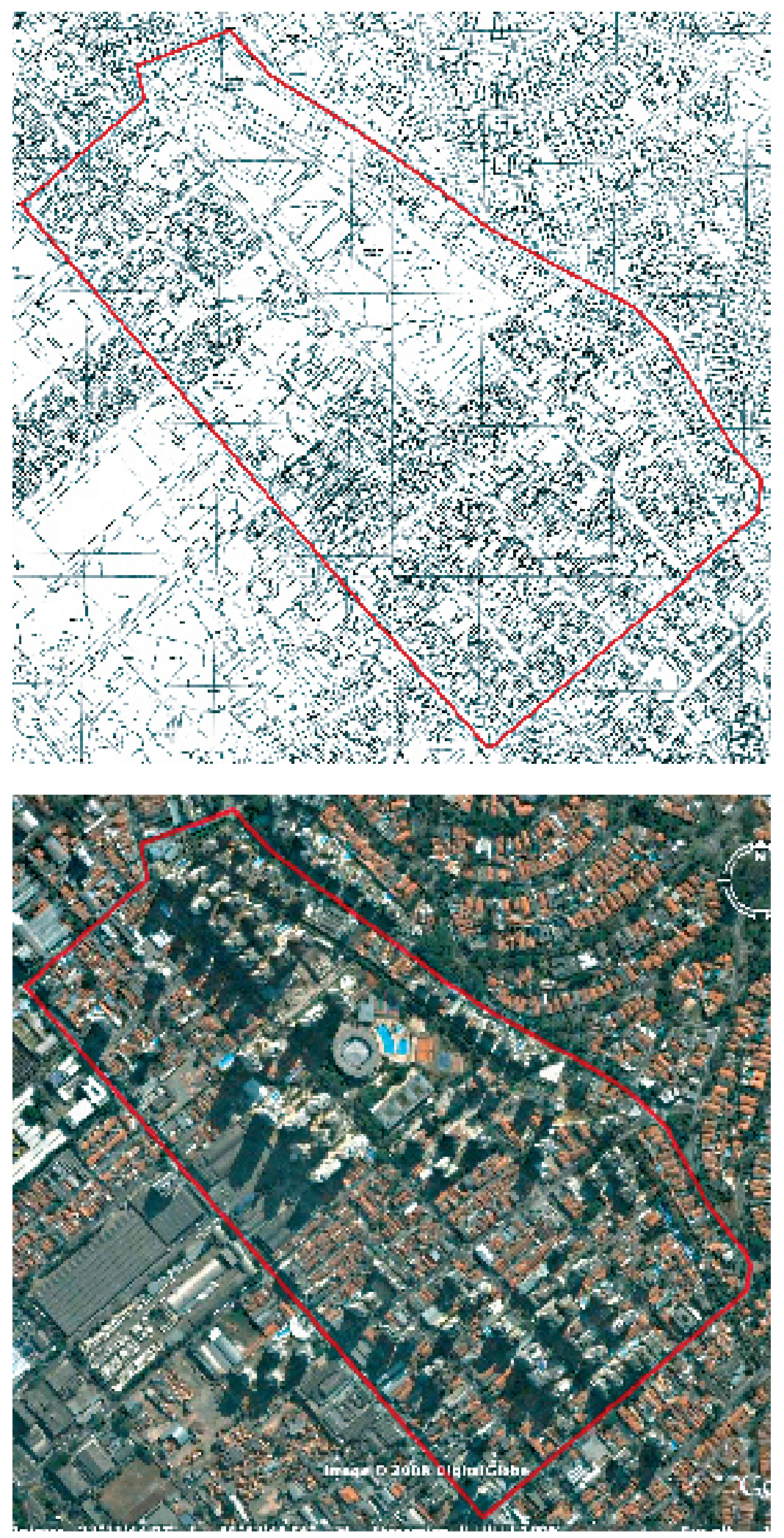

Figura 4.25 - Mapa do gegran do bairro da Vila

Leopoldina. em destaque a área levantada do bairro. (Fonte: Gegran).
Figura 4.26 - Foto aérea do bairro da Vila Leopoldina. em destaque a área levantada do bairro.

(Fonte: Google Earth). 


\section{7- A TRANSFORMAÇÃO DO TECIDO URBANO DA VILA LEOPOLDINA.}

O bairro da Vila Leopoldina, como vimos, foi fruto de dois loteamentos: um "arruamento colonial”, em 1894, com a divisão da área em pequenas chácaras de 1.000,00 m2; e outro em 1926, quando parte do primeiro loteamento foi novamente dividido em lotes menores, destinados às classes mais populares.

Assim como em outros loteamentos populares, os lotes foram vendidos sem que houvesse nenhum tipo de infra-estrutura; esta foi sendo instalada no bairro na medida do crescimento populacional. Concluímos portanto, que, assim como no Itaim Bibi, no processo de sua formação o bairro sofreu primeiramente um parcelamento, seguido de um processo de edificação e posteriormente um processo de urbanização, ou seja, $\mathrm{P}+\mathrm{E}+\mathrm{U}$.

Não havendo restrições de loteamento quanto ao tamanho e o uso das construções, a região foi ocupada tanto por indústrias como por residências populares. Pelo menos três configurações produtivas imobiliárias podem ter atuado na região: a configuração produtiva por encomenda, produzindo algumas casas mais requintadas, e principalmente, as sedes das indústrias da região, cuja produção depende de um alto valor de uso dos seus edifícios e, portanto, exigem construções projetadas para se adequarem aos seus processos industriais; a auto-produção, executada pelos próprios operários que adquiriram os lotes; e a rentista, produzindo pequenos renques de casas ou armazéns para aluguel.

$\mathrm{Na}$ época de sua formação, a região da Vila Leopoldina estava situada na periferia da mancha urbana de São Paulo, sem relações com bairros vizinhos que, loteados pela Cia. City no modelo "cidade jardim", foram destinados às classes de alta renda. Podemos considerar que o tecido urbano do bairro nesta época era o do "tipo 1".

Com a atuação da incorporação imobiliária a partir da década de 1990, o bairro vem se transformando rapidamente. Muitos de seus sobrados e galpões industriais já foram substituídos por empreendimentos residenciais, alguns com várias torres de edi-

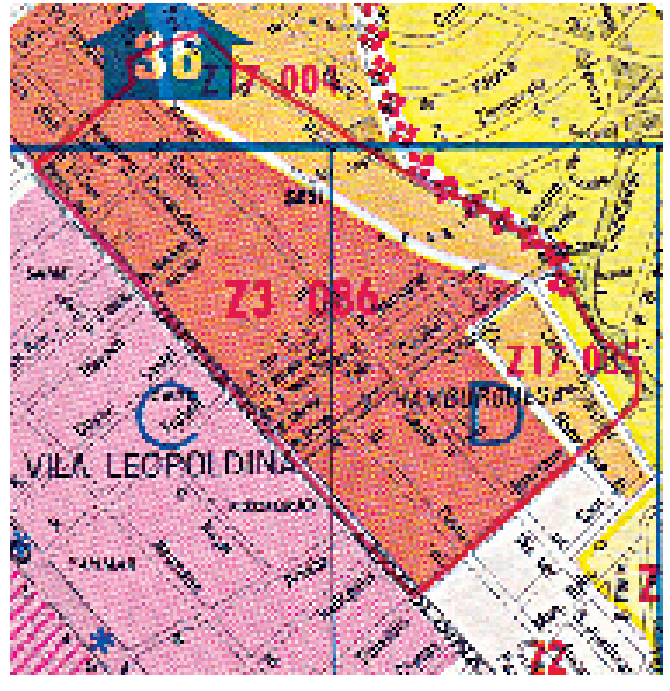

Figura 4.27 - Zoneamento bairro do Itaim Bibi. Fonte: Geomapas, 1998 fícios e uma vasta área de lazer no térreo. Assim como aconteceu no Itaim Bibi, com a valorização da região a população de renda mais baixa, moradora dos pequenos sobrados, vem sendo substituída por uma população de renda média alta, à qual são destinados os novos produtos imobiliários lançados na região. Isso acarreta também o surgimento de serviços e comércios mais sofisticados, como restaurantes, academias, concessionárias, entre outros. Podemos perceber claramente que a infra-estrutura da região, principalmente no que se refere às vias de circulação de automóveis, já está obsoleta, necessitando de ampliação. As ruas são estreitas e mantêm fluxo de veículos na duas direções; a rua Carlos Weber, apesar de ser o atual foco de atuação do mercado imobiliário, não é uma via estrutural, nem ao menos coletora. Até os dias de hoje o principal acesso ao bairro se faz pela estreita avenida Imperatriz Leopoldina. Outra opção é a rua Schilling, que dá acesso ao bairro através do seu bairro vizinho, o City Bela Aliança. Podemos concluir que a verticalização, ainda em processo de consolidação, vem transformando o tecido urbano do bairro, que hoje é algo próximo ao "tipo 2", e nos próximos anos pode evoluir para o "tipo 4". 


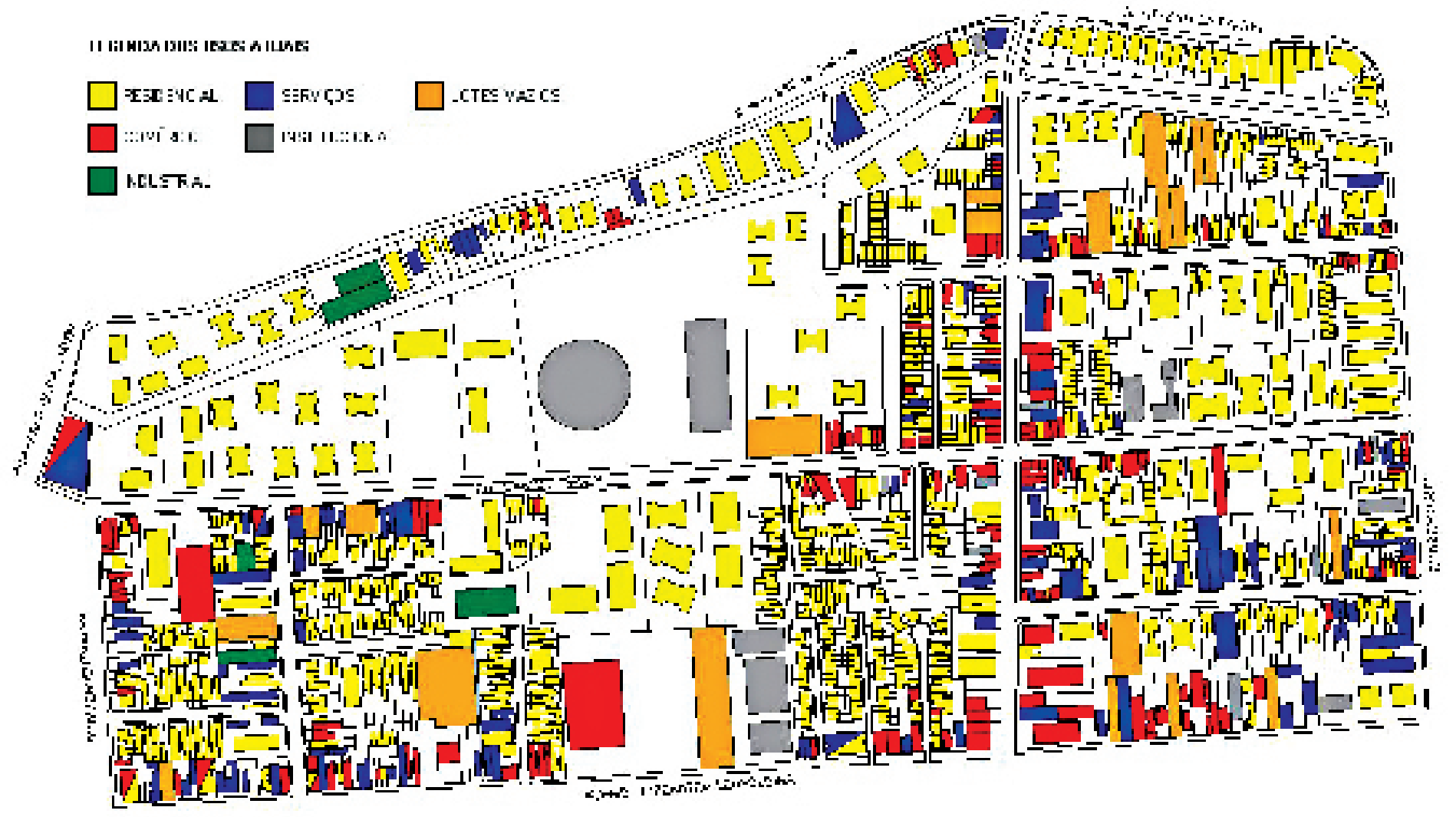

Figura 4.28 - Planta da área levantada do bairro da Vila Leopoldina mostrando o uso das construções. (Fonte: elaborado pelo autor através de levantamento de campo). 


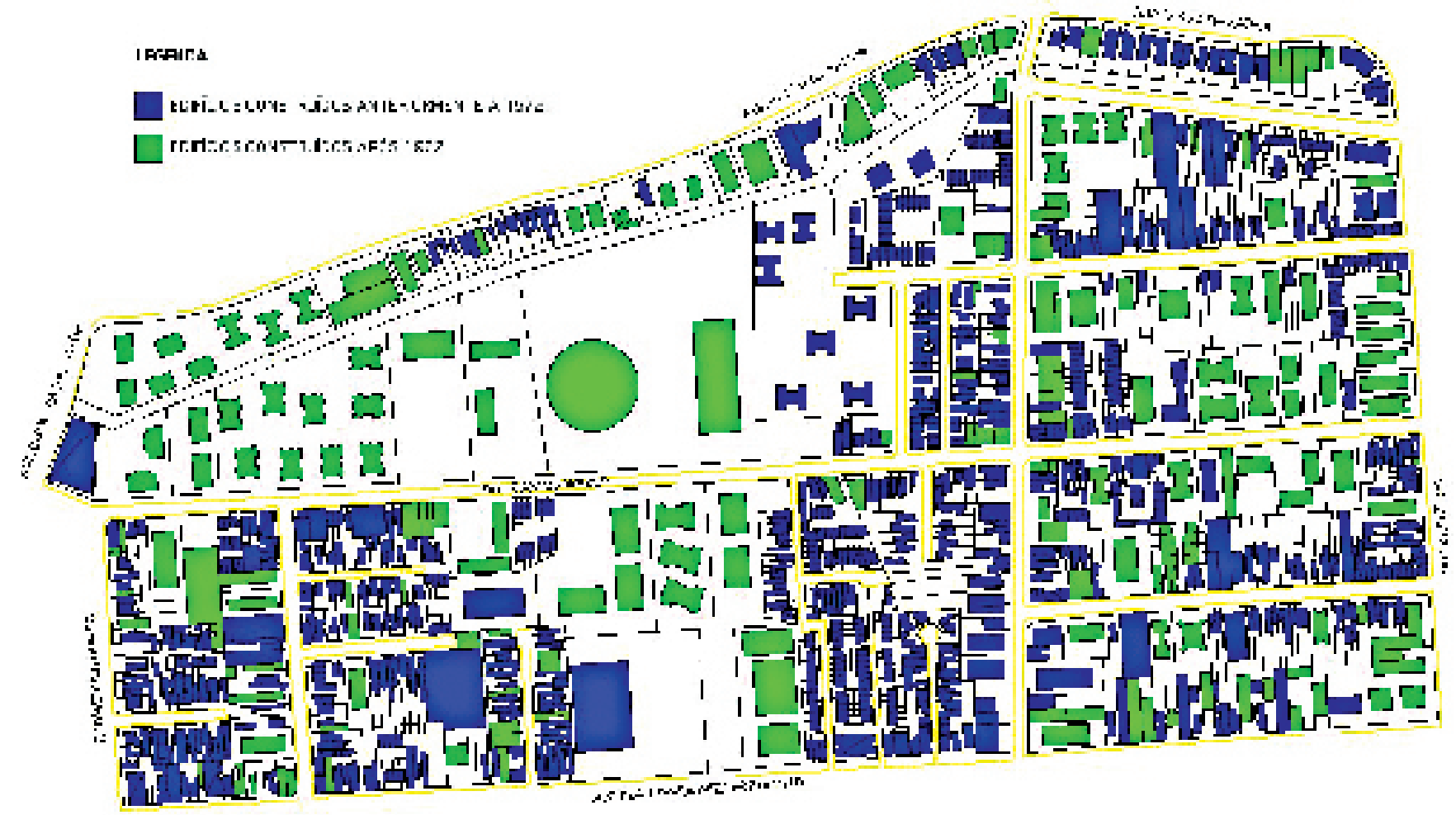

Figura 4.29 - Planta da área levantada do bairro da Vila Leopoldina mostrando as construções anteriores e posteriores à lei de zoneamento de 1972. (Fonte: elaborado pelo autor através de levantamento de campo). 


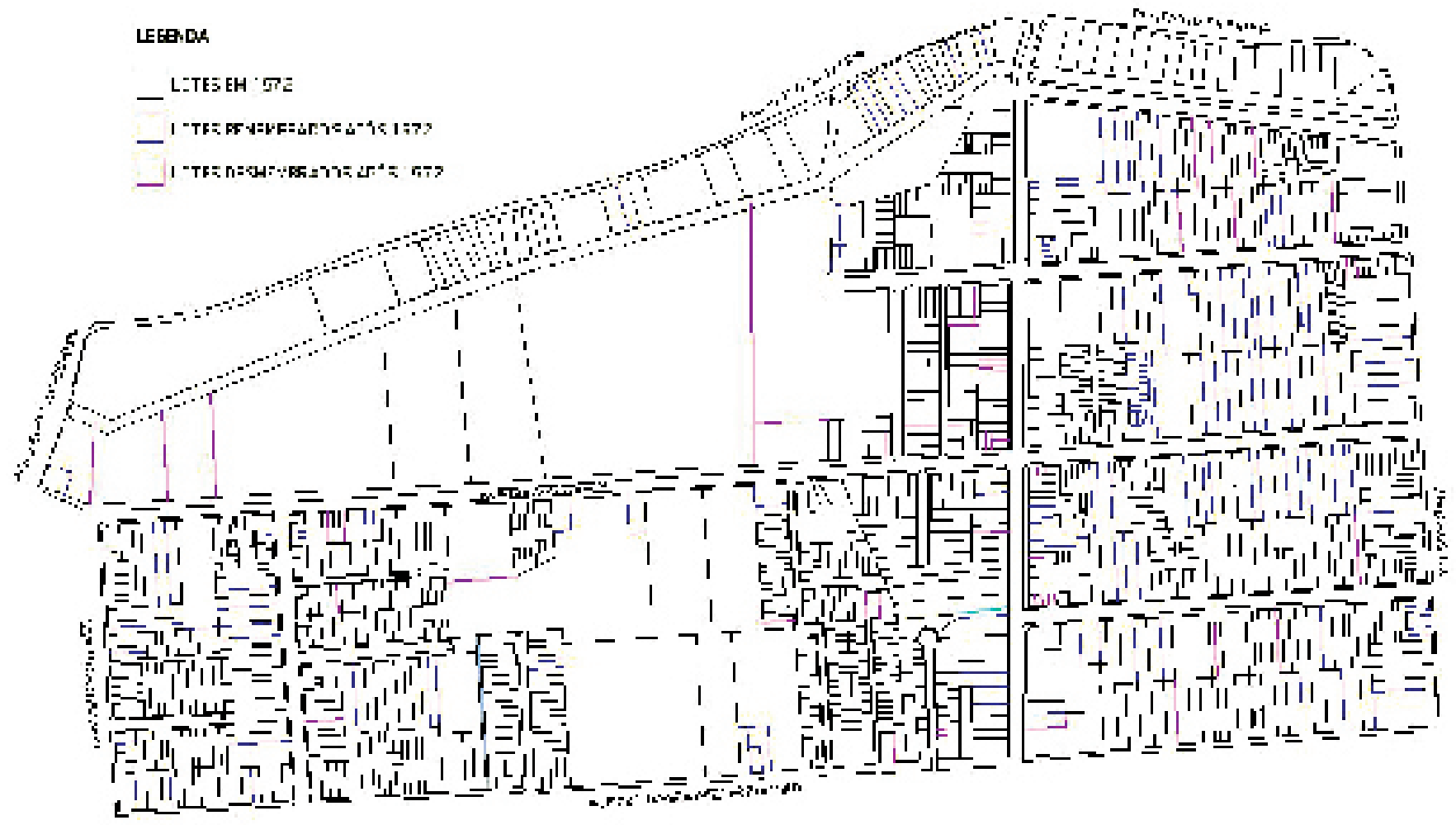

Figura 4.30 - Planta da área levantada do bairro do Itaim Bibi mostrando os desmembramentos e

remembramentos dos lotes da região após 1972. (Fonte: elaborado pelo autor através de levantamento de campo). 


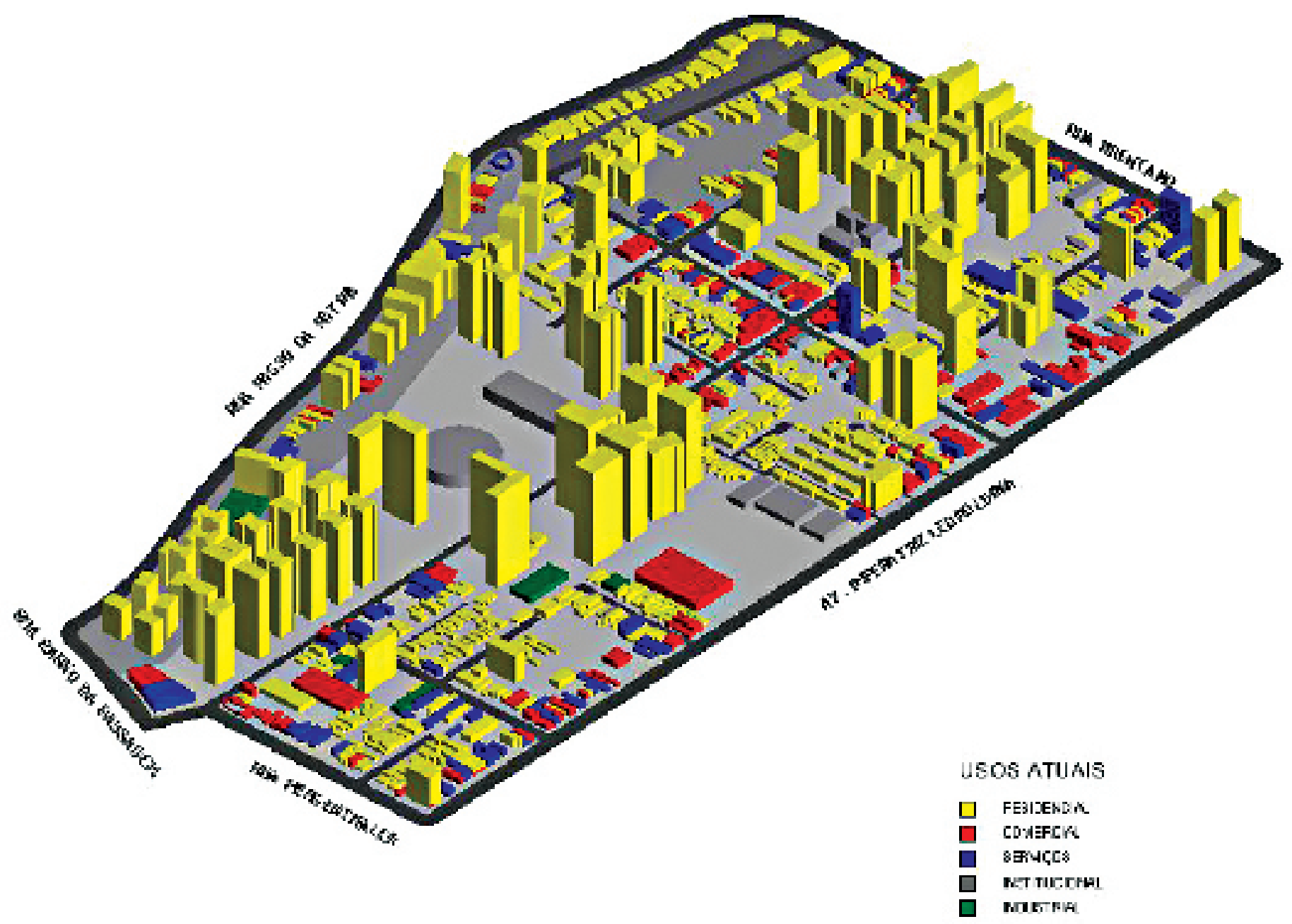

Figura 4.31 - Maquete eletrônica da área levantada do bairro da Vila Leopoldina mostrando os usos atuais. (Fonte: elaborado pelo autor através de levantamento de campo). 


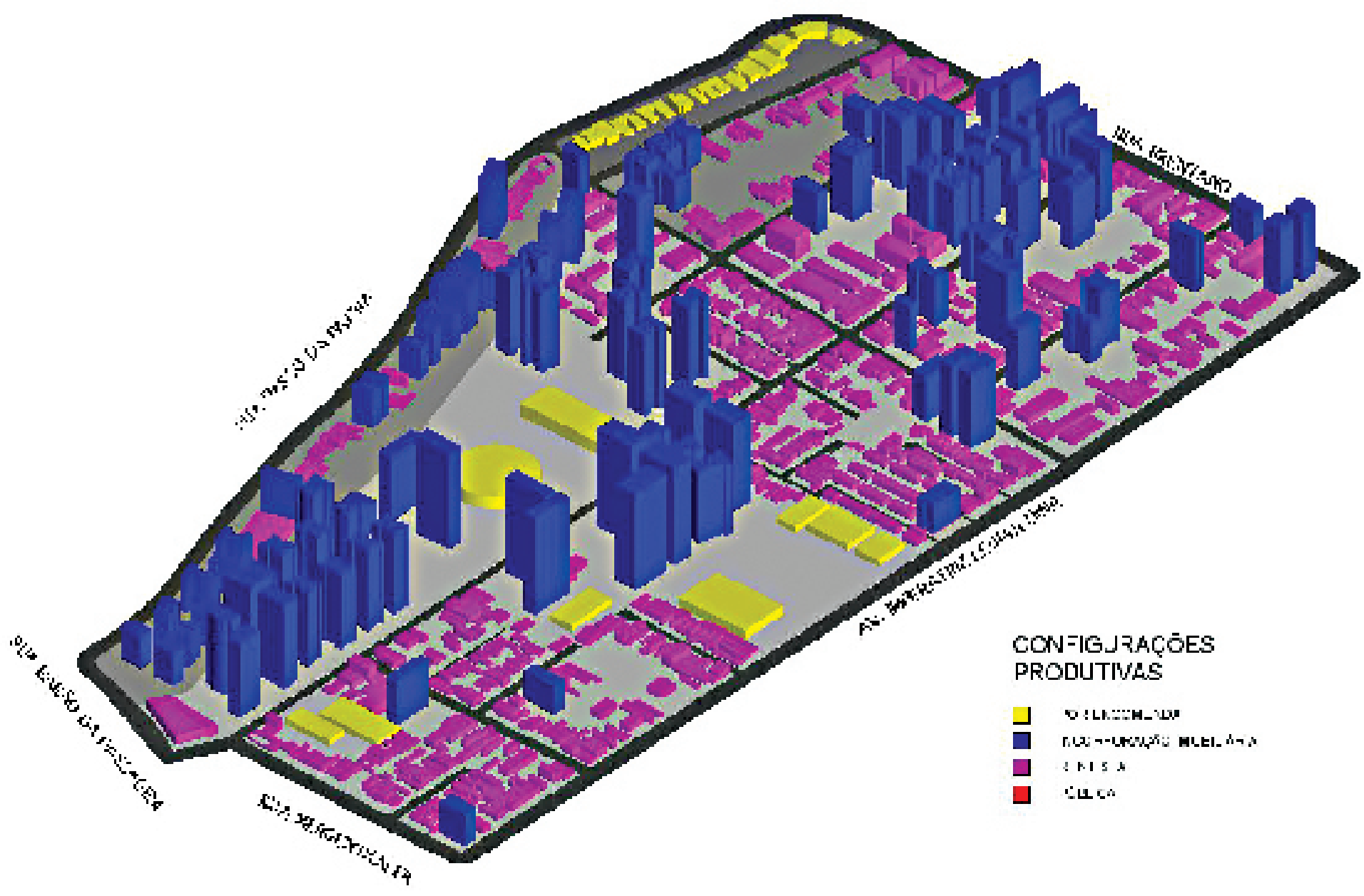

Figura 4.32 - maquete eletrônica da área levantada do bairro do Itaim Bibi mostrando as prováveis configurações produtivas imobiliárias. (Fonte: elaborado pelo autor através de levantamento de campo). 
10. 0 tecido urbano básico, segundo o prof. Cândido Malta Campos Filho, é composto pelas áreas públicas, como as vias e praças, e pelas áreas institucionais destinadas às escolas, creches, museus, entre outros. Uma das principais características do tecido urbano básico é justamente o seu forte caráter de permanência.

\subsection{ANÁLISE DOS TECIDOS URBANOS ATUAIS.}

Ao analisar a evolução urbana de cada um dos três bairros levantados, pudemos perceber que os mesmos sofreram grandes transformações desde sua formação até os dias de hoje. Ao compararmos, porém, os mapas históricos - Sara Brasil, de 1930 e GEGRAN, de 1972 - com uma foto aérea recente, percebemos, que apesar dessas transformações, não houve grandes alterações em seus respectivos tecidos urbanos básicos ${ }^{10}$. Concluímos, portanto, que as transformações ocorridas na morfologia de cada um dos bairros se deu por meio da transformação de outro elemento formador do tecido urbano: a tipologia edificada. Através dos levantamentos de campo realizados nos três bairros, pudemos constatar que a tipologia edificada foi transformada principalmente por uma intensa atuação da incorporação imobiliária.

Segundo Antonucci (2005), os edifícios de Higienópolis, construídos principalmente no período entre 1933 e 1964, apresentavam volumes em forma de lâminas, com marquises e rampas de acesso como elementos de ligação entre o espaço urbano público e o espaço privado. Suas implantações eram pensadas para que os espaços livres dos lotes fossem percebidos como uma continuidade do espaço da cidade, muitos com passagens entre ruas ou galerias de lojas, criando espaços semi-privados que proporcionavam uma relação mais fluída entre o edifício e a cidade. Antonucci cita como exemplo os edifícios Louveira, de 1949, projetado por Vilanova Artigas, e o edifício Bretagne, projetado por Artacho Jurado. O edifício Louveira, situado junta à praça Villaboim, é composto por dois blocos em formato de lâminas paralelas; o espaço ajardinado entre as lâminas cria uma continuidade espacial com a praça, integrando visualmente o jardim do edifício ao entorno à sua volta. O edifício Bretagne, com sua implantação em forma de "L", permite a integração de sua área de lazer com a avenida Higienópolis onde está situado.

Os edifícios do Itaim Bibi, principalmente os que foram executados posteriormente a 1975, ou seja, após a lei de zoneamento no 7.805 e o Código de Edificações, têm formatos diferentes. Como foi visto no capítulo 2 deste trabalho, por conta da fórmula de Adiron estes edifícios ocupam uma parcela pequena, por volta de 30\% do lote, para assim atingirem um coeficiente de aproveitamento igual a 4, máximo permitido para a Z3 em que estão inseridos. $\mathrm{O}$ maior coeficiente em menor área de projeção faz com que a altura do edifício aumente, aumentando também os seus recuos obrigatórios representados pelas faixas de aeração e iluminação. Quando se trata de edifícios com uma unidade por pavimento, em que a faixa de iluminação - a mais restritiva - pôde estar situada apenas em uma de suas faces, as possibilidades de implantação do edifício foram maiores; mas quando se trata de prédios com dois ou mais apartamentos por pavimento, em que a faixa de iluminação deve estar presente em todas as faces do edifício, a única possibilidade de implantação possível encontrada pelo arquiteto foi colocar o edifício no centro do lote. Assim como os edifícios de Higienópolis, os do Itaim costumam ter pouca ou nenhuma área de lazer comum. Quando existem, se restringem a um salão de festas e, quando muito, a uma pequena piscina.

Os edifícios da Vila Leopoldina têm características semelhantes aos do Itaim quanto à forma de torre e a implantação no centro do lote. A mudança de tipologia se deu pela mudança no tipo de produto imobiliário. Na década de 1990 os incorporadores passam a preferir terrenos grandes, com possibilidade de implantação de duas ou mais torres de 
edifícios e uma vasta área de lazer no térreo, repleta de equipamentos de uso exclusivo de seus proprietários. Uma boa área de lazer, assim como um bom aparato de segurança, passa a ser requisito obrigatório a qualquer empreendimento que aspire a ter prestígio e torna-se seu principal chamariz publicitário. Para que se viabilize economicamente, seu custo de produção e manutenção deve ser dividido pelo maior número de unidades possível. Edifícios com poucas unidades se tornam pouco rentáveis, e com taxas de condomínio muito elevadas.

Ao compararmos os tecidos urbanos de cada um dos três bairros pudemos verificar suas semelhanças e diferenças. O bairro de Higienópolis e do Itaim Bibi têm tecidos urbanos bastante semelhantes. Em ambos pudemos verificar a presença de comércio e serviços de âmbito local e diversificado, como padarias sofisticadas, casas de produtos importados, restaurantes finos; sempre qualificados para atender um público de média e alta renda. Verificamos também, nos dois casos, uma forte circulação de pedestres nas calçadas passeando entre as lojas, indo a restaurantes, colégios e universidades ou simplesmente caminhando pelo bairro. O intenso uso do espaço público tem como conseqüência a valorização deste: as praças são bem conservadas, os restaurantes se abrem para rua e colocam suas mesas nas calçadas que, em geral, se encontram limpas e bem arrumadas. Os espaços públicos de Higienópolis são geralmente mais generosos que os do bairro do Itaim, suas calçadas são mais largas e mais arborizadas e existem ainda duas praças - Buenos Aires e Villaboim - também bastante arborizadas. A única praça do Bairro do Itaim - a praça D. Gastão Liberal Pinto - não tem área verde, é muito mais um entroncamento entre vias de intenso tráfego de automóveis que propriamente um espaço de estar e de lazer. Estas diferenças se devem provavelmente às origens dos bairros: Higienópolis teve como origem um loteamento aristocrático, enquanto o Itaim Bibi teve como origem um loteamento popular.

Muitos dos estabelecimentos comerciais do bairro de Higienópolis estão situados no pavimento térreo de edifícios residenciais; o uso misto dos lotes garante que sempre haverá no bairro uma mistura de usos. No bairro do Itaim não é comum encontrarmos prédios de apartamentos com algum tipo de comércio ou serviço no térreo. Isso acontece apenas em algumas ruas, como a João Cachoeira, mas em edifícios de conjuntos comerciais. A grande maioria dos estabelecimentos comerciais do bairro está situada nos poucos sobrados remanescentes, que estão constantemente ameaçados de demolição para a construção de novos empreendimentos estritamente residenciais. $\mathrm{O}$ aumento populacional gerado pela verticalização aumenta a demanda por comércio e serviços na região. Os sobradinhos passam então a ter um alto valor imobiliário quando usados comercialmente, proporcionando valores de aluguéis cada vez maiores para seus proprietários rentistas, que, por sua vez, preferem mantê-los alugados a vendê-los para incorporadores imobiliários. Este ponto de equilíbrio é fundamental para garantir ao bairro a presença daquilo que o torna atrativo: a diversidade de usos.

O tecido urbano do bairro da Vila Leopoldina é bastante diferente dos outros dois bairros estudados. Apesar de também haver na região comércio e serviços de âmbito local e diversificado, estes, na maioria dos casos, não são dirigidos ao padrão de vida dos novos moradores do bairro. São, na sua maioria, oficinas mecânicas, lojas de ferragens ou de materiais de construção, pequenas butiques, restaurantes e bares populares. Fruto de um 
loteamento popular, os espaços públicos da Vila Leopoldina são acanhados, suas ruas e calçadas são estreitas, pouco arborizadas e sem praças ou áreas verdes.

Ao contrário dos outros dois casos, a tipologia produzida pela incorporação imobiliária não é predominante no bairro da Vila Leopoldina. Podemos constatar a forte presença de uma tipologia produzida pela configuração produtiva rentista, como armazéns e renques de pequenos sobrados, estes últimos ocupados tanto por residências como por comércio e serviços. O avanço da produção de edifícios na Vila Leopoldina, no entanto, está apenas no começo. Assim como aconteceu em Higienópolis e no Itaim Bibi, a incorporação imobiliária deve, em poucos anos, impor a sua tipologia característica ao bairro, substituindo a maior parte dos sobradinhos e armazéns rentistas por edifícios de apartamentos até que, como ocorreu no Itaim, haja um equilíbrio entre a demanda da população moradora por comércio e serviços e os poucos sobrados remanescentes com este tipo de uso.

A tipologia dos empreendimentos imobiliários que vêm sendo edificados na Vila Leopoldina é bastante diferente daquela que se desenvolveu em bairros como o Itaim Bibi e Higienópolis. Enquanto nestes dois bairros os empreendimentos geralmente eram compostos de uma única torre residencial, ocupando terrenos de oitocentos a dois mil metros quadrados, com pouca área de lazer comum, os empreendimentos da Vila Leopoldina são geralmente compostos por várias torres residenciais, ocupando terrenos de cinco mil a quinze mil metros quadrados, repletos de equipamentos de lazer e contando com serviços de uso exclusivo de seus condôminos. Seus grandes terrenos - algumas vezes ocupando uma quadra inteira - dão frente (ou as costas) para várias ruas com seus perímetros invariavelmente murados e uma única portaria de acesso. Embora a maioria dos empreendimentos de bairros como Higienópolis e Itaim Bibi tenham se fechado com grades e portões, este isolamento não fazia parte da concepção inicial do projeto, nem das estratégias de sua comercialização, mas se torna uma maneira de adaptação ao novo conceito de segurança. O local de socialização entre os habitantes destes dois bairros, no entanto, continua sendo a rua e outros espaços públicos, enquanto que nos novos empreendimentos da Vila Leopoldina, os espaços de socialização são privativos e com controle de acesso, sem a heterogeneidade das ruas. Como visto no capítulo 2, esta falta de comprometimento do empreendimento imobiliário com o tecido urbano a sua volta, ocasiona uma desvalorização do espaço público, fazendo com que este tenha perda de qualidade. A perda de qualidade realimenta o processo, fazendo com que cada vez mais novos empreendimentos dêem as costas ao espaço da cidade. 
CONCLUSÃO 
Neste trabalho analisamos os principais fatores que influenciaram a tipologia arquitetônica dos edifícios de apartamentos produzidos pela incorporação imobiliária em São Paulo nas últimas décadas e como a produção deste setor imobiliário vem alterando a paisagem da cidade.

A partir do estudo das teorias e metodologias de análise da morfologia urbana presentes na obra de pensadores como Aldo Rossi, Philippe Panerai e Manuel de Solà-Morales, pudemos verificar a importância da análise tipológica para a compreensão da formação do espaço das cidades. Para Rossi a tipologia arquitetônica deve estar associada à morfologia urbana, estabelecendo uma correspondência entre a forma da cidade e os tipos edificados. Panerai considera o tecido urbano como sendo formado pela sobreposição de diferentes tipos de traçados, diferentes tipos de parcelamento e diferentes tipos de edificações. Destaca o valor dos tecidos urbanos e das arquiteturas ordinárias, que constituem a forma permanente das cidades. Solà-Morales, por sua vez, analisa as formas de crescimento urbano a partir da ação voluntária de diferentes formas de gestão e ocupação do solo - o parcelamento, a urbanização e a edificação.

Na metodologia proposta por Candido Malta Campos Filho teve destaque a importância da análise das configurações produtivas imobiliárias na formação e evolução dos diferentes tipos de tecidos urbanos das cidades. Pudemos observar que a tipologia edificada depende de sua configuração produtiva imobiliária e que o estudo do tipo deve necessariamente envolver o estudo da configuração produtiva.

Nos levantamentos de campo realizados, especialmente o levantamento dos tecidos urbanos de três bairros da cidade, pudemos confirmar um pressuposto lançado ainda na introdução deste trabalho: a incorporação imobiliária é o grande agente transformador do espaço da cidade de São Paulo nas últimas décadas. Concluímos, portanto, que era necessário compreender as especificidades deste tipo de configuração produtiva - incorporação imobiliária - para entender as transformações que estão ocorrendo na paisagem da cidade.

Através da leitura de textos de teóricos de autores como Topalov e Jaramillo, pudemos compreender as características específicas deste setor produtivo que o distinguem de outras atividades industriais, como, por exemplo, a dependência do solo urbano para a renovação de seu ciclo de produção e o grande período de giro de capital comparado a outros segmentos produtivos.

Novamente recorremos às teorias de Campos Filho para compreendermos os processos da especulação imobiliária, que encarecem o solo urbano e criam dificuldades para este setor produtivo. Concluímos que o alto custo do solo urbano interfere de maneira determinante na tipologia produzida pela incorporação imobiliária, uma vez que, para diluir este custo, os empresários do setor pressionam os governos municipais por coeficientes de aproveitamento cada vez maiores.

Vimos que a lei 7.805 de 1972, ao determinar os parâmetros de aproveitamento, uso e ocupação de cada uma das zonas da cidade, acabou também influenciando o preço do solo urbano e, conseqüentemente, a tipologia edificada em cada pedaço da cidade.

A busca dos empreendedores imobiliários pelo limite máximo de aproveitamento dos lotes faz com que a legislação urbana (que define estes limites) também seja determinante 
na formação da tipologia edificada pela incorporação imobiliária. Destacamos principalmente as conseqüências tipológicas da fórmula de Adiron, mecanismo introduzido na lei de zoneamento que proporcionou o aumento dos coeficientes de aproveitamento dos lotes na medida em que se diminuíam as taxas de ocupação. Mostramos que o aumento na altura dos edifícios, conseqüência da aplicação da fórmula, acarreta o aumento dos recuos obrigatórios correspondentes às faixas de aeração e iluminação. Demonstramos que por conta dos grandes recuos, as possibilidades de implantação do edifício ficam reduzidas muitas vezes à única alternativa que é colocá-lo no centro do lote. A implantação das edificações passa então a não ser mais fruto de um desenho urbano pensado para que seus espaços privados sejam uma continuidade dos espaços da cidade. Concluímos que o fato do edifício estar implantado no centro do lote desestimula o uso comercial do térreo das edificações nas zonas onde o uso misto é permitido, favorecendo o surgimento de bolsões exclusivos de moradia para específicas faixas de renda. Vimos ainda que a diminuição das taxas de ocupação fez com que os empreendimentos, para se viabilizarem, necessitassem de terrenos maiores, limitando as possibilidades de negócios imobiliários para os pequenos investidores, favorecendo assim as empresas incorporadoras.

Vimos também as estratégias de que os empreendedores imobiliários lançam mão para aumentar a velocidade de vendas de seus produtos, diminuindo assim o tempo de giro de seu capital. Na busca da definição de um produto com alto valor de troca, o arquiteto e urbanista perde espaço frente ao profissional de marketing que, com suas ferramentas mercadológicas, se propõe a definir os valores arquitetônicos que irão definir a paisagem urbana. Segurança, homogeneidade social, equipamentos de serviços e lazer de uso exclusivo são os valores utilizados pelos profissionais de marketing para acelerar as vendas e que se traduzem em muros altos, cercas eletrificadas, guaritas fortificadas e regras de inclusão e exclusão. "É uma cidade de muros em que a qualidade do espaço público está mudando imensamente e de maneiras opostas àquilo que se poderia esperar de uma sociedade que foi capaz de consolidar uma democracia política" (CALDEIRA, 2000, p. 255)

Acreditamos que o aprofundamento da análise dos tipos arquitetônicos e de como estes afetam o meio urbano nos tornará mais qualificados para avaliar as tipologias que estão sendo praticadas pelos agentes produtores dos espaços das cidades, dotando-nos de ferramentas críticas para questionar estas ações e restituindo ao arquiteto e urbanista o papel social que lhe cabe, qual seja, o de orientar o crescimento e as transformações do espaço urbano visando ao desenvolvimento da cidadania e dos valores democráticos. 


\section{REFERÊNCIAS BIBLIOGRÁFICAS}


ANTONUCCI, Denise; Morfologia urbana e legislação urbanística: estudos de setores de bairros na cidade de São Paulo no período de 1972 - 2002 São Paulo, Tese de Doutoramento - FAUUSP, 2005.

ARGAN, Giulio Carlo; Projeto e destino, São Paulo, Ed. Ática, 2001.

ARGAN, Giulio Carlo; A história na metodologia de projeto, in Revista Caramelo $n^{\circ} 6$, FAUUSP, outono de 1993.

ARRIGHI, Giovanni ; O Longo Século XX, UNESP Editora, 1996.

BARBARA, Fernanda. Duas tipologias habitacionais: O conjunto Ana Rosa e o edifício Copan - Contexto e análise de dois projetos realizados em São Paulo na década de 50. São Paulo, Dissertação de Mestrado - FAUUSP, 2004.

BARONE, Ana Cláudia Castilho; Team 10 : arquitetura como crítica, São Paulo, Annablume, FAPESP, 2002.

CAldeIRA, Teresa Pires do Rio; Cidade de Muros Crime, Segregação e Cidadania em São Paulo. São Paulo, Edusp 2000.

CAMPOS FILHO, Candido Malta; Cidades brasileiras: seu controle ou o caos O que cidadãos devem fazer para humanização das cidades do Brasil. Studio Nobel, $4^{\circ}$ edição. São Paulo; 2001.

CAMPOS FILHO, Cândido M. Reinvente seu bairro. Caminhos para você participar do planejamento de sua cidade. São Paulo: Editora 34, 2003 a.

CAMPOS FILHO, Cândido M. Um desafio para os novos arquitetos e urbanistas brasileiros. São Paulo, Ementa da disciplina Atelier de Projetos Urbanos I do curso de Pós-Graduação da Faculdade de Arquitetura e Urbanismo da Universidade de São Paulo, 2003b.

CAMPOS FILHO, Cândido M. Tecidos urbanos brasileiros do século XX para o XXI. São Paulo, Texto apresentado para o $51^{\circ}$ CONGRESSO INTERNACIONAL AMERICANISTAS, São Paulo, 2003c.

CAMPOS FILHO, Cândido M. A produção do espaço urbano: seus agentes produtores, apropriadores, consumidores e usuários, e tipologias de estrutura e de tecidos urbanos resultantes. Ementa da disciplina Atelier de Projetos Urbanos I do curso de Pós-Graduação da Faculdade de Arquitetura e Urbanismo da Universidade de São Paulo, 2004a. 
CAMPOS FILHO, Cândido M. Breve comentário sobre a bibliografia indicada como prioritária. Ementa da disciplina Atelier de Projetos Urbanos I do curso de Pós-Graduação da Faculdade de Arquitetura e Urbanismo da Universidade de São Paulo, 2004b.

CAZOLlATO, Jozé Donizete. Código Geomapas do zoneamento: parcelamento, uso e ocupação do solo no município de São Paulo. São Paulo: Geomapas, 1998.

CORBUSIER, Le, A Carta de Atenas, São Paulo: HUCITEC: EDUSP, 1993

COUQUHOUN, Alan, Tipologia e metodologia de projeto, in NESBITT, Kate (org.), Uma nova agenda para a arquitetura - Antologia teórica 1965 - 1995. São Paulo, Cosacnaif, 2006.

COSTA, André. A Imagem de Arquitetura e a arquitetura da Imagem: uma investigação acerca da construção dos discursos na produção do espaço urbano. Dissertação de Mestrado. FAU-USP, 2002.

DUARTE, Guilherme Callegari Leme. O marketing imobiliário dentro de lógica cultural do atual estágio do sistema capitalista. Análise de propagandas imobiliárias residenciais de classe media e alta. Trabalho de Formação e Graduação. FAU-USP. 2005.

FELDMAN, Sarah; Planejamento e Zoneamento - São Paulo 1947 - 1972. Tese de doutoramento. FAU-USP. 1996.

FIGUEROA, Mário; Habitação coletiva em São Paulo 1928 - 1972. Tese de doutoramento. FAU-USP. 2002.

FIX, Mariana de Azevedo Barreto; São Paulo cidade global. Fundamentos financeiros de uma miragem. São Paulo, Boitempo Editorial. 2007.

GRACIA, Francisco de, Construir en lo construído, Madrid, Editorial Nerea, 1992.

HARVEY, David, Condição pós-moderna, uma pesquisa sobre as origens da mudança cultural, Edições Loyola, São Paulo, 2006

HARVEY, David, A Produção Capitalista do Espaço, Annablume Editora, 2005

JACOBS, Jane; Morte e vida das grandes cidades. São Paolo, Martins Fontes, 2001. 
JARAMILLO, Samuel. Las formas de producción del espacio construído en Bogotá. Bogotá, In PRADILLA, Emilio. (org) Ensayos sobre el problema de la vivienda en México. México: Latina UNAM, 1982.

KOPP, Anatole. Quando o moderno não era um estilo e sim uma causa. São Paulo, Nobel/Edusp, 1990.

LAMAS, José M. Garcia, Morfologia Urbana e Desenho da Cidade, Lisboa: Fundação Calouste Gulbenkian e Fundação para Ciência e Tecnologia, 1999.

LOPES, Helena de queiroz Ferreira e TOLEDO, Vera Lúcia Vilhena de; Itaim-Bibi; São Paulo, PMSP DPH, 1988.

LYNCH, Kevin R. ; A imagem da cidade. São Paulo, Martins Fontes, 1997

MONTANER, Josep Maria, Depois do movimento moderno - Arquitetura da segunda metade do Séc. XX, Editora Gustavo Gili SA, Barcelona, 2001.

PANERAI, Philippe; CASTEX, Jean; DEPAULE, Jean-Charles. Formas Urbanas: de la manzana al bloque. Barcelona: Editorial Gustavo Gili, 1986.

PANERAI, Philippe. Análise Urbana. Brasília: Editora Universidade de Brasília, 2006.

PANERAI, Philippe; MANGIN, David. Proyetar la Ciudad. Madrid: Celeste Ediciones, 2002.

PRADO, Maria Cecília Naclério Homem. Higienópolis, grandeza e decadência de um bairro paulista. São Paulo, PMSP DPH, 1980.

RODRIGUEZ, Maria Elizabet Paez. Radial Leste, Brás e Mooca:diretrizes para requalificação urbana. São Paulo: Dissertação de Mestrado - FAUUSP, 2006.

ROLNIK, Raquel - A cidade e a lei: legislação, política urbana e território na cidade de São Paulo. São Paulo: Studio Nobel: FAPESP, 2003.

ROSSI, Aldo; A Arquitetura da Cidade, São Paulo, Martins Fontes, 2001.

SANTOS, Wanderley dos; Lapa. São Paulo, PMSP DPH, 1980 
SEGATTO, José Antonio (Coord.); Lapa: Evolução Histórica. São Paulo, PMSP DPH, 1988.

SOLÁ-MORALES Y RUBIÓ, Manuel de; Las formas de crescimiento urbano, Editora UPC, Barcelona, 1997.

SPOSATI, Aldaiza; Cidade em pedaços; Organização José Roberto de Toledo. São Paulo, Brasiliense, 2001.

STRÖHER, Ronaldo de Azambuja. Quatremere de Quincy e Jean Nicolas Louis Durand - Algumas considerações sobre a interpretação do conceito de tipo em arquitetura, in $O$ Tipo na arquitetura da teoria ao projeto. RS, Ed. Unisinos, 2001.

STRÖHER, Eneida Ripoll, Considerações sobre o conceito de tipologia arquitetônica, in O Tipo na arquitetura da teoria ao projeto. RS, Ed. Unisinos, 2001.

TOLEDO, Benedito Lima de; São Paulo: três cidades em um século. São Paulo, Cosac \& Naify, Duas Cidades, 2004.

TOPALOV, Cristian; La Urbanizacion Capitalista: algunos elementos para su análisis. Coleccion Diseño: Ruptura y Alternativas. Mexico, Editorial Edicol. 1979.

VIDLER, Anthony, A terceira tipologia, in NESBITT, Kate (org.), Uma nova agenda para a arquitetura - Antologia teórica 1965 - 1995. São Paulo, Cosacnaif, 2006.

YASUNAGA, Emílio. Verticalizacão Habitacional no Município de São Paulo. São Paulo, Dissertação de Mestrado - FAUUSP, 2007. 
ANEXO 


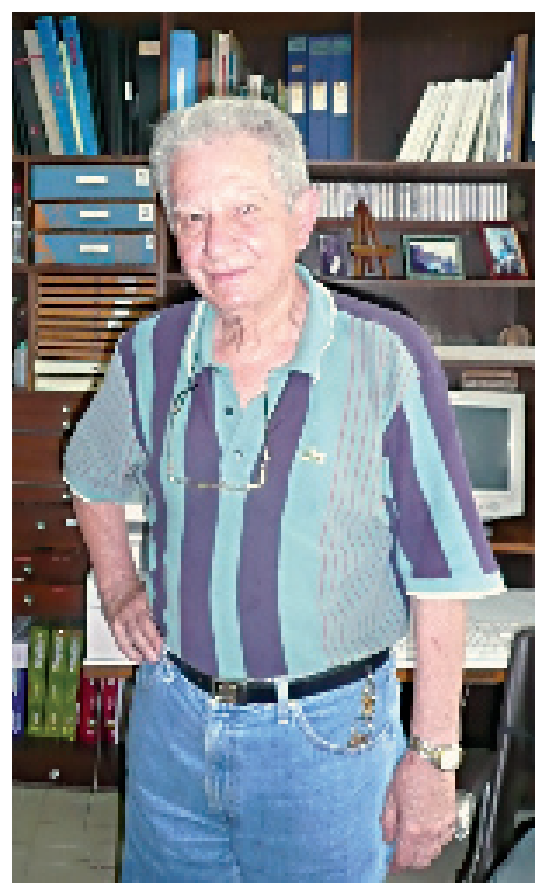

\section{Entrevista com Benjamin Adiron Ribeiro}

Benjamin Adiron Ribeiro foi coordenador da COGEP, Coordenadoria Geral de Planejamento em 1972. Foi o responsável pela formulação de Lei 7.805/72, Lei de Zoneamento, Parcelamento, Uso e Ocupação do Solo, assim como a demarcação dos perímetros de todas as zonas de uso da cidade.

Jorge: Adiron, eu vou aqui fazer um pequeno histórico, o senhor me corrija por favor, se estiver errado... O senhor foi coordenador geral de planejamento, na época da COGEP...

Adiron: Isto. Deixa eu esclarecer já de saída. Esse título de coordenador geral de planejamento era de fato correspondente e legalmente à de Secretário de Planejamento. Por que se usava de preferência coordenador? Porque que a legislação, que fui quem preparei para criar esse órgão, colocou como coordenador? Porque a idéia era que Planejamento deveria coordenar todas as atividades da prefeitura, então colocar só mais um secretário seria para competir com os demais. Então eu insisti na época em que foi criada, época do prefeito Figueiredo Ferraz, em que não fosse dado o título de secretaria, mas de coordenadoria de planejamento para que o coordenador tivesse legalmente a atribuição de coordenar todo o trabalho de planejamento. Agora, nós estamos falando das atividades próprias de cada secretaria, mas uma das atividades de cada secretaria municipal, do governo é planejar. Então esse planejamento teria que ser coordenado, por isso então coordenador.

Jorge: Coordenadoria que depois se transformou em SEMPLA.

Adiron: Depois se transformou, regrediu.

Jorge: Regrediu?

Adiron: Regrediu para secretaria. Por que? Porque os demais secretários e os prefeitos nunca aceitaram esta atribuição de que alguém deveria coordenar o trabalho deles nesta área de Planejamento.

Jorge: O senhor entrou nessa coordenadoria em que época?

Adiron: Veja bem, a coordenadoria de planejamento foi criada em 72, tá certo? Eu já estava na prefeitura há muito anos no Departamento de Urbanismo, que era um departamento integrante da Secretaria de Obras. Antigamente quem cuidava de tudo 
era a Secretaria de Obras, tá certo? Projetos de áreas de todo tipo, de planejamento da cidade. Então o departamento especializado da Secretaria de Obras era o Departamento de Urbanismo, no qual eu trabalhei muitos anos. Dentro da do Departamento de Urbanismo, ao longo dos anos, eu e outros colegas que trabalhavam lá, a maioria arquitetos, tinha alguns engenheiros também, nós chegamos a conclusão de que planejamento era muito mais do que o Departamento de Urbanismo fazia, era uma atividade que devia ser muito mais abrangente não podia se limitar quase que exclusivamente ao problema viário de circulação de veículos que era quase que a única atividade do Departamento de Urbanismo. Então nós fomos insistindo com sucessivos prefeitos para que eles criassem um órgão próprio de planejamento fora da Secretaria de Obras, capaz de exercer plenamente a função do planejamento urbano, que inclui programas sociais, que inclui programas econômicos, que inclui programas ambientais principalmente. E por fim, o Figueiredo Ferraz que era um homem extremamente inteligente, um homem de cultura muito aguçada, um dos melhores prefeitos que nós tivemos, por estranho que pareça, só ficou 2 anos, foi expulso pelo Laudo Natel. O prefeito era nomeado naquela época... Então o Figueiredo Ferraz se convenceu disso e criou a coordenadoria de planejamento, e ao mesmo tempo, um pouco depois, como conseqüência da criação da COGEP, ele criou a EMURB. Foi uma conseqüência, uma coisa saiu da outra, e por que? Porque também nós, do antigo Departamento de Urbanismo, estávamos absolutamente convencidos de que ação direta, principalmente de renovação urbana, que era muito importante, continua sendo hoje, tinha que ser exercida por uma empresa com uma estrutura realmente empresarial e não por um órgão apenas regulador tá certo? Então tinha que haver uma ação direta do poder público sobre o processo de renovação urbana, que na época já era tão importante como continua a ser até hoje. Então criou-se a EMURB. Foram os dois órgãos criados sucessivamente.

\section{Jorge: O Sr. foi para a COGEP...}

Adiron: Eu fui... Primeiro o Ferraz levou para a COGEP o amigo dele, que tinha sido colega de turma na Politécnica, que era o Robertão, Roberto Cerqueira César. Ele trouxe Roberto Cerqueira César, que tinha o escritório de arquitetura dele, nunca tinha trabalhado no setor público. Ele trouxe o Roberto Cerqueira César, portanto, da iniciativa privada, porque era colega dele, era amigo pessoal e o colocou como Coordenador do projeto. Mas aí ele criou a EMURB e o Roberto diz "não, eu me interesso mais pela ação direta, tô mais acostumado com a ação direta". Então o que ele fez? Ele levou o Cerqueira César para a EMURB e o deixou durante algum tempo exercendo as duas funções. Mas o Cerqueira César, o Robertão, logo percebeu que não era possível, que não dava para acumular as duas funções Na época eu era diretor da COGEP, era diretor justamente de um dos setores da COGEP, que eles chamavam de planejamento. Então o Cerqueira César propôs ao Ferraz que ele ficasse só na EMURB e que me colocasse na Coordenadoria. Eu era um simples funcionário municipal, na verdade, não tinha nenhum apoio político, não tinha nenhum relacionamento com políticos, era um funcionário de carreira, portanto permanente. Então o Cerqueira César que era um homem muito inteligente, de bom senso, convenceu o Ferraz que era melhor colocar uma pessoa da máquina nesta área que era uma área que exigia experiência, e foi então isto. 
Jorge: E até porque a essa altura estava-se esboçando essa lei [de zoneamento], e o sr. era o funcionário da prefeitura, era o grande especialista em zoneamento.

Adiron: Nós tínhamos (...) dois especialistas dentro do Departamento de Urbanismo. Éramos eu na área de legislação e controle do uso do solo e o Luis San Girardi na área de código de edificações, que era mais especificamente a área de controle de projetos de edificações. Então éramos os dois grandes especialistas no Departamento de Urbanismo, tá certo? Então eu era especialista nesta área de controle do uso do solo, e legislação sobre o uso do solo, e por causa disto o meu interesse era produzir uma lei de uso do solo para o município da capital. Você sabe que até então, 1972, não existia nenhuma legislação completa de uso do solo na capital de São Paulo? Na época já tinha seus 4 milhões de habitantes um pouco mais. Não tinha, não existia, havia o Código de Obras do Estado que era a única coisa que tratava assim muito de leve em alguns artigos sobre os problemas de uso do solo. Se preocupavam muita mais com os projetos de edificações, com as regras que deviam ser obedecidas nos projetos, mas muito pouco sobre uso do solo. Então não havia controle de uso do solo no município que estava crescendo de forma explosiva, tava crescendo de uma forma brutal.

Jorge: Como surgiu a idéia do zoneamento?

Adiron: A idéia do zoneamento já vinha um pouco anterior viu, então, só memorando, em 1956, nós tivemos um prefeito, que ficou aí um pouco mais de ano... Os prefeitos mudavam assim de uma maneira impressionante porque eram nomeados, quer dizer, mudava governador mudava prefeito. Governador brigava com o cara, trocava de prefeito... era assim. Então foi nomeado um médico, bom sujeito, chamado Vladimir Toledo Pizza. Bom sujeito viu, gostava muito dele como pessoa. O Pizza tinha ouvido falar alguma coisa sobre o assunto, não entendia nada desta área especifica de legislação urbana, é evidente, ele era um médico. Mas ele decidiu contratar um serviço de análise social do aglomerado paulistano, que envolvia a capital e os municípios que estavam na época mais ligados. Ele decidiu isso porque havia lido um trabalho feito para o Rio de Janeiro por um sociólogo francês chamado Lebret. Então o Padre Lebret, que já era muito conhecido mundialmente como um sociólogo que analisava problemas urbanos, problemas sociais, foi contratado pelo governador do Rio de Janeiro para fazer uma análise social do Rio de Janeiro. E o Vladimir Toledo Pizza deu uma examinada naquilo e disse "Podíamos fazer alguma coisa assim também em São Paulo, é uma análise importante pra gente ter conhecimento dos problemas com mais detalhes". Então ele contratou o serviço do Lebret em 56 , tá certo? Na época eu nem tava no Brasil, eu tinha imigrado pros Estados Unidos, literalmente imigrei, e fui trabalhar em Nova Iorque, fui trabalhar em planejamento urbano e fiquei trabalhando lá durante algum tempo. Mas eu voltei exatamente na época em que o trabalho tava sendo entregue, e o prefeito não era mais o Vladimir Pizza, que ficou um pouco mais de uma ano, a única coisa realmente permanente que ele fez foi contratar esse serviço. O prefeito era o Ademar de Barros que tinha se encaixado na prefeitura para substituir o Vladimir Pizza. E quando eu voltei o trabalho estava sendo justamente entregue à prefeitura. Demorou 2 anos, deve ter sido feito em 55-56 e pega um pedacinho de 57. E eu compareci a entrega oficial do trabalho que foi feito assim como os políticos gostam de fazer com certo estardalhaço fazendo de conta que ele era mentor da idéia, 
etc, etc. (...). Isso então foi o começo, o trabalho do Lebret, o melhor trabalho de pesquisa urbana feita até hoje em São Paulo. Isso foi em 55-56, portanto já faz mais de 50 anos. Nunca mais se fez um trabalho de padrão tão bom como aquele do padre Lebret. Mas no trabalho que ele fez o problema de uso do solo era levantado. Entre a análise toda que ele fez do aglomerado paulista, muito bem feita, com detalhes tremendos, muito detalhado, o problema de uso do solo era levantado pra demonstrar que já existia uma espécie de estrutura espontânea de desenvolvimento urbano em SP. A cidade estava crescendo muito rapidamente dentro de uma orientação espontânea, mas que tinha um certo sentido, quer dizer, surgiam as os nucleozinhos urbanos de periferia, em geral em torno de alguns equipamentos que se instalavam em determinados lugares. Começava com uma vendinha depois o negócio virava um empório, depois aparecia uma padaria ali pertinho, uma farmácia se instalava... Então era essa a forma pela qual os bairros iam surgindo e começavam. Era espontâneo, mas estava dentro das características recomendáveis para o desenvolvimento urbano. Quer dizer, as unidades urbanas devem se desenvolver em torno de equipamentos essenciais, tá certo?

\section{Jorge: Centralidades.}

Adiron: Então ele, o Lebret, chamou isso aí de unidade de primeiro grau ou qualquer nome semelhante. Depois aos poucos surgiam outros nucleozinhos desse tipo na região, loteamentos eram feitos, a maioria deles de forma bastante desordenada, sem qualquer planejamento, sem nenhuma orientação. Os loteadores, os proprietários de terra ou grileiros - a maior parte na verdade eram grileiros, não eram nem proprietário realmente, mas eles pegavam a terra lá, e se ninguém reclamasse eles dividiam e vendiam - eram mal feitos, desenhos de área e do centro muito mal feitos e sem qualquer preocupação, mas para poder atrair os compradores dos lotes, eles próprios patrocinavam uma padaria para se instalar ali. Porque alguém tinha que comprar pão todo dia, tinha que comprar leite. Então o Lebret constatou isso aí e conseguiu, de uma certa forma, localizar o que ele chamava de unidade elementar, que era esse grupinho em volta de alguns pequenos equipamentos. Depois a unidade de segundo grau, que geram várias unidades elementares que passavam a contar com a escola pública, que o governo ia lá e construía, ou com algum tipo de equipamento que exigia uma clientela maior, um mercado um pouco maior... Então [surgia] essa unidade de segundo grau e depois aparecia um centro de bairro com uma concentração maior de comércio e de serviços e assim por diante. Ele dividiu geograficamente a cidade em unidades escalonados, tá certo? Quer dizer, o que era uma unidade elementar, toda a localização delas no território, o que podia ser já classificado como unidade de segundo grau, de terceiro grau, que seria o que hoje nós chamamos de Subprefeitura, quer dizer, onde é que era o centro de desenvolvimento histórico de várias áreas da cidade. Ele fez esse trabalho que era muito mais de planejamento, de estrutura geográfica e administrativa do que propriamente um trabalho de análise social. É curioso, ele acabou resvalando do contrato inicial, que era para uma análise das condições sociais, (...) para uma analise da estrutura de organização urbana da cidade de São Paulo. $\mathrm{O}$ relatório final dele deu muito mais ênfase a isto do que propriamente à questões de problemas sociais. Esse foi o primeiro produto que nós tivemos de uma analise completa de como estava ocorrendo o uso do solo da cidade de São Paulo, na medida em que ela estava crescendo de forma explosiva. (...) Então esse é o que eu considero o documento 
básico dos estudos de desenvolvimento urbano da nossa cidade. Depois disto, alguns anos depois, veio o prefeito Faria Lima que, se eu estou bem lembrado, ele deve ter entrado em 65 ou 64, por ai... Foi antes, foi em 64 pelo menos. Foi certamente no tempo do regime militar, tá certo? Ele por estranho que pareça foi sucessor do Prestes Maia. Prestes Maia foi prefeito anterior ao Faria Lima. O Prestes Maia que era um engenheiro-arquiteto; antigamente esse negócio era o que existia, era a Politécnica que tinha seu curso de engenharia e tinha como uma das ramificações a especialização em arquitetura. Então o sujeito se formava engenheiro-arquiteto na Politécnica naquela época, e o Prestes Maia era um engenheiro-arquiteto. Ele se supunha arquiteto, porque fazia projetos de arquitetura, mas eram muito ruins, eram pesadões. Tem vários, vários exemplos de projetos do Prestes Maia aqui em São Paulo, mas eu sempre achei muito pesados. Mas era um homem honesto e muito trabalhador, bom trabalhador, ele era realmente aquilo, não tinha uma visão... Ele passou a ser considerado urbanista porque ele foi prefeito de São Paulo no tempo do Getulio Vargas, nomeado, durante 8 anos sucessivos. Foi o prefeito que teve mandato mais longo na prefeitura de São Paulo que eu conheço. Ele foi prefeito 8 anos sucessivos na ditadura de Getúlio Vargas. E na época ele desenvolveu um plano de grandes avenidas para a cidade de São Paulo que é o que tinha sido feito em Paris, é o que tinha sido feito em outras grandes cidades do mundo e ele resolveu fazer em São Paulo. Então o grande trabalho do Prestes Maia como prefeito foi desenvolver aquele plano das avenidas. E que até hoje, por estranho que pareça, ainda constituem a estrutura viária básica da cidade de São Paulo, (...). Então o Prestes Maia, depois de passar esses 8 anos, ficou conhecido como urbanista porque a principal preocupação dele era viária, quase que o urbanismo para ele era sistema viário, era circulação. Ele nunca pensou em outros aspectos do planejamento urbano porque na época não se pensava, não se falava. Então é isso: Prestes Maia foi um grande viarista. Ele desenvolvia os projetos quase que pessoalmente em cima da prancheta, era notável viu! Ele levava ao detalhe, e o cuidado dele quando fazia os projetos viários de até localizar a posição que deviam ficar as árvores no passeio. Ele fazia tudo aquilo lá e ficava horas e horas, como prefeito! A gente procurava pra falar com Prestes Maia e ele tava na prancheta desenhando e dizia para não chatear porque ele tava ocupado. Eu trabalhei com Prestes Maia, trabalhei no gabinete dele. Ele foi o primeiro prefeito que me requisitou pra trabalhar no gabinete dele, isso já na segunda gestão porque na segunda gestão ele foi eleito, tá certo? Ele não foi nomeado, ele foi eleito. Ele era um homem que tinha muito bom conceito, era um homem honesto, foi eleito e teve uma gestão como prefeito eleito bastante boa viu? Só o fato de ser honesto no caso de um prefeito já coloca o camarada como um bom prefeito. Basta isso! Além disso, ele era trabalhador. Mas continuava a ser apenas um viarista, ele não era um urbanista, nunca considerei o Prestes Maia um urbanista, ele era um viarista, um camarada que se preocupava com o sistema viário da cidade. Ele entendia que aquilo lá era a coisa mais importante. Eu não entendo... Minha a opinião é diferente, mas ele entendia que era a coisa mais importante. Eu acho que sistema viário é um dos aspectos que tem que ser somados dentro de um conceito mais completo de organização do espaço urbano. Então Prestes Maia fez uma gestão muito boa e com estas características: ele fazia obras, gastava o dinheiro que prefeitura tinha e assim mesmo ainda economizava um pouco. Ele não pedia empréstimos. Ele não começava a hipotecar a prefeitura para o futuro. Temos dinheiro, fazemos. Não temos, não fazemos. Ele trabalhava com o dinheiro que ele tinha, não era um demagogo, um desses políticos que ficam hipotecando, colocando a prefei- 
tura para pagar no futuro aquilo que ele vai fazer agora pra adquirir votos. Não, era um homem honesto. Os políticos que fazem o contrário são desonestos. São basicamente políticos desonestos. Estão mais preocupados com a carreira deles do que com o futuro da cidade que eles estão administrando. Isso é um ponto importante em planejamento urbano! Eu vou mostrar daqui a pouco porque a honestidade no trabalho público é um dos fatores mais importantes, fundamental.

Bom, o Prestes Maia quando saiu, ele transferiu a prefeitura e entregou aquela prefeitura, que estava uma beleza em termos de organização, em termos de disponibilidade financeira, e entregou pro Faria Lima, que era um homem desconhecido. Faria Lima era um militar da aeronáutica, era brigadeiro, tenente brigadeiro. (...) Ele era tenente e estava na cúpula, ele tinha atingido o máximo dentro da carreira militar dele e era grande amigo do Jânio Quadros, ele era cupincha do grupinho do Jânio Quadros. Então Jânio Quadros quando foi governador do estado, levou o Faria Lima para ser seu o secretário de obras. Então o Faria Lima começou a carreira pública dele como secretario de obras do estado de SP no governo do Jânio Quadros. E quando terminou o governo do Jânio Quadros e se procedeu a eleição de um novo prefeito de São Paulo o Jânio Quadros indicou o Faria Lima. Ele era um homem desconhecido (...), mas foi indicado pelo Jânio Quadros e o Jânio Quadros, na época, elegia quem ele quisesse. Se ele indicasse um hipopótamo pra candidato a prefeito ele seria eleito sem a menor sombra de dúvida. E o Faria Lima, lógico, foi eleito porque era o candidato do Jânio Quadros e entrou na prefeitura como um político desconhecido. Mas ele não era burro não. Eu briguei muito com o Faria Lima. Eu tive muitos atritos com Faria Lima. Trabalhei com ele o tempo todo, toda a gestão dele ponta a ponta, eu trabalhei junto com ele. Nunca fui secretario de planejamento com ele porque ele só colocava os cupinchas dele em postos importantes, mas na verdade eu era o principal assessor de planejamento do gabinete dele. Então, por causa disso, eu tinha que ter contato permanente com ele. E brigava o tempo todo com ele, ele era extremamente grosseiro, era militar, não é que ele fosse grosseiro por isso, é porque essa é a forma de comportamento que os militares adotam: tratar os subordinados de forma grosseira. (...) E o Faria Lima assim que entrou disse: "bom quero fazer obra", por que? Porque ele recebeu a prefeitura em ótimas condições financeiras, sem dívidas, e ainda com dinheiro em caixa. E por coincidência houve uma mudança na legislação federal que coincidiu com o inicio da gestão do Faria Lima, foi uma sorte tremenda que ele teve. Havia um artigo 20 qualquer na constituição, em que as prefeituras das capitais não podiam receber um determinado valor que era distribuído pra todos os municípios dos pais, como parte do retorno da arrecadação federal. Menos pras capitais, curioso não é? Era um negocio estranho porque eles entendiam que a capital tinha uma estrutura de arrecadação mais avançado que os municípios menores. Mas exatamente no inicio [da gestão Faria Lima] o pessoal derrubou este [artigo], e ele passou a receber. E era bastante dinheiro pra uma cidade grande como São Paulo, quer dizer, era uma porcentagem do governo federal em São Paulo, que era muito dinheiro. Então ele contava com o que tinha em caixa deixado pelo Prestes Maia e mais todo esse dinheiro que tava recebendo de mão beijada, assim que ele começou a administração dele. Então ele (...) disse: "Bom vamos fazer obra! Temo que fazer muita obra!" Ele queria ser governador, evidentemente. Todo prefeito de São Paulo quer ser governador. TODO prefeito de São Paulo quer ser governador. Ele entrou na prefeitura de São Paulo hoje, hoje a tarde ele já é candidato a governador, tá certo? É assim. A prefeitura de São Paulo sempre foi degrau no entendimento dos políti- 
cos. Então: “temo que fazer muita obra. Vamos ver quais são os projetos!". Não tinha projetos! Não havia quase projeto nenhum... Por que? Não é que os Prestes Maia não tivesse deixado projetos, deixou muitos! Prestes Maia era um especialista em fazer um montão. Só que todos eles dependiam de desapropriações, de aprovação prévia da câmara municipal... Era um processo que demorava, que era demorado, não é? Então pra fazer imediatamente, pra pegar o projeto e tacar ali e tal, praticamente existia muito pouca coisa. Ele queria fazer centenas de viadutos, centenas de pontes, centenas de avenidas, só que não tinha projetos, eram escassos, eram poucos... E ele ficou uma fera, viu?! Ih! como esbravejou o Faria Lima viu! Então, levando em consideração aquilo que os assessores diziam pra ele, entre eles eu, que era um dos assessores dele; e o que o pessoal do Instituto de Arquitetos também começou a levar pra ele de forma insistente, ele resolveu que São Paulo precisava fazer um Plano Diretor. Porque não tinha! Nunca tinha tido um plano diretor, urbanístico. Na época quase nenhuma cidade no Brasil tinha, não existia. "Vamos fazer o Plano Diretor pra cidade de São Paulo porque nós precisamos ter uma forma de produzir projetos em grande escala". Aí ele concordou com o Instituto de Arquitetos, que tinha que fazer assim. E essa foi a primeira briga que eu tive com Faria Lima, porque o Instituto de Arquitetos, erroneamente; os arquitetos infelizmente têm, como qualquer outra categoria profissional, são todas iguais as categorias profissionais, tem esse espírito coorporativo, coorporativista. Eles queriam que o Plano Diretor da cidade de São Paulo fosse elaborado em concurso, através de um concurso, em que os arquitetos tivessem a oportunidade de então captar um projeto grande, um trabalho grande. E a minha opinião, já naquela época, era totalmente diferente: eu entendia que planejamento urbano é uma coisa contínua, permanente, não pode ser episódico, não pode ser um projeto, um concurso, um lugar pra fazer um plano, eu sempre achava que isso era uma estupidez, uma burrice. E o que eu dizia ao Faria Lima é o seguinte: "Não, vamos criar um órgão de planejamento urbano bem estruturado pra cidade de São Paulo, nós não temos! O Departamento de Urbanismo é uma coisa ridícula, ridícula, não faz planejamento urbano. Vamos criar de fato um sistema de planejamento urbano, em que tenha um órgão da prefeitura e tenha as estruturas do setor privado que participem do sistema", tá certo? "Participem do sistema!". Mas um sistema permanente, não um sistema que mude com cada prefeito, e que se assegure a [sua] permanência através de uma forma legal, de maneira que um prefeito não possa, pura e simplesmente, atirar tudo no lixo e começar de novo, como todos os prefeitos sempre fizeram. Então essa foi a primeira briga que eu tive. Mas venceu o Instituto de Arquitetos e ele resolveu contratar um Plano Urbanístico Básico - PUB. Plano Urbanístico Básico, um negócio grandioso! Então ele decidiu: "Vamos fazer um concurso internacional! Não vai ser um concurso aqui pro pessoal do IAB, não. Eles tão pensando o quê? Nada disso, vai ser um concurso internacional! Eu quero os melhores urbanistas do mundo pra desenvolver o Plano Urbanístico Básico da cidade de São Paulo!". Então ele tinha, vamos dizer, essa megalomania, ele era um pouco megalomaníaco.... e fez! Então ele chamou o diretor do Departamento de Urbanismo, que na época era uma excelente pessoa, chamado Carlos Lodi. (...) Esse nome é pouco conhecido, mas ele é 20 vezes melhor... era colega, estava no mesmo nível, na época, do Berrini, do Luis Carlos Berrini. Os dois trabalhavam no Departamento de Urbanismo, estavam no mesmo nível. O Lodi era 10 vezes melhor que o Berrini. Hoje o Berrini é avenida, o Lodi não é nada! Morreu e não é nem viela sanitária! Tá certo? O Lodi era 20 vezes mais competente que o Berrini. Muito! Era um homem que tinha visão do proble- 
ma urbano. Ele sabia que o Departamento de Urbanismo não fazia planejamento urbano, porque ele conhecia, ele tinha uma certa cultura na área de planejamento urbano. Carlos Brasil Lodi, excelente pessoa! Filho de italianos, lógico né? Com esse sobrenome! (...). Mas então ele [Faria Lima] chamou o Carlos Lodi e disse: "Bom, nós temos o que fazer! Eu vou criar aqui um negócio chamado Grupo Executivo do Planejamento, GEP, para administrar esse concurso, essa concorrência internacional que eu quero fazer para a elaboração do PUB. Eu já tenho todos os membros designados para o GEP. O presidente..." - o presidente que no caso era o cupincha... ele só nomeava os cupinchas dele pra cargos importantes... era o Quitanilha, advogado, que ia ser presidente de um Grupo de Planejamento, não entendia nada disso evidentemente. (...) E um dos membros lá do conselho do GEP era Ester Figueiredo Ferraz, também advogada excelente pessoa, irmã do futuro prefeito que era o Luis Carlos. Bom, (...), ele [Faria lima] já tinha criado o GEM antes do GEP. Ele criou o GEM antes porque que era preocupação maior dele: era Grupo Executivo do Metrô, GEM. Foi criado um pouco antes do GEP. Então "eu vou criar o GEM" e na verdade ele colocou o Quintanilha no GEM, no grupo do metrô, "mas agora eu vou criar também o GEP porque eu to vendo que nós não temos plano diretor, e metrô vai demorar muito tempo ainda porque não tem nem projeto", ainda não havia nada. "Então eu queria que você me arranjasse um secretario executivo que vai a ser a pessoa que vai trabalhar... que o resto do pessoal é mais feito assim pra... que é o cara que vai trabalhar! E que não me encha a paciência, mas que trabalhe e que entenda do negócio e que fale inglês, que isso aí vai ser um concurso internacional!". Então o Lodi coçou a sua cabeça, coçou, "só se for o Adiron, não? O Adiron trabalhou nos Estados Unidos alguns anos, ele fala bem inglês e ele conhece o assunto." Eu era quase que padrão zero no Departamento de Urbanismo. Então (...) fui nomeado Secretario Executivo do GEP, e o GEP ficou então com a função de contratar grupos internacionais, urbanistas internacionais para desenvolver o Plano Urbanístico Básico de São Paulo. Foi feito uma concorrência, foi obtido um financiamento muito generoso através do FINEP, que era um órgão que financiava esse tipo de coisas na época, e veja bem, o valor era na época considerado abusivo: 5 milhões de dólares! Hoje é trocado! Na época era um valor abusivo, era um negócio que o pessoal ficava estarrecido! 5 milhões de dólares pra contratar um Plano Urbanístico Básico!? Fizemos. Foi feita a concorrência internacional, foi escolhido um grupo misto em que haviam alguns escritórios americanos e alguns, dois, brasileiros. Os grupos se consorciaram, foi feita a análise de todas as propostas, eram umas vinte propostas de grupos internacionais, alguns deles muito importantes e foi escolhido aquele grupo cuja a proposta foi considerada a melhor. Na verdade fui eu quem escolhi, porque os outros membros lá do tal GEP não entendiam nada do negócio, eles jogavam tudo nas minhas costas: "você apresenta ai os relatórios das analises..." e eu ia apresentando e eles iam aceitando sem discutir muito. Então foi escolhido um grupo. Esse grupo desenvolveu o Plano Urbanístico Básico. Eles tiveram prazo muito curto porque quando terminou o processo de escolha já tinham passado 2 anos. Foi um processo muito mais longo do que deveria ter sido, porque havia uma série de problemas de caráter legal que tinham que superados e tudo mais. E alguns dos grupos recorreram do resultado... Só quando faltava menos de 2 anos pra terminar - eram quatro anos a gestão dos prefeitos - quando faltava menos de 2 anos pra terminar a gestão do Faria Lima começou enfim o trabalho de preparação do Plano Urbanístico Básico. Olha, foram reunidos aqui em São Paulo durante um pouco mais de um ano, 100 técnicos em planejamento urbano internacionais, 100! 
Que trabalharam quase que o tempo todo aqui. Pessoas de padrão bastante alto. Foi realmente um grupo de padrão muito alto que trabalhou mais de um ano elaborando o Plano Urbanístico Básico pra a cidade de SP.

Jorge: Quem eram os autores do projeto que ganhou?

Adiron: Então vamo lá: Isso aqui é o relatório resumo. O relatório real era uma um negocio que ocupava metade de um sala. Então (...) na época nos recebemos financiamento do FINEP que era um órgão do governo federal e, porque foi escolhido um escritório americano, a USAID também financiou uma parte dos custos. Do Brasil nós tínhamos a Montreal, que existe até hoje como consultoria de engenharia, e tínhamos um grupo chamado ASPLAN, que já sumiu e que tinha um pessoal de padrão muito bom. Tinha um pessoal que era aqui de São Paulo e dos Estados Unidos. Nós tínhamos 2 grupos: um deles chamava-se DAILY que era um grupo bastante conhecido nos Estados Unidos, Leo Daily, era um grupo bastante conhecido nos Estados Unidos. Tínhamos um grupo chamado Engineers e tinha um grupo chamado Wilbour Smith, que era na época um urbanista muito conhecido também nos Estados Unidos. E do Brasil nos tínhamos a ASPLAN e tínhamos a Montor-Montreal, tá certo? Foi esse grupo, mais ou menos 100 especialistas que tinham de fato competência e fizeram um plano tecnicamente muito bom. E curiosamente falando, eles refizeram a pesquisa, foram obrigados a refazer toda a pesquisa do aglomerado urbano sobre todos os aspectos e isso leva bastante tempo porque já era bastante grande a cidade na época. E por coincidência, eles concordaram que a cidade estava se desenvolvendo ainda dentro daquele modelo mais ou menos esboçado pelo Lebret, quer dizer, (...) já tinham passado muitos anos, já tinham passado 10 anos, mas o crescimento da cidade ainda mais ou menos mantinha aquele tipo... não era tão desordenada como o pessoal pensava, havia uma certa coerência na forma pela qual a cidade estava se desenvolvendo, estava crescendo. Então eles apresentaram uma proposta de Plano Urbanístico Básico extremamente detalhada (...) em que, coerentemente, eles faziam uma proposta de infra-estrutura física e uma proposta de organização do espaço urbano, através de regulamentação do uso do solo. Então a primeira forma ordenada pela qual surgiu uma proposta de legislação de uso do solo foi feita, apresentada pelo Plano Urbanístico Básico. A minha função pessoal nesse Plano Urbanístico Básico foi coordenar a equipe da prefeitura que acompanhou os trabalhos. Nós tínhamos que acompanhar os trabalhos e participar de todas as decisões e a minha função era coordenar esse grupo. Bom então, primeira proposta de legislação de uso de solo ocorreu, portanto, em 1967, praticamente 10 anos depois da entrega da pesquisa Lebret. Só que Plano Urbanístico Básico foi recebido num momento infeliz, porque ele foi entregue no final... Afinal, só conseguiram entregar no final da administração do Faria Lima. Então o Faria Lima que tinha tanto interesse nesse plano porque podia gerar projetos para ele fazer obras, porque ele só tava interessado em fazer obras, ele não tava interessado em planejamento, ele queria fazer obra. Faria Lima acabou não aproveitando e por singular coincidência, foi entregue... eu diria que no penúltimo dia da gestão dele (...). Ele fez um estardalhaço, ele tava saindo da prefeitura queria ser governador, fez, evidentemente, um estardalhaço pra receber o Plano Urbanístico Básico e no dia seguinte foi embora. E olha, era papel! O que eles entregaram de cópias do relatório... O relatório principal era um volumes dessa grossura assim, desse tamanho, mas centenas, milhares. (...). E no dia seguinte assumiu o 
prefeito que foi nomeado. Que não foi eleito hein? O município da capital teve essas idas e vindas. As vezes o prefeito era eleito... de repente mudava a legislação e ele passava a ser nomeado... de repente voltava outra vez e aparecia um prefeito que tinha que ser [eleito] ... Bom, Paulo Maluf sucedeu ao Faria Lima... Paulo Maluf entrou e alguns dias depois, não foi assim tão repentino, eu diria que talvez uns 10 dias depois ele, (...) passando por uma sala lá, quando ele tava indo em direção ao gabinete dele, tava com a porta aberta e ele viu um montão de volumes, de coisas acumuladas enchendo a sala. Ele olhou, perguntou lá pro assessor... "escuta o que tem naquela sala lá que ta tão cheia?". "Ah, aquilo é o PUB que foi entregue. O PUB lá no final do Faria Lima". Era isso aqui: milhares de exemplares disso e milhares de exemplares do relatório detalhado. "PUB? Aquilo lá é o PUB? AH! deixa eu dar uma olhada". E a primeira coisa que ele viu aqui nesse volume, você vai notar que não tem mais, hein(!), uma pagina inteira com a fotografia do Faria Lima: "Administração Faria Lima", ele abriu viu aquilo e disse: "Pode queimar tudo! Pode queimar tudo! Manda para o incinerador da prefeitura! Toda a edição! Manda tudo pro incinerador da prefeitura!" Eram milhares, o cara saiu de lá, o assessor dele, que era engenheiro, chateado, encontrou o Sangirardi (...) e disse: "O Maluf mandou queimar todo o PUB, por no fogo! Diz ele que é promoção política do Faria Lima. Só peça de promoção política”. Sangirardi saiu preocupado, porque ele também tinha participado da coisa toda e chegou no Departamento de Urbanismo e disse: "Olha, vai ser tudo queimado, vai ser tudo incinerado, vão incinerar! Levamos aí não sei quanto tempo para acompanhar e preparar o $1^{\circ}$ Plano Urbanístico e vai ser tocado tudo no fogo, viu!". Eu soube do negócio e fui lá conversar com Sangirardi e disse: "Olha Sangirardi não podemos deixar. Não é que seja uma maravilha das maravilhas, nem que seja o que devia ter sido feito, não é nada disso. Nós devíamos ter montado um sistema de planejamento, isso seria o certo. Mas queimar também não tá certo. Me parece que isto seria criminoso. Vamos fazer o seguinte, vamos nos reunir em grupo aqui do depto. de urbanismo e vamos conversar com o Maluf, vamos bater um papo com ele e vamos mostrar a ele que esse não é o caminho". Então fomos montamos um grupo. Sangirardi, eu e mais dois ou três, e fomos conversar com o Maluf. O Sangirardi era cupincha do Maluf. Ele tinha um amigo do peito chamado Paulo Ritcher, e o Paulo Ritcher, era de fato o engenheiro principal da Eucatex, do grupo da família Maluf. Ele era de fato o engenheiro que comandava as indústrias de madeira e de compensados que a família Maluf tinha, e por causa disso ele tinha muita influência sobre o Maluf. O Maluf que de fato não entendia nada de nada; o Maluf no começo da carreira era realmente uma negação total, não entendia coisa nenhuma, era um sujeito presunçoso. Nunca tive simpatia pessoal por ele. Então [...] o Sangirardi conseguiu que o Paulo Ritcher obtivesse uma audiência nossa com o prefeito. Conversamos e foi feita a seguinte proposta: quer dizer o choque que o prefeito tinha, que o Maluf tinha tido é porque abrindo a folha aqui, a primeira coisa que ele viu foi a enorme fotografia do Faria Lima. Foi feita a seguinte proposta: vamos arrancar essa folha pô, paciência! Vamos contratar aí um grupo de bedéis para pura e simplesmente, nessas milhares de exemplares, arrancar essa folha de todos eles. Pronto, aí desaparece o problema! [risos]. E foi feito. Então por isso que está assim, você entende? [mostra o volume com a encadernação estragada] Foi arrancada a fotografia. E ai ele concordou: "está bom, vai. Mas tira essa porcaria do gabinete porque eu não quero isso aquil" Então foi tudo levado para o depto. de urbanismo onde encheu as salas; e alguém tinha que tomar conta daquilo. Então eu recebi..., eu continuava a ser secretário executivo do GEP, por estranho que pareça. Era um 
negocio que tinha sido criado para um fim específico de contratar e acompanhar a produção do Plano Urbanístico Básico, mas como o prefeito seguinte não se lembrou de extinguir o órgão que tinha sido criado por decreto, o órgão continuou a existir e como a função de secretario executivo não tinha nenhuma vantagem pessoal, e nem projeção [...] ou coisas assim, eu continuei a ser o secretario executivo. O Maluf não me conhecia, nem sabia quem eu era, mas também resolveu: "esse negócio não existe vai, como não existe deixa como está na prefeitura". Então eu recebi a incumbência de cuidar do acervo do Plano Urbanístico Básico. O acervo Plano Urbanístico Básico ocupou duas salas do depto. de urbanismo, porque não era só essa edição do relatório final, tinha toda a parte de pesquisa que eram centenas e milhares de planos, questionários, de requisitos, de originais de todo tipo. Tudo. E até o material técnico, material de desenho, tudo, foi entregue a prefeitura, aquilo lá pertencia a prefeitura. E foi colocado lá e eu não sabia o que fazer com aquilo. Então eu fiz aquilo que era lógico, eu distribuí coleções do relatório do PUB para todas as bibliotecas que eu pude no Estado de São Paulo, para todas as prefeituras do Estado de São Paulo, e passei a atender todos os técnicos, arquitetos, engenheiros que estavam interessados em ter uma coleção. E assim mesmo eu não consegui acabar com a edição. Pra todo mundo que aparecia lá, com todo prazer e com a maior alegria, eu oferecia a eles uma coleção que eles quase que tinham que contratar um carro para levar, viu. Então foi isso. Estou sendo excessivamente prolixo?

Eu estou querendo dar apenas a notícia mais ou menos por alto de como a coisa evoluiu para chegarmos onde nós queremos chegar.

Jorge: No zoneamento.

Adiron: Para chegarmos no zoneamento. Isso foi então em 1967. Mas o PUB ficou parado porque o Paulo Maluf não quis que aquilo tivesse continuidade, tá certo? Não quis. Ele até concordou em dar um pouco mais de estrutura pro setor de planejamento, esse crédito eu tenho que dar a ele, dar um pouco mais de estrutura, [...] mas como eu não me entendia com ele, eu acabei não sendo usado na administração dele. Eu fiquei lá encostado como secretário executivo do GEP, que não existia. O GEP era Adiron e mais Adiron, somando tudo era só. Eu era o único funcionário! Eles me deram uma sala, uma escrivaninha e uma cadeira. No fim, minha função acabou sendo essa. Mas curiosamente, veja que coisa estranha: o órgão passou a ser uma dependência do Departamento de Urbanismo. Na verdade, legalmente pertencia ao gabinete do prefeito, mas eu fiquei ali, com uma sala no Departamento de Urbanismo, cujo diretor já era, por essa altura, o Sangirardi, que era o cupincha do Paulo Richter, que era o amigo do Paulo Maluf. E foi assim durante toda a gestão do Maluf, eu não tive nenhuma atuação. Mas terminou a gestão do Maluf e aí veio o Figueiredo Ferraz. E o Figueiredo Ferraz que era um homem inteligente, que era amigo do Robertão, o Roberto Cerqueira César, arquiteto colega nosso, criou a COGEP. Levou o Robertão para tocar a COGEP. Em seguida criou a EMURB e colocou o Robertão para cuidar da EMURB, e por fim o Robertão disse "olha vamos colocar na COGEP o Adiron, porque não dá para tocar as duas coisas, não dá". E o Ferraz me nomeou sem me consultar, estranho não? Nem me deu uma telefonada para "vem cá, escuta, vou te nomear". Não, chego lá um dia para trabalhar e estava lá, no diário oficial em cima da minha mesa, meu nome como secretário de planejamento... Não falou nada! Nem o Robertão... Pensei em recusar, não é assim que se faz... Então eu fui na primeira audiência que o prefeito me 
concedeu e disse a ele: "Escuta prefeito, o senhor me nomeou aqui para coordenadoria da COGEP... Tudo bem, eu sou do quadro permanente da prefeitura, acho que é muito correto nomear pessoas do quadro permanente da prefeitura para esses cargos técnicos. O senhor me nomeou aqui, mas eu queria ponderar o seguinte: se eu tiver que trabalhar contigo aqui eu quero ter $1^{\circ}$ ) liberdade de ação e $2^{\circ}$ ) eu quero desenvolver e apresentar duas coisas que o município de São Paulo nunca teve. Primeiro um Plano Diretor. Nós nunca tivemos um plano aprovado por lei. Nunca! E nem o informal, porque o PUB jamais foi levado a sério. Então eu queria apresentar uma proposta de Plano Diretor, e em seguida, como conseqüência, apresentar uma proposta de legislação e de zoneamento. Se o senhor quiser concordar com isso eu fico. Se o senhor quiser só empurrar esse assunto com a barriga eu não fico". Ele disse: "mas é isso mesmo que eu quero! Ainda bem! Bem que o Robertão disse que você tinha orientação nesse sentido! É isso mesmo, pode preparar, nós encaminhamos!" Então, a partir daí eu preparei primeiro uma proposta de Plano Diretor para cidade. Foi a primeira coisa. Foi em 71, gestão do Figueiredo Ferraz que foi aprovada no final de 71. Você dever ter esse material. Foi o primeiro Plano Diretor aprovado para a cidade de São Paulo, foi o primeiro.

Jorge: Plano Diretor de Desenvolvimento Integrado.

Adiron: Plano P-D-D-I São Paulo, Plano Diretor aprovado no final de 71.

Jorge: Elaborado na gestão do Figueiredo Ferraz "porque São Paulo precisava parar".

Adiron: É, não era é bem isso. Isso aí foi a mídia que criou, porque o Ferraz disse a infeliz frase de que São Paulo precisava parar. Mas a orientação do Plano Diretor não tinha nada a ver com isso, pode ficar certo de que não era nada disso. Isso foi só uma frase que a mídia criou. E carimbaram em cima da testa do Ferraz essa frase porque ele realmente disse isso uma vez. Uma frase infeliz ao meu ver. Mas não é [isso]. O PDDI era um plano integrado, a orientação era que o planejamento urbano tinha que ser $1^{\circ}$ ) contínuo, $2^{\circ}$ ), tinha quer ser dinâmico, constantemente se atualizando, e não a cada dez anos, mas constantemente, e tinha que se integrado, tinha que colocar como interdependentes todas as funções geográficas. Esta era a orientação. O Plano Diretor de Desenvolvimento Integrado, eu sou autor do plano, então pode parecer que eu esteja tentando defender um filho de estimação ou coisa assim... Não é o caso. Infelizmente é a verdade histórica: não é grande coisa! Diga-se de passagem, eu jamais fiquei satisfeito com aquilo. Não é grande coisa. Mas é o que se podia fazer na época dentro das limitações do conhecimento urbano que se existia nos pais. Era o que podia se fazer na época. Eu recebi outro dia um telefonema que eu achei muito engraçado. Isso é um parêntese. Meu amigo Rubem Botti, arquiteto, você deve conhecer o Botti, sócio do Rubin. O Botti me telefonou... Há uns três ou quatro anos que eu não falava com o Botti. Eu até estranhei o fato dele me telefonar, viu. Ele me telefona e me disse "escuta Adiron, eu não pude deixar de telefonar hoje para você porque me pediram para escrever um artigo para o Estado de São Paulo, sobre o novo Plano Diretor que está sendo elaborado. E eu, para rememorar, resolvi dar uma lidazinha no seu plano, de tantos anos atrás, e fiquei estarrecido!", disse o Botti, isso por telefone, "fiquei estarrecido, porque aquele plano é muito melhor do que eles estão preparando agora. Continua sendo muito melhor do o que eles estão propondo agora, 
fiquei estarrecido!", disse ele. É um plano claro, em que as coisas são ditas de forma extremamente claras, objetiva e tem coerência. Tem coerência e nenhum objetivo externo ao planejamento urbano, nem de demagogia política, nem aparelhamento do estado como fez a Erundina, como fez a Martha Suplicy nesse catastrófico plano que ela conseguiu aprovar, que é catastrófico o plano que ela conseguiu aprovar! "Aquele seu plano podia ter os seus defeitos mas pelo menos era claro, objetivo e coerente." Então o que era o plano, o PDDI? O PDDI basicamente era o seguinte: você tem aqui vamos dizer por hipótese o município de São Paulo. na verdade havia uma [...] preocupação de que o aglomerado urbano não era só o município de São Paulo, não tinha problema de divisa não, o aglomerado urbano era todo aquele conjunto que funcionava como grande metrópole. Havia esta preocupação quando foi feito o PDDI. Se apagou um pouco essa preocupação ao longo dos anos eu não sei porquê. Mas nós tínhamos aqui o Vale do Tiete com as marginais do Tiete; nós tínhamos aqui, o Vale do Pinheiros com as marginais do Pinheiros; e o PUB tinha desenvolvido uma proposta que era um sistema de vias expressas que consistia basicamente nisto: Norte-Sul, Leste-Oeste. Então consistia em fazer uma grelha de vias expressas para resolver definitivamente o problema de circulação de veículos no aglomerado urbano paulistano. A grelha de vias era uma proposta inteligente, teoricamente e tecnicamente perfeitamente defensável. Porque a via expressa, você sabe, é um negocio que foi criado pelos americanos, ela não tem cruzamentos, por isso ela chama expressa. Ela tem em cada ponto de intersecção com outras vias todo um sistema de alças e viadutos que permitem a entrada e saída sem a colocação de sinais, semáforos, seja o que for. Então ela permite uma situação contínua dos veículos. A proposta do PUB era criar em São Paulo uma grelha de vias expressas e eles propuseram inclusive quais as localizações adequadas. Hoje eles estão desenvolvendo um pedacinho da grelha chamando de Rodoanel. É um pedacinho daquela antiga grelha, tá certo, mas só um pedaço, infelizmente. $\mathrm{Na}$ estrutura urbana, basicamente a circulação seria esta. O que aconteceria com o território? Ficaria dividido em parcelas circundadas por vias expressas. Teoricamente seriam, vamos dizer, quadrados. Na verdade, por causa da nossa geografia, da topografia, nunca seriam quadrados, teriam outra forma. Então, se você está aqui, e você quer vir aqui, em qualquer outro ponto disto aqui, você tem uma porção de opções tá certo? Se uma das vias estiver um pouco mais congestionada você, pura e simplesmente, pula para cá, para lá, com a mesma rapidez, praticamente, você chega lá. Um montão de opções para se deslocar do ponto "a" para o ponto "b", tá certo? Isto é inteligente do ponto de vista de solução viária. Custo? Muito alto! Muito alto, porque uma via expressa, é evidente, exige uma quantidade de obras de arte tremenda: viadutos, pontes, as vezes túneis... tudo. Então o custo é muito alto, nós sabemos disso. Mas com o dinheiro que se joga fora em porcarias, em besteiras e em roubalheiras; se isto pudesse ser aplicado aqui daria. Porque na época a cidade ainda não era tão grande e ainda havia os espaços que eles escolheram, as linhas e outros percursos que eles escolheram e que foram cuidadosamente estudados para atingir o mínimo de áreas construídas. Impossível eliminar totalmente o problema de atravessar algumas áreas construídas, mas o mínimo. Era viável, do ponto de vista de execução, era viável, desde que fosse dado imediatamente o inicio da execução. Esse era o ponto número um do PUB, que eu transferi para o PDDI. Adotei a proposta do PUB na área de vias expressas por que isso resolve indefinidamente o problema. Porque se a cidade for crescendo você pura e simplesmente vai fazendo novos elementos de vias 


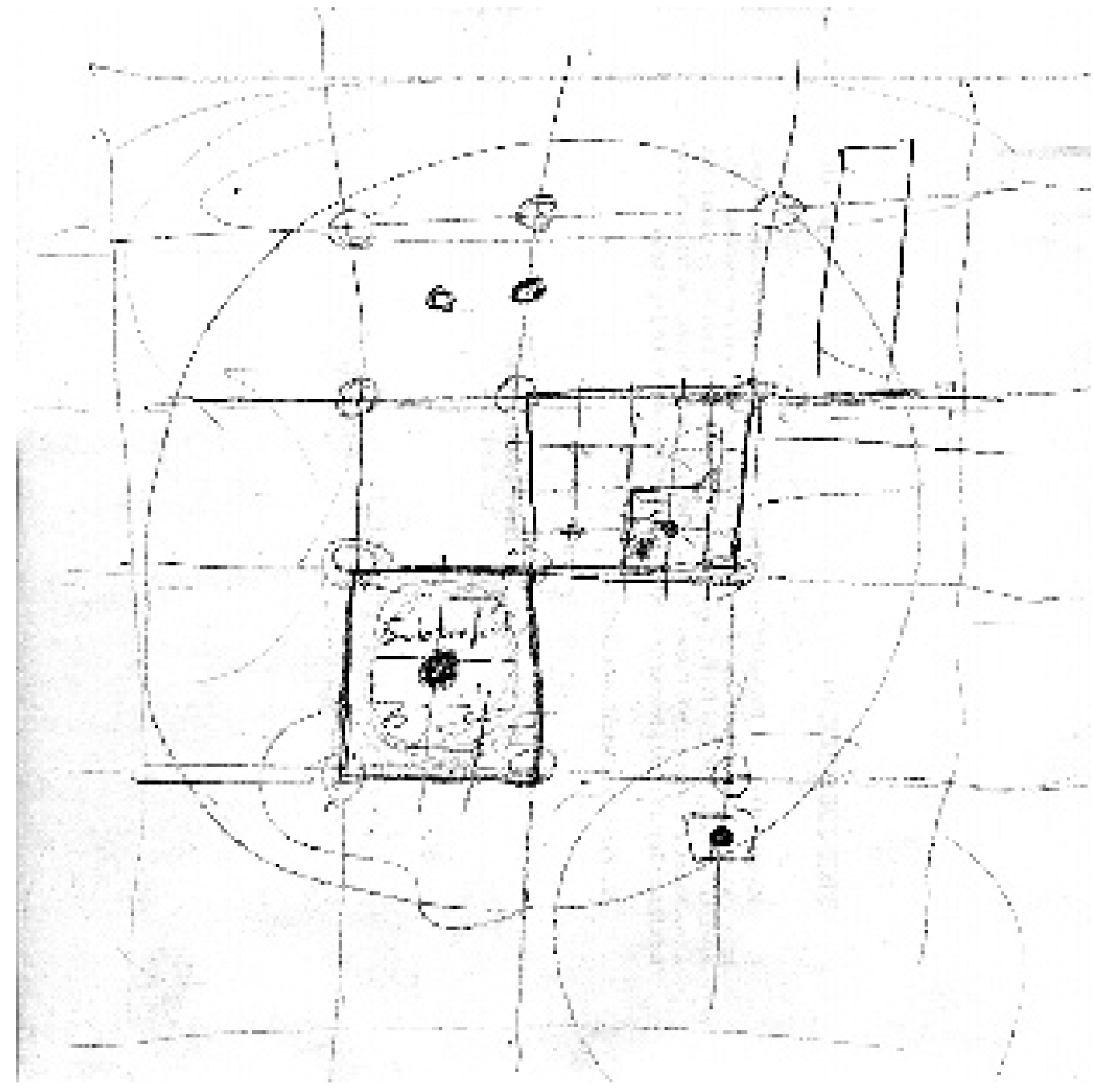

expressas tá certo? Teoricamente perfeito. Do ponto de vista de execução, teria alguns problemas, mas superáveis, possíveis.

Então as unidades que seriam definidas por contorno das vias expressas seriam as unidades completas. É o que o Lebret já tinha chamado de unidades completas, o PUB continuou chamando de unidades completas e que hoje nós chamamos de Subprefeituras. Foram chamadas durante muito tempo de distritos. E o Faria Lima erroneamente chamou de Administração Regional, nome que pegou. Por que o Faria Lima chamou isso aqui de administração regional? Era distrito, o nome correto era distrito, geograficamente é distrito, administrativamente é distrito. Faria Lima chamou de administração regional... Não tem nada de regional. Regional é um negócio amplo. Ele chamou porque no Rio de Janeiro chamava e ele era carioca, muita gente não sabe disso, Faria Lima era carioca.
Croqui executado por Adiron Ribeiro durante a entrevista mostrando o esquema teórico da grelha de vias expressas e das unidades escalonadas. 
Então ele pegou a administração regional que existia na cidade do Rio de Janeiro e passou a chamar os distritos de Administração Regional, nome que pegou e ficou durante muitos e muitos anos até se transformar em Subprefeitura que era a idéia original. Então isto aqui seria uma Subprefeitura. Quer dizer, isto aqui teria um centro principal que era o centro de uma cidade, a subprefeitura seria de fato uma pequena cidade, sempre, e como havia essa barreira, a subprefeitura teria que conter todos os elementos básicos de uma cidade, de um aglomerado urbano: área industrial, áreas verdes necessárias, centros comerciais, divisão em unidades menores que seriam chamadas então de bairros e unidades ainda menores que seriam chamadas de unidades elementares e que alguns chamam de unidades de vizinhança. Inicia-se com uma unidade de vizinhança chega-se ao bairro e chega-se a Subprefeitura. Então isto era a proposta: cada subprefeitura teria seu sistema viário, adaptado na medida do possível, porque aí não era possível fazer a coisa tão completa com o mesmo sistema de grelhas de avenidas principais. Aí [as vias] não seriam vias expressas, mas com os cruzamentos sempre que possível facilitados em níveis diferentes ou passando por baixo ou passando por cima, tentando eliminar o tanto quanto o possível a ocorrência de sinais e de semáforos. Então cada uma dessa seriam divididas, partíamos da unidade de vizinhança e chegávamos a administração da cidade. Isto era a estrutura de organização de espaço que o PUB propôs, baseada na pesquisa Lebret. Em grande parte baseada na pesquisa Lebret.

Jorge: E que você adotou...

Adiron: Eu peguei isso aqui... Eu não inventei nada. Em urbanismo nunca se inventa nada! Nós temos que pegar o desenvolvimento histórico das coisas e ir verificando como é que a coisa está caminhando e de que forma pode-se [continuar]. Infelizmente, nosso pessoal aqui gosta de inventar... Eles são amigos de inventar... Cada prefeito que entra acha que deve fazer um Plano Diretor e que muda tudo!! Ele acha que tem que mudar tudo! Então isto foi o PDDI. Basicamente era isto. Era uma legislação de uso do solo em que você pegava a unidade de vizinhança, que tinha um pequeno centro de prestação de serviços e de comércio e uma área basicamente residencial. A área residencial era Z1; a área de prestação de pequenos serviços mas que também podia ser usada para uso residencial era Z2; o centro de bairro, pega aqui quatro unidades de vizinhança, tem um centro mais importante, aqui isso seria Z3; você pegou um certo número de bairros e desenvolveu um centro especializado... Consolação é especializado em lustres, tá certo? Sei lá, o Bom Retiro é especializado em roupa, e assim por diante. Então isso era $Z 4$, e os centros principais, as subprefeituras eram Z5. Então basicamente era isso: Z1, Z2, Z3, Z4, Z5.

Jorge: A gente vê que todos os pequenos bairros têm sua Z4, a sua Z3.

Adiron: Têm o seu centrozinho comercial, todos. Por causa disso. Porque a base era isso.

Jorge: a Z5 era mais o centro de São Paulo.

Adiron: $\mathrm{O}$ centro era para ser $\mathrm{Z} 5$ por que? Porque naquela época realmente o centro era o centro. Não existia esse negocio de Avenida Paulista não. Avenida Paulista era uma avenida residencial, era uma belíssima avenida residencial. O centro era o centro. Então 
aquilo era a Z5, que era o centro principal da cidade, tá certo? E os centros das subprefeituras eram Z4. Uma sexta zona era o que nós chamávamos de zona industrial, por quê? São Paulo sempre foi conhecida como uma cidade industrial. É a característica de estrutura econômica mais importante da cidade. Então nós prevíamos a criação de distritos industriais. O PDDI previa a criação de distritos, coisa que a cidade nunca teve. A maior cidade industrial da América Latina nunca teve um distrito industrial, extravagância não é? Para nós que somos urbanistas isso parece uma incoerência. Então o PDDI chamou esses futuros distritos industriais e também as áreas que já tinham grande concentração de indústrias naquela época, chamou de Z6, zona industrial. Depois selecionou uma série de áreas cujo destino estavam vazias, por exemplo, área de Parelheiros, grandes parte área de implementação de mananciais e outras grandes áreas lá da Cantareira e algumas outras grandes áreas vazias e chamou de zonas de usos especiais, Z8. Então eram oito as zonas que caracterizavam a proposta da legislação de uso do solo que constava no PDDI. Não estamos ainda falando da legislação de zoneamento, isso constava do PDDI, tá certo? Foi aprovado o PDDI e transformado em lei. Foi a primeira lei de Plano Diretor da cidade, no final de 71. Então, a partir daí já era possível preparar a legislação de uso do solo, nunca antes, tinha que ser consequiência do plano diretor, tá certo? Então a partir daí foi elaborada a proposta de lei de uso do solo, popularmente chamada de Lei de Zoneamento.

Jorge: que é 7.805 ?

Adiron: que é a 7.805 .

Jorge: de novembro de 72 .

Adiron: Um ano depois, quase. Uma primeira [PDDI] de dezembro de 71 a segunda [7.805], foi praticamente um ano para [preparar]. A preparação, principalmente a delimitação de cada perímetro de zona, era um negócio perigosíssimo... Era um negócio perigosíssimo porque as pressões em cima disso, as pressões se tornariam brutais!

Jorge: Era essa a minha pergunta.

Adiron: Porque envolvia valores imobiliários muito grandes!

Jorge: Qual foi o critério para definição?

Adiron: O critério básico, pode dar risada, foi o seguinte: [...] o Ferraz, que era um homem honesto, sabia muito bem que o negócio ia ser uma briga de foice no escuro na hora de definir os limites de cada perímetro. Então ele me chamou e disse: "Olha Adiron, eu lamento muito, mas você não vai ter mais hora de folga neste ano que vai correr enquanto você está de preparando a proposta. Você vai ter que trabalhar não oito horas, nem seis que é a sua obrigação como funcionário, você vai trabalhar doze, quatorze por dia e não vai ganhar um centavo a mais por causa disso." Eu digo "Por que prefeito? Eu tenho lá minha equipe, por que eu tenho que trabalhar tanto assim?" Ele disse: "Porque você vai ter que, pessoalmente, delimitar todos os perímetros. Vai ser a sua obrigação pessoal! Você 
não vai poder entregar isso a ninguém, ninguém! Você é a única pessoa na qual eu tenho confiança, portanto o seu trabalho vai ter que incluir, além de redigir a lei sob todos os outros aspectos, você vai ter que sentar na prancheta você mesmo, e não vai poder dar acesso a essa informação a ninguém, você não pode dar acesso a essa informação porque na hora que você der acesso começa uma briga, principalmente se esse acesso for privilegiado". Então foi isso, viu Jorge, eu passei um ano desgraçado, o pior ano da minha vida. Fiz esse trabalho, não transpirou nenhuma informação e o projeto foi para câmara dos vereadores pronto. O Ferraz chamou os vereadores... ele tinha os votos necessários na câmara, você sabe como é que monta esse sistema de a maioria necessária pelos prefeitos... Ele fez esse jogo antes. Então ele chamou os vereadores e disse: "olha vocês não vão poder ficar discutindo isso não. Toda a parte conceitual vocês vêm discutindo há dois anos, desde que começou a elaboração do Plano Diretor, que já foi aprovado. Toda a parte conceitual tem sido discutida exaustivamente, não só por vocês, vereadores, políticos como por todos os interessados: IAB, Ordem dos Advogados... Todo mundo! Os aspectos conceituais foram discutidos, os padrões foram todos discutidos, a definição dos tipos de zona e a forma pela qual cada tipo de zona seria controlado foi discutido exaustivamente por todo mundo dentro e fora da prefeitura, dentro e fora da câmara municipal. Agora, os perímetros, infelizmente vocês não vão poder ficar discutindo. Porque senão não vai dar. Primeiro porque as pressões vão ser muito violentas sobre vocês, agora que está entregue a proposta; e segundo porque isso não vai acabar nunca, nós não conseguir aprovar essa legislação nem daqui a dez anos. Então na hora que eu entregar a proposta para vocês, vocês vão ter dois ou três dias para aprovar". Isso nunca aconteceu na Câmara Municipal! E o grupo dele, que era a maioria, teve que obedecer a orientação. Receberam e aprovaram. Então realmente a proposta não transpirou em tempo útil para que houvesse uma movimentação. Foi assim!

Jorge: E qual foi o seu critério, Adiron, para a delimitação?

Adiron: Bom, agora, o meu critério: A maior parte do meu trabalho foi baseado na pesquisa Lebret, e nas atualizações que haviam sido feitas. Porque o PUB refez toda pesquisa urbana e atualizou... Isso porque a cidade tinha crescido bastante em dez anos e [o PUB] atualizou. Eu tinha todo esse material. Então este foi o critério: o que é estritamente residencial, vamos procurar nos levantamentos cadastrais e topográficos para ver qual é a situação atual. Então o critério foi baseado na estrutura que já existia, corrigida apenas dentro desta orientação de transformar a cidade numa cidade de grelhas viárias. Essa foi a correção. Então foi isso, o critério foi esse foi baseado na pesquisa urbana disponível na época. Nós tínhamos também naquela época que foi extremamente útil um levantamento topográfico cadastral.

\section{Jorge: GEGRAM}

Adiron: Não, pela VASP Cruzeiro do Sul, que havia desenvolvido um projeto, um contrato de levantamento topográfico cadastral do aglomerado. Foi contrato pela prefeitura, mas abrangia o aglomerado paulistano e que era extremamente detalhado, extremamente detalhado. Nós tínhamos ali cada prediozinho da cidade, cada construçãozinha da 
cidade eu sabia exatamente qual era o uso daquilo, era extremamente detalhado. Então aquilo foi basicamente o elemento que definiu os detalhes.

\section{Jorge: Não era o GEGRAN?}

Adiron: Foi, então você está me corrigindo sim, o contrato para o aglomerado paulistano deve ter sido feito pela GEGRAM não pela prefeitura. Pensando bem no caso a prefeitura dificilmente teria interesse por causa do custo de abranger outros municípios. Mas em todo caso era o que nós tínhamos e era muito bem feito e muito detalhado.

Jorge: O GEGRAM tem a divisão cadastral, tem as construções, as curvas de nível.

Adiron: Tem tudo.

Jorge: Mas não tem os usos.

Adiron: Não, os usos a gente ou deduzia ou apelava para o PUB ou para o Lebret. Ou ia ao local. $\mathrm{Na}$ época eu tive que usar muito serviço de helicóptero que na época era um tipo de equipamento raro, mas a prefeitura tinha um helicóptero. Então eu usei muito intensamente para dirimir duvidas quando existiam. Mas em todo caso, nós tínhamos levantamentos de equipamentos, isso nós tínhamos com bastante detalhe porque a prefeitura fez [o levantamento de] todas as escolas de todos os tipos, particulares, privadas do governo do Estado, da própria prefeitura... Isso nós tínhamos tudo localizado. E nós tínhamos um levantamento bastante detalhado de equipamentos de comércio, todas as farmácias estavam cuidadosamente localizadas e assim por diante. Nós tínhamos cadastros de uso. [...].

Jorge: E o senhor acabou não sofrendo pressões?

Adiron: Olha, por duas razões Jorge, eu vou dizer francamente a você: eu não sofri pressões por duas razoes, porque eu deveria ter sofrido assim mesmo, porque o pessoal sabia que o serviço tinha sido concentrado nas minhas costas.... Mas acontece que eu tinha uma certa fama na época; e a minha fama era de honestidade total, quer dizer, não admitia nem inicio de qualquer conversa que envolvesse qualquer tipo de proposta ilegítima... o pessoal sabia disso. Os políticos sabiam disso, o pessoal do setor imobiliário, do SECOVI principalmente, que me conhecia muito bem, do IAB... O pessoal naquela época me conhecia, então eu tinha desenvolvido uma fama de um camarada intratável, absolutamente intratável! Então eles nem arriscaram. Eu acho até interessante isso porque eu trabalhei 33 anos no setor de planejamento urbano de São Paulo; 33 anos! Nunca recebi sequer uma aproximaçãozinha de tentativa de corrupção. Curioso não é? Isso é quase impossível de acontecer hoje. Então é isso, o histórico então da coisa é essa: chegamos a lei de zoneamento através, primeiro da pesquisa Lebret depois do PUB.

Jorge: Depois, com a queda do prefeito Figueiredo Ferraz, que foi retirado da prefeitura pelo governador Laudo Natel, sai toda a equipe inclusive a equipe do COGEP.

Adiron: Todo mundo sai, foi todo mundo substituído. 
Jorge: O novo prefeito Miguel Colassuono nomeia para o seu lugar o urbanista João Leão.

Adiron: João Evangelista Leão. Que era filho de um sujeito excelente o Lucas Leão, muito bom sujeito.

Jorge: O Leão apresenta um ano depois uma nova lei de zoneamento que a lei 8001/73. O que a lei 8001 muda em relação a lei 7805 de 72 ?

Adiron: Pouca coisa para falar com franqueza. O Leão era um camarada... ele não entendia muito da coisa, ele era um engenheiro civil. Ele trabalhava, evidentemente, na EMPLASA, que era controlada pelo Colassuono, como Secretario de Planejamento do Estado. Portanto ele estava ligado ao Colassuono através trabalho que ele fazia, mas na verdade ele não era um urbanista. Mas era um bom sujeito, eu gostava muito do Leão. Um sujeito correto, viu! Então ele mudou pouca coisa. Ele acrescentou algumas zonas, fez uns detalhamentos de algumas zonas que subdividiu em vários tipos de subzonas... Basicamente foi isso que ele fez, acrescentou mais alguns dispositivos, mas rigorosamente a 8001 mudou pouco a 7.805 . [...].

Jorge: E a famosa Fórmula de Adiron, que leva seu nome?

Adiron: Na primeira lei.

Jorge: Ela surgiu na lei 7805. Foi por isso ela é conhecida com o seu nome.

Adiron: Foi por isso que ela recebeu essa designação. Como é que surgiu a Fórmula de Adiron? Isso talvez interesse a você.

Jorge: Me interessa muito.

Adiron: Então aí nós temos que lembrar o seguinte: que o trabalho do urbanista, você sabe que a maioria dos urbanistas que desenvolvem legislação, eles estão ligados ao poder público. Eles são urbanistas que estão dentro, permanentemente como funcionário de carreira do setor publico, ou eventualmente convocados, trazidos de fora durante uma administração. [...] Bom, mas o trabalho deles, seja um urbanista de carreira pública, seja um urbanista eventualmente convocado, trazido de fora para exercer funções dentro do poder público, está excessivamente amarrado pelas conveniências políticas do prefeito. [...] E dentro desse conceito de planejamento urbano local, municipal, quem manda e decide é o prefeito. A nossa estrutura política administrativa é esta. Por mais que se fale em democracia, na nossa estrutura ela não existe, porque ela concentra nas mãos de uma única pessoa todas as decisões que interessam a um aglomerado urbano, quando na verdade isso devia ser resultado da ação conjunta das parcelas da sociedade. O prefeito devia ser apenas um executor. Ele é executivo, devia executar o que foi decidido pela sociedade dentro de um sistema, de uma estrutura montada para levar a análise e decisões. Mas não é. Portanto não há nenhuma democracia sobre esse aspecto dentro da gestão político-administrativa que nós adotamos. O prefeito é quem decide tudo. Hoje continua a ser exatamente isso, ele decide tudo. Mas ele tem pelo menos um teórico 
sistema de controle que é a Câmara Municipal. A Câmara Municipal é eleita e portanto tem os representantes das parcelas da população. Então ela, teoricamente, deve exercer a função de realmente controlar a ação do prefeito, de maneira que ele não fique como um déspota, que pode decidir por conta própria o que ele bem entender. [...] Então é isto, você tem o prefeito que em última análise acaba quase sempre sendo um reizinho e você tem a câmara municipal que negocia vantagens pessoais com o prefeito. [...] Os vereadores negociam para obter vantagens para os cupinchas deles ou para os caras que pagaram eles. O prefeito tem que estar constantemente negociando. Então aquilo que o urbanista propõe, e é afinal encaminhado a aprovação legal, nem sempre é aquilo que o urbanista realmente queria. Aliás, raramente é aquilo que o urbanista realmente queria. É aquilo que se tornou possível dentro de toda esta estrutura que existe político-administrativa. Então esta primeira lei de zoneamento poderia ser muito melhor se ela tivesse sido encaminhada na forma como eu propus inicialmente. Mas eu tive que negociar por determinação do prefeito, que era um homem extremamente honesto, mas ele era político, quer dizer, estava numa função política e tinha que negociar com os vereadores. Então uma das negociações, nós havíamos estabelecidos, você que conhece a lei 7805, nós havíamos estabelecido num quadro "2" quais eram as taxas de ocupação dos terrenos permitidos em cada zona e quais os coeficientes de aproveitamento permitidos em cada zona, que eram relativamente rigorosos em face da liberdade que se existia até então. Até então a liberdade era muito grande. A primeira restrição que se fez com coeficiente de aproveitamento em São Paulo, muitos anos antes na década de 50, foi estabelecer o coeficiente máximo 6. Quem mandava, teoricamente, no planejamento urbano, como pessoa de prestígio, era o professor Anhaia Melo. E havia a tal de CPCO, não se ainda existe com esse nome até hoje: Comissão Permanente do Código de Obras. O Anhaia Melo era um dos membros do conselho da CPCO, que estudava essas coisas. E o Anhaia Melo impôs que se fosse estabelecido este coeficiente, que seria o mínimo de controle, porque não existia nenhum controle, o sujeito podia construir 10, 20 vezes a área de um terreno se ele quisesse.

Jorge: E a Lei 7.805 reduziu para 4.

Adiron: Nem isso, para o máximo 3.5. Quadro 2, veja o quadro dois: 3.5. reduziu par 3.5. $[\mathrm{CA}=] 1$ aplicava-se à $\mathrm{Z1}$ e Z2 como coeficiente de aproveitamento máximo. 2 aplicavase a Z3. 3 aplicava-se a Z4, e 3.5 aplicava-se a Z5! 3.5 não 4. De 6 para 3.5, o que era um baque para os investidores imobiliários da época, para o SECOVI, que ficou apavorado. O SECOVI era gente boa, viu. Continua ser até hoje e curiosamente uma boa parte dos caras que estão hoje aí no SECOVI era os que já estavam em 72, inclusive o Romeu Chap Chap, grande amigo, eu sempre gostei muito do Romeu Chap Chap porque ele foi contemporâneo nosso lá do Mackenzie. [...] E esse pessoal acompanhou e participou muito intensamente. A gente tem que dar crédito a esse pessoal viu? Porque eles podiam estar interessados, coorporativamente interessados no máximo de vantagens que eles pudessem tirar para o setor de construção civil, mas, honestamente, eles participaram realmente de todos os debates desde que se começou a debater o Plano Diretor de 71 e depois a Lei de Zoneamento de 72. O pessoal do SECOVI foi dos que mais participaram, e eles participaram de forma produtiva, isto é, eles traziam sugestões que muitas vezes eu levava em conta porque eram sugestões de um pessoal que tinha muita experiência nessa 
área e não podiam ser ignorados. Mas no fim veio o esse negocio do coeficiente de aproveitamento e eles acharam que esses valores que estão ai no quadro 2 , muito drásticos demais. Porque muita gente já havia adquirido terrenos, imóveis, a preços baseados no coeficiente de aproveitamento que era 6 e de repente o máximo cair para 3.5 e na maioria dos casos cair para menos do que 3.5... Então nós discutimos muito isso, viu? E eu era absolutamente inflexível. Eu dizia: "olha nós temos que colocar um pouco de ordem na casa. Para vocês isso vai ser um problema, um prejuízo talvez, mas só num primeiro impacto, porque depois as coisas se acomodam, e o mercado imobiliário se acomoda a qualquer legislação desde que seja uma legislação séria e obedecido por todo mundo. Então vocês não devem ficar tão apavorados assim. Eu acredito que alguns possam ter até algum prejuízo, mas paciência, qualquer tipo de legislação restritiva, e a nossa legislação agora vai ter que ser especialmente restritiva porque a cidade vem crescendo de forma desordenada. Então quando a gente cria uma legislação absolutamente nova ela tem que ser mais restritiva, tá certo?" Mas no fim eles me vieram com seguinte proposta... No SECOVI eram Paulo Germano, Romeu Chap Chap, Samuel Con e mais uma meia dúzia de outros cujo nome eu nem lembro mais. Mas gente boa, pessoal bom. Eu discutia com eles de forma bastante profissional. Eles me vieram com a seguinte proposta: escuta nós não podíamos, através de uma negociação, quem sabe pagando taxas extras ou coisa assim, nós não podíamos obter um coeficiente melhor? Eu ouvi essa proposta e disse: Não! Não podemos, não podemos! Mas se vocês quiserem negociar outra coisa eu aceito a negociação. Vocês têm aqui nesse quadro 2, na proposta de lei, a taxa de ocupação, que a meu ver é generosa, e não difere muito daquilo que é permitido no Código de Obras. [...] Então vamos negociar isso, não vamos negociar vocês pagarem uma taxa por fora para obter um coeficiente maior porque isso aí vira negociata, deixa de ser negociação e vira negociata! Vamos negociar a taxa de ocupação? Então vamos. Então começamos a negociar e levamos eu diria que um mês debatendo a negociação em torno da taxa de ocupação.

Jorge: E qual era a intenção de em relacionar o coeficiente de aproveitamento com a taxa de ocupação?

Adiron: Isto é muito importante porque, veja Jorge, você sabe muito bem o que é a taxa de ocupação, você tem um lote e pela legislação, você só pode ocupar uma parte deste lote com a projeção da edificação, e o restante tem que ficar livre de edificação. Por que? Para você melhorar, certamente, as condições de insolação, as condições de ventilação dos aposentos... É um problema basicamente de salubridade. Como era a legislação anterior? Havia um mínimo que era fixado e como não havia zonas, era fixado de um modo geral, genérico para as edificações. Em muitos casos não havia nenhum recuo obrigatório, quer dizer, se você tinha uma face que não tinha nenhum vão de iluminação e de ventilação você podia encostar [no recuo], se você tinha duas faces que não tinha vãos, você podia encostar. Então se as únicas faces que tinha ventilação fossem essas duas, só essas duas é que tinham que ter recuo. Era esta a legislação. Fazendo um parênteses com a questão do coeficiente de aproveitamento, a legislação também era deficiente, porque a legislação original do código de obras determinava um gabarito que em última análise era o que determinava o aproveitamento. A legislação em torno do gabarito tinha a ver com a largura da via pública. Então se você podia construir no alinhamento você tinha uma Fórmula matemática em que podia chegar ao gabarito X. Mas se você aumentasse 
o recuo, ou fizesse um recuo por sua conta, não obrigatório, você ficava com uma largura maior entre a outra face, e aí você podia aumentar [a altura do prédio].

Jorge: Tinha uma representação que saía num ângulo, do outro lado da rua...

Adiron: Isso, era isso. Então qual era forma? Qual era a forma típica das edificações na época? Era escadinha. Quer dizer, o cara ele fazia alguns andares aqui, depois para poder aumentar um pouco ele fazia aqui, chegava ali no limite e a forma final era a escadinha. Horrorosa do ponto de vista arquitetura, era uma desgraça! Mas era esta legislação. Isto aqui era o que o Sangirardi defendia. É por isso que eu briguei tanto com ele, briguei muito do ponto de vista conceitual porque isso aqui era o que ele defendia. Eu disse "não, vamos negociar a taxa de ocupação. Vocês vão poder receber como bônus um coeficiente de aproveitamento maior, que é o que vocês querem, ou seja, uma área construída maior para vocês venderem, vocês vão poder vender mais edificação, desde que vocês estabeleçam uma forma pela qual quanto mais área livre vocês deixarem em torno da edificação, mais vocês possam construir. Não é subir, não é questão de gabarito, mas de área construída. Qual era a vantagem de você obter espaço vazio maior nas edificações? Havia várias vantagens as que eu coloquei para eles foram as seguintes: "primeira vantagem, do ponto de vista de forma das edificações, vocês vão poder desenvolver projetos muito mais limpos acabar com esse negócio de escadinha. Vocês não vão depender de escadinha e de largura de rua. Vocês vão depender só de área vazias que vocês vão ter que deixar a mais. Então, vocês vão poder desenvolver projetos de melhor padrão arquitetônico. Esta é a primeira! Segunda: vocês evidentemente vão ter que aumentar todos os recuos, tá certo? Para poder deixar mais áreas livres só aumentando os recuos em relação a edificação. Isto em termos de salubridade é extremamente favorável. Mais ventilação, mais insolação". Mas a terceira disse a eles; ninguém falou nisso na época, ninguém discutia isso, ninguém, isto foi uma inovação que eu introduzi na discussão do problema exatamente nesta época. "Terceira é que nós vamos poder deixar mais áreas de infiltração para as águas pluviais nas edificações. Isto que eu considero de extrema importância porque vocês conhecem o problema de inundações em São Paulo e vocês estão sabendo que uma das causas importantes do problema de inundações periódicas é a impermeabilização do piso da cidade através das edificações e através da pavimentação das vias públicas... Vai sobrando cada vez menos solo livre para a infiltração. Eu vou colocar que a área que vocês tiveram que deixar vai ter que ser obrigatoriamente sem impermeabilização, jardim, área não impermeabilizada, porque vocês podem deixar esta área aqui e depois usar para estacionamento pavimentando ruas, etc, e não vai adiantar nada."

Jorge: De qualquer forma tinha o subsolo embaixo que ocupava o terreno inteiro...

Adiron: É o que eu falo, acabou não funcionando porque isso aí foi uma das alterações que você me perguntou, esse negócio da 8.001 .

Jorge: Você citou o professor Anhaia Mello, pelo que eu sei, você me corrija se eu estiver errado, o Anhaia Melo era um mentor intelectual desse pessoal do planejamento da COGEP ele teve uma briga histórica com o Prestes Maia. O Anhaia Melo queria uma cidade de densidades mais baixas. 
Adiron: Ele queria uma cidade mais horizontal.

Jorge: E eu não sei se você compartilhava dessa idéia do Anhaia Melo, de cidade de baixas densidades baseada no automóvel, ou seja, ela era mais espraiada. A pergunta que faço: como que você enxerga esse adensamento provocado pela aplicação da fórmula? Porque a aplicação da formula proporcionou um adensamento.

Adiron: Primeiro o Anhaia Melo. Ele foi um pioneiro, ele tinha uma noção bastante boa do que fosse planejamento urbano. Ainda não tão completa como se tem hoje, mas em todo caso ele tinha uma idéia muito mais completa do que o Prestes Maia tinha do que fosse planejamento urbano. O Prestes Maia era conhecido como urbanista mas ele era só um viarista, só. O Anhaia Melo tinha horizontes mais largos e ele foi de fato o mentor do planejamento urbano durante muitos anos. Não da COGEP, porque naquela época ele já estava afastado. Eu não tive um convívio, a não ser muito limitado, com o Anhaia Melo no começo da minha carreira, quando eu não era pessoa importante no Departamento de Urbanismo, era um engenheiro padrão zero... Tive um pequeníssimo contato com ele. Mas gostava, admirava muito o professor Anhaia Melo, ele foi pioneiro em questão de divulgar o conceito mais completo de planejamento urbano. Quando eu comecei de fato a ter uma atuação maior, que foi com a COGEP, ele já estava afastado. Ele não teve na COGEP nem no GEP anterior. No PUB ele já estava muito velhinho, era muito respeitado mas não tinha mais uma atuação. Eu diria que a atuação dele foi até final da década de 50. No tempo da pesquisa do Lebret ele era uma pessoa que tinha uma atuação bastante razoável. Bom, agora essa questão de adensamento, deixe eu lhe contar, eu posso, posso fazer umas viagens em volta do assunto que não tem nada a ver com isto?

Jorge: Claro.

Adiron: Um dos meus maiores amigos em termos profissionais e em termos de amizade pessoal foi o arquiteto Oswaldo Bractk , não sei se você conheceu pessoalmente o Oswaldo Bractk?

Jorge: Pessoalmente não.

Adiron: um homem excelente, excelente. Primeiro um grande arquiteto. Sem sombra de dúvida, um dos grandes arquitetos que nós tivemos no país.

Jorge: Com certeza.

Adiron: Segundo, uma pessoa extremamente estimada. Eu e o Bratck fomos amigos fraternos durante mais de 40 anos, e discutimos muito em torno de todos os aspectos pertinentes ao desenvolvimento urbano, à estrutura urbana. Eu não discutia arquitetura porque eu não tinha altura suficiente para discutir esse assunto com ele, não dava, ele era muito, muito superior. Mas eu discutia planejamento urbano com ele porque nesta área ele me considerava um especialista, e então era ele quem me pedia opiniões e freqüentemente orientação para alguns trabalhos que ele chegou a fazer e que envolviam planejamento urbano. Aí ele nunca deixava de me chamar e de me pedir esclarecimentos. 
Durante 40 anos, no mínimo uma vez por mês, e às vezes até mais, eu ia almoçar com Bratck na chácara que ele tinha em Itapecerica da Serra. Por sinal uma linda chácara em Itapecerica da Serra, linda, onde ele reunia, todos os finais de semana, os amigos dele para bater papo e para almoçar com ele. Ele já estava ficando velhinho, ele e a esposa dele, então era a forma que ele achava de reunir o grupo que ele gostava, de gente que ele gostava para conversar e oferecer a eles um almoço, que era sábado ou domingo. Havia um grupo que ia no sábado, ... você conheceu o Golfio?

\section{Jorge: Não.}

Adiron: Golfio, arquiteto trabalhou muitos anos com Brackt, depois teve o escritório próprio dele. Era um chileno que fugiu da ditadura do Pinochet e veio pro Brasil. Esse era grande amigo porque trabalhou no escritório do Brackt, trabalhou junto com Bratck durante muitos anos. Esse ia sábado e domingo! Ele era solteirão, tava sempre lá. O Golfio era conviva obrigatório. E eu ia no mínimo uma vez por mês almoçar com ele, ou sábado ou domingo. Então isso me permitia conversar bastante com ele e com outros arquitetos e outros companheiros nem sempre arquitetos. As vezes eram até banqueiros e outros amigos do Bratck. O Bratck trabalhava para gente rica... O único defeito que eu via no Brackt, como arquiteto, sempre foi esse: ele só trabalhou para gente rica a vida inteira. Nunca fez trabalhos que não fosse para gente rica. Ganhou dinheiro por causa disso, se tornou um homem rico. Não só por causa disso... Ele acertou um determinado negócio que fez em que recebeu parte dos honorários... Ele projetou o bairro do Morumbi pro Ademar de Barros e recebeu como parte do pagamento uma enorme área e com isso ele enriqueceu porque o negócio valorizou mesmo. Valorizou mesmo! Mas o Bratck tinha um conceito de desenvolvimento urbano, de utopia urbana que era diferente do meu. Para ele a cidade tinha que ser "o retorno ao campo". Portanto a cidade tinha que ter essa característica de baixa densidade.

\section{Jorge: Cidade jardim?}

Adiron: Cidade jardim. E nos projetos que ele fez, um deles famoso, a Vila Serra do Navio, não sei se você já ouviu falar?

\section{Jorge: Sim.}

Adiron: A Vila Serra do Navio tinha essa característica, era uma cidade horizontalíssima, tudo térrea, então baixíssima densidade. Este era o conceito de Oswaldo Brackt. E eu atendendo a pedidos dele, ele foi muito insistente, eu escrevi um livro sobre a Vila Serra do Navio. Ele me pediu porque quis que o projeto que ele fez para Serra do Navio fosse analisada por um especialista que ressaltasse as qualidades e até os defeitos daquele projeto urbanístico. Era um projeto urbanístico, não era só arquitetônico, era um projeto urbanístico. E por insistência dele eu acabei escrevendo o livro sobre a Vila Serra do Navio o qual eu introduzi algumas criticas. Bom, o livro foi editado pela editora Pini, que tinha um arquiteto que fazia toda a programação gráfica do livro e por causa disso tinha que ler. Um dia o cara, nem me lembro o nome dele, mas um dia ele me procurou e disse: "escuta você é amigo ou inimigo do Brackt?". Digo: "somos amigos". "Não, porque tem 
algumas coisas que você está dizendo aqui... Você está sentando o pau no projeto dele, você não pode fazer isso!" Eu digo: "Posso! Posso e ele até gostou e ele até me agradeceu porque era isso que ele queria, uma pessoa honesta examinando o projeto que ele fez. Portanto eu não sou inimigo do Bratck não, sou amigo dele!" Bom, então o conceito que o Bratck tinha era de retorno ao campo, era de cidade jardim. Mais tarde, alguns anos depois desse livro da Serra do Navio, ele me propôs escrevermos um segundo livro. Então seria um livro em que alguns outros projetos que ele e fez que não foram executados, alguns dos quais eu tinha até participado, tinha me associado a ele para desenvolver mas infelizmente não foram executados. Ele queria que esses projetos fossem apresentados para os estudiosos do assunto, estudantes de arquitetura principalmente, que tivessem interessados em planejamento urbano, tivessem mais material para estudar esses conceitos de planejamento urbano. Eram projetos que envolviam muita conceituação de planejamento. Era um grande projeto para uma grande mineradora, MBR, ali na vizinhança de Belo Horizonte. Hoje ainda é uma área de exploração de mineral, de ferro, e a MBR tinha uma extraordinária área, muito grande, naquela região, parte da área explorava o minério de ferro e continua explorando até hoje, mas grande parte da área não ia ser usada para a exploração porque não tinha as características de formação geológica, mas estava lá, área linda, viu. Então a MBR que gostava muito do Bratck já tinha encomendado dele o projeto da Vila Serra do Navio; foi a MBR que encomendou esse projeto para o Bratck na década de 50. Então a MBR pediu para o Bratck fazer um estudo de reaproveitamento de toda área que não ia ser usada para fins de mineração naquela região próxima de Belo Horizonte. E o Bratck então começou a fazer esse estudo e me pediu para trabalhar junto com ele. O Golfio trabalhou conosco e mais algumas outras pessoas, um grupo, ele montou um grupo e nós tivemos trabalhando naquilo durante bastante tempo. Mas toda a orientação do Bratck era nesse sentido, cidade de baixíssima densidade. Ele propôs ali, na verdade, a criação de uma cidade satélite junto a Belo Horizonte. Padrão muito alto, padrão muito alto, mas com essa característica de horizontalidade de baixa densidade. $\mathrm{Na}$ época eu discuti muito com ele sobre isto. Então neste livro que ele me pediu para escrever, o capitulo final... Era um livro que examinava vários projetos ele desenvolveu, um projeto muito interessante no litoral do Rio de Janeiro, que era um projeto muito bonito; o cara era um arquiteto espetacular, era espetacular! Como arquiteto o cara era espetacular. [...] Mas nós nos reunimos então na casa dele; ele tinha um escritório, um lugar gostoso, onde ele trabalhava ainda. Eu o Golfio íamos lá passarmos algumas horas toda semana desenvolvendo esse livro. [...] A gente discutia, usava esse sistema de gravar todas as nossas reuniões e depois eu pegava as gravações e ia traduzindo aquilo em texto escrito. O último capítulo era isto: utopia! Qual como vai ser a cidade do futuro? Como vai ser a cidade do futuro? Em última análise o que todo urbanista está preocupado é saber como vai ser a cidade do futuro. Eu propus a ele que nós desenvolvêssemos três propostas de cidade do futuro, três: uma seria a proposta dele, Brackt; outra a proposta do Golfio, excelente arquiteto, já faleceu infelizmente; e outra seria minha proposta de cidade do futuro. Seriam três modelos oferecidos então aos estudiosos que eventualmente gostariam de ver três propostas de cidade do futuro. E a proposta do Bratck que foi desenvolvida era evidentemente o retorno ao campo, era uma cidade horizontal com muito espaço e como conseqüência um sistema viário extremamente desenvolvido para poder permitir a circulação de um ponto ao outro sempre. Defeito da baixa densidade é que ela força a ampliação desmedida do sistema viário, esse é o defeito que eu sempre 
achei neste tipo de solução. Muito bonito em termos de utopia, mas a meu ver não tem nada a ver com o que vai ser a sociedade do futuro. A meu ver o aglomerado urbano tem que traduzir a sociedade, tem que ter a forma para conter adequadamente a sociedade na forma pela qual ela se organiza e funciona. Esta é a minha visão de qual seja a utopia, qual deva ser o planejamento urbano. O Golfio desenvolveu a proposta, dele que era intermediária. O Golfio era chileno, mas eu diria que ele era mais mineiro, ele não gostava de ir nem muito contra um, nem contra o outro, nem muito a favor, ele ficava numa posição sempre intermediária. E a minha proposta, que não é de fato o que eu considero o ideal, mas como já tínhamos duas propostas com dois modelos, eu peguei e desenvolvi uma proposta de um terceiro modelo extremo, que era proposta de adensamento através de edificações de grande porte. Na minha proposta então você perguntou qual seria a minha opinião, não é bem esta, mas numa proposta em que a gente está pensando em qual vai ser a cidade do futuro eu enxerguei o seguinte: que a cidade do futuro vai ser uma sociedade em que a organização vai ser extremamente comunitária, vai ser muito mais próxima do desenvolvimento de atividades em comum do que do individualismo. Estamos caminhando muito mais para o desenvolvimento de atividades em comum do que para o individualismo que é o que caracteriza as propostas urbanas de baixa densidade. E que o transporte na cidade do futuro não vai ser mais o transporte individual, isso vai acabar, o transporte vai ser sempre coletivo, sempre, e que, portanto a cidade do futuro vai ser uma cidade coletiva em que você vai concentrar todas as atividades dentro de estruturas gigantescas. Então a minha proposta eram de edifícios com um quilômetro de altura, mil metros de altura.

Jorge: Em que época é essa?

Adiron: Isto foi agora, recentemente, o Bratck tinha 85 anos, então isso faz dez anos, quase dez anos. Esta ia ser, e eu acredito que vá ser, não é que eu gostaria muito que fosse não, isso é que acredito que vai ser a cidade, eu acredito que esta vai ser a cidade do futuro. E cada uma dessas estruturas seria uma cidade, uma cidade dentro de uma única estrutura, em que você tem tudo, com transporte vertical, e parcialmente com transporte horizontal. Você tem tudo, trabalho, lazer, serviços, todas as atividades concentradas. Qual é a característica da organização do espaço? Você tem, primeiro, o problema de salubridade. Você tem que assegurar num projeto deste tipo as características de salubridade para as áreas utilizadas. Isto a arquitetura vai ter que desenvolver projetos que assegurem este tipo de salubridade. Segundo, o problema de deslocamentos verticais e horizontais que você tem que resolver através de projetos de arquitetura, e você tem que ter tudo ali, tudo. E qual é a conseqüência em termos de organização de espaço? A conseqüência é esta: você vai concentrar as atividades e você vai deixar [o resto] como área verde. Ao invés de você ter isto aqui, tudo cheio de vias e com um pouquinho de área verde no meio disso, não você vai ter tudo isso de área verde e com todas as atividades [concentradas] aqui. Então você saiu daqui, ai sim você cai no campo, agricultura e lazer. Esta era a minha proposta extrema. Eu discuti muito com o Bratck ele não aceitava isso de jeito nenhum. Ele disse "não, não é isso". Todos os projetos de arquitetura dele tinham essa característica de horizontalidade. No fim nós terminamos o livro, o livro estava prontinho, mas ele não queria que eu incluísse a minha proposta, ele não aceitava. Ele estava com 89 anos, 90 anos, mas ainda era muito briguentos. Ele diz "não, Adiron, 
me faz esse favor em especial tira essa sua proposta”... E o Golfio estava com ele. Eu digo "não tiro, caro Brackt. O que posso eu fazer é o seguinte: eu saio do livro e vocês dois publicam o restante. Eu saio do livro, pura e simplesmente. Mas, não é que eu gostaria não, Bratck, eu também gostaria de morar no campo da mesma forma que você, num lugar assim gostoso, eu também sou individualista, mas a sociedade do futuro não vai ser individualista, infelizmente. E eu como urbanista, a visão que eu tenho da sociedade do futuro não é uma sociedade individualista, é de uma sociedade comunitária, então eu tenho que ser coerente com a visão que eu tenho do futuro, esta vai ser a cidade do futuro: 100 de espaço verde e 1 de área ocupada é isto". E não publicamos o livro, hein! Mas não foi por isso não. No fim ele já velhinho, já muito mal de saúde... Ele estava de fato muito mal de saúde. Nós contratamos a editora Pini que preparou a edição toda, estava prontinho o livro para entrar no prelo... Aí o Bratck morreu. E os filhos dele que sabiam que ele queria mudar isso aqui... Os filhos dele se recusaram a prosseguir, não foi por minha culpa que não publicamos, foi os filhos, o Carlos e o Roberto que sabiam que o Oswaldo tinha objeções a publicar esta minha proposta no livro, eles então decidiram não publicar. Está bom, eles disseram "não você pode publicar em seu nome, o livro todo" disseram eles. Eu digo: "eu não faço isso de jeito nenhum, esqueça, esqueçam o assunto". Então foi esquecido o assunto. O livro está pronto...

Jorge: Quem sabe um dia ainda, não é?

Adiron: E é um bonito livro viu! É um livro bonito, inclusive a parte dos projetos do Bratck não conhecidos... Bonitos, lindos os projetos, mas não foi publicado, infelizmente.

Jorge: Adiron, eu tenho uma questão em relação a Fórmula que se refere a Z2, Z11, Z17, Z18... ? Por que na Z2 principalmente, que é a grande área da cidade, só se pode aplicar a Fórmula de Adiron e conseguir o coeficiente a mais, para a categoria de uso conjunto residencial?

Adiron: Residencial, só residencial. É por causa da estrutura...

Jorge: É que não é só residencial. Porque tinha a R2-02 que era prédio residenciai e tinha o conjunto residencial R3-01 ou 02, conjunto residencial, que era mais restritiva ainda por conta da exigência do círculo de 16 metros.

Adiron: Então veja bem, era por causa da estrutura que havia sido proposta para a cidade. Havia sido proposta essa estrutura que eu mostrei para você em que nos interessava que cada unidade escalonada ou unidades urbanas escalonadas tivesse uma característica que era a seguinte: ela teria, por exemplo, a unidade elementar que seria a unidade residencial; ela teria um centrozinho comercial e de serviços para um raio de atendimento mais ou menos definido para atender determinados tipos de necessidades da população que pudessem ser alcançados a pé. Mas isso tinha que ser concentrado num ponto, tanto quanto possível do ponto de vista teórico, não do ponto de vista prático isso não ocorreria nunca, tanto quanto possível eqüidistante dos limites, para que todos os moradores daquela unidade pudessem chegar aqui a pé. O deslocamento dentro da unidade elementar seria sempre a pé. 500 metros era o limite que nós estabelecíamos para a unidade 
elementar. Então não nos interessava que começasse a ser jogado uma coisa aqui, uma coisa ali para o cara que está aqui ter que caminhar um quilômetro até chegar lá, nós queríamos tanto quanto possível criar um núcleo, um núcleo de prestação de serviço e um pequeno comércio que pudesse ser alcançado a pé.

Jorge: Que era Z3 e a Z4.

Adiron: Então, que seria a Z3, tá certo? Agora depois que você somasse várias dessas unidades elementares, você teria um centro maior um pouco, em que você já podia se deslocar de ônibus ou de carro para chegar lá, mas tanto quanto possível também concentrado, mas não começar dispersar isso um pedacinho aqui, um pedacinho lá porque senão você perderia a organicidade. E quando você juntasse várias dessas unidades de segundo grau, formasse uma unidade que nós chamando então de distrito que seria hoje a Subprefeitura. Então você teria um centro completo, em que teria governo, que teria uma série de equipamentos para atender as necessidades de uma população muito maior, mas tanto quanto possível geograficamente também eqüidistante, então era esta a orientação da legislação de zoneamento, do plano diretor, primeiro do Plano Diretor e depois como conseqüência da legislação do zoneamento, da lei 7805 .

Jorge: Ou seja, se eu entendi na Z2, a Fórmula de Adiron só permite o incentivo do coeficiente a mais apenas para uso residencial para não acontecer de dispersar o comércio?

Adiron: Para não dispersar, para manter a estrutura urbana que estava sendo proposta, para não criar então esta pulverização que desestruturaria o sistema viário. Porque o sistema viário é conseqüência do uso, ele tem que ser conseqüência do uso, está certo? A razão pela qual a Fórmula de Adiron foi aplicada apenas para uso residencial na Zona Z2: é que nós não queríamos que houvesse uma dispersão, que permanecesse o objetivo da legislação de criar núcleos de atendimento geograficamente acessíveis na unidade elementar a pé e nas outras unidades com transporte coletivo simples, o uso do automóvel era deixado só para trajetos maiores. O nosso objetivo não era estimular o uso de automóvel, muita gente fala que a grelhas de vias expressas era um estímulo ao uso do automóvel. Seria se não tivesse como base todo esse tipo de estruturação urbana em que o uso do automóvel era tanto quanto possível dispensável. Essa grelha de vias expressas que não foi executada como eu lhe disse, passou a receber uma denominação jocosa e pejorativa exatamente porque não foi executada, passou a ser chamada de grelha de vias impressas! Porque ela só existia no papel, tá certo? [risos]

Jorge: Eu só tenho mais duas perguntas. Bom, em 75 sai Laudo Natel, entra o Paulo Egidio que nomeia como prefeito o Olavo Setúbal, e você, por sua vez, retorna a Coordenadoria. Esse seu retorno durou um ano, como foi esse retorno a COGEP? Você teve oportunidade de rever a Lei 8001 do Leão ? Isso era necessário ou nem era necessário?

Adiron: [...] O meu retorno então OK. Saiu o Ferraz que foi chutado para fora, levou um pontapé no traseiro do Laudo Natel, essa história é muito conhecida. E eu sai junto com ele, evidente. Todo mundo que estava com ele saiu junto com o Ferraz. Então foi colocado lá Miguel Colassuono o qual eu não tenho nenhuma admiração, nenhuma. E 
foi colocado na COGEP o Evangelista Leão, que é ótima pessoa, mas que não era de fato uma pessoa que tivesse experiência nesta área. Não tinha. Tinha pouca experiência. Mas era um homem honesto, era um homem correto, extremamente correto. A lei 8001 já estava pronta quando ele assumiu, mas estava na fase de discussão. Na verdade fui quem elaborei basicamente a lei porque eu entendia que toda legislação de zoneamento, da mesma forma que o plano diretor, tinha que ser dinâmica, tinha que ir a medida que a experiência fosse demonstrando necessidade e sofrendo modificações. Então a lei estava pronta, o texto estava praticamente pronto. E ele então recebeu do Colassuono a incumbência de dar os retoques finais e coloca-la em condições de ser enviada a câmara. Ele deu os retoques... Sofreu infelizmente uma série de pressões em alguns pontos dos quais eu não tinha aceitado a pressão... E ele cedeu porque o Colossoano cedeu, não é porque ele pessoalmente... Cedeu algumas coisas que não eram boas, que não eram realmente boas. Foram para atender a interesses de terceiros, escusos. O Colossoano, eu não tinha nenhuma admiração por ele, nenhuma, nunca tive nenhuma admiração, eu tinha uma série de restrições pessoais com ele. Mas então foi encaminhada a proposta, o projeto da lei 8001 com aquelas alterações com as quais eu provavelmente na época não teria aceitado e foram aprovadas e ela veio substituir a 7805 . Ela era, eu diria $80 \%$ a lei 7805 que continuava, com $20 \%$ de modificações, algumas saudáveis, algumas não tanto. Então foi isto que ocorreu com a lei 8001. Era uma associação saudável da 7805, da lei de zoneamento original, porque a lei de zoneamento, como planejamento urbano é dinâmico, tem que sofrer continuamente as alterações ditadas pelas mudanças tecnológicas e sociais que vão ocorrendo no aglomerado urbano. A lei não pode ficar parada ali como se fosse uma cadeia, como se fosse uma corrente prendendo a cidade, tá certo? Mas continuou a prevalecer a Fórmula de Adiron para esses aspectos que eu expliquei. A origem da Fórmula de Adiron foi aquela que expliquei a você: uma discussão que eu tive com o pessoal do SECOVI e chegamos a fórmula original. Eu não vou dizer que é produção matemática minha não... Eu estabeleci as condições: eu quero isto, eu que quero negociar a taxa de ocupação, se vocês me apresentarem alguma coisa em que a taxa de ocupação se reduza eu estudo, se for razoável, eu aceito.

Jorge: Essas modificações nem tão saudáveis que foram feitas na 8001, quando você voltou para a COGEP não era o caso de rever?

Adiron: Olha quando eu voltei para a COGEP, então você me pergunta por que eu voltei para a COGEP, por que eu voltei para a COGEP? Porque eu não era amigo do Setúbal coisa nenhuma nem conhecia pessoalmente o Setúbal. Eu era e continuava a ser amigo do Robertão, que tinha estado conosco na prefeitura mas que naquela época, como ele era grande amigo do Paulo Egídio também, naquela época o Robertão tinha ido ser Secretário dos Negócios Metropolitanos do Estado. Mas o Setúbal sim, era amigo do Robertão. Ele e o Ferraz tinham sido contemporâneos e talvez até colegas de classe na Politécnica. Então o Setúbal telefonou para o Robertão, que era Secretário dos Negócios Metropolitanos do Paulo Egídio, recém nomeado Governador do Estado e disse: "Escuta o Paulo Egídio está me pedindo para assumir a prefeitura, eu ainda não respondi, o que você acha?" O Robertão disse "acho que é uma boa idéia, é um trabalho bonito, é sempre um negócio bonito, você é uma pessoa que tem muita experiência administrativa, acho que seria muito bom para a cidade de São de Paulo se concordasse em aceitar o convite". en- 
tão ele disse "sim, ok, aliás, eu já estava propenso a aceitar, mas eu preciso conversar... Eu gostaria de conversar com você pois eu queria conversar com uma pessoa que conhecesse a prefeitura a fundo. Antes de assumir eu quero ter todas as informações". Era um homem, evidentemente, um administrador de muita experiência, de uma inteligência brilhante, brilhante o Setúbal. "Então eu queria ter um bom papo com você porque eu quero conhecer o máximo sobre as características da prefeitura e tudo mais". Então vira o Robertão para ele e diz: "eu fiquei lá dois anos. Quem conhece isso é o Adiron, ele é o especialista em organização interna da prefeitura. Conversa com ele”. E o Setúbal me telefonou. Ele era o presidente do aglomerado do Itaú e sob este aspecto eu conhecia o nome dele, eu sabia o quem ele era. Então ele telefona e eu vou atender meu telefone aqui, já morava nesta casa, diz: "Aqui é o Olavo Setúbal". Cocei a cabeça... "Olavo Setúbal, eu conheço alguém com esse nome... O único Olavo Setúbal que eu ouvi falar é o presidente do Itaú. Será que eu estou com problema no Itaú? [risos] Tão sério que até o presidente... [risos]. Não tenho um tostão no Itaú". Nem conta eu tinha no Itaú. Eu digo "pois não presidente, o que o senhor precisa?" Ele disse "olha, eu falei com o Robertão, eu estou sendo convidado, é confidencial por favor, eu não quero que essa informação vaze, eu estou sendo convidado pelo Paulo Egídio para assumir a prefeitura". Era nomeação, o prefeito era nomeação do governador. "Estou sendo convidado para assumir a prefeitura. E eu conversei com Robertão que é meu colega de Politécnica e que eu sei que ele conhece bem a prefeitura porque ele esteve lá com o Figueiredo Ferraz, e ele me disse que a pessoa que realmente entende daquilo é você. Então que queria bater um papo com você para ter pelo menos um conhecimento das características básicas da estrutura, do funcionamento daquele negócio. Você quer marcar, você pode marcar uma hora comigo para a gente conversar?" Eu digo "pois não, eu sou aliás funcionário de carreira da prefeitura, se você é o futuro prefeito eu sou obrigado a atender a sua convocação. Não é nem questão de saber se eu quero [risos], aí não tem muito o que discutir". "Então por favor, venha aqui amanhã tal hora, me procure". A sede do Itaú na época era no centro, na Quinze de Novembro. "Venha aqui e tal e procure na portaria pelo Cláudio Lembo, peça para falar com o Cláudio Lembo, ele é meu assessor e vai te trazer então ao meu gabinete". No dia seguinte eu fui lá na hora que ele tinha marcado, lá na portaria e disse que estava ali na convocação de Olavo Setúbal, mas quem me atenderia era o Cláudio Lembo. Então desceu o Cláudio Lembo que era oficial de gabinete do Setúbal, lá no banco Itaú, assessor jurídico, e o Lembo então me levou ao gabinete do Setúbal e participou da nossa conversa lá durante uns quinze minutos, depois ele tinha outras coisas para tratar e foi embora. Então eu fiquei duas horas conversando com o Setúbal explicando a ele o que era a prefeitura, como é que a coisa funcionava, quais eram as características operacionais de cada secretaria, quais eram as atribuições de cada secretaria, que tipo de pessoal ele ia encontrar em termos de competência em cada área, porque eu conhecia bem, conhecia bem a prefeitura naquela época e a prefeitura também não era tão grande como é agora, cresceu muito. Então a nossa conversa levou duas horas, no fim ele me agradeceu e fez todas as perguntas que ele achou que seriam pertinentes, eu respondi naquilo que era possível responder, ele me agradeceu muito e disse o seguinte: "você não quer me fazer um favor?", diz ele, “Você que conhece o pessoal da prefeitura o pessoal de melhor nível, eu não quero levar o pessoal do Itaú para lá, eu acho que não vou despir um santo para vestir outro, eu preciso do pessoal do banco Itaú aqui no banco Itaú. Eu quero usar o máximo do pessoal da prefeitura". Isso aliás é básico em termos de organização de grupos de tra- 
balho, não é? A experiência. "Eu quero usar o máximo que for possível o pessoal da prefeitura. Então você não quer me preparar uma lista do pessoal melhor da prefeitura em cada área, me prepare uma lista do pessoal melhor que você possa me recomendar em cada área." Eu digo "pois não, mas isso leva algum tempo, eu não posso sacar de cabeça na hora, eu tenho que pensar um pouco, analisar um pouco. Eu posso entregar uma lista amanhã; eu vou levar, sei lá duas, três horas preparando essa lista". Ele disse "então me faça o favor, encaminhe amanhã por escrito e peça para entregar para o Cláudio Lembo que ele me traz". Então eu voltei para casa sentei, fiquei duas ou três horas aqui nessa mesa preparando uma lista daquilo que eu conhecia do pessoal da prefeitura e indicando quais seriam as pessoas de maior experiência e ou de maior confiabilidade para ocupar cada tipo de função. Foi uma lista bastante grande que eu acabei transformando numa espécie de quadro, uma tabela que eu atribui notas. Então foi detalhado, eu levei quatro horas fazendo o trabalho, eu atribui notas, quer dizer: fulano de tal, ele pode assumir tais, ou tais ou tais funções. Ele é melhor nisto, tá certo? Fulano de tal pode tal e tal, ele é melhor nisto. E assim por diante. Tinha lá, sei lá, uma centena de pessoas que eu conhecia bem, recomendadas para ocupar então as variadas funções importantes. O secretariado não, porque o secretariado é sempre político, quer dizer o prefeito ele nomeia de acordo com o interesse dos partidos que o estão apoiando, mas o pessoal a partir de diretor sim. Levei lá no Banco Itaú, dentro de um envelope grande, entreguei lá para o cara e disse "olha, entregue isso aí para o Dr. Cláudio Lembo que ele sabe o que é". E vim embora e não pensei mais no assunto, não pensei mais no assunto, voltei para casa. Daí a dois dias saiu publicado nos jornais o secretariado municipal do Olavo Setúbal, e tive a desagradável surpresa de verificar que eu estava colocado ali, novamente como coordenador da COGEP, que era secretaria de planejamento, novamente. Eu liguei para o Setúbal... Para conseguir falar com presidente do Itaú era sempre muito complicado, mas em todo caso depois de vai para lá e vem para cá durante bastante tempo, eu consegui falar com ele e disse: "Olha prefeito, eu estou vendo aqui no diário oficial que eu fui nomeado novamente coordenador da COGEP. Estou lhe telefonando para dizer que não aceito a nomeação, não quero mais ser coordenador da COGEP. Fiquei muito ressentido com a forma pela a qual o Ferraz foi colocado para fora da prefeitura pelo Laudo Natel, fiquei ressentido, não foi justo, não foi uma forma justa nem decente. Não quero voltar mais para este tipo de função. Eu vou trabalhar com vocês na prefeitura com o maior prazer, dentro da minha área de planejamento urbano, mas secretário eu não sou, eu não quero mais, eu não aceito mais. E mais ainda, eu já combinei e já acertei com o Robertão, nosso amigo comum, que eu vou trabalhar com ele, não na prefeitura, mas no Governo do Estado, vou ser presidente da EMPLASA, me interessa muito mais do que ficar aqui na Prefeitura. Eu estou muito mais interessado em planejamento regional do que em planejamento local, então isso já está acertado, lamento bastante". O Setúbal não disse nada, ele disse "ah! deixa comigo", e desligou o telefone. Daí a meia hora me telefona o Robertão, com quem eu já tinha acertado que eu ia trabalhar com ele, estava tudo certinho, ia ser presidente da EMPLASA. Me telefona o Robertão e muito sem jeito e desviando para cá e para lá o Robertão disse "Olha Adiron esquece aquele negócio de trabalhar na EMPLASA, vai. O Setúbal me telefonou e você vai ter que trabalhar com ele, ele não quer nem conversa. Diz ele que não aceita nenhum tipo de objeção. Ele é um camarada autoritário, extremamente autoritário... Ele disse que você já foi designado para trabalhar lá e não tem que espernear e nem recusar... De maneira que lamento muito, eu não posso entrar em atrito com 
Setúbal porque aí eu vou entrar em atrito com o Paulo Egídio que é amigão do Setúbal, não dá! Lamento muito, eu vou colocar outra pessoa na EMPLASA". E aí não teve jeito, viu, não tive como recusar, porque eu não tinha outro caminho, fui trabalhar com o Setúbal mas disse a ele: "Olha eu vou trabalhar, mas vou trabalhar chateado, eu vou trabalhar de má vontade, porque eu não queria ficar trabalhando aqui”, disse isso para ele, disse claramente. E trabalhei, trabalhei um ano lá, mas sempre criando atrito... Eu queria sair! Então eu fui de uma inflexibilidade... Nenhum jogo de cintura! Fui de uma inflexibilidade total com ele, com os outros secretários dele, com todos os vereadores, briguei com todos, de ponta a ponta, todos, porque eu não queria ficar lá.

Jorge: Você tinha o tal poder de veto, não tinha?

Adiron: Eu tinha o poder de veto, tinha, tinha o poder de veto.

Jorge: Que pelo que eu sei foi isso o que causou uma briga com os vereadores.

Adiron: Foi. Então eu briguei com eles durante um ano porque eu queria que o Setúbal me mandasse embora e consegui! Obtive sucesso, obtive sucesso! Fiz muito pouca coisa durante um ano... Eu queria fazer tanta coisa e tinha tanta coisa para ser feita, porque o Setúbal e o Cláudio Lembo principalmente, do qual eu não gosto nem um pouco...

Jorge: É o Cláudio Lembo que foi Governador?

Adiron: É, é o Cláudio Lembo, foi governador. Foi um dos poucos caras que ele levou do Itaú com ele. Foi um dos poucos que ele levou, para ser Secretário de Negócios Jurídicos ou coisa semelhante na Prefeitura. Mas não gosto do Claúdio Lembo, acho que ele é um camarada acomodatício, muito político de jeitinho, eu não gosto disso. Então eu logo me atritei com o Cláudio Lembo, comecei a me atritar de cara com o Cláudio Lembo. Tive discussões extremamente explosivas com o Setúbal, desagradáveis. Desagradáveis porque eu queria que ele me mandasse embora, mas ele não me mandava embora, ele não me mandava embora. Até que eu comecei a me atritar violentamente com os vereadores, aí ele não teve jeito, porque foram os vereadores que exigiram que ele me mandasse embora. Aí já não era mais um problema dele. Porque senão os vereadores não iam aprovar o orçamento do ano seguinte! Eu estava lá já há quase um ano e estava na época em que os vereadores tinham que aprovar, e como eu tinha brigado com todos os vereadores, colocaram o Setúbal na parede: "Ou manda o Adiron embora ou nós não aprovamos o orçamento". Foi só isso, o problema foi esse. Ai o Setúbal me chamou lá e disse: "Olha Adiron, agora não tem jeito, eu preciso que orçamento seja aprovado não tem outro jeito. Eu tenho que te mandar embora, me faça um favor, entre com o seu pedido de demissão, por razões pessoais, e assim você sai como se tivesse tomado a iniciativa". Eu digo "Não faço isso prefeito, não faço isso, o senhor tem que me mandar embora, é o único jeito [risos], não saio [risos] sem ser mandado embora. Eu não entro com nenhum pedido de demissão, é problema seu! [risos]. Ou você me manda embora ou eu continuo!" Ele disse: "Ah! Então, nesse caso, eu vou ter que te mandar embora". Eu digo: "Manda! Aliás você está sabendo que estou querendo ir embora não é de hoje. Porque você e o Cláudio Lembo estão fazendo acertos com os vereadores com os quais eu nunca concordei, vocês 
estão introduzindo safadezas na legislação de zoneamento com as quais você sabe que eu não concordo, tá certo? Não concordo!" E uma das últimas que ele tinha feito lá, que era a provação de uma lei safadíssima, de modificação de perímetros e zoneamentos... Safadíssima! Eu pura e simplesmente consegui uma brechazinha legal, e como presidente que eu era da Comissão Orientadora da Lei de Zoneamento, que era a comissão que tomava decisões finais, eu pura e simplesmente bloqueie aquela lei com base legal. Eu bloqueie através de uma portaria da tal comissão, do Conselho Orientador do Zoneamento da cidade. Bloqueie. Mas com a anuência dos membros do Conselho Orientador, não fiz isso de iniciativa não, eu levei o assunto ao conselho orientador que eram os representantes de praxe, do Instituto dos Arquitetos, da OAB, do não sei o quê, inclusive do SECOVI. Eu convoquei uma reunião e apresentei o problema e disse "Olha, essa lei aqui é uma lei safada, foi aprovada agora pelos vereadores fazendo uma porção de alterações nos perímetros da Lei de Zoneamento que são negociatas feitas por cada vereador que estava interessado em um grupo... Eu não aceito, não aceito! Eu já tinha avisado aos vereadores que eu não aceitava, eles sabem disto, mas eles aprovaram a lei assim mesmo, mandaram para ser sancionada pelo prefeito. Eu procurei o prefeito disse a ele que as negociatas eram tais e tais, ponto por ponto eu mostrei em cada perímetro o que tinha acontecido. O prefeito arregalou o olho e disse que tinha que conversar com Cláudio Lembo porque nessa área era o Cláudio Lembo que era o conselheiro jurídicodele. E no dia seguinte sancionou a lei, sem me falar mais nada, sem me dizer uma palavra! Sancionou a lei quando eu tinha dito a ele que aquilo era uma negociata sem vergonha, safada. Então a última estância possível é esse conselho", que era o Conselho Deliberativo do Planejamento da cidade. "Então cabe a nós bloquear a aplicação desta lei e a maneira de bloquear é esta", mostrei a eles "está aqui, faz parte das atribuições do Conselho bloquear qualquer lei desde que haja uma base legal e temos tal e tal base legal". Olha, a maioria, nem todos, alguns evidentemente tinham medo, alguns tinham medo, mas a maioria deles, inclusive o pessoal do SECOVI, concordou e fizemos uma votação. Foi baixada portanto uma resolução do conselho dizendo que aquela lei ficaria com a aplicação suspensa até que fosse introduzida as tais ou tais cautelas. Eu apelei para uma possibilidade que nós tínhamos que era o plebiscito local, quer dizer, nós faríamos um plebiscito, nós ouviríamos a população de cada área afetada pelas modificações que, e eu tinha certeza de que a população não estava de acordo porque era safadeza mesmo, tá certo? Então foi isso, eu fiz isto. Isto saiu publicado, esta minha portaria de presidente de um conselho, não de Secretário de Planejamento, mas de presidente de um conselho. Encaminhei ao diário oficial, porque tinha que ser publicado no diário oficial, portaria de um presidente de um conselho municipal. Foi publicado e no dia seguinte foi uma rebordosa na câmara dos vereadores! Foi! Eu fui chamado de, nem vou dizer os nomes que era dali para baixo! Dali para baixo! [risos] E os vereadores nomearam uma comissão que procurou o prefeito naquele dia mesmo... Eles por unanimidade votaram e baixaram um voto de censura ao Secretário de Planejamento, de censura e desconfiança ao Secretário de Planejamento. Procuraram o prefeito em comissão e disseram: "Olha, ou você manda esse cara embora imediatamente, põe para fora imediatamente, ou você não vai ter esse orçamento aprovado o ano que vem, não tem mesmo, aí não aprovamos". E foi aí que o prefeito me chamou e disse "olha, infelizmente está assim e tal, você peça demissão", eu digo "não peço, me demita é simples. [risos] Você está com a caneta na mão, me demita pô, e daí? Não peço, não vou alegar que por motivos pessoais eu estou pedindo demissão porque não é verdade, 
demita." E ele então não teve outro jeito, me demitiu. Não nem tinha completado um ano que estava lá... Sem poder fazer nada, porque eu estava cerceado de todo lado, sem poder trabalhar... Um ano lá brigando só, só brigando e aí fui demitido.

Jorge: O seu sucessor foi o Cândido Malta Campos Filho...

Adiron: Foi o Candinho, excelente pessoa.

Jorge: ...que é o meu orientador neste trabalho...

Adiron: Excelente pessoa, eu gosto demais do Candinho como pessoa, muito.

Jorge: Ele me contou parte dessa história, ele falou mesmo que você vetou, ele falou de um veto que você fez com os vereadores e acabou caindo, e ele me conta que o Setúbal, quando o convidou falou assim: "olha, você vai ter que negociar esses vetos com a câmara e tal". O Cândido fez uma série de complementos, criou a Z17, Z18 e tal. Na verdade eu queria saber, para terminar, sua opinião, o comentário que você tem, sobre essa nova lei de zoneamento.

Adiron: Da que está em vigor, ou da que está em preparo?

Jorge: A que está em preparo, porque a que está em vigor vai ser totalmente mudada pela que está...

Adiron: Felizmente vai ser totalmente mudada! Porque esta que está em vigor é uma catástrofe, é uma calamidade! É uma lei PT, é uma lei PT! Uma calamidade! Bom então eu vou dizer a você Jorge, não vou dizer a você o que eu penso dessa proposta de lei de Plano Diretor, não, não vou. Vou dizer a você o que eu penso de lei de Plano Diretor. Depois que preparei a primeira lei de Plano Diretor, tá certo? A minha opinião sobre esse assunto, eu fui estudando, eu fui analisando, a experiência que a gente vai adquirindo profissionalmente ao longo da vida me levou a seguinte conclusão: que planejamento urbano é uma atividade essencialmente dinâmica e que tem que acompanhar muito de perto a evolução das características de um aglomerado urbano. Muito de perto. E que a característica básica de uma lei de Plano Diretor é a imobilidade, a imobilidade. Você sabe quanto tempo levou para a minha lei de Plano Diretor ser substituída? Vinte, vinte e poucos anos! Vinte e poucos anos, sem nenhuma alteração como lei de Plano Diretor, nenhuma, isso é um absurdo, um absurdo total. Ela tinha que evoluir muito ao longo de vinte e poucos anos... Não sofreu nenhuma alteração em vinte e poucos anos! O que sofreu foi a lei de zoneamento, é diferente. Mas a lei de Plano Diretor não, continua a grelha de vias expressas quando já não tinha a menor viabilidade de ser executado porque nenhum prefeito tomou qualquer providência para executar aquilo nenhum, nunca! Foi pura e simplesmente abandonada. E era obrigação legal porque era a lei do Plano Diretor em vigor. Nunca nenhum deles levou a sério, mas ela ficou em vigor durante mais de vinte anos! Então a conclusão a que eu cheguei foi a seguinte: é que planejamento urbano não se faz através de leis de Plano Diretor, esta foi a minha conclusão, como urbanista, não se faz. Se faz através de um sistema, de uma estrutura de planejamento urbano que é 
muito diferente de uma lei de Plano Diretor. Uma estrutura de planejamento urbano tem que envolver toda a sociedade, principalmente aquelas parcelas da sociedade que têm uma atuação mais presente nos problemas de desenvolvimento urbano, tá certo? Então o que nós temos que ter é um sistema de planejamento urbano que adote diretrizes de desenvolvimento urbano e que não seja sujeito a veneta de prefeitos que entram e saem, de vereadores que querem ganhar dinheiro as custas de modificação de perímetros, não. Isto tem que ser uma estrutura diferente, que seja permanente e que seja representativa da sociedade como um todo. Se não for assim não dá para fazer planejamento urbano, porque fica essa palhaçada de cada prefeito querer dizer o que ele acha, quando ele não entende nada disso. O Setúbal era bom sujeito mas não entendia nada de planejamento urbano! Era bom sujeito, eu gostava dele pessoalmente... Briguei com ele, realmente briguei, mas não foi por causa das características dele, ele era um homem muito bem educado e continua a ser, está velhinho agora, muito bem educado. Eu gostava dele como pessoa, mas não como prefeito. Porque ele estava querendo ser governador, então para ser governador ele não podia se atritar e ele pegou o Cláudio Lembo, que este eu não gosto pessoalmente, eu não gosto dele pessoalmente. Entregou o Cláudio Lembo para ser o guru político dele para fazer os acertos aqui, os acertos ali, então é isso viu! O Plano Diretor, lei, como ferramenta de controle do desenvolvimento urbano não funciona, não funciona, o que funciona é uma estrutura de planejamento urbano em que a sociedade seja realmente, realmente, não de brincadeira, participante e que tenha a palavra final, e não a palavra final fique por conta de um prefeitinho vagabundo qualquer, por um Colassuono qualquer, uma besta quadrada qualquer deste tipo que é um cavalga duro o Colassuono, sempre foi. Não, tem que ser a sociedade estruturada para controlar o desenvolvimento da cidade e decidir, decidir e não apenas ser consultada para ser ou não aceita, para decidir. Mas para fazer isso é necessário que a gente mude a Constituição do país. E a Constituição do país, e a constituição dos estados, e a constituição dos municípios... Há necessidade de adaptação da legislação maior das constituições de cada escalão governamental para que a decisão sobre planejamento urbano e regional passe a ser da sociedade organizada e não de indivíduos que politicamente podem, pura e simplesmente, fazer mudanças que a longo prazo não interessam a sociedade mas que só interessem a carreira política deles. Então eu nem leio mais proposta de Plano Diretor. A última proposta de Plano Diretor que eu li foi a da Erundina, foi a última. Esse Plano Diretor que está em vigor agora da Martha Suplicy, da administração da Martha Suplicy, eu fui obrigado a ler porque o Instituto de Engenharia me obrigou, eles queriam ouvir a minha opinião através de uma série de palestras que eu teria que fazer lá no Instituto de Engenharia e para isso eu fui obrigado a ler. Não é que eu achava que aquilo valesse alguma coisa, não valia nada, não valia nada! Mas fui obrigado a ler pelo menos, fui lá e fiz as palestras e disse "Não adianta, Plano Diretor como lei é extremamente imobilizante porque tem uma extrema dificuldade para sofrer alterações, para sofrer qualquer tipo de mudança há necessidade de negociações que são longas e quase sempre as negociações implicam em introduzir mais safadezas mais para atender fulano ou ciclano. Então Plano Diretor como lei não funciona, não é uma ferramenta de trabalho decente que possa ser usada. Não é mais, pode ser que tenha sido há cinqüenta anos atrás, eu estava enganado quando eu fiz o primeiro Plano Diretor porque eu pensava que era belíssima ferramenta... Não é. O primeiro Plano Diretor que eu fiz nunca foi realmente aplicado, 
nunca foi aplicado na cidade de São Paulo. Ficou em vigor vinte e poucos anos e nunca foi aplicado. A estrutura da cidade não se desenvolveu conforme o Plano Diretor, que era a lei, mas conforme as conveniências de momento de cada prefeito e de cada governador que ia assumindo. Então não funciona. Se é inútil é melhor não perder tempo com isso, não vamos perder tempo com essa porcaria. Está aí o novo prefeito, o Cassab. Ele está propondo agora um novo Plano Diretor. Não adianta nada. Vai adiantar tanto quanto o da Martha Suplicy, como adiantou o Plano Diretor do Jânio Quadros e como adiantou o meu plano diretor: nada, nada! A cidade continua a crescer de forma desordenada, caótica, porque nós nunca tivemos planejamento sério, honesto. Para ter planejamento sério é preciso que nós tenhamos políticos sério e isso é muito difícil. Foi por isso que eu me afastei dessa área Jorge. Eu me afastei prematuramente, eu estava no auge em termos de carreira profissional, eu estava lá em cima, eu tinha chegado, quer dizer, conhecia o assunto, eu me afastei com o Setúbal. Eu, quando saí do Setúbal, eu saí de forma violenta, de forma desaforada. Não sei se você ouviu falar na história do abacaxi ?

Jorge: O Cândido me contou...

Adiron: Foi de forma desaforada e nunca mais eu pus os pés lá, nunca mais desenvolvi trabalhos para a prefeitura de São Paulo, nunca mais. Porque eu cheguei a conclusão de que trabalhar em conjunto com a extrema corrupção dos políticos era impossível; trabalhar de forma séria era impossível! Então eu estava perdendo meu tempo, estava me desgastando. Continuei a estudar o assunto é claro, porque eu me interesso muito, continuei a prestar serviços de consultoria, mas nunca aqui na cidade de São Paulo. As vezes para governadores de outros estados, as vezes para prefeitos de grandes cidades. Passei todo o resto da minha carreira profissional como consultor para assuntos específicos de desenvolvimento urbano em diferentes áreas. Mas a prefeitura de São Paulo eu disse na hora que eu saí e fiz, nunca mais pus os pés lá dentro. E o prefeito Setúbal devia pura e simplesmente ter me mandado embora. Ele devia ter me demitido por nunca mais ter comparecido a prefeitura depois que eu saí... Eu não podia, eu era funcionário de carreira, não podia, tinha que continuar comparecendo, assinando o ponto... Nunca mais pus os pés lá dentro. E o Setúbal, por bondade dele, ele não me mandou embora. Ele podia me mandar por abandono, não pus os pés lá dentro. Para não ficar inteiramente à toa, eu aceitei um convite do Mário Covas, que foi prefeito mais tarde, tá certo? E fui trabalhar, não na prefeitura, mas na COMGÁS, assunto do qual eu não entendia nada, não era a minha especialidade, produção de gás, distribuição de gás, fui ser diretor da COMGÁS e daí? Tive que aprender. Então fiquei lá durante um ano aprendendo, fiquei aprendendo o que era aquilo, depois de um ano eu passei realmente a dirigir a COMGÁS a fazer aquele negócio funcionar, então é isso. A minha saída da prefeitura foi traumática, violenta, traumática e violenta. O Setúbal ficou meu inimigo... Eu não, eu não tinha condições de ficar inimigo dele, ele era o dono da coisa, do Itaú e do resto, tá certo? Mas ele ficou meu inimigo, ele nunca mais falou comigo. Nós nos encontramos várias vezes depois disso, em eventos e coisas, ele virava o rosto para o outro lado e não falava nem bom dia, nem boa tarde. Ele ficou meu inimigo. Ele e o Lembo, ficaram meus inimigos por causa desta minha saída violenta. Foi violenta, mas paciência, o que eu ia fazer? Paciência, não dava mais para suportar aquele tipo de ambiente de corrupção, não dava. Eu acho que planejamento urbano só se faz com honestidade não tem outra maneira. 
Depois do gravador desligado, Adiron pede pra completar um pensamento:

Jorge: Pode falar.

Adiron: Então para completar. Você me perguntou, assim genericamente, qual foi a influência da Fórmula de Adiron sobre a conformação física dos edifícios da cidade de São Paulo, sobre o padrão de projeto de arquitetura na cidade de São Paulo. Então, eu estou convencido de que a atual Avenida Paulista, para dar um exemplo, é resultado típico da aplicação da Fórmula de Adiron, porque os projetos que ocorriam na Avenida Paulista antes da Fórmula de Adiron eram os projetos escadinha, era porcaria, encostando dos dois lados, [coisa] que não podia, ocupando o máximo que pudesse, tá certo? Depois da Fórmula de Adiron, eles passaram a ser projetos bem feitos com uma conformação arquitetônica evidentemente muito melhor, com uma qualidade em termos de salubridade muito maior. Então eu diria que a Fórmula de Adiron teve esta conseqüência benéfica, de melhorar a qualidade arquitetônica das edificações, das grandes edificações da cidade de São Paulo. E o resultado que nós podemos ver hoje é a Avenida Paulista que foi quase toda ela projetada como conseqüência da Fórmula de Adiron.

Jorge: Nesse meu trabalho e eu faço uma análise crítica da Fórmula... E eu concordo plenamente com essa questão da salubridade, da insolação e tal. Eu tenho no entanto uma crítica: no meu entender a projeção não deveria contar no pavimento térreo. Tem essa questão de permeabilidade do solo que é muito importante... Mas têm duas coisas que eu acho que são conseqüência dessa fórmula: uma é o fato de você construir em menos área, ou seja, em menos projeção. Se você construísse a mesma coisa em menos projeção o prédio naturalmente cresceria; quando você ainda ganha potencial construtivo, o prédio cresce em progressão geométrica.

Adiron: Muito mais. Aumenta a densidade. Há um aumento de densidade.

Jorge: $\mathrm{Na} \mathrm{Z} 2$, por exemplo, que é a grande parte da cidade, você tinha a ocupação de 0,50 e coeficiente 1 . Se você fizer a ocupação de 0,25 , metade, você constrói o dobro. Nesse caso o prédio cresce quatro vezes.

Adiron: Quatro vezes, a densidade aumenta em proporção.

Jorge: Agora existe também o código de obras que depois de 75 não é? Que estabelece as faixas de iluminação e ventilação, principalmente a faixa de iluminação que é aquela mais restritiva. E ela é proporcional justamente a altura dos prédios. Quando os prédios cresceram muito por conta da aplicação da fórmula, essas faixas cresceram muito.

Adiron: Cresceram.

Jorge: Eu trabalhei com mercado imobiliário...

Adiron: Você foi, você foi uma vítima. 
Jorge: $\mathrm{O}$ incorporador sempre vai optar pelo maior coeficiente, claro.

Adiron: Evidente, mais área para vender.

Jorge: Então os arquitetos sempre vão trabalhar com a menor projeção.

Adiron: Com a menor projeção

Jorge: E por conta dos grandes recuos... Eu senti isso na pele: de 200 projetos que eu participei, os 200 tinham as mesmas características de implantação, que era uma torre centralizada no lote. Porque os recuos eram tão grandes que não sobrava outra opção. Existia uma tipologia que eu gostava muito na década de 50, daqueles prédios em lâmina, que tinham muita área livre também... Essa tipologia, por exemplo, não ficou mais possível, mas essa nem é a grande questão, porque é meramente uma questão de forma. A minha maior critica é em relação a taxa de ocupação. Como os prédios foram parar lá no meio do lote e como o pavimento térreo não podia ultrapassar a projeção do pavimento tipo, porque se não aumentaria a projeção do empreendimento e abaixaria o coeficiente, os térreos ficaram contidos na projeção.

Adiron: Ficaram contidos na projeção.

Jorge: E isso, ao meu entender, desestimulou o uso misto das edificações. Porque, se na Z2 a Fórmula de Adiron só podia para uso residencial, na Z3, Z4, Z5, podia para qualquer um, inclusive para usos mistos, e essas zonas permitiam os usos mistos. Mas apesar dessa permissão existir, de fato isto não acontecia e por que? Porque não era atraente para um comércio ou um serviço que o estabelecimento dele ficasse longe da rua...

Adiron: Lógico, lógico que não.

Jorge: ...lá centralizado no lote. E até por questões de segurança do condomínio, porque a pessoa tinha que entrar no lote e tal. O que aconteceu? O uso misto das edificações foi se extinguindo.

Adiron: Foi.

Jorge: E eu acho isso ruim para cidade.

Adiron: Concordo plenamente.

Jorge: Aconteceu que [a fórmula] acabou criando bolsões residenciais Mesmo em Z2 e Z3, [os lotes] têm apenas um uso, e aquele uso misto que proporcionaria uma vida urbana mais interessante, uma permeabilidade dos pavimentos térreos e mais gente na rua acabou. Hoje, mesmo os bairros que são valorizados pela sua vida urbana interessante como é, por exemplo, Higienópolis, como é Jardins, como é Moema, como é Itaim... Moema, por exemplo, é um bairro onde você desce do seu apartamento e num raio de 500 metros você encontra restaurantes, farmácias e isso é muito valorizado pelas pessoas. 


\section{Adiron: É.}

Jorge: E como é valorizado pelas pessoas, o mercado imobiliário valoriza, por que tem demanda. E daí eles vão ocupando os lotes, retirando inclusive os sobrados que são ocupados pelo comércio e serviço que tanto atraem as pessoas; e numa relação meio paradoxal, eles vão retirando do bairro aquilo que justamente é o que as pessoas gostam naquele bairro. Fazendo uma projeção para o infinito, vai chegar uma hora que vão ter acabado todo comércio e serviço do lugar. Por que? Porque só vai ter edifícios residenciais sem comercio e serviço embaixo. Eu escrevo isso no meu trabalho, que uma decorrência dessa Fórmula foi a diminuição do uso misto no lote, não na quadra, na quadra permite claro, mas no lote acabou. Mesmo nas zonas em que é permitido ele não acontece pelo fato do térreo estar sempre distante da rua, no centro [do lote]. Eu concordo plenamente com a questão de salubridade, se o prédio vai ser maior que ele seja mais estreito para permitir insolação e areação, mas acho que isso não deveria valer para o pavimento térreo, para que o térreo pudesse também se aproximar da rua e continuar permitindo essa diversidade de usos que eu acho riquíssima.

Adiron: OK. Muito bom. Então só para complementar isso aí, primeiro, eu cheguei a falar sobre aquela proposta então que eu estava tentando incluir naquele meu livro que estava fazendo com o Bratck da cidade vertical, quer dizer uma estrutura com a cidade completa, uma estrutura completa e em volta área livre. Está dentro deste tipo de raciocínio, daquilo que você esta falando, isto é, tanto quanto possível facilitar o acesso da população a todo tipo de serviço e de funções; o trabalho deve ter fácil acesso, os serviços devem ter fácil acesso. Então se você tem um edifício que permite o acesso a serviços, a comércio você esta evidentemente reduzindo a necessidade de circulação pelo sistema viário da cidade, corretíssimo. Agora, não se esqueça disto: primeiro, nos estávamos trabalhando dentro de uma estrutura coerente; a lei de zoneamento era uma lei resultante de uma proposta de Plano Diretor que tinha a sua conformação de uso, de espaço definido. E nesta conformação uma das características mais importantes eram as unidades urbanas escalonadas. Se você, nesta primeira lei de zoneamento, tivesse introduzido essa forma de ocupação, você estaria dispersando equipamentos de uso cotidiano, comercial e de serviços pela cidade toda, desde que estivesse ali um prédio, desde que estivesse ali um prédio residencial [com comercio ou serviços no térreo], então isso iria contra a proposta ordenada de unidades urbanas escalonadas, tá certo?

\section{Jorge: Certo.}

Adiron: Então esse é primeiro aspecto. E o segundo é que quando eu preparei e apresentei o primeiro Plano Diretor da cidade e a primeira lei de zoneamento da cidade a minha idéia, que era a idéia dos urbanistas naquela época, e hoje continua a ser, é que todo esse tipo de legislação fosse dinâmica, isto é, que a própria aplicação da legislação fosse evidenciando pontos que deveriam sofrer alterações para melhor. A idéia é que isso fosse sendo aperfeiçoado. Infelizmente não foi, quer dizer, a própria lei de zoneamento quando sofreu alterações foi para atender negociatas de vereadores, de grupinhos, não foi para melhorar. Então concordo totalmente com você quando você diz que um grande edifício deve abrigar atividades variadas, não precisa ser só residencial, concordo totalmente 
com você. É como se fosse uma unidade urbana elementar, como se fosse uma pequena unidade de vizinhança.

Jorge: E até eu perguntei isso da Z2 o porquê da restrição [apenas para o uso] residencial, principalmente porque a Z2 é a maior parte da cidade. Sempre me intrigou, me incomodou de certa forma o fato de só poder ter residência quando um prédio de uso misto na Z2 seria muito interessante.

Adiron: Mas se tivéssemos conseguido implantar este modelo, esse problema não teria aparecido porque você teria esse tipo de equipamento de uso cotidiano sempre a uma distância de 500 metros, que você podia alcançar facilmente a pé; era até saudável você caminhar um pouco em vez de ficar só subindo e descendo de elevador. Havia então uma série de razões que levaram a determinar... Mas a idéia básica infelizmente não subsistiu, que era que esse tipo de trabalho era dinâmico que não era para ter um Plano Diretor que era para durar 20 anos nem uma lei de zoneamento que só sofreu alterações para pior ao longo de 20 anos, para atender interesses escusos de grupos. Só! Não sofreu alterações para melhor, só para atender interesses escusos, tá certo? Então concordo totalmente com você, isto é, quanto mais você puder misturar usos dentro do ambiente urbano, com as suficientes cautelas para que uns usos não prejudiquem ou incomodem os outros, tanto melhor. Esta é, teoricamente, a melhor solução que você pode obter. Agora eles eliminaram a Fórmula de Adiron o que você viu? Foi eliminada, não está mais na lei, você não sabia disso? A Martha Suplicy mandou eliminar. Ela não gostava de mim! Foi por isso só, não foi por outra razão não. O que você está vendo? Você passa no largo de Pompéia, você passa no antigo supermercado Matarazzo e você vê um aleijão brutal, uma brutalidade, uma brutalidade!

Jorge: $\mathrm{O}$ que é aquilo?

Adiron: Porque não é mais a Fórmula de Adiron que está prevalecendo. Agora eles ocupam tudo, com o máximo de aproveitamento possível através do que eles chamam de negociação em que eles pagam ...

Jorge: A tal de Outorga Onerosa.

Adiron: que é só negociata, não é negociação, é só negociata. Aí muita gente ganha dinheiro, tá certo? Então é isso, a Fórmula de Adiron não existe mais na legislação, ela foi eliminada e as conseqüências vão começar a ver, vai piorar muito o padrão das edificações.

Jorge: Eu entendo a Outorga Onerosa [da seguinte maneira]: baixou-se [o coeficiente] para ter que pagar para se chegar a quatro...

Adiron: Então, o negócio é indecente! Não é planejamento urbano. A gente não abaixa para poder receber dinheiro, para dar de volta, não, isso não é planejamento urbano.

Jorge: Não, o que eu entendo Adiron é... Vila Olímpia, por exemplo. Lá o mercado imobiliário substitui todos aqueles sobrados, as ruas são estreitas, constroem prédios com 
coeficiente quatro, o que acontece com a infra-estrutura urbana? Fica pequena, insuficiente, ou seja, a infra-estrutura urbana, de esgoto, ruas e tal não serve mais para todas aquelas construções. Como é um bairro rico e as construtoras tem muito acesso ao poder, o que vai acontecer? O poder municipal, ao invés de fazer mais infra-estrutura onde realmente precisa, vai usar o dinheiro para substituir uma infra-estrutura que já existia [na Vila Olímpia]. Essa obra de substituição é paga pela prefeitura que recolhe impostos, viabilizado pelos impostos, ou seja, é paga pela população inteira e vai valorizar os imóveis daquelas pessoas que estão lá. Isso para mim se caracteriza como um processo de concentração de renda que é umas dos piores problemas que a gente tem no nosso país. Eu entendo a Outorga Onerosa como um mecanismo... O coeficiente gratuito é dois, você pode chegar a quatro, de acordo como poderia, mas você vai pagar uma taxa para prefeitura, porque essa taxa, na teoria, vai servir para substituir a infra-estrutura que será necessária pelo aumento da densidade. Ou seja, como após essa construção vai ser necessária uma reformulação da infra-estrutura, que essa reformulação seja paga por essa taxa de Outorga Onerosa e não mais pelos recursos da prefeitura.

Adiron: Pela totalidade da população.

Jorge: Então, eu entendo como uma coisa positiva... Na teoria, na prática eu não sei.

Adiron: OK na teoria corretíssimo, na prática infelizmente virou negociata. Você sabe disso tão bem quanto eu. Mas o que eu quero dizer é o seguinte: no momento em que você estabelece qual é a vantagem, a conveniência urbanística de você adensar determinados perímetros e não adensar outros perímetros, você está fazendo planejamento urbano, você está na verdade legislando sobre a organização do espaço territorial. Isto aí você só pode fazer se você fizer de maneira honesta e decente, sem negociação nenhuma, aqui pode aqui não pode, por que? Por causa disso ou por causa da infra-estrutura ou por causa de qualquer outros motivos e razões, tá certo? A médio e longo prazo na zona em que você permite construções maiores já de cara, sem nenhum tipo de Outorga Onerosa, sem fazer esse passa-moleque... Eu chamo isso de passa-moleque... Sem fazer isso de passa-moleque, a médio e longo prazo você vai de fato recuperar o valor que você precisa para reforçar a infra-estrutura por que você vai pagar imposto e IPTU sobre muito mais [área construída] do que você pagaria se você fizesse térreo, se você fizesse dois pavimentos. Então o retorno que vai haver não vai ser a curto prazo, você não vai pagar uma taxa hoje, negociar, mas vai ter sim o mesmo retorno, só que num prazo maior, tá certo? Ao longo dos anos. E planejamento se faz a médio e a longo prazo, não se faz para obter vantagens hoje ou para fazer uma negociata hoje, não. Não é assim que se faz planejamento, você tem que enxergar os resultados a médio e longo prazo. Então é a forma do urbanista raciocinar, se ele raciocinar sempre com o curto prazo, pague agora porque você esta fazendo agora, ele não estará fazendo conceitualmente planejamento urbano, ele estará fazendo uma imposição de arrecadação de dinheiro, que teoricamente seria só para prefeitura, para interesse coletivo, mas que infelizmente nós sabemos que não acontece bem assim, que acaba não sendo bem isso.

Jorge: Eu entendo muito bem que o zoneamento, na verdade, foi um retrato do que já existia. 
Adiron: Foi sim, por que foi resultado da pesquisa do Lebret, da pesquisa do PUB.

Jorge: Adiron, fala-se muito do tal eixo sudoeste, que vai do sul para o oeste passando pelo centro, que ele é concentrador da maior diversidade de zonas, e das zonas mais permissivas portanto... A parte [da cidade] fora disso é uma grande Z2, pontilhados de Z3 e de Z4. O que acaba concentrando grande parte da economia da cidade, dos empregos e tudo mais aqui na zona sudoeste. Eu estou falando isso para perguntar se você não sentiu vontade de criar nessas zonas mais distantes uma diversidade tão grande quanto existe aqui [na região sudoeste].

Adiron: Para você entender o mapa da lei de zoneamento como foi proposta originalmente, você teria que aplicar aqui em cima a grelha das vias expressas.

\section{Jorge: Certo.}

Adiron: Aquela parte da proposta não foi teórica, não. Nós adotamos a malha de vias expressas que havia sido exaustivamente estudada pelo PUB, pelo pessoal que tinha extrema competência para fazer isso. Então não era pura e simplesmente pegar um esquadro, não. As vias expressas propostas pelo PUB, que resultavam genericamente numa grelha, mas não era nada de quadradinho não, ela acompanhava todas as necessidades em termos de viabilidade, em termos de execução futura, mas resultava em última análise numa série de unidades. Se você aplicar isto aqui em cima você vai perceber que é coerente. Dentro de cada unidade a malha de vias expressas era completada por uma malha de avenidas principais. Se você aplicasse a malha de via expressa mais a malha de avenidas principais você ia encontrar o porquê que é Z3 aqui, o porque que é Z4 aqui, tá certo? Você vai encontrar tudo com coerência. Agora havia uma área muito adensada que nós não podíamos pura e simplesmente jogar no chão; e nesta área foi mantida o adensamento, sob um controle um pouco maior porque se reduziu o coeficiente de aproveitamento. Havia uma área que era pouquíssimo adensada, foi mantido com o seguinte raciocínio: que a cidade não é um ser morto, a cidade é um ser vivo, e a legislação tem ser também dinâmica. Então admite-se que se as tendências de crescimento indicassem que, em determinada região da cidade, estava caminhando para um desenvolvimento maior então a legislação e o zoneamento imediatamente estudariam aquilo ali para verificar quais alterações convenientes. É que na época havia áreas totalmente vazias cuja vocação nós não podíamos pura e simplesmente chutar... OK, continuam vazias, continuam só com Z2, só com pouquíssima coisa, só uns pontinhos de Z3. Um processo de planejamento tem que ser dinâmico! Não é questão para rever daqui a dez anos, nada disso! Plano Diretor é revisto a cada semana! A equipe permanente, o sistema permanente de planejamento tem que estar continuamente trabalhando. É isso, o conceito básico é este. 
